\title{
Sludge Treatment Project Engineered Container Retrieval and Transfer System Preliminary Design Hazard and Operability Study
}

Prepared for the U.S. Department of Energy

Assistant Secretary for Environmental Management

Contractor for the U.S. Department of Energy under Contract DE-AC06-08RL14788

CHzMHILL

Plateau Remediation Company

P.O. Box 1600

Richland, Washington 99352 
PRC-STP-00467

Revision 0

EDC \#: ECR-11-001234

\section{Sludge Treatment Project Engineered Container Retrieval and Transfer System Preliminary Design Hazard and Operability Study}

Project No: STP

Document Type: RPT

Program/Project: STP

C. A. Carro

Authorization Basis Services, Inc.

Date Published

July 2011

Prepared for the U.S. Department of Energy

Assistant Secretary for Environmental Management

Contractor for the U.S. Department of Energy

under Contract DE-AC06-08RL14788

CH2MHILL

Plateau Remediation Company

P.O. Box 1600

Richland, Washington

Nancy A Fouad

Release Approval

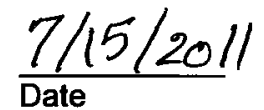

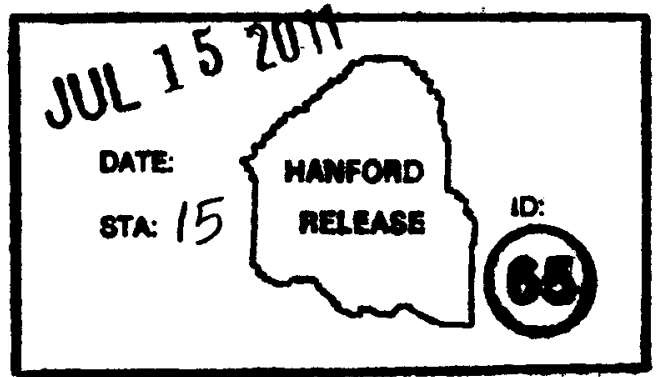

Release Stamp 
PRC-STP-00467

Revision 0

TRADEMARK DISCLAIMER

Reference herein to any specific commercial product, process,

or service by trade name, trademark, manufacturer, or

otherwise, does not necessarily constitute or imply its

endorsement, recommendation, or favoring by the United

States Government or any agency thereof or its contractors or subcontractors.

This report has been reproduced from the best available copy.

Printed in the United States of America

Total Pages: $\quad 240$ 


\section{CONTENTS}

$1.0 \quad$ INTRODUCTION

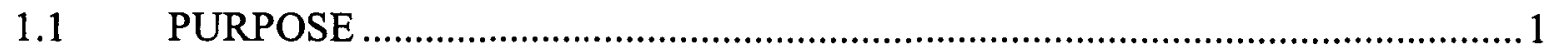

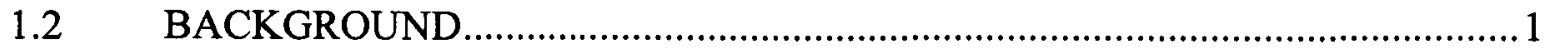

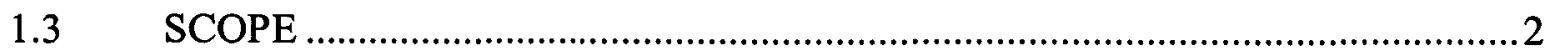

$2.0 \quad$ FACILITY AND PROCESS DESCRIPTION SUMMARY …….......................................

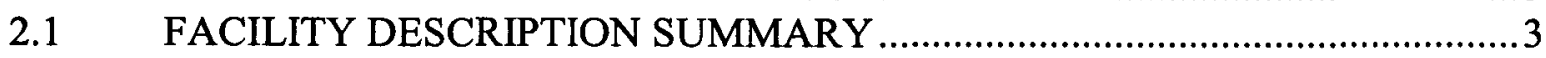

2.1.1 Sludge Transportation and Storage Containers ....................................... 3

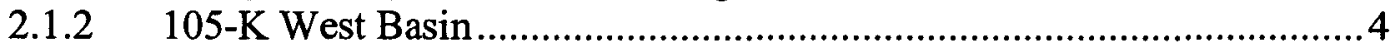

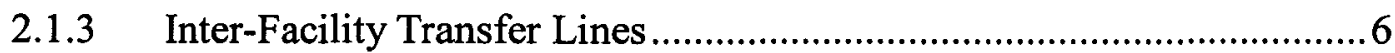

2.1.4 Modified KW Basin Annex ................................................................

2.1.5 Modified KW Basin Annex Confinement Ventilation System ..............8

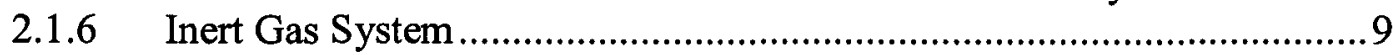

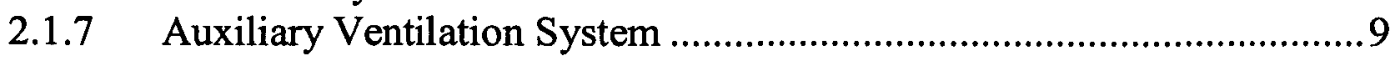

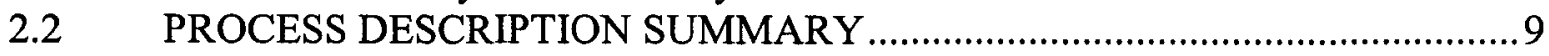

2.2.1 Operating Mode 1: Preparing STSC ...................................................

2.2.2 Operating Mode 2: Sludge Transfer into STSC..................................10

2.2.3 Operating Mode 3: Flush Transfer Line ...............................................11

2.2.4 Operating Mode 4. Add Flocculant to Decant from STSC...................12

2.2.5 Operating Mode 5: Decant Supernate from STSC ................................12

2.2.6 Operating Mode 6: Backwash Sand Filter to STSC ............................12

2.2.7 Operating Mode 7: Remove Excess Sludge from STSC ......................12

2.2.8 Operating Mode 8: Disconnect Piping from STSC and Inert STSC with Nitrogen..........................................................................13

2.2.9 Operating Mode 9: Inert/Pressurize STS Cask with Nitrogen...............13

2.3 OPERATING SEQUENCE AND INTERLOCK DEFINITION .......................14

2.3.1 Nuclear Safety Shutdown Interlock I-1 ..............................................14

2.3.2 Decant Interlock I-2 ...................................................................15

2.3.3 Process Emergency Stop Interlock I-3 ................................................ 15

2.3.4 Normal Process Shutdown Interlock I-4 ..........................................16

2.3.5 Normal Process Flush Interlock I-5 .................................................. 17

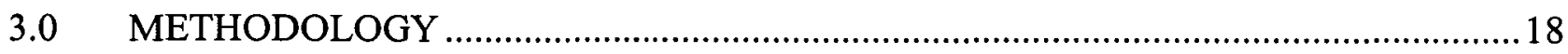

$3.1 \quad$ IDENTIFICATION OF UNDESIRABLE CONSEQUENCES ………............19

3.1.1 Process Parameters and Nodes ....................................................... 19

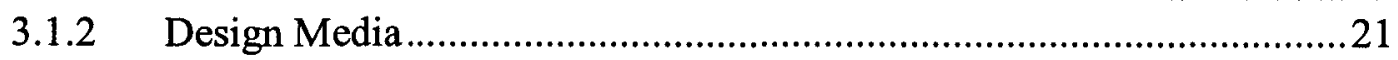

3.1.3 HAZOP Team .............................................................................21

3.2 UNMITIGATED FREQUENCY AND CONSEQUENCE ESTIMATES ..........22

4.0 RESULTS

4.1 HAZARD AND OPERABILTY STUDY RESULTS ...............................24

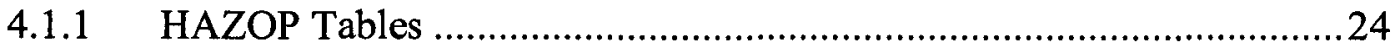

4.1.2 Identified Hazardous Conditions .................................................24 
4.2 UNMITIGATED FREQUENCY AND CONSEQUENCE LEVEL

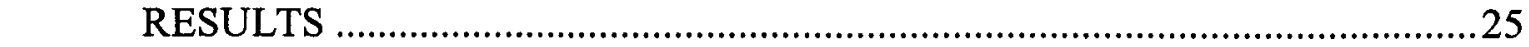

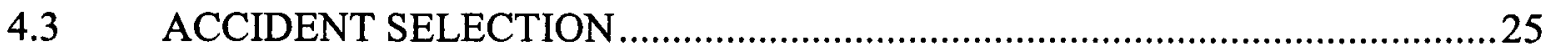

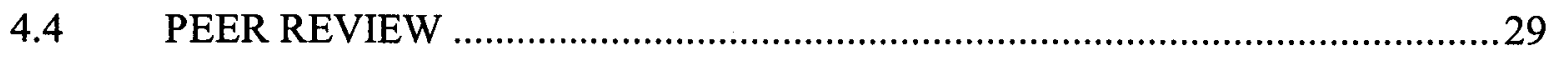

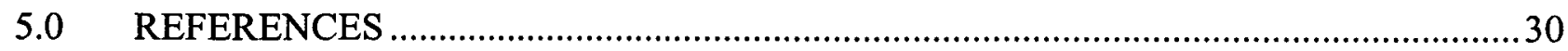

\section{APPENDICES}

A PROCESS FLOW DIAGRAMS AND PIPING AND INSTRUMENTATION

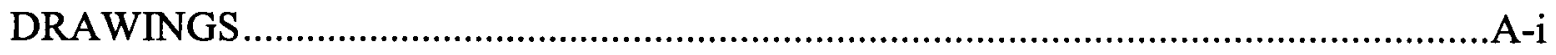

B HAZARD AND OPERABILILTY STUDY MEETING ATTENDEES ........................... B-i

C HAZARD AND OPERABILILTY STUDY RESULTS.............................................

D FREQUENCY AND CONSEQUENCE LEVEL RESULTS ………………..................

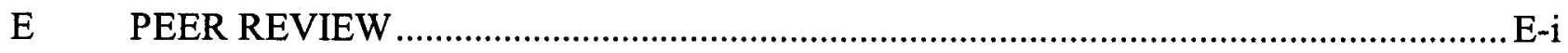

\section{TABLES}

Table 2-1. Estimated Sludge Volumes and Depth in Engineered Containers ................................5

Table 2-2. Maximum Settled Sludge Volume per Sludge Transport and Storage Container

Table 2-3. Nuclear Safety Shutdown Interlock I-1 ............................................................. 14

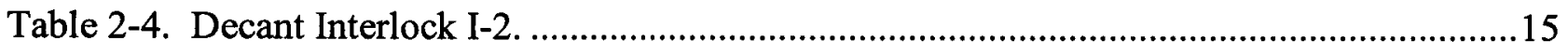

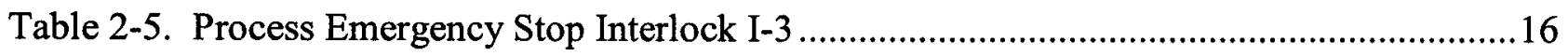

Table 2-6. Normal Process Shutdown Interlock I-4 .................................................................16

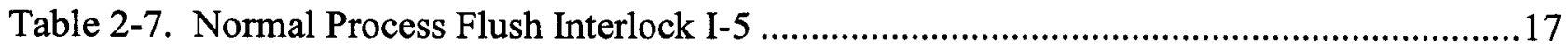

Table 3-1. Process Parameters and Deviations.....................................................................19

Table 3-2. Collocated Worker and Offsite Public Consequence Levels....................................22

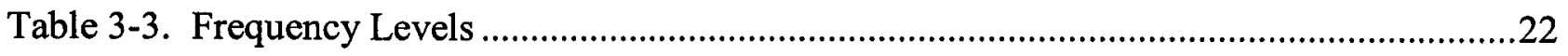

Table 4-1. Summary of Unmitigated Onsite and Offsite Consequences....................................26

Table 4-2. Correlation of Hazardous Conditions to HAZOP Table Entries..................................27 


\section{LIST OF TERMS}

ASME

CHPRC

DOE-RL

ECRTS

HAZOP

HEPA

IXM

$\mathrm{KE}$

KW

P\&ID

STP

STS

STSC
American Society of Mechanical Engineers

CH2M HILL Plateau Remediation Company

U.S. Department of Energy Richland Operations Office

Engineered Container Retrieval and Transfer System

Hazard and Operability

High Efficiency Particulate Air (filter)

Ion exchange module

105-K East (Basin)

105-K West (Basin)

Piping and Instrument Diagram

Sludge Treatment Project

Sludge Transport System

sludge transport and storage container 
PRC-STP-00467 REV 0

\subsection{INTRODUCTION}

\subsection{PURPOSE}

This Hazard and Operability (HAZOP) study addresses the Sludge Treatment Project (STP) Engineered Container Retrieval and Transfer System (ECRTS) preliminary design for retrieving sludge from underwater engineered containers located in the 105-K West (KW) Basin, transferring the sludge as a sludge-water slurry (hereafter referred to as "slurry") to a Sludge Transport and Storage Container (STSC) located in a Modified KW Basin Annex, and preparing the STSC for transport to T Plant using the Sludge Transport System (STS).

\subsection{BACKGROUND}

There are six, underwater engineered containers located in the KW Basin that, at the time of sludge retrieval, will contain an estimated volume of $5.2 \mathrm{~m}^{3}$ of $\mathrm{KW}$ Basin floor and pit sludge, $18.4 \mathrm{~m}^{3}$ of 105-K East (KE) Basin floor, pit, and canister sludge, and $3.5 \mathrm{~m}^{3}$ of settler tank sludge. The KE and $\mathrm{KW}$ Basin sludge consists of fuel corrosion products (including metallic uranium, and fission and activation products), small fuel fragments, iron and aluminum oxide, sand, dirt, operational debris, and biological debris. The settler tank sludge consists of sludge generated by the washing of $\mathrm{KE}$ and $\mathrm{KW}$ Basin fuel in the Primary Clean Machine. A detailed description of the origin of sludge and its chemical and physical characteristics can be found in HNF-41051, Preliminary STP Container and Settler Sludge Process System Description and Material Balance.

In summary, the ECRTS retrieves sludge from the engineered containers and hydraulically transfers it as a slurry into an STSC positioned within a trailer-mounted STS cask located in a Modified KW Basin Annex. The slurry is allowed to settle within the STSC to concentrate the solids and clarify the supernate. After a prescribed settling period the supernate is decanted. The decanted supernate is filtered through a sand filter and returned to the basin. Subsequent batches of slurry are added to the STSC, settled, and excess supernate removed until the prescribed quantity of sludge is collected. The sand filter is then backwashed into the STSC. The STSC and STS cask are then inerted and transported to T Plant.

The ECRTS conceptual design has been completed and is documented in PRC-STP-00166, CD-1 Report for the Sludge Treatment Project Engineered Container Retrieval and Transfer System. Hazard analyses, accident analyses, and control decisions were performed in support of the ECRTS conceptual design culminating in the issuance of PRC-STP-00156, Sludge Treatment Project Engineered Container Retrieval and Transfer System Conceptual Safety Design Report. Following U.S. Department of Energy, Richland Operations Office (DOE-RL) approval of the conceptual design, work began on the ECRTS preliminary design. As documented in PRC-STP-00346, Sludge Treatment Project Engineered Container Retrieval and Transfer System Draft Preliminary Design Hazard and Operability Study, and PRC-STP-00382, Sludge Treatment Project Engineered Container Retrieval and Transfer System Draft Preliminary Design Hazard Analysis Supplement 1, hazard analyses of an early draft of the preliminary 
design were performed in order to provide early integration of safety into the preliminary design process.

In accordance with the guidance in DOE-STD-1189-2008, Integration of Safety into the Design Process, this HAZOP study confirms and adds details to the conceptual design hazard analyses and the draft preliminary design HAZOP study.

\subsection{SCOPE}

This HAZOP study addresses the following process steps:

1. Retrieving sludge from an Engineered Container

2. Transferring the slurry to an STSC

3. Decanting the STSC

4. Backwashing the Sand Filter into the STSC

5. Purging the STSC with nitrogen

6. Purging the STS cask with nitrogen

7. Pressurizing the STS cask with nitrogen

8. Adding flocculant to the slurry during transfer

9. Adding flocculant to the supernate

10. Automatically flushing the transfer line

11. Recovering excess sludge from an over-filled STSC.

This HAZOP does not address the transportation of STSCs to T Plant. Transportation safety will be addressed by the submittal of a Shipment Evaluation Checklist in accordance with the requirements of DOE/RL-2001-36, Hanford Sitewide Transportation Document.

This HAZOP study does not address construction and equipment installation activities at the KW Basin. Hazards associated with such activities will be addressed by the Occupational Safety and Health Program (e.g., automated job hazard analysis). Construction and equipment installation activities will also be subject to the Unreviewed Safety Question process relative to their potential for impacts to existing $100 \mathrm{~K}$ Area nuclear facilities. 
PRC-STP-00467 REV 0

\subsection{FACILITY AND PROCESS DESCRIPTION SUMMARY}

The facility and process description summaries provided below are supported by process flow diagrams and piping and engineering diagrams (P\&IDs) provided in Appendix A and the information contained in HNF-41051.

\subsection{FACILITY DESCRIPTION SUMMARY}

Engineered container retrieval and transfer operations will be conducted in the existing KW Basin and at a new Modified KW Basin Annex. Material transfers between the KW Basin and the Modified KW Basin Annex will be performed using hose-in-hose transfer lines located within an above-ground shielded hose chase running between the two structures.

\subsubsection{Sludge Transportation and Storage Containers}

Engineered container retrieval and transfer operations will use two different STSC designs, one for settler tank sludge and one for $\mathrm{KW}$ and $\mathrm{KE}$ Basin containerized sludge. The two designs are the same except that the STSC for settler tank sludge contains an inner cylinder as described below.

An STSC used for settler tank sludge is an ASME Section VIII pressure vessel rated at 150 psi. It is approximately $10 \mathrm{ft}$ tall and $5 \mathrm{ft}$ in diameter with elliptical heads top and bottom, and contains a centrally located inner cylinder. The STSC shell and bottom elliptical head are constructed of $1 / 2$-in. thick stainless steel, and the top elliptical head is constructed of $3 / 4$-in. thick stainless steel. The inner cylinder is constructed of $1 / 4$-in thick stainless steel and is approximately $24 \mathrm{in}$. in diameter. The top of the inner cylinder is welded to a flange that bolts to the STSC 26-in. diameter nozzle. The bottom of the cylinder, which is closed by an elliptical head, extends to near the bottom of the STSC.

There are eight holes in the inner cylinder. Four are located at the top where the cylinder is welded to the flange. Another four are located approximately $1 / 2$-in. above the tangent line of the top elliptical head, which is approximately $17 \mathrm{in}$. below the flange. The holes are $4 \mathrm{in}$. diameter and are equally spaced around the diameter of the cylinder. The annular region created by the inner cylinder contains sludge whereas the inside of the cylinder contains water which provides a heat transfer mechanism for heat generated by radiolytic decay and by the reaction of uranium metal with water. The design capacity of an STSC for settler tank sludge is approximately $2.89 \mathrm{~m}^{3}$ when filled to a level $1.5 \mathrm{in}$. below the tangent line of the top elliptical head.

As previously stated, an STSC used for $\mathrm{KE}$ and $\mathrm{KW}$ containerized sludge is the same design as that used for settler tank sludge except there is no inner cylinder. The design capacity of an STSC for KE and KW containerized sludge is approximately $3.5 \mathrm{~m}^{3}$ when filled to a level 1.5 in. below the tangent line of the top elliptical head. 
Both STSC designs are provided with a skirt around the bottom elliptical head. The skirt is provided with an index notch that is located and sized such that an STSC can be properly placed in an STS cask in only one orientation. The tops of both STSC designs are provided with nozzles for process connections.

The decant pump suction nozzle is connected to a floating decant suction head located inside the STSC. The overfill recovery nozzle is connected to an overfill recovery tool which is permanently installed inside the STSC. In addition to the nozzles, two lifting fixtures are located on the top of the STSC with a safe working load of $20,000 \mathrm{lbs}$.

Another design feature of the STSCs is an internal sloped fin that extends from the top tangent line to the bottom of the STSC at a slope of 5 degrees. The function of this fin is to provide an obstruction that will collapse a rising plug of sludge, should such a plug occur due to the formation of a vessel spanning bubble during storage for an extended period of time. A vessel spanning bubble can occur when the shear strength of the sludge is sufficiently high to hinder the release of gases generated in the sludge. As documented in PNNL-19345, The Disruption of Vessel-Spanning Bubbles with Sloped Fins in Flat-Bottom and 2:1 Elliptical-Bottom Vessels, tests using sludge surrogates in a cylindrical container demonstrate the a sloped fin inside the STSC provides sufficient obstruction to cause sludge plug failure.

\subsubsection{5-K West Basin}

Fuel Storage Basin. The 105-KW fuel storage basin is a below-ground, reinforced-concrete rectangular pool approximately $125 \mathrm{ft} \times 67 \mathrm{ft}$. The walls of the basin are $20 \mathrm{ft}-9 \mathrm{in}$. high, with a nominal operating water depth of $15 \mathrm{ft}-10$ in. to $16 \mathrm{ft}-10 \mathrm{in}$. at $105-\mathrm{KW}$ Basin. The basin floor is a 2-ft thick (nominal) reinforced-concrete mat. Reinforcing steel connects the basin mat to the walls. An operating deck of steel grating is suspended over the basin. The operating deck is at ground elevation.

The basin is covered by a one-story steel superstructure. The exterior walls are steel-framed with corrugated asbestos cement panels. The superstructure consists of roof trusses and purlins that transfer loads to structural support columns. The roof structure supports the floor grating, flexible transfer crane, and a series of monorails over the basins. The $105-\mathrm{KW}$ fuel storage basin has a structural cantilevered roof with metal-seamed panels located above and extending $10 \mathrm{ft}$ north of the original basin roof.

Engineered Containers. There are six Engineered Containers (SCS-CON-210 through -260) that rest on the floor of the KW Basin. The containers are rigid, self-supporting, free-standing structures of bolted stainless steel construction. The dimensions of the containers are approximately 13-ft high by $5-\mathrm{ft}$ wide by $11 \mathrm{ft} 10 \mathrm{in}$. long. The containers are further described in HNF-SD-WM-SAR-062, KW Basin Final Safety Analysis Report, Section 2.5.10, "105-KW Sludge Containerization System."

Engineered Containers SCS-CON-210 and -220 contain KW Basin floor and pit sludge. Engineered Container SCS-CON-230 contains sludge retrieved from the settler tanks. 
Engineered Containers SCS-CON-240, -250, and -260 contain KE Basin floor, pit, and canister sludge. Table 2-1 provides the average depth and volume of sludge in the containers.

Table 2-1. Estimated Sludge Volumes and Depth in Engineered Containers.*

\begin{tabular}{|l|c|c|c|c|c|c|}
\hline & \multicolumn{2}{|c|}{ KW Originating } & $\begin{array}{c}\text { Settler Tank } \\
\text { Sludge }\end{array}$ & \multicolumn{3}{c|}{ KE Originating } \\
\cline { 2 - 7 } & SCS-CON-210 & SCS-CON-220 & SCS-CON-230 & SCS-CON-240 & SCS-CON-250 & SCS-CON-260 \\
\hline $\begin{array}{l}\text { Average } \\
\text { Sludge } \\
\text { Depth }\end{array}$ & $3.6 \mathrm{ft}$ & $1.8 \mathrm{ft}$ & $3.25 \mathrm{ft}$ & $2.7 \mathrm{ft}$ & $5.7 \mathrm{ft}$ & $6.0 \mathrm{ft}$ \\
\hline $\begin{array}{l}\text { Sludge } \\
\text { Volume }\end{array}$ & $4.22 \mathrm{~m}^{3}$ & $1.0 \mathrm{~m}^{3}$ & $3.5 \mathrm{~m}^{3}$ & $2.6 \mathrm{~m}^{3}$ & $7.7 \mathrm{~m}^{3}$ & $8.1 \mathrm{~m}^{3}$ \\
\hline
\end{tabular}

*From Table 2-1, HNF-41051, 2009, Preliminary STP Container and Settler Sludge Process System Description and Material Balance, Rev. 7, CH2M HILL Plateau Remediation Company, Richland, Washington.

$\mathrm{KE}=105-\mathrm{K}$ East.

$\mathrm{KW}=105-\mathrm{K}$ West.

Sludge Retrieval. Sludge will be retrieved from the Engineered Containers by use of a hydrolance, which is a proprietary sludge retrieval device manufactured by Xago Nuclear Ltd. The Xago HydroLance ${ }^{\mathrm{TM}^{1}}$ has three principal components: a Coanda fluidizer head, high pressure fluidizing jets, and an eductor. The Coanda head provides local fluidization of the sludge to allow insertion of the HydroLance into the sludge bed. The fluidizing jets, mounted at the end of the hydrolance, function to periodically mobilize the sludge bed within the Engineered Container to facilitate efficient sludge retrieval. The eductor provides the motive force to transfer the sludge-water slurry out of the container to an in-line booster pump.

The Xago HydroLance ${ }^{\mathrm{TM}}$ operates using Ion Exchange Module (LXM) water supplied from either the Basin Water Recirculation and Cooling System or the Skimmer Water Cleanup System. These systems are described in HNF-SD-WM-SAR-062, Section 2.5.7, "Basin Water System." A fluidizing pump (STP-P-52) provides IXM water at approximately $42 \mathrm{gpm}$ and $385 \mathrm{psi}$ to the fluidizing jets. A motive flow pump (STP-P-51) provides IXM water at approximately $32 \mathrm{gpm}$ and $175 \mathrm{psi}$ to the eductor, and approximately $9 \mathrm{gpm}$ to the Coanda head.

The hydrolance transfers approximately $70 \mathrm{gpm}$ of retrieved slurry at a nominal solids content of 5 vol\% through an underwater hose to a skid-mounted, underwater booster pump (ECRT-P-101). To minimize plugging, the hose is $1.5 \mathrm{in}$. in diameter, which is six times the diameter of the largest sludge particles. At a flow rate of $70 \mathrm{gpm}$, the velocity in the hose is $12.7 \mathrm{ft} / \mathrm{s}$, which is greater than the critical velocity of $12.3 \mathrm{ft} / \mathrm{s}$ required to avoid settling of solids in the transfer

\footnotetext{
${ }^{1}$ Xago Hydrolance ${ }^{\mathrm{TM}}$ is a registered trademark of NuVision Engineering
} 
line, as calculated in PRC-STP-00021, Preliminary Hydraulic Analysis for Direct Loading of Sludge Transport and Storage Containers.

The booster pump is required to overcome pressure loss in the approximately $235 \mathrm{ft}$ of transfer hose and piping and the approximately 35 -ft elevation gain from the basin floor to the transfer line service box in the Modified KW Basin Annex. The booster pump is a skid-mounted, industrial hose pump (similar in design to a peristaltic pump) located on the basin floor. The pump provides the motive force to pump slurry to the STSC at approximately $70 \mathrm{gpm}$ and 100 psi. Pressure relief is provided by two downstream rupture disks. The slurry is transferred by an underwater hose to the ingress/egress pipe. The ingress/egress pipe provides the transition from the underwater transfer line to the above water transfer line. A second ingress/egress pipe provides the transition point for the transfer of filtered STSC supernate from the Modified KW Basin Annex to the basin.

A 50-gallon flush tank (ECRT-T-101) is located on the basin deck. This tank is used to automatically flush the slurry transfer line downstream of the booster pump given a loss of power or activation of the Nuclear Safety Shutdown interlock sequence (I-1) which de-energizes the booster pump. The tank, pressurized with air, is connected to a normally closed valve which is connected by a hose to a nozzle on the discharge side of the booster pump.

\subsubsection{Inter-Facility Transfer Lines}

There are four transfer lines between the KW Basin and the Modified KW Basin Annex housed within a shielded hose chase. A slurry transfer line (and an associated spare) is used to transfer slurry from the KW Basin to the Modified KW Basin Annex; a decant line is used to transfer filtered STSC supernate from the Modified KW Basin Annex sand filter vault to the KW Basin; and an IXM water line is used to transfer IXM water to the Modified KW Basin Annex. The slurry transfer line can also be used to transfer slurry from the STSC back to an engineered container in the KW Basin in the event of an STSC overfill.

The slurry transfer lines and decant line are of hose-in-hose construction with associated leak detection. The hoses are made of ethylene-propylene-diene monomer material. The lines are housed within a covered, concrete trench that provides shielding to reduce the dose rate to facility workers. The inner hose is $1.5 \mathrm{in}$. in diameter, and the outer hose is 4 in. in diameter. The IXM water line is a single hose. Heat trace is provided for freeze protection.

At the KW Basin, the slurry transfer line and decant line connect to the two ingress/egress pipes where they penetrate the $\mathrm{KW}$ Basin building wall. At the Modified KW Basin Annex, the slurry transfer line and decant line transition from an exterior shielded hose chase to an interior shielded hose chase.

The annular space of the slurry transfer line hose-in-hose and decant line hose-in-hose drain back to the $\mathrm{K}$ West Bain via their respective ingress-egress pipes. The ingress/egress pipes are equipped with leak detectors to detect liquid in the annular region and shut down the associated transfer pumps. 


\subsubsection{Modified KW Basin Annex}

The Modified KW Basin Annex is located approximately $10 \mathrm{ft}$ north of the new north wall of the $105 \mathrm{KW}$ Fuel Transfer System Annex. It consists of a Sludge Loading Bay, a Mechanical Equipment Room, a High-Efficiency Particular Air (HEPA) Filter Room, stair enclosure, and personnel Change Room.

The Modified KW Basin Annex is a steel frame and reinforced-concrete structure approximately $53 \mathrm{ft}$ long, 29.5 wide, and $39 \mathrm{ft}$ high. The facility is provided with a 14-ft wide, 16-foot high roll-up door on the east side. The Sludge Transport System STS trailer is backed into the facility through the roll-up door, positioned on a truck scale, and aligned with process equipment. It is then disconnected from the tractor. The STS consists of a trailer with a work platform and handrails providing access to the transportation cask. The cask, which contains an empty STSC when it arrives at the facility, is anchored to, and is an integral part of, the trailer. A 10-ton bridge crane is provided to remove the cask lid to provide access to the top of the STSC and to assist in making and breaking STSC nozzle connections. The Modified KW Annex has a mezzanine located approximately $20 \mathrm{ft}$ above the facility floor and positioned above the STS trailer work platform.

Inside the Modified KW Basin Annex, the slurry transfer line and decant line are housed within a shielded vault structure, referred to as the hose-in-hose shielded duct. The shielded duct terminates at the transfer line service box located on the Modified KW Basin Annex mezzanine. The slurry transfer line is routed from the transfer line service box directly to the STSC. The decant line is routed to the decant pump box within a shielded trough. From the decant pump box, the decant line is routed to directly to the STSC.

The transfer line service box contains piping and valves normally configured for slurry transfers to the STSC. In the event the STSC is filled with a quantity of sludge that exceeds established limits, the system can be reconfigured to remove sludge from the STSC using the overfill recovery tool and return it to an engineered container in the $\mathrm{KW}$ Basin via the slurry transfer line. An air-operated, double-diaphragm pump (i.e., ECRT-P-301) located in the box provides the motive force for the transfer. IXM water is provided to the box to backflush lines as necessary, and to spray down the interior of the box in the event of a loss of primary containment. A leak detector, interlocked to shut down booster pump ECRT-P-101, IXM water pumps ECRT-P-51 and -52, and the overfill recovery pump, is located within the box.

The decant pump box contains piping and valves for decanting the STSC to the sand filter (and from there back to the KW Basin) and for transferring sand filter backwash to the STSC. An air-operated, double-diaphragm pump (i.e., decant pump ECRT-P-201) located in the box provides the motive force for decanting the STSC. For sand filter backwashing operations, the system is reconfigured to bypass the decant pump. IXM water is provided to the decant pump box to backflush lines as necessary and to spray down the interior of the box in the event of a loss of primary containment; a leak detector, interlocked to shut down the decant pump and IXM water pumps, is located within the box. 
The sand filter system is located inside a modular shielded housing, referred to as the sand filter enclosure. The sand filter enclosure is located on the floor level of the Modified KW Basin Annex. The sand filter system is comprised of two cylindrical type vertical sand filters configured in parallel. The filter housings are 24 -in. in diameter and 56-in. in height. The sand filters media is comprised of anthracite, sand, garnet and quartz materials. Each sand filter is connected to the ventilation system via a vent line that is opened to perform an air sparge of the filter media. The sand filter enclosure contains piping and valves for filtering the supernate and transferring it to the $\mathrm{KW}$ Basin, and for backwashing the sand filter and transferring it to the STSC via the decant pump box. IXM water is provided to the enclosure for backwashing the sand filter and to spray down the interior of enclosure in the event of a loss of primary containment. A leak detector, interlocked to shut down the decant pump and IXM water is located within the enclosure.

\subsubsection{Modified KW Basin Annex Confinement Ventilation System}

The Modified KW Annex is serviced by a confinement ventilation system. In summary, approximately $4,800 \mathrm{cfm}$ of conditioned air is supplied to the facility. The supply air is comprised of approximately $3200 \mathrm{cfm}$ of outside air and $1600 \mathrm{cfm}$ of recirculated air. Approximately $4100 \mathrm{cfm}$ of air is HEPA-filtered and exhausted through a stack to the environment via redundant HEPA filter trains located in a filter room on the south side of the Modified KW Basin. There is approximately $900 \mathrm{cfm}$ of inleakage air.

The confinement ventilation system maintains negative air pressure differentials such that air flows from areas of lower contamination potential to areas of higher contamination potential. Four ventilation zones $(1,2,3$, and $3 \mathrm{~A})$ have been defined. Zone 1 provides primary confinement and services the STSC. A passive, inlet HEPA filter on Nozzle F2 provides inlet air, and the STSC is exhausted by the ventilation system through a connection at Nozzle F1. The ventilation system will maintain a pressure of -1.0 in. wc. with respect to atmosphere with both process lines disconnected. The resultant airflow (approximately $150 \mathrm{cfm}$ ) is more than adequate to compensate for volume displacement due to sludge filling and sand filter backwash cycles. A minimum airflow rate of $1 \mathrm{cfm}$ into the container is always ensured to dilute hydrogen generated by the sludge (see Section 2.1.7, "Auxiliary Ventilation System). Air from the STSC passes through a moisture separator prior to HEPA filtration.

Zone 2 provides secondary confinement and services transfer line service box, decant pump box, and the sand filter enclosure, which are maintained at a pressure of $-0.5 \mathrm{in}$. wc. relative to atmosphere. The transfer line service box and decant pump box are directly exhaust by the ventilation system. The sand filter enclosure is indirectly exhausted via its hose-in-hose connection to the decant pump box (i.e., the air flows through the annular region between the two hoses).

Zone 3 provides tertiary confinement and services the remainder of the Modified KW Basin Annex. This area of the facility will be maintained free of contamination and respiratory protection will not be required during normal operations. This Zone is maintained at a pressure 
of -0.05 in. wc. relative to atmosphere when all facility doors are closed. Zone $3 \mathrm{~A}$ also provides tertiary confinement and services the filter room. It is maintained at a pressure of -0.08 in. wc. relative to atmosphere. The change room and stair enclosure are operated at atmospheric pressure and have no zone designation.

\subsubsection{Inert Gas System}

The inert gas system provides nitrogen gas to purge the STSC and STS cask. The system is comprised of a nitrogen bottle station (located outside the northwest corner of the Modified KW Basin Annex) and associated piping, hoses, pressure regulators, valving, and pressure and flow instrumentation. After STSC process lines have been disconnected and nozzles capped, the breather inlet filter is removed and a purge line connected. After the STSC has been purged, the ventilation exhaust line is disconnected from the STSC and the nozzle capped. The nitrogen supply is then disconnected and a sintered metal filter placed on the nozzle.

The STS cask is also inerted with nitrogen to prevent hydrogen generated by the sludge from reaching a flammable concentration. To inert the cask, a vent port tool is connected to the cask lid and the ventilation exhaust line. A second vent port tool is connected to the side of the STS cask near the bottom, and to the nitrogen gas supply. After filling the cask with nitrogen, the vent port tools are disconnected and the ports on the STS cask configured for shipment.

\subsubsection{Auxiliary Ventilation System}

The auxiliary ventilation system is designed to provide active ventilation to the STSC in the event of failure of the process ventilation system. A minimum ventilation flow rate of $1 \mathrm{cfm}$ is provided through a connection to a nitrogen bottle station, located adjacent to the inert gas system bottles, but operating independently of that system. Flow of nitrogen is activated automatically upon detection of low flow (i.e., $<5 \mathrm{cfm}$ ) in the STSC inlet ventilation line. As documented in PRC-STP-00301, STP - ECRTS - Thermal and Gas Analyses for Sludge Transport and Storage Container (STSC) in Modified KW Annex, modeling of hydrogen generation in a fully loaded STSC demonstrates that a ventilation flow rate of $1 \mathrm{cfm}$ is adequate to ensure the hydrogen concentration remains below $25 \%$ under worst-case environmental conditions.

\subsection{PROCESS DESCRIPTION SUMMARY}

HNF-41051, Section 5.3, "Operating Modes," describes nine operating modes for filling an STSC with sludge and preparing it for transportation to T Plant.

\subsubsection{Operating Mode 1: Preparing STSC}

An STSC arrives at the Modified KW Basin Annex pre-loaded in an STS cask. Once the trailer is properly positioned on the truck scale, the tractor is decoupled from the trailer and driven away from the facility. 
The bridge crane is used to remove the STS cask lid which is placed on the transport trailer. The empty weight of the STSC/STS cask on the transport trailer is then obtained. The slurry transfer line, decant/backwash line, instrumentation, and exhaust ventilation connections are then made at the appropriate STSC nozzles. The slurry transfer line and decant/backwash lines are connected to the STSC using a pipe-in-pipe coaxial connector. The STSC is then filled with water by connecting an IXM water line to a nozzle on the 26-in. flange. Water is added to the STSC to the fill limit of $3.5 \mathrm{~m}^{3}$ (or $2.89 \mathrm{~m}^{3}$ for settler tank sludge) as indicated by the liquid level instrumentation. The IXM water line is then disconnected from the STSC and the purge outlet line is attached to the nozzle. The liquid level in the STSC and the weight of the water-filled STSC/STS cask on the trailer are recorded. The IXM water in the STSC is then transferred to the KW Basin using the decant pump. For this transfer, the sand filter is bypassed. The STSC is now ready to receive sludge.

\subsubsection{Operating Mode 2: Sludge Transfer into STSC}

The bottom sections of the Engineered Containers are divided into eight separate compartments. To retrieve sludge, a hoist will be used to position the hydrolance over one of the eight bottom compartments. The IXM water to the Coanda head is then turned on (i.e., motive water pump ECRT-P-51) and the hydrolance is lowered near the bottom of the sludge bed. The fluidizing jets are pulsed using fluidizing pump ECRT-P-52 to undercut layers of sludge above the hydrolance. The sludge fluidized by the jets flows freely to and into the hydrolance suction created by the eductor and is transferred to booster pump ECRT-P-101 which pumps the sludge to the STSC. The weight of the sludge above the undercut section causes the sludge bed to collapse down and toward the hydrolance suction. When no more fluidized sludge is available, the fluidizing jets are pulsed to again undercut the sludge causing a collapse. This process is repeated until as much sludge as possible is retrieved from that location. The hydrolance is then retrieved, lowered over a different container compartment, and sludge retrieval re-initiated.

The rate at which sludge is retrieved principally depends on the frequency at which the fluidizing jets are operated. The flowsheet value at which sludge is retrieved is nominally 5 vol. $\%$ solids. The retrieved sludge-water slurry will vary in volume percent solids content ranging up to approximately $15 \mathrm{vol}$. \% based on equipment testing with simulants. Operators use readings from a percent solids meter (AI-710-101) as an aid in operating the fluidizing jets.

The in-basin flocculant addition system may be used during sludge retrieval and transfer to add flocculant to the slurry in order to enhance sludge settling in the STSC. Flocculant is injected at the suction-side of booster pump ECRT-P-101.

The STSC design capacity defines the volume of nominally 5 vol. $\%$ solids slurry that is transferred in a given batch. At $70 \mathrm{gpm}$ and assuming an empty STSC, it takes approximately 10 minutes to reach the $2.89 \mathrm{~m}^{3}$ design capacity for settler tank sludge, and 13 minutes to reach the $3.5 \mathrm{~m}^{3}$ design capacity for the remaining containerized sludge. Differential weight is the primary process control parameter indicating the quantity of sludge in an STSC. 
The containerized sludge that originated in the $\mathrm{KW}$ and $\mathrm{KE}$ Basin is assumed to settle in an STSC to 26 and 25 vol. \% solids, respectively. Settler tank sludge is assumed to settle to 30 vol.\% solids. The volume of KW and KE settled sludge in an STSC is limited to the values listed in Table 2-2 so that the sludge remains contained within the STSC in the event that sludge expansion due to gas generation and oxide formation were to occur at the safety basis expansion rates. The volume of settler tank sludge in an STSC is limited to protect thermal and gas generation analysis assumptions.

Table 2-2. Maximum Settled Sludge Volume per Sludge Transport and Storage Container.*

\begin{tabular}{|l|c|c|c|c|}
\hline \multicolumn{1}{|c|}{ Sludge Type } & $\begin{array}{c}\text { STSC Design } \\
\text { Capacity }\left(\mathbf{m}^{\mathbf{3}}\right)\end{array}$ & $\begin{array}{c}\text { Safety Basis } \\
\text { Combined Sludge } \\
\text { Expansion Factor }\end{array}$ & $\begin{array}{c}\text { Maximum Sludge } \\
\text { Volume }\left(\mathbf{m}^{\mathbf{3}}\right)\end{array}$ & $\begin{array}{c}\text { Volume of } \\
\text { Water Above } \\
\text { Settled Sludge } \\
\left(\mathbf{m}^{\mathbf{3}}\right)\end{array}$ \\
\hline $\begin{array}{l}\text { KE Containerized } \\
\text { Sludge }\end{array}$ & 3.5 & 1.66 & 2.1 & 1.4 \\
\hline $\begin{array}{l}\text { KW Containerized } \\
\text { Sludge }\end{array}$ & 3.5 & 2.13 & 1.6 & 1.9 \\
\hline Settler tank Sludge & 2.89 & 3.04 & 0.5 & 2.39 \\
\hline
\end{tabular}

*From Table 3-2, HNF-41051, 2011, Preliminary STP Container and Settler Sludge Process System Description and Material Balance, Rev. 7, CH2M HILL Plateau Remediation Company, Richland, Washington.

$\mathrm{KE}=105-\mathrm{K}$ East.

$\mathrm{KW}=105-\mathrm{K}$ West.

STSC $=$ Sludge Transport and Storage Container.

\subsubsection{Operating Mode 3: Flush Transfer Line}

Due to expected variations in the volume percent solids contained in the retrieved sludge-water slurry, multiple batches of slurry must be retrieved, settled, and excess supernate decanted in order to fill an STSC to the maximum sludge volumes shown in Table 2-3. Following each batch transfer of slurry into the STSC, the transfer line is flushed with KW Basin water. To perform the flush, the hydrolance is withdrawn from the sludge in the engineered container while still operating, which allows basin water to flush solids forward to the booster pump. Flow through the hydrolance is then stopped. Basin water is then introduced into the suction side of the booster pump at valve ECRT-AOV-101 to complete the line flush. A total of approximately 50 gallons $\left(0.19 \mathrm{~m}^{3}\right)$ of basin water is added to the STSC during a flush.

In the event of a loss of power or activation of the Nuclear Safety Shutdown interlock (I-1), the slurry transfer line on the discharge side of the booster pump is automatically flushed with 50 gallons of water from flush tank ECRT-TK-101. 


\subsubsection{Operating Mode 4. Add Flocculant to Decant from STSC}

After allowing the retrieved sludge slurry to settle for approximately 16 hours, the supernatant in the STSC is recirculated at 20 gpm through decant pump ECRT-P-201 and piping in the Decant Pump Box, the Transfer Line Service Box and back into the STSC. The decant pump is an air operated, double-diaphragm pump. The turbidity of the STSC supernatant is measured during recirculation. If the supernatant turbidity is in excess of 210 NTUs $(90 \mathrm{mg} / \mathrm{L})$, the Annex Flocculant Addition System is used to add flocculant through an inline mixer in the Decant Pump Box.

\subsubsection{Operating Mode 5: Decant Supernate from STSC}

Once the supernate turbidity is determined to be acceptable, the supernate is withdrawn from the STSC through the floating decant head and transferred to the sand filter. The sand filter is assumed to remove $100 \%$ of particles $\geq 5 \mu \mathrm{m}$ in size. The filtered supernate is returned to the $\mathrm{KW}$ Basin via the decant line.

After decanting the excess supernate, the liquid level in the STSC and the weight of the STSC/STS cask on the trailer are recorded. The buoyant sludge weight in the STSC is determined to ensure the STSC is not overfilled with sludge. Additional batches of slurry are retrieved from an engineered container and transferred into the STSC as previously described until the maximum allowable sludge quantity is reached in the STSC.

\subsubsection{Operating Mode 6: Backwash Sand Filter to STSC}

Following the last decant of supernate from the STSC, the solids captured by the sand filter are backwashed to the STSC. The backwash is performed using IXM water from the Basin Water Skimmer System. The transfer line used to send the sand filter backwash into the STSC is the same transfer line used to decant supernate from the STSC. The decant pump is bypassed to enable the transfer of the sand filter backwash solution and solids into the STSC. After the filter backwash has been performed, the backwash line is flushed with approximately one and one-half line volumes of IXM water. The liquid level in the STSC and the weight of the STSC/STS on the trailer are recorded. The mass of settled sludge in the STSC is determined to ensure the STSC is not overfilled with sludge.

\subsubsection{Operating Mode 7: Remove Excess Sludge from STSC}

An overfill recovery tool is permanently installed in each STSC for use in the event that excess sludge needs to be removed from the STSC. To use the tool, blanks on the overfill recovery nozzle are removed and the overfill recovery tool is connected via hoses to IXM dilution water, 
overfill recovery fluidizing water pump ECRT-P-302, and overfill recovery pump ECRT-P-301. Underwater in the $\mathrm{K}$ West Basin, the slurry transfer line is disconnected from the discharge side of the booster pump and connected to an overfill recovery nozzle on an engineered container. The overfill recovery tool uses IXM water from the fluidizing water pump to fluidize sludge in the STSC, which is diluted with IXM dilution water and then pumped via the slurry transfer line to an engineered container in $\mathrm{K}$ West Basin by the overfill recovery pump. The overfill recovery pump is an air operated, double-diaphragm pump. Following the removal of excess sludge, the overfill recovery pump and slurry transfer line are flushed with IXM water to the engineered container and to the STSC. The IXM water line and the slurry pump line are then disconnected from the overfill recovery tool and the nozzle blank re-installed.

\subsubsection{Operating Mode 8: Disconnect Piping from STSC and Inert STSC with Nitrogen}

A final flush of the fill and decant transfer lines are made using IXM water to remove residual solids. The air release valves on the slurry transfer line and decant line are then opened and the coaxial connectors are lifted approximately 2 inches to allow the lines to drain from the high point to the STSC. The slurry transfer line, decant line, and instrumentation, are then removed from the STSC nozzles. The 4-in. diameter ventilation line is also disconnected from the STSC and capped, leaving only the purge inlet and purge outlet lines connected. The slurry transfer line, decant line, and nozzles on the STSC are surveyed and decontaminated as necessary. The lines are then placed into their storage area on the mezzanine and the STSC nozzles are capped.

To prevent hydrogen generated by the sludge from reaching a flammable concentration in the STSC, the STSC is inerted with nitrogen from the Inert Gas System. To inert the STSC, the valve on the supply vent HEPA filter is closed and the nitrogen gas supply valve is opened. The STSC is purged with nitrogen until the oxygen concentration in the purge outlet line is less than $0.1 \%$ as measured by an oxygen analyzer. After the STSC has been successfully inerted, the purge outlet line is disconnected from the STSC and the nozzle capped. The nitrogen purge inlet is then disconnected and a NucFil $\AA^{2}$ filter placed on the nozzle. A final radiological survey of the STSC is conducted and the lid placed back on the STS cask.

\subsubsection{Operating Mode 9: Inert/Pressurize STS Cask with Nitrogen}

To prevent hydrogen generated by the sludge from reaching a flammable concentration in the STS cask, the cask is inerted with nitrogen from the Inert Gas System. To inert the cask, a vent port tool is connected to the cask lid. A drain port tool is then connected to the side of the STS cask near the bottom. The drain port tool is connected to the Inert Gas System and the STS cask is purged with nitrogen gas until the oxygen concentration is less than $0.1 \%$ as measured by an oxygen analyzer. The vent port tool is then removed.

\footnotetext{
${ }^{2}$ NucFil $\circledast$ is a registered trademark of Nuclear Filter Technology
} 
The STS cask must be pressurized with nitrogen to between 3 and 15 psig. Pressurizing to greater than 3 psig prevents air inleakage during transportation. Pressurizing to less than 15 psig ensures that the STS cask will not exceed its pressure rating during transportation. To pressurize the cask, needle valve ECRT-V-607 is opened and the cask pressurized to within the required range as indicated on pressure indicator PI-760-606. The drain port tool is then disconnected. The tractor is the reconnected to the STS trailer and the shipment transported to T Plant for interim storage.

\subsection{OPERATING SEQUENCE AND INTERLOCK DEFINITION}

PRC-STP-00358, Operating Sequence and Interlock Definition Document for the Engineered Container Retrieval and Transfer System (ECRTS), describes the ECRTS operating sequence, process inputs, and interlock definitions. The process and safety interlocks are described below. All process and safety interlocks are designed to fail safe, i.e., loss of signal in the interlock loop will assert the interlock and cause the control functions to occur. Interlock circuits utilize fail safe normally open contacts that are energized for normal operation. Indicators for status of permissives will illuminate upon loss of permissive.

\subsubsection{Nuclear Safety Shutdown Interlock I-1}

Interlock I-1 is the Nuclear Safety Shutdown Interlock. The purpose of the interlock is to prevent or mitigate accidents that could cause a spray release of slurry. Interlock I-1 will be asserted and indicated by the any of the events shown in Table 2-3.

Table 2-3. Nuclear Safety Shutdown Interlock I-1

\begin{tabular}{|l|l|l|}
\hline \multicolumn{1}{|c|}{ I-1 Initiating Event } & \multicolumn{1}{c|}{ Detector* } & \multicolumn{1}{c|}{ Indicator* $^{*}$} \\
\hline Sludge transfer hose leak & LDE/LDK-710-101 & ECRT-IL-104 \\
\hline Transfer line service box leak & LDE/LDK-710-102 & ECRT-IL-116 \\
\hline Transfer hose nozzle leak & LDE/LDK-710-103 & ECRT-IL-117 \\
\hline Seismic switch activation & VS-710-103A/B & ECRT-IL-133 \\
\hline Transfer timer timeout & KS-710-101 & ECRT-IL-134 \\
\hline
\end{tabular}

*See piping and instrumentation diagrams provided in Appendix A.

Assertion of Interlock I-1 will cause the following actions:

- Sludge transfer booster pump ECRT-P-101 shuts down via a signal from ECRT-PNL-102 to a safety significant contactor in ECRT-PNL-105. This interrupts the $480 \mathrm{AC}$ power to the pump motor.

- Triggers Decant Interlock I-2 
- Triggers Process Emergency Stop Interlock I-3

- Energizes basin audible/visible alarm on ECRT-ANN-103

- Overfill recovery pump ECRT-P-103 shuts down via a signal from ECRT-PNL-103 to safety significant solenoid valve ECRT-SOV-762 to close ECRT-AOV-761 air supply.

\subsubsection{Decant Interlock I-2}

Decant Interlock I-2 will be asserted and indicated by any of the events shown in Table 2-4.

Table 2-4. Decant Interlock I-2

\begin{tabular}{|l|l|l|}
\hline \multicolumn{1}{|c|}{ I-2 Initiating Event } & \multicolumn{1}{|c|}{ Detector* } & \multicolumn{1}{c|}{ Indicator* $^{*}$} \\
\hline Decant hose leak & LDE/LDK-720-201 & ECRT-IL-201 \\
\hline Decant nozzle leak & LDE/LDK-720-204 & ECRT-IL-217 \\
\hline Decant pump box leak & LDE/LDK-720-202 & ECRT-IL-205 \\
\hline Sand filter enclosure leak & LDE/LDK-720-203 & ECRT-IL-220 \\
\hline Decant stream high turbidity & ASH-720-202 & ECRT-IL-221 \\
\hline Decant pump loss of suction & ASH-720-202 & PI-720-201 \\
\hline Emergency stop on PNL-101 & ECRT-ES-1 & $\begin{array}{l}\text { ECRT-IL-13, } \\
\text { ECRT-ANN-201 }\end{array}$ \\
\hline Emergency stop on PNL-102 & ECRT-ES-2 & $\begin{array}{l}\text { ECRT-IL-13, } \\
\text { ECRT-ANN-201 }\end{array}$ \\
\hline Emergency stop on PNL-103 & ECRT-ES-3 & To be determined \\
\hline
\end{tabular}

*See piping and instrumentation diagrams provided in Appendix A.

Assertion of Interlock I-2 will cause the following actions:

- Closes ECRT-AOV-760, shutting down the decant pump ECRTP-201

- Shuts down annex flocculant pump ECRT-P-204

- Indicates an I-2 trip on ECRT-ANN-201.

\subsubsection{Process Emergency Stop Interlock I-3}

Process Emergency Stop Interlock I-3 serves to shut down all flows into the STSC and open the transfer line bladder flush valve. Interlock I-3 will be asserted and indicated by the events shown in Table 2-5. 
PRC-STP-00467 REV 0

Table 2-5. Process Emergency Stop Interlock I-3

\begin{tabular}{|l|l|l|}
\hline \multicolumn{1}{|c|}{ I-3 Initiating Event } & \multicolumn{1}{|c|}{ Detector* } & \multicolumn{1}{c|}{ Indicator* } \\
\hline Assertion of Interlock I-1 & N/A & ECRT-IL-120 \\
\hline Loss of electrical power & N/A & N/A \\
\hline High-high level in the STSC & LSH-740-402 & ECRT-IL-402 \\
\hline $\begin{array}{l}\text { Emergency Stop button at } \\
\text { ECRT-PNL-101 is pressed }\end{array}$ & ECRT-ES-1 & $\begin{array}{l}\text { ECRT-IL-13, } \\
\text { ECRT-ANN-201 }\end{array}$ \\
\hline $\begin{array}{l}\text { Emergency Stop button at } \\
\text { ECRT-PNL-201 is pressed }\end{array}$ & ECRT-ES-2 & $\begin{array}{l}\text { ECRT-IL-13, } \\
\text { ECRT-ANN-201 }\end{array}$ \\
\hline $\begin{array}{l}\text { Indication of a general fault by } \\
\text { ECRT-PNL-101 }\end{array}$ & ECRT-ES-3 & ECRT-IL-119 \\
\hline Emergency stop on PNL-103 & ECRT-ES-3 & To be determined \\
\hline
\end{tabular}

*See piping and instrumentation diagrams provided in Appendix A.

Assertion of Interlock I-3 will cause the following actions:

- Shutdown of motive flow pump ECRT-P-51 (via ECRT-VFD-51)

- Shutdown of fluidizing pump ECRT-P-52 (via ECRT-VFD-52)

- Shutdown of sludge transfer booster pump ECRT-P-101 (via ECRT-VFD-101)

- Closes annex IXM water supply valve ECRT-AOV-701

- Closes overfill recovery AODD pump air supply valve ECRT-AOV-761

- Shutdown of overfill recovery motive water pump ECRT-P-302

- Opens IXM bladder flush valve ECRT-AOV-102

- Energizes audible and visible indication of an I-3 trip on ECRT-ANN-201

- Energizes basin/EOC audible/visible alarm on ECRT-PNL-101 and -102.

\subsubsection{Normal Process Shutdown Interlock I-4}

Interlock I-4 is the Normal Process Shutdown Interlock. All of the permissive conditions shown in Table 2-6 are required to de-assert Interlock I-4 and enable a slurry transfer.

Table 2-6. Normal Process Shutdown Interlock I-4 (two sheets)

\begin{tabular}{|l|l|l|}
\hline \multicolumn{1}{|c|}{ I-4-Permissive } & \multicolumn{1}{|c|}{ Detector* $^{*}$} & \multicolumn{1}{|c|}{ Indicator* $^{*}$} \\
\hline Transfer line ECRT-H-107 connected & ZS-710-109 & ECRT-IL-118 \\
\hline Transfer line ECRT-H-203 connected & ZS-720-205 & ECRT-IL-218 \\
\hline
\end{tabular}


Table 2-6. Normal Process Shutdown Interlock I-4 (two sheets)

\begin{tabular}{|l|l|l|}
\hline \multicolumn{1}{|c|}{ I-4-Permissive } & \multicolumn{1}{|c|}{ Detector* } & \multicolumn{1}{c|}{ Indicator* } \\
\hline STSC normal S/D not reached & LSHH-740-401 & To be determined \\
\hline $\begin{array}{l}\text { Transfer line bladder flush valve } \\
\text { ECRT-AOV-113 enabled }\end{array}$ & ZS-710-111 & $\begin{array}{l}\text { ECRT-IL-13, } \\
\text { ECRT-ANN-201 }\end{array}$ \\
\hline
\end{tabular}

*See piping and instrumentation diagrams provided in Appendix A.

Loss of any I-4 permissive will assert Interlock I-4 and cause the following actions:

- Shutdown of sludge transfer booster pump ECRT-P-101 (via ECRT-VFD-101)

- Closes IXM water inlet valve ECRT-AOV-1

- Indicates an I-4 trip on ECRT-ANN-201.

\subsubsection{Normal Process Flush Interlock I-5}

Normal Process Flush Interlock I-5 will be asserted and indicated by the events shown in Table 2-7.

Table 2-7. Normal Process Flush Interlock I-5

\begin{tabular}{|l|l|l|}
\hline \multicolumn{1}{|c|}{ I-5-Initiating Event } & \multicolumn{1}{|c|}{ Detector* } & \multicolumn{1}{c|}{ Indicator* $^{*}$} \\
\hline STSC flush level reached & LSH-740-401 & ECRT-IL-121 \\
\hline STSC weight setpoint reached & DWSH-740-401 & ECRT-IL-121 \\
\hline
\end{tabular}

*See piping and instrumentation diagrams provided in Appendix A.

Assertion of Interlock I-5 will cause the following actions:

- Open flush valve ECRT-AOV-101 (via solenoid ECRT-SOV-101)

- Shutdown of motive flow pump ECRT-P-51 (via ECRT-VFD-51)

- Indicates an I-5 trip on ECRT-ANN-201

- Shutdown of basin flocculant pump ECRT-P-203. 


\subsection{METHODOLOGY}

10 CFR 830, Nuclear Facility Safety, requires the documented safety analysis of a Hazard Category 2 nuclear facility to evaluate normal, abnormal, and accident conditions. For guidance on the evaluation of normal and abnormal operations, 10 CFR 830 refers to DOE-STD-3009-94, Preparation Guide for U.S. Department of Energy Nonreactor Nuclear Facility Documented Safety Analyses, Section 3.3, "Hazard Analysis."

As discussed in Section 3.3 of DOE-STD-3009-94, the experience and judgment of the hazard analysts are used to select a hazard evaluation technique. A graded approach is applied wherein a technique is selected that is sufficiently detailed to provide an appropriately comprehensive examination of hazards given the complexity of the operation and the degree of design maturity. For the ECRTS preliminary design, two hazard analysis techniques have been selected, i.e., HAZOP and What-If.

The HAZOP methodology was developed for application in the chemical industry and is best suited to processes with defined material and energy flow paths. Accordingly, the HAZOP methodology is applied to the following ECRTS processes:

- Retrieving sludge from an Engineered Container

- Transferring the slurry to an STSC

- Decanting the STSC

- Backwashing the Sand Filter into the STSC

- Purging the STSC with nitrogen

- Purging the STS cask with nitrogen

- Pressurizing the STS cask with nitrogen

- Adding flocculant to the slurry during transfer

- Adding flocculant to the supernate

- Automatically flushing the transfer line

- Recovering excess sludge from an over-filled STSC.

As described in Guidelines for Hazard Evaluation Procedures (AIChE 2008), in a HAZOP study a group of experienced people systematically review a process to determine if deviations from the design or operational intent can lead to undesirable consequences. Such deviations represent abnormal conditions, and the resulting undesirable consequences can be categorized as either an operational upset (e.g., delay in processing) or as a specific hazardous condition (e.g., uncontrolled release). Accidents occur when abnormal conditions that can result in a hazardous condition are not prevented or controlled.

The What-If methodology is applied to ECRTS activities that do not have defined material and energy flow paths. Examples include driving the STS trailer into the Modified KW Basin Annex, removing the STS cask lid, and connecting process lines to the STSC. The What-If methodology is also used to address natural phenomenon hazards and external events. As described in AIChE 2008, a What-If analysis is performed by an experienced group of people who identify possible abnormal situations, their consequences, and possible safeguards. As with the HAZOP 
methodology, the consequences can be an operational upset or a specific hazardous condition. The What-If hazard analyses are documented separately in PRC-STP-00473, Sludge Treatment Project Engineered Container Retrieval and Transfer System Preliminary Design Hazard Analysis Supplement 1.

\subsection{IDENTIFICATION OF UNDESIRABLE CONSEQUENCES}

\subsubsection{Process Parameters and Nodes}

A HAZOP uses a fixed set of guidewords that are applied to specific process parameters.

For example, the guide word "no" combined with the process parameter "flow" results in the deviation "no flow." For each deviation the possible causes, consequences, and controls are then identified. The process parameters and deviations used in the ECRTS HAZOP study are shown in Table 3-1.

Table 3-1. Process Parameters and Deviations (two sheets)

\begin{tabular}{|l|l|}
\hline \multicolumn{1}{|c|}{ Process Parameter } & \multicolumn{1}{c|}{ Deviation } \\
\hline \multirow{4}{*}{ Flow } & No \\
\cline { 2 - 2 } & Low \\
\cline { 2 - 2 } & High \\
\cline { 2 - 2 } & Reverse \\
\cline { 2 - 2 } & Misdirected \\
\hline \multirow{4}{*}{ Pressure } & Low \\
\cline { 2 - 2 } & High \\
\hline \multirow{4}{*}{ Concentration } & No \\
\cline { 2 - 2 } & Low \\
\cline { 2 - 2 } & High \\
\hline \multirow{2}{*}{ Composition } & Other \\
\hline \multirow{2}{*}{ Level } & Leak \\
\cline { 2 - 2 } & Rupture \\
\hline \multirow{2}{*}{ Temperature } & Low \\
\cline { 2 - 2 } & High \\
\hline & Low \\
\cline { 2 - 2 } & High \\
\hline
\end{tabular}


Table 3-1. Process Parameters and Deviations (two sheets)

\begin{tabular}{|l|l|}
\hline \multicolumn{1}{|c|}{ Process Parameter } & \multicolumn{1}{c|}{ Deviation } \\
\hline \multirow{4}{*}{ Time Procedure } & Too short/fast/soon \\
\cline { 2 - 2 } & Too long/slow/late \\
\cline { 2 - 2 } & Skip action \\
\cline { 2 - 2 } & Wrong action \\
\hline
\end{tabular}

Sections of equipment with definite boundaries (e.g., a line between two vessels) within which process parameters are investigated for deviations are referred to as nodes. For the preliminary design HAZOP study, the ECRTS design and operations were sectioned into the following nodes:

Node 1. Sludge Retrieval

1.a. IXM Water to Xago Hydrolance ${ }^{\mathrm{TM}}$ Fluidizing Jets

1.b. IXM Motive Water to Xago Hydrolance ${ }^{\mathrm{TM}}$

Node 2. Sludge Transfer

2.a. Engineered Container to Ingress/Egress Pipe

2.b Ingress/Egress Pipe to STSC

2.c. STSC

2.d. STSC Ventilation

Node 3. STSC Decant

Node 4. Sand Filter Backwash

Node 5. STSC Nitrogen Purge

Node 6. STS Nitrogen Purge

Node 7. STS Cask Pressurization

Node 8 In-Basin Flocculant Addition System

Node 9. Annex Flocculant Addition System

9.a. Flocculant Tank to In-Line Mixer

9.b. Decant Recirculation

Node 10. Transfer Line Automatic Flush 


\section{Node 11 Overfill Recovery}

11.a IXM Water to Recovery Tool Fluidizing Jets

11.b IXM Water to Recovery Tool Dilution Water

11.c STSC to Pump ECRT-P-301

11.d Pump ECRT-P-301 to Engineered Container.

For each node, the design intent for each applicable process parameter has been defined. These define the boundaries of normal operations.

\subsubsection{Design Media}

The draft preliminary design HAZOP was performed based on the P\&IDs available at the time of its performance. Preliminary design work continued during and after completion of the draft preliminary HAZOP study resulting in a revised set of P\&IDs (see Appendix A). Nuclear safety and process engineering personnel performed a sheet-by-sheet comparison of the two sets of diagrams and generated an annotated set of P\&IDs that identified additions, deletions, and revisions. The comparison is documented in PRC-STP-00440, Sludge Treatment Project Engineered Container and Retrieval and Transfer System Preliminary Design Hazard Analysis $P \& I D$ Comparison.

\subsubsection{HAZOP Team}

At the draft preliminary design stage, undesirable consequences were identified by a team of subject matter experts from the following CHPRC organizational disciplines:

- STP Nuclear Safety

- $100 \mathrm{~K}$ Area Nuclear Safety

- STP Radiological Control

- $100 \mathrm{~K}$ Area Radiological Control

- STP Operations

- $100 \mathrm{~K}$ Area Operations

- STP Occupational Safety and Health

- $100 \mathrm{~K}$ Area Occupational Safety and Health

- ECRTS Engineering.

Additional attendees included representatives from the following organizational disciplines:

- ECRTS Engineering

- STP Quality Assurance

- $100 \mathrm{~K}$ Emergency Preparedness

- Criticality Safety

- Transportation Safety 
- T Plant Nuclear Safety

- DOE-RL Nuclear Safety.

To evaluate the impact of the design changes that occurred since completion of the draft preliminary design HAZOP study, nuclear safety personnel and the responsible design authority for a given node reviewed each previously evaluated process parameter deviation and the associated undesirable consequences using the annotated P\&IDs contained in PRC-STP-00440. This review resulted in a redline/strikeout set of revised HAZOP study tables that were submitted to the HAZOP team for review, comment, and concurrence.

In support of the preliminary design, additional HAZOP team meetings were held to evaluate STS Cask Pressurization and Overfill Recovery. STS Cask Pressurization was partially addressed in the draft preliminary design HAZOP study as part of the STS Purge node. During the P\&ID comparison review it was determined that cask pressurization should be addressed as a separate node. Overfill Recovery was not addressed in the draft preliminary design HAZOP because the design was not sufficiently mature to warrant evaluation at that time.

A list of HAZOP meeting attendees is provided in Appendix B.

\subsection{UNMITIGATED FREQUENCY AND CONSEQUENCE ESTIMATES}

Unmitigated radiological consequence and frequency levels were assigned to hazardous conditions identified by the HAZOP study. The onsite and offsite radiological consequence levels are shown in Tables 3-2 and 3-3, respectively.

Table 3-2. Collocated Worker and Offsite Public Consequence Levels.*

\begin{tabular}{|l|c|c|}
\hline \multicolumn{1}{|c|}{$\begin{array}{c}\text { Consequence } \\
\text { Level }\end{array}$} & Collocated Worker $(\mathbf{1 0 0} \mathbf{~ m})$ & Offsite Public \\
\hline High & $>100 \mathrm{rem}$ & $>25 \mathrm{rem}$ \\
\hline Moderate & $\geq 25 \mathrm{rem}$ & $\geq 5 \mathrm{rem}$ \\
\hline Low & $<25 \mathrm{rem}$ & $<5 \mathrm{rem}$ \\
\hline
\end{tabular}

*From Table 2-1, PRC-STD-NS-8739, CHPRC Safety Analysis and Risk Assessment Handbook (SARAH), Rev. 0 .

Table 3-3. Frequency Levels*

\begin{tabular}{|l|l|}
\hline \multicolumn{1}{|c|}{ Frequency Level } & \multicolumn{1}{c|}{ Frequency } \\
\hline Anticipated & Above $1 \mathrm{E}-2 / \mathrm{yr}$ \\
\hline Unlikely & $1 \mathrm{E}-4$ to $1 \mathrm{E}-2 / \mathrm{yr}$ \\
\hline Extremely Unlikely & $1 \mathrm{E}-6$ to $1 \mathrm{E}-4 / \mathrm{yr}$ \\
\hline Beyond Extremely Unlikely & Below $1 \mathrm{E}-6 / \mathrm{yr}$ \\
\hline
\end{tabular}

*Derived from Table 2-2, PRC-STD-NS-8739. 


\section{PRC-STP-00467 REV 0}

For each hazardous condition evaluated for the offsite public and collocated worker, an evaluation of the unmitigated consequence to the facility worker was performed to determine if the hazardous condition could result in prompt death, serious injury, or a significant radiological exposure. In accordance with the suggested evaluation criterion in DOE-STD-1189-2008, Appendix C, "Facility Worker Hazard Evaluation," a significant radiological exposure was defined as $100 \mathrm{rem}$ total effective dose equivalent. If it was judged that the hazardous condition could result in prompt death, serious injury, or a significant radiological exposure, then a "High" facility worker consequence was assigned. 


\subsection{RESULTS}

\subsection{HAZARD AND OPERABILTY STUDY RESULTS}

\subsubsection{HAZOP Tables}

The results of the HAZOP study are documented in tabular format in Appendix C. The table column headings are as follows:

Item: This column assigns a unique identifier to each process parameter and associated deviation.

Process Parameter: This column identifies the process parameter being studied, e.g., "flow." Refer to Table 3-1 for listing of process parameters.

Deviation: This column identifies the deviation being studied, e.g., "no" flow. Refer to Table 3-1 for a listing of deviations.

Cause: This column identifies the cause or causes for the deviation. For example, a no flow condition could be caused by a closed valve.

Consequences: This column identifies the consequences associated with the process parameter deviation.

Candidate Controls: This column identifies engineered and administrative controls that could be credited with preventing or mitigating the consequences of the process deviation.

Remarks: This column documents review team discussions and design details pertinent to the evaluation of the process derivation.

\subsubsection{Identified Hazardous Conditions}

The hazardous conditions identified by the HAZOP study are:

- Spray release

- Splash and splatter/pool release

- Hydrogen deflagration

- STSC overpressurization

- Radiological Control

- Airborne radioactive material

- Contamination

- High external dose rate 
- Industrial Safety

- Hose whip

- Oxygen deficient atmosphere.

The hose whip and oxygen deficient atmosphere hazardous conditions are considered to be standard industrial hazards that are addressed by the Occupational Safety and Health safety management program.

The HAZOP study did not explicitly identify a nuclear criticality as a hazardous condition. However, the sludge stored in the six engineered containers in the KW Basin contains more than a minimum critical mass of fissile material such that an inadvertent nuclear criticality must be addressed. As documented in PRC-STP-00163, Criticality Safety Evaluation for Engineered Container and Settler Sludge Retrieval, Transfer, Transportation, and Interim Storage (Phase 1), it is anticipated that future criticality safety evaluation reports prepared for ECRTS will demonstrate that a criticality cannot occur due to the form and distribution of the fissile material.

\subsection{UNMITIGATED FREQUENCY AND CONSEQUENCE LEVEL RESULTS}

The unmitigated frequency and consequence levels assigned to each hazardous condition are documented in Appendix D. The majority of the hazardous conditions were assigned an "Anticipated" frequency based on human error or a mechanical failure as the initiating event. The facility worker, collocated worker, and offsite public unmitigated consequence levels for hazardous conditions resulting in an uncontrolled release of radioactive material, a hydrogen deflagration, and an STS cask overpressurization are summarized in Table 4-1. The consequence levels in Table 4-1 were assigned based on accident analysis consequences reported in PRC-STP-CN-N-00401, Sludge Treatment Project Engineered Container Retrieval and Transfer System Draft Preliminary Design Accident Analysis.

\subsection{ACCIDENT SELECTION}

The hazardous conditions listed in Table 4-1 require accident analysis to quantify the unmitigated consequences. The results of the accident analysis will then be used to select, as necessary, safety structures, systems, and components.

Table 4-2 identifies the specific HAZOP table entries (i.e., Item No.) that resulted in a hazardous condition warranting accident analysis. 
PRC-STP-00467 REV 0

Table 4-1. Summary of Unmitigated Frequency and Consequence Levels

\begin{tabular}{|c|c|c|c|c|c|}
\hline \multirow{2}{*}{$\begin{array}{l}\text { Hazardous } \\
\text { Condition }\end{array}$} & \multirow[b]{2}{*}{ Source Material ${ }^{1}$} & \multirow{2}{*}{$\begin{array}{l}\text { Unmitigated } \\
\text { Frequency }\end{array}$} & \multicolumn{3}{|c|}{ Unmitigated Consequence } \\
\hline & & & $\begin{array}{l}\text { Facility } \\
\text { Worker }\end{array}$ & Onsite & Offsite \\
\hline \multirow{5}{*}{ Spray Leak } & Slurry (retrieval and transfer) & A & $\mathrm{H}$ & $\mathrm{H}$ & $\mathrm{L}$ \\
\hline & STSC supernate & A & $\mathrm{L}$ & L & $\mathrm{L}$ \\
\hline & Sand filter backwash & A & $\mathrm{L}$ & $\mathrm{L}$ & $\mathrm{L}$ \\
\hline & $\begin{array}{l}\text { Slurry (overfill recovery line } \\
\text { failure) }\end{array}$ & A & $\mathrm{H}$ & $\mathrm{H}$ & $\mathrm{L}$ \\
\hline & $\begin{array}{l}\text { Slurry (overfill recovery } \\
\text { diaphragm pump failure) }\end{array}$ & A & $\mathrm{L}$ & $\mathrm{L}$ & $\mathrm{L}$ \\
\hline \multirow{5}{*}{$\begin{array}{l}\text { Splash and } \\
\text { Splatter/Pool }\end{array}$} & Slurry (retrieval and transfer) & A & $\mathrm{L}$ & $\mathrm{L}$ & $\mathrm{L}$ \\
\hline & STSC supernate & A & L & $\mathrm{L}$ & $\mathrm{L}$ \\
\hline & Sand filter backwash & A & $\mathrm{L}$ & $\mathrm{L}$ & $\mathrm{L}$ \\
\hline & $\begin{array}{l}\text { Slurry (overfill recovery line } \\
\text { failure) }\end{array}$ & A & L & L & $\mathrm{L}$ \\
\hline & $\begin{array}{l}\text { Slurry (overfill recovery } \\
\text { diaphragm pump failure) }\end{array}$ & A & $\mathrm{L}$ & $\mathrm{L}$ & $\mathrm{L}$ \\
\hline \multirow{5}{*}{$\begin{array}{l}\text { Hydrogen } \\
\text { Deflagration }\end{array}$} & STSC & A & $\mathrm{H}^{2}$ & $\mathrm{~L}$ & $\mathrm{~L}$ \\
\hline & Transfer Line Service Box & A & $\mathrm{H}^{2}$ & $\mathrm{~L}$ & $\mathrm{~L}$ \\
\hline & Decant Pump Box ${ }^{3}$ & A & $\mathrm{H}^{2}$ & L & $\mathrm{L}$ \\
\hline & Sand Filter ${ }^{3}$ & A & $\mathrm{H}^{2}$ & $\mathrm{~L}$ & $\mathrm{~L}$ \\
\hline & Sand Filter Enclosure ${ }^{3}$ & A & $\mathrm{H}^{2}$ & $\mathrm{~L}$ & $\mathrm{~L}$ \\
\hline Overpressurization & Sludge slurry & A & $\mathrm{L}$ & $\mathrm{L}$ & $\mathrm{L}$ \\
\hline
\end{tabular}

${ }^{1}$ Consequences based on settler tank sludge which has a higher radionuclide inventory than KE or KW Basin sludge. For a given hazardous condition (e.g., spray release) the consequences vary as a function of the estimated volume percent solids.

${ }^{2} \mathrm{~A}$ high consequence is assigned to the facility worker for hydrogen deflagrations based on the potential for prompt death or serious injury.

${ }^{3}$ PRC-STP-CN-N-00401 does not analyze hydrogen deflagrations in the Decant Pump Box, sand filter, or Sand Filter Enclosure. The low consequences are qualitatively assigned based on the low consequences calculated for deflagrations in the STSC and Transfer Line Service Box.

$A=$ Anticipated

$\mathrm{H}=$ High

$\mathrm{L}=$ Low

$\mathrm{M}=$ Moderate 
Table 4-2. Correlation of Hazardous Conditions to HAZOP Table Entries (three sheets)

\begin{tabular}{|c|c|c|c|c|}
\hline $\begin{array}{l}\text { Hazardous } \\
\text { Condition }\end{array}$ & Source Material & \multicolumn{3}{|c|}{ HAZOP Item No." } \\
\hline \multirow{3}{*}{ Spray Leak Release } & Sludge slurry & $\begin{array}{l}1 . a-4 \\
1 . b-4 \\
2 . a-4 \\
2 . b-3 \\
2 . b-4 . a \\
2 . b-5 . b \\
2 . b-5 . c\end{array}$ & $\begin{array}{l}2 . b-5 . d \\
2 . b-7 \\
2 . b-10 \\
2 . b-12 \\
8-4 . a \\
8-4 . b\end{array}$ & $\begin{array}{l}10-4 \\
11 . d-5 . a \\
11 . d-7 \\
11 . d-8 \\
11 . d-9\end{array}$ \\
\hline & STSC supernate & $\begin{array}{l}3-7 \\
3-9 . a \\
3-13 . a \\
3-13 . b \\
3-13 . c \\
3-13 . d\end{array}$ & $\begin{array}{l}3-17 . b \\
9 . a-4 \\
9 . a-6 \\
9 . a-7 \\
9 . a-13 . a \\
\text { 9.a-13.b }\end{array}$ & $\begin{array}{l}9 . b-5 . c \\
9 . b-7 \\
9 . b-13 . a \\
9 . b-13 . b \\
9 . b-16 \\
9 . b-17\end{array}$ \\
\hline & Sand filter backwash & $\begin{array}{l}4-7 \\
4-13 . a \\
4-13 . b\end{array}$ & & \\
\hline $\begin{array}{l}\text { Splash and } \\
\text { Splatter/Pool } \\
\text { Release }\end{array}$ & Sludge slurry & $\begin{array}{l}1 . a-4 \\
1 . b-4 \\
2 . a-4 \\
2 . b-3 \\
2 . b-4 . a \\
2 . b-4 . b \\
2 . b-5 . a \\
2 . b-5 . b \\
2 . b-5 . c \\
2 . b-5 . d \\
2 . b-7 \\
2 . b-10 \\
2 . b-12 \\
2 . c-10 . a \\
2 . c-10 . b\end{array}$ & $\begin{array}{l}2 . d-14 \\
8-4 . a \\
8-4 . b \\
10-4 \\
11 . a-3 \\
11 . a-4 \\
11 . a-7 \\
11 . a-8 \\
11 . a-10 \\
11 . b-3 \\
11 . b-4 \\
11 . b-7 \\
11 . b-8 \\
11 . b-10 \\
11 . c-1\end{array}$ & $\begin{array}{l}11 . c-2 \\
11 . c-4 \\
11 . c-8 \\
11 . c-11 \\
11 . d-1 \\
11 . d-2 \\
11 . d-5 . a \\
11 . d-5 . d \\
11 . d-6 \\
11 . d-7 \\
11 . d-8 \\
11 . d-9 \\
11 . d-12\end{array}$ \\
\hline
\end{tabular}


Table 4-2. Correlation of Hazardous Conditions to HAZOP Table Entries (three sheets)

\begin{tabular}{|c|c|c|c|c|}
\hline Hazardous & Source Material & \multicolumn{3}{|c|}{ HAZOP Item No." } \\
\hline \multirow[t]{2}{*}{$\begin{array}{l}\text { Splash and } \\
\text { Splatter/Pool } \\
\text { Release } \\
\text { (continued) }\end{array}$} & STSC Supernate & $\begin{array}{l}3-5 . a \\
3-5 . b \\
3-5 . c \\
3-5 . d \\
3-5 . e \\
3-5 . f \\
3-5 . g \\
3-7 \\
3-9 . a \\
3-13 . a \\
3-13 . b \\
3-13 . c\end{array}$ & $\begin{array}{l}3-13 . d \\
3-16 \\
3-17 . b \\
4-4 \\
8-4 . a \\
8-4 . b \\
9 . a-4 \\
9 . a-6 \\
9 . a-7 \\
9 . a-13 . a \\
9-a \cdot 13 . b \\
9 . b-5 . a\end{array}$ & $\begin{array}{l}9 . b-5 . b \\
9 . b-5 . c \\
9 . b-5 . d \\
9 . b-5 . e \\
9 . b-5 . f \\
9 . b-7 \\
9 . b-13 . a \\
9 . b-13 . b \\
9 . b-16 \\
9 . b-17\end{array}$ \\
\hline & Sand filter backwash & $\begin{array}{l}4-5 . a \\
4-5 . b \\
4-5 . c \\
4-5 . d\end{array}$ & $\begin{array}{l}4-5 . e \\
4-5 . f \\
4-7\end{array}$ & $\begin{array}{l}4-12 . a \\
4-13 . a \\
4-13 . b\end{array}$ \\
\hline \multirow[t]{2}{*}{$\begin{array}{l}\text { Hydrogen } \\
\text { Deflagration }\end{array}$} & STSC & $\begin{array}{l}2 . c-7 . a \\
2 . c-10 . b \\
2 . c-10 . d \\
2 . d-1 \\
2 . d-2 \\
2 . d-10 . b \\
2 . d-13 \\
5-1 \\
5-5 . a \\
5-5 . b \\
5-9 \\
5-10 . a \\
5-10 . b \\
5-12 . b \\
5-13\end{array}$ & $\begin{array}{l}5-14 \\
5-16 \\
11 . a-1 \\
11 . a-2 \\
11 . a-3 \\
11 . a-5 \\
11 . a-6 \\
11 . a-9 \\
11 . a-11 \\
11 . b-1 \\
11 . b-2 \\
11 . b-5 \\
11 . b-6 \\
11 . b-9\end{array}$ & $\begin{array}{l}11 . b-11 \\
11 . c-1 \\
11 . c-2 \\
11 . c-3 \\
11 . c-9 \\
11 . c-11 \\
11 . d-1 \\
11 . d-2 \\
11 . d-3 \\
11 . d-6 \\
11 . d-7 \\
11 . d-10 \\
11 . d-12\end{array}$ \\
\hline & STS Cask & $\begin{array}{l}6-1 \\
6-5 \\
6-7 . a \\
6-7 . b \\
6-9 \\
6-10 . a \\
6-10 . b \\
6-11\end{array}$ & $\begin{array}{l}6-13 . a \\
6-13 . b \\
6-14 \\
6-16 \\
7-1 \\
7-4 \\
7-5 \\
7-7 . a\end{array}$ & $\begin{array}{l}7-7 . b \\
7-8 . a \\
7-8 . b \\
7-9 \\
7-11 . a \\
7-11 . b \\
7-12 \\
7-14\end{array}$ \\
\hline
\end{tabular}


Table 4-2. Correlation of Hazardous Conditions to HAZOP Table Entries (three sheets)

\begin{tabular}{|c|c|c|c|c|}
\hline $\begin{array}{l}\text { Hazardous } \\
\text { Condition }\end{array}$ & Source Material & \multicolumn{3}{|c|}{ HAZOP Item No." } \\
\hline \multirow{4}{*}{$\begin{array}{l}\text { Hydrogen } \\
\text { Deflagration } \\
\text { (continued) }\end{array}$} & Transfer Line Service Box & $\begin{array}{l}2 . b-5 . a \\
2 . b-12 \\
9 . b-5 . b\end{array}$ & $\begin{array}{l}9 . b .-7 \\
9 . b-13 . b\end{array}$ & $9 . b-17$ \\
\hline & Decant Pump Box ${ }^{2}$ & $\begin{array}{l}3-5 . a \\
3-5 . b \\
3-13 . c\end{array}$ & $\begin{array}{l}9 . a-7 \\
9 . a-13 . a \\
9 . b-5 . a\end{array}$ & $\begin{array}{l}9 . b-7 \\
9 . b-13 . b \\
9 . b-17\end{array}$ \\
\hline & Sand Filter ${ }^{2}$ & \multicolumn{3}{|l|}{$4-16$} \\
\hline & Sand Filter Enclosure ${ }^{2}$ & $\begin{array}{l}3-13 . b \\
3-13 . c\end{array}$ & $\begin{array}{l}4-13 \cdot a \\
4-13 . b\end{array}$ & \\
\hline $\begin{array}{l}\text { STS Cask } \\
\text { Overpressurization }\end{array}$ & Sludge slurry & $\begin{array}{l}2 . c-7 . a \\
2 . c-10 . b \\
2 . c-10 . d \\
5-13 \\
6-13 . a \\
6-13 . b \\
7-3 \\
7-7 . a \\
7-7 . b \\
7-13 \\
11 . a-1 \\
11 . a-2\end{array}$ & $\begin{array}{l}11 . a-5 \\
11 . a-6 \\
11 . a-9 \\
11 . a-11 \\
11 . b-1 \\
11 . b-2 \\
11 . b-5 \\
11 . b-6 \\
11 . b-9 \\
11 . b-11 \\
11 . . c-1 \\
11 . c-2\end{array}$ & $\begin{array}{l}11 . c-3 \\
11 . c-9 \\
11 . c-11 \\
11 . d-1 \\
11 . d-2 \\
11 . d-3 \\
11 . d-6 \\
11 . d-7 \\
11 . d-10 \\
11 . d-12\end{array}$ \\
\hline
\end{tabular}

*See Appendices C and D

\subsection{PEER REVIEW}

A peer review of this Hazard and Operability Study was performed in accordance with the requirements of PRC-PRO-NS-700, Safety Basis Development. The peer review is documented in Appendix E. 


\subsection{REFERENCES}

10 CFR 830, "Nuclear Safety Management," Code of Federal Regulations, as amended.

AIChE, 2008, Guidelines for Hazard Evaluation Procedures, Third Edition, Center for Chemical Process Safety, John Wiley\& Sons, Inc., Hoboken, New Jersey.

DOE/RL-2001-36, 2010, Hanford Sitewide Transportation Document, Rev. 10D, U.S. Department of Energy, Richland Operations Office, Richland, Washington.

DOE-STD-1 189-2008, 2008, Integration of Safety Into the Design Process, U.S. Department of Energy, Washington D.C.

DOE-STD-3009-2006, 2006, Preparation Guide for U.S. Department of Energy Nonreactor Nuclear Facility Documented Safety Analyses, Change Notice No. 3, U.S. Department of Energy, Washington D.C.

HNF-41051, 2011, Preliminary STP Container and Settler Sludge Process System Description and Material Balance, Rev. 7, CH2M HILL Plateau Remediation Company, Richland, Washington.

HNF-SD-WM-SAR-062, 2010, K Basins Final Safety Analysis Report, Rev. 15C, CH2M HILL Plateau Remediation Company, Richland, Washington.

PNNL-19354, 2010, The Disruption of Vessel-Spanning Bubbles with Sloped Fins in FlatBottom and 2:1 Elliptical-Bottom Vessels, Rev. 0, Pacific Northwest National Laboratory, Richland, Washington.

PRC-PRO-NS-700, Safety Basis Development, Rev. 0, Change 8, CH2M HILL Plateau Remediation Company, Richland, Washington.

PRC-STD-NS-8739, CHPRC Safety Analysis and Risk Assessment Handbook (SARAH), Rev. 0, CH2M HILL Plateau Remediation Company, Richland, Washington.

PRC-STP-00021, 2009, Preliminary Hydraulic Analysis for Direct Loading of Sludge Transport and Storage Containers, Rev. B, CH2M HILL Plateau Remediation Company, Richland, Washington.

PRC-STP-00156, 2010, Sludge Treatment Project Engineered Container Retrieval and Transfer System Conceptual Design Report, Rev. 0, CH2M HILL Plateau Remediation Company, Richland, Washington.

PRC-STP-00163, 2010, Criticality Safety Evaluation for Engineered Container and Settler Sludge Retrieval, Transfer, Transportation, and Interim Storage (Phase 1), Rev. 0, CH2M HILL Plateau Remediation Company, Richland, Washington.

PRC-STP-00166, 2010, CD-1 Report for the Sludge Treatment Project Engineered Container Retrieval and Transfer System, Rev. 0, CH2M HILL Plateau Remediation Company, Richland, Washington.

PRC-STP-00301, 2010, STP-ECRTS - Thermal and Gas Analyses for Sludge Transport and Storage Container (STSC) Storage In Modified KW Annex, Rev. 0, CH2M HILL Plateau Remediation Company, Richland, Washington. 
PRC-STP-00346, 2011, Sludge Treatment Project Engineered Container Retrieval and Transfer System Draft Preliminary Design Hazard and Operability Study, Rev. 1, CH2M HILL Plateau Remediation Company, Richland, Washington.

PRC-STP-00358, 2011, Operation Sequence and Interlock Definition Document for Engineered Container Retrieval and Transfer System (ECRTS), Rev. 1, CH2M HILL Plateau Remediation Company, Richland, Washington.

PRC-STP-00382, 2010, Sludge Treatment Project Engineered Container Retrieval and Transfer System Draft Preliminary Design Hazard Analysis Supplement 1, Rev. 0, CH2M HILL Plateau Remediation Company, Richland, Washington.

PRC-STP-00382, 2011, Sludge Treatment Project Engineered Container Retrieval and Transfer System Draft Preliminary Design Hazard Analysis Supplement 1, Rev. 0A, CH2M HILL Plateau Remediation Company, Richland, Washington.

PRC-STP-00440, 2011, Sludge Treatment Project Engineered Container and Retrieval and Transfer System Preliminary Design Hazard Analysis P\&ID Comparison, Rev. 0, CH2M HILL Plateau Remediation Company, Richland, Washington.

PRC-STP-00473, 2011, Sludge Treatment Project Engineered Container Retrieval and Transfer System Preliminary Design Hazard Analysis Supplement 1, Rev. 0, CH2M HILL Plateau Remediation Company, Richland, Washington.

PRC-STP-CN-N-00401, 2011, Sludge Treatment Project Engineered Container Retrieval and Transfer System Draft Preliminary Design Accident Analysis, Rev. 1, CH2M HILL Plateau Remediation Company, Richland, Washington. 
PRC-STP-00467 REV 0

\section{APPENDIX A \\ PROCESS FLOW DIAGRAMS AND \\ PIPING AND INSTRUMENTATION DRAWINGS}


Figure A-1. STP ECRTS Process System PFD (H-1-92300, Rev. G, Sheet 1 of 2)

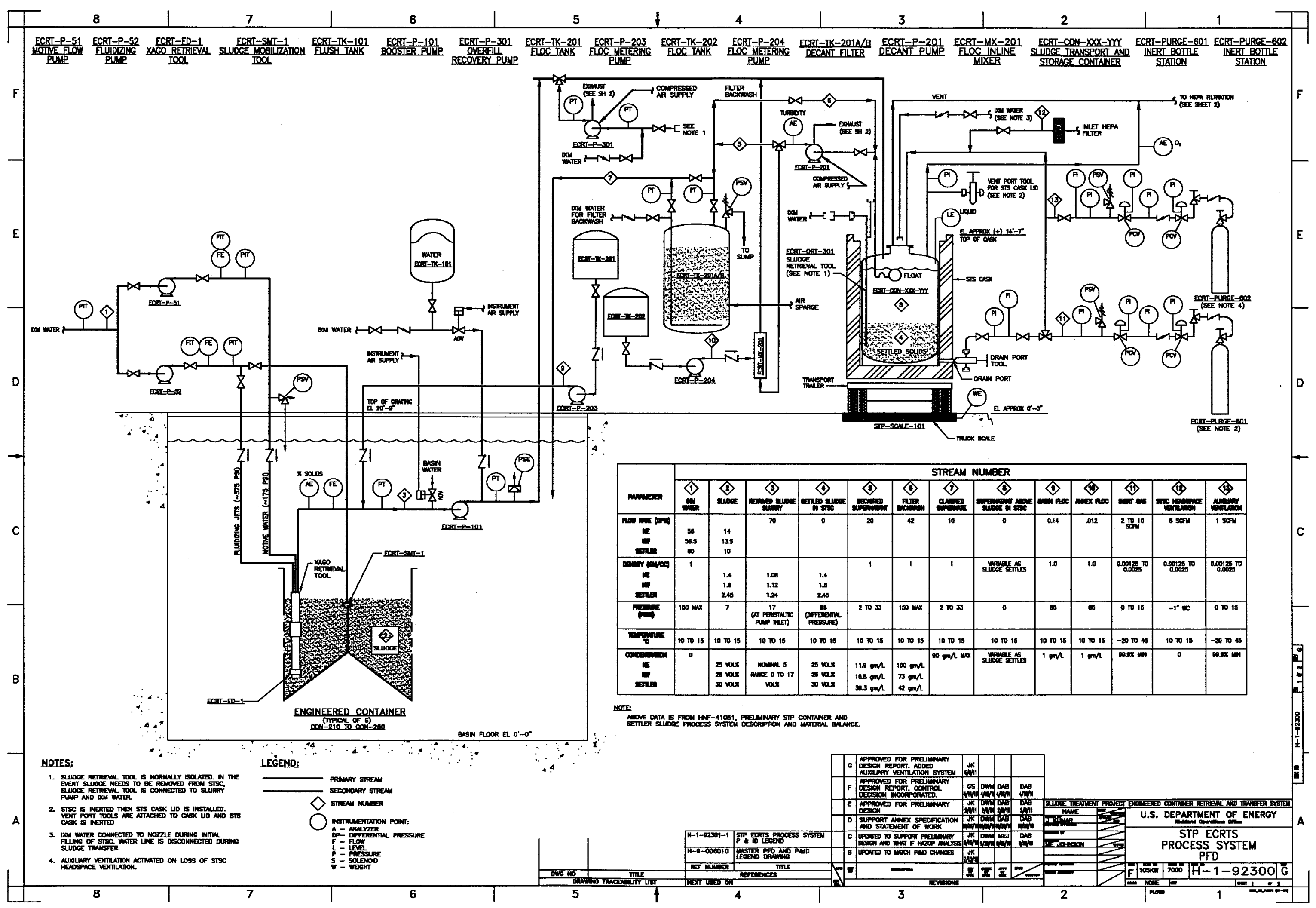


Figure A-2. STP ECRTS Process System PFD (H-1-92300, Rev. G, Sheet 2 of 2)

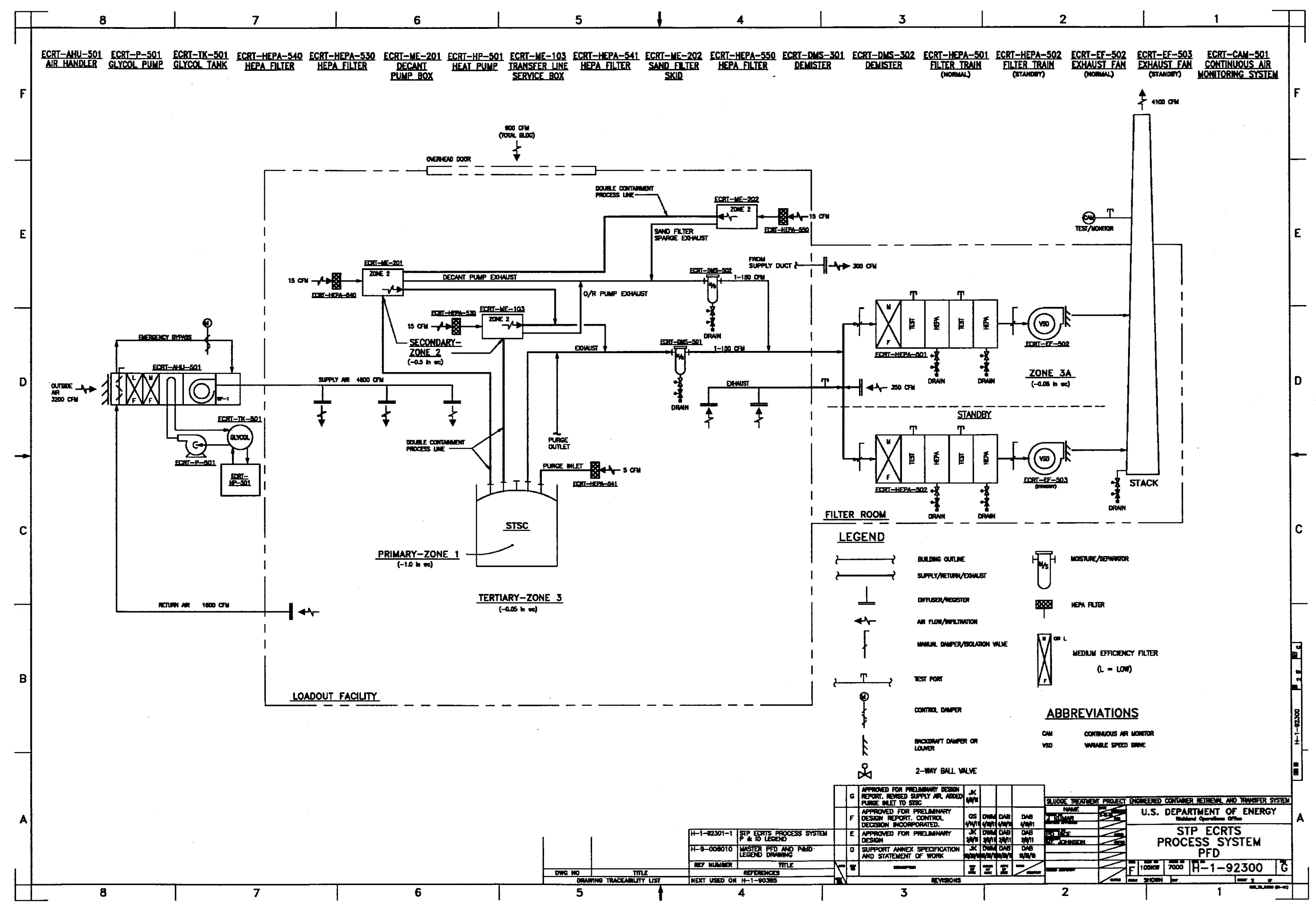


Figure A-3. STP ECRTS Process System P\&ID Legend (H-1-92301, Rev. M, Sheet 1 of 13)

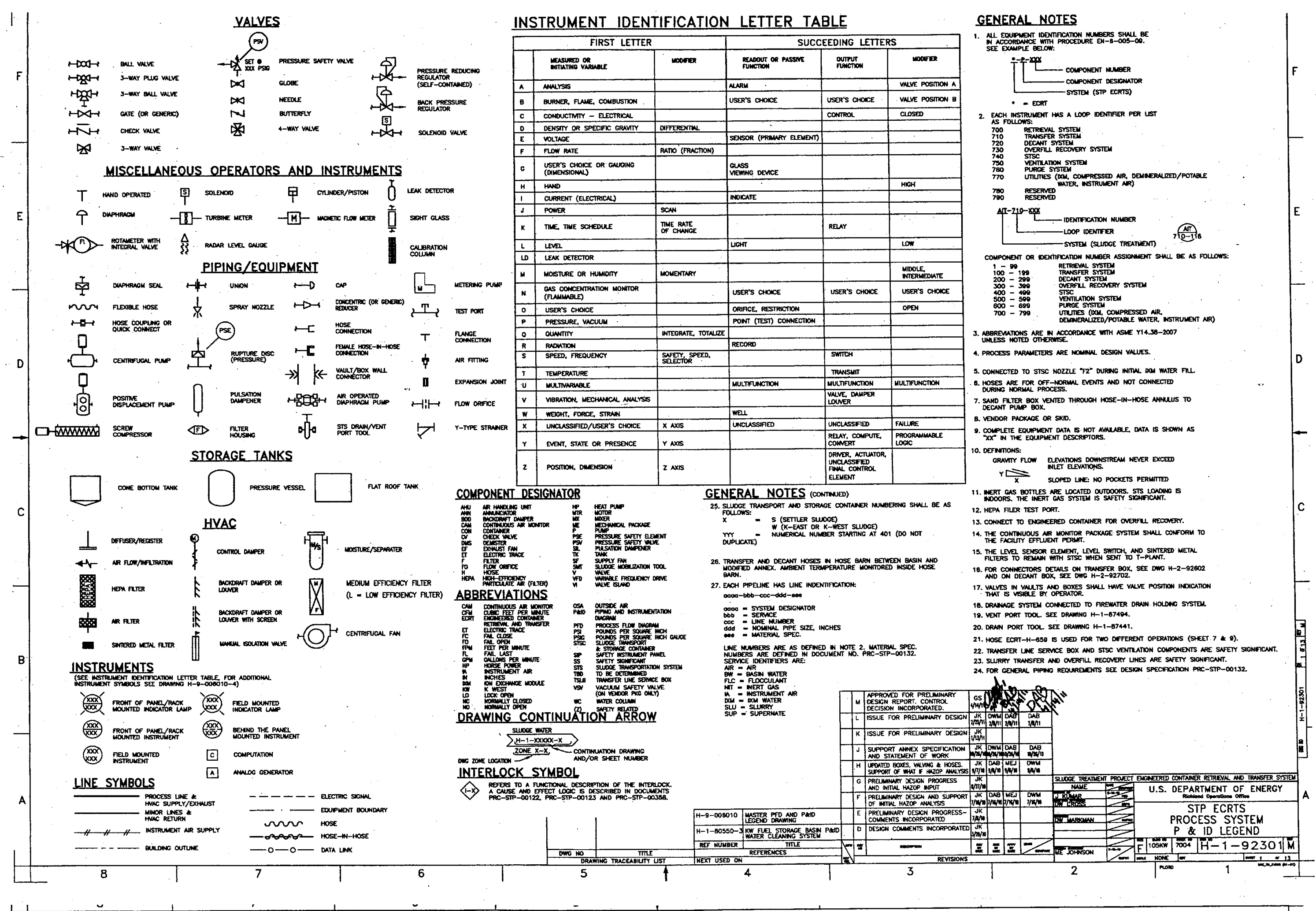


Figure A-4. STP ECRTS Process System Retrieval P\&ID (H-1-92301, Rev. M, Sheet 2 of 13)

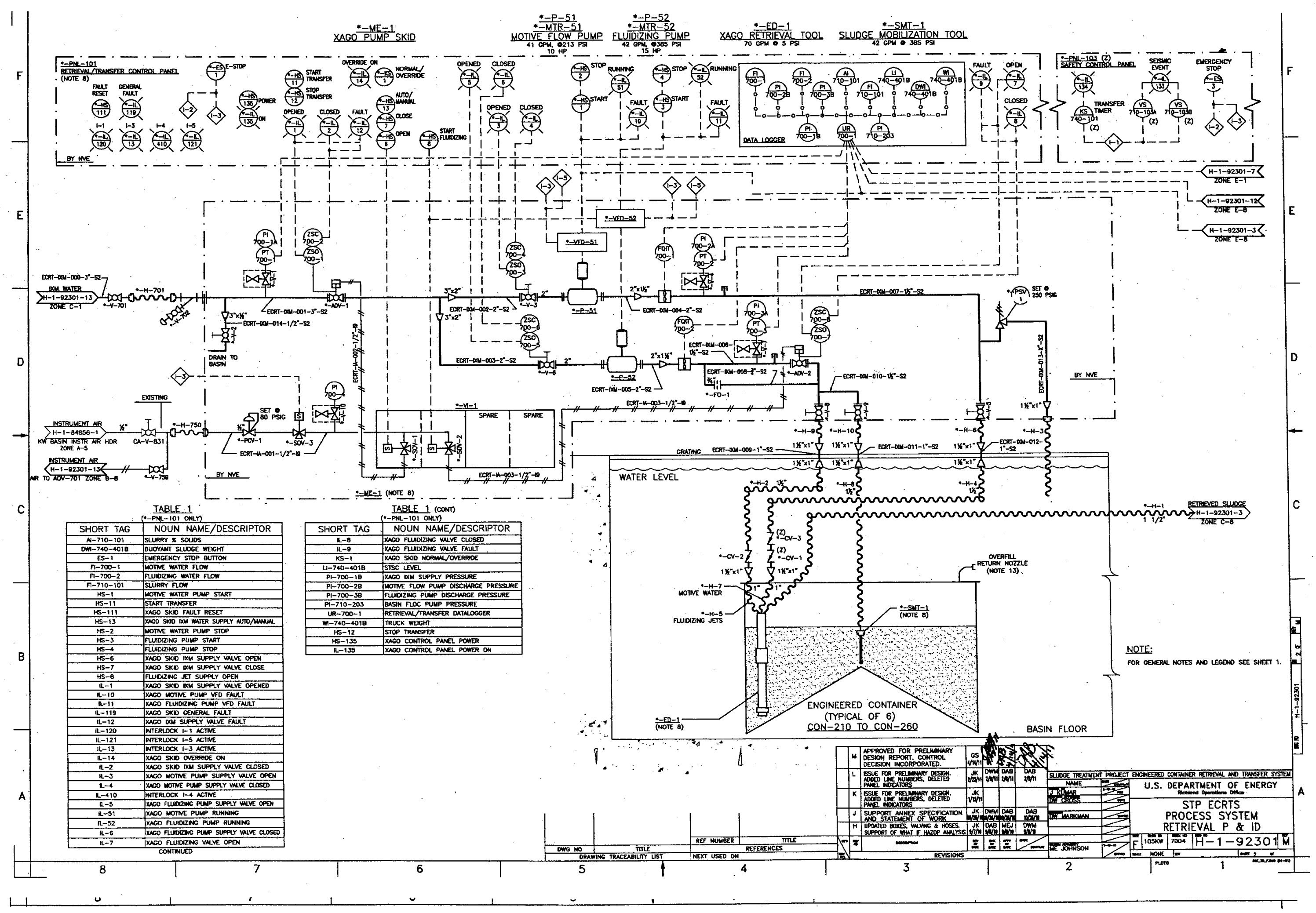


Figure A-5. STP ECRTS Process System Transfer P\&ID (H-1-92301, Rev. M, Sheet 3 of 13)

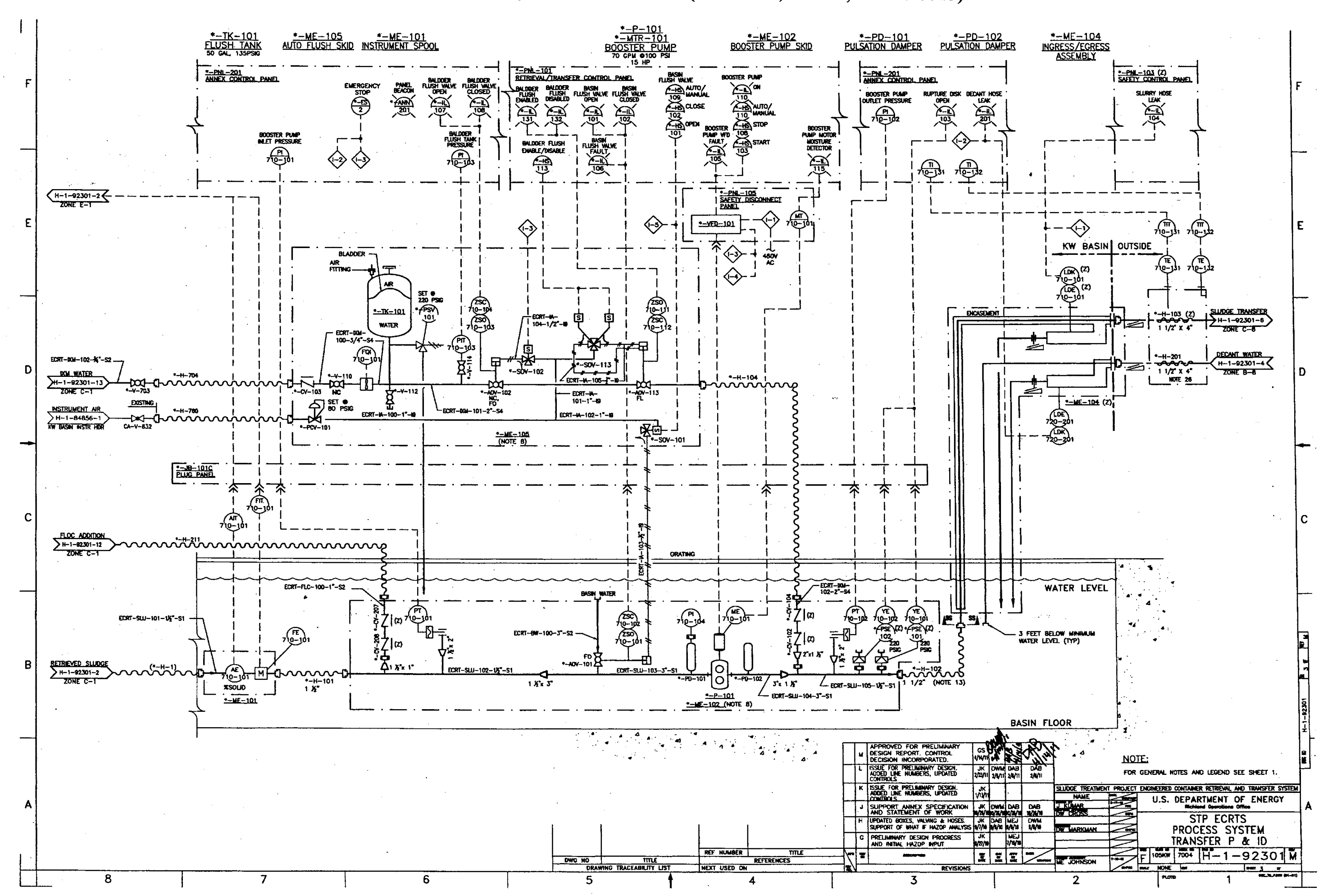


Figure A-6. Process System Filter P\&ID (H-1-92301, Rev. L, Sheet 4 of 13)

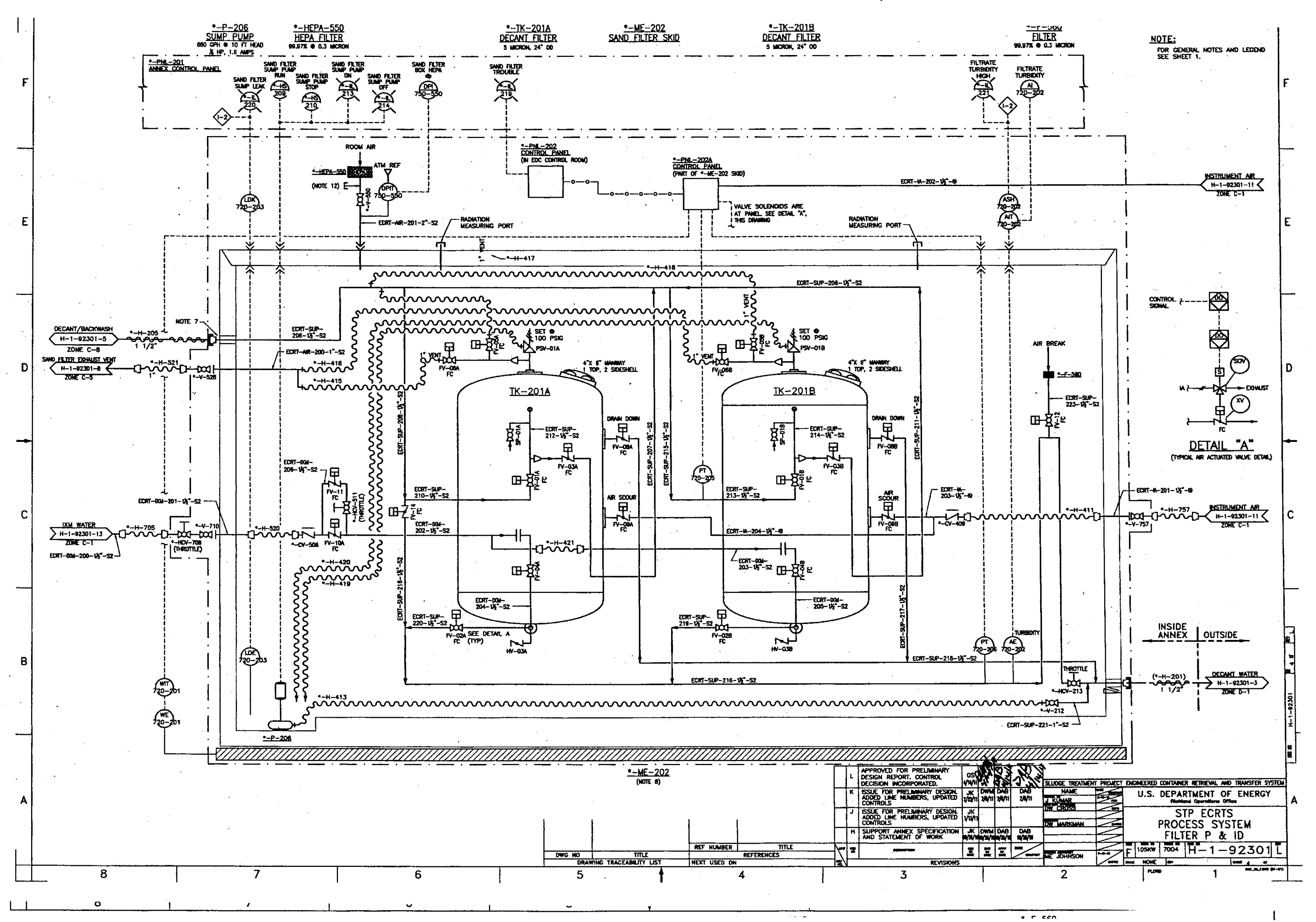


Figure A-7. STP ECRTS Process System Decant P\&ID (H-1-92301, Rev. L, Sheet 5 of 13)

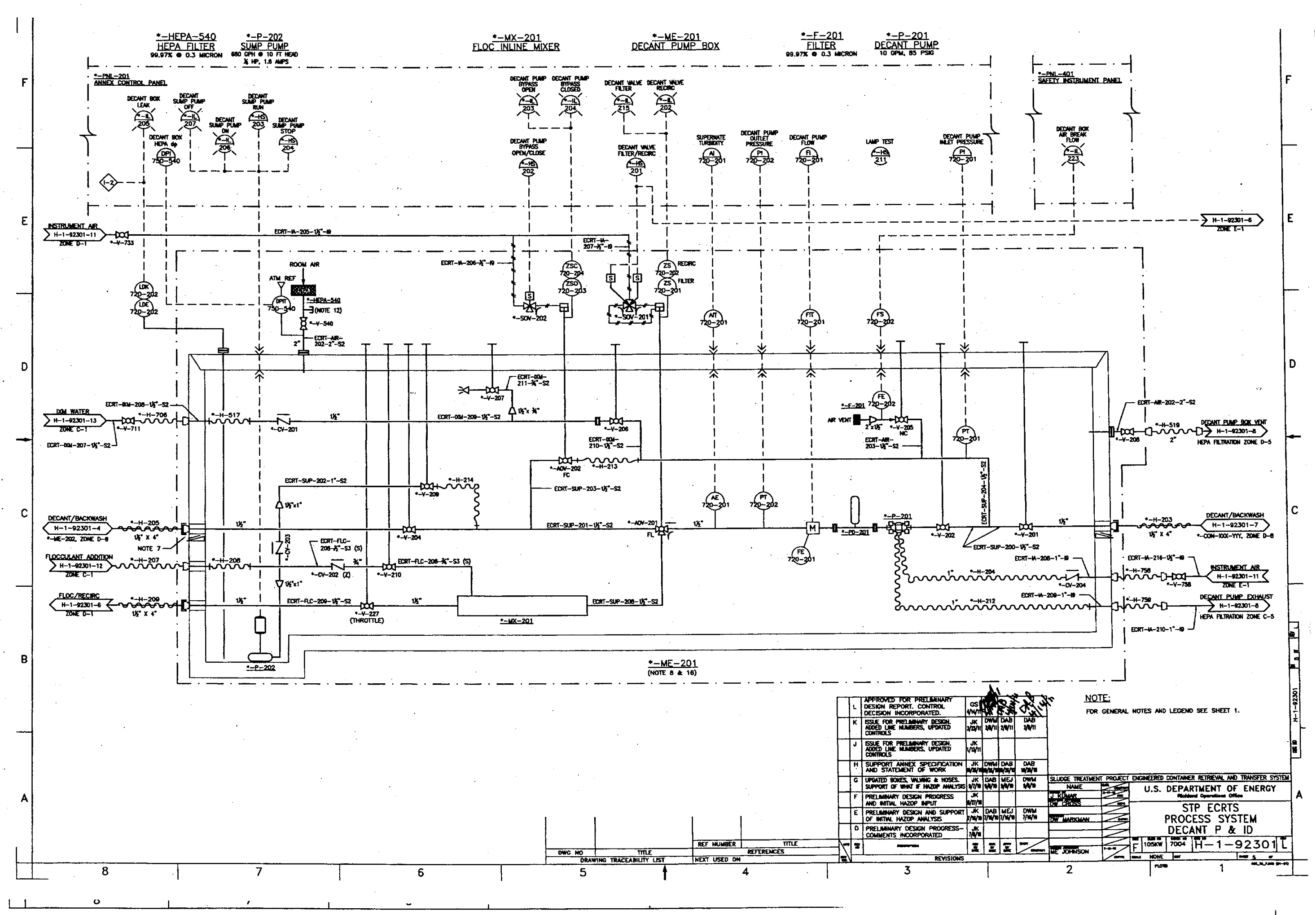


Figure A-8. STP ECRTS Process System Transfer P\&ID (H-1-92301, Rev. M, Sheet 6 of 13)

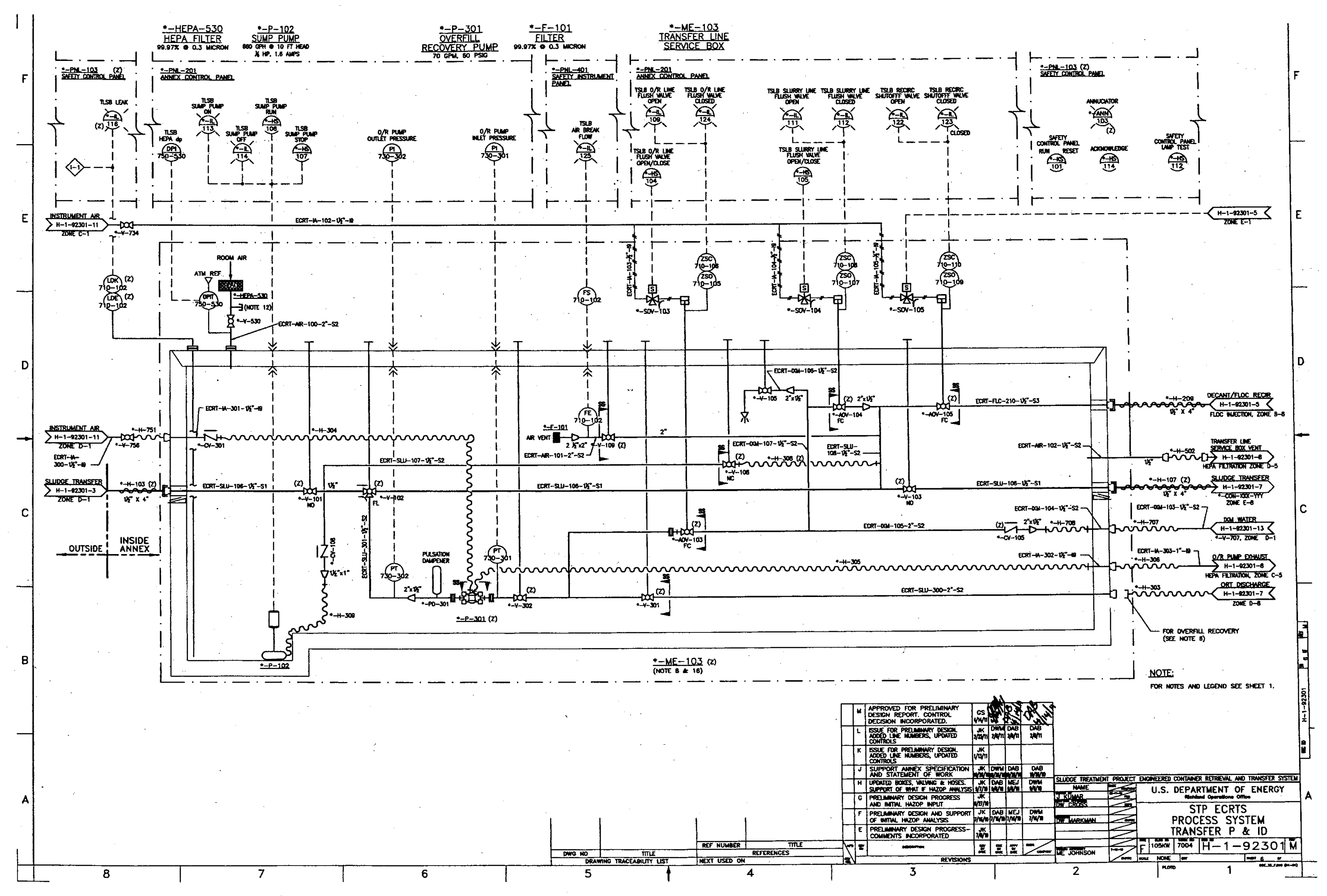


Figure A-9. STP ECRTS Process System Transfer STSC P\&ID (H-1-92301, Rev. M, Sheet 7 of 13)

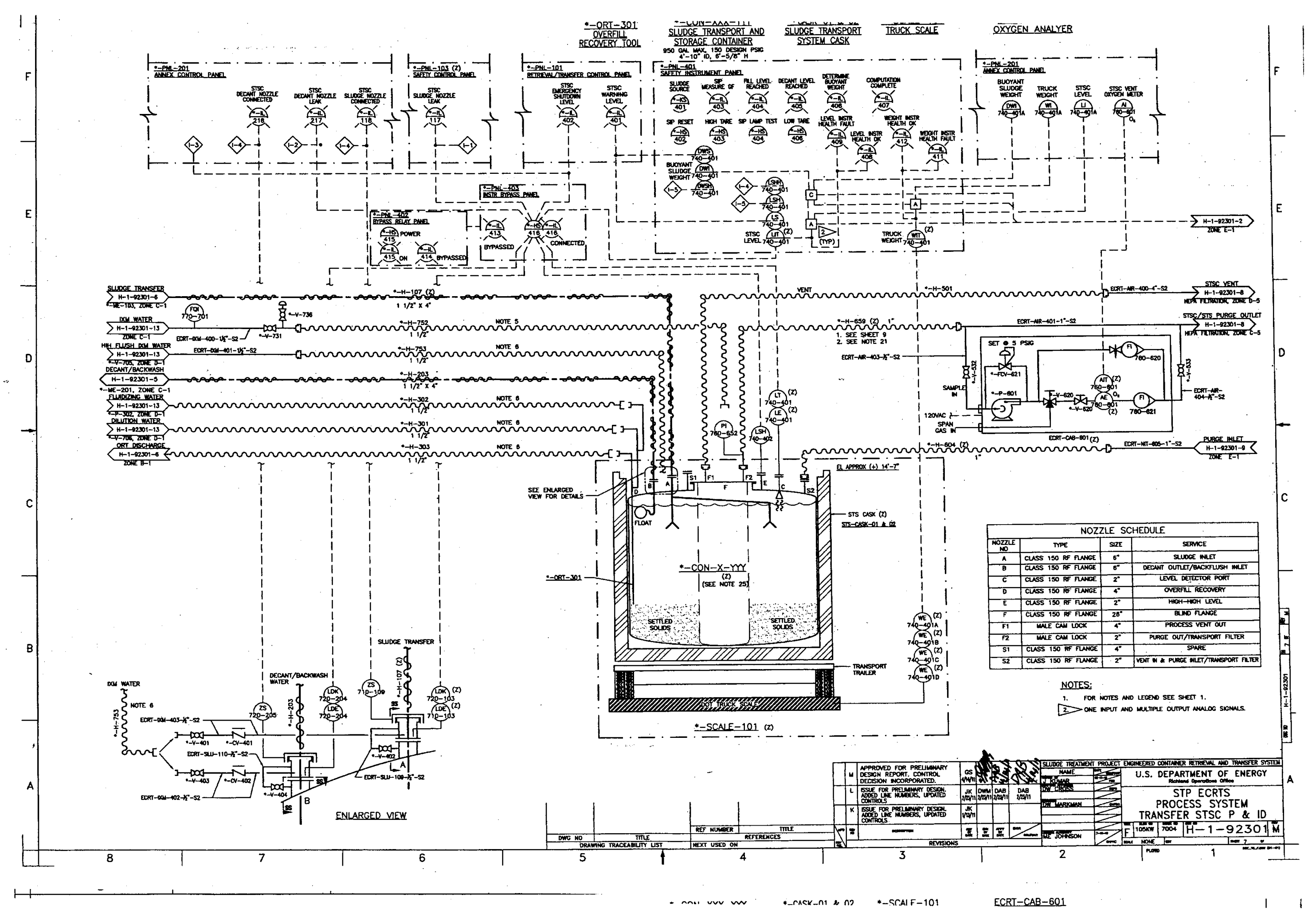

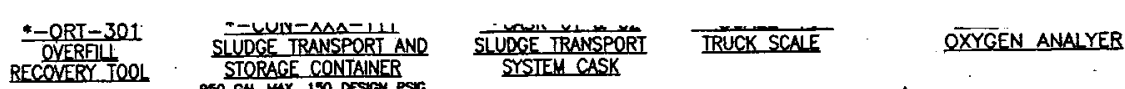


Figure A-10. Process System Ventilation P\&ID (H-1-92301, Rev. L, Sheet 8 of 13)

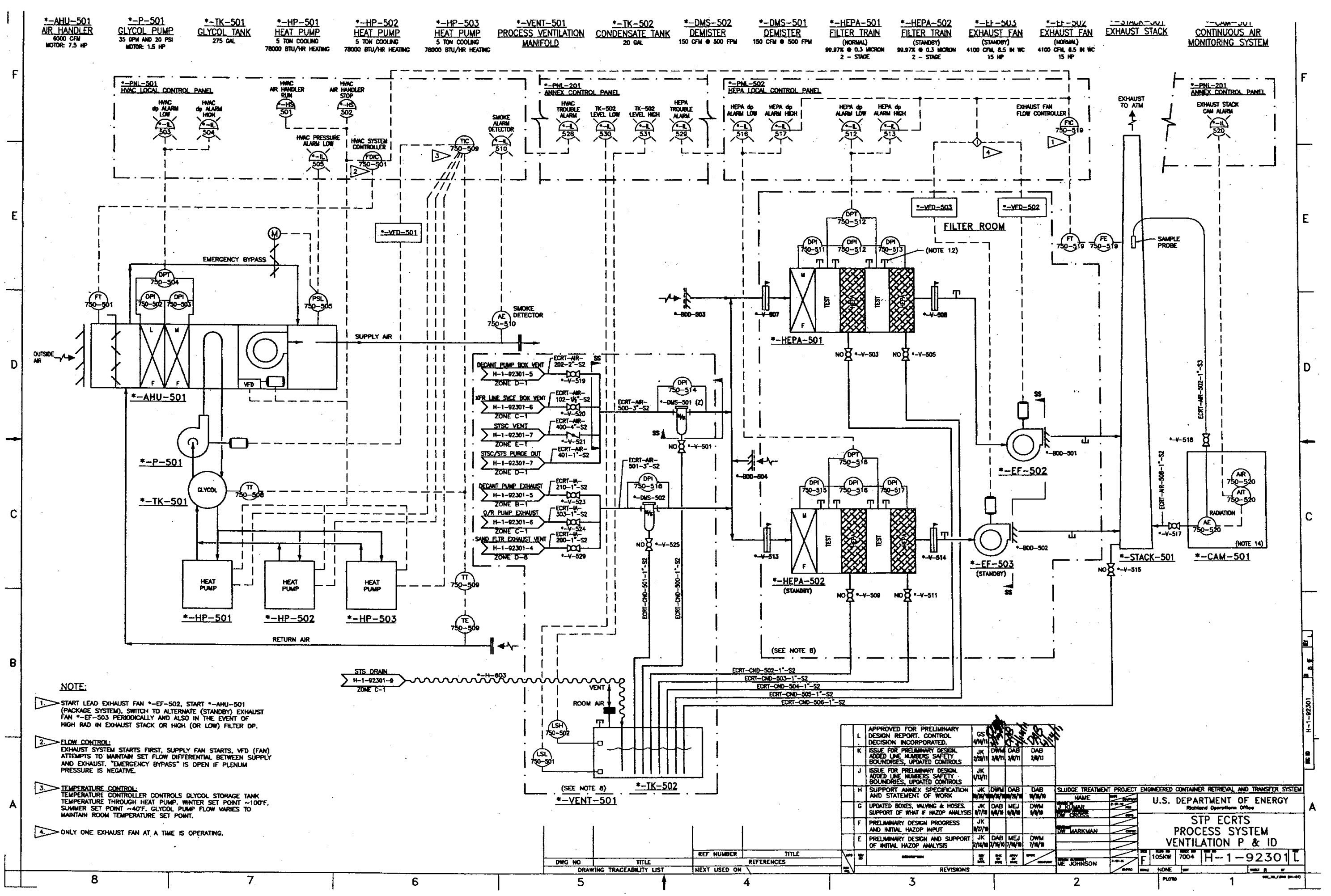


Figure A-11. STP ECRTS Process System Gas Purging P\&ID (H-1-92301, Rev. L, Sheet 9 of 13)

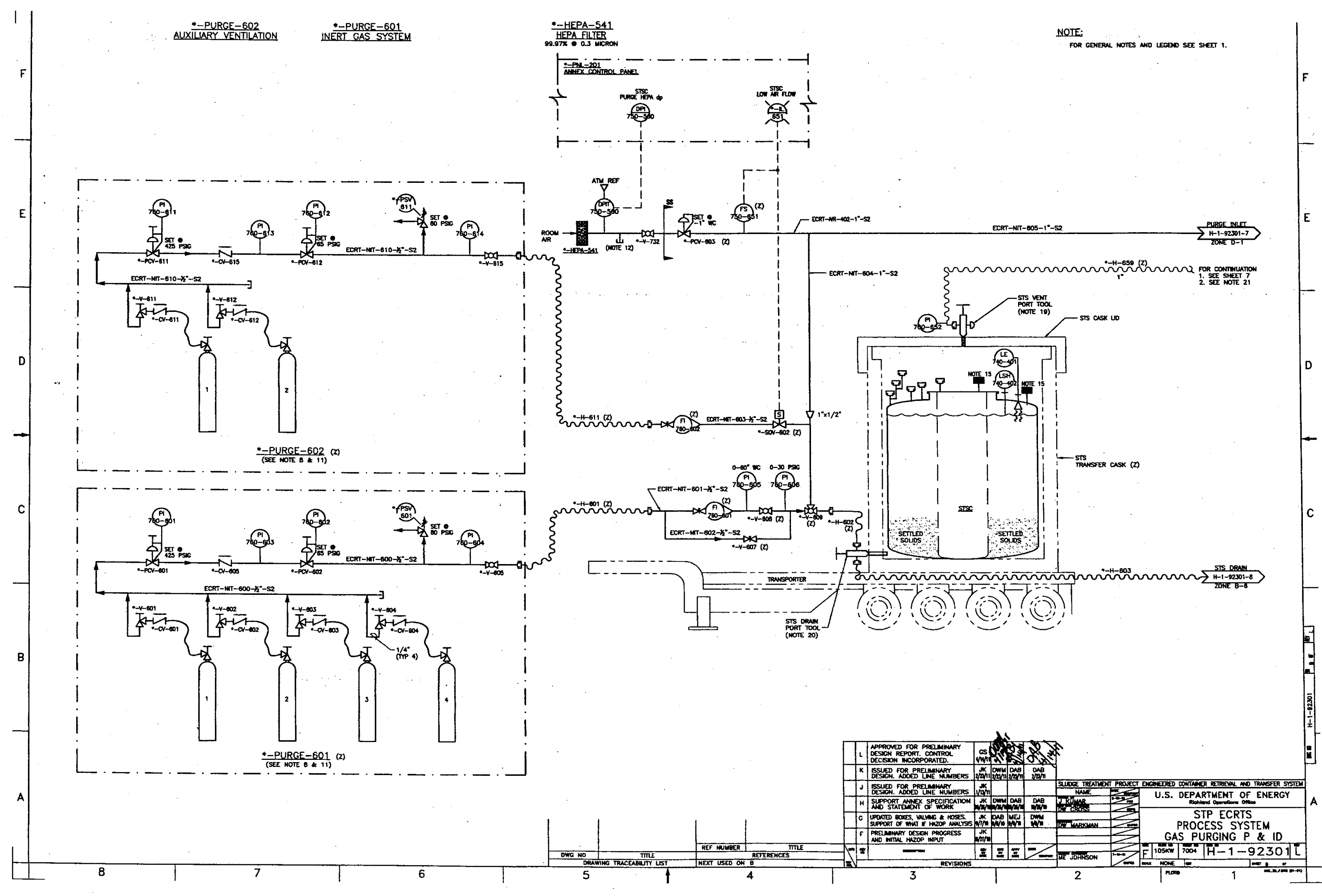


Figure A-12. STP ECRTS Process System Instrument Air P\&ID (H-1-92301, Rev. L, Sheet 10 of 13)

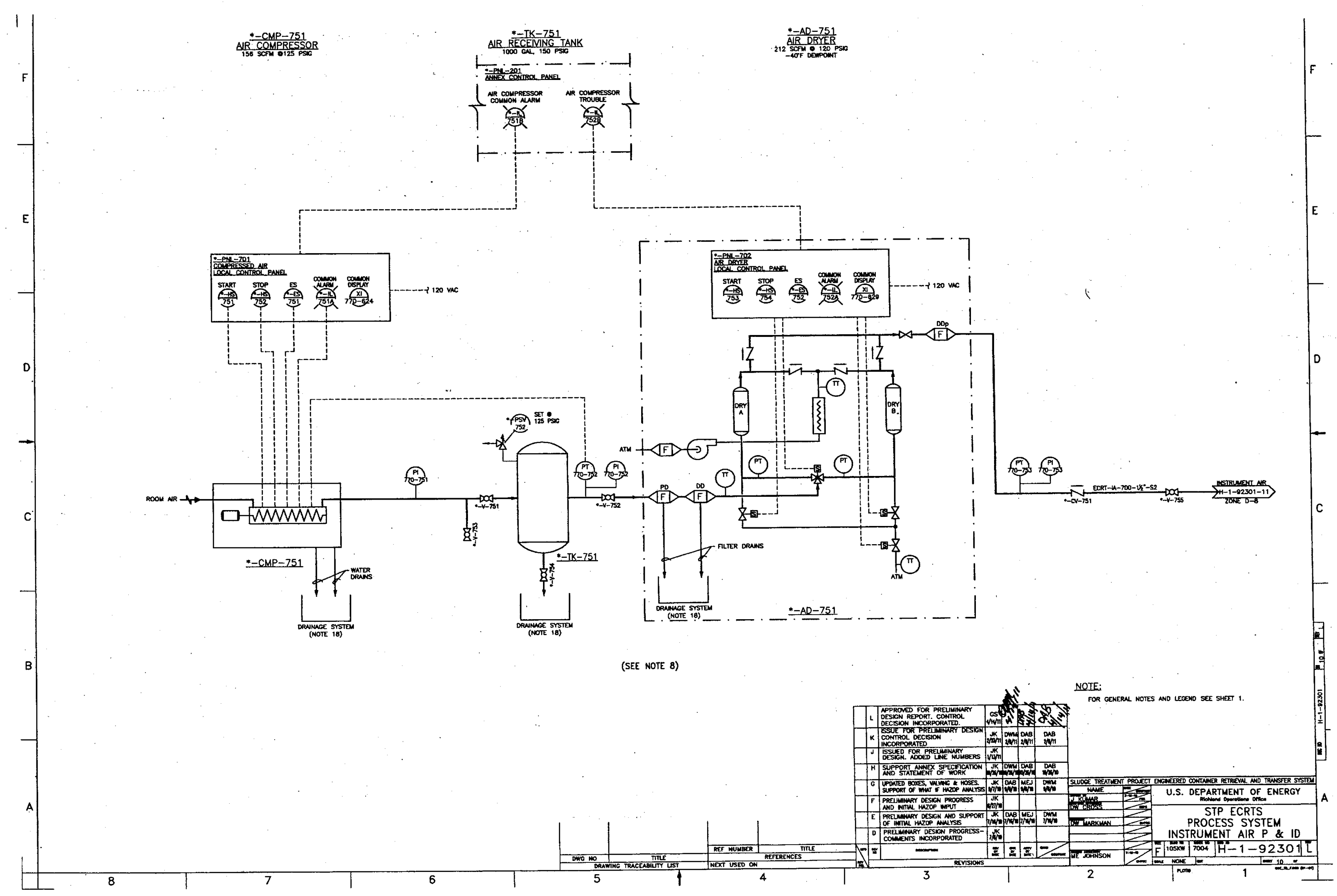


Figure A-13. STP ECRTS Process System Instrument Air P\&ID (H-1-92301, Rev. L, Sheet 11 of 13)

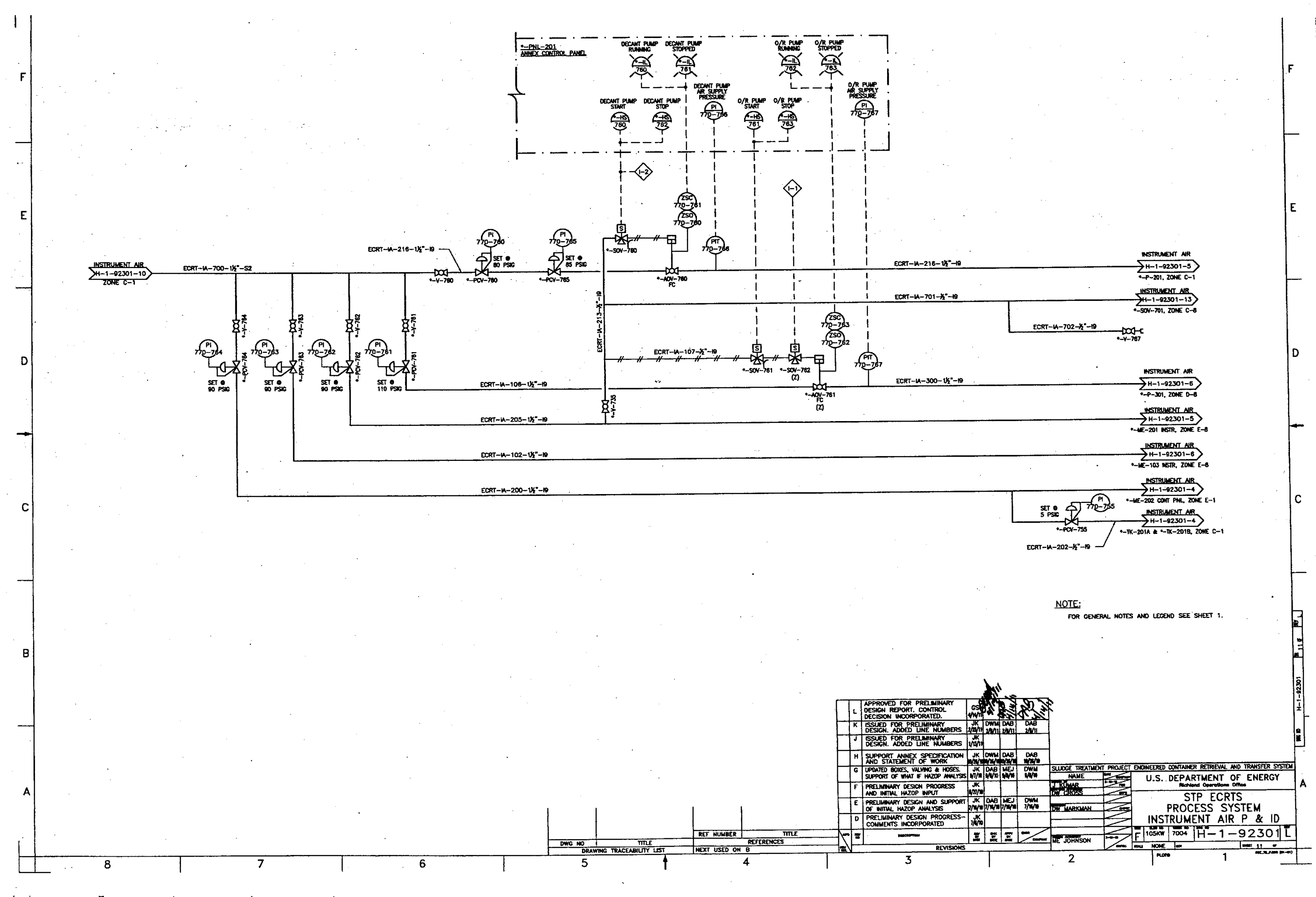


Figure A-14. STP ECRTS Process System Flocculant P\&ID (H-1-92301, Rev. K, Sheet 12 of 13)

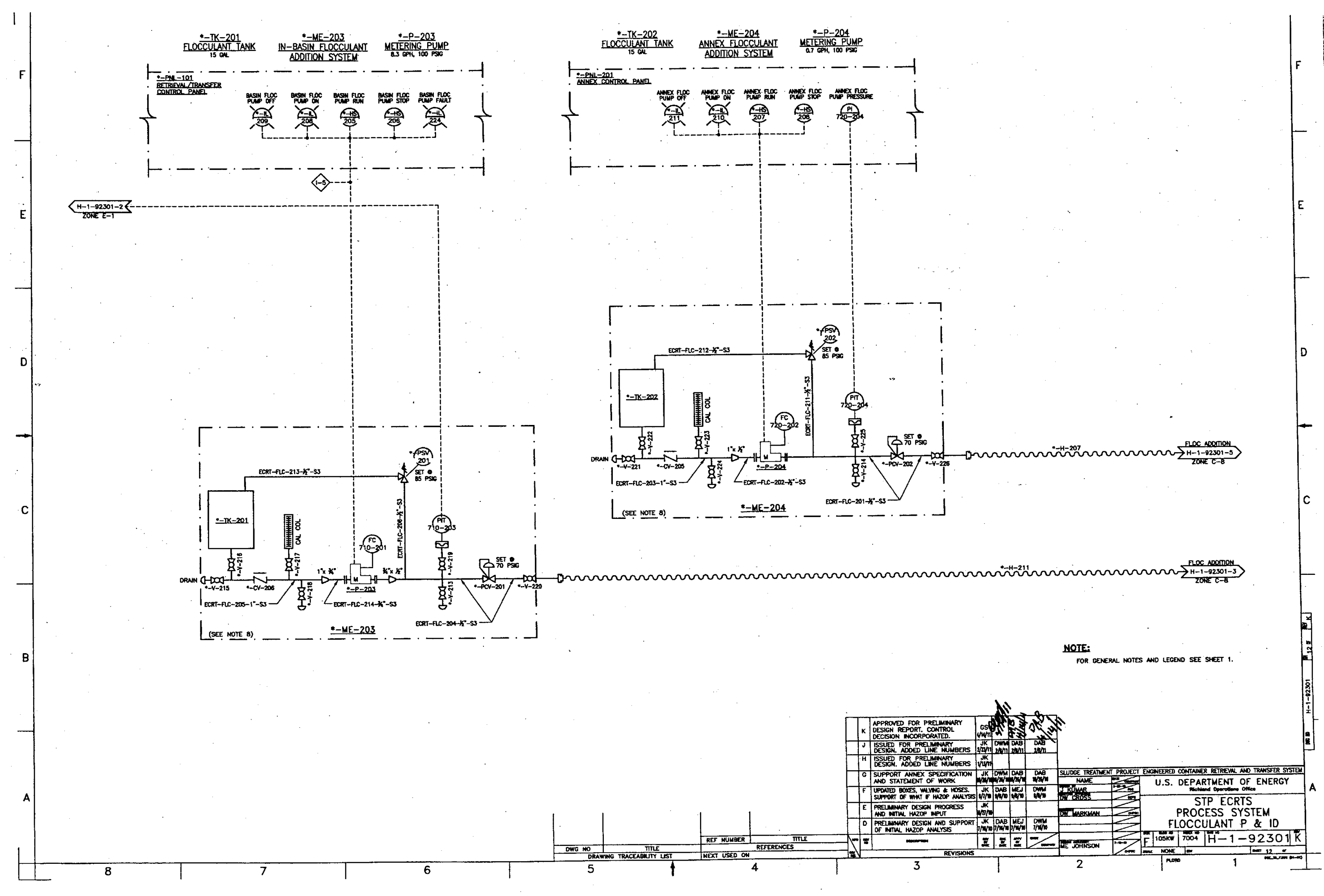


Figure A-15. STP ECRTS Process System IXM Water P\&ID (H-1-92301, Rev. H, Sheet 13 of 13)

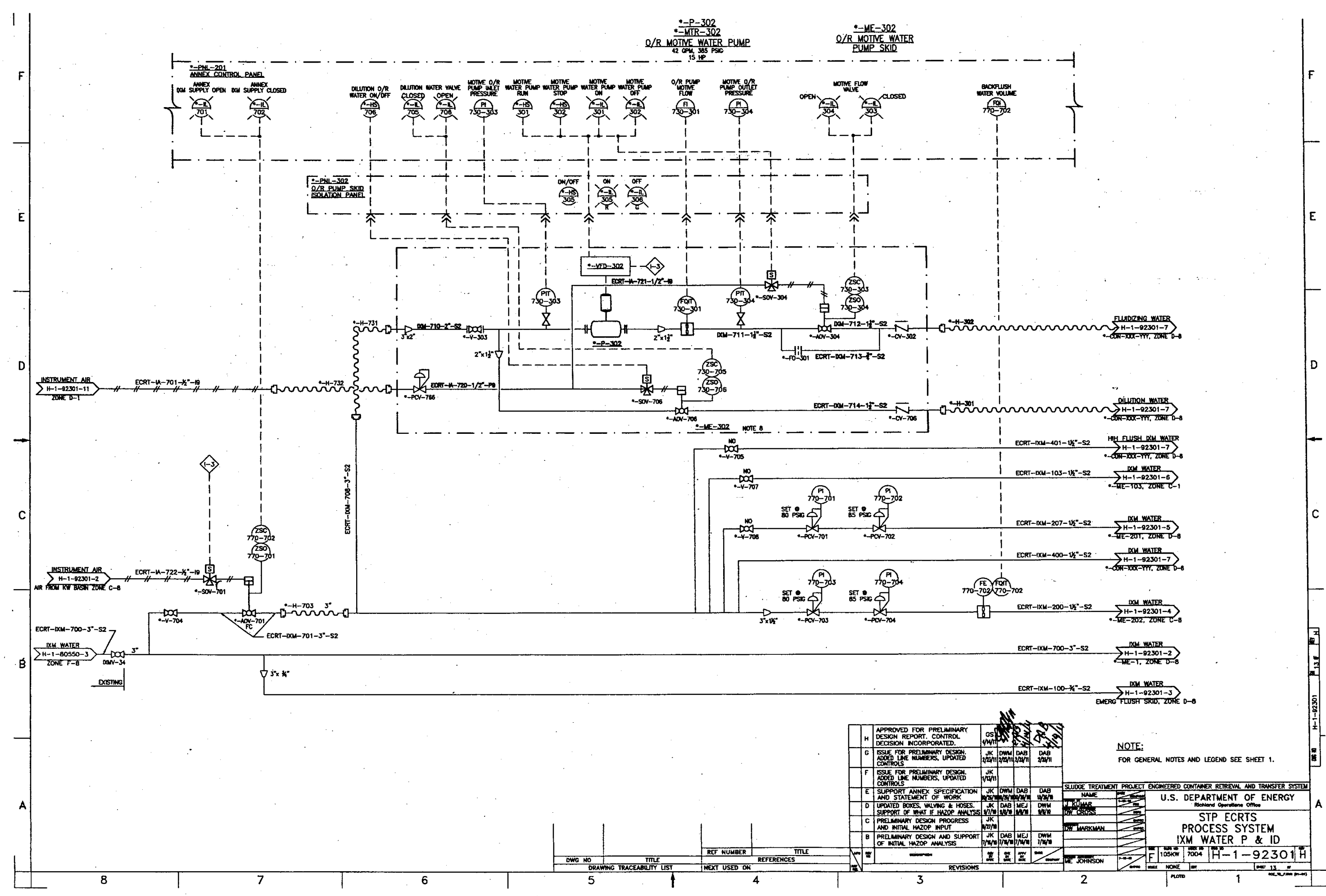


APPENDIX B

HAZARD AND OPERABILITY STUDY MEETING ATTENDEES 
Table B-1. ECRTS Draft Preliminary Design HAZOP Meeting Participants August 9, 10 and 12, 2010

\begin{tabular}{|c|c|c|c|c|}
\hline \multirow{2}{*}{ Name } & \multirow{2}{*}{ Organization } & \multicolumn{3}{|c|}{ Dates Present } \\
\hline & & $8 / 9$ & $8 / 10$ & $8 / 12$ \\
\hline \multicolumn{5}{|c|}{ HAZOP Team } \\
\hline Craig Carro & STP Nuclear Safety - Facilitator & $X$ & $\mathrm{X}$ & $\mathrm{X}$ \\
\hline Robin Sullivan & PNNL - Scribe & $\mathrm{X}$ & $\mathrm{X}$ & $\mathrm{X}$ \\
\hline Ralph Crowe & STP Nuclear Safety & $\mathrm{X}$ & $\mathrm{X}$ & $\mathrm{X}$ \\
\hline Gail Chaffee & 100 K Area Nuclear Safety & $\mathrm{X}$ & $\mathrm{X}$ & $\mathrm{X}$ \\
\hline Lindsay Nelsen & STP Radiological Control & $\mathrm{X}$ & - & - \\
\hline Gary Hastings & 100 K Area Radiological Control & $\mathrm{X}$ & $\mathrm{X}$ & $\mathrm{X}$ \\
\hline Steve Burke & $100 \mathrm{~K}$ Area Operations & $\mathrm{X}$ & - & - \\
\hline Jeff Broussard & $100 \mathrm{~K}$ Area Operations & - & $\mathrm{X}$ & $\mathrm{X}$ \\
\hline Jim Mathews & STP Operations & $\mathrm{X}$ & $\mathrm{X}$ & $\mathrm{X}$ \\
\hline Dewey Burbank & ECRTS Process Engineering & $\mathrm{X}$ & $X$ & $\mathrm{X}$ \\
\hline Daniel Wood & $100 \mathrm{~K}$ Area Occupational Safety and Health & $\mathrm{X}$ & $X$ & - \\
\hline Daren Schwartz & $100 \mathrm{~K}$ Area Occupational Safety and Health & & & $\mathrm{X}$ \\
\hline Shaun Dunfee & STP Occupational Safety and Health & $\mathrm{X}$ & - & - \\
\hline \multicolumn{5}{|c|}{ Additional Attendees } \\
\hline Dennis Hamilton & ECRTS Project Manager & $\mathrm{X}$ & $\mathrm{X}$ & $\mathrm{X}$ \\
\hline Rick Raymond & STP Chief Engineer & $X$ & $\mathrm{X}$ & - \\
\hline Jim Frederickson & ECRTS Engineering Manager & $\mathrm{X}$ & - & - \\
\hline John Dearing & ECRTS Engineering & $\mathrm{X}$ & - & $\mathrm{X}$ \\
\hline
\end{tabular}


Table B-1. ECRTS Draft Preliminary Design HAZOP Meeting Participants

August 9, 10 and 12, 2010

\begin{tabular}{|c|c|c|c|c|}
\hline \multirow{2}{*}{ Name } & \multirow{2}{*}{ Organization } & \multicolumn{3}{|c|}{ Dates Present } \\
\hline & & $8 / 9$ & $\mathbf{8} / 10$ & 8/12 \\
\hline Mark Hall & ECRTS Engineering & $\mathrm{X}$ & - & - \\
\hline Geoff Barnes & ECRTS Engineering & - & $\mathrm{X}$ & - \\
\hline Tarandeep Dhaliwal & ECRTS Engineering & - & - & $\mathrm{X}$ \\
\hline Jim Criddle & ECRTS Engineering & - & - & $\mathrm{X}$ \\
\hline Bob Meichle & STP Nuclear Safety & $\mathrm{X}$ & $\mathrm{X}$ & $\mathrm{X}$ \\
\hline Joel Cannon & STP Quality Assurance & $\mathrm{X}$ & $\mathrm{X}$ & $\mathrm{X}$ \\
\hline Rick Garza & $100 \mathrm{~K}$ Area Emergency Preparedness & $\mathbf{X}$ & - & $\mathrm{X}$ \\
\hline Raymond Puigh & Criticality Safety & $X$ & $\mathrm{X}$ & - \\
\hline Alvia Bridges & Transportation Safety & $\mathrm{X}$ & - & $\mathrm{X}$ \\
\hline Jake Jacobs & SWOC Nuclear Safety & - & - & $\mathrm{X}$ \\
\hline Greg Morgan & RL Nuclear Safety & $X$ & - & - \\
\hline Dennis Clapp & RL Nuclear Safety & $X$ & $\mathrm{X}$ & - \\
\hline
\end{tabular}




\begin{tabular}{|c|c|}
\hline \multicolumn{2}{|c|}{$\begin{array}{l}\text { Table B-2. ECRTS Preliminary Design HAZOP Meeting Participants } \\
\text { Overfill Recovery } \\
\text { May 31, } 2011\end{array}$} \\
\hline NAME & ORGANIZATION \\
\hline \multicolumn{2}{|r|}{ HAZOP Team } \\
\hline Craig Carro & STP Nuclear Safety - Facilitator \\
\hline Bob Meichle & STP Nuclear Safety - Scribe \\
\hline Paul Patterson & 100-K Area Nuclear Safety \\
\hline Daren Schwartz & $100 \mathrm{~K}$ Area Occupational Safety and Health \\
\hline Dewey Burbank & ECRTS Process Engineering \\
\hline Susan Omberg Carro & STP Fire Protection Engineering \\
\hline Darryl Willoughby & $100 \mathrm{~K}$ Area Operations \\
\hline \multicolumn{2}{|c|}{ Additional Attendees } \\
\hline Rick Raymond & STP Chief Engineer, SDIT Chair \\
\hline Gary Franz & STP Nuclear Safety Lead \\
\hline Dennis Hamilton & ECRTS Project Manager \\
\hline John Dearing & ECRTS Seismic Design Engineer \\
\hline Jim Criddle & ECRTS Engineering \\
\hline Harold Mashaw & ECRTS Engineering \\
\hline Tom Vincent & Design Agent (AREVA) \\
\hline Greg Morgan & RL Nuclear Safety \\
\hline
\end{tabular}




\begin{tabular}{|c|c|}
\hline \multicolumn{2}{|c|}{$\begin{array}{l}\text { Table B-3. ECRTS Preliminary Design HAZOP Meeting Participants } \\
\text { STS Cask Pressurization } \\
\text { June 14, } 2011\end{array}$} \\
\hline NAME & ORGANIZATION \\
\hline \multicolumn{2}{|r|}{ HAZOP Team } \\
\hline Craig Carro & STP Nuclear Safety - Facilitator \\
\hline Bob Meichle & STP Nuclear Safety - Scribe \\
\hline Lindsay Nelsen & STP Radiological Control \\
\hline Dewey Burbank & ECRTS Process Engineering \\
\hline Susan Omberg Carro & STP Fire Protection Engineering \\
\hline Daren Schwartz & $100 \mathrm{~K}$ Area Occupational Safety and Health \\
\hline Darryl Willoughby & $100 \mathrm{~K}$ Area Operations \\
\hline \multicolumn{2}{|c|}{ Additional Attendees } \\
\hline Gary Franz & STP Nuclear Safety Lead \\
\hline Jim Frederickson & ECRTS Engineering Manager \\
\hline John Dearing & ECRTS Seismic Design Engineer \\
\hline Harold Mashaw & ECRTS Engineering \\
\hline Tom Vincent & Design Agent (AREVA) \\
\hline
\end{tabular}


APPENDIX C

HAZARD AND OPERABILITY STUDY RESULTS

$\mathrm{C}-\mathrm{i}$ 
APPENDIX C

HAZARD AND OPERABILITY STUDY RESULTS

\begin{tabular}{|c|c|c|}
\hline Process Parameter & Design Intent & Remarks \\
\hline Flow & $42 \mathrm{gpm}$ & $\begin{array}{l}\text { Motive force is fluidizing pump ECRT-P-52. The } 42 \mathrm{gpm} \text { is the flow rate when the fluidizing jets are pulsed. } \\
\text { When the jets are not pulsed, } 2-13 \mathrm{gpm} \text { flows to the fluidizing jets via bypass flow orifice ECRT-FO-1. }\end{array}$ \\
\hline Pressure & $\begin{array}{l}\text { Upstream of pump ECRT-P-52 }=100-130 \mathrm{psi} \\
\text { Downstream of pump ECRT-P-52 }=385 \mathrm{psi}\end{array}$ & $\begin{array}{l}\text { When the operators pulse the fluidizing jets, valve ECRT-AOV- } 2 \text { opens and high pressure water is directed } \\
\text { to the jets. }\end{array}$ \\
\hline Concentration & Not applicable & $\begin{array}{l}\text { The Skimmer Water Cleanup System takes basin water and pumps it first through a sand filter (for water } \\
\text { clarity) and then through an IXM (to remove ionic species). The IXM water concentration is not a critical } \\
\text { attribute of Xago Hydrolance }{ }^{\mathrm{m}} \text { operability, i.e., fluidizing jet performance would be identical using basin water } \\
\text { versus IXM water. }\end{array}$ \\
\hline Composition & Not applicable & $\begin{array}{l}\text { There are no other process fluids at the KW Basin that could be inadvertently connected or directed to the } \\
\text { Xago pump skid. }\end{array}$ \\
\hline Structural Integrity & Maintain integrity under normal operating conditions & The IXM water lines are a combination of piping and hoses. \\
\hline Level & Not applicable & There are no vessels associated with this node. \\
\hline Temperature & Not applicable & $\begin{array}{l}\text { Temperature is not a process parameter that is monitored or controlled. The } 1.3 \text { million gallons of water in } \\
\text { the KW Basin are maintained at a temperature of } 10-15^{\circ} \mathrm{C} \text {. The IXM water is approximately the same } \\
\text { temperature as the basin water, i.e., the pumps of the Skimmer Water Cleanup System do not impart } \\
\text { significant thermal energy to the water. Fluctuations in basin water temperature occur very slowly. The IXM } \\
\text { water temperature is not a critical attribute of Xago Hydrolance }{ }^{\mathrm{m}} \text { operability, i.e., fluidizing jet performance } \\
\text { would be identical for a wide range of basin water temperatures. }\end{array}$ \\
\hline Time Procedure & Periodic pulses lasting 3 to 10 seconds & $\begin{array}{l}\text { The fluidizer jets are pulsed to undercut layers of sludge above the Xago Hydrolance }{ }^{m} \text {. Operators pulse the } \\
\text { jets based on readings from the } \% \text { solids meter (Al-710-101). }\end{array}$ \\
\hline
\end{tabular}




\begin{tabular}{|c|c|c|c|c|c|c|c|}
\hline \multirow{2}{*}{ Item } & \multirow{2}{*}{$\begin{array}{l}\text { Process } \\
\text { Parameter }\end{array}$} & \multirow{2}{*}{ Deviation } & \multirow{2}{*}{ Cause } & \multirow{2}{*}{ Consequences } & \multicolumn{2}{|c|}{ Candidate Controls } & \multirow{2}{*}{ Remarks } \\
\hline & & & & & Engineered & Administrative & \\
\hline 1.a-1 & Flow & No & $\begin{array}{l}\text { - No IXM water supply } \\
\text { from the Skimmer } \\
\text { Water Cleanup System } \\
\text { - A normally-open valve is } \\
\text { closed } \\
\text { - Fluidizing jets are } \\
\text { plugged }\end{array}$ & $\begin{array}{l}\text { Operational Upset: } \\
\text { If there is no flow to the fluidizing jets } \\
\text { because there is no IXM water supply, } \\
\text { then there will be no water to the fluidizing } \\
\text { jets and there will be no motive water. } \\
\text { Booster pump ECRT-P-101 will continue } \\
\text { to operate but will be suction-starved. } \\
\text { The Xago Hydrolance' could plug. The } \\
\text { rupture disk downstream of booster pump } \\
\text { ECRT-P-101 could rupture. } \\
\text { If there is no flow to the fluidizing jets } \\
\text { because valve ECRT-V-701 or } \\
\text { ECRT-AOV-1 is closed, then there will be } \\
\text { no water to the fluidizing jets and there } \\
\text { will be no motive water. Consequences } \\
\text { are as stated above. } \\
\text { If there is no flow to the fluidizing jets } \\
\text { because valve ECRT-V-6 or valve } \\
\text { ECRT-V-8 is closed, then sludge in the } \\
\text { Engineered Container will not be undercut } \\
\text { and thus will not collapse into the zone of } \\
\text { influence of the Coanda head. This will } \\
\text { result in a reduced vol\% solids content of } \\
\text { the retrieved sludge which could result in } \\
\text { additional fill/decant cycles. } \\
\text { If there is no flow to the fluidizing jets } \\
\text { because valve ECRT-V-8 is closed, then } \\
\text { fluidizing pump ECRT-P-52 would } \\
\text { deadhead and could overheat. } \\
\text { Deadheading the pump would result in } \\
\text { high pressure in the line downstream of } \\
\text { the pump (see Item } 1 . a-6 \text { below). }\end{array}$ & $\begin{array}{l}\text { - Valve position indicators } \\
\text { - IXM water pressure } \\
\text { instrumentation (PT-700-1B, } \\
-2 \mathrm{~B},-3 \mathrm{~B} \text { ) } \\
\text { - IXM water flow rate } \\
\text { instrumentation (FIT-700-1, } \\
-2 \text { ) } \\
\text { - \% solids instrumentation } \\
\text { (AE-710-101) }\end{array}$ & $\begin{array}{l}\text { - Procedures } \\
\text { - Training } \\
\text { - Conduct of operations } \\
\text { verifies proper system } \\
\text { configuration }\end{array}$ & $\begin{array}{l}\text { It would be readily apparent to operators at the } \\
\text { start-up of retrieval operations if there was no } \\
\text { IXM water supply. } \\
\text { Fluidizing pump ECRT-P-52 is a centrifugal } \\
\text { pump. If it was not operating IXM water would } \\
\text { still flow through the pump at the flow rate and } \\
\text { pressure provided by the IXM water system. } \\
\text { Valves ECRT-AOV-1 is an air-operated valve. } \\
\text { The valve close on loss of air. The valve also } \\
\text { closes on loss of power to solenoid-operated } \\
\text { valve ECRT-SOV-1. } \\
\text { If ECRT-AOV-2 fails to open it does not result in } \\
\text { a "no flow" condition to the fluidizer jets because } \\
\text { of flow through bypass flow orifice ECRT-FO-1. } \\
\text { The flow rate through this orifice is } 2-13 \text { gpm. }\end{array}$ \\
\hline
\end{tabular}




\begin{tabular}{|c|c|c|c|c|c|c|c|}
\hline \multirow{2}{*}{ Item } & \multirow{2}{*}{$\begin{array}{l}\text { Process } \\
\text { Parameter }\end{array}$} & \multirow{2}{*}{ Deviation } & \multirow{2}{*}{ Cause } & \multirow{2}{*}{ Consequences } & \multicolumn{2}{|c|}{ Candidate Controls } & \multirow{2}{*}{ Remarks } \\
\hline & & & & & Engineered & Administrative & \\
\hline 1.a-2 & Flow & Low & $\begin{array}{l}\text { - Low IXM water supply } \\
\text { flow rate from the } \\
\text { Skimmer Water Cleanup } \\
\text { System } \\
\text { - Fluidizing pump } \\
\text { ECRT-P-52 not } \\
\text { operating } \\
\text { - Fluidizing pump } \\
\text { ECRT-P-52 speed low } \\
\text { - A normally-open valve is } \\
\text { partially closed } \\
\text { - Fluidizing jets are } \\
\text { partially plugged } \\
\text { - Valve ECRT-AOV-2 is } \\
\text { closed }\end{array}$ & $\begin{array}{l}\text { Operational Upset: } \\
\text { If there is low flow to the fluidizing jets } \\
\text { because there is a low flow rate from the } \\
\text { IXM water supply, then sludge in the } \\
\text { Engineered Container may not be } \\
\text { effectively undercut and thus will not } \\
\text { collapse into the zone of influence of the } \\
\text { Coanda head. This will result in a } \\
\text { reduced vol\% solids content of the } \\
\text { retrieved sludge which could result in } \\
\text { additional fill/decant cycles. } \\
\text { If there is low flow to the fluidizing jets } \\
\text { because of a low pump speed or because } \\
\text { valve ECRT-V-701 or ECRT-AOV-1 is } \\
\text { partially closed, then sludge in the } \\
\text { Engineered Container may not be } \\
\text { effectively undercut and thus will not } \\
\text { collapse into the zone of influence of the } \\
\text { Coanda head. The consequences are as } \\
\text { stated above. } \\
\text { If there is low flow to the fluidizing jets } \\
\text { because valve ECRT-V-6 or valve } \\
\text { ECRT-V-8 is partially closed, then sludge } \\
\text { in the Engineered Container may not be } \\
\text { effectively undercut and thus will not } \\
\text { collapse into the zone of influence of the } \\
\text { Coanda head. The consequences are as } \\
\text { stated above. }\end{array}$ & $\begin{array}{l}\text { - Valve position indicators } \\
\text { - IXM water pressure } \\
\text { instrumentation (PT-700-1B, } \\
-2 \mathrm{~B},-3 \mathrm{~B} \text { ) } \\
\text { - IXM water flow rate } \\
\text { instrumentation (FIT-700-1, } \\
-2 \text { ) } \\
\text { - \% solids instrumentation } \\
\text { (AE-710-101) }\end{array}$ & $\begin{array}{l}\text { - Procedures } \\
\text { - Training } \\
\text { - Conduct of operations } \\
\text { verifies proper system } \\
\text { configuration }\end{array}$ & $\begin{array}{l}\text { Fluidizing pump ECRT-P- } 52 \text { is a centrifugal } \\
\text { pump. If it was not operating IXM water would } \\
\text { still flow through the pump at the flow rate and } \\
\text { pressure provided by the IXM water system. } \\
\text { The fluidizing pump speed is controlled by } \\
\text { variable frequency drive ECRT-VFD-52. The } \\
\text { pump speed will be set during pre-operational } \\
\text { testing. There will be no procedural steps } \\
\text { directing operators to adjust the pump speed. }\end{array}$ \\
\hline 1.a-3 & Flow & High & \begin{tabular}{|l} 
Fluidizing pump \\
ECRT-P-52 speed high
\end{tabular} & $\begin{array}{l}\text { Operational Upset: } \\
\text { If there is high flow to the fluidizing jets, } \\
\text { then the vol\% solids could be temporarily } \\
\text { reduced and sludge could flow out of the } \\
\text { Engineered Container into the basin. }\end{array}$ & $\begin{array}{l}\text { - IXM water flow rate } \\
\text { instrumentation (FIT-700-2) } \\
\text { - \% solids instrumentation } \\
\text { (AE-710-101) }\end{array}$ & $\begin{array}{l}\text { - Procedures } \\
\text { - Training }\end{array}$ & $\begin{array}{l}\text { The fluidizing pump speed is controlled by } \\
\text { variable frequency drive ECRT-VFD- } 5 \text {. The } \\
\text { pump speed will be set during pre-operational } \\
\text { testing. There will be no procedural steps } \\
\text { directing operators to adjust the pump speed. }\end{array}$ \\
\hline
\end{tabular}




\begin{tabular}{|c|c|c|c|c|c|c|c|}
\hline \multirow{2}{*}{ Item } & \multirow{2}{*}{$\begin{array}{l}\text { Process } \\
\text { Parameter }\end{array}$} & \multirow{2}{*}{ Deviation } & \multirow{2}{*}{ Cause } & \multirow{2}{*}{ Consequences } & \multicolumn{2}{|c|}{ Candidate Controls } & \multirow{2}{*}{ Remarks } \\
\hline & & & & & Engineered & Administrative & \\
\hline 1. $a-4$ & Flow & Reverse & $\begin{array}{l}\text { Booster pump } \\
\text { ECRT-P-101 runs in } \\
\text { reverse (see remarks) }\end{array}$ & $\begin{array}{l}\text { Uncontrolled Release/Radiological } \\
\text { Control: } \\
\text { If booster pump ECRT-P-101 runs in } \\
\text { reverse, then sludge/basin water could } \\
\text { flow into the fluidizing jet IXM water } \\
\text { supply line to a point above the basin } \\
\text { water (see remarks). } \\
\text { If the fluidizing jet IXM water supply line } \\
\text { failed due to the pressure generated by } \\
\text { pump ECRT-P-101, then a spray or } \\
\text { splash and splatter/pool release could } \\
\text { occur. } \\
\text { If air is pumped into an Engineered } \\
\text { Container, then it will bubble to the } \\
\text { surface of basin water and could result in } \\
\text { elevated airborne radioactivity levels. }\end{array}$ & $\begin{array}{l}\text { - IXM water pressure } \\
\text { instrumentation (PT-700-1B, } \\
-3 B \text { ) } \\
\text { - IXM water flow rate } \\
\text { instrumentation (FIT-700-1, } \\
-2 \text { ) } \\
\text { - Check valve ECRT-CV-2 }\end{array}$ & $\begin{array}{l}\text { - Procedures } \\
\text { - Training } \\
\text { - Pre-operational testing } \\
\text { - Radiological Control } \\
\text { Program }\end{array}$ & $\begin{array}{l}\text { Fluidizing pump ECRT-P-52 is a centrifugal } \\
\text { pump. Once installed correctly, as verified by } \\
\text { pre-operational testing, it cannot pump in the } \\
\text { reverse direction even if the blade rotation is } \\
\text { reversed. } \\
\text { The design of booster pump ECRT-P-101 is } \\
\text { such that it can be operated in the reverse } \\
\text { direction. However, there are no plans to } \\
\text { operate the pump in reverse. } \\
\text { Operating the pump in reverse would be one } \\
\text { option for clearing a plugged Xago Hydrolance } \\
\text { or transfer line. However, other means to clear a } \\
\text { plug exist. For example, IXM water can be } \\
\text { connected to basin water flush valve } \\
\text { ECRT-AOV-101 and used to flush the line in the } \\
\text { reverse direction. } \\
\text { If booster pump ECRT-P-101 was run in } \\
\text { reverse, then the sludge in the line and basin } \\
\text { water would be pumped out of the Coanda head } \\
\text { and into the Engineered Container. In order for } \\
\text { sludge/basin water to be forced into the } \\
\text { fluidizing jets, the sludge in the container around } \\
\text { the fluidizing jet zone of influence would need to } \\
\text { be sufficiently strong to not yield to the pressure } \\
\text { of the reverse flow. This is considered to be an } \\
\text { extremely unlikely event. }\end{array}$ \\
\hline 1.a-5 & Flow & $\begin{array}{l}\text { Misdirected } \\
\text { (to sludge } \\
\text { mobilization } \\
\text { tool) }\end{array}$ & $\begin{array}{l}\text { Valve ECRT-V-8 closed } \\
\text { and valve ECRT-V-9 } \\
\text { open- }\end{array}$ & $\begin{array}{l}\text { Operational Upset: } \\
\text { If valve ECRT-V-8 is closed and valve } \\
\text { ECRT-V- } 9 \text { is open, then fluidizing jet } \\
\text { water will be misdirected to the sludge } \\
\text { mobilization tool. Sludge in the } \\
\text { Engineered Container will not be undercut } \\
\text { in the vicinity of the Xago Hydrolance }{ }^{T M} \\
\text { and thus will not collapse into the zone of } \\
\text { influence of the Coanda head. This will } \\
\text { result in a reduced vol\% solids content of } \\
\text { the retrieved sludge which could result in } \\
\text { additional fill/decant cycles }\end{array}$ & Valve position indicators & $\begin{array}{l}\text { - Procedures } \\
\text { - Training } \\
\text { - Operations verifies } \\
\text { proper system } \\
\text { configuration }\end{array}$ & \\
\hline
\end{tabular}




\begin{tabular}{|c|c|c|c|c|c|c|c|}
\hline \multirow{2}{*}{ Item } & \multirow{2}{*}{$\begin{array}{l}\text { Process } \\
\text { Parameter }\end{array}$} & \multirow{2}{*}{ Deviation } & \multirow{2}{*}{ Cause } & \multirow{2}{*}{ Consequences } & \multicolumn{2}{|c|}{ Candidate Controls } & \multirow{2}{*}{ Remarks } \\
\hline & & & & & Engineered & Administrative & \\
\hline 1.a.-6 & Flow & $\begin{array}{l}\text { Misdirected } \\
\text { (to Xago }^{\text {to }} \\
\text { Hydrolance }^{\mathrm{TM}} \\
\text { motive water } \\
\text { connection) }\end{array}$ & $\begin{array}{l}\text { Operator error in making } \\
\text { hose connections }\end{array}$ & $\begin{array}{l}\text { Operational Upset: } \\
\text { If fluidizing jet hose ECRT-H-2 was } \\
\text { erroneously connected to the Xago } \\
\text { Hydrolance } \\
\text { and motive water hose water connector; } \\
\text { connected to the fluidizing jet connector, } \\
\text { then sludge would not be efficiently } \\
\text { retrieved because (1) the motive water } \\
\text { would not fluidize the sludge effectively } \\
\text { and (2) the fluidizing jet flow rate is low } \\
\text { when the jets are not operated. }\end{array}$ & None & $\begin{array}{l}\text { - Procedures } \\
\text { - Training } \\
\text { - Operations verifies } \\
\text { proper system } \\
\text { configuration }\end{array}$ & $\begin{array}{l}\text { There are two Xago Hydrolances }{ }^{T M} \text { in the basin; } \\
\text { one located in the center bay and one located in } \\
\text { the east bay. Erroneous process connections } \\
\text { could occur when switching retrieval operations } \\
\text { from one bay to the next. The connections are } \\
\text { made at the grating level. }\end{array}$ \\
\hline $1 . a-7$ & Pressure & Low & $\begin{array}{l}\text { - Fluidizing pump } \\
\text { ECRT-P-52 not } \\
\text { operating } \\
\text { - Fluidizing pump speed } \\
\text { low }\end{array}$ & $\begin{array}{l}\text { Operational Upset: } \\
\text { If the fluidizing jet pressure was low, then } \\
\text { sludge in the Engineered Container may } \\
\text { not be effectively undercut and thus will } \\
\text { not collapse into the zone of influence of } \\
\text { the Coanda head. This will result in a } \\
\text { reduced vol\% solids content of the } \\
\text { retrieved sludge which could result in } \\
\text { additional fill/decant cycles. }\end{array}$ & $\begin{array}{l}\text { - IXM water pressure } \\
\text { instrumentation (PT-700-3B) } \\
\text { - IXM water flow rate } \\
\text { instrumentation (FIT-700-2) } \\
\text { - \% solids instrumentation } \\
\text { (AE-710-101) }\end{array}$ & $\begin{array}{l}\text { - Procedures } \\
\text { - Training }\end{array}$ & \\
\hline $1 . a-8$ & Pressure & High & $\begin{array}{l}\text { - Fluidizing pump speed } \\
\text { high } \\
\text { - A normally-open valve is } \\
\text { closed } \\
\text { - Fluidizing jets are } \\
\text { plugged }\end{array}$ & $\begin{array}{l}\text { Uncontrolled Release/Industrial Safety: } \\
\text { If the pressure is high, then the fluidizing } \\
\text { jet IXM water supply line could fail at a } \\
\text { location above the basin water. This } \\
\text { would result in a spill of IXM water (see } \\
\text { remarks). } \\
\text { If the failure occurred in hose ECRT-H-9, } \\
\text { located above the basin water, then the } \\
\text { hose could potentially whip and injure a } \\
\text { facility worker. }\end{array}$ & $\begin{array}{l}\text { - Valve position indicators } \\
\text { - Piping designed in } \\
\text { accordance with B31.3, } \\
\text { "Process Piping." } \\
\text { - IXM water pressure } \\
\text { instrumentation (PT-700-3B) } \\
\text { - Hose tie-downs }\end{array}$ & $\begin{array}{l}\text { - Procedures } \\
\text { - Training } \\
\text { - Conduct of operations } \\
\text { verifies proper system } \\
\text { - Ranfiguration } \\
\text { - Radiological Control } \\
\text { Program } \\
\text { - Industrial Safety } \\
\text { Program }\end{array}$ & $\begin{array}{l}\text { Relative to B31.3, the piping and hoses are } \\
\text { designed to withstand the deadhead pressure of } \\
\text { fluidizing pump ECRT-P-52. } \\
\text { Spills of IXM water constitute a minor } \\
\text { radiological hazard to facility workers based on } \\
\text { operational experience at the KW Basin. }\end{array}$ \\
\hline
\end{tabular}


Table C-2. HAZOP Results, Node 1.a., Sludge Retrieval - IXM Water to Xago Hydrolance " Fluidizing Jets

\begin{tabular}{|c|c|c|c|c|c|c|c|}
\hline \multirow{2}{*}{ Item } & \multirow{2}{*}{$\begin{array}{l}\text { Process } \\
\text { Parameter }\end{array}$} & \multirow{2}{*}{ Deviation } & \multirow{2}{*}{ Cause } & \multirow{2}{*}{ Consequences } & \multicolumn{2}{|c|}{ Candidate Controls } & \multirow{2}{*}{ Remarks } \\
\hline & & & & & Engineered & Administrative & \\
\hline 1.a-9 & Structural Integrity & Leak/rupture & $\begin{array}{l}\text { - High pressure } \\
\text { - Manufacturing flaw } \\
\text { - Procurement error }\end{array}$ & $\begin{array}{l}\text { Uncontrolled Release/Industrial Safety: } \\
\text { If the fluidizing jet IXM water supply line } \\
\text { failed at a location above the basin water, } \\
\text { then IXM water would be spilled (see } \\
\text { remarks). } \\
\text { If a rupture of hose ECRT-H-9 occurred, } \\
\text { then the hose, located above the basin } \\
\text { water could potentially whip and injure a } \\
\text { facility worker. }\end{array}$ & $\begin{array}{l}\text { - Piping designed in } \\
\text { accordance with B31.3, } \\
\text { "Process Piping." } \\
\text { - IXM water pressure } \\
\text { instrumentation (PT-700-3B) } \\
\text { - Hose tie-downs }\end{array}$ & $\begin{array}{l}\text { - Procedures } \\
\text { - Training } \\
\text { - Hydro testing } \\
\text { - Quality Assurance } \\
\text { Program } \\
\text { - Radiological Control } \\
\text { Program } \\
\text { - Industrial Safety } \\
\text { Program }\end{array}$ & $\begin{array}{l}\text { Relative to B31.3, the piping and hoses } \\
\text { designed to withstand the deadhead pressure of } \\
\text { fluidizing pump ECRT-P-52. } \\
\text { Spills of IXM water constitute a minor } \\
\text { radiological hazard to facility workers based on } \\
\text { operational experience at the KW Basin. }\end{array}$ \\
\hline 1.a-10 & Time Procedure & Too short & $\begin{array}{l}\text { - Operator error } \\
\text { - Equipment failure } \\
\text { (ECRT-HS-8, } \\
\text { ECRT-SOV-2, } \\
\text { ECRT-AOV-2) } \\
\text { - Loss of instrument air }\end{array}$ & $\begin{array}{l}\text { Operational Upset: } \\
\text { If the fluidizing jet pulse duration is too } \\
\text { short, then sludge in the Engineered } \\
\text { Container will not be undercut and thus } \\
\text { will not collapse into the zone of influence } \\
\text { of the Coanda head. This will result in a } \\
\text { reduced vol\% solids content of the } \\
\text { retrieved sludge which could result in } \\
\text { additional fill/decant cycles. }\end{array}$ & $\begin{array}{l}\text { - \% solids instrumentation } \\
\text { (AE-710-101) } \\
\text { Valve ECRT-AOV-2 position } \\
\text { and fault condition indicator } \\
\text { instrumentation (ZSO-700-7, } \\
\text { and -8) }\end{array}$ & $\begin{array}{l}\text { - Procedures } \\
\text { - Training }\end{array}$ & $\begin{array}{l}\text { To operate the fluidizing jets, the operator } \\
\text { presses and holds the "start fluidizing" switch. } \\
\text { This increases the speed of ECRT-P-52 and } \\
\text { opens valve ECRT-SOV-2 that provides } \\
\text { instrument air to valve ECRT-AOV-2 which then } \\
\text { opens permitting IXM water flow to the fluidizing } \\
\text { jets. The jets are typically pulsed for of duration } \\
\text { of } 3 \text { to } 10 \text { seconds. In this deviation, the } \\
\text { duration of the pulses is less than } 3 \text { seconds. }\end{array}$ \\
\hline $1 . a-11$ & Time Procedure & Too long & $\begin{array}{l}\text { - Operator error } \\
\text { - Equipment failure } \\
\text { (ECRT-HS-8, } \\
\text { ECRT-SOV-2, } \\
\text { ECRT-AOV-2) }\end{array}$ & $\begin{array}{l}\text { Operational Upset: } \\
\text { If the fluidizing jet pulse duration is too } \\
\text { long, then the average vol\% solids } \\
\text { content of the retrieved sludge will be } \\
\text { lower than desired which could result in } \\
\text { additional fill/decant cycles. } \\
\text { In the extreme case where the jets are } \\
\text { turned on and left on, then } 42 \mathrm{gpm} \text { of IXM } \\
\text { water would be added to the Engineered } \\
\text { Container while only } \sim 30 \mathrm{gpm} \text { net would } \\
\text { be withdrawn by the transfer system. } \\
\text { Consequently, } 12 \mathrm{gpm} \text { of sludge/water } \\
\text { slurry would flow from the engineered } \\
\text { container into the basin. }\end{array}$ & $\begin{array}{l}\text { - \% solids instrumentation } \\
\text { (AE-710-101) } \\
\text { - Valve ECRT-AOV-2 position } \\
\text { and fault condition indicator } \\
\text { instrumentation (ZSO-700-7, } \\
\text { and -8) } \\
\text { - IXM water flow rate } \\
\text { instrumentation (FIT-700-2) }\end{array}$ & $\begin{array}{l}\text { - Procedures } \\
\text { - Training }\end{array}$ & $\begin{array}{l}\text { In this deviation, the duration of the pulses is } \\
\text { greater than } 10 \text { seconds. }\end{array}$ \\
\hline
\end{tabular}


Table C-2. HAZOP Results, Node 1.a., Sludge Retrieval - IXM Water to Xago Hydrolance "m Fluidizing Jets

\begin{tabular}{|c|c|c|c|c|c|c|c|}
\hline \multirow{2}{*}{ Item } & \multirow{2}{*}{$\begin{array}{l}\text { Process } \\
\text { Parameter }\end{array}$} & \multirow{2}{*}{ Deviation } & \multirow{2}{*}{ Cause } & \multirow{2}{*}{ Consequences } & \multicolumn{2}{|c|}{ Candidate Controls } & \multirow{2}{*}{ Remarks } \\
\hline & & & & & Engineered & Administrative & \\
\hline 1.a-12 & Time Procedure & Skip action & Operator error & $\begin{array}{l}\text { Operation Upset: } \\
\text { If the fluidizing jets are not pulsed, then } \\
\text { sludge will not be mobilized and drawn } \\
\text { into the Coanda head. This will result in a } \\
\text { reduced vol\% solids content of the } \\
\text { retrieved sludge which could result in } \\
\text { additional fill/decant cycles. }\end{array}$ & $\begin{array}{l}\text { \% solids instrumentation } \\
\text { (AE-710-101) }\end{array}$ & $\begin{array}{l}\text { - Procedures } \\
\text { - Training }\end{array}$ & \\
\hline 1.a-13 & Time Procedure & $\begin{array}{l}\text { Wrong action } \\
\text { (too frequent) }\end{array}$ & $\begin{array}{l}\text { - Operator error } \\
\text { - Erroneous \% solids } \\
\text { indication }\end{array}$ & $\begin{array}{l}\text { Operational Upset: } \\
\text { If the operator pulses the fluidizing jets } \\
\text { too frequently, then the average vol\% } \\
\text { solids of the retrieved sludge will be } \\
\text { higher than desired. If the frequency is } \\
\text { sufficiently high, the consequences are } \\
\text { the same as pulsing for too long, i.e., the } \\
\text { average vol\% solids content of the } \\
\text { retrieved sludge will be lower than } \\
\text { desired. }\end{array}$ & $\begin{array}{l}\text { \% solids instrumentation } \\
\text { (AE-710-101) }\end{array}$ & N/A & $\begin{array}{l}\text { In this deviation, operators pulse the fluidizing } \\
\text { gets more frequently than required. }\end{array}$ \\
\hline
\end{tabular}




\begin{tabular}{|c|c|c|}
\hline Process Parameter & Design Intent & Remarks \\
\hline Flow & Nominally 41 gpm & $\begin{array}{l}\text { Motive force is motive flow pump ECRT-P-51. Variable frequency drive (ECRT-VFD-510) varies the speed of } \\
\text { the motive flow pump as a function of the flow rate at the booster pump suction as measured by flow element } \\
\text { FE-710-101. The speed is increased or decreased to maintain a flow rate of approximately } 70 \mathrm{gpm} \text {. }\end{array}$ \\
\hline Pressure & $\begin{array}{l}\text { Upstream of pump ECRT-P-51 = 100-130 psi } \\
\text { Downstream of pump ECRT-P-51 = } 213 \mathrm{psi}\end{array}$ & None \\
\hline Concentration & Not applicable & $\begin{array}{l}\text { The Skimmer Water Cleanup System takes basin water and pumps it first through a sand filter (for water } \\
\text { clarity) and then through an IXM (to remove ionic species). The IXM water composition/concentration is not a } \\
\text { critical attribute of Xago Hydrolance "' operability, i.e., Coanda performance would be identical using basin } \\
\text { water versus IXM water. }\end{array}$ \\
\hline Composition & Not applicable & $\begin{array}{l}\text { There are no other process fluids at the KW Basin that could be inadvertently connected or directed to the } \\
\text { Xago pump skid. }\end{array}$ \\
\hline Structural Integrity & Maintain integrity under normal operating conditions & The IXM water lines are a combination of piping and hoses. \\
\hline Level & Not applicable & There are no vessels associated with this node. \\
\hline Temperature & Not applicable & $\begin{array}{l}\text { Temperature is not a process parameter that is monitored or controlled. The } 1.3 \text { million gallons of water in the } \\
\text { KW Basin is maintained at a temperature of } 10-15^{\circ} \mathrm{C} \text {. The IXM water is approximately the same temperature } \\
\text { as the basin water, i.e., the pumps of the Skimmer Water Cleanup System do not impart significant thermal } \\
\text { energy to the water. Fluctuations in basin water temperature occur very slowly. The IXM water temperature } \\
\text { is not a critical attribute of Xago Hydrolance }{ }^{\mathrm{w}} \text { operability, i.e., Coanda head performance would be identical } \\
\text { for a wide range of basin water temperatures. }\end{array}$ \\
\hline Time Procedure & $\begin{array}{l}\text { The motive water is turned on prior to lowering the } \\
\text { Xago Hydrolance "into the sludge }\end{array}$ & $\begin{array}{l}\text { A portion of the motive water flow is directed to the Coanda head which fluidizes the sludge near the bottom of } \\
\text { the Xago Hydrolance thus allowing it to penetrate the sludge column and be lowered to the bottom of the } \\
\text { Engineered Container. }\end{array}$ \\
\hline
\end{tabular}


Table C-4. HAZOP Results, Node 1.b., Sludge Retrieval - IXM Motive Water to Xago Hydrolance ${ }^{\text {TI }}$

\begin{tabular}{|c|c|c|c|c|c|c|c|}
\hline \multirow{2}{*}{ Item } & \multirow{2}{*}{$\begin{array}{l}\text { Process } \\
\text { Parameter }\end{array}$} & \multirow{2}{*}{ Deviation } & \multirow{2}{*}{ Cause } & \multirow{2}{*}{ Consequences } & \multicolumn{2}{|c|}{ Candidate Controls } & \multirow{2}{*}{ Remarks } \\
\hline & & & & & Engineered & Administrative & \\
\hline 1.b-1.a & Flow & $\begin{array}{l}\text { No } \\
\text { (at start-up) }\end{array}$ & $\begin{array}{l}\text { - No IXM water supply from } \\
\text { the Skimmer Water } \\
\text { Cleanup System } \\
\text { - A normally-open valve is } \\
\text { closed }\end{array}$ & $\begin{array}{l}\text { Operational Upset: } \\
\text { If there is no motive water flow because } \\
\text { there is no IXM water supply, or because } \\
\text { valve ECRT-V-701, ECRT-AOV-1, } \\
\text { ECRT-V-3, or valve ECRT-V-5 is closed, } \\
\text { then there will be no motive water. } \\
\text { Consequently, it may not be possible to } \\
\text { lower the Xago Hydrolance }{ }^{\text {tw }} \text { into the } \\
\text { sludge bed. } \\
\text { Booster pump ECRT-P-101 will continue } \\
\text { to operate but will be suction-starved. } \\
\text { The Xago Hydrolance could plug. The } \\
\text { rupture disk downstream of booster pump } \\
\text { ECRT-P-101 could rupture. } \\
\text { If there is no motive water flow because } \\
\text { valve ECRT-V-5 is closed, then motive } \\
\text { flow pump ECRT-P-51 would deadhead } \\
\text { and could overheat. Deadheading the } \\
\text { pump would result in high pressure in the } \\
\text { line downstream of the pump (see ltem } \\
1 . b-6 \text { below). }\end{array}$ & $\begin{array}{l}\text { - Valve position indicators } \\
\text { IXM water pressure } \\
\text { instrumentation (PT-700-1B, } \\
-2 \mathrm{~B},-3 \mathrm{~B}) \\
\text { - IXM water flow rate } \\
\text { instrumentation (FIT-700-1, } \\
-2 \text { ) } \\
\text { \% solids instrumentation } \\
\text { (AE-710-01) }\end{array}$ & $\begin{array}{l}\text { - Procedures } \\
\text { - Training } \\
\text { - Conduct of operations } \\
\text { verifies proper system } \\
\text { configuration }\end{array}$ & $\begin{array}{l}\text { It would be readily apparent to operators at } \\
\text { the start-up of retrieval operations if there } \\
\text { was no IXM water supply. } \\
\text { Motive pump ECRT-P-51 is a centrifugal } \\
\text { pump. If it was not operating IXM water } \\
\text { would still flow through the pump at the flow } \\
\text { rate and pressure provided by the IXM water } \\
\text { system. } \\
\text { Valves ECRT-AOV-1 is an air-operated } \\
\text { valve. The valve close on loss of air. The } \\
\text { valve also closes on loss of power to } \\
\text { solenoid-operated valve ECRT-SOV-1. }\end{array}$ \\
\hline
\end{tabular}




\begin{tabular}{|c|c|c|c|c|c|c|c|}
\hline \multirow{2}{*}{ Item } & \multirow{2}{*}{$\begin{array}{l}\text { Process } \\
\text { Parameter }\end{array}$} & \multirow{2}{*}{ Deviation } & \multirow{2}{*}{ Cause } & \multirow{2}{*}{ Consequences } & \multicolumn{2}{|c|}{ Candidate Controls } & \multirow{2}{*}{ Remarks } \\
\hline & & & & & Engineered & Administrative & \\
\hline 1.b-1.b & Flow & \begin{tabular}{|l} 
No \\
(during \\
operation)
\end{tabular} & $\begin{array}{l}\text { - No IXM water supply from } \\
\text { the Skimmer Water } \\
\text { Cleanup System } \\
\text { - A normally-open valve is } \\
\text { closed }\end{array}$ & $\begin{array}{l}\text { Operational Upset: } \\
\text { If there is no motive water flow because } \\
\text { there is no IXM water supply, or because } \\
\text { valve ECRT-V-701, ECRT-AOV-1, } \\
\text { ECRT-V-3, or valve ECRT-V- } 5 \text { is closed, } \\
\text { then there will be no motive water. } \\
\text { Booster pump ECRT-P-101 will continue } \\
\text { to operate but will be suction-starved. } \\
\text { The Xago Hydrolance } \text { ' could plug. The } \\
\text { rupture disk downstream of booster pump } \\
\text { ECRT-P-101 could rupture. } \\
\text { If there is no motive water flow because } \\
\text { valve ECRT-V-5 is closed, then motive } \\
\text { flow pump ECRT-P-51 would deadhead } \\
\text { and could overheat. Deadheading the } \\
\text { pump would result in high pressure in the } \\
\text { line downstream of the pump (see Item } \\
1 . b-6 \text { below). }\end{array}$ & $\begin{array}{l}\text { - Valve position indicators } \\
\text { - IXM water pressure } \\
\text { instrumentation (PT-700-1B, } \\
-2 \mathrm{~B},-3 \mathrm{~B} \text { ) } \\
\text { - IXM water flow rate } \\
\text { instrumentation (FIT-700-1, } \\
-2 \text { ) } \\
\text { - \% solids instrumentation } \\
\text { (AE-710-01) }\end{array}$ & $\begin{array}{l}\text { - Procedures } \\
\text { - Training } \\
\text { - Conduct of operations } \\
\text { verifies proper system } \\
\text { configuration }\end{array}$ & $\begin{array}{l}\text { Motive pump ECRT-P-51 is a centrifugal } \\
\text { pump. If it was not operating IXM water } \\
\text { would still flow through the pump at the flow } \\
\text { rate and pressure provided by the IXM water } \\
\text { system. }\end{array}$ \\
\hline 1.b-2 & Flow & Low & $\begin{array}{l}\text { - Low IXM water supply } \\
\text { flow rate from the } \\
\text { Skimmer Water Cleanup } \\
\text { System } \\
\text { - Motive flow pump } \\
\text { ECRT-P-51 not operating } \\
\text { - Motive flow pump } \\
\text { ECRT-P-51 speed low } \\
\text { - A normally-open valve is } \\
\text { partially closed }\end{array}$ & $\begin{array}{l}\text { Operational Upset: } \\
\text { Similar to the no flow deviation, if the } \\
\text { motive water flow is low because of a low } \\
\text { flow rate from the IXM water supply, } \\
\text { booster pump ECRT-P-101 will continue } \\
\text { to operate but will be suction-starved. } \\
\text { The Xago Hydrolance } \\
\text { rupture could plug downstream of booster pump } \\
\text { ECRT-P-101 could rupture. } \\
\text { If there is low motive water flow because } \\
\text { valve ECRT-V-701 or ECRT-AOV-1 is } \\
\text { partially closed, then booster pump } \\
\text { ECRT-P-101 will continue to operate but } \\
\text { will be suction-starved. The } \\
\text { consequences are as stated above. }\end{array}$ & $\begin{array}{l}\text { - Valve position indicators } \\
\text { - IXM water pressure } \\
\text { instrumentation (PT-700-1B, } \\
-2 \mathrm{~B},-3 \mathrm{~B} \text { ) } \\
\text { - IXM water flow rate } \\
\text { instrumentation (FIT-700-1) } \\
\text { - \% solids instrumentation } \\
\text { (AE-710-01) }\end{array}$ & $\begin{array}{l}\text { - Procedures } \\
\text { - Training } \\
\text { - Conduct of operations } \\
\text { verifies proper system } \\
\text { configuration }\end{array}$ & $\begin{array}{l}\text { Motive flow pump ECRT-P-51 is a centrifugal } \\
\text { pump. If it was not operating IXM water } \\
\text { would still flow through the pump at the flow } \\
\text { rate and pressure provided by the IXM water } \\
\text { system. }\end{array}$ \\
\hline
\end{tabular}


Table C-4. HAZOP Results, Node 1.b., Sludge Retrieval - IXM Motive Water to Xago Hydrolance ${ }^{\mathrm{TM}}$

\begin{tabular}{|c|c|c|c|c|c|c|c|}
\hline \multirow{2}{*}{ Item } & \multirow{2}{*}{$\begin{array}{l}\text { Process } \\
\text { Parameter }\end{array}$} & \multirow{2}{*}{ Deviation } & \multirow{2}{*}{ Cause } & \multirow{2}{*}{ Consequences } & \multicolumn{2}{|c|}{ Candidate Controls } & \multirow{2}{*}{ Remarks } \\
\hline & & & & & Engineered & Administrative & \\
\hline 1.b-3 & Flow & High & $\begin{array}{l}\text { Motive flow pump ECRT-P } 5 \\
\text { speed high }\end{array}$ & $\begin{array}{l}\text { Operational Upset: } \\
\text { If the motive water flow rate is high but } \\
\text { less than } 70 \mathrm{gpm} \text {, then the vol\% solids } \\
\text { content of the retrieved sludge will be } \\
\text { reduced. } \\
\text { If the motive water flow rate is greater } \\
\text { than } 70 \mathrm{gpm} \text {, then only IXM water would } \\
\text { be transferred and flow in excess of } \\
70 \text {-gpm would be directed into the } \\
\text { Engineered Container. }\end{array}$ & $\begin{array}{l}\text { - IXM water pressure } \\
\text { instrumentation (PT-700-3B) } \\
\text { - IXM water flow rate } \\
\text { instrumentation (FIT-700-1) } \\
\text { \% \% solids instrumentation } \\
\text { (AE-710-01) }\end{array}$ & $\begin{array}{l}\text { - Procedures } \\
\text { - Training }\end{array}$ & \\
\hline $1 . b-4$ & Flow & Reverse & $\begin{array}{l}\text { Booster pump ECRT-P-101 } \\
\text { runs in reverse (see } \\
\text { remarks) }\end{array}$ & $\begin{array}{l}\text { Uncontrolled Release/Radiological } \\
\text { Control: } \\
\text { If booster pump ECRT-P-101 runs in } \\
\text { reverse, then sludge/basin water could } \\
\text { flow into the motive water IXM water } \\
\text { supply line to a point above the basin } \\
\text { water. } \\
\text { If the motive water IXM water supply line } \\
\text { failed due to the pressure generated by } \\
\text { pump ECRT-P-101, then a spray or } \\
\text { splash and splatter/pool release could } \\
\text { occur. } \\
\text { If air is pumped into an Engineered } \\
\text { Container, then it will bubble to the } \\
\text { surface of basin water and could result in } \\
\text { elevated airborne radioactivity levels. }\end{array}$ & $\begin{array}{l}\text { - IXM water pressure } \\
\text { instrumentation (PT-700-1B, } \\
\text {-2B) } \\
\text { IXM water flow rate } \\
\text { instrumentation (FIT-700-1) } \\
\text { - Check valves ECRT-CV-1 } \\
\text { and ECRT-CV-3 }\end{array}$ & $\begin{array}{l}\text { - Procedures } \\
\text { - Training } \\
\text { - Radiological Control } \\
\text { Program }\end{array}$ & See Table C-2, Item 1.a-4 \\
\hline 1.b-5 & Flow & $\begin{array}{l}\text { Misdirected } \\
\text { (to basin) }\end{array}$ & $\begin{array}{l}\text { Pressure safety valve } \\
\text { ECRT-PSV-1 inadvertently } \\
\text { opens }\end{array}$ & $\begin{array}{l}\text { Operational Upset: } \\
\text { If pressure safety valve ECRT-PSV-1 is } \\
\text { open, then all or a portion of the motive } \\
\text { water will be directed into the basin. } \\
\text { Sludge will not be retrieved or will be } \\
\text { retrieved at a reduced rate. }\end{array}$ & None & None & \\
\hline
\end{tabular}


Table C-4. HAZOP Results, Node 1.b., Sludge Retrieval - IXM Motive Water to Xago Hydrolance ${ }^{\text {TM }}$

\begin{tabular}{|c|c|c|c|c|c|c|c|}
\hline \multirow{2}{*}{ Item } & \multirow{2}{*}{$\begin{array}{l}\text { Process } \\
\text { Parameter }\end{array}$} & \multirow{2}{*}{ Deviation } & \multirow{2}{*}{ Cause } & \multirow{2}{*}{ Consequences } & \multicolumn{2}{|c|}{ Candidate Controls } & \multirow{2}{*}{ Remarks } \\
\hline & & & & & Engineered & Administrative & \\
\hline 1.a.-6 & Flow & $\begin{array}{l}\text { Misdirected } \\
\text { (to Xago } \\
\text { Hydrolance TM } \\
\text { fluidizing jet } \\
\text { connection) }\end{array}$ & $\begin{array}{l}\text { Operator error in making } \\
\text { hose connections }\end{array}$ & $\begin{array}{l}\text { Operational Upset: } \\
\text { If motive water hose ECRT-H-4 was } \\
\text { erroneously connected to the Xago } \\
\text { Hydrolance }{ }^{\mathrm{TM}} \text { fluidizing jet connector and } \\
\text { fluidizing hose ECRT-H-2 was connected } \\
\text { to motive water connector, then sludge } \\
\text { would not be efficiently retrieved because } \\
\text { (1) the motive water would not fluidize the } \\
\text { sludge effectively and (2) the fluidizing jet } \\
\text { flow rate is low when the jets are not } \\
\text { operated. }\end{array}$ & None & $\begin{array}{l}\text { - Procedures } \\
\text { - Training } \\
\text { - Operations verifies proper } \\
\text { system configuration }\end{array}$ & $\begin{array}{l}\text { There are two Xago Hydrolances }{ }^{\mathrm{TM}} \text {; one } \\
\text { located in the center bay and one located in } \\
\text { the east bay. Process connection errors } \\
\text { could occur when switching retrieval } \\
\text { operations from one bay to the next. The } \\
\text { connections are made at the grating level. }\end{array}$ \\
\hline $1 . b-6$ & Pressure & Low & $\begin{array}{l}\text { - Motive flow pump } \\
\text { ECRT-P-51 not operating } \\
\text { - Motive flow pump speed } \\
\text { set incorrectly }\end{array}$ & $\begin{array}{l}\text { Operational Upset: } \\
\text { If the motive water pressure is low, then } \\
\text { the flow rate will be low. Booster pump } \\
\text { ECRT-P-101 will continue to operate but } \\
\text { will be suction-starved. The Xago } \\
\text { Hydrolance could plug. The rupture disk } \\
\text { downstream of booster pump } \\
\text { ECRT-P-101 could rupture. }\end{array}$ & $\begin{array}{l}\text { - IXM water pressure } \\
\text { instrumentation (PT-700-2B) } \\
\text { - IXM water flow rate } \\
\text { instrumentation (FIT-700-2) } \\
\text { - \% solids instrumentation } \\
\text { (AE-710-01) }\end{array}$ & $\begin{array}{l}\text { - Procedures } \\
\text { - Training }\end{array}$ & \\
\hline $1 . \mathrm{b}-7$ & Pressure & High & $\begin{array}{l}\text { - A normally-open valve is } \\
\text { closed } \\
\text { - Booster pump } \\
\text { ECRT-P-101 not } \\
\text { operating }\end{array}$ & $\begin{array}{l}\text { Uncontrolled Release/Industrial Safety: } \\
\text { If the pressure is high, then the motive } \\
\text { water IXM water supply line could fail at a } \\
\text { location above the basin water. This } \\
\text { would result in a spill of IXM water (see } \\
\text { remarks). } \\
\text { If the failure occurred in hose ECRT-H-10, } \\
\text { located above the basin water, then the } \\
\text { hose could whip and potentially injure a } \\
\text { facility worker. }\end{array}$ & $\begin{array}{l}\text { - Pressure safety valve } \\
\text { ECRT-PSV-1 } \\
\text { - Valve position indicators } \\
\text { - IXM water pressure } \\
\text { instrumentation (PT-700-2B) } \\
\text { - Hose tie-downs }\end{array}$ & $\begin{array}{l}\text { - Procedures } \\
\text { - Training } \\
\text { - Conduct of operations } \\
\text { verifies proper system } \\
\text { configuration } \\
\text { - Radiological Control } \\
\text { Program } \\
\text { - Industrial Safety Program }\end{array}$ & $\begin{array}{l}\text { Pressure safety valve ECRT-PSV-1 provided } \\
\text { for compliance with B31.3, "Process Piping." } \\
\text { Spills of IXM water constitute a minor } \\
\text { radiological hazard to facility workers based } \\
\text { on operational experience at the KW Basin. }\end{array}$ \\
\hline
\end{tabular}




\begin{tabular}{|c|c|c|c|c|c|c|c|}
\hline \multirow{2}{*}{ Item } & \multirow{2}{*}{$\begin{array}{l}\text { Process } \\
\text { Parameter }\end{array}$} & \multirow{2}{*}{ Deviation } & \multirow{2}{*}{ Cause } & \multirow{2}{*}{ Consequences } & \multicolumn{2}{|c|}{ Candidate Controls } & \multirow{2}{*}{ Remarks } \\
\hline & & & & & Engineered & Administrative & \\
\hline $1 . b-8$ & Structural Integrity & Leak/rupture & $\begin{array}{l}\text { - High pressure } \\
\text { - Manufacturing flaw } \\
\text { - Procurement error }\end{array}$ & $\begin{array}{l}\text { Uncontrolled Release/Industrial Safety: } \\
\text { If the motive water IXM water supply line } \\
\text { failed at a location above the basin water, } \\
\text { then IXM water would be spilled (see } \\
\text { remarks). } \\
\text { If a rupture of hose ECRT-H-10 occurred, } \\
\text { then the hose could whip and potentially } \\
\text { injure a facility worker. }\end{array}$ & $\begin{array}{l}\text { - IXM water pressure } \\
\text { instrumentation (PT-700-3B) } \\
\text { - Hose tie-downs }\end{array}$ & $\begin{array}{l}\text { - Procedures } \\
\text { - Training } \\
\text { - Hydro testing } \\
\text { - Quality Assurance Program } \\
\text { - Radiological Control } \\
\text { Program } \\
\text { - Industrial Safety Program }\end{array}$ & $\begin{array}{l}\text { Spills of IXM water constitute a minor } \\
\text { radiological hazard to facility workers based } \\
\text { on operational experience at the KW Basin. }\end{array}$ \\
\hline 1.b-9 & Time Procedure & Too fast & $\begin{array}{l}\text { - Operator error } \\
\text { - Hoist control failure }\end{array}$ & $\begin{array}{l}\text { Operational Upset: } \\
\text { If the Xago Hydrolance }{ }^{\mathrm{m}} \text { is lowered too } \\
\text { quickly into the sludge, then the } \\
\text { hydrolance could become plugged. } \\
\text { Booster pump ECRT-P-101 will continue } \\
\text { to operate but will be suction-starved. The } \\
\text { rupture disk downstream of booster pump } \\
\text { ECRT-P-101 could rupture }\end{array}$ & $\begin{array}{l}\text { - Hoist operates at fixed speed } \\
\text { - \% solids instrumentation } \\
\text { (AE-710-01) }\end{array}$ & $\begin{array}{l}\text { - Procedures } \\
\text { - Training }\end{array}$ & $\begin{array}{l}\text { The Xago Hydrolance }{ }^{\mathrm{m}} \text { is lowered into the } \\
\text { sludge by the use of a hoist. }\end{array}$ \\
\hline 1.b-10 & Time Procedure & Too slow & $\begin{array}{l}\text { - Operator error } \\
\text { - Hoist control failure }\end{array}$ & $\begin{array}{l}\text { Operational Upset: } \\
\text { If the Xago Hydrolance }{ }^{\text {tm }} \text { is lowered too } \\
\text { slowly, then there will be a reduced } \\
\text { vol\% solids content of the retrieved } \\
\text { sludge which could result in additional } \\
\text { fill/decant cycles. }\end{array}$ & $\begin{array}{l}\text { - Hoist operates at fixed speed } \\
\text { - \% solids instrumentation } \\
\text { (AE-710-01) } \\
\text { - IXM water flow rate } \\
\text { instrumentation (FT-700-2) }\end{array}$ & $\begin{array}{l}\text { - Procedures } \\
\text { - Training }\end{array}$ & \\
\hline 1.b-11 & Time Procedure & Skip action & Operator error & $\begin{array}{l}\text { Operation Upset: } \\
\text { If the Xago Hydrolance }{ }^{\mathrm{m}} \text { is not lowered } \\
\text { into the sludge, then only IXM water } \\
\text { would be transferred to the STSC. }\end{array}$ & $\begin{array}{l}\text { \% solids instrumentation } \\
\text { (AE-710-01) }\end{array}$ & $\begin{array}{l}\text { - Procedures } \\
\text { - Training }\end{array}$ & \\
\hline 1.b-12 & Time Procedure & Wrong action & N/A & N/A & N/A & N/A & $\begin{array}{l}\text { There are no wrong actions that an operator } \\
\text { could make relative to lowering the Xago } \\
\text { Hydrolance }{ }^{\mathbf{m}} \text { in addition to the deviations too } \\
\text { fast, too slow, and skip action. }\end{array}$ \\
\hline
\end{tabular}


Table C-5. Normal Operating Conditions, Node 2.a., Sludge Transfer - Engineered Container to Ingress/Egress Pipe

\begin{tabular}{|c|c|c|}
\hline Process Parameter & Design Intent & Remarks \\
\hline Flow & $70 \mathrm{gpm}$ & Motive force is booster pump ECRT-P-101 \\
\hline Pressure & $\begin{array}{l}\text { Upstream of pump ECRT-P-101 }=-5 \text { to } 0 \mathrm{psi} \\
\text { At booster pump ECRT-P-101 discharge }=80-100 \mathrm{psi}\end{array}$ & $\begin{array}{l}\text { The discharge pressure is a function of the vol\% solids in the sludge. A higher vol\% solids will } \\
\text { result in a higher discharge pressure. }\end{array}$ \\
\hline Concentration & $\begin{array}{l}\text { KE/KW sludge: minimum average } 5 \text { vol\% solids } \\
\text { Settler tank sludge: minimum average } 2 \text { vol\% solids }\end{array}$ & $\begin{array}{l}\text { For engineered containers } 210,220,240,250, \text { and } 260 \text { the as-settled sludge in the containers is } \\
24-25 \text { vol\% solids. For engineered container } 230 \text { (which contains settler tank sludge) the as-settled } \\
\text { sludge in the container is } 30 \text { vol\% solids. During transfers, operators control the volume percent } \\
\text { solids by pulsing the fluidizing jets based on readings from the percent solids meter. The process } \\
\text { flowsheet concentration is an average of at least } 5 \text { vol\% solids for } \mathrm{KE} / \mathrm{KW} \text { sludge and at least } 2 \\
\text { vol\% solids for settler tank sludge. In testing conducted with } \mathrm{KW} \text { sludge simulant, the Xago } \\
\text { Hydrolance transferred an average } 10.3 \text { vol\% solids with a peak of } 16.3 \text { vol\% solids. In testing } \\
\text { with settler tank sludge simulant, the average was } 4.4 \text { vol\% solids with a peak of } 8.1 \text { vol\% solids. }\end{array}$ \\
\hline Composition & Addressed in Node 2.c & $\begin{array}{l}\text { Deviations from the intended composition of the transfer are initiated in this node (i.e., Xago } \\
\text { Hydrolance }{ }^{T M} \text { inserted into wrong engineered container) but the associated potential consequences } \\
\text { occur at the STSC. Deviations in composition are therefore addressed in Node 2.c, "Sludge } \\
\text { Transfer - STSC." }\end{array}$ \\
\hline Structural Integrity & Maintain integrity under normal operating conditions & $\begin{array}{l}\text { The transfer lines from the engineered containers to the ingress/egress pipe are a combination of } \\
\text { piping and hoses. }\end{array}$ \\
\hline Level & Not applicable & $\begin{array}{l}\text { Level is "not applicable" because there are no vessels associated with this node. However, this } \\
\text { node is part of the Sludge Transfer node which does include transfer to the STSC. STSC normal } \\
\text { operating fill levels, which determine the time procedure of the transfer, are as follows: } \\
\text { KE/KW sludge }=3.31 \mathrm{~m}^{3} \text { of slurry } \\
\text { Settler tank sludge }=2.7 \mathrm{~m}^{3} \text { of slurry. } \\
\text { The STSC level is specifically addressed in Node 2.c., "Sludge Transfer - STSC." }\end{array}$ \\
\hline Temperature & Not applicable & $\begin{array}{l}\text { Temperature is not a process parameter that is monitored or controlled. The } 1.3 \text { million gallons of } \\
\text { water in the } \mathrm{KW} \text { Basin is maintained at a temperature of } 10-15^{\circ} \mathrm{C} \text {. The sludge in the containers } \\
\text { and the IXM motive water and fluidizing jet water are approximately the same temperature as the } \\
\text { basin water. Accordingly, the sludge transfer will also be approximately the same temperature as } \\
\text { the basin water. A calculation of the temperature increase due to booster pump operation indicates } \\
\text { a less than } 0.5^{\circ} \mathrm{F} \text { temperature increase. }\end{array}$ \\
\hline
\end{tabular}


Table C-5. Normal Operating Conditions, Node 2.a., Sludge Transfer - Engineered Container to Ingress/Egress Pipe

Process Parameter

Time Procedure
Design Intent

KE/KW sludge: First fill $=$ nominally 13 minutes

Settler tank sludge: First fill $=$ nominally 10 minutes
Remarks

For KE/KW sludge, $3.31 \mathrm{~m}^{3}$ of slurry is transferred into an STSC. For settler tank sludge the

volume transferred is $2.7 \mathrm{~m}^{3}$. At the planned transfer rate of $70 \mathrm{gpm}$, it takes approximately

minutes to transfer $3.31 \mathrm{~m}^{3}$, and approximately 10 minutes to transfer $2.7 \mathrm{~m}^{3}$. Following the first

fill/decant cycle, additional sludge transfers will be of shorter duration. 
Table C-6. HAZOP Results, Node 2.a., Sludge Transfer - Engineered Container to Ingress/Egress Pipe

\begin{tabular}{|c|c|c|c|c|c|c|c|}
\hline \multirow{2}{*}{ Item } & \multirow{2}{*}{ Process Parameter } & \multirow{2}{*}{ Deviation } & \multirow{2}{*}{ Cause } & \multirow{2}{*}{ Consequences } & \multicolumn{2}{|c|}{ Candidate Controls } & \multirow{2}{*}{ Remarks } \\
\hline & & & & & Engineered & Administrative & \\
\hline 2.a-1 & Flow & No & $\begin{array}{l}\text { - Booster pump } \\
\text { ECRT-P-101 is not } \\
\text { operating } \\
\text { - A normally-open valve } \\
\text { downstream of booster } \\
\text { pump ECRT-P-101 is } \\
\text { closed } \\
\text { - Transfer line plugged }\end{array}$ & $\begin{array}{l}\text { Operational Upset: } \\
\text { If there is no flow, then sludge will not be } \\
\text { transferred to the STSC. } \\
\text { If there is no flow in the transfer line and } \\
\text { motive flow pump ECRT-P-5 continues to } \\
\text { operate, then } 41 \text { gpm of IXM water will be } \\
\text { pumped into the Engineered Container. } \\
\text { This would disturb the sludge bed and } \\
\text { result in a carry-over of sludge into the } \\
\text { basin. } \\
\text { If there is no flow because a normally } \\
\text { open valve in closed, then booster pump } \\
\text { ECRT-P-101 would deadhead. This } \\
\text { would result in high pressure in the } \\
\text { transfer line downstream of the pump and } \\
\text { opening of rupture disk ECRT-PSE-101 or } \\
-102 \text { leading to a discharge of sludge } \\
\text { under the basin water surface (see Item } \\
2 . a-6 \text { below). }\end{array}$ & $\begin{array}{l}\text { - Booster pump "on" indicator } \\
\text { light (ECRT-IL-110) } \\
\text { - Valve position indicators } \\
\text { - Flow rate instrumentation } \\
\text { (FIT-710-101) } \\
\text { - Pressure instrumentation } \\
\text { (PT-710-101, -102) } \\
\text { - STSC level instrumentation } \\
\text { (LE-740-401) } \\
\text { - Rupture disks } \\
\text { ECRT-PSE-101 and -102. }\end{array}$ & $\begin{array}{l}\text { - Procedures } \\
\text { - Training } \\
\text { - Conduct of operations } \\
\text { verifies proper system } \\
\text { configuration } \\
\text { - Administrative control on } \\
\text { basin water level }\end{array}$ & $\begin{array}{l}\text { Rupture disks provided for compliance with } \\
\text { B31.3, "Process Piping." }\end{array}$ \\
\hline 2.a-2 & Flow & Low & $\begin{array}{l}\text { - Booster pump } \\
\text { ECRT-P-101 speed low } \\
\text { - A normally-open valve is } \\
\text { partially closed } \\
\text { - Transfer line partially } \\
\text { plugged }\end{array}$ & $\begin{array}{l}\text { Operational Upset: } \\
\text { If there is low flow in the transfer line, then } \\
\text { it will take longer to fill the STSC to the } \\
\text { required level. } \\
\text { If the flow rate is low enough, then solids } \\
\text { will not be transferred and could plug the } \\
\text { line. } \\
\text { If the line becomes completely plugged, } \\
\text { then it would deadhead the pump } \\
\text { resulting in a high pressure in the transfer } \\
\text { line downstream of the pump (see } \\
\text { Item } 2 . a-6 \text { below). }\end{array}$ & $\begin{array}{l}\text { - Valve position indicators } \\
\text { - Flow rate instrumentation } \\
\text { (FIT-710-101) } \\
\text { - Pressure instrumentation } \\
\text { (PTI-710-101, -102) } \\
\text { - STSC level instrumentation } \\
\text { (LE-740-401) } \\
\text { - Rupture disks } \\
\text { ECRT-PSE-101 and -102 }\end{array}$ & $\begin{array}{l}\text { - Procedures } \\
\text { - Training } \\
\text { - Conduct of operations } \\
\text { verifies proper system } \\
\text { configuration } \\
\text { - Administrative control on } \\
\text { basin water level }\end{array}$ & $\begin{array}{l}\text { Rupture disks provided for compliance with } \\
\text { B31.3, "Process Piping." } \\
\text { Rupture disks ECRT-PSE-101 and -102 } \\
\text { prevent the uncontrolled release above the } \\
\text { basin water as addressed in Node } 2 . b \text {. } \\
\text { The booster pump speed is controlled by } \\
\text { variable frequency drive ECRT-VFD-101. } \\
\text { The pump speed will be set during } \\
\text { pre-operational testing. There will be no } \\
\text { procedural steps directing operators to } \\
\text { adjust the pump speed. }\end{array}$ \\
\hline
\end{tabular}


Table C-6. HAZOP Results, Node 2.a., Sludge Transfer - Engineered Container to Ingress/Egress Pipe

\begin{tabular}{|c|c|c|c|c|c|c|c|}
\hline \multirow{2}{*}{ Item } & \multirow{2}{*}{ Process Parameter } & \multirow{2}{*}{ Deviation } & \multirow{2}{*}{ Cause } & \multirow{2}{*}{ Consequences } & \multicolumn{2}{|c|}{ Candidate Controls } & \multirow{2}{*}{ Remarks } \\
\hline & & & & & Engineered & Administrative & \\
\hline 2.a-3 & Flow & High & $\begin{array}{l}\text { Booster pump } \\
\text { ECRT-P-101 speed high }\end{array}$ & $\begin{array}{l}\text { Operational Upset: } \\
\text { If the flow rate is high, then the STSC will } \\
\text { be filled faster. } \\
\text { If the flow rate is sufficiently high, then the } \\
\text { booster pump will become } \\
\text { suction-starved. This could cause rupture } \\
\text { disk ECRT-PSE-101 or }-102 \text { downstream } \\
\text { of the pump to rupture and sludge would } \\
\text { be released under the basin water } \\
\text { surface. }\end{array}$ & $\begin{array}{l}\text { - Flow rate instrumentation } \\
\text { (FIT-710-101) } \\
\text { - Pressure instrumentation } \\
\text { (PI-710-101, -102) } \\
\text { - STSC level instrumentation } \\
\text { (LE-740-401) Rupture disks } \\
\text { ECRT-PSE-101 and -102 }\end{array}$ & $\begin{array}{l}\text { - Procedures } \\
\text { - Training } \\
\text { - Administrative control on } \\
\text { basin water level }\end{array}$ & $\begin{array}{l}\text { Rupture disks provided for compliance with } \\
\text { B31.3, "Process Piping." } \\
\text { Rupture disks ECRT-PSE-101 and -102 } \\
\text { prevent the uncontrolled release above the } \\
\text { basin water as addressed in Node 2.b. } \\
\text { The booster pump speed is controlled by } \\
\text { variable frequency drive ECRT-VFD-101. } \\
\text { The pump speed will be set during } \\
\text { pre-operational testing. There will be no } \\
\text { procedural steps directing operators to } \\
\text { adjust the pump speed. }\end{array}$ \\
\hline 2.a-4 & Flow & Reverse & $\begin{array}{l}\text { Booster pump } \\
\text { ECRT-P-101 runs in } \\
\text { reverse (see remarks) } \\
\text { See also Table C-8, Item } \\
\text { 2.b-4 }\end{array}$ & $\begin{array}{l}\text { Uncontrolled Release/Radiological } \\
\text { Control: } \\
\text { The consequences are as stated in } \\
\text { Table C-2, Item 1.a-4, and Table C-4, } \\
\text { Item 1.b-4. }\end{array}$ & $\begin{array}{l}\text { - Flow rate instrumentation } \\
\text { (FIT-710-101) } \\
\text { - Pressure instrumentation } \\
\text { (PT-710-101, -102) } \\
\text { - Check valves ECRT-CV-1 } \\
\text { and ECRT-CV-3 }\end{array}$ & $\begin{array}{l}\text { - Procedures } \\
\text { - Training } \\
\text { - Radiological Control } \\
\text { Program }\end{array}$ & See Table C-2, Item 1.a-4 \\
\hline 2.a-5 & Pressure & Low & $\begin{array}{l}\text { - Booster pump } \\
\text { ECRT-P-101 speed low } \\
\text { - Low vol\% solids }\end{array}$ & $\begin{array}{l}\text { Operational Upset: } \\
\text { If the booster pump speed is low, then the } \\
\text { flow rate will be low. The consequences } \\
\text { are as stated in ltem } 2 . a-2 \text { above. } \\
\text { If the slurry concentration is low, then the } \\
\text { booster pump discharge pressure will be } \\
\text { low. }\end{array}$ & $\begin{array}{l}\text { - Flow rate instrumentation } \\
\text { (FIT-710-101) } \\
\text { - Pressure instrumentation } \\
\text { (PT-710-101, -102) } \\
\text { - STSC level instrumentation } \\
\text { (LE-740-401) }\end{array}$ & $\begin{array}{l}\text { - Procedures } \\
\text { - Training }\end{array}$ & \\
\hline
\end{tabular}


Table C-6. HAZOP Results, Node 2.a., Sludge Transfer - Engineered Container to Ingress/Egress Pipe

\begin{tabular}{|c|c|c|c|c|c|c|c|}
\hline \multirow{2}{*}{ Item } & \multirow{2}{*}{ Process Parameter } & \multirow{2}{*}{ Deviation } & \multirow{2}{*}{ Cause } & \multirow{2}{*}{ Consequences } & \multicolumn{2}{|c|}{ Candidate Controls } & \multirow{2}{*}{ Remarks } \\
\hline & & & & & Engineered & Administrative & \\
\hline 2.a-6 & Pressure & High & $\begin{array}{l}\text { - Booster pump } \\
\text { ECRT-P-101 speed high } \\
\text { - A normally-open valve is } \\
\text { closed } \\
\text { - Transfer line plugged } \\
\text { - High vol\% solids }\end{array}$ & $\begin{array}{l}\text { Operational Upset: } \\
\text { If the booster pump speed is high, then } \\
\text { the flow rate will be high and the STSC } \\
\text { will be filled faster. } \\
\text { If the pressure is sufficiently high, then } \\
\text { rupture disk ECRT-PSE-101 or -102 } \\
\text { would fail and sludge would be released } \\
\text { under the basin water surface. } \\
\text { In an unmitigated scenario where no } \\
\text { credit is taken for the rupture disks, then } \\
\text { high pressure could result in a transfer } \\
\text { line failure and, for this particular node, } \\
\text { sludge would be released under the basin } \\
\text { water surface. }\end{array}$ & $\begin{array}{l}\text { - Valve position indicators } \\
\text { - Flow rate instrumentation } \\
\text { (FIT-710-101) } \\
\text { - Pressure instrumentation } \\
\text { (PT-710-101, -102) } \\
\text { - Rupture disks } \\
\text { ECRT-PSE-101 and } \\
\text { ECRT-PSE-102 }\end{array}$ & $\begin{array}{l}\text { - Procedures } \\
\text { - Training } \\
\text { - Conduct of operations } \\
\text { verifies proper system } \\
\text { configuration } \\
\text { - Administrative control on } \\
\text { basin water level }\end{array}$ & $\begin{array}{l}\text { Rupture disks provided for compliance with } \\
\text { B31.3, "Process Piping." } \\
\text { Rupture disks ECRT-PSE-101 and -102 } \\
\text { prevent the uncontrolled release above the } \\
\text { basin water as addressed in Node 2.b. }\end{array}$ \\
\hline 2.a-7 & Concentration & No & $\begin{array}{l}\text { Xago Hydrolance }{ }^{\mathrm{m}} \text { not } \\
\text { lowered into sludge due to: } \\
\text { - Operator error } \\
\text { - Hoist control failure }\end{array}$ & $\begin{array}{l}\text { Operational Upset: } \\
\text { If the Xago Hydrolance }{ }^{m} \text { is not lowered } \\
\text { into the sludge, then only IXM water and } \\
\text { basin water will be transferred to the } \\
\text { STSC. This would result in an additional } \\
\text { fill/decant cycle. }\end{array}$ & $\begin{array}{l}\text { \% solids instrumentation } \\
\text { (AE-710-101) }\end{array}$ & $\begin{array}{l}\text { - Procedures } \\
\text { - Training }\end{array}$ & \\
\hline 2.a-8 & Concentration & Low & $\begin{array}{l}\text { - Fluidizing jet } \\
\text { maloperation (see } \\
\text { Table C-2) } \\
\text { - High motive water flow } \\
\text { rate } \\
\text { - Xago Hydrolance } \\
\text { lowered too slow }\end{array}$ & $\begin{array}{l}\text { Operational Upset: } \\
\text { If the vol\% solids is low, then additional } \\
\text { fill/decant cycles will be required. }\end{array}$ & $\begin{array}{l}\text { - \% solids instrumentation } \\
\text { (AE-710-101) } \\
\text { - IXM water pressure } \\
\text { instrumentation (PT-700-1B, } \\
-2 \mathrm{~B},-3 \mathrm{~B} \text { ) } \\
\text { - IXM water flow rate } \\
\text { instrumentation (FIT-700-1, } \\
\text {-2) }\end{array}$ & $\begin{array}{l}\text { - Procedures } \\
\text { - Training }\end{array}$ & \\
\hline
\end{tabular}


Table C-6. HAZOP Results, Node 2.a., Sludge Transfer - Engineered Container to Ingress/Egress Pipe

\begin{tabular}{|c|c|c|c|c|c|c|c|}
\hline \multirow{2}{*}{ Item } & \multirow{2}{*}{ Process Parameter } & \multirow{2}{*}{ Deviation } & \multirow{2}{*}{ Cause } & \multirow{2}{*}{ Consequences } & \multicolumn{2}{|c|}{ Candidate Controls } & \multirow{2}{*}{ Remarks } \\
\hline & & & & & Engineered & Administrative & \\
\hline $2 . a-9$ & Concentration & High & $\begin{array}{l}\text { - Xago Hydrolance }{ }^{\mathrm{m}} \\
\text { lowered into sludge too } \\
\text { fast } \\
\text { - Fluidizing jets pulsed too } \\
\text { frequently }\end{array}$ & $\begin{array}{l}\text { Operational Upset: } \\
\text { If the vol\% solids is too high, then sludge } \\
\text { may settle out in the transfer line and form } \\
\text { a plug. If a plug forms and booster pump } \\
\text { ECRT-P-101 continues to operate, then } \\
\text { rupture disk ECRT-PSE-101 or -102 } \\
\text { would fail and sludge would be released } \\
\text { under the surface of the basin water. } \\
\text { In an unmitigated scenario where no } \\
\text { credit is taken for the rupture disk, then } \\
\text { high pressure could result in a transfer } \\
\text { line failure and, for this particular node, } \\
\text { sludge would be released under the } \\
\text { surface of the basin water. }\end{array}$ & $\begin{array}{l}\text { - \% solids instrumentation } \\
\text { (AE-710-101) } \\
\text { - Flow rate instrumentation } \\
\text { (FIT-710-101) } \\
\text { - Pressure instrumentation } \\
\text { (PT-710-101, -102) } \\
\text { - Rupture disk ECRT-PSE-101 } \\
\text { and -102 }\end{array}$ & $\begin{array}{l}\text { - Procedures } \\
\text { - Training } \\
\text { - Administrative control on } \\
\text { basin water level }\end{array}$ & $\begin{array}{l}\text { Rupture disks provided for compliance with } \\
\text { B31.3, "Process Piping." }\end{array}$ \\
\hline 2.a-10 & Composition & Other & See Table C-10, Item 2.c-7 & See Table C-10, Item 2.c-7 & See Table C-10, Item 2.c-7 & See Table C-10, Item 2.c-7 & $\begin{array}{l}\text { Deviations from the intended composition of } \\
\text { the transfer are initiated in this node } \\
\text { (i.e., Xago Hydrolance }{ }^{T M} \text { inserted into wrong } \\
\text { engineered container) but the associated } \\
\text { potential consequences occur at the STSC. } \\
\text { Deviations in composition are therefore } \\
\text { addressed in Node 2.c, "Sludge Transfer - } \\
\text { STSC." }\end{array}$ \\
\hline 2.a-11 & Structural Integrity & Leak/rupture & $\begin{array}{l}\text { - High pressure (see } \\
\text { Item 2.a-6 above) } \\
\text { - Pulsation damper failure } \\
\text { - Manufacturing flaw } \\
\text { - Procurement error }\end{array}$ & $\begin{array}{l}\text { Operational Upset: } \\
\text { For this particular node, if the transfer line } \\
\text { failed, sludge would be released under } \\
\text { the surface of the basin water }\end{array}$ & $\begin{array}{l}\text { - Flow rate instrumentation } \\
\text { (FIT-710-101) } \\
\text { - Pressure instrumentation } \\
\text { (PT-710-101, -102) }\end{array}$ & $\begin{array}{l}\text { - Procedures } \\
\text { - Training } \\
\text { - Hydro testing } \\
\text { - Visual observation } \\
\text { - Quality Assurance Program } \\
\text { - Administrative control on } \\
\text { basin water level }\end{array}$ & \\
\hline 2.a-12 & Time Procedure & Too fast & $\begin{array}{l}\text { High flow rate (see } \\
\text { Item 2.a-3 above) }\end{array}$ & $\begin{array}{l}\text { Operational Upset: } \\
\text { If the flow rate is high, then the STSC will } \\
\text { be filled to the required level in a shorter } \\
\text { time period. }\end{array}$ & $\begin{array}{l}\text { - Flow rate instrumentation } \\
\text { (FIT-710-101) } \\
\text { - Pressure instrumentation } \\
\text { (PT-710-101, -102) } \\
\text { - STSC level instrumentation } \\
\text { (LE-740-401) }\end{array}$ & $\begin{array}{l}\text { - Procedures } \\
\text { - Training }\end{array}$ & \\
\hline
\end{tabular}


PRC-STP-00467 REV 0

Table C-6. HAZOP Results, Node 2.a., Sludge Transfer - Engineered Container to Ingress/Egress Pipe

\begin{tabular}{|c|c|c|c|c|c|c|c|}
\hline \multirow{2}{*}{ Item } & \multirow{2}{*}{ Process Parameter } & \multirow{2}{*}{ Deviation } & \multirow{2}{*}{ Cause } & \multirow{2}{*}{ Consequences } & \multicolumn{2}{|c|}{ Candidate Controls } & \multirow{2}{*}{ Remarks } \\
\hline & & & & & Engineered & Administrative & \\
\hline 2.a-13 & Time Procedure & Too slow & $\begin{array}{l}\text { Low flow rate (see } \\
\text { Item 2.a-2 above) }\end{array}$ & $\begin{array}{l}\text { Operational Upset: } \\
\text { If the flow rate is low, then it will take } \\
\text { longer to fill the STSC to the required } \\
\text { level. }\end{array}$ & $\begin{array}{l}\text { - Flow rate instrumentation } \\
\text { (FIT-710-101) } \\
\text { - Pressure instrumentation } \\
\text { (PT-710-101, -102) } \\
\text { - STSC level instrumentation } \\
\text { (LE-740-401) }\end{array}$ & $\begin{array}{l}\text { - Procedures } \\
\text { - Training }\end{array}$ & \\
\hline 2.a-14 & Time Procedure & Skip action & $N / A$ & N/A & N/A & N/A & $\begin{array}{l}\text { There is no skipped action associated with } \\
\text { this node. }\end{array}$ \\
\hline 2.a-15 & Time Procedure & Wrong action & N/A & N/A & N/A & N/A & $\begin{array}{l}\text { There is no wrong action associated with this } \\
\text { node. }\end{array}$ \\
\hline
\end{tabular}


Table C-7. Normal Operating Conditions, Node 2.b., Sludge Transfer - Ingress/Egress Pipe to STSC

\begin{tabular}{|c|c|c|}
\hline Process Parameter & Design Intent & Remarks \\
\hline Flow & $70 \mathrm{gpm}$ & Motive force is booster pump ECRT-P-101 \\
\hline Pressure & At booster pump ECRT-P-101 discharge $=80-100 \mathrm{psi}$ & $\begin{array}{l}\text { The discharge pressure is a function of the vol\% solids in the sludge. A higher vol\% solids will } \\
\text { result in a higher discharge pressure. }\end{array}$ \\
\hline Concentration & $\begin{array}{l}\text { KE/KW sludge: minimum average } 5 \text { vol\% solids } \\
\text { Settler tank sludge: minimum average } 2 \text { vol\% solids }\end{array}$ & 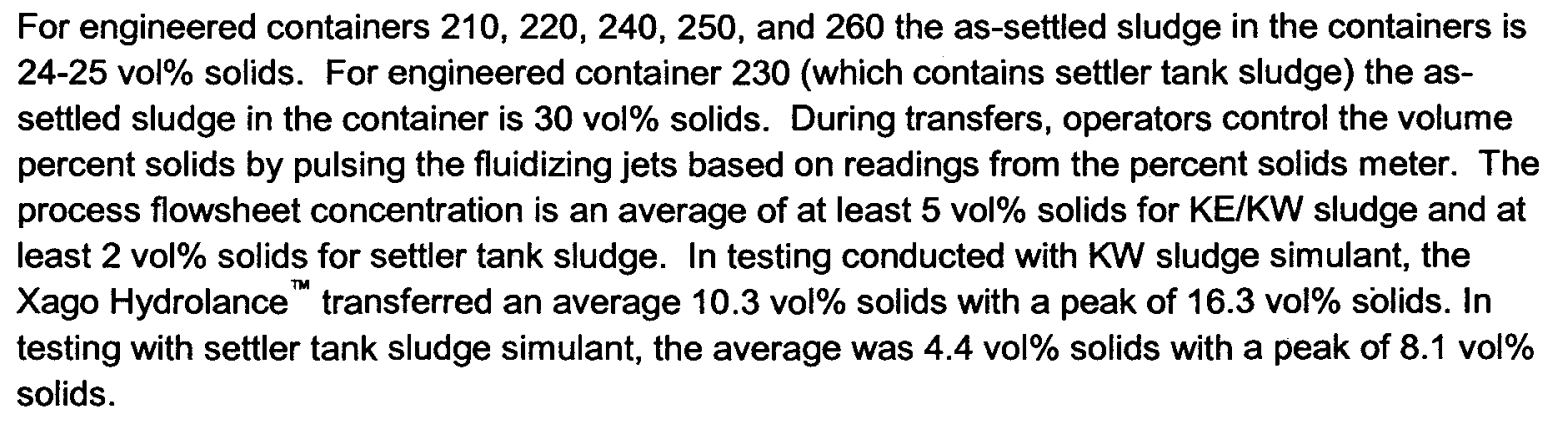 \\
\hline Composition & $\begin{array}{l}\text { KE/KW sludge is to be transferred to an STSC that does not } \\
\text { contain an inner core } \\
\text { Settler tank sludge to transferred to an STSC that contains and } \\
\text { inner core }\end{array}$ & Deviations in composition are addressed in Node 2.c, "Sludge Transfer - STSC." \\
\hline Structural Integrity & Maintain integrity under normal operating conditions & $\begin{array}{l}\text { The transfer lines from the engineered containers to the ingress/egress pipe are a combination of } \\
\text { piping and hoses. }\end{array}$ \\
\hline Level & Not applicable & $\begin{array}{l}\text { Level is "not applicable" because there are no vessels associated with this node. However, this } \\
\text { node is part of the Sludge Transfer node which does include transfer to the STSC. STSC normal } \\
\text { operating fill levels, which determine the time procedure of the transfer, are as follows: } \\
\text { KE } / K W \text { sludge }=3.3 \mathrm{~m}^{3} \text { of slurry } \\
\text { Settler tank sludge }=2.7 \mathrm{~m}^{3} \text { of slurry. } \\
\text { The STSC level is specifically addressed in Node 2.c., "Sludge Transfer - STSC." }\end{array}$ \\
\hline Temperature & Not applicable & $\begin{array}{l}\text { Temperature is not a process parameter that is monitored or controlled. The } 1.3 \text { million gallons } \\
\text { of water in the KW Basin is maintained at a temperature of a } 10-15^{\circ} \mathrm{C} \text {. The sludge in the } \\
\text { containers and the IXM motive water and fluidizing jet water are approximately the same } \\
\text { temperature as the basin water. Accordingly, the sludge transfer will also be approximately the } \\
\text { same temperature as the basin water. A calculation of the temperature increase due to booster } \\
\text { pump operation indicates a less than } 0.5^{\circ} \mathrm{F} \text { temperature increase. }\end{array}$ \\
\hline
\end{tabular}


Table C-7. Normal Operating Conditions, Node 2.b., Sludge Transfer - Ingress/Egress Pipe to STSC

\begin{tabular}{|l|l|l|}
\hline \multicolumn{1}{|c|}{ Process Parameter } & \multicolumn{1}{|c|}{ Design Intent } & \multicolumn{1}{c|}{ Remarks } \\
\hline Time Procedure & KE/KW sludge: First fill $=13$ minutes \\
Settler tank sludge: First fill $=10$ minutes & $\begin{array}{l}\text { For } \mathrm{KE} / \mathrm{KW} \text { sludge, } 3.31 \mathrm{~m}^{3} \text { of slurry is transferred into an STSC. For settler tank sludge the } \\
\text { volume transferred is } 2.7 \mathrm{~m}^{3} \text {. At the planned transfer rate of } 70 \text { gpm, it takes approximately } 13 \\
\text { minutes to transfer } 3.31 \mathrm{~m}^{3}, \text { and approximately } 10 \text { minutes to transfer } 2.7 \mathrm{~m} \text {. Following the first } \\
\text { fill/decant cycle, additional sludge transfers will be of shorter duration. }\end{array}$ \\
\hline
\end{tabular}


Table C-8. HAZOP Results, Node 2.b., Sludge Transfer - Ingress/Egress Pipe to STSC

\begin{tabular}{|c|c|c|c|c|c|c|c|}
\hline \multirow{2}{*}{ Item } & \multirow{2}{*}{ Process Parameter } & \multirow{2}{*}{ Deviation } & \multirow{2}{*}{ Cause } & \multirow{2}{*}{ Consequences } & \multicolumn{2}{|c|}{ Candidate Controls } & \multirow{2}{*}{ Remarks } \\
\hline & & & & & Engineered & Administrative & \\
\hline $2 . b-1$ & Flow & No & See Table C-6, Item 2.a-1 & See Table C-6, Item 2.a-1 & See Table C-6, Item 2.a-1 & See Table C-6, Item 2.a-1 & See Table C-6, Item 2.a-1 \\
\hline 2.b-2 & Flow & Low & See Table C-6, Item 2.a-2 & See Table C-6, Item 2.a-2 & See Table C-6, Item 2.a-2 & See Table C-6, Item 2.a-2 & See Table C-6, Item 2.a-2 \\
\hline 2.b-3 & Flow & High & $\begin{array}{l}\text { Booster pump ECRT-P-101 } \\
\text { speed high }\end{array}$ & $\begin{array}{l}\text { Uncontrolled Release: } \\
\text { If the flow rate is high because booster } \\
\text { pump ECRT-P-101 speed is high, then } \\
\text { the booster pump will become } \\
\text { suction-starved. This could cause } \\
\text { rupture disk ECRT-PSE-101 or -102 } \\
\text { downstream of the booster pump to } \\
\text { rupture and sludge would be released } \\
\text { under the basin water surface. } \\
\text { In an unmitigated scenario where no } \\
\text { credit is taken for the rupture disks, then } \\
\text { the transfer line downstream of the } \\
\text { booster pump could fail (see remarks). } \\
\text { This could result in an airborne spray or } \\
\text { splash and splatter/pool release of } \\
\text { sludge. } \\
\text { See also Item } 2 . b-6 \text { below. }\end{array}$ & $\begin{array}{l}\text { - Flow rate instrumentation } \\
\text { (FIT-710-101) } \\
\text { - Pressure instrumentation } \\
\text { (PT-710-101, -102) } \\
\text { - Rupture disks } \\
\text { ECRT-PSE-101 and -102 } \\
\text { - Secondary containment with } \\
\text { leak detection } \\
\text { - Modified KW Basin Annex } \\
\text { confinement ventilation } \\
\text { - Continuous air monitors }\end{array}$ & 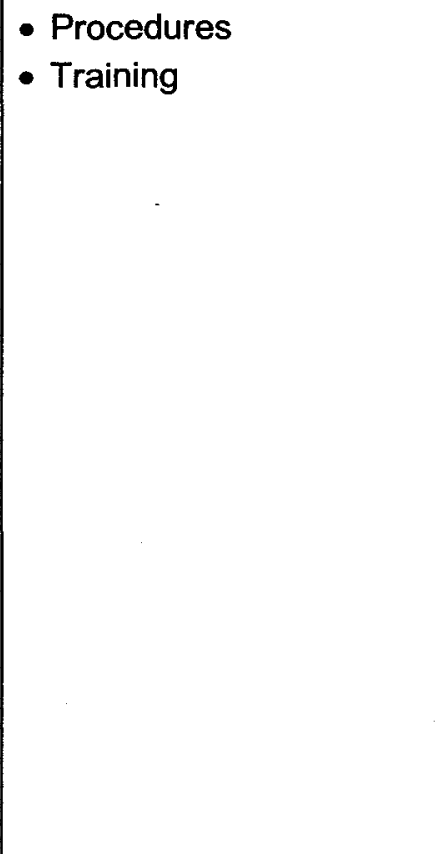 & $\begin{array}{l}\text { If the booster pump was suction-starved and } \\
\text { a rupture disk did not rupture, it is possible } \\
\text { that the transfer line downstream of the } \\
\text { booster pump could fail. The booster pump } \\
\text { speed is controlled by variable frequency } \\
\text { drive ECRT-VFD-101. The pump speed will } \\
\text { be set during pre-operational testing. There } \\
\text { will be no procedural steps directing } \\
\text { operators to adjust the pump speed. } \\
\text { Rupture disks provided for compliance with } \\
\text { B31.3, "Process Piping." }\end{array}$ \\
\hline 2.b-4.a & Flow & Reverse & $\begin{array}{l}\text { Booster pump ECRT-P-101 } \\
\text { runs in reverse }\end{array}$ & See Table C-6, Item 2.a-4 & See Table C-6, Item 2.a-4 & See Table C-6, Item 2.a-4 & See Table C-6, Item 2.a-4 \\
\hline 2.b-4.b & Flow & Reverse & $\begin{array}{l}\text { Siphon from STSC (see } \\
\text { remarks) }\end{array}$ & $\begin{array}{l}\text { Uncontrolled Release: } \\
\text { If sludge was siphoned from the STSC } \\
\text { due to a breach in the transfer line, then } \\
\text { a splash and splatter/pool release could } \\
\text { occur. }\end{array}$ & $\begin{array}{l}\text { - Secondary containment with } \\
\text { leak detectior } \\
\text { - Modified KW Basin Annex } \\
\text { confinement ventilation } \\
\text { - Continuous air monitors }\end{array}$ & - Procedures & $\begin{array}{l}\text { For a siphon to occur: (1) the liquid level in } \\
\text { the STSC would need to be above the level } \\
\text { of the distributor heads, and (2) a breech in } \\
\text { the transfer line below the elevation of the } \\
\text { liquid level would need to occur prior to } \\
\text { opening the transfer line high-point siphon } \\
\text { break. If a siphon occurred, sludge would } \\
\text { then be drawn from the STSC until it } \\
\text { reached the level of the distributer heads at } \\
\text { which point a siphon break would be } \\
\text { established. } \\
\text { If the STSC was full of sludge, approximately } \\
190 \text { gallons could be siphoned out. }\end{array}$ \\
\hline
\end{tabular}


Table C-8. HAZOP Results, Node 2.b., Sludge Transfer - Ingress/Egress Pipe to STSC

\begin{tabular}{|c|c|c|c|c|c|c|c|}
\hline \multirow{2}{*}{ Item } & \multirow{2}{*}{ Process Parameter } & \multirow{2}{*}{ Deviation } & \multirow{2}{*}{ Cause } & \multirow{2}{*}{ Consequences } & \multicolumn{2}{|c|}{ Candidate Controls } & \multirow{2}{*}{ Remarks } \\
\hline & & & & & Engineered & Administrative & \\
\hline 2.b-5.a & Flow & $\begin{array}{l}\text { Misdirected } \\
\text { (into Transfer } \\
\text { Line Service } \\
\text { Box) }\end{array}$ & $\begin{array}{l}\text { - Valving error such that } \\
\text { sludge enters box via IXM } \\
\text { water spray nozzles } \\
\text { - Valving error such that } \\
\text { sludge enters box via } \\
\text { siphon break } \\
\text { - Valving error such that } \\
\text { sludge enters box via } \\
\text { sump pump }\end{array}$ & $\begin{array}{l}\text { Uncontrolled Release: } \\
\text { If sludge is misdirected into the Transfer } \\
\text { Line Service Box, then a splash and } \\
\text { splatter/pool release would occur. } \\
\text { Hydrogen Deflagration: } \\
\text { If sludge is misdirected into the Transfer } \\
\text { Line Service Box, then hydrogen } \\
\text { generated by the sludge could } \\
\text { accumulate in the box resulting in a } \\
\text { deflagration. }\end{array}$ & $\begin{array}{l}\text { - Valve position indicators } \\
\text { - Check valve ECRT-CV-106 } \\
\text { (on sump pump transfer line) } \\
\text { - Secondary containment with } \\
\text { leak detection } \\
\text { - Transfer Line Service Box } \\
\text { active ventilation } \\
\text { - Modified KW Basin Annex } \\
\text { confinement ventilation } \\
\text { - Continuous air monitors }\end{array}$ & $\begin{array}{l}\text { - Procedures } \\
\text { - Training } \\
\text { - Conduct of operations } \\
\text { verifies proper system } \\
\text { configuration } \\
\text { - Leak detection alarm } \\
\text { response } \\
\text { - Modified KW Basin Annex } \\
\text { is unmanned during decant } \\
\text { operations }\end{array}$ & \\
\hline 2.b-5.b & Flow & $\begin{array}{l}\text { Misdirected } \\
\text { (into Transfer } \\
\text { Line Service Box } \\
\text { IXM water } \\
\text { supply }\end{array}$ & Valving error & $\begin{array}{l}\text { Uncontrolled Release: } \\
\text { If sludge is misdirected into the Transfer } \\
\text { Line Service Box IXM water supply, then } \\
\text { a spray or splash and splatter/pool } \\
\text { release could occur. }\end{array}$ & $\begin{array}{l}\text { - Valve position indicators } \\
\text { - Isolation valve } \\
\text { ECRT-AOV-104 } \\
\text { - Check valve ECRT-CV-105 } \\
\text { - Continuous air monitors }\end{array}$ & $\begin{array}{l}\text { - Procedures } \\
\text { - Training } \\
\text { - Conduct of operations } \\
\text { verifies proper system } \\
\text { configuration } \\
\text { - Modified KW Basin Annex } \\
\text { is unmanned during decant } \\
\text { operations }\end{array}$ & \\
\hline 2.b-5.c & Flow & $\begin{array}{l}\text { Misdirected } \\
\text { (into } \\
\text { decantflocculant } \\
\text { recirculation } \\
\text { line) }\end{array}$ & Valving error & $\begin{array}{l}\text { Uncontrolled Release: } \\
\text { If sludge is misdirected into the } \\
\text { decant/flocculant recirculation line, then } \\
\text { the line could be overpressurized and fail } \\
\text { resulting in as spray or splash and } \\
\text { splatter/pool release. }\end{array}$ & $\begin{array}{l}\text { - Valve position indicators } \\
\text { - Isolation valve } \\
\text { ECRT-AOV-105 } \\
\text { - Check valve ECRT-CV-202 } \\
\text { - Secondary containment with } \\
\text { lead detection } \\
\text { - Continuous air monitors }\end{array}$ & $\begin{array}{l}\text { - Procedures } \\
\text { - Training } \\
\text { - Conduct of operations } \\
\text { verifies proper system } \\
\text { configuration } \\
\text { - Modified KW Basin Annex } \\
\text { is unmanned during decant } \\
\text { operations }\end{array}$ & $\begin{array}{l}\text { Check valve ECRT-CV-202 is located in the } \\
\text { Decant Box. }\end{array}$ \\
\hline
\end{tabular}


Table C-8. HAZOP Results, Node 2.b., Sludge Transfer - Ingress/Egress Pipe to STSC

\begin{tabular}{|c|c|c|c|c|c|c|c|}
\hline \multirow{2}{*}{ Item } & \multirow{2}{*}{ Process Parameter } & \multirow{2}{*}{ Deviation } & \multirow{2}{*}{ Cause } & \multirow{2}{*}{ Consequences } & \multicolumn{2}{|c|}{ Candidate Controls } & \multirow{2}{*}{ Remarks } \\
\hline & & & & & Engineered & Administrative & \\
\hline 2.b-5.d & Flow & $\begin{array}{l}\text { Misdirected } \\
\text { (to overfill } \\
\text { recovery pump) }\end{array}$ & Valving error & $\begin{array}{l}\text { Uncontrolled Release: } \\
\text { If the slurry flow is misdirect to the overfill } \\
\text { recovery pump, then booster pump } \\
\text { ECRT-P-101 will deadhead resulting in } \\
\text { high pressure in the transfer line. In an } \\
\text { unmitigated scenario where no credit is } \\
\text { taken for the rupture disks, then high } \\
\text { pressure could result in a transfer line } \\
\text { failure resulting in an airborne spray or } \\
\text { splash and splatter/pool release. }\end{array}$ & $\begin{array}{l}\text { - Valve position indicators } \\
\text { - Flow rate instrumentation } \\
\text { (FIT-710-101) } \\
\text { - Pressure instrumentation } \\
\text { (PT-710-101, -102) } \\
\text { - Rupture disks } \\
\text { ECRT-PSE-101 and -102 } \\
\text { - Secondary containment with } \\
\text { leak detection } \\
\text { - Modified KW Basin Annex } \\
\text { confinement ventilation } \\
\text { - Continuous air monitors }\end{array}$ & $\begin{array}{l}\text { - Procedures } \\
\text { - Training } \\
\text { - Conduct of operations } \\
\text { verifies proper system } \\
\text { configuration }\end{array}$ & $\begin{array}{l}\text { Rupture disks provided for compliance with } \\
\text { B31.3, "Process Piping." }\end{array}$ \\
\hline $2 . b-6$ & Pressure & Low & See Table C-6, Item 2.a-5 & See Table C-6, Item 2.a-5 & See Table C-6, Item 2.a-5 & See Table C-6, Item 2.a-5 & See Table C-6, Item 2.a-5 \\
\hline 2.b-7 & Pressure & High & $\begin{array}{l}\text { - Booster pump } \\
\text { ECRT-P-101 speed high } \\
\text { - A normally-open valve is } \\
\text { closed } \\
\text { - Transfer line plugged }\end{array}$ & $\begin{array}{l}\text { Uncontrolled Release: } \\
\text { In an unmitigated scenario where no } \\
\text { credit is taken for the rupture disks, then } \\
\text { high pressure could result in a transfer } \\
\text { line failure resulting in an airborne spray } \\
\text { or splash and splatter/pool release. }\end{array}$ & $\begin{array}{l}\text { - Valve position indicators } \\
\text { - Flow rate instrumentation } \\
\text { (FIT-710-101) } \\
\text { - Pressure instrumentation } \\
\text { (PT-710-101, -102) } \\
\text { - Rupture disks } \\
\text { ECRT-PSE-101 and -102 } \\
\text { - Secondary containment with } \\
\text { leak detection } \\
\text { - Modified KW Basin Annex } \\
\text { confinement ventilation } \\
\text { - Continuous air monitors }\end{array}$ & $\begin{array}{l}\text { - Procedures } \\
\text { - Training } \\
\text { - Conduct of operations } \\
\text { verifies proper system } \\
\text { configuration }\end{array}$ & $\begin{array}{l}\text { Secondary containment includes the } \\
\text { hose-in-hose transfer line and the transfer } \\
\text { line service box. } \\
\text { Rupture disks provided for compliance with } \\
\text { B31.3, "Process Piping." }\end{array}$ \\
\hline 2.b-8 & Concentration & No & See Table C-6, Item 2.a-7 & See Table C-6, Item 2.a-7 & See Table C-6, Item 2.a-7 & See Table C-6, Item 2.a-7 & See Table C-6, Item 2.a-7 \\
\hline 2.b-9 & Concentration & Low & See Table C-6, Item 2.a-8 & See Table C-6, Item 2.a-8 & See Table C-6, Item 2.a-8 & See Table C-6, Item 2.a-8 & See Table C-6, Item 2.a-8 \\
\hline
\end{tabular}


Table C-8. HAZOP Results, Node 2.b., Sludge Transfer - Ingress/Egress Pipe to STSC

\begin{tabular}{|c|c|c|c|c|c|c|c|}
\hline \multirow{2}{*}{ Item } & \multirow{2}{*}{ Process Parameter } & \multirow{2}{*}{ Deviation } & \multirow{2}{*}{ Cause } & \multirow{2}{*}{ Consequences } & \multicolumn{2}{|c|}{ Candidate Controls } & \multirow{2}{*}{ Remarks } \\
\hline & & & & & Engineered & Administrative & \\
\hline 2.b-10 & Concentration & High & $\begin{array}{l}\text { - Xago Hydrolance }{ }^{\text {m }} \\
\text { lowered into sludge too } \\
\text { fast } \\
\text { - Fluidizing jets pulsed too } \\
\text { frequently }\end{array}$ & $\begin{array}{l}\text { Operational Upset: } \\
\text { If the vol\% solids is too high, then sludge } \\
\text { may settle out in the transfer line and } \\
\text { form a plug. If a plug forms and booster } \\
\text { pump ECRT-P-101 continues to operate, } \\
\text { then rupture disk ECRT-PSE-101 would } \\
\text { fail and sludge would be released under } \\
\text { the surface of the basin water. } \\
\text { Uncontrolled Release: } \\
\text { In an unmitigated scenario where no } \\
\text { credit is taken for the rupture disk, then } \\
\text { high pressure could result in a transfer } \\
\text { line failure resulting in an airborne spray } \\
\text { or splash and splatter/pool release. }\end{array}$ & $\begin{array}{l}\text { - Flow rate instrumentation } \\
\text { (FIT-710-101) } \\
\text { - Pressure instrumentation } \\
\text { (PE-710-101, -102) } \\
\text { - Rupture disks } \\
\text { ECRT-PSE-101 and -102 } \\
\text { - Secondary containment with } \\
\text { leak detection } \\
\text { - Modified KW Basin Annex } \\
\text { confinement ventilation } \\
\text { - Continuous air monitors }\end{array}$ & $\begin{array}{l}\text { - Procedures } \\
\text { - Training }\end{array}$ & $\begin{array}{l}\text { Rupture disks provided for compliance with } \\
\text { B31.3, "Process Piping." }\end{array}$ \\
\hline 2.b-11 & Composition & Other & See Table C-10, Item 2.c-7 & See Table C-10, Item 2.c-7 & See Table C-10, Item 2.c-7 & See Table C-10, Item 2.c-7 & $\begin{array}{l}\text { Deviations in composition are addressed in } \\
\text { Node 2.c, "Sludge Transfer - STSC." }\end{array}$ \\
\hline 2.b-12 & Structural Integrity & Leak/rupture & $\begin{array}{l}\text { - High pressure (see } \\
\text { Item 2.b-7 above) } \\
\text { - Pulsation damper failure } \\
\text { - Manufacturing flaw } \\
\text { - Procurement error } \\
\text { - External event }\end{array}$ & $\begin{array}{l}\text { Uncontrolled Release: } \\
\text { If the transfer line leaks or ruptures, then } \\
\text { there will be an airborne spray or splash } \\
\text { and splatter/pool release. } \\
\text { Hydrogen Deflagration: } \\
\text { If the transfer line leaks or ruptures } \\
\text { inside the transfer line service box, then } \\
\text { sludge would be spilled into the box. } \\
\text { Hydrogen generated by the sludge could } \\
\text { accumulate in the box resulting in a } \\
\text { deflagration. }\end{array}$ & $\begin{array}{l}\text { - Flow rate instrumentation } \\
\text { (FI-710-101) } \\
\text { - Pressure instrumentation } \\
\text { (PI-710-101, -102) } \\
\text { - Rupture disk ECRT-PSE-101 } \\
\text { and -102 } \\
\text { - Secondary containment with } \\
\text { leak detection } \\
\text { - Modified KW Basin Annex } \\
\text { confinement ventilation } \\
\text { - Continuous air monitors }\end{array}$ & $\begin{array}{l}\text { - Procedures } \\
\text { - Training } \\
\text { - Hydro testing } \\
\text { - Quality Assurance Program } \\
\text { - Leak detection alarm } \\
\text { response }\end{array}$ & $\begin{array}{l}\text { Rupture disks provided for compliance with } \\
\text { B31.3, "Process Piping." }\end{array}$ \\
\hline 2.b-13 & Time Procedure & Too fast & See Table C-6, Item 2.a-12 & See Table C-6, Item 2.a-12 & See Table C-6, Item 2.a-12 & See Table C-6, Item 2.a-12 & See Table C-6, Item 2.a-12 \\
\hline 2.b-14 & Time Procedure & Too slow & See Table C-6, Item 2.a-13 & See Table C-6, Item 2.a-13 & See Table C-6, Item 2.a-13 & See Table C-6, Item 2.a-13 & See Table C-6, Item 2.a-13 \\
\hline 2.b-15 & Time Procedure & Skip action & N/A & N/A & N/A & N/A & $\begin{array}{l}\text { There is no skipped action associated with } \\
\text { this node. }\end{array}$ \\
\hline
\end{tabular}


Table C-8. HAZOP Results, Node 2.b., Sludge Transfer - Ingress/Egress Pipe to STSC

\begin{tabular}{|c|c|c|c|c|c|c|c|}
\hline \multirow{2}{*}{ Item } & \multirow{2}{*}{ Process Parameter } & \multirow{2}{*}{ Deviation } & \multirow{2}{*}{ Cause } & \multirow{2}{*}{ Consequences } & \multicolumn{2}{|c|}{ Candidate Controls } & \multirow{2}{*}{ Remarks } \\
\hline & & & & & Engineered & Administrative & \\
\hline 2.b-16 & Time Procedure & Wrong action & N/A & N/A & $N / A$ & N/A & $\begin{array}{l}\text { There is no wrong action associated with this } \\
\text { node. }\end{array}$ \\
\hline
\end{tabular}


Table C-9. Normal Operating Conditions, Node 2.c., Sludge Transfer - STSC

\begin{tabular}{|c|c|c|}
\hline Process Parameter & Design Intent & Remarks \\
\hline Flow & $70 \mathrm{gpm}$ & Sludge flows into the STSC at $70 \mathrm{gpm}$. \\
\hline Pressure & -1 in. wg & The Modified KW Annex ventilation system maintains the STSC at negative air pressure differential relative to the surrounding room. \\
\hline Concentration & $\begin{array}{l}\text { Not applicable } \\
\text { (see as-settled sludge level) }\end{array}$ & $\begin{array}{l}\text { The volume percent solids in the STSC is a function of the volume percent solids of the slurry transferred in; consequences associated } \\
\text { with high and low solids in the transfer lines are addressed in Tables C-3-, C-5, and C-7. Relative to the sludge in the STSC, the volume } \\
\text { percent solids is addressed as a limit on the volume of the as-settled sludge; see table entry for "as-settled sludge level." }\end{array}$ \\
\hline Composition & $\begin{array}{l}\text { KEIKW sludge is to be transferred into an STSC } \\
\text { that does not contain an inner core } \\
\text { Settler tank sludge is to be transferred into an } \\
\text { STSC that contains an inner core }\end{array}$ & $\begin{array}{l}\text { There are two STSC designs: one for KE and KW Basin sludge stored in Engineered Containers } 210,220,240,250 \text {, and } 260 \text {, and one } \\
\text { for settler tank sludge stored in Engineered Container } 230 \text {. The difference in design is that the STSC for settler tank sludge containers } \\
\text { an inner cylinder. The annular region created by the inner cylinder contains sludge whereas the inside of the cylinder contains water } \\
\text { which provides a heat transfer mechanism for heat generated by radiolytic decay and by the reaction of uranium metal with water. }\end{array}$ \\
\hline Structural Integrity & $\begin{array}{l}\text { Maintain integrity under normal operating } \\
\text { conditions }\end{array}$ & The STSC is a pressure vessel rated at $150 \mathrm{psi}$. \\
\hline \multirow{2}{*}{ Level } & $\begin{array}{l}\text { Slurry level: } \\
\text { KE/KW sludge }=3.3 \mathrm{~m}^{3} \text { of slurry } \\
\text { Settler tank sludge }=2.7 \mathrm{~m}^{3} \text { of slurry }\end{array}$ & 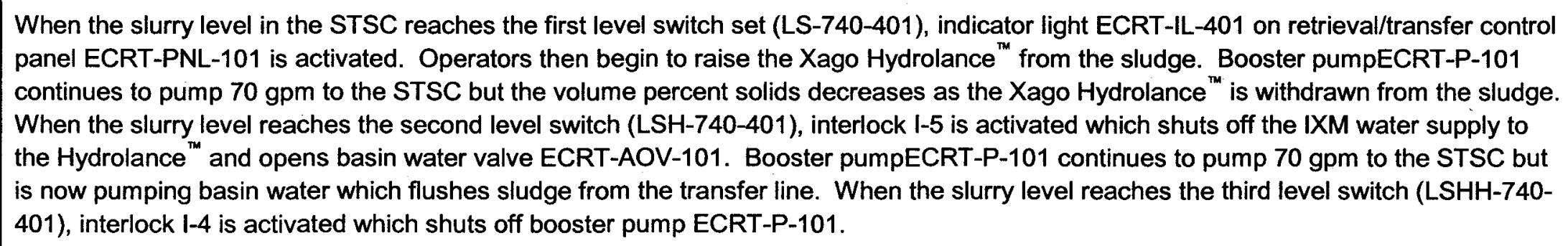 \\
\hline & $\begin{array}{l}\text { As-settled sludge level: } \\
\mathrm{KE} \text { sludge }=2.1 \mathrm{~m}^{3} \\
\mathrm{KW} \text { sludge }=1.6 \mathrm{~m}^{3} \\
\text { Settler tank sludge }=0.5 \mathrm{~m}^{3}\end{array}$ & $\begin{array}{l}\text { The KE and KW sludge volume limits are established so that sludge would still be contained within the STSC in the event of safety basis } \\
\text { sludge expansion. If the limits were exceeded, then the expanding sludge could escape the STSC through vent ports during storage at T } \\
\text { Plant. The settler sludge volume limit is established to maintain thermal stability. } \\
\text { The actual as-settled sludge level in the STSC is not measured. What is measured is the differential weight between an STSC filled with } \\
\text { water and an STSC filled with water and sludge. Using the as-settled sludge densities in HNF-SD-WM-TI-015, Vol 2, the differential } \\
\text { weight can be correlated to an as-settled sludge volume. }\end{array}$ \\
\hline Temperature & Not applicable & $\begin{array}{l}\text { Temperature is not a process parameter that is monitored or controlled. The } 1.3 \text { million gallons of water in the KW Basin is maintained at } \\
\text { a temperature of a } 10-15^{\circ} \mathrm{C} \text {. The sludge in the containers and the IXM motive water and fluidizing jet water are approximately the same } \\
\text { temperature as the basin water. Accordingly, the sludge transferred to the STSC will also be approximately the same temperature as the } \\
\text { basin water. A calculation of the temperature increase due to booster pump operation indicates a less than } 0.5^{\circ} \mathrm{F} \text { temperature increase. }\end{array}$ \\
\hline Time Procedure & $\begin{array}{l}\text { KE/KW sludge: First fill }=13 \text { minutes } \\
\text { Settler tank sludge: } \text { First fill }=10 \text { minutes }\end{array}$ & $\begin{array}{l}\text { For KE/KW sludge, } 3.31 \mathrm{~m}^{3} \text { of slurry is transferred into an STSC. For settler tank sludge the volume transferred is } 2.7 \mathrm{~m}^{3} \text {. At the } \\
\text { planned transfer rate of } 70 \mathrm{gpm} \text {, it takes approximately } 13 \text { minutes to transfer } 3.31 \mathrm{~m}^{3} \text {, and approximately } 10 \text { minutes to transfer } 2.7 \mathrm{~m}^{3} \text {. } \\
\text { Following the first fill/decant cycle, additional sludge transfers will be of shorter duration. }\end{array}$ \\
\hline
\end{tabular}




\begin{tabular}{|c|c|c|c|c|c|c|c|}
\hline \multicolumn{8}{|c|}{ Table C-10. HAZOP Results, Node 2.c., Sludge Transfer - STSC } \\
\hline \multirow{2}{*}{ Item } & \multirow{2}{*}{ Process Parameter } & \multirow{2}{*}{ Deviation } & \multirow{2}{*}{ Cause } & \multirow{2}{*}{ Consequences } & \multicolumn{2}{|c|}{ Candidate Controls } & \multirow{2}{*}{ Remarks } \\
\hline & & & & & Engineered & Administrative & \\
\hline 2.c-1 & Flow & No & $\begin{array}{l}\text { - Booster pump } \\
\text { ECRT-P-101 is not } \\
\text { operating } \\
\text { - A normally-open valve } \\
\text { downstream of booster } \\
\text { pump ECRT-P-101 is } \\
\text { closed }\end{array}$ & $\begin{array}{l}\text { Operational Upset: } \\
\text { If there is no flow, then sludge will not be } \\
\text { transferred to the STSC. }\end{array}$ & $\begin{array}{l}\text { - Valve position indicators } \\
\text { - Flow rate instrumentation } \\
\text { (FIT-710-101) } \\
\text { - Pressure instrumentation } \\
\text { (PE-710-101, -102) } \\
\text { - STSC level instrumentation } \\
\text { (LE-740-401) }\end{array}$ & $\begin{array}{l}\text { - Procedures } \\
\text { - Training } \\
\text { - Conduct of operations } \\
\text { verifies proper system } \\
\text { configuration }\end{array}$ & \\
\hline $2 . c-2$ & Flow & Low & $\begin{array}{l}\text { - Booster pump } \\
\text { ECRT-P-101 speed low } \\
\text { - A normally-open valve is } \\
\text { partially closed }\end{array}$ & $\begin{array}{l}\text { Operational Upset: } \\
\text { If the flow rate is low, then it will take } \\
\text { longer to fill the STSC to the required } \\
\text { level. }\end{array}$ & $\begin{array}{l}\text { - Valve position indicators } \\
\text { - Flow rate instrumentation } \\
\text { (FIT-710-101) } \\
\text { - Pressure instrumentation } \\
\text { (PT-710-101, -102) } \\
\text { - STSC level instrumentation } \\
\text { (LE-740-401) }\end{array}$ & $\begin{array}{l}\text { - Procedures } \\
\text { - Training } \\
\text { - Conduct of operations } \\
\text { verifies proper system } \\
\text { configuration }\end{array}$ & \\
\hline $2 . c-3$ & Flow & High & $\begin{array}{l}\text { Booster pump ECRT-P-101 } \\
\text { speed high }\end{array}$ & $\begin{array}{l}\text { Operational Upset: } \\
\text { If the flow rate is high, then the STSC will } \\
\text { be filled faster. }\end{array}$ & $\begin{array}{l}\text { - Flow rate instrumentation } \\
\text { (FIT-710-101) } \\
\text { - Pressure instrumentation } \\
\text { (PE-710-101, -102) } \\
\text { - STSC level instrumentation } \\
\text { (LE-740-401) }\end{array}$ & $\begin{array}{l}\text { - Procedures } \\
\text { - Training }\end{array}$ & \\
\hline 2.c-4.a & Flow & Reverse & $\begin{array}{l}\text { Booster pump ECRT-P-101 } \\
\text { runs in reverse }\end{array}$ & See Table C-6, Item 2.a-4 & See Table C-6, Item 2.a-4 & See Table C-6, Item 2.a-4 & See Table C-6, Item 2.a-4 \\
\hline 2.c-4.b & Flow & Reverse & Siphon from STSC & See Table C-8, Item 2.b-4.b & See Table C-8, Item 2.b-4.b & See Table C-8, Item 2.b-4.b & See Table C-8, Item 2.b-4.b \\
\hline $2 . c-5$ & Pressure & Low & See Table C-12, Item 2.d-5 & See Table C-12, Item 2.d-5 & See Table C-12, Item 2.d-5 & See Table C-12, Item 2.d-5 & $\begin{array}{l}\text { Under normal operating conditions, the } \\
\text { ventilation system maintains a pressure of } \\
-1 \text { in. wg in the STSC during transfers. The } \\
\text { STSC ventilation system is specifically } \\
\text { addressed in Node 2.d. }\end{array}$ \\
\hline
\end{tabular}


Table C-10. HAZOP Results, Node 2.c., Sludge Transfer - STSC

\begin{tabular}{|c|c|c|c|c|c|c|c|}
\hline \multirow{2}{*}{ Item } & \multirow{2}{*}{ Process Parameter } & \multirow{2}{*}{ Deviation } & \multirow{2}{*}{ Cause } & \multirow{2}{*}{ Consequences } & \multicolumn{2}{|c|}{ Candidate Controls } & \multirow{2}{*}{ Remarks } \\
\hline & & & & & Engineered & Administrative & \\
\hline $2 . c-6$ & Pressure & High & See Table C-12, Item 2.d-6 & See Table C-12, Item 2.d-6 & See Table C-12, Item 2.d-6 & See Table C-12, Item 2.d-6 & $\begin{array}{l}\text { Under normal operating conditions, the } \\
\text { ventilation system maintains a pressure of } \\
-1 \text { in. wg in the STSC during transfers. The } \\
\text { STSC ventilation system is specifically } \\
\text { addressed in Node 2.d. }\end{array}$ \\
\hline 2.c-7.a & Composition & $\begin{array}{l}\text { Other } \\
\text { (settler tank } \\
\text { sludge } \\
\text { retrieved } \\
\text { instead of } \\
\text { KE/KW } \\
\text { sludge) }\end{array}$ & $\begin{array}{l}\text { Xago Hydrolance }{ }^{\mathrm{m}} \text { lowered } \\
\text { into incorrect Engineered } \\
\text { Container due to operator } \\
\text { error }\end{array}$ & $\begin{array}{l}\text { Overpressurization: } \\
\text { The STSC sludge limits have been } \\
\text { established, in part, to prevent the } \\
\text { sludge from reaching a temperature of } \\
\text { approximately } 100^{\circ} \mathrm{C} \text { in order to prevent } \\
\text { excessive headspace pressures. If the } \\
\text { Xago Hydrolance } \\
\text { lowered is erroneously } \\
\text { tank sludge } \text { SCS-CON-230, then settler } \\
\text { STSC without an annulus. Placing } \\
\text { settler tank sludge in an STSC without } \\
\text { an annulus could result in the sludge } \\
\text { temperature reaching } 100^{\circ} \mathrm{C} \text { and } \\
\text { overpressurizing the STS cask. } \\
\text { Hydrogen Deflagration: } \\
\text { The STSC sludge limits have been } \\
\text { established, in part, to control the } \\
\text { hydrogen concentration in the } \\
\text { headspace of the STSC. Placing settler } \\
\text { tank sludge in an STSC without an } \\
\text { annulus could result in a hydrogen } \\
\text { deflagration. }\end{array}$ & $\begin{array}{l}\text { - Overfill recovery tool } \\
\text { - Modified KW Basin Annex } \\
\text { confinement ventilation } \\
\text { - STSC active ventilation } \\
\text { - Auxiliary ventilation system } \\
\text { - Nitrogen gas purge } \\
\text { - Continuous air monitors }\end{array}$ & $\begin{array}{l}\text { - Procedures } \\
\text { - Training } \\
\text { - Administrative control on } \\
\text { shipping window }\end{array}$ & $\begin{array}{l}\text { If the deviation was discovered, the overfill } \\
\text { recovery tool could be used to remove the } \\
\text { majority of the settler tank sludge from the } \\
\text { STSC without an inner core and return it to } \\
\text { SCS-CON-230. } \\
\text { There is no labeling at the grating level to } \\
\text { indicate which Engineered Container is } \\
\text { below. The location of Engineered } \\
\text { Containers is known from facility general } \\
\text { arrangement drawings. Specifically, } \\
\text { SCS-CON-210, }-220 \text {, and -230 are located } \\
\text { in the Bay } 2 \text { (center bay) in a left to right } \\
\text { sequence when facing north. } \\
\text { SCS-CON-240, -250, and -260 are located } \\
\text { in Bay } 1 \text { (east bay) in a left to right } \\
\text { sequence when facing north. }\end{array}$ \\
\hline
\end{tabular}


Table C-10. HAZOP Results, Node 2.c., Sludge Transfer - STSC

\begin{tabular}{|c|c|c|c|c|c|c|c|}
\hline \multicolumn{8}{|c|}{ Table C-10. HAZOP Results, Node 2.c., Sludge Transfer - STSC } \\
\hline \multirow{2}{*}{ Item } & \multirow{2}{*}{ Process Parameter } & \multirow{2}{*}{ Deviation } & \multirow{2}{*}{ Cause } & \multirow{2}{*}{ Consequences } & \multicolumn{2}{|c|}{ Candidate Controls } & \multirow{2}{*}{ Remarks } \\
\hline & & & & & Engineered & Administrative & \\
\hline 2.c-7.b & Composition & $\begin{array}{l}\text { Other } \\
\text { (KE/KW } \\
\text { sludge } \\
\text { retrieved } \\
\text { instead of } \\
\text { settler tank } \\
\text { sludge) }\end{array}$ & $\begin{array}{l}\text { Xago Hydrolance }{ }^{m} \text { lowered } \\
\text { into incorrect Engineered } \\
\text { Container due to operator } \\
\text { error }\end{array}$ & $\begin{array}{l}\text { Radiological Control: } \\
\text { If the Xago Hydrolance }{ }^{\mathrm{m}} \text { is erroneously } \\
\text { lowered into a container other than } \\
\text { SCS-CON-230, then KE or KW Basin } \\
\text { sludge would be retrieved into an STSC } \\
\text { with an inner core. This could result in } \\
\text { higher than expected dose rates at the } \\
\text { top of the STSC. In addition, If the } \\
\text { sludge were to subsequently expand at } \\
\text { the safety basis expansion rate, then } \\
\text { sludge could escape the STSC during } \\
\text { long-term storage at T Plant. }\end{array}$ & Overfill recovery tool & $\begin{array}{l}\text { - Procedures } \\
\text { - Training } \\
\text { - Radiological Control } \\
\text { Program. }\end{array}$ & $\begin{array}{l}\text { If the deviation was discovered, the overfill } \\
\text { recovery tool could be used to remove the } \\
\text { majority of the KE/KW sludge from the } \\
\text { STSC with an inner core and return it the } \\
\text { originating Engineered Container. }\end{array}$ \\
\hline 2.c-7.c & Composition & $\begin{array}{l}\text { Other } \\
\text { (KE sludge } \\
\text { retrieved } \\
\text { instead of } \\
\text { KW sludge) }\end{array}$ & $\begin{array}{l}\text { Xago Hydrolance }{ }^{\text {ma }} \text { lowered } \\
\text { into incorrect Engineered } \\
\text { Container due to operator } \\
\text { error }\end{array}$ & $\begin{array}{l}\text { Operational Upset: } \\
\text { If the Xago Hydrolance }{ }^{\mathrm{m}} \text { is erroneously } \\
\text { lowered into SCS-CON-240, }-250 \text {, or } \\
-260 \text { instead of SCS-CON-210 or }-220 \text {, } \\
\text { then KE sludge would be retrieved } \\
\text { instead of KW sludge. There are no } \\
\text { associated hazardous conditions. }\end{array}$ & None & $\begin{array}{l}\text { - Procedures } \\
\text { - Training }\end{array}$ & $\begin{array}{l}\text { If the deviation was discovered, then } \\
\text { additional sludge could be added to the } \\
\text { STSC up to the KE sludge level limit. }\end{array}$ \\
\hline 2.c-7.d & Composition & $\begin{array}{l}\text { Other } \\
\text { (KW sludge } \\
\text { retrieved } \\
\text { instead of } \\
\text { KE sludge) }\end{array}$ & $\begin{array}{l}\text { Xago Hydrolance }{ }^{m} \text { lowered } \\
\text { into incorrect Engineered } \\
\text { Container due to operator } \\
\text { error }\end{array}$ & $\begin{array}{l}\text { Radiological Control (T Plant): } \\
\text { If the Xago Hydrolance } \\
\text { lowered is erroneously } \\
\text { instead of SCS-CON-210 or } 220 \\
\text { then KW sludge would be retrieved } \\
\text { instead of KE sludge. Consequently, the } \\
\text { STSC volume limit for KW sludge would } \\
\text { be exceeded. If the sludge were to } \\
\text { subsequently expand at the safety basis } \\
\text { expansion rate, then sludge could } \\
\text { escape the STSC during long-term } \\
\text { storage at T Plant. }\end{array}$ & Overfill recovery tool & $\begin{array}{l}\text { - Procedures } \\
\text { - Training } \\
\text { - Radiological Control } \\
\text { Program }\end{array}$ & $\begin{array}{l}\text { If the deviation was discovered, the overfill } \\
\text { recovery tool could be used to remove } K W \\
\text { sludge to within the } K W \text { sludge level limit. }\end{array}$ \\
\hline
\end{tabular}


Table C-10. HAZOP Results, Node 2.c., Sludge Transfer - STSC

\begin{tabular}{|c|c|c|c|c|c|c|c|}
\hline \multirow{2}{*}{ Item } & \multirow{2}{*}{ Process Parameter } & \multirow{2}{*}{ Deviation } & \multirow{2}{*}{ Cause } & \multirow{2}{*}{ Consequences } & \multicolumn{2}{|c|}{ Candidate Controls } & \multirow{2}{*}{ Remarks } \\
\hline & & & & & Engineered & Administrative & \\
\hline 2.c-8 & Structural Integrity & Leak/rupture & $\begin{array}{l}\text { - High pressure (see } \\
\text { Table 2-12, Item 2.d-6.b) } \\
\text { - Manufacturing flaw } \\
\text { - Corrosion }\end{array}$ & $\begin{array}{l}\text { Uncontrolled Release: } \\
\text { For non-pressurized scenarios, if the } \\
\text { breach occurred above the liquid level, } \\
\text { then contaminated air could exit the } \\
\text { STSC. } \\
\text { For non-pressurized scenarios, if the } \\
\text { breach occurred below the liquid level, } \\
\text { then sludge would leak into the STS } \\
\text { cask. } \\
\text { The consequences of a leak due to high } \\
\text { pressure are as stated in Table 2-12, } \\
\text { Item 2.d-6b. }\end{array}$ & $\begin{array}{l}\text { - STSC active ventilation } \\
\text { - Modified KW Basin Annex } \\
\text { confinement ventilation } \\
\text { - Continuous air monitors }\end{array}$ & $\begin{array}{l}\text { - Procedures } \\
\text { - Training } \\
\text { - Hydro testing } \\
\text { - Quality Assurance Program }\end{array}$ & $\begin{array}{l}\text { The STSC active ventilation system } \\
\text { maintains a negative air pressure differential } \\
\text { of }-1 \text { in. wg. }\end{array}$ \\
\hline 2.c-9.a & $\begin{array}{l}\text { Level } \\
\text { (slurry) }\end{array}$ & Low & $\begin{array}{l}\text { - Instrumentation and control } \\
\text { failure } \\
\text { - Booster pump } \\
\text { ECRT-P-101 failure } \\
\text { - Loss of electrical power }\end{array}$ & $\begin{array}{l}\text { Operational Upset: } \\
\text { If the transfer is stopped when the slurry } \\
\text { level is low, then additional fill/decant } \\
\text { cycles would be required. }\end{array}$ & None & None & \\
\hline $2 . c-9 . b$ & $\begin{array}{l}\text { Level } \\
\text { (as-settled sludge) }\end{array}$ & Low & $\begin{array}{l}\text { - Instrumentation and control } \\
\text { failure } \\
\text { - Operator error }\end{array}$ & $\begin{array}{l}\text { Operational Upset: } \\
\text { If an STSC is sent to T Plant with a low } \\
\text { as-settled sludge level, then additional } \\
\text { STSCs will be required to complete the } \\
\text { project. }\end{array}$ & None & None & \\
\hline 2.c-10.a & $\begin{array}{l}\text { Level } \\
\text { (KE/KW slurry) }\end{array}$ & High & $\begin{array}{l}\text { Instrumentation and control } \\
\text { failure }\end{array}$ & $\begin{array}{l}\text { Uncontrolled Release: } \\
\text { If the KE/KW slurry transfer is not } \\
\text { stopped, then the STSC will be overfilled } \\
\text { and slurry will be pumped into the } 4 \text {-in } \\
\text { and } 1 \text {-in. ventilation exhaust lines and } \\
\text { into the } 1 \text {-in. ventilation inlet line leading } \\
\text { to a splash and splatter/pool release. }\end{array}$ & $\begin{array}{l}\text { - Level switches } \\
\text { LS/LSH/LSHH-740-401 } \\
\text { - High level switch } \\
\text { LSH-740-402 } \\
\text { - Emergency stop switch } \\
\text { ECRT-ES-1 } \\
\text { - Modified KW Basin Annex } \\
\text { confinement ventilation } \\
\text { - Continuous air monitors }\end{array}$ & $\begin{array}{l}\text { - Procedures } \\
\text { - Training }\end{array}$ & $\begin{array}{l}\text { High level switch LSH-740-402 and } \\
\text { emergency stop switch ECRT-ES-1 activate } \\
\text { sequence } 1-3 \text { which shuts of booster pump } \\
\text { ECRT-P-101 and IXM water pumps } \\
\text { ECRT-P-51, and }-52 \text {. }\end{array}$ \\
\hline
\end{tabular}




\begin{tabular}{|c|c|c|c|c|c|c|c|}
\hline \multirow{2}{*}{ Item } & \multirow{2}{*}{ Process Parameter } & \multirow{2}{*}{ Deviation } & \multirow{2}{*}{ Cause } & \multirow{2}{*}{ Consequences } & \multicolumn{2}{|c|}{ Candidate Controls } & \multirow{2}{*}{ Remarks } \\
\hline & & & & & Engineered & Administrative & \\
\hline 2.c-10.b & $\begin{array}{l}\text { Level } \\
\text { (settler tank slurry) }\end{array}$ & High & $\begin{array}{l}\text { Instrumentation and control } \\
\text { failure }\end{array}$ & $\begin{array}{l}\text { Uncontrolled Release: } \\
\text { If the settler tank slurry transfer is not } \\
\text { stopped, then the STSC will be ovefilled } \\
\text { and slurry will be pumped into the } 4 \text {-in } \\
\text { and } 1 \text {-in. ventilation exhaust lines and } \\
\text { into the } 1 \text {-in. ventilation inlet line leading } \\
\text { to a splash and splatter/pool release. } \\
\text { Overpressurization: } \\
\text { Thermal modeling of settler tank sludge } \\
\text { in an STSC with an annulus assumes } \\
\text { that the core region is filled with water. } \\
\text { If the settler sludge level is high, then a } \\
\text { small amount of sludge could enter the } \\
\text { core region. If a large amount of sludge } \\
\text { was present in the core region, then the } \\
\text { sludge temperature could eventually } \\
\text { reach } 100{ }^{\circ} \mathrm{C} \text { and overpressurize the } \\
\text { STS cask. } \\
\text { Hydrogen Deflagration: } \\
\text { Gas generation analyses of settler } \\
\text { sludge in an STSC with an annulus } \\
\text { assume that the core region if filled with } \\
\text { water. If the settler sludge level is high, } \\
\text { then a small amount of sludge could } \\
\text { enter the core region. If a large amount } \\
\text { of sludge was present in the core region, } \\
\text { a hydrogen deflagration could occur. }\end{array}$ & $\begin{array}{l}\text { - Level switches } \\
\text { LS/LSH/LSHH-740-401 } \\
\text { - High level switch } \\
\text { LSH-740-402 } \\
\text { - Emergency stop switch } \\
\text { ECRT-ES-1 } \\
\text { - Modified KW Basin Annex } \\
\text { confinement ventilation } \\
\text { - STSC active ventilation } \\
\text { - Auxiliary ventilation system } \\
\text { - Nitrogen gas purge } \\
\text { - Continuous air monitors }\end{array}$ & $\begin{array}{l}\text { - Procedures } \\
\text { - Training } \\
\text { - Administrative control on } \\
\text { shipping window }\end{array}$ & $\begin{array}{l}\text { It is unlikely that a large amount of sludge } \\
\text { could enter the core region. The core region } \\
\text { and STSC are initially filled with IXM water } \\
\text { to a specified level. The volume of the core } \\
\text { region above this level is approximately } \\
33 \text { gallons. Thus if the STSC were to be } \\
\text { overfilled, the maximum amount of settler } \\
\text { slurry that could enter the core region would } \\
\text { be } 33 \text { gallons at } 5 \text { vol\% solid, which is } \\
\text { equivalent to } 0.02 \mathrm{~m}^{3} \text { of as-settled sludge. } \\
\text { A worst-case scenario would be if there was } \\
\text { no IXM water in the core region and the } \\
\text { STSC was overfilled. As IXM water is } \\
\text { supplied to the STSC by overfilling the core } \\
\text { region, if there was no IXM water in the core } \\
\text { region there would be no IXM water in the } \\
\text { STSC. This condition would be readily } \\
\text { apparent to operators who record the weight } \\
\text { of the STSC when it is empty and again } \\
\text { when it is filled with water. }\end{array}$ \\
\hline 2.c-10.c & $\begin{array}{l}\text { Level } \\
\text { (KE/KW as-settle sludge) }\end{array}$ & High & $\begin{array}{l}\text { - Instrumentation and control } \\
\text { failure } \\
\text { - Operator error }\end{array}$ & $\begin{array}{l}\text { Radiological Control (T Plant) } \\
\text { If the as-settled sludge level is high and } \\
\text { the sludge was to subsequently expand } \\
\text { at the safety basis expansion rate, then } \\
\text { sludge could escape the STSC during } \\
\text { long-term storage at T Plant. }\end{array}$ & $\begin{array}{l}\text { - Differential weight switch } \\
\text { DWSH-740-401 } \\
\text { - STSC level indicator } \\
\text { LIT-740-401 } \\
\text { - Truck weight indicator } \\
\text { WIT-740-401 } \\
\text { - Overfill recovery tool }\end{array}$ & $\begin{array}{l}\text { - Procedures } \\
\text { - Training } \\
\text { - STSC sludge limit } \\
\text { verification } \\
\text { - Radiological Control } \\
\text { Program }\end{array}$ & $\begin{array}{l}\text { The STSC as-settled sludge limits for } \\
\text { KE and KW sludge ( } 2.1 \text { and } 1.6 \mathrm{~m}^{3} \text {, } \\
\text { respectively) are based on ensuring that } \\
\text { sludge it still contained in the STSC during } \\
\text { storage at T Plant } \\
\text { Differential weight switch DWSH-740-401 } \\
\text { activates interlock I-5 which opens the basin } \\
\text { flush valve and terminates the slurry } \\
\text { transfer. The switch is set to prevent } \\
\text { exceeding as-settled sludge limits. }\end{array}$ \\
\hline
\end{tabular}




\begin{tabular}{|c|c|c|c|c|c|c|c|}
\hline \multicolumn{8}{|c|}{ Table C-10. HAZOP Results, Node 2.c., Sludge Transfer - STSC } \\
\hline \multirow{2}{*}{ Item } & \multirow{2}{*}{ Process Parameter } & \multirow{2}{*}{ Deviation } & \multirow{2}{*}{ Cause } & \multirow{2}{*}{ Consequences } & \multicolumn{2}{|c|}{ Candidate Controls } & \multirow{2}{*}{ Remarks } \\
\hline & & & & & Engineered & Administrative & \\
\hline 2.c-10.d & $\begin{array}{l}\text { Level } \\
\text { (settler tank as-settled } \\
\text { sludge) }\end{array}$ & High & $\begin{array}{l}\text { - Instrumentation and control } \\
\text { failure } \\
\text { - Operator error }\end{array}$ & $\begin{array}{l}\text { Overpressurization: } \\
\text { Settler tank sludge limits have been } \\
\text { established, in part, to prevent the } \\
\text { sludge from reaching a temperature of } \\
100^{\circ} \mathrm{C} \text { in order to prevent excessive } \\
\text { headspace pressures. If the as-settled } \\
\text { sludge level is high, then the sludge } \\
\text { temperature could reach } 100^{\circ} \mathrm{C} \text { and } \\
\text { overpressurize the STS cask. } \\
\text { Hydrogen Deflagration: } \\
\text { The settler tank sludge limits have been } \\
\text { established, in part, to control the } \\
\text { hydrogen concentration in the } \\
\text { headspace of the STSC. If the as- } \\
\text { settled sludge level is high, then a } \\
\text { hydrogen deflagration could occur. }\end{array}$ & $\begin{array}{l}\text { - Differential weight switch } \\
\text { DWSH-740-401 } \\
\text { - STSC level indicator } \\
\text { LIT-740-401 } \\
\text { - Truck weight indicator } \\
\text { WIT-740-401 } \\
\text { - Overfill recovery tool } \\
\text { - Modified KW Basin Annex } \\
\text { confinement ventilation } \\
\text { - STS active ventilation } \\
\text { - Auxiliary ventilation system } \\
\text { - Nitrogen gas purge } \\
\text { - Continuous air monitors }\end{array}$ & $\begin{array}{l}\text { - Procedures } \\
\text { - Training } \\
\text { - STSC sludge limit } \\
\text { verification } \\
\text { - Administrative control on } \\
\text { shipping window }\end{array}$ & $\begin{array}{l}\text { As stated in HNF-41051, the STSC } \\
\text { as-settled sludge limit for settler tank sludge } \\
\left(0.5 \mathrm{~m}^{3}\right) \text { is based thermal and hydrogen gas } \\
\text { generation analyses to avoid exceeding a } \\
\text { temperature of } 100^{\circ} \mathrm{C} \text {. }\end{array}$ \\
\hline 2.c-11 & Time Procedure & Too fast & See Table C-6, Item 2a-12 & See Table C-6, Item 2a-12 & See Table C-6, Item 2a-12 & See Table C-6, Item 2a-12 & See Table C-6, Item 2a-12 \\
\hline 2.c-12 & Time Procedure & Too slow & See Table C-6, Item 2.a-13 & See Table C-6, Item 2.a-13 & See Table C-6, Item 2.a-13 & See Table C-6, Item 2.a-13 & See Table C-6, Item 2.a-13 \\
\hline 2.c-13 & Time Procedure & Skip action & N/A & N/A & N/A & N/A & $\begin{array}{l}\text { There is no skipped action associated with } \\
\text { this node. }\end{array}$ \\
\hline 2.c-14 & Time Procedure & $\begin{array}{l}\text { Wrong } \\
\text { action }\end{array}$ & N/A & N/A & N/A & N/A & $\begin{array}{l}\text { There is no wrong action associated with } \\
\text { this node. }\end{array}$ \\
\hline
\end{tabular}


Table C-11. Normal Operating Conditions, Node 2.d., Sludge Transfer - STSC Ventilation

\begin{tabular}{|c|c|c|}
\hline Process Parameter & Design Intent & Remarks \\
\hline Flow & $5 \mathrm{cfm}$ (at -1 in. wg) & $\begin{array}{l}\text { The ventilation system is credited with maintaining a flow rate of }>1 \mathrm{cfm} \text { when sludge is present in the STSC to prevent } \\
\text { flammable concentrations of Hydrogen in the STSC headspace. }\end{array}$ \\
\hline Pressure & -1 in. wg & $\begin{array}{l}\text { The Modified KW Annex ventilation system maintains the STSC at negative air pressure differential relative to the } \\
\text { surrounding room. }\end{array}$ \\
\hline & Inlet: Not Applicable & See "Composition" \\
\hline Concentration & $\begin{array}{l}\text { Outlet: } \\
\text { Moisture }<100 \% \text { relative humidity } \\
\text { Radionuclides }=\text { TBD }\end{array}$ & $\begin{array}{l}\text { The allowable relative humidity for HEPA filters is } 70 \% \text {. The STSC exhaust air is diluted by approximately } 40: 1 \text { in the HEPA } \\
\text { filter plenum by building exhaust air. The calculated relative humidity in the HEPA fitter plenum is } \sim 50 \% \text { relative humidity } \\
\text { when exhaust from demisters ERCT-DMS-501 and -502 is saturated. Testing to-date at MASF has not detected any liquid } \\
\text { in the STSC exhaust stream. } \\
\text { The radionuclide content of the STSC exhaust air stream has not been quantitatively estimated. }\end{array}$ \\
\hline Composition & Room Air & $\begin{array}{l}\text { Room air is drawn into the STSC via inlet HEPA filter ECRT-HEPA- } 541 \text { and hose ECRT-H-604. Hose ECRT-H-604 is a 1-in. } \\
\text { hose that connects to the STSC at Nozzle S2. }\end{array}$ \\
\hline Structural Integrity & $\begin{array}{l}\text { Maintain integrity under normal operating } \\
\text { conditions }\end{array}$ & The STSC ventilation flow path is a combination of hoses, ductwork and HEPA filters. \\
\hline Level & $5-17$ gallons & Tank ECRT-TK-502 is a 20 gallon tank. It is equipped with high and low level alarms set at 17 and 5 gallons, respectively. \\
\hline Temperature & Not applicable & $\begin{array}{l}\text { Ventilation air temperature is not a process parameter that is monitored or controlled. The annex HVAC system is design to } \\
\text { maintain a minimum temperature of } 65^{\circ} \mathrm{F}\left(18^{\circ} \mathrm{C}\right) \text { given an outside temperature of } 0^{\circ} \mathrm{F} \text {, and a maximum temperature of } \\
80^{\circ} \mathrm{F}\left(27^{\circ} \mathrm{C}\right) \text { given an outside temperature of } 105^{\circ} \mathrm{F} \text {. }\end{array}$ \\
\hline Time Procedure & Not applicable & $\begin{array}{l}\text { The ventilation system is connected to the STSC when process connections are first made and operates continuously until it } \\
\text { is time to prepare the STSC for shipping (see Node 5, "STSC Purge"). }\end{array}$ \\
\hline
\end{tabular}




\begin{tabular}{|c|c|c|c|c|c|c|c|}
\hline \multirow{2}{*}{ Item } & \multirow{2}{*}{ Process Parameter } & \multirow{2}{*}{ Deviation } & \multirow{2}{*}{ Cause } & \multirow{2}{*}{ Consequences } & \multicolumn{2}{|c|}{ Candidate Controls } & \multirow{2}{*}{ Remarks } \\
\hline & & & & & Engineered & Administrative & \\
\hline 2.d-1 & Flow & No & $\begin{array}{l}\text { - Air inlet valve } \\
\text { ECRT-V-732 closed } \\
\text { - STSC inlet HEPA filter } \\
\text { plugged } \\
\text { - Exhaust fan } \\
\text { ECRT-EF-502 or -503 not } \\
\text { operating }\end{array}$ & $\begin{array}{l}\text { Hydrogen Deflagration: } \\
\text { If there is no ventilation system flow, then } \\
\text { a hydrogen deflagration could occur. } \\
\text { Radiological Control: } \\
\text { If there is no ventilation system flow, then } \\
\text { the pressure in the STSC will be slightly } \\
\text { greater than atmospheric during a } \\
\text { transfer. See Item 2.d-6.a below. }\end{array}$ & $\begin{array}{l}\text { - Valve position indicators } \\
\text { - STSC pressure indicator } \\
\text { PI-760-652 } \\
\text { - STSC inlet ventilation flow } \\
\text { rate instrumentation } \\
\text { (FS-750-651) interlocked to } \\
\text { Auxiliary Ventilation System } \\
\text { - Auxiliary Ventilation System } \\
\text { - STSC inlet HEPA filter } \\
\text { differential pressure } \\
\text { instrumentation } \\
\text { (DPIT-750-560) } \\
\text { - Exhaust HEPA filter } \\
\text { differential pressure } \\
\text { instrumentation } \\
\text { (DPI-750-512, and -516) } \\
\text { - Redundant exhaust fans } \\
\text { - Modified KW Basin Annex } \\
\text { confinement ventilation (given } \\
\text { operable exhaust fan) } \\
\text { - Continuous air monitors }\end{array}$ & $\begin{array}{l}\text { - Procedures } \\
\text { - Training } \\
\text { - Radiological Control } \\
\text { Program } \\
\text { - Conduct of operations } \\
\text { verifies proper system } \\
\text { configuration }\end{array}$ & \\
\hline 2.d-2 & Flow & Low & $\begin{array}{l}\text { - Inlet HEPA filter partially } \\
\text { plugged } \\
\text { - Air Inlet and outlet valves } \\
\text { set incorrectly } \\
\text { - Exhaust fan } \\
\text { ECRT-EF-502 or -503 } \\
\text { speed low }\end{array}$ & $\begin{array}{l}\text { Hydrogen Deflagration: } \\
\text { If the flow rate falls below } 1 \mathrm{cfm} \text {, then a } \\
\text { hydrogen deflagration could occur. }\end{array}$ & $\begin{array}{l}\text { - Valve position indicators } \\
\text { - STSC pressure indicator } \\
\text { PI-760-652 } \\
\text { - STSC inlet ventilation flow } \\
\text { rate instrumentation } \\
\text { (FS-750-651) interlocked to } \\
\text { Auxiliary Ventilation System } \\
\text { - Auxiliary Ventilation System } \\
\text { - Exhaust HEPA filter } \\
\text { differential pressure } \\
\text { instrumentation } \\
\text { (DPI-750-512, and -516) } \\
\text { - Redundant exhaust fans } \\
\text { - Modified KW Basin Annex } \\
\text { confinement ventilation } \\
\text { - Continuous air monitors }\end{array}$ & $\begin{array}{l}\text { - Procedures } \\
\text { - Training } \\
\text { - Conduct of operations } \\
\text { verifies proper system } \\
\text { configuration }\end{array}$ & \\
\hline
\end{tabular}


Table C-12. HAZOP Results, Node 2.d., Sludge Transfer - STSC Ventilation

\begin{tabular}{|c|c|c|c|c|c|c|c|}
\hline \multirow{2}{*}{ Item } & \multirow{2}{*}{ Process Parameter } & \multirow{2}{*}{ Deviation } & \multirow{2}{*}{ Cause } & \multirow{2}{*}{ Consequences } & \multicolumn{2}{|c|}{ Candidate Controls } & \multirow{2}{*}{ Remarks } \\
\hline & & & & & Engineered & Administrative & \\
\hline 2.d-3 & Flow & High & $\begin{array}{l}\text { - Air inlet and outlet valves } \\
\text { set incorrectly } \\
\text { - Exhaust fan } \\
\text { ECRT-EF-502 or -503 } \\
\text { speed high }\end{array}$ & $\begin{array}{l}\text { Radiological Control: } \\
\text { If the flow rate is high, then more aerosol } \\
\text { may be swept out of the STSC. This } \\
\text { could result in increased deposition in the } \\
\text { vent line resulting in an increased dose } \\
\text { rate and an increased potential for } \\
\text { contamination. See also Item 2.d-8.a } \\
\text { below. }\end{array}$ & $\begin{array}{l}\text { - Valve position indicators } \\
\text { - STSC pressure indicator } \\
\text { PI-760-652 } \\
\text { - STSC inlet ventilation flow } \\
\text { rate instrumentation } \\
\text { (FS-750-651) } \\
\text { - Exhaust HEPA filter } \\
\text { differential pressure } \\
\text { instrumentation } \\
\text { (DPI-750-512, and -516) } \\
\text { - Redundant exhaust fans } \\
\text { - Modified KW Basin Annex } \\
\text { confinement ventilation } \\
\text { - Continuous air monitors }\end{array}$ & $\begin{array}{l}\text { - Procedures } \\
\text { - Training } \\
\text { - Radiological Control } \\
\text { Program } \\
\text { - Conduct of operations } \\
\text { verifies proper system } \\
\text { configuration }\end{array}$ & \\
\hline $2 . d-4$ & Flow & Reverse & N/A & N/A & N/A & N/A & $\begin{array}{l}\text { There is no motive force to create a reverse } \\
\text { flow during transfers. }\end{array}$ \\
\hline $2 . d-5$ & Pressure (absolute) & $\begin{array}{l}\text { Low } \\
\text { (less than } \\
-1.0 \text { in. wg) }\end{array}$ & $\begin{array}{l}\text { - Air inlet and outlet valves } \\
\text { set incorrectly } \\
\text { - Exhaust fan } \\
\text { ECRT-EF-502 or }-503 \\
\text { speed high }\end{array}$ & $\begin{array}{l}\text { Radiological Control: } \\
\text { If the pressure is low (i.e., less than } \\
-1.0 \text { in. wg), then the flow rate will } \\
\text { increase. If the flow rate is high, then } \\
\text { more aerosol may be swept out of the } \\
\text { STSC. Consequences are as stated in } \\
\text { Item } 2 . d-3 \text { above. }\end{array}$ & $\begin{array}{l}\text { - Valve position indicators } \\
\text { - STSC pressure indicator } \\
\text { PI-760-652 } \\
\text { - Exhaust HEPA filter } \\
\text { differential pressure } \\
\text { instrumentation } \\
\text { (DPI-750-512, and -516) } \\
\text { - Redundant exhaust fans } \\
\text { - Modified KW Basin Annex } \\
\text { confinement ventilation } \\
\text { - Continuous air monitors }\end{array}$ & $\begin{array}{l}\text { - Procedures } \\
\text { - Training } \\
\text { - Radiological Control } \\
\text { Program } \\
\text { - Conduct of operations } \\
\text { verifies proper system } \\
\text { configuration }\end{array}$ & $\begin{array}{l}\text { Under normal operating conditions, the } \\
\text { ventilation system establishes a pressure of } \\
-1 \text { in. wg in the STSC during transfers. The } \\
\text { maximum negative pressure the STSC can } \\
\text { experience is approximately }-2 \text { in. wg. }\end{array}$ \\
\hline
\end{tabular}


Table C-12. HAZOP Results, Node 2.d., Sludge Transfer - STSC Ventilation

\begin{tabular}{|c|c|c|c|c|c|c|c|}
\hline \multicolumn{8}{|c|}{ Table C-12. HAZOP Results, Node 2.d., Sludge Transfer - STSC Ventilation } \\
\hline \multirow{2}{*}{ Item } & \multirow{2}{*}{ Process Parameter } & \multirow{2}{*}{ Deviation } & \multirow{2}{*}{ Cause } & \multirow{2}{*}{ Consequences } & \multicolumn{2}{|c|}{ Candidate Controls } & \multirow{2}{*}{ Remarks } \\
\hline & & & & & Engineered & Administrative & \\
\hline 2.d-6 & Pressure (absolute) & $\begin{array}{l}\text { High } \\
\text { (greater than } \\
-1.0 \text { in. wg) }\end{array}$ & $\begin{array}{l}\text { - No flow (see Item 2.d-1, } \\
\text { above) } \\
\text { - Low flow (see Item 2.d-2, } \\
\text { above) }\end{array}$ & $\begin{array}{l}\text { Radiological Control: } \\
\text { If the pressure in the STSC is greater } \\
\text { than atmospheric, then the potential } \\
\text { exists for a spread of contamination. }\end{array}$ & $\begin{array}{l}\text { - Valve position indicators } \\
\text { - STSC pressure indicator } \\
\text { PI-760-652 } \\
\text { - STSC inlet ventilation flow } \\
\text { rate instrumentation } \\
\text { (ECRT-IL-651) } \\
\text { - Exhaust HEPA filter } \\
\text { differential pressure } \\
\text { instrumentation } \\
\text { (DPI-750-512, and -516) } \\
\text { - Redundant exhaust fans } \\
\text { - Modified KW Basin Annex } \\
\text { confinement ventilation } \\
\text { - Continuous air monitors }\end{array}$ & $\begin{array}{l}\text { - Procedures } \\
\text { - Training } \\
\text { - Radiological Control } \\
\text { Program } \\
\text { - Conduct of operations } \\
\text { verifies proper system } \\
\text { configuration }\end{array}$ & $\begin{array}{l}\text { The supply air to the STSC is room air } \\
\text { infiltration via HEPA filter ECRT-HEPA- } 541 \text {. } \\
\text { In this node, the only energy source } \\
\text { available to pressurize the STSC is the } \\
70 \text { gpm transfer. Air is exhausted from the } \\
\text { STSC via } 4 \text {-in. vent line ECRT-H-501 and } \\
1 \text {-in. vent line ECRT-H-659. There will only } \\
\text { be a slight increase in pressure as both the } \\
4 \text {-in. and } 1 \text { in. vents lines will still be open. }\end{array}$ \\
\hline 2.d-7.a & $\begin{array}{l}\text { Concentration } \\
\text { (moisture in STSC } \\
\text { exhaust) }\end{array}$ & Low & No sludge in STSC & None & None & None & \\
\hline $2 . d-7 . b$ & $\begin{array}{l}\text { Concentration } \\
\text { (radionuclide in STSC } \\
\text { exhaust) }\end{array}$ & Low & No sludge in STSC & None & None & None & \\
\hline 2.d-8.a & $\begin{array}{l}\text { Concentration } \\
\text { (moisture in STSC } \\
\text { exhaust) }\end{array}$ & High & $\begin{array}{l}\text { High flow rate, see Item } \\
2 . d-3 \text { above }\end{array}$ & $\begin{array}{l}\text { Radiological Control: } \\
\text { If there is too much moisture in the } \\
\text { exhaust air, then the HEPA filters could } \\
\text { be damaged. }\end{array}$ & $\begin{array}{l}\text { - STSC pressure indicator } \\
\text { PI-760-652 } \\
\text { - STSC inlet ventilation flow } \\
\text { rate instrumentation } \\
\text { (ERCT-IL-651) } \\
\text { - Demisters ECRT-DMS-501 } \\
\text { and -502 } \\
\text { - Exhaust HEPA filter } \\
\text { differential pressure } \\
\text { instrumentation } \\
\text { (DPI-750-512, and -516) } \\
\text { - Redundant HEPA filter trains } \\
\text { - Modified KW Basin Annex } \\
\text { confinement ventilation } \\
\text { - Continuous air monitors }\end{array}$ & $\begin{array}{l}\text { - Procedures } \\
\text { - Training } \\
\text { - Radiological Control } \\
\text { Program }\end{array}$ & \\
\hline
\end{tabular}




\begin{tabular}{|c|c|c|c|c|c|c|c|}
\hline \multirow{2}{*}{ Item } & \multirow{2}{*}{ Process Parameter } & \multirow{2}{*}{ Deviation } & \multirow{2}{*}{ Cause } & \multirow{2}{*}{ Consequences } & \multicolumn{2}{|c|}{ Candidate Controls } & \multirow{2}{*}{ Remarks } \\
\hline & & & & & Engineered & Administrative & \\
\hline 2.d-8.b & $\begin{array}{l}\text { Concentration } \\
\text { (radionuclide in STSC } \\
\text { exhaust)) }\end{array}$ & High & $\begin{array}{l}\text { High flow rate, see } \\
\text { Item 2.d-3 }\end{array}$ & $\begin{array}{l}\text { Radiological Control: } \\
\text { If the flow rate is high, then more aerosol } \\
\text { may be swept out of the STSC. This } \\
\text { could result in increased deposition in the } \\
\text { vent line resulting in an increased dose } \\
\text { rate and an increased potential for } \\
\text { contamination. }\end{array}$ & $\begin{array}{l}\text { - STSC pressure indicator } \\
\text { PI-760-652 } \\
\text { - STSC inlet ventilation flow } \\
\text { rate instrumentation } \\
\text { (ECRT-IL-651) } \\
\text { - Exhaust HEPA filter } \\
\text { differential pressure } \\
\text { instrumentation } \\
\text { (DPI-750-512, and -516) } \\
\text { - Redundant exhaust fans } \\
\text { - Modified KW Basin Annex } \\
\text { confinement ventilation } \\
\text { - Continuous air monitors }\end{array}$ & $\begin{array}{l}\text { - Procedures } \\
\text { - Training } \\
\text { - Radiological Control } \\
\text { Program }\end{array}$ & \\
\hline 2.d-9 & $\begin{array}{l}\text { Composition } \\
\text { (STSC inlet) }\end{array}$ & $\begin{array}{l}\text { Other } \\
\text { (nitrogen) }\end{array}$ & $\begin{array}{l}\text { Air inlet and nitrogen purge } \\
\text { valves set incorrectly }\end{array}$ & $\begin{array}{l}\text { Operational Upset: } \\
\text { When set to purge the STSC, the gas } \\
\text { purge system flows } 10 \mathrm{cfm} \text { of nitrogen. } \\
\text { If the air inlet and nitrogen purge valves } \\
\text { were set incorrectly, then the gas purge } \\
\text { system would deliver } 10 \mathrm{cfm} \text { of nitrogen. } \\
\text { This is more than the normal } 5 \mathrm{cfm} \text { of } \\
\text { room air drawn in through HEPA ECRT- } \\
\text { HEPA- } 541 \text {. The pressure in the STSC } \\
\text { would increase above }-1 \text { in wg. }\end{array}$ & $\begin{array}{l}\text { - Valve position indicators } \\
\text { - STSC inlet ventilation flow } \\
\text { rate instrumentation } \\
\text { (ECRT-IL-651) }\end{array}$ & $\begin{array}{l}\text { - Procedures } \\
\text { - Training } \\
\text { - Conduct of operations } \\
\text { verifies proper system } \\
\text { configuration }\end{array}$ & \\
\hline 2.d-10.a & $\begin{array}{l}\text { Structural Integrity } \\
\text { (STSC inlet line) }\end{array}$ & Leak/rupture & $\begin{array}{l}\text { - Physical damage to inlet } \\
\text { line } \\
\text { - Hose ECRT-H-604 } \\
\text { disconnects from STSC at } \\
\text { nozzle S2 }\end{array}$ & $\begin{array}{l}\text { Operational Upset: } \\
\text { The inlet line is under suction. If there is } \\
\text { leak/rupture in the line, then room air will } \\
\text { be drawn into line via the leak/rupture. Air } \\
\text { that is drawn in through the leak/rupture } \\
\text { would not be filtered by inlet HEPA filter } \\
\text { ECRT-HEPA-541. }\end{array}$ & $\begin{array}{l}\text { STSC inlet ventilation flow rate } \\
\text { instrumentation (ECRT-IL-651) }\end{array}$ & $\begin{array}{l}\text { - Procedures } \\
\text { - Training }\end{array}$ & \\
\hline
\end{tabular}


Table C-12. HAZOP Results, Node 2.d., Sludge Transfer - STSC Ventilation

\begin{tabular}{|c|c|c|c|c|c|c|c|}
\hline \multirow{2}{*}{ Item } & \multirow{2}{*}{ Process Parameter } & \multirow{2}{*}{ Deviation } & \multirow{2}{*}{ Cause } & \multirow{2}{*}{ Consequences } & \multicolumn{2}{|c|}{ Candidate Controls } & \multirow{2}{*}{ Remarks } \\
\hline & & & & & Engineered & Administrative & \\
\hline 2.d-10.b & $\begin{array}{l}\text { Structural Integrity } \\
\text { (STSC outlet line) }\end{array}$ & Leak/rupture & $\begin{array}{l}\text { - Physical damage to outlet } \\
\text { line(s) } \\
\text { - Hose ECRT-H-501 } \\
\text { disconnects from STSC at } \\
\text { nozzle F1 } \\
\text { - Hose ECRT-H-659 } \\
\text { disconnects from STSC at } \\
\text { nozzle F2 }\end{array}$ & $\begin{array}{l}\text { Hydrogen Deflagration: } \\
\text { If there is a leak/rupture in the outlet line, } \\
\text { then the flow rate through the STSC will } \\
\text { decrease. If the flow rate drops below } \\
1 \mathrm{cfm} \text {, a hydrogen deflagration could } \\
\text { occur. } \\
\text { Radiological Control: } \\
\text { The interior of the outlet lines will be } \\
\text { contaminated. Although the lines are } \\
\text { under negative pressure, if there is a } \\
\text { leak/rupture then a spread of } \\
\text { contamination could occur. }\end{array}$ & $\begin{array}{l}\text { - STSC inlet ventilation flow } \\
\text { rate instrumentation } \\
\text { (FS-750-651) interlocked to } \\
\text { Auxiliary Ventilation System } \\
\text { - Auxiliary Ventilation System } \\
\text { - Modified KW Basin Annex } \\
\text { confinement ventilation (given } \\
\text { operable exhaust fan) } \\
\text { - Continuous air monitors }\end{array}$ & $\begin{array}{l}\text { - Procedures } \\
\text { - Training } \\
\text { - Radiological Control } \\
\text { Program }\end{array}$ & \\
\hline 2.d.-10.c & $\begin{array}{l}\text { Structural Integrity } \\
\text { (exhaust HEPA filters) }\end{array}$ & Leak/rupture & $\begin{array}{l}\text { - High differential pressure } \\
\text { (e.g., moisture build-up, } \\
\text { particulate loading) } \\
\text { - Incorrect installation } \\
\text { - Manufacturing flaw } \\
\text { - Mechanical insult }\end{array}$ & $\begin{array}{l}\text { Radiological Control: } \\
\text { If the HEPA filters leak/rupture, then the } \\
\text { exhaust air from the STSC would not be } \\
\text { filtered, or would not be filtered as } \\
\text { efficiently. }\end{array}$ & $\begin{array}{l}\text { - Demisters ECRT-DMS-501 } \\
\text { and -502 } \\
\text { - Exhaust HEPA filter } \\
\text { differential pressure } \\
\text { instrumentation } \\
\text { (DPI-750-512, and -516) } \\
\text { - Redundant HEPA filter trains }\end{array}$ & $\begin{array}{l}\text { - HEPA filter inspection and } \\
\text { testing } \\
\text { - Quality Assurance Program } \\
\text { - Radiological Control } \\
\text { Program }\end{array}$ & \\
\hline 2.d-11 & $\begin{array}{l}\text { Level } \\
\text { (demisters) }\end{array}$ & Low & None & None & None & None & \\
\hline 2.d-12 & $\begin{array}{l}\text { Level } \\
\text { (demisters) }\end{array}$ & High & $\begin{array}{l}\text { High moisture content of } \\
\text { STSC exhaust air (see } \\
\text { Item 2.d-8.a) or other inlet } \\
\text { stream coupled with closed } \\
\text { isolation valve } \\
\text { ECRT-V-501) }\end{array}$ & $\begin{array}{l}\text { Radiological Control: } \\
\text { If the liquid level in the demisters is high, } \\
\text { then moisture will not be removed from } \\
\text { the airstream. This could result in } \\
\text { moisture build-up on the HEPA filters } \\
\text { resulting in their failure. }\end{array}$ & $\begin{array}{l}\text { - Demister differential pressure } \\
\text { instrumentation DPI-750-514 } \\
\text { and DPI-750-518 } \\
\text { - Exhaust HEPA filter } \\
\text { differential pressure } \\
\text { instrumentation } \\
\text { (DPI-750-512, and -516) } \\
\text { - Redundant HEPA filter trains }\end{array}$ & $\begin{array}{l}\text { - Procedures } \\
\text { - Training } \\
\text { - Radiological Control } \\
\text { Program }\end{array}$ & \\
\hline
\end{tabular}


PRC-STP-00467 REV 0

Table C-12. HAZOP Results, Node 2.d., Sludge Transfer - STSC Ventilation

\begin{tabular}{|c|c|c|c|c|c|c|c|}
\hline \multicolumn{8}{|c|}{ Table C-12. HAZOP Results, Node 2.d., Sludge Transfer - STSC Ventilation } \\
\hline \multirow{2}{*}{ Item } & \multirow{2}{*}{ Process Parameter } & \multirow{2}{*}{ Deviation } & \multirow{2}{*}{ Cause } & \multirow{2}{*}{ Consequences } & \multicolumn{2}{|c|}{ Candidate Controls } & \multirow{2}{*}{ Remarks } \\
\hline & & & & & Engineered & Administrative & \\
\hline 2.d-13 & $\begin{array}{l}\text { Level } \\
\text { (condensate tank) }\end{array}$ & Low & $\begin{array}{l}\text { - Instrumentation failure } \\
\text { - Operator error (failure to } \\
\text { add water to tank) }\end{array}$ & $\begin{array}{l}\text { Radiological Control: } \\
\text { If the liquid level in condensate tank } \\
\text { ECRT-TK-502 drops below the diplegs, } \\
\text { then the ventilation system will draw room } \\
\text { air through the tank via the condensate } \\
\text { tank vent. This will unbalance the } \\
\text { confinement ventilation system airflows } \\
\text { with the result that negative air pressure } \\
\text { differentials may not be properly } \\
\text { maintained leading to a spread of } \\
\text { contamination. } \\
\text { Hydrogen Deflagration: } \\
\text { If the airflows are unbalanced to the point } \\
\text { that less than } 1 \text { cfm is exhausted from the } \\
\text { STSC, then a hydrogen deflagration could } \\
\text { occur. }\end{array}$ & $\begin{array}{l}\text { - Condensate tank level } \\
\text { instrumentation } \\
\text { (LSL-750-501) } \\
\text { - STSC inlet ventilation flow } \\
\text { rate instrumentation } \\
\text { (FS-750-651) interlocked to } \\
\text { Auxiliary Ventilation System } \\
\text { - Auxiliary ventilation system } \\
\text { - Modified KW Basin Annex } \\
\text { confinement ventilation } \\
\text { - Continuous air monitors }\end{array}$ & $\begin{array}{l}\text { - Procedures } \\
\text { - Training } \\
\text { - Radiological Control } \\
\text { Program }\end{array}$ & The condensate tank functions as a seal pot. \\
\hline 2.d-14 & $\begin{array}{l}\text { Level } \\
\text { (condensate tank) }\end{array}$ & High & $\begin{array}{l}\text { - High moisture content of } \\
\text { STSC exhaust air (see } \\
\text { Item 2.d-8.a) or other inlet } \\
\text { air stream } \\
\text { - STSC Overfill } \\
\text { - Sand filter valving error } \\
\text { (see Table C-14, Item } \\
\text { 3-5.c and Table C-16, } \\
\text { Item 4-5.c) }\end{array}$ & $\begin{array}{l}\text { Uncontrolled Release: } \\
\text { If the liquid level in condensate tank } \\
\text { ECRT-TK-502 is high, then the liquid can } \\
\text { overflow the tank resulting in a splash and } \\
\text { splatter/pool release. }\end{array}$ & $\begin{array}{l}\text { - Condensate tank level } \\
\text { instrumentation } \\
\text { (LSH-750-501) } \\
\text { - Modified KW Basin Annex } \\
\text { confinement ventilation } \\
\text { - Continuous air monitors }\end{array}$ & $\begin{array}{l}\text { - Procedures } \\
\text { - Training } \\
\text { - Radiological Control } \\
\text { Program }\end{array}$ & \\
\hline
\end{tabular}




\begin{tabular}{|c|c|c|}
\hline \multicolumn{3}{|c|}{ Table C-13. Normal Operating Conditions, Node 3, STSC Decant } \\
\hline Process Parameter & Design Intent & Remarks \\
\hline Flow & $10-40 \mathrm{gpm}$ & $\begin{array}{l}\text { Motive force is decant pump ECRT-P-201. Decant pump ECRT-P-201 is an air-operated, double-diaphragm (AODD) pump. } \\
\text { In testing at MASF the decant rate is typically } 20-25 \mathrm{gpm} \text {. }\end{array}$ \\
\hline Pressure & 85 psig & $\begin{array}{l}\text { Pressure is controlled by the air pressure supplied to decant pump ECRT-P-201. The instrument air system produces } 212 \\
\text { scfm of dry air at } 120 \text { psig. Pressure control valves are used to regulate the pressure to the pump. }\end{array}$ \\
\hline \multirow[t]{2}{*}{ Concentration } & $\begin{array}{l}\text { Decanted supernate: } \\
\text { KE sludge }=11.9 \mathrm{~g} / \mathrm{L} \\
\mathrm{KW} \text { sludge }=16.8 \mathrm{~g} / \mathrm{L} \\
\text { Settler tank sludge }=39.3 \mathrm{~g} / \mathrm{L}\end{array}$ & $\begin{array}{l}\text { The concentrations shown are maximums as documented in HNF- } 40151 \text {. } \\
\text { The use of flocculant may be required to lower the turbidity of the decanted supernate. See Node } 8 \text { and Node } 9 \text {. }\end{array}$ \\
\hline & $\begin{array}{l}\text { Clarified supernate: } \\
\leq 90 \mathrm{mg} / \mathrm{L}\end{array}$ & $\begin{array}{l}\text { The } 90 \mathrm{mg} / \mathrm{L} \text { value has been established to maintain adequate basin water clarity. PNNL has developed a correlation } \\
\text { between turbidity and solids concentration; } 210 \mathrm{NTUs} \text { roughly correlates to } 90 \mathrm{mg} / \mathrm{L} \text {. In testing at MASF, the clarified } \\
\text { supernate has been between } 5 \text { and } 10 \mathrm{NTUs} \text {. }\end{array}$ \\
\hline Composition & STSC supernate & None \\
\hline \multirow[t]{2}{*}{ Level } & $\begin{array}{l}\text { STSC level at start of decant: } \\
\text { KE/KW sludge }=925 \text { gal } \\
\text { Settler tank sludge }=765 \text { gal } \\
\text { STSC level at end of final decant: } \\
\text { KE sludge }=2.1 \mathrm{~m}^{3} \\
\mathrm{KW} \text { sludge }=1.6 \mathrm{~m}^{3} \\
\text { Settler tank sludge }=0.5 \mathrm{~m}^{3}\end{array}$ & $\begin{array}{l}\text { The level in the STSC is established by level switch LSHH-740-401. When the level reaches the setting for this switch, } \\
\text { booster pump ECRT-P-101 is shut off. This establishes the level at the start of the decant. } \\
\text { Level switch LSHH-740-401 is the same for both KE/KW sludge and settler tank sludge. The difference in the two volumes is } \\
\text { due to the STSC inner cylinder used for settler tank sludge. } \\
\text { The STSC level at the end of the final decant is assumed to be the as-settled sludge limits. }\end{array}$ \\
\hline & $\begin{array}{l}\text { Sand filter level: } \\
\text { Typically the sand filter is full (i.e., there is } \\
\text { no headspace) throughout the decant } \\
\text { process }\end{array}$ & $\begin{array}{l}\text { There is a headspace in the sand filters during the backwash process when the filters are partially drained preparatory to } \\
\text { performance of an air scour. See Node } 4 \text {. } \\
\text { Testing as MASF has shown that there may be a headspace in the sand filter if the AODD pumps air into the sand filter at } \\
\text { the end of a decant cycle. }\end{array}$ \\
\hline Structural Integrity & $\begin{array}{l}\text { Maintain integrity under normal operating } \\
\text { conditions }\end{array}$ & None \\
\hline
\end{tabular}




\begin{tabular}{|c|c|c|}
\hline Process Parameter & Design Intent & Remarks \\
\hline Temperature & Not applicable & $\begin{array}{l}\text { Temperature is not a process parameter that is monitored or controlled. When initially transferred to the STSC, the slurry } \\
\text { temperature will be approximately } 10-15^{\circ} \mathrm{C} \text { (i.e., the same as basin water). Once transferred, the slurry temperature will } \\
\text { slowly increase based on two factors: (1) the ambient temperature in the Modified KW Basin Annex, and (2) the quantity of } \\
\text { uranium metal in the slurry and rate of uranium metal oxidation. The annex HVAC system is design to maintain a minimum } \\
\text { temperature of } 65^{\circ} \mathrm{F}\left(18^{\circ} \mathrm{C} \text { ) given an outside temperature of } 0^{\circ} \mathrm{F} \text {, and a maximum temperature of } 80^{\circ} \mathrm{F}\left(27^{\circ} \mathrm{C}\right) \text { given an }\right. \\
\text { outside temperature of } 105^{\circ} \mathrm{F} \text {. }\end{array}$ \\
\hline & Settling Time: 16 hours & $\begin{array}{l}\text { The flowsheet model conservatively assumes flocculant is not added and the slurry is allowed to settle for } 16 \text { hours prior to } \\
\text { decant. }\end{array}$ \\
\hline Time Procedure & $\begin{array}{l}\text { Transfer Time: } \\
\text { KE sludge } \sim 37 \mathrm{~min} \\
\mathrm{KW} \text { sludge } \sim 48 \mathrm{~min} \\
\text { Settler tank sludge } \sim 67 \mathrm{~min}\end{array}$ & $\begin{array}{l}\text { The transfer times are estimates based on (1) level switch LSHH-740-401, (2) the as-settled sludge limits for an STSC as } \\
\text { shown in Table C-9, and (3) a decant flow rate of } 10 \mathrm{gpm} \text {. } \\
\text { In practice, the transfer will continue until the in-line turbidity instrumentation/interlock shuts off the instrument air supply to } \\
\text { decant pump ECRT-P-201. }\end{array}$ \\
\hline
\end{tabular}




\begin{tabular}{|c|c|c|c|c|c|c|c|}
\hline \multicolumn{8}{|c|}{ Table C-14. HAZOP Results, Node 3, STSC Decant } \\
\hline \multirow{2}{*}{ Item } & \multirow{2}{*}{$\begin{array}{l}\text { Process } \\
\text { Parameter }\end{array}$} & \multirow{2}{*}{ Deviation } & \multirow{2}{*}{ Cause } & \multirow{2}{*}{ Consequences } & \multicolumn{2}{|c|}{ Candidate Controls } & \multirow{2}{*}{ Remarks } \\
\hline & & & & & Engineered & Administrative & \\
\hline $3-1$ & Flow & No & $\begin{array}{l}\text { - Decant pump } \\
\text { ECRT-P-201 not } \\
\text { operating } \\
\text { - A normally-opened valve } \\
\text { is closed } \\
\text { - Sand filter media } \\
\text { plugged }\end{array}$ & $\begin{array}{l}\text { Operational Upset: } \\
\text { If there is no flow, then the STSC will not } \\
\text { be decanted. } \\
\text { If there is no flow because a } \\
\text { normally-opened valve is closed or } \\
\text { because the sand filter media is plugged, } \\
\text { then decant pump ECRT-P-201 will } \\
\text { deadhead resulting in a high pressure. } \\
\text { See item 3-7 below. }\end{array}$ & $\begin{array}{l}\text { - Decant line pressure } \\
\text { instrumentation (PT-720-202) } \\
\text { - Decant line flow } \\
\text { instrumentation (FE-720-201) } \\
\text { - Select valves automatically } \\
\text { positioned } \\
\text { - Manual valve position } \\
\text { indicators }\end{array}$ & $\begin{array}{l}\text { - Procedures } \\
\text { - Training } \\
\text { - Conduct of operations } \\
\text { verifies proper system } \\
\text { configuration }\end{array}$ & \\
\hline $3-2$ & Flow & Low & $\begin{array}{l}\text { - Low air pressure to } \\
\text { decant pump } \\
\text { ECRT-P-201 } \\
\text { - A normally-opened valve } \\
\text { is partially closed } \\
\text { - High sand filter } \\
\text { differential pressure } \\
\text { - Vacuum leak }\end{array}$ & $\begin{array}{l}\text { Operational Upset: } \\
\text { If the flow rate is low, then it will take } \\
\text { longer to decant the STSC. }\end{array}$ & $\begin{array}{l}\text { - Decant line pressure } \\
\text { instrumentation (Pt-720-202) } \\
\text { - Decant line flow } \\
\text { instrumentation (FE-720-201) } \\
\text { - Select valves automatically } \\
\text { positioned } \\
\text { - Manual valve position } \\
\text { indicators }\end{array}$ & $\begin{array}{l}\text { - Procedures } \\
\text { - Training } \\
\text { - Conduct of operations } \\
\text { verifies proper system } \\
\text { configuration }\end{array}$ & \\
\hline 3-3 & Flow & High & $\begin{array}{l}\text { High air pressure to } \\
\text { decant pump ECRT-P-201 }\end{array}$ & $\begin{array}{l}\text { Operational Upset: } \\
\text { If the flow rate is high, then the STSC will } \\
\text { be decanted faster and the filtering will be } \\
\text { less efficient. } \\
\text { If the flow rate is sufficiently high, then } \\
\text { channeling of the sand filter media could } \\
\text { occur which would reduce the efficiency } \\
\text { of the media resulting in fine particulates } \\
\text { being returned to the basin and possible } \\
\text { clouding of the basin water. } \\
\text { The higher flow rate will result in a higher } \\
\text { differential pressure across the sand filter. } \\
\text { See also Item 3-7 below. }\end{array}$ & $\begin{array}{l}\text { - Pressure control valve } \\
\text { ECRT-PCV-760 } \\
\text { - Pressure control valve } \\
\text { ECRT-PCV-765 } \\
\text { - Decant line pressure } \\
\text { instrumentation (PT-720-201) } \\
\text { - Decant line flow } \\
\text { instrumentation (FE-720-201) } \\
\text { - Sand filter differential } \\
\text { pressure instrumentation } \\
\text { (PT-720-205 and -206) }\end{array}$ & $\begin{array}{l}\text { - Procedures } \\
\text { - Training }\end{array}$ & $\begin{array}{l}\text { The maximum pump flow rate of } 40 \mathrm{gpm} \\
\text { may not be sufficient to cause channeling }\end{array}$ \\
\hline
\end{tabular}




\begin{tabular}{|c|c|c|c|c|c|c|c|}
\hline \multirow{2}{*}{ Item } & \multirow{2}{*}{$\begin{array}{l}\text { Process } \\
\text { Parameter }\end{array}$} & \multirow{2}{*}{ Deviation } & \multirow{2}{*}{ Cause } & \multirow{2}{*}{ Consequences } & \multicolumn{2}{|c|}{ Candidate Controls } & \multirow{2}{*}{ Remarks } \\
\hline & & & & & Engineered & Administrative & \\
\hline $3-4$ & Flow & Reverse & N/A & N/A & N/A & N/A & $\begin{array}{l}\text { The only way to get reverse flow during } \\
\text { decant would be install decant pump } \\
\text { ECRT-P-201 backwards. Such an error } \\
\text { would be discovered during pre-operational } \\
\text { testing. }\end{array}$ \\
\hline 3-5.a & Flow & $\begin{array}{l}\text { Misdirected } \\
\text { (into Decant } \\
\text { Pump Box) }\end{array}$ & $\begin{array}{l}\text { - Valving error such that } \\
\text { supernate enters box via } \\
\text { IXM water spray nozzles } \\
\text { - Valving error such that } \\
\text { supernate enters box via } \\
\text { siphon break }\end{array}$ & $\begin{array}{l}\text { Uncontrolled Release: } \\
\text { If supernate is misdirected into the Decant } \\
\text { Pump Box, then a splash and } \\
\text { splatter/pool release will occur. } \\
\text { Hydrogen deflagration: } \\
\text { If supernate is misdirected into the Decant } \\
\text { Pump Box, then hydrogen generated by } \\
\text { the supernate could accumulate in the } \\
\text { box resulting in a deflagration. }\end{array}$ & $\begin{array}{l}\text { - Manual valve position } \\
\text { indicators } \\
\text { - Secondary confinement with } \\
\text { leak detection } \\
\text { - Leak detection interlocked to } \\
\text { shut off Decant pump } \\
\text { ECRT-P-201 } \\
\text { - Decant Pump Box } \\
\text { HEPA-filtered active } \\
\text { ventilation } \\
\text { - Modified KW Basin Annex } \\
\text { confinement ventilation } \\
\text { - Continuous air monitors }\end{array}$ & $\begin{array}{l}\text { - Procedures } \\
\text { - Training } \\
\text { - Conduct of operations } \\
\text { verifies proper system } \\
\text { configuration } \\
\text { - Modified KW Basin Annex is } \\
\text { unmanned during decant } \\
\text { operations } \\
\text { - Leak detection alarm } \\
\text { response } \\
\text { - Visual observation }\end{array}$ & $\begin{array}{l}\text { The Decant Box is provided with Plexiglas } \\
\text { windows that allow visual observation. }\end{array}$ \\
\hline 3-5.b & Flow & \begin{tabular}{|l|} 
Misdirected \\
(into Sand Filter \\
Enclosure)
\end{tabular} & $\begin{array}{l}\text { - Pressure safety valve } \\
\text { PSV-1A or -01B open } \\
\text { - Drain valve HV-03A/3B } \\
\text { open } \\
\text { - Valving error such that } \\
\text { supernate enters } \\
\text { enclosure via siphon } \\
\text { break (see remarks) }\end{array}$ & $\begin{array}{l}\text { Uncontrolled Release: } \\
\text { If supernate is misdirected into the Sand } \\
\text { Filter Enclosure, then a splash and } \\
\text { splatter/pool release will occur. } \\
\text { Hydrogen Deflagration: } \\
\text { If supernate is misdirected into the Sand } \\
\text { Filter Enclosure, then hydrogen generated } \\
\text { by the supernate could accumulate in the } \\
\text { enclosure resulting in a deflagration. }\end{array}$ & $\begin{array}{l}\text { - Manual valve position } \\
\text { indicators } \\
\text { - Select valves automatically } \\
\text { positioned } \\
\text { - Secondary confinement with } \\
\text { leak detection } \\
\text { - Leak detection interlocked to } \\
\text { shut off Decant pump } \\
\text { ECRT-P-201 } \\
\text { - Sand Filter Enclosure } \\
\text { HEPA-filtered active } \\
\text { ventilation } \\
\text { - Modified KW Basin Annex } \\
\text { confinement ventilation } \\
\text { - Continuous air monitors }\end{array}$ & $\begin{array}{l}\text { - Procedures } \\
\text { - Training } \\
\text { - Conduct of operations } \\
\text { verifies proper system } \\
\text { configuration } \\
\text { - Modified KW Basin Annex is } \\
\text { unmanned during decant } \\
\text { operations } \\
\text { - Leak detection alarm } \\
\text { response }\end{array}$ & $\begin{array}{l}\text { If pressure safety valve PSV-01A or -01B } \\
\text { opens, then supernate will be directed in a } \\
\text { controlled manner to the Sand Filter } \\
\text { Enclosure sump. } \\
\text { To get flow into the enclosure via the siphon } \\
\text { break, valve FV-12 would have to be open. }\end{array}$ \\
\hline
\end{tabular}




\begin{tabular}{|c|c|c|c|c|c|c|c|}
\hline \multicolumn{8}{|c|}{ Table C-14. HAZOP Results, Node 3, STSC Decant } \\
\hline \multirow{2}{*}{ Item } & \multirow{2}{*}{$\begin{array}{l}\text { Process } \\
\text { Parameter }\end{array}$} & \multirow{2}{*}{ Deviation } & \multirow{2}{*}{ Cause } & \multirow{2}{*}{ Consequences } & \multicolumn{2}{|c|}{ Candidate Controls } & \multirow{2}{*}{ Remarks } \\
\hline & & & & & Engineered & Administrative & \\
\hline 3-5.c & Flow & $\begin{array}{l}\text { Misdirected } \\
\text { (into sand filter } \\
\text { sparge } \\
\text { exhaust) }\end{array}$ & Valving error (FV-06A/B) & $\begin{array}{l}\text { Uncontrolled Release: } \\
\text { If supernate is misdirected into the sand } \\
\text { filter sparge exhaust, then catch tank } \\
\text { ECRT-TK-502 will overflow and a splash } \\
\text { and splatter/pool release will occur. }\end{array}$ & $\begin{array}{l}\text { - Select valves automatically } \\
\text { positioned } \\
\text { - Catch tank level } \\
\text { instrumentation } \\
\text { (LSH-750-502) } \\
\text { - Modified KW Basin Annex } \\
\text { confinement ventilation } \\
\text { - Continuous air monitors }\end{array}$ & $\begin{array}{l}\text { - Procedures } \\
\text { - Training } \\
\text { - Modified KW Basin Annex is } \\
\text { unmanned during decant } \\
\text { operations }\end{array}$ & $\begin{array}{l}\text { Valves FV-06A and FV-06B are single } \\
\text { barriers preventing the flow of decanted } \\
\text { supernate into the ventilation system. }\end{array}$ \\
\hline $3-5 . d$ & Flow & $\begin{array}{l}\text { Misdirected } \\
\text { (into Decant } \\
\text { Pump Box IXM } \\
\text { water supply) }\end{array}$ & Valving error & $\begin{array}{l}\text { Uncontrolled Release: } \\
\text { If supernate is misdirected into the Decant } \\
\text { Pump Box IXM water supply, then a } \\
\text { splash and splatter/pool release could } \\
\text { occur. }\end{array}$ & $\begin{array}{l}\text { - Manual valve position } \\
\text { indicators } \\
\text { - Check valve ECRT-CV-201 } \\
\text { - Modified KW Basin Annex } \\
\text { confinement ventilation } \\
\text { - Continuous air monitors }\end{array}$ & $\begin{array}{l}\text { - Procedures } \\
\text { - Training } \\
\text { - Conduct of operations } \\
\text { verifies proper system } \\
\text { configuration } \\
\text { - Modified KW Basin Annex is } \\
\text { unmanned during decant } \\
\text { operations }\end{array}$ & \\
\hline 3-5.e & Flow & $\begin{array}{l}\text { Misdirected } \\
\text { (into Sand Filter } \\
\text { Enclosure IXM } \\
\text { water supply) }\end{array}$ & Valving error & $\begin{array}{l}\text { Uncontrolled Release: } \\
\text { If supernate is misdirected into the Sand } \\
\text { Filter Enclosure IXM water supply, then a } \\
\text { splash and splatter/pool release could } \\
\text { occur. }\end{array}$ & $\begin{array}{l}\text { - Select valves automatically } \\
\text { positioned } \\
\text { - Check valve ECRT-CV-506 }\end{array}$ & $\begin{array}{l}\text { - Procedures } \\
\text { - Training } \\
\text { - Modified KW Basin Annex is } \\
\text { unmanned during decant } \\
\text { operations } \\
\text { - Continuous air monitors }\end{array}$ & \\
\hline 3-5.f & Flow & $\begin{array}{l}\text { Misdirected } \\
\text { (into Sand Filter } \\
\text { Enclosure } \\
\text { instrument air } \\
\text { supply) }\end{array}$ & Valving error & $\begin{array}{l}\text { Uncontrolled Release: } \\
\text { If supernate is misdirected into the Sand } \\
\text { Filter Enclosure instrument air supply, } \\
\text { then a splash and splatter/pool release } \\
\text { could occur. }\end{array}$ & $\begin{array}{l}\text { - Select valves automatically } \\
\text { positioned } \\
\text { - Check valve ECRT-CV-409 }\end{array}$ & $\begin{array}{l}\text { - Procedures } \\
\text { - Training } \\
\text { - Modified KW Basin Annex is } \\
\text { unmanned during decant } \\
\text { operations } \\
\text { - Continuous air monitors }\end{array}$ & \\
\hline
\end{tabular}




\begin{tabular}{|c|c|c|c|c|c|c|c|}
\hline \multirow{2}{*}{ Item } & \multirow{2}{*}{$\begin{array}{l}\text { Process } \\
\text { Parameter }\end{array}$} & \multirow{2}{*}{ Deviation } & \multirow{2}{*}{ Cause } & \multirow{2}{*}{ Consequences } & \multicolumn{2}{|c|}{ Candidate Controls } & \multirow{2}{*}{ Remarks } \\
\hline & & & & & Engineered & Administrative & \\
\hline 3-5.g & Flow & $\begin{array}{l}\text { Misdirected } \\
\text { (into flocculant } \\
\text { addition supply) }\end{array}$ & Valving error & $\begin{array}{l}\text { Uncontrolled Release: } \\
\text { If supernate is misdirected into the } \\
\text { flocculant addition supply, then a splash } \\
\text { and splatter/pool release could occur. }\end{array}$ & $\begin{array}{l}\text { - Manual valve position } \\
\text { indicators } \\
\text { - Check valve ECRT-CV-202 } \\
\text { - Modified KW Basin Annex } \\
\text { confinement ventilation }\end{array}$ & $\begin{array}{l}\text { - Procedures } \\
\text { - Training } \\
\text { - Conduct of operations } \\
\text { verifies proper system } \\
\text { configuration } \\
\text { - Modified KW Basin Annex is } \\
\text { unmanned during decant } \\
\text { operations } \\
\text { - Continuous air monitors }\end{array}$ & \\
\hline $3-5-h$ & Flow & $\begin{array}{l}\text { Misdirected } \\
\text { (bypass filter } \\
\text { media) }\end{array}$ & Valving error & $\begin{array}{l}\text { Operational Upset: } \\
\text { If the filter media is bypassed, then the } \\
\text { decanted supernate will be transferred } \\
\text { directly to the basin which could cloud the } \\
\text { basin water. }\end{array}$ & $\begin{array}{l}\text { - Select valves automatically } \\
\text { positioned } \\
\text { - Clarified supernate turbidity } \\
\text { instrumentation (AE-720-202) }\end{array}$ & $\begin{array}{l}\text { - Procedures } \\
\text { - Training }\end{array}$ & \\
\hline $3-6$ & Pressure & Low & $\begin{array}{l}\text { Low air pressure to decant } \\
\text { pump ECRT-P-201 }\end{array}$ & $\begin{array}{l}\text { Operational Upset: } \\
\text { If the air pressure is low, then the flow } \\
\text { rate will be low and it will take longer to } \\
\text { decant the STSC. }\end{array}$ & $\begin{array}{l}\text { Instrument air line pressure } \\
\text { instrumentation (PT-770-766) }\end{array}$ & $\begin{array}{l}\text { - Procedures } \\
\text { - Training }\end{array}$ & \\
\hline
\end{tabular}




\begin{tabular}{|c|c|c|c|c|c|c|c|}
\hline \multicolumn{8}{|c|}{ Table C-14. HAZOP Results, Node 3, STSC Decant } \\
\hline \multirow{2}{*}{ Item } & \multirow{2}{*}{$\begin{array}{l}\text { Process } \\
\text { Parameter }\end{array}$} & \multirow{2}{*}{ Deviation } & \multirow{2}{*}{ Cause } & \multirow{2}{*}{ Consequences } & \multicolumn{2}{|c|}{ Candidate Controls } & \multirow{2}{*}{ Remarks } \\
\hline & & & & & Engineered & Administrative & \\
\hline 3-7 & Pressure & High & $\begin{array}{l}\text { - High air pressure to } \\
\text { decant pump } \\
\text { ECRT-P-201 } \\
\text { - A normally-opened valve } \\
\text { is closed } \\
\text { - Sand filter media } \\
\text { plugged }\end{array}$ & $\begin{array}{l}\text { Uncontrolled Release: } \\
\text { If the pressure is high, then the decant } \\
\text { line or sand filter could fail resulting in an } \\
\text { airborne spray or splash and splatter/pool } \\
\text { release. }\end{array}$ & $\begin{array}{l}\text { - Piping designed in } \\
\text { accordance with B31.3, } \\
\text { "Process Piping" } \\
\text { - Select valves automatically } \\
\text { positioned } \\
\text { - Manual valve position } \\
\text { indicators } \\
\text { - Pressure control valve } \\
\text { ECRT-PCV-760 and -765 } \\
\text { - Decant line pressure } \\
\text { instrumentation (PT-720-202) } \\
\text { - Sand filter differential } \\
\text { pressure instrumentation } \\
\text { (PT-720-205 and -206) } \\
\text { - Secondary containment with } \\
\text { leak detection } \\
\text { - Leak detection interlocked to } \\
\text { shut off Decant pump } \\
\text { ECRT-P-201 } \\
\text { - Decant Pump Box } \\
\text { HEPA-filtered active } \\
\text { ventilation } \\
\text { - Sand Filter Enclosure } \\
\text { HEPA-filtered active } \\
\text { ventilation } \\
\text { - Modified KW Basin Annex } \\
\text { confinement ventilation } \\
\text { - Continuous air monitors } \\
\text { - Pressure safety valve } \\
\text { PSV-01A and -01B (see } \\
\text { remarks) }\end{array}$ & $\begin{array}{l}\text { - Procedures } \\
\text { - Training } \\
\text { - Conduct of operations } \\
\text { verifies proper system } \\
\text { configuration } \\
\text { - Modified KW Basin Annex is } \\
\text { unmanned during decant } \\
\text { operations }\end{array}$ & $\begin{array}{l}\text { If Pressure safety valve PSV-01A or -01B } \\
\text { opens, then supernate will be directed in a } \\
\text { controlled manner to the Sand Filter } \\
\text { Enclosure sump. }\end{array}$ \\
\hline 3-8.a & $\begin{array}{l}\text { Concentration } \\
\text { (decanted } \\
\text { supernate) }\end{array}$ & Low & N/A & N/A & N/A & N/A & $\begin{array}{l}\text { A low turbidity in the decanted supernate is } \\
\text { desirable. }\end{array}$ \\
\hline
\end{tabular}




\begin{tabular}{|c|c|c|c|c|c|c|c|}
\hline \multirow{2}{*}{ Item } & \multirow{2}{*}{$\begin{array}{l}\text { Process } \\
\text { Parameter }\end{array}$} & \multirow{2}{*}{ Deviation } & \multirow{2}{*}{ Cause } & \multirow{2}{*}{ Consequences } & \multicolumn{2}{|c|}{ Candidate Controls } & \multirow{2}{*}{ Remarks } \\
\hline & & & & & Engineered & Administrative & \\
\hline 3-8.b & $\begin{array}{l}\text { Concentration } \\
\text { (clarified } \\
\text { supernate) }\end{array}$ & Low & N/A & N/A & N/A & N/A & $\begin{array}{l}\text { A low solids concentration in the clarified } \\
\text { supernate is desirable. }\end{array}$ \\
\hline 3-9.a & $\begin{array}{l}\text { Concentration } \\
\text { (decanted } \\
\text { supernate) }\end{array}$ & High & $\begin{array}{l}\text { - Settling time too short } \\
\text { - Operator error }\end{array}$ & $\begin{array}{l}\text { Operational Upset: } \\
\text { If the turbidity is too high, then the sand } \\
\text { filter will begin to plug resulting in a high } \\
\text { differential pressure. This would require } \\
\text { additional backwashes. } \\
\text { Uncontrolled Release: } \\
\text { If the high turbidity results in plugging the } \\
\text { sand filter, then decant pump } \\
\text { ECRT-P-201 will deadhead resulting in a } \\
\text { high pressure. The consequences are as } \\
\text { stated in Item 3-7 above. }\end{array}$ & $\begin{array}{l}\text { - Turbidity instrumentation } \\
\text { (ASH-720-201) } \\
\text { - Sand filter differential } \\
\text { pressure instrumentation } \\
\text { (PT-720-205 and -206) } \\
\text { - Decant line pressure } \\
\text { instrumentation (PT-720-202) } \\
\text { - Secondary containment with } \\
\text { leak detection } \\
\text { - Modified KW Basin Annex } \\
\text { confinement ventilation } \\
\text { - Continuous air monitors }\end{array}$ & $\begin{array}{l}\text { - Procedures } \\
\text { - Training } \\
\text { - Conduct of operations } \\
\text { verifies proper system } \\
\text { configuration } \\
\text { - Modified KW Basin Annex is } \\
\text { unmanned during decant } \\
\text { operations }\end{array}$ & \\
\hline 3-9.b & $\begin{array}{l}\text { Concentration } \\
\text { (clarified } \\
\text { supernate) }\end{array}$ & High & $\begin{array}{l}\text { - Incorrect filter media } \\
\text { - Filter media channeling }\end{array}$ & $\begin{array}{l}\text { Operational Upset: } \\
\text { If there is a high concentration of solids in } \\
\text { the clarified supernate, then in-basin } \\
\text { activities will be impacted due to water } \\
\text { clarity issues. }\end{array}$ & $\begin{array}{l}\text { - Sand filter differential } \\
\text { pressure instrumentation } \\
\text { (PT-720-205 and -206) } \\
\text { - Clarified supernate turbidity } \\
\text { instrumentation (AE-720-202) }\end{array}$ & $\begin{array}{l}\text { - Procedures } \\
\text { - Training }\end{array}$ & \\
\hline $3-10$ & Composition & $\begin{array}{l}\text { Other } \\
\text { (air) }\end{array}$ & $\begin{array}{l}\text { - Failure of turbidity } \\
\text { instrumentation } \\
\text { - Operator error }\end{array}$ & $\begin{array}{l}\text { Operational Upset: } \\
\text { If the decant turbidity instrumentation fails } \\
\text { or there is an operator error, then the } \\
\text { pump will continue to decant the STSC } \\
\text { until the floating decant head comes to } \\
\text { rest on the sludge. (see remarks). }\end{array}$ & $\begin{array}{l}\text { - Turbidity instrumentation } \\
\text { (AE-720-201) } \\
\text { - Sand filter differential } \\
\text { pressure instrumentation } \\
\text { (PT-720-205 and -206) } \\
\text { - Decant line pressure } \\
\text { instrumentation (PT-720-202) }\end{array}$ & $\begin{array}{l}\text { - Procedures } \\
\text { - Training }\end{array}$ & $\begin{array}{l}\text { In testing at MASF, when the floating decant } \\
\text { head came to rest on the sludge it pumped } \\
\text { sludge to the sand filter. } \\
\text { If the AODD pump is allowed to continue } \\
\text { operating it will begin to pump air. If air is } \\
\text { pumped into the sand filter to the point that it } \\
\text { dewaters the media, then the filter may not } \\
\text { perform effectively in the future, in which } \\
\text { case it would have to be replaced. }\end{array}$ \\
\hline 3-11.a & \begin{tabular}{|l} 
Level \\
(STSC)
\end{tabular} & Low & $\begin{array}{l}\text { STSC not filled to proper } \\
\text { level (see Table C-10, } \\
\text { Items 2.c-9.a and .9b) }\end{array}$ & $\begin{array}{l}\text { Operational Upset: } \\
\text { If the STSC liquid level is low, then the } \\
\text { decant will be accomplished in a shorter } \\
\text { period of time. }\end{array}$ & $\begin{array}{l}\text { - STSC level switches } \\
\text { LS/LSH/LSHH-740-401 }\end{array}$ & $\begin{array}{l}\text { - Procedures } \\
\text { - Training }\end{array}$ & \\
\hline
\end{tabular}




\begin{tabular}{|c|c|c|c|c|c|c|c|}
\hline \multicolumn{8}{|c|}{ Table C-14. HAZOP Results, Node 3, STSC Decant } \\
\hline \multirow{2}{*}{ Item } & \multirow{2}{*}{$\begin{array}{l}\text { Process } \\
\text { Parameter }\end{array}$} & \multirow{2}{*}{ Deviation } & \multirow{2}{*}{ Cause } & \multirow{2}{*}{ Consequences } & \multicolumn{2}{|c|}{ Candidate Controls } & \multirow{2}{*}{ Remarks } \\
\hline & & & & & Engineered & Administrative & \\
\hline 3-11.b & $\begin{array}{l}\text { Level } \\
\text { (Sand Filter) }\end{array}$ & Low & $\begin{array}{l}\text { - Leaking valve (see } \\
\text { remarks) } \\
\text { - Diaphragm failure such } \\
\text { that air from AODD } \\
\text { pump is entrained in } \\
\text { decanted supernate }\end{array}$ & $\begin{array}{l}\text { Operational Upset: } \\
\text { If the liquid level is low such that it falls } \\
\text { below the level of the sand filter media, } \\
\text { then the filtering efficiency of the sand } \\
\text { filter will decrease. }\end{array}$ & $\begin{array}{l}\text { - Select valves automatically } \\
\text { positioned } \\
\text { - Manual valve position } \\
\text { indicators }\end{array}$ & $\begin{array}{l}\text { - Procedures } \\
\text { - Training } \\
\text { - Conduct of operations } \\
\text { verifies proper system } \\
\text { configuration }\end{array}$ & $\begin{array}{l}\text { If drain down valve FV- } 08 \mathrm{~A} \text { or }-08 \mathrm{~B} \text { leaked } \\
\text { and the siphon break was not open, then } \\
\text { liquid in the sand fitter would be siphoned to } \\
\text { the basin to the level of the drain down } \\
\text { valve. }\end{array}$ \\
\hline 3-12.a & $\begin{array}{l}\text { Level } \\
\text { (STSC) }\end{array}$ & High & $\begin{array}{l}\text { STSC not filled to proper } \\
\text { level (see Table C-10, } \\
\text { Items 2.c-10.a and -b) }\end{array}$ & $\begin{array}{l}\text { Operational Upset: } \\
\text { If the STSC liquid level is high, then it will } \\
\text { take longer to decant the STSC (see } \\
\text { remarks). }\end{array}$ & $\begin{array}{l}\text { - STSC level switches } \\
\text { LS/LSH/LSHH-740-401 }\end{array}$ & $\begin{array}{l}\text { - Procedures } \\
\text { - Training }\end{array}$ & $\begin{array}{l}\text { This Item assumes that the liquid level is } \\
\text { higher than normal, but that the STSC has } \\
\text { not been overfilled to the point that it } \\
\text { overflows. Such a scenario is addressed in } \\
\text { Node 2.c. }\end{array}$ \\
\hline $3-12 . b$ & $\begin{array}{l}\text { Level } \\
\text { (Sand Filter) }\end{array}$ & High & N/A & N/A & N/A & N/A & $\begin{array}{l}\text { The design intent is for the sand filter to be } \\
\text { full (i.e., no head space) }\end{array}$ \\
\hline 3-13.a & $\begin{array}{l}\text { Structural } \\
\text { Integrity }\end{array}$ & $\begin{array}{l}\text { Leak/rupture } \\
\text { (diaphragm } \\
\text { pump) }\end{array}$ & $\begin{array}{l}\text { Decant pump } \\
\text { ECRT-P-201 diaphragm } \\
\text { failure }\end{array}$ & $\begin{array}{l}\text { Uncontrolled Release: } \\
\text { If the decant pump diaphragm failed, then } \\
\text { supernate could enter the pump exhaust } \\
\text { resulting in a spray or splash and } \\
\text { splatter/pool release. }\end{array}$ & $\begin{array}{l}\text { - Decant line pressure } \\
\text { instrumentation (PT-720-202) } \\
\text { - Decant line flow } \\
\text { instrumentation (FE-720-201) } \\
\text { - HEPA filtration of decant } \\
\text { pump exhaust } \\
\text { - Continuous air monitors }\end{array}$ & $\begin{array}{l}\text { - Procedures } \\
\text { - Training } \\
\text { - Modified KW Basin Annex is } \\
\text { unmanned during decant } \\
\text { operations }\end{array}$ & \\
\hline
\end{tabular}




\begin{tabular}{|c|c|c|c|c|c|c|c|}
\hline \multicolumn{8}{|c|}{ Table C-14. HAZOP Results, Node 3, STSC Decant } \\
\hline \multirow{2}{*}{ Item } & \multirow{2}{*}{$\begin{array}{l}\text { Process } \\
\text { Parameter }\end{array}$} & \multirow{2}{*}{ Deviation } & \multirow{2}{*}{ Cause } & \multirow{2}{*}{ Consequences } & \multicolumn{2}{|c|}{ Candidate Controls } & \multirow{2}{*}{ Remarks } \\
\hline & & & & & Engineered & Administrative & \\
\hline 3-13.b & $\begin{array}{l}\text { Structural } \\
\text { Integrity }\end{array}$ & $\begin{array}{l}\text { Leak/rupture } \\
\text { (sand fiter) }\end{array}$ & $\begin{array}{l}\text { - High pressure (see } \\
\text { Item 3-7 above) } \\
\text { - Manufacturing flaw }\end{array}$ & $\begin{array}{l}\text { Uncontrolled Release: } \\
\text { If the sand filter fails, then a spray or } \\
\text { splash and splatter/pool release will occur } \\
\text { inside the sand filter enclosure. } \\
\text { Hydrogen Deflagration: } \\
\text { If the sand filter fails, then decanted } \\
\text { supernate would be spilled into the sand } \\
\text { filter enclosure. Hydrogen generated by } \\
\text { the supernate could accumulate in the } \\
\text { enclosure resulting in a deflagration. }\end{array}$ & $\begin{array}{l}\text { - Decant line pressure } \\
\text { instrumentation (PT-720-202) } \\
\text { - Decant line flow } \\
\text { instrumentation (FE-720-201) } \\
\text { - Pressure safety valve } \\
\text { PSV-01A and -01B (see } \\
\text { remarks) } \\
\text { - Secondary containment with } \\
\text { leak detection } \\
\text { - Leak detection interlocked to } \\
\text { shut off Decant pump } \\
\text { ECRT-P-201 } \\
\text { - Sand Filter Enclosure } \\
\text { HEPA-filtered confinement } \\
\text { ventilation } \\
\text { - Modified KW Basin Annex } \\
\text { confinement ventilation } \\
\text { - Continuous air monitors }\end{array}$ & $\begin{array}{l}\text { - Procedures } \\
\text { - Training } \\
\text { - Quality Assurance Program } \\
\text { - Modified KW Basin Annex is } \\
\text { unmanned during decant } \\
\text { operations } \\
\text { - Leak detection alarm } \\
\text { response }\end{array}$ & $\begin{array}{l}\text { If Pressure safety valve PSV-01A or -01B } \\
\text { opens, then supernate will directed in a } \\
\text { controlled manner to the Sand Filter } \\
\text { Enclosure sump. }\end{array}$ \\
\hline 3-13.c & $\begin{array}{l}\text { Structural } \\
\text { Integrity }\end{array}$ & $\begin{array}{l}\text { Leak/rupture } \\
\text { (decant line - } \\
\text { STSC to sand } \\
\text { filter) }\end{array}$ & $\begin{array}{l}\text { - High pressure (see } \\
\text { Item 3-7 above) } \\
\text { - Manufacturing flaw } \\
\text { - Hose connection } \\
\text { decouples }\end{array}$ & $\begin{array}{l}\text { Uncontrolled Release: } \\
\text { If the decant line fails, then a spray or } \\
\text { splash and splatter/pool release of STSC } \\
\text { supernate will occur. } \\
\text { Hydrogen deflagration: } \\
\text { If the decant line leaks or ruptures inside } \\
\text { the decant pump box, then decanted } \\
\text { supernate would be spilled into the box. } \\
\text { Hydrogen generated by the supernate } \\
\text { could accumulate in the box resulting in a } \\
\text { deflagration. }\end{array}$ & $\begin{array}{l}\text { - Decant line pressure } \\
\text { instrumentation (PT-720-202) } \\
\text { - Decant line flow } \\
\text { instrumentation (FE-720-201) } \\
\text { - Secondary containment with } \\
\text { leak detection } \\
\text { - Leak detection interlocked to } \\
\text { shut off Decant pump } \\
\text { ECRT-P-201 } \\
\text { - Decant Pump Box } \\
\text { HEPA-fittered confinement } \\
\text { - Sand Filter Enclosure } \\
\text { HEPA-filtered confinement } \\
\text { ventilation } \\
\text { - Modified KW Basin Annex } \\
\text { confinement ventilation } \\
\text { - Continuous air monitors }\end{array}$ & $\begin{array}{l}\text { - Procedures } \\
\text { - Training } \\
\text { - Modified KW Basin Annex is } \\
\text { unmanned during decant } \\
\text { operations } \\
\text { - Leak detection alarm } \\
\text { response }\end{array}$ & $\begin{array}{l}\text { The decant line is under suction from the } \\
\text { STSC to decant pump ECRT-P-201. }\end{array}$ \\
\hline
\end{tabular}




\begin{tabular}{|c|c|c|c|c|c|c|c|}
\hline \multicolumn{8}{|c|}{ Table C-14. HAZOP Results, Node 3, STSC Decant } \\
\hline \multirow{2}{*}{ Item } & \multirow{2}{*}{$\begin{array}{l}\text { Process } \\
\text { Parameter }\end{array}$} & \multirow{2}{*}{ Deviation } & \multirow{2}{*}{ Cause } & \multirow{2}{*}{ Consequences } & \multicolumn{2}{|c|}{ Candidate Controls } & \multirow{2}{*}{ Remarks } \\
\hline & & & & & Engineered & Administrative & \\
\hline 3-13.d & $\begin{array}{l}\text { Structural } \\
\text { Integrity }\end{array}$ & $\begin{array}{l}\text { Leak/rupture } \\
\text { (decant line- } \\
\text { sand filter to } \\
\text { basin) }\end{array}$ & $\begin{array}{l}\text { - Manufacturing flaw } \\
\text { - Hose connection } \\
\text { decouples } \\
\text { - External event }\end{array}$ & $\begin{array}{l}\text { Uncontrolled Release: } \\
\text { If the decant line fails, then a spray or } \\
\text { splash and splatter/pool release of filtered } \\
\text { STSC supernate will occur. }\end{array}$ & $\begin{array}{l}\text { - Secondary containment with } \\
\text { leak detection } \\
\text { - Leak detection interlocked to } \\
\text { shut off Decant pump } \\
\text { ECRT-P-201 } \\
\text { - Sand Filter Enclosure } \\
\text { HEPA-filtered active } \\
\text { ventilation } \\
\text { - Modified KW Basin Annex } \\
\text { confinement ventilation } \\
\text { - Continuous air monitors }\end{array}$ & $\begin{array}{l}\text { - Procedures } \\
\text { - Training } \\
\text { - Modified KW Basin Annex is } \\
\text { unmanned during decant } \\
\text { operations }\end{array}$ & \\
\hline $3-14$ & Time Procedure & Too short & $\begin{array}{l}\text { Instrumentation and } \\
\text { control failure }\end{array}$ & $\begin{array}{l}\text { Operational Upset: } \\
\text { If the decant occurs for too short a time, } \\
\text { then less volume will be available for the } \\
\text { subsequent slurry transfer. This will result } \\
\text { in additional fill /decant cycles. }\end{array}$ & $\begin{array}{l}\text { - Turbidity instrumentation } \\
\text { (AE-720-201) }\end{array}$ & $\begin{array}{l}\text { - Procedures } \\
\text { - Training }\end{array}$ & \\
\hline $3-15$ & Time Procedure & Too long & See Item 3-10 above & See ltem 3-10 above & See ltem 3-10 above & See Item 3-10 above & See ltem 3-10 above \\
\hline $3-16$ & Time Procedure & Skip action & Operator error & $\begin{array}{l}\text { Uncontrolled Release: } \\
\text { If the decant is not performed, the next } \\
\text { process step is to backwash the sand } \\
\text { filters. This would result in pumping } \\
20-45 \mathrm{gpm} \text { of IXM water into the STSC. } \\
\text { The STSC would go solid and liquid } \\
\text { would be pumped into the } 4 \text {-in and } 1 \text {-in. } \\
\text { ventilation exhaust lines and into the } 1 \text {-in. } \\
\text { ventilation inlet line leading to a splash } \\
\text { and splatter/pool release. }\end{array}$ & $\begin{array}{l}\text { - High level switch } \\
\text { LSH-740-402 } \\
\text { - Emergency stop switch } \\
\text { ECRT-ES-1 } \\
\text { - Modified KW Basin Annex } \\
\text { confinement ventilation }\end{array}$ & $\begin{array}{l}\text { - Procedures } \\
\text { - Training } \\
\text { - Modified KW Basin Annex is } \\
\text { unmanned during decant } \\
\text { operations } \\
\text { - Continuous air monitors }\end{array}$ & \\
\hline 3-17.a & Time Procedure & $\begin{array}{l}\text { Wrong action } \\
\text { (backwash } \\
\text { instead of } \\
\text { decant) }\end{array}$ & Operator error & See item 3-16 above & See item 3-16 above & See item 3-16 above & See item 3-16 above \\
\hline
\end{tabular}


Table C-14. HAZOP Results, Node 3, STSC Decant

\begin{tabular}{|c|c|c|c|c|c|c|c|}
\hline \multirow{2}{*}{ Item } & \multirow{2}{*}{$\begin{array}{l}\text { Process } \\
\text { Parameter }\end{array}$} & \multirow{2}{*}{ Deviation } & \multirow{2}{*}{ Cause } & \multirow{2}{*}{ Consequences } & \multicolumn{2}{|c|}{ Candidate Controls } & \multirow{2}{*}{ Remarks } \\
\hline & & & & & Engineered & Administrative & \\
\hline 3-17.b & Time Procedure & $\begin{array}{l}\text { Wrong action } \\
\text { (recirculate } \\
\text { instead of } \\
\text { decant) }\end{array}$ & Operator error & $\begin{array}{l}\text { Operational Upset: } \\
\text { If the supernate is recirculated instead of } \\
\text { decanted, then no filtering of the } \\
\text { supernate will occur (see remarks). }\end{array}$ & See Item 3-7 above. & $\begin{array}{l}\text { - Procedures } \\
\text { - Training }\end{array}$ & $\begin{array}{l}\text { Decant and recirculation operations are } \\
\text { initiated by an operator pushing a button on } \\
\text { the control panel. In this case, an operator } \\
\text { erroneously pushes the recirculation button. }\end{array}$ \\
\hline
\end{tabular}




\begin{tabular}{|c|c|c|}
\hline \multicolumn{3}{|c|}{ Table C-15. Normal Operating Conditions, Node 4, Sand Filter Backwash } \\
\hline Process Parameter & Design Intent & Remarks \\
\hline Flow & 20-45 gpm & $\begin{array}{l}\text { IXM water from the Skimmer Water Cleanup System is used to backwash the sand filters. The motive force is } \\
\text { pump IXM-P-1 that is part of the Skimmer Water Cleanup System. The flow rate is set by throttle valve HCV- } 511 \text {. }\end{array}$ \\
\hline Pressure & $100-130 \mathrm{psi}$ & $\begin{array}{l}\text { The Skimmer Water Cleanup System supplies IXM water at } 100-130 \text { psi. IXM water pressure for sand filter decant } \\
\text { is not controlled. } \\
\text { Subsequent to the HAZOP meetings, it was determined that the P\&ID would be revised to include pressure } \\
\text { regulation that would limit the pressure to } 80-85 \text { psi. }\end{array}$ \\
\hline Concentration & $\begin{array}{l}\text { Solids concentration: } \\
\text { KE sludge }=100 \mathrm{~g} / \mathrm{L} \\
\mathrm{KW} \text { sludge }=73 \mathrm{~g} / \mathrm{L} \\
\text { Settler tank sludge }=42 \mathrm{~g} / \mathrm{L}\end{array}$ & None \\
\hline Composition & IXM water containing sludge solids & $\begin{array}{l}\text { There are no other process fluids at the KW Basin that could be inadvertently connected and used to backwash the } \\
\text { sand fiters. }\end{array}$ \\
\hline \multirow[t]{2}{*}{ Level } & $\begin{array}{l}\text { STSC level at start of backwash: } \\
\mathrm{KE} \text { sludge }=2.1 \mathrm{~m}^{3} \\
\mathrm{KW} \text { sludge }=1.6 \mathrm{~m}^{3} \\
\text { Settler tank sludge }=0.5 \mathrm{~m}^{3} \\
\mathrm{STSC} \text { level at completion of backwash: } \\
\mathrm{KE} / \mathrm{KE} \text { sludge }=3.3 \mathrm{~m}^{3} \text { of slurry } \\
\text { Settler tank sludge }=2.7 \mathrm{~m}^{3} \text { of slurry }\end{array}$ & $\begin{array}{l}\text { The STSC level at the start of the backwash is assumed to be equal to the as-settled sludge limits, i.e., multiple } \\
\text { fill/decant cycles have taken place and the final decant lowered the level the values shown. } \\
\text { The liquid level in the STSC at the end of the backwash is established by level switch LSHH-740-401. LSHH-740- } \\
401 \text { activates interlock I-4 which closes valve ECRT-AOV-701 which stops IXM water flow to the sand filters thus } \\
\text { terminating the backwash. }\end{array}$ \\
\hline & $\begin{array}{l}\text { Sand filter: } \\
\text { At the start of the backwash the sand filter is at the } \\
\text { level of drain down valve FV-08A/B } \\
\text { At the completion of the backwash the sand filter is } \\
\text { full, i.e., there is no headspace. }\end{array}$ & None \\
\hline Structural Integrity & Maintain integrity under normal operating conditions & None \\
\hline Temperature & Not applicable & $\begin{array}{l}\text { Temperature is not a process parameter that is monitored or controlled. The } 1.3 \text { million gallons of water in the } \mathrm{KW} \\
\text { Basin are maintained at a temperature of } 10-15^{\circ} \mathrm{C} \text {. The IXM water is approximately the same temperature as the } \\
\text { basin water, i.e., the pumps of the Skimmer Water Cleanup System do not impart significant thermal energy to the } \\
\text { water. }\end{array}$ \\
\hline
\end{tabular}




\begin{tabular}{|l|l|l|}
\hline \multicolumn{2}{|c|}{ Table C-15. Normal Operating Conditions, Node 4, Sand Filter Backwash } \\
\hline \multicolumn{1}{|c|}{ Process Parameter } & \multicolumn{1}{|c|}{ Design Intent } & \multicolumn{1}{|c|}{ Remarks } \\
\hline Time Procedure & $\begin{array}{l}\text { Transfer Time: } \\
\text { KE sludge } \sim 7 \text { to } 15 \mathrm{~min} \\
\text { KW sludge } \sim 10 \text { to } 23 \mathrm{~min} \\
\text { Settler tank sludge } \sim 13 \text { to } 29 \mathrm{~min}\end{array}$ & $\begin{array}{l}\text { The transfer time estimates are based on the starting and ending STSC levels and assuming a backwash flow rate } \\
\text { of 20-45 gpm. }\end{array}$ \\
\hline
\end{tabular}




\begin{tabular}{|c|c|c|c|c|c|c|c|}
\hline \multicolumn{8}{|c|}{ Table C-16. HAZOP Results, Node 4, Sand Filter Backwash } \\
\hline \multirow{2}{*}{ Item } & \multirow{2}{*}{$\begin{array}{l}\text { Process } \\
\text { Parameter }\end{array}$} & \multirow{2}{*}{ Deviation } & \multirow{2}{*}{ Cause } & \multirow{2}{*}{ Consequences } & \multicolumn{2}{|c|}{ Candidate Controls } & \multirow{2}{*}{ Remarks } \\
\hline & & & & & Engineered & Administrative & \\
\hline $4-1$ & Flow & No & $\begin{array}{l}\text { - No IXM water supply } \\
\text { from the Skimmer } \\
\text { Water Cleanup System } \\
\text { - A normally-open valve } \\
\text { is closed } \\
\text { - Backwash line plugged }\end{array}$ & $\begin{array}{l}\text { Operational Upset: } \\
\text { If there is no flow, then sand filter will not } \\
\text { be backwashed. } \\
\text { If there is no flow because a } \\
\text { normally-opened valve is closed or } \\
\text { because a line is plugged, then the } \\
\text { pressure will be high (see ltem 4-7 } \\
\text { below). }\end{array}$ & $\begin{array}{l}\text { - Select valves automatically } \\
\text { controlled } \\
\text { - Backflush water volume } \\
\text { instrumentation (FE-720-202) } \\
\text { - STSC level switches } \\
\text { LS/LSH/LSHH-740-401 } \\
\text { - Pressure instrumentation } \\
\text { (PT-720-201) }\end{array}$ & $\begin{array}{l}\text { - Procedures } \\
\text { - Training } \\
\text { - Conduct of operations } \\
\text { verifies proper system } \\
\text { configuration }\end{array}$ & \\
\hline $4-2$ & Flow & Low & $\begin{array}{l}\text { - Low flow rate from the } \\
\text { Skimmer Water Cleanup } \\
\text { System } \\
\text { - Throttle valve HCV-511 } \\
\text { set incorrectly } \\
\text { - A normally-opened valve } \\
\text { is partially closed } \\
\text { - Sand filter media } \\
\text { partially plugged }\end{array}$ & $\begin{array}{l}\text { Operational Upset: } \\
\text { If the flow rate is low, then solids may not } \\
\text { be effectively backwashed from the sand } \\
\text { filter. This will result in additional } \\
\text { decant/backwash cycles. }\end{array}$ & $\begin{array}{l}\text { - Select valves automatically } \\
\text { controlled } \\
\text { - Manual valve position } \\
\text { indicators } \\
\text { - Backflush water volume } \\
\text { (FE-720-202) } \\
\text { - STSC level switches } \\
\text { LS/LSH/LSHH-740-401 } \\
\text { - Pressure instrumentation } \\
\text { (PT-720-201) }\end{array}$ & $\begin{array}{l}\text { - Procedures } \\
\text { - Training } \\
\text { - Conduct of operations } \\
\text { verifies proper system } \\
\text { configuration }\end{array}$ & \\
\hline $4-3$ & Flow & High & $\begin{array}{l}\text { - High flow rate from the } \\
\text { Skimmer Water Cleanup } \\
\text { System } \\
\text { - Throttle valve HCV-511 } \\
\text { set incorrectly }\end{array}$ & $\begin{array}{l}\text { Operational Upset: } \\
\text { If the flow rate is high, then the sand filter } \\
\text { media could be disturbed and flushed into } \\
\text { the STSC. }\end{array}$ & $\begin{array}{l}\text { - Select valves automatically } \\
\text { controlled } \\
\text { - Manual valve position } \\
\text { indicators } \\
\text { - Backflush water volume } \\
\text { (FE-720-202) } \\
\text { - STSC level switches } \\
\text { LS/LSH/LSHH-740-401 }\end{array}$ & $\begin{array}{l}\text { - Procedures } \\
\text { - Training } \\
\text { - Conduct of operations } \\
\text { verifies proper system } \\
\text { configuration }\end{array}$ & \\
\hline $4-4$ & Flow & Reverse & $\begin{array}{l}\text { Breach in the IXM water } \\
\text { supply line results in } \\
\text { siphoning of supernate } \\
\text { from the STSC } \\
\text { See also Table C-14, } \\
\text { Item 3-5.3 }\end{array}$ & $\begin{array}{l}\text { Uncontrolled Release: } \\
\text { If the IXM water supply line is breached, } \\
\text { then STSC supernate could be siphoned } \\
\text { from the STSC. The supernate would be } \\
\text { filtered by a portion of the sand filter bed. }\end{array}$ & Check valve ECRT-CV-506 & $\begin{array}{l}\text { - Procedures } \\
\text { - Training }\end{array}$ & \\
\hline
\end{tabular}




\begin{tabular}{|c|c|c|c|c|c|c|c|}
\hline \multirow{2}{*}{ Item } & \multirow{2}{*}{$\begin{array}{l}\text { Process } \\
\text { Parameter }\end{array}$} & \multirow{2}{*}{ Deviation } & \multirow{2}{*}{ Cause } & \multirow{2}{*}{ Consequences } & \multicolumn{2}{|c|}{ Candidate Controls } & \multirow{2}{*}{ Remarks } \\
\hline & & & & & Engineered & Administrative & \\
\hline 4-5.a & Flow & $\begin{array}{l}\text { Misdirected } \\
\text { (into Sand Filter } \\
\text { Enclosure) }\end{array}$ & $\begin{array}{l}\text { - Pressure safety valve } \\
\text { PSV-1A or -01B open } \\
\text { - Valving error such that } \\
\text { supernate enters } \\
\text { enclosure via siphon } \\
\text { break (see remarks) }\end{array}$ & $\begin{array}{l}\text { Uncontrolled Release: } \\
\text { If the release is via pressure safety valve } \\
\text { PSV-1A or }-01 \mathrm{~B} \text {, then sand filter } \\
\text { backwash will be misdirected into the } \\
\text { Sand Filter Enclosure and a splash and } \\
\text { splatter/pool release will occur }\end{array}$ & $\begin{array}{l}\text { - Manual valve position } \\
\text { indicators } \\
\text { - Select valves automatically } \\
\text { controlled } \\
\text { - Secondary confinement with } \\
\text { leak detection } \\
\text { - Sand Filter Enclosure } \\
\text { HEPA-filtered active } \\
\text { ventilation } \\
\text { - Modified KW Basin Annex } \\
\text { confinement ventilation } \\
\text { - Continuous air monitors }\end{array}$ & $\begin{array}{l}\text { - Procedures } \\
\text { - Training } \\
\text { - Conduct of operations } \\
\text { verifies proper system } \\
\text { configuration } \\
\text { - Modified KW Basin Annex is } \\
\text { unmanned during backwash } \\
\text { operations }\end{array}$ & $\begin{array}{l}\text { When a backwash is performed, siphon } \\
\text { break valve FV-12 is open and valves } \\
F V-02 A \text { and }-02 B \text { are closed. If, at the start } \\
\text { of backwash, valve FV-02A or }-02 B \text { opened, } \\
\text { then liquid would be released into the } \\
\text { enclosure via FV-12. } \\
\text { When a backwash is performed, siphon } \\
\text { break valves FV-12 is open and drain down } \\
\text { valves FV-08A and }-08 B \text { are closed. If, at } \\
\text { the start of backwash, valve FV-08A and } \\
-08 B \text { opened, then liquid would be released } \\
\text { into the enclosure via FV-12. } \\
\text { As shown on drawing H-1-92301, Sheet } 4 \text {, } \\
\text { the leak detector element in the Sand Filter } \\
\text { Enclosure (LDE-720-203) activates interlock } \\
\text { I-2. Interlock } 1-2 \text { does not shut off IXM water } \\
\text { for sand filter backwash. }\end{array}$ \\
\hline 4-5.b & Flow & $\begin{array}{l}\text { Misdirected } \\
\text { (into Decant } \\
\text { Pump Box) }\end{array}$ & $\begin{array}{l}\text { - Valving error such that } \\
\text { sand filter backwash } \\
\text { enters box via IXM water } \\
\text { spray nozzles } \\
\text { - Valving error such that } \\
\text { supernate enters box via } \\
\text { siphon break }\end{array}$ & $\begin{array}{l}\text { Uncontrolled Release: } \\
\text { If sand filter backwash is misdirected into } \\
\text { the Decant Pump Box, then a splash and } \\
\text { splatter/pool release will occur. }\end{array}$ & $\begin{array}{l}\text { - Manual valve position } \\
\text { indicators } \\
\text { - Secondary confinement with } \\
\text { leak detection } \\
\text { - Decant Pump Box } \\
\text { HEPA-filtered active } \\
\text { ventilation } \\
\text { - Modified KW Basin Annex } \\
\text { confinement ventilation } \\
\text { - Continuous air monitors }\end{array}$ & $\begin{array}{l}\text { - Procedures } \\
\text { - Training } \\
\text { - Conduct of operations } \\
\text { verifies proper system } \\
\text { configuration } \\
\text { - Modified KW Basin Annex is } \\
\text { unmanned during backwash } \\
\text { operations }\end{array}$ & \\
\hline 4-5.c & Flow & $\begin{array}{l}\text { Misdirected } \\
\text { (into sand filter } \\
\text { sparge } \\
\text { exhaust) }\end{array}$ & Valving error (FV-06A/B) & $\begin{array}{l}\text { Uncontrolled Release: } \\
\text { If backwash is misdirected into the sand } \\
\text { filter sparge exhaust, then catch tank } \\
\text { ECRT-TK- } 502 \text { will overflow and a splash } \\
\text { and splatter/pool release will occur. }\end{array}$ & $\begin{array}{l}\text { - Select valves automatically } \\
\text { controlled } \\
\text { - Catch tank level } \\
\text { instrumentation } \\
\text { (LSH-750-502) } \\
\text { - Modified KW Basin Annex } \\
\text { confinement ventilation } \\
\text { - Continuous air monitors }\end{array}$ & $\begin{array}{l}\text { - Procedures } \\
\text { - Training } \\
\text { - Modified KW Basin Annex is } \\
\text { unmanned during backwash } \\
\text { operations }\end{array}$ & \\
\hline
\end{tabular}




\begin{tabular}{|c|c|c|c|c|c|c|c|}
\hline \multicolumn{8}{|c|}{ Table C-16. HAZOP Results, Node 4, Sand Filter Backwash } \\
\hline \multirow{2}{*}{ Item } & \multirow{2}{*}{$\begin{array}{l}\text { Process } \\
\text { Parameter }\end{array}$} & \multirow{2}{*}{ Deviation } & \multirow{2}{*}{ Cause } & \multirow{2}{*}{ Consequences } & \multicolumn{2}{|c|}{ Candidate Controls } & \multirow{2}{*}{ Remarks } \\
\hline & & & & & Engineered & Administrative & \\
\hline 4-5.d & Flow & $\begin{array}{l}\text { Misdirected } \\
\text { (into Decant } \\
\text { Pump Box IXM } \\
\text { water supply) }\end{array}$ & Valving error & $\begin{array}{l}\text { Uncontrolled Release: } \\
\text { If sand filter backwash is misdirected into } \\
\text { the Decant Pump Box IXM water supply, } \\
\text { then a splash and splatter/pool release } \\
\text { could occur. }\end{array}$ & $\begin{array}{l}\text { - Manual valve position } \\
\text { indicators } \\
\text { - Check valve ECRT-CV-201 } \\
\text { - Modified KW Basin Annex } \\
\text { confinement ventilation } \\
\text { - Continuous air monitors }\end{array}$ & $\begin{array}{l}\text { - Procedures } \\
\text { - Training } \\
\text { - Conduct of operations } \\
\text { verifies proper system } \\
\text { configuration } \\
\text { - Modified KW Basin Annex is } \\
\text { unmanned during backwash } \\
\text { operations }\end{array}$ & \\
\hline 4-5.e & Flow & $\begin{array}{l}\text { Misdirected } \\
\text { (into Sand Filter } \\
\text { Enclosure } \\
\text { instrument air } \\
\text { supply) }\end{array}$ & Valving error & $\begin{array}{l}\text { Uncontrolled Release: } \\
\text { If misdirected into the Sand Filter } \\
\text { Enclosure instrument air supply, then a } \\
\text { splash and splatter/pool release could } \\
\text { occur. The release would be primarily } \\
\text { IXM water. }\end{array}$ & $\begin{array}{l}\text { - Select valves automatically } \\
\text { controlled } \\
\text { - Check valve ECRT-CV-409 } \\
\text { - Modified KW Basin Annex } \\
\text { confinement ventilation } \\
\text { - Continuous air monitors }\end{array}$ & $\begin{array}{l}\text { - Procedures } \\
\text { - Training } \\
\text { - Modified KW Basin Annex is } \\
\text { unmanned during backwash } \\
\text { operations }\end{array}$ & \\
\hline 4-5.f & Flow & $\begin{array}{l}\text { Misdirected } \\
\text { (into flocculant } \\
\text { addition supply) }\end{array}$ & Valving error & $\begin{array}{l}\text { Uncontrolled Release: } \\
\text { If sand filter backwash is misdirected into } \\
\text { the flocculant addition supply, then a } \\
\text { splash and splatter/pool release could } \\
\text { occur. }\end{array}$ & $\begin{array}{l}\text { - Manual valve position } \\
\text { indicators } \\
\text { - Check valve ECRT-CV-202 } \\
\text { - Modified KW Basin Annex } \\
\text { confinement ventilation } \\
\text { - Continuous air monitors }\end{array}$ & $\begin{array}{l}\text { - Procedures } \\
\text { - Training } \\
\text { - Conduct of operations } \\
\text { verifies proper system } \\
\text { configuration } \\
\text { - Modified KW Basin Annex is } \\
\text { unmanned during backwash } \\
\text { operations }\end{array}$ & \\
\hline 4-6 & Pressure & Low & $\begin{array}{l}\text { - Low water pressure from } \\
\text { Skimmer Water Cleanup } \\
\text { System } \\
\text { - Throttle valve HCV-511 } \\
\text { set incorrectly } \\
\text { - A normally-opened valve } \\
\text { is partially closed } \\
\text { - Sand filter media } \\
\text { partially plugged }\end{array}$ & $\begin{array}{l}\text { Operational Upset: } \\
\text { If the pressure is low, then solids may not } \\
\text { be effectively backwashed from the sand } \\
\text { filter. This will result in additional } \\
\text { decant/backwash cycles. }\end{array}$ & $\begin{array}{l}\text { - Select valves automatically } \\
\text { controlled } \\
\text { - Manual valve position } \\
\text { indicators } \\
\text { - Differential pressure } \\
\text { instrumentation (PT-720-205 } \\
\text { and -206) }\end{array}$ & $\begin{array}{l}\text { - Procedures } \\
\text { - Training } \\
\text { - Conduct of operations } \\
\text { verifies proper system } \\
\text { configuration }\end{array}$ & \\
\hline
\end{tabular}


Table C-16. HAZOP Results, Node 4, Sand Filter Backwash

\begin{tabular}{|c|c|c|c|c|c|c|c|}
\hline \multirow{2}{*}{ Item } & \multirow{2}{*}{$\begin{array}{l}\text { Process } \\
\text { Parameter }\end{array}$} & \multirow{2}{*}{ Deviation } & \multirow{2}{*}{ Cause } & \multirow{2}{*}{ Consequences } & \multicolumn{2}{|c|}{ Candidate Controls } & \multirow{2}{*}{ Remarks } \\
\hline & & & & & Engineered & Administrative & \\
\hline 4-7 & Pressure & High & $\begin{array}{l}\text { - High water pressure } \\
\text { from the Skimmer Water } \\
\text { Cleanup System } \\
\text { - Throttle valve HCV-511 } \\
\text { set incorrectly } \\
\text { - A normally-opened } \\
\text { valve is closed }\end{array}$ & $\begin{array}{l}\text { Operational Upset: } \\
\text { If the flow rate is high, then the sand filter } \\
\text { media could be disturbed and flushed into } \\
\text { the STSC. } \\
\text { Uncontrolled Release: } \\
\text { If a normally-opened valve is closed, then } \\
\text { high pressure could result in a failure in } \\
\text { the filter backwash system resulting in a } \\
\text { spray or splash and splatter/pool release. }\end{array}$ & $\begin{array}{l}\text { - Piping designed in } \\
\text { accordance with B31.3, } \\
\text { "Process Piping" } \\
\text { - Select valves automatically } \\
\text { controlled } \\
\text { - Manual valve position } \\
\text { indicators } \\
\text { - Differential pressure } \\
\text { instrumentation (PT-720-205 } \\
\text { and -206) } \\
\text { - Pressure safety valve } \\
\text { PSV-01A/B } \\
\text { - Secondary confinement with } \\
\text { leak detection } \\
\text { - Sand Filter Enclosure } \\
\text { HEPA-filtered active } \\
\text { ventilation } \\
\text { - Decant Pump Box } \\
\text { HEPA-filtered active } \\
\text { ventilation } \\
\text { - Modified KW Basin Annex } \\
\text { confinement ventilation } \\
\text { - Continuous air monitors }\end{array}$ & $\begin{array}{l}\text { - Procedures } \\
\text { - Training } \\
\text { - Conduct of operations } \\
\text { verifies proper system } \\
\text { configuration } \\
\text { - Modified KW Basin Annex is } \\
\text { unmanned during backwash } \\
\text { operations }\end{array}$ & $\begin{array}{l}\text { If Pressure safety valve PSV-01A or -01B } \\
\text { opens, then backwash will directed in a } \\
\text { controlled manner to the Sand Filter } \\
\text { Enclosure sump. } \\
\text { As shown on drawing H-1-92301, Sheet 4, } \\
\text { the leak detector element in the Sand Filter } \\
\text { Enclosure (LDE-720-203) activates interlock } \\
\text { I-2. Interlock } 1-2 \text { does not shut off IXM water } \\
\text { for sand filter backwash. } \\
\text { As shown on drawing H-1-92301, Sheet } 5 \text {, } \\
\text { the leak detector element in the Decant } \\
\text { Pump Box (LDE-720-202) activates interlock } \\
\text { I-1. Interlock I-1 does not shut off IXM water } \\
\text { for sand filter backwash. }\end{array}$ \\
\hline $4-8$ & Concentration & Low & $\begin{array}{l}\text { - Low IXM water flow rate } \\
\text { (see Item } 4.2 \text { above) } \\
\text { - Low IXM water pressure } \\
\text { (see Item } 4.6 \text { above) }\end{array}$ & $\begin{array}{l}\text { Operational Upset: } \\
\text { If the solids concentration in the } \\
\text { backwash is low, then the sand filter } \\
\text { media is not being effectively } \\
\text { backwashed. This will result in additional } \\
\text { decant/backwash cycles. }\end{array}$ & See ltems 4.2 and 4.6 above & See Items 4.2 and 4.6 above & $\begin{array}{l}\text { The concentration may normally be lower } \\
\text { than the design intent. The concentration of } \\
\text { solids in any given backwash evolution will } \\
\text { depend on the quantity of solids collected on } \\
\text { the filter media which in turn is a function of } \\
\text { the solids concentration in the decanted } \\
\text { supernate. }\end{array}$ \\
\hline $4-9$ & Concentration & High & N/A & N/A & N/A & N/A & $\begin{array}{l}\text { A high solids concentration in the sand filter } \\
\text { backwash is desirable. }\end{array}$ \\
\hline
\end{tabular}




\begin{tabular}{|c|c|c|c|c|c|c|c|}
\hline \multicolumn{8}{|c|}{ Table C-16. HAZOP Results, Node 4, Sand Filter Backwash } \\
\hline \multirow{2}{*}{ Item } & \multirow{2}{*}{$\begin{array}{l}\text { Process } \\
\text { Parameter }\end{array}$} & \multirow{2}{*}{ Deviation } & \multirow{2}{*}{ Cause } & \multirow{2}{*}{ Consequences } & \multicolumn{2}{|c|}{ Candidate Controls } & \multirow{2}{*}{ Remarks } \\
\hline & & & & & Engineered & Administrative & \\
\hline $4-10$ & Composition & $\begin{array}{l}\text { Other } \\
\text { (instrument air) }\end{array}$ & $\begin{array}{l}\text { Valving error (see } \\
\text { remarks) }\end{array}$ & $\begin{array}{l}\text { Operational Upset: } \\
\text { If a valving error occurs, then instrument } \\
\text { air could be directed to the STSC via the } \\
\text { decant/backwash line. }\end{array}$ & $\begin{array}{l}\text { - Select valves automatically } \\
\text { controlled } \\
\text { - STSC active ventilation }\end{array}$ & $\begin{array}{l}\text { - Procedures } \\
\text { - Training }\end{array}$ & $\begin{array}{l}\text { IXM water from the Skimmer Water Cleanup } \\
\text { System is used to backwash the sand filters. } \\
\text { As stated in Table C-15, there are no other } \\
\text { process fluids at the KW Basin that could be } \\
\text { inadvertently connected and used to } \\
\text { backwash the sand filters. However, prior to } \\
\text { backwashing, the sand filter is partially } \\
\text { drained and a } 5 \mathrm{cfm} \text { air scour is performed } \\
\text { using instrument air. This air is normally } \\
\text { exhausted via valve FV-07ABB to the sand } \\
\text { filter sparge exhaust line. A valving error } \\
\text { could occur such that the exhaust air is } \\
\text { routed back to the STSC via the } \\
\text { decant/backwash line. }\end{array}$ \\
\hline 4-11.a & $\begin{array}{l}\text { Level } \\
\text { (STSC at start of } \\
\text { backwash) }\end{array}$ & Low & N/A & $N / A$ & N/A & N/A & $\begin{array}{l}\text { As stated in Table C-15, the STSC level at } \\
\text { the start of the backwash is assumed to be } \\
\text { equal to the as-settled sludge limits. The } \\
\text { only way the level could be lower would be if } \\
\text { the STSC failed and liquid drained into the } \\
\text { STS cask (see Table C-10, Item 2.c-8). }\end{array}$ \\
\hline 4-11.b & $\begin{array}{l}\text { Level } \\
\text { (Sand Filter at } \\
\text { start of } \\
\text { backwash) }\end{array}$ & Low & $\begin{array}{l}\text { Siphon break not opened } \\
\text { (see remarks) }\end{array}$ & $\begin{array}{l}\text { Operational Upset: } \\
\text { If the liquid level drops below the level of } \\
\text { the filter media, then the de-watered filter } \\
\text { media will not perform as intended in } \\
\text { subsequent decant/backwash cycles and } \\
\text { would likely need to be replaced. }\end{array}$ & $\begin{array}{l}\text { Select valves automatically } \\
\text { controlled }\end{array}$ & $\begin{array}{l}\text { - Procedures } \\
\text { - Training }\end{array}$ & $\begin{array}{l}\text { In order to perform an air sparge, valve } \\
\text { FV-08A/B is opened to establish a flow path } \\
\text { to the sand filter sparge exhaust. If siphon } \\
\text { break valve FV-12 is not opened, then the } \\
\text { contents of the sand filter will be siphoned } \\
\text { back to the basin which will de-water the } \\
\text { sand filter media. }\end{array}$ \\
\hline 4-12.a & $\begin{array}{l}\text { Level } \\
\text { (STSC at end of } \\
\text { backwash) }\end{array}$ & High & $\begin{array}{l}\text { Instrumentation and } \\
\text { control failure }\end{array}$ & $\begin{array}{l}\text { Uncontrolled Release: } \\
\text { If the backwash is not stopped, then the } \\
\text { STSC will go solid and sand fitter } \\
\text { backwash will be pumped into the 4-in } \\
\text { and } 1 \text {-in. ventilation exhaust lines and into } \\
\text { the } 1 \text {-in. ventilation inlet line leading to a } \\
\text { splash and splatter/pool release. }\end{array}$ & $\begin{array}{l}\text { - STSC level switches } \\
\text { LS/LSH/LSHH-740-401 } \\
\text { - High level switch } \\
\text { LSH-740-402 }\end{array}$ & $\begin{array}{l}\text { - Procedures } \\
\text { - Training }\end{array}$ & \\
\hline
\end{tabular}




\begin{tabular}{|c|c|c|c|c|c|c|c|}
\hline \multicolumn{8}{|c|}{ Table C-16. HAZOP Results, Node 4, Sand Filter Backwash } \\
\hline \multirow{2}{*}{ Item } & \multirow{2}{*}{$\begin{array}{l}\text { Process } \\
\text { Parameter }\end{array}$} & \multirow{2}{*}{ Deviation } & \multirow{2}{*}{ Cause } & \multirow{2}{*}{ Consequences } & \multicolumn{2}{|c|}{ Candidate Controls } & \multirow{2}{*}{ Remarks } \\
\hline & & & & & Engineered & Administrative & \\
\hline 4-12.b & $\begin{array}{l}\text { Level } \\
\text { (Sand Filter at } \\
\text { end of } \\
\text { backwash) }\end{array}$ & High & N/A & N/A & N/A & N/A & $\begin{array}{l}\text { At the completion of the backwash the sand } \\
\text { filter is full, i.e., there is no headspace. }\end{array}$ \\
\hline 4-13.a & $\begin{array}{l}\text { Structural } \\
\text { Integrity }\end{array}$ & $\begin{array}{l}\text { Leak/rupture } \\
\text { (sand filter) }\end{array}$ & $\begin{array}{l}\text { - High pressure (see } \\
\text { Item 4-7 above) } \\
\text { - Manufacturing flaw }\end{array}$ & $\begin{array}{l}\text { Uncontrolled Release: } \\
\text { If the sand filter fails, then a spray or } \\
\text { splash and splatter/pool release will } \\
\text { occur. } \\
\text { Hydrogen Deflagration: } \\
\text { If the sand filter fails, then sand filter } \\
\text { backwash would be spilled into the sand } \\
\text { filter enclosure. Hydrogen generated by } \\
\text { the backwash could accumulate in the } \\
\text { enclosure resulting in a deflagration. }\end{array}$ & $\begin{array}{l}\text { - Decant line pressure } \\
\text { instrumentation (PT-720-201) } \\
\text { - Decant line flow } \\
\text { instrumentation (FE-720-201) } \\
\text { - Pressure safety valve } \\
\text { PSV-01A and -01B (see } \\
\text { remarks) } \\
\text { - Secondary containment with } \\
\text { leak detection } \\
\text { - Sand Filter Enclosure } \\
\text { HEPA-filtered confinement } \\
\text { ventilation } \\
\text { - Modified KW Basin Annex } \\
\text { confinement ventilation } \\
\text { - Continuous air monitors }\end{array}$ & $\begin{array}{l}\text { - Procedures } \\
\text { - Training } \\
\text { - Quality Assurance Program } \\
\text { - Modified KW Basin Annex is } \\
\text { unmanned during backwash } \\
\text { operations } \\
\text { - Leak detection alarm } \\
\text { response }\end{array}$ & $\begin{array}{l}\text { If Pressure safety valve PSV-01A or -01B } \\
\text { opens, then backwash will directed in a } \\
\text { controlled manner to the Sand Filter } \\
\text { Enclosure sump. } \\
\text { As shown on drawing H-1-92301, Sheet } 4 \text {, } \\
\text { the leak detector element in the Sand Filter } \\
\text { Enclosure (LDE-720-203) activates interlock } \\
\text { I-2. Interlock I-2 does not shut off IXM water } \\
\text { for sand filter backwash. }\end{array}$ \\
\hline 4-13.b & $\begin{array}{l}\text { Structural } \\
\text { Integrity }\end{array}$ & $\begin{array}{l}\text { Leak/rupture } \\
\text { (backwash line } \\
\text { - sand filter to } \\
\text { STSC) }\end{array}$ & $\begin{array}{l}\text { - High pressure (see } \\
\text { Item 4-7 above) } \\
\text { - Manufacturing flaw } \\
\text { - Hose connection } \\
\text { decouples }\end{array}$ & $\begin{array}{l}\text { Uncontrolled Release: } \\
\text { If the backwash line fails, then a spray or } \\
\text { splash and splatter/pool release will } \\
\text { occur. } \\
\text { Hydrogen deflagration: } \\
\text { If the backwash line leaks or ruptures } \\
\text { inside the sand filter enclosure, then sand } \\
\text { filter backwash would be spilled into the } \\
\text { sand filter enclosure. Hydrogen } \\
\text { generated by the backwash could } \\
\text { accumulate in the box resulting in a } \\
\text { deflagration. }\end{array}$ & $\begin{array}{l}\text { - Decant line pressure } \\
\text { instrumentation (PT-720-201) } \\
\text { - Decant line flow } \\
\text { instrumentation (FE-720-201) } \\
\text { - Secondary containment with } \\
\text { leak detection } \\
\text { - Decant Pump Box } \\
\text { HEPA-filtered confinement } \\
\text { - Sand Filter Enclosure } \\
\text { HEPA-filtered confinement } \\
\text { ventilation } \\
\text { - Modified KW Basin Annex } \\
\text { confinement ventilation } \\
\text { - Continuous air monitors }\end{array}$ & $\begin{array}{l}\text { - Procedures } \\
\text { - Training } \\
\text { - Modified KW Basin Annex is } \\
\text { unmanned during backwash } \\
\text { operations } \\
\text { - Leak detection alarm } \\
\text { response }\end{array}$ & $\begin{array}{l}\text { As shown on drawing H-1-92301, Sheet 4, } \\
\text { the leak detector element in the Sand Filter } \\
\text { Enclosure (LDE-720-203) activates interlock } \\
\text { I-2. Interlock I-2 does not shut off IXM water } \\
\text { for sand filter backwash. } \\
\text { As shown on drawing H-1-92301, Sheet 5, } \\
\text { the leak detector element in the Decant } \\
\text { Pump Box (LDE-720-202) activates interlock } \\
\text { I-1. Interlock I-1 does not shut off IXM water } \\
\text { for sand filter backwash. }\end{array}$ \\
\hline
\end{tabular}




\begin{tabular}{|c|c|c|c|c|c|c|c|}
\hline \multicolumn{8}{|c|}{ Table C-16. HAZOP Results, Node 4, Sand Filter Backwash } \\
\hline \multirow{2}{*}{ Item } & \multirow{2}{*}{$\begin{array}{l}\text { Process } \\
\text { Parameter }\end{array}$} & \multirow{2}{*}{ Deviation } & \multirow{2}{*}{ Cause } & \multirow{2}{*}{ Consequences } & \multicolumn{2}{|c|}{ Candidate Controls } & \multirow{2}{*}{ Remarks } \\
\hline & & & & & Engineered & Administrative & \\
\hline 4-14 & Time Procedure & Too short & $\begin{array}{l}\text { Instrumentation and } \\
\text { control failure }\end{array}$ & $\begin{array}{l}\text { Operational Upset: } \\
\text { If the backwash occurs for too short a } \\
\text { time, then the backwash will be } \\
\text { incomplete and additional } \\
\text { decant/backwash cycles may be required. }\end{array}$ & $\begin{array}{l}\text { STSC level switches } \\
\text { LS/LSH/LSHH-740-401 }\end{array}$ & $\begin{array}{l}\text { - Procedures } \\
\text { - Training }\end{array}$ & \\
\hline 4-15 & Time Procedure & Too long & See Item 4-12.a above & See ltem 4-12.a above & See Item 4-12.a above & See Item 4-12.a above & See Item 4-12.a above \\
\hline 4-16 & Time Procedure & Skip action & Operator error & $\begin{array}{l}\text { Operational Upset: } \\
\text { If the backwash is not performed, then the } \\
\text { differential pressure on the sand filter will } \\
\text { be higher when the next STSC is } \\
\text { processed. } \\
\text { Hydrogen Deflagration: } \\
\text { If the backwash is not performed, then } \\
\text { hydrogen generated by the sludge } \\
\text { captured on the sand filter media could } \\
\text { accumulate in the headspace of the sand } \\
\text { filter resulting in a deflagration. }\end{array}$ & $\begin{array}{l}\text { - Differential pressure } \\
\text { instrumentation (PT-720-205 } \\
\text { and -206) } \\
\text { - Sand Filter Enclosure HEPA } \\
\text { filtered ventilation } \\
\text { - Modified KW Basin Annex } \\
\text { confinement ventilation } \\
\text { - Continuous air monitors }\end{array}$ & $\begin{array}{l}\text { - Procedures } \\
\text { - Training } \\
\text { - Modified KW Basin Annex is } \\
\text { unmanned during backwash } \\
\text { operations } \\
\text { - Leak detection alarm } \\
\text { response }\end{array}$ & \\
\hline 4-17 & Time Procedure & $\begin{array}{l}\text { Wrong action } \\
\text { (decant instead } \\
\text { of backwash) }\end{array}$ & Operator error & $\begin{array}{l}\text { Operational Upset: } \\
\text { If a decant is initiated instead of a } \\
\text { backwash, then the floating decant head } \\
\text { would be at the same elevation as when } \\
\text { the previous decant ended. When the } \\
\text { decant pump started in the recirculation } \\
\text { mode, the AODD would pump either air or } \\
\text { sludge (see remarks).. }\end{array}$ & $\begin{array}{l}\text { Turbidity instrumentation } \\
\text { (AE-720-201) }\end{array}$ & $\begin{array}{l}\text { - Procedures } \\
\text { - Training }\end{array}$ & $\begin{array}{l}\text { In testing at MASF, when the floating decant } \\
\text { head came to rest on the sludge it pumped } \\
\text { sludge to the sand filter. } \\
\text { If the AODD pump is allowed to continue } \\
\text { operating it will begin to pump air. If air is } \\
\text { pumped into the sand filter to the point that it } \\
\text { dewaters the media, then the filter may not } \\
\text { perform effectively in the future, in which } \\
\text { case it would have to be replaced. }\end{array}$ \\
\hline
\end{tabular}




\begin{tabular}{|c|c|c|}
\hline Process Parameter & Design Intent & Remarks \\
\hline Flow & $10 \mathrm{cfm}$ & The nitrogen flow rate to the STSC is $10 \mathrm{cfm}$. \\
\hline Pressure & $65 \mathrm{psi}$ & $\begin{array}{l}\text { The STSC is rated at } 150 \mathrm{psi} \text {. The pressure safety valve is set at } 80 \mathrm{psi} \text { because that same nitrogen supply system is used } \\
\text { to inert the STS cask, which has pressure rating of } 80 \mathrm{psi} \text {. }\end{array}$ \\
\hline Concentration & $0.1 \%$ oxygen & The STSC will be purged with nitrogen until the oxygen concentration in the STSC reaches $0.1 \%$. \\
\hline Composition & Nitrogen & $\begin{array}{l}\text { The selection of nitrogen as the inerting gas is discussed in PRC-STP-00273, Analysis of Argon and Nitrogen Purging and } \\
\text { Inerting of Sludge Transport and Storage Container (STSC) and Sludge Transport System (STS) Cask. }\end{array}$ \\
\hline \multirow{2}{*}{ Level } & STSC headspace $=0.469 \mathrm{~m}^{3}$ & $\begin{array}{l}\text { The liquid level in the STSC at the end of the backwash is established by level switch LSHH-740-401. The headspace above } \\
\text { this liquid level is equal to } 0.469 \mathrm{~m}^{3} \text {. }\end{array}$ \\
\hline & Nitrogen volume $>100 \mathrm{scfm}$ & $\begin{array}{l}\text { As documented in PRC-STP-00273, at a rate of } 10 \mathrm{cfm} \text { the STSC is purged for less than } 10 \text { minutes to attain } 0.1 \% \text { oxygen. } \\
\text { Therefore, in excess of } 100 \mathrm{scfm} \text { of nitrogen is required to purge the STSC. }\end{array}$ \\
\hline Structural Integrity & $\begin{array}{l}\text { Maintain integrity under normal operating } \\
\text { conditions }\end{array}$ & None \\
\hline Temperature & Not applicable & $\begin{array}{l}\text { Temperature is not a process parameter that is monitored or controlled. The nitrogen bottles are stored outside such that the } \\
\text { gas temperature will fluctuate with the ambient air temperature. The typical temperature fluctuations that over the course of } \\
\text { several days will have no impact on the operability of the Nitrogen Gas Supply system. }\end{array}$ \\
\hline Time Procedure & 10 minutes & $\begin{array}{l}\text { The purge will be performed until the oxygen concentration in the STSC reaches } 0.1 \% \text { oxygen. The } 10 \text { minute value is } \\
\text { based calculated in PRC-STP- } 00273 \text { based on a headspace of } 0.469 \mathrm{~m}^{3} \text { and a nitrogen flow rate of } 10 \mathrm{cfm} \text {. }\end{array}$ \\
\hline
\end{tabular}

PRC-STP-00273, 2010, Analysis of Argon and Nitrogen Purging and Inerting of Sludge Transport and Storage Container (STSC) and Sludge Transport System (STS) Cask, Rev. 1, CH2M HILL Plateau Remediation Company, Richland, Washington. 


\begin{tabular}{|c|c|c|c|c|c|c|c|}
\hline \multirow{2}{*}{ Item } & \multirow{2}{*}{$\begin{array}{l}\text { Process } \\
\text { Parameter }\end{array}$} & \multirow{2}{*}{ Deviation } & \multirow{2}{*}{ Cause } & \multirow{2}{*}{ Consequences } & \multicolumn{2}{|c|}{ Candidate Controls } & \multirow{2}{*}{ Remarks } \\
\hline & & & & & Engineered & Administrative & \\
\hline $5-1$ & Flow & No & $\begin{array}{l}\text { - Nitrogen bottles empty } \\
\text { - A normally-opened } \\
\text { valve is closed }\end{array}$ & $\begin{array}{l}\text { Hydrogen Deflagration: } \\
\text { If there is no nitrogen flow, then the STSC } \\
\text { will not be inerted. This could result in a } \\
\text { hydrogen deflagration. }\end{array}$ & $\begin{array}{l}\text { - Nitrogen pressure } \\
\text { instrumentation (PI-760-604, } \\
\text { PI-760-605) } \\
\text { - Nitrogen flow instrumentation } \\
\text { (FI-760-601) } \\
\text { - Oxygen concentration } \\
\text { instrumentation (AE-760-601) } \\
\text { - STSC active ventilation (see } \\
\text { remarks) } \\
\text { - Valve position indicators } \\
\text { - Modified KW Basin Annex } \\
\text { confinement ventilation } \\
\text { - Continuous air monitors }\end{array}$ & $\begin{array}{l}\text { - Procedures } \\
\text { - Training } \\
\text { - Conduct of operations } \\
\text { verifies proper system } \\
\text { configuration } \\
\text { - Administrative control } \\
\text { requiring verification of } \mathrm{O}_{2} \\
\text { concentration }\end{array}$ & $\begin{array}{l}\text { If there is no nitrogen flow, a hydrogen } \\
\text { deflagration can be prevented by } \\
\text { re-establishing STSC active ventilation. }\end{array}$ \\
\hline $5-2$ & Flow & Low & $\begin{array}{l}\text { - Flow rate set incorrectly } \\
\text { - A normally-opened } \\
\text { valve is partially closed } \\
\text { - Pressure control valve } \\
\text { failure }\end{array}$ & $\begin{array}{l}\text { Operational Upset: } \\
\text { If the nitrogen flow rate is low, then it will } \\
\text { take longer to inert the STSC. }\end{array}$ & $\begin{array}{l}\text { - Nitrogen flow instrumentation } \\
\text { (FI-760-601) } \\
\text { - Oxygen concentration } \\
\text { instrumentation (AE-760-601) } \\
\text { - Valve position indicators }\end{array}$ & $\begin{array}{l}\text { - Procedures } \\
\text { - Training } \\
\text { - Conduct of operations } \\
\text { verifies proper system } \\
\text { configuration }\end{array}$ & \\
\hline $5-3$ & Flow & High & $\begin{array}{l}\text { - Flow rate set incorrectly } \\
\text { - Pressure control valve } \\
\text { failure }\end{array}$ & $\begin{array}{l}\text { None: } \\
\text { If the nitrogen flow rate is high, then the } \\
\text { STSC will be inerted in a shorter period of } \\
\text { time. }\end{array}$ & $\begin{array}{l}\text { - Nitrogen flow instrumentation } \\
\text { (FI-760-601) } \\
\text { - Oxygen concentration } \\
\text { instrumentation (AE-760-601) } \\
\text { - Valve position indictors }\end{array}$ & $\begin{array}{l}\text { - Procedures } \\
\text { - Training } \\
\text { - Conduct of operations } \\
\text { verifies proper system } \\
\text { configuration }\end{array}$ & \\
\hline $5-4$ & Flow & Reverse & N/A & N/A & N/A & N/A & $\begin{array}{l}\text { There are no mechanisms by which a } \\
\text { reverse flow could be established. }\end{array}$ \\
\hline
\end{tabular}




\begin{tabular}{|c|c|c|c|c|c|c|c|}
\hline \multirow{2}{*}{ Item } & \multirow{2}{*}{$\begin{array}{l}\text { Process } \\
\text { Parameter }\end{array}$} & \multirow{2}{*}{ Deviation } & \multirow{2}{*}{ Cause } & \multirow{2}{*}{ Consequences } & \multicolumn{2}{|c|}{ Candidate Controls } & \multirow{2}{*}{ Remarks } \\
\hline & & & & & Engineered & Administrative & \\
\hline 5-5.a & Flow & $\begin{array}{l}\text { Misdirected } \\
\text { (flow into STS } \\
\text { cask) }\end{array}$ & $\begin{array}{l}\text { Valve ECRT-V-609 set } \\
\text { incorrectly (see remarks) }\end{array}$ & $\begin{array}{l}\text { Hydrogen Deflagration: } \\
\text { If the nitrogen flow is misdirected to the } \\
\text { STS cask, then the STSC will not be } \\
\text { inerted. This could result in a hydrogen } \\
\text { deflagration. }\end{array}$ & $\begin{array}{l}\text { - Nitrogen flow instrumentation } \\
\text { (FI-760-601) } \\
\text { - Oxygen concentration } \\
\text { instrumentation (AE-760-601) } \\
\text { - Valve position indicators } \\
\text { - STSC active ventilation (see } \\
\text { remarks) } \\
\text { - Modified KW Basin Annex } \\
\text { confinement ventilation } \\
\text { - Continuous air monitors }\end{array}$ & $\begin{array}{l}\text { - Procedures } \\
\text { - Training } \\
\text { - Conduct of operations } \\
\text { verifies proper system } \\
\text { configuration } \\
\text { - Administrative control } \\
\text { requiring verification of } \mathrm{O}_{2} \\
\text { concentration }\end{array}$ & $\begin{array}{l}\text { If valve ECRT-V-609 is set incorrectly, then } \\
\text { nitrogen will flow into the STS cask instead of } \\
\text { into the STSC. From the STS cask, the } \\
\text { nitrogen would enter the Loading Bay. } \\
\text { The Loading Bay air change rate is } 4.2 / \mathrm{hr} \text {. } \\
\text { This represents approximately } 3,300 \mathrm{cfm} \text { of } \\
\text { flow. The } 10 \mathrm{cfm} \text { of nitrogen associated with } \\
\text { a misdirected flow does not result in an } \\
\text { oxygen deficient atmosphere. } \\
\text { If there is no nitrogen flow to the STSC, a } \\
\text { hydrogen deflagration could be prevented by } \\
\text { re-establishing STSC active ventilation. }\end{array}$ \\
\hline 5-5.b & Flow & $\begin{array}{l}\text { Misdirected } \\
\text { (flow into } \\
\text { Annex) }\end{array}$ & $\begin{array}{l}\text { Valve ECRT-V-732 open } \\
\text { (see remarks) }\end{array}$ & $\begin{array}{l}\text { Hydrogen Deflagration: } \\
\text { If the nitrogen flow is misdirected into the } \\
\text { Loading Bay, then the STSC will not be } \\
\text { inerted. This could result in a hydrogen } \\
\text { deflagration. }\end{array}$ & $\begin{array}{l}\text { - Nitrogen flow instrumentation } \\
\text { (FI-760-601) } \\
\text { - Oxygen concentration } \\
\text { instrumentation (AE-760-601) } \\
\text { - Valve position indicator } \\
\text { - STSC active ventilation } \\
\text { - Modified KW Basin Annex } \\
\text { confinement ventilation } \\
\text { - Continuous air monitors }\end{array}$ & $\begin{array}{l}\text { - Procedures } \\
\text { - Training } \\
\text { - Conduct of operations } \\
\text { verifies proper system } \\
\text { configuration } \\
\text { - Administrative control } \\
\text { requiring verification of } \mathrm{O}_{2} \\
\text { concentration }\end{array}$ & $\begin{array}{l}\text { If valve ECRT-V- } 732 \text { is open, then nitrogen } \\
\text { could flow into the Loading Bay via the STSC } \\
\text { ventilation inlet HEPA filter thus bypassing } \\
\text { the STSC. } \\
\text { The Loading Bay air change rate is } 4.2 / \mathrm{hr} \text {. } \\
\text { This represents approximately } 3,300 \mathrm{cfm} \text { of } \\
\text { flow. The } 10 \mathrm{cfm} \text { of nitrogen associated with } \\
\text { a misdirected flow does not result in an } \\
\text { oxygen deficient atmosphere. } \\
\text { If there is no nitrogen flow to the STSC, a } \\
\text { hydrogen deflagration could be prevented by } \\
\text { re-establishing STSC active ventilation. }\end{array}$ \\
\hline $5-6$ & Pressure & Low & $\begin{array}{l}\text { - Flow rate set incorrectly } \\
\text { - A normally-opened } \\
\text { valve is partially closed } \\
\text { - Pressure control valve } \\
\text { failure }\end{array}$ & $\begin{array}{l}\text { Operational Upset: } \\
\text { If the nitrogen pressure is low, then it will } \\
\text { take longer to inert the STSC. }\end{array}$ & $\begin{array}{l}\text { - Nitrogen pressure } \\
\text { instrumentation (PI-760-604, } \\
\text { PI-760-605, PI-760-606) } \\
\text { - Nitrogen flow instrumentation } \\
\text { (FI-760-601) } \\
\text { - Oxygen concentration } \\
\text { instrumentation (AE-760-601) } \\
\text { - Valve position indicators }\end{array}$ & $\begin{array}{l}\text { - Procedures } \\
\text { - Training } \\
\text { - Conduct of operations } \\
\text { verifies proper system } \\
\text { configuration }\end{array}$ & \\
\hline
\end{tabular}


Table C-18. HAZOP Results, Node 5, STSC Nitrogen Purge

\begin{tabular}{|c|c|c|c|c|c|c|c|}
\hline \multicolumn{8}{|c|}{ Table C-18. HAZOP Results, Node 5, STSC Nitrogen Purge } \\
\hline \multirow{2}{*}{ Item } & \multirow{2}{*}{$\begin{array}{l}\text { Process } \\
\text { Parameter }\end{array}$} & \multirow{2}{*}{ Deviation } & \multirow{2}{*}{ Cause } & \multirow{2}{*}{ Consequences } & \multicolumn{2}{|c|}{ Candidate Controls } & \multirow{2}{*}{ Remarks } \\
\hline & & & & & Engineered & Administrative & \\
\hline 5-7.a & Pressure & $\begin{array}{l}\text { High } \\
\text { (nitrogen } \\
\text { supply } \\
\text { system) }\end{array}$ & $\begin{array}{l}\text { - Flow rate set incorrectly } \\
\text { - Pressure control valve } \\
\text { failure }\end{array}$ & $\begin{array}{l}\text { Industrial Safety: } \\
\text { If the pressure is high, then a nitrogen } \\
\text { supply hose (ECRT-H-601 or } \\
\text { ECRT-H-604) could fail and whip causing } \\
\text { a facility worker injury. } \\
\text { See also ltem } 5-13 \text { below. }\end{array}$ & $\begin{array}{l}\text { - Nitrogen pressure } \\
\text { instrumentation (PI-760-604, } \\
\text { PI-760-605, PI-760-606) } \\
\text { - Valve position indicators } \\
\text { - Pressure safety valve } \\
\text { ECRT-PSV-601 } \\
\text { - Hose tie-downs }\end{array}$ & $\begin{array}{l}\text { - Procedures } \\
\text { - Training } \\
\text { - Conduct of operations } \\
\text { verifies proper system } \\
\text { configuration } \\
\text { - Industrial Safety Program }\end{array}$ & $\begin{array}{l}\text { High pressure could also result in a leak or } \\
\text { rupture of the nitrogen supply line. See Item } \\
5-13 \text { below. }\end{array}$ \\
\hline $5-7 . b$ & Pressure & $\begin{array}{l}\text { High } \\
\text { (STSC) }\end{array}$ & $\begin{array}{l}\text { Pressure control valve } \\
\text { failure }\end{array}$ & $\begin{array}{l}\text { None: } \\
\text { The STSC cannot be isolated from the } \\
\text { ventilation system during the nitrogen } \\
\text { purge (see remarks).. }\end{array}$ & N/A & - N/A & $\begin{array}{l}\text { At the draft preliminary design, it was } \\
\text { possible to isolate the STSC by closing } \\
\text { valves on the } 4 \text { in. and } 1 \text { in. ventilation lines. } \\
\text { The valve on the } 1 \text { in. line has since been } \\
\text { removed. }\end{array}$ \\
\hline $5-8$ & Concentration & $\begin{array}{l}\text { Low } \\
\left(\mathrm{O}_{2}\right)\end{array}$ & $\begin{array}{l}\text { Purge duration too long } \\
\text { (see Item 5-15 below) }\end{array}$ & $\begin{array}{l}\text { None: } \\
\text { There is no hazard if the oxygen } \\
\text { concentration in the STSC is less than } \\
0.1 \% \text {. }\end{array}$ & N/A & N/A & \\
\hline $5-9$ & Concentration & $\begin{array}{l}\text { High } \\
\left(\mathrm{O}_{2}\right)\end{array}$ & $\begin{array}{l}\text { - Purge duration too short } \\
\text { (see Item 5-14 below) } \\
\text { - Insufficient nitrogen } \\
\text { supply } \\
\text { - No nitrogen flow (see } \\
\text { Item 5-1 above) } \\
\text { - Misdirected nitrogen } \\
\text { flow (see Item 5-5.a, } \\
\text { and .b above) }\end{array}$ & $\begin{array}{l}\text { Hydrogen Deflagration: } \\
\text { If the oxygen concentration in the STSC is } \\
\text { high, then the STSC will not be inerted. } \\
\text { This could result in a hydrogen } \\
\text { deflagration. }\end{array}$ & $\begin{array}{l}\text { - Oxygen concentration } \\
\text { instrumentation (AE-760-601) } \\
\text { - Nitrogen pressure } \\
\text { instrumentation (PI-760-604, } \\
\text { PI-760-605, PI-760-606) } \\
\text { - Nitrogen flow instrumentation } \\
\text { (FI-760-601) } \\
\text { - STSC active ventilation } \\
\text { - Modified KW Basin Annex } \\
\text { confinement ventilation } \\
\text { - Continuous air monitors }\end{array}$ & $\begin{array}{l}\text { - Procedures } \\
\text { - Training } \\
\text { - Conduct of operations } \\
\text { verifies proper system } \\
\text { configuration } \\
\text { - Administrative control } \\
\text { requiring verification of } \mathrm{O}_{2} \\
\text { concentration }\end{array}$ & \\
\hline $5-10 . a$ & Composition & $\begin{array}{l}\text { Other } \\
\text { (oxidant) }\end{array}$ & $\begin{array}{l}\text { Gas bottles containing an } \\
\text { oxidant (e.g., air) installed } \\
\text { at Inert Bottle Station }\end{array}$ & $\begin{array}{l}\text { Hydrogen Deflagration: } \\
\text { If gas bottles containing an oxidant are } \\
\text { installed at the Inert Bottle Station, then } \\
\text { the STSC will not be inerted. This could } \\
\text { result in a hydrogen deflagration. }\end{array}$ & $\begin{array}{l}\text { - Nitrogen-specific fixtures } \\
\text { - Oxygen concentration } \\
\text { instrumentation (AE-760-601) } \\
\text { - Modified KW Basin Annex } \\
\text { confinement ventilation } \\
\text { - Continuous air monitors }\end{array}$ & $\begin{array}{l}\text { - Procedures } \\
\text { - Training } \\
\text { - Quality Assurance Program } \\
\text { - Administrative control } \\
\text { requiring verification of } \mathrm{O}_{2} \\
\text { concentration }\end{array}$ & \\
\hline
\end{tabular}




\begin{tabular}{|c|c|c|c|c|c|c|c|}
\hline \multirow{2}{*}{ Item } & \multirow{2}{*}{$\begin{array}{l}\text { Process } \\
\text { Parameter }\end{array}$} & \multirow{2}{*}{ Deviation } & \multirow{2}{*}{ Cause } & \multirow{2}{*}{ Consequences } & \multicolumn{2}{|c|}{ Candidate Controls } & \multirow{2}{*}{ Remarks } \\
\hline & & & & & Engineered & Administrative & \\
\hline $5-10 . b$ & Composition & $\begin{array}{l}\text { Other } \\
\text { (helium) }\end{array}$ & $\begin{array}{l}\text { Gas bottles containing } \\
\text { helium installed at Inert } \\
\text { Bottle Station }\end{array}$ & $\begin{array}{l}\text { Hydrogen Deflagration: } \\
\text { If helium gas bottles are installed, then } \\
\text { too much counter-current flow will occur } \\
\text { and the STSC will not be inerted (see } \\
\text { remarks). }\end{array}$ & $\begin{array}{l}\text { - Nitrogen-specific fixtures } \\
\text { - Modified KW Basin Annex } \\
\text { confinement ventilation } \\
\text { - Continuous air monitors }\end{array}$ & $\begin{array}{l}\text { - Procedures } \\
\text { - Training } \\
\text { - Quality Assurance Program }\end{array}$ & $\begin{array}{l}\text { PRC-STP-00273 calculates counter-current } \\
\text { flow (of nitrogen out of the STSC and air into } \\
\text { the STSC).and establishes the dwell period } \\
\text { after nozzle closure and before STS cask } \\
\text { closure. If helium gas is used, instead of } \\
\text { nitrogen, then there will be greater } \\
\text { counter-current flow and the STSC/STS cask } \\
\text { will not be inerted. }\end{array}$ \\
\hline 5-11.a & Level & $\begin{array}{l}\text { High } \\
\text { (STSC liquid } \\
\text { level) }\end{array}$ & $\begin{array}{l}\text { Instrumentation and } \\
\text { control failure }\end{array}$ & $\begin{array}{l}\text { None: } \\
\text { If the liquid level in the STSC is high, then } \\
\text { the STSC will be inerted in a shorter } \\
\text { period of time. }\end{array}$ & $\begin{array}{l}\text { - Oxygen concentration } \\
\text { instrumentation (AE-760-601) } \\
\text { - Level switches } \\
\text { LS/LSH/LSHH-740-401 }\end{array}$ & $\begin{array}{l}\text { - Procedures } \\
\text { - Training }\end{array}$ & \\
\hline $5-11 . b$ & Level & $\begin{array}{l}\text { High } \\
\text { (nitrogen } \\
\text { bottle volume }\end{array}$ & N/A & N/A & N/A & N/A & N/A \\
\hline 5-12.a & Level & $\begin{array}{l}\text { Low } \\
\text { (STSC liquid } \\
\text { level) }\end{array}$ & $\begin{array}{l}\text { Instrumentation and } \\
\text { control failure }\end{array}$ & $\begin{array}{l}\text { Operational Upset: } \\
\text { If the liquid level in the STSC is low, then } \\
\text { it will take longer to inert the STSC. }\end{array}$ & $\begin{array}{l}\text { - Oxygen concentration } \\
\text { instrumentation (AE-760-601) } \\
\text { - Level switches } \\
\text { LS/LSH/LSHH-740-401 }\end{array}$ & $\begin{array}{l}\text { - Procedures } \\
\text { - Training }\end{array}$ & \\
\hline $5-12 . b$ & Level & $\begin{array}{l}\text { Low } \\
\text { (nitrogen } \\
\text { bottle volume) }\end{array}$ & $\begin{array}{l}\text { - Leak in supply system } \\
\text { - Operator error (low } \\
\text { pressure bottles not } \\
\text { replaced as needed) }\end{array}$ & $\begin{array}{l}\text { Hydrogen Deflagration: } \\
\text { If the nitrogen volume is low, then there } \\
\text { could be insufficient nitrogen to inert the } \\
\text { STSC. This could result in a hydrogen } \\
\text { deflagration. }\end{array}$ & $\begin{array}{l}\text { - Inert gas system pressure } \\
\text { indicator PI-760-601 } \\
\text { - Oxygen concentration } \\
\text { instrumentation (AE-760-601) } \\
\text { - Modified KW Basin Annex } \\
\text { confinement ventilation } \\
\text { - Continuous air monitors }\end{array}$ & $\begin{array}{l}\text { - Procedures } \\
\text { - Training } \\
\text { - Conduct of operations } \\
\text { verifies proper system } \\
\text { configuration } \\
\text { - Administrative control } \\
\text { requiring verification of } \mathrm{O}_{2} \\
\text { concentration. }\end{array}$ & \\
\hline
\end{tabular}




\begin{tabular}{|c|c|c|c|c|c|c|c|}
\hline \multirow{2}{*}{ Item } & \multirow{2}{*}{$\begin{array}{l}\text { Process } \\
\text { Parameter }\end{array}$} & \multirow{2}{*}{ Deviation } & \multirow{2}{*}{ Cause } & \multirow{2}{*}{ Consequences } & \multicolumn{2}{|c|}{ Candidate Controls } & \multirow{2}{*}{ Remarks } \\
\hline & & & & & Engineered & Administrative & \\
\hline $5-13$ & Structural Integrity & $\begin{array}{l}\text { Leak/rupture } \\
\text { (nitrogen } \\
\text { supply } \\
\text { system) }\end{array}$ & $\begin{array}{l}\text { - Overpressurization } \\
\text { - Hose disconnects }\end{array}$ & $\begin{array}{l}\text { Hydrogen Deflagration: } \\
\text { If a leak or rupture in the nitrogen supply } \\
\text { occurs, then the STSC will not be inerted. } \\
\text { This could result in a hydrogen } \\
\text { deflagration. } \\
\text { Oxygen Deficient Atmosphere: } \\
\text { If a leak or rupture in the nitrogen supply } \\
\text { occurs, then an oxygen deficient } \\
\text { atmosphere could form. }\end{array}$ & $\begin{array}{l}\text { - Oxygen concentration } \\
\text { instrumentation (AE-760-601) } \\
\text { - Nitrogen pressure } \\
\text { instrumentation (PI-760-604, } \\
\text { PI-760-605, PI-760-606) } \\
\text { - Nitrogen flow instrumentation } \\
\text { (FI-760-601) } \\
\text { - STSC active ventilation } \\
\text { - Modified KW Basin Annex } \\
\text { confinement ventilation } \\
\text { - Continuous air monitors }\end{array}$ & $\begin{array}{l}\text { - Procedures } \\
\text { - Training } \\
\text { - Conduct of operations } \\
\text { verifies proper system } \\
\text { configuration } \\
\text { - Industrial Safety Program }\end{array}$ & $\begin{array}{l}\text { If the STS cask cannot be inerted, a } \\
\text { hydrogen deflagration could be prevented by } \\
\text { re-establishing STSC active ventilation. } \\
\text { Depending on the location of the nitrogen } \\
\text { supply system leak, the flow rate could be } \\
\text { much greater than } 10 \mathrm{cfm} \text { and thus constitute } \\
\text { an oxygen deficient atmosphere hazard. }\end{array}$ \\
\hline $5-14$ & Time Procedure & Too short & $\begin{array}{l}\text { - Operator error } \\
\text { - Instrumentation failure } \\
\text { (AE-760-601) }\end{array}$ & $\begin{array}{l}\text { Hydrogen Deflagration: } \\
\text { If the purge occurs for too short a period } \\
\text { of time (i.e., before the oxygen } \\
\text { concentration reaches } 0.1 \% \text { ), then a } \\
\text { hydrogen deflagration could occur. }\end{array}$ & $\begin{array}{l}\text { - Oxygen concentration } \\
\text { instrumentation (AE-760-601) } \\
\text { - Modified KW Basin Annex } \\
\text { confinement ventilation } \\
\text { - Continuous air monitors }\end{array}$ & $\begin{array}{l}\text { - Procedures } \\
\text { - Training } \\
\text { - Administrative control } \\
\text { requiring verification of } \mathrm{O}_{2} \\
\text { concentration }\end{array}$ & \\
\hline $5-15$ & Time Procedure & Too long & $\begin{array}{l}\text { - Operator error } \\
\text { - Instrumentation failure } \\
\text { (AE-760-601) }\end{array}$ & $\begin{array}{l}\text { None: } \\
\text { There is no hazard if the oxygen } \\
\text { concentration in the STSC is less than } \\
0.1 \% \text {. }\end{array}$ & N/A & N/A & \\
\hline $5-16$ & Time Procedure & Skip action & Operator error & $\begin{array}{l}\text { Hydrogen Deflagration: } \\
\text { If the STSC is not inerted, then a } \\
\text { hydrogen deflagration could occur. }\end{array}$ & $\begin{array}{l}\text { - Modified KW Basin Annex } \\
\text { confinement ventilation } \\
\text { - Continuous air monitors }\end{array}$ & $\begin{array}{l}\text { - Procedures } \\
\text { - Training } \\
\text { - Administrative control } \\
\text { requiring verification of } \mathrm{O}_{2} \\
\text { concentration }\end{array}$ & \\
\hline $5-17$ & Time Procedure & Wrong action & N/A & N/A & N/A & $N / A$ & $\begin{array}{l}\text { There is no wrong action associated with this } \\
\text { node. }\end{array}$ \\
\hline
\end{tabular}




\begin{tabular}{|c|c|c|}
\hline Process Parameter & Design Intent & Remarks \\
\hline Flow & $10 \mathrm{cfm}$ (when inerting the cask) & The nitrogen flow rate to the STS Cask is set at $10 \mathrm{cfm}$ when the cask is being inerted. \\
\hline Pressure & Nitrogen gas supply $=65 \mathrm{psi}$ & $\begin{array}{l}\text { The STS cask has is rated at } 80 \mathrm{psig} \text {. } \\
\text { A pressure control valve is set at } 65 \mathrm{psi} \text { and a pressure safety valve is set at } 80 \mathrm{psi} \text {. }\end{array}$ \\
\hline Concentration & $0.1 \%$ oxygen & The STS cask will be purged with nitrogen until the oxygen concentration in the cask reaches $0.1 \%$. \\
\hline Composition & Nitrogen & $\begin{array}{l}\text { The selection of nitrogen as the inerting gas is discussed in PRC-STP-00273, Analysis of Argon and Nitrogen Purging and } \\
\text { Inerting of Sludge Transport and Storage Container (STSC) and Sludge Transport System (STS) Cask. }\end{array}$ \\
\hline Level & Nitrogen volume $>240 \mathrm{scfm}$ & $\begin{array}{l}\text { As documented in PRC-STP-00273, at a rate of } 10 \mathrm{cfm} \text { the STS Cask is purged for } 24 \text { minutes to attain } 0.1 \% \text { oxygen. } \\
\text { Therefore, in excess of } 240 \mathrm{scfm} \text { of nitrogen is required to purge the STS cask. }\end{array}$ \\
\hline Structural Integrity & $\begin{array}{l}\text { Maintain integrity under normal operating } \\
\text { conditions }\end{array}$ & None \\
\hline Temperature & Not applicable & $\begin{array}{l}\text { Nitrogen gas temperature is not a process parameter that is monitored or controlled. The nitrogen bottles are stored outside } \\
\text { such that the gas temperature will fluctuate with the ambient air temperature. The typical temperature fluctuations that over } \\
\text { the course of several days will have no impact on the operability of the Nitrogen Gas Supply system. }\end{array}$ \\
\hline Time Procedure & 24 minutes & $\begin{array}{l}\text { The purge will be performed until the oxygen concentration in the STS Cask reaches } 0.1 \% \text { oxygen. The } 24 \text { minute value is } \\
\text { calculated in PRC-STP- } 00273 \text { based on a headspace of } 1.236 \mathrm{~m}^{3} \text { and a nitrogen flow rate of } 10 \mathrm{cfm} \text {. }\end{array}$ \\
\hline
\end{tabular}

PRC-STP-00273, 2010, Analysis of Argon and Nitrogen Purging and Inerting of Sludge Transport and Storage Container (STSC) and S/udge Transport System (STS) Cask, Rev. 1, CH2M HILL Plateau Remediation Company, Richland, Washington. 


\begin{tabular}{|c|c|c|c|c|c|c|c|}
\hline \multicolumn{8}{|c|}{ Table C-20. HAZOP Results, Node 6, STS Cask Nitrogen Purge } \\
\hline \multirow{2}{*}{ Item } & \multirow{2}{*}{$\begin{array}{l}\text { Process } \\
\text { Parameter }\end{array}$} & \multirow{2}{*}{ Deviation } & \multirow{2}{*}{ Cause } & \multirow{2}{*}{ Consequences } & \multicolumn{2}{|c|}{ Candidate Controls } & \multirow{2}{*}{ Remarks } \\
\hline & & & & & Engineered & Administrative & \\
\hline $6-1$ & Flow & No & $\begin{array}{l}\text { - Nitrogen bottles empty } \\
\text { - A normally-opened } \\
\text { valve is closed }\end{array}$ & $\begin{array}{l}\text { Hydrogen Deflagration: } \\
\text { If there is no nitrogen flow, then the STS } \\
\text { cask will not be inerted. This could result } \\
\text { in a hydrogen deflagration. }\end{array}$ & $\begin{array}{l}\text { - Inert gas system pressure } \\
\text { instrumentation (PI-760-601 } \\
\text { through -606) } \\
\text { - Flow indicator FI-760-601 } \\
\text { - Valve position indicators } \\
\text { - Oxygen concentration } \\
\text { instrumentation (AE-760-601) } \\
\text { - Modified KW Basin Annex } \\
\text { confinement ventilation } \\
\text { - Continuous air monitors }\end{array}$ & $\begin{array}{l}\text { - Procedures } \\
\text { - Training } \\
\text { - Conduct of operations } \\
\text { verifies proper system } \\
\text { configuration } \\
\text { - Administrative control } \\
\text { requiring verification of } \mathrm{O}_{2} \\
\text { concentration }\end{array}$ & \\
\hline $6-2$ & Flow & Low & $\begin{array}{l}\text { - Low nitrogen pressure } \\
\text { - Flow rate set incorrectly } \\
\text { - A normally-opened } \\
\text { valve is partially closed }\end{array}$ & $\begin{array}{l}\text { Operational Upset: } \\
\text { If the nitrogen flow rate is low, then it will } \\
\text { take longer to inert the STS cask. }\end{array}$ & $\begin{array}{l}\text { - Inert gas system pressure } \\
\text { instrumentation (PI-760-601 } \\
\text { through -606) } \\
\text { - Flow indicator FI-760-601 } \\
\text { - Valve position indicators } \\
\text { - Oxygen concentration } \\
\text { instrumentation (AE-760-601) }\end{array}$ & $\begin{array}{l}\text { - Procedures } \\
\text { - Training } \\
\text { - Conduct of operations } \\
\text { verifies proper system } \\
\text { configuration } \\
\text { - Administrative control } \\
\text { requiring verification of } \mathrm{O}_{2} \\
\text { concentration }\end{array}$ & \\
\hline $6-3$ & Flow & High & $\begin{array}{l}\text { Pressure control valve } \\
\text { failure }\end{array}$ & $\begin{array}{l}\text { None: } \\
\text { If the nitrogen flow rate is high, then the } \\
\text { STS cask will be inerted in a shorter } \\
\text { period of time. }\end{array}$ & $\begin{array}{l}\text { - Inert gas system pressure } \\
\text { instrumentation (PI-760-601 } \\
\text { through -606) } \\
\text { - Flow indicator FI-760-601 } \\
\text { - Valve position indicators } \\
\text { - Oxygen concentration } \\
\text { instrumentation (AE-760-601) }\end{array}$ & $\begin{array}{l}\text { - } \text { Procedures } \\
\text { - Training } \\
\text { - Conduct of operations } \\
\text { verifies proper system } \\
\text { configuration }\end{array}$ & \\
\hline $6-4$ & Flow & Reverse & N/A & N/A & N/A & N/A & $\begin{array}{l}\text { There are no mechanisms by which a } \\
\text { reverse flow could be established. }\end{array}$ \\
\hline
\end{tabular}




\begin{tabular}{|c|c|c|c|c|c|c|c|}
\hline \multicolumn{8}{|c|}{ Table C-20. HAZOP Results, Node 6, STS Cask Nitrogen Purge } \\
\hline \multirow{2}{*}{ Item } & \multirow{2}{*}{$\begin{array}{l}\text { Process } \\
\text { Parameter }\end{array}$} & \multirow{2}{*}{ Deviation } & \multirow{2}{*}{ Cause } & \multirow{2}{*}{ Consequences } & \multicolumn{2}{|c|}{ Candidate Controls } & \multirow{2}{*}{ Remarks } \\
\hline & & & & & Engineered & Administrative & \\
\hline $6-5$ & Flow & \begin{tabular}{|l} 
Misdirected \\
(flow into \\
Annex)
\end{tabular} & $\begin{array}{l}\text { Valve ECRT-V-609 set } \\
\text { incorrectly }\end{array}$ & $\begin{array}{l}\text { Hydrogen Deflagration: } \\
\text { If valve ECRT-V-609 is mispositioned, } \\
\text { then the nitrogen flow would be directed } \\
\text { to the STSC purge inlet where it would } \\
\text { deadhead against the male Staubli } \\
\text { connector. The STS cask would not be } \\
\text { inerted. } \\
\text { Industrial Safety } \\
\text { If valve ECRT-V- } 609 \text { is mispositioned, } \\
\text { then the nitrogen flow would deadhead } \\
\text { against the male Staubli connector at a } \\
\text { pressure of } 65 \text { psig. Unmitigated, this } \\
\text { could result in failure of piping or hoses } \\
\text { which in turn could result in hose whip } \\
\text { and the potential for an oxygen deficient } \\
\text { atmosphere. }\end{array}$ & $\begin{array}{l}\text { - Oxygen concentration } \\
\text { instrumentation (AE-760-601) } \\
\text { - Flow indicator FI-760-601 } \\
\text { - Valve position indicators } \\
\text { - Piping and hoses designed to } \\
\text { B31.3, "Process Piping“ } \\
\text { - Hose tie-downs } \\
\text { - Modified KW Basin Annex } \\
\text { confinement ventilation } \\
\text { - Continuous air monitors }\end{array}$ & $\begin{array}{l}\text { - Procedures } \\
\text { - Training } \\
\text { - Conduct of operations } \\
\text { verifies proper system } \\
\text { configuration } \\
\text { - Administrative control } \\
\text { requiring verification of } \mathrm{O}_{2} \\
\text { concentration } \\
\text { - Industrial Safety Program }\end{array}$ & \\
\hline $6-6$ & Pressure & Low & $\begin{array}{l}\text { - A normally-opened } \\
\text { valve is partially closed } \\
\text { - Pressure control valve } \\
\text { failure }\end{array}$ & $\begin{array}{l}\text { Operational Upset: } \\
\text { If the nitrogen pressure is low, then it will } \\
\text { take longer to inert the STS cask. }\end{array}$ & $\begin{array}{l}\text { - Inert gas system pressure } \\
\text { instrumentation (PI-760-601 } \\
\text { through -606) } \\
\text { - Oxygen concentration } \\
\text { instrumentation (AE-760-601) } \\
\text { - Valve position indicators }\end{array}$ & $\begin{array}{l}\text { - Procedures } \\
\text { - Training } \\
\text { - Conduct of operations } \\
\text { verifies proper system } \\
\text { configuration } \\
\text { - Administrative control } \\
\text { requiring verification of } \mathrm{O}_{2} \\
\text { concentration }\end{array}$ & \\
\hline
\end{tabular}




\begin{tabular}{|c|c|c|c|c|c|c|c|}
\hline \multicolumn{8}{|c|}{ Table C-20. HAZOP Results, Node 6, STS Cask Nitrogen Purge } \\
\hline \multirow{2}{*}{ Item } & \multirow{2}{*}{$\begin{array}{c}\text { Process } \\
\text { Parameter }\end{array}$} & \multirow{2}{*}{ Deviation } & \multirow{2}{*}{ Cause } & \multirow{2}{*}{ Consequences } & \multicolumn{2}{|c|}{ Candidate Controls } & \multirow{2}{*}{ Remarks } \\
\hline & & & & & Engineered & Administrative & \\
\hline 6-7.a & Pressure & $\begin{array}{l}\text { High } \\
\text { (nitrogen } \\
\text { supply } \\
\text { system) }\end{array}$ & $\begin{array}{l}\text { - A normally-opened } \\
\text { valve is partially closed } \\
\text { - Pressure control valve } \\
\text { failure }\end{array}$ & $\begin{array}{l}\text { Industrial Safety: } \\
\text { If the pressure is high, then the piping or } \\
\text { hoses could fail. This could result in hose } \\
\text { whip and the potential for an oxygen } \\
\text { deficient atmosphere. } \\
\text { Hydrogen Deflagration: } \\
\text { If the pressure is high, then the piping or } \\
\text { hoses could fail such that the STS cask is } \\
\text { not inerted. This could result in a } \\
\text { hydrogen deflagration. }\end{array}$ & $\begin{array}{l}\text { - Inert gas system pressure } \\
\text { instrumentation (PI-760-601 } \\
\text { through -606) } \\
\text { - Pressure safety valve } \\
\text { ECRT-PSV-601 } \\
\text { - Valve position indicators } \\
\text { - Piping and hoses designed to } \\
\text { B31.3, "Process Piping" } \\
\text { - Oxygen concentration } \\
\text { instrumentation (AE-760-601) } \\
\text { - Hose tie-downs } \\
\text { - Modified KW Basin Annex } \\
\text { confinement ventilation } \\
\text { - Continuous air monitors }\end{array}$ & $\begin{array}{l}\text { - Procedures } \\
\text { - Training } \\
\text { - Conduct of operations } \\
\text { verifies proper system } \\
\text { configuration } \\
\text { - Industrial Safety Program } \\
\text { - Administrative control } \\
\text { requiring verification of } \mathrm{O}_{2} \\
\text { concentration }\end{array}$ & \\
\hline 6-7.b & Pressure & $\begin{array}{l}\text { High } \\
\text { (STS cask) }\end{array}$ & $\begin{array}{l}\text { Pressure control valve } \\
\text { failure and vent port tool } \\
\text { closed }\end{array}$ & $\begin{array}{l}\text { Radiological Control: } \\
\text { If the pressure is high, then the STS cask } \\
\text { mechanical seal could fail. If the inside of } \\
\text { the STS cask was contaminated, then } \\
\text { contaminated nitrogen would be } \\
\text { discharged into the loading bay. } \\
\text { Hydrogen Deflagration: } \\
\text { Overpressurizing the STS cask would } \\
\text { cause the mechanical seal to fail. This } \\
\text { would allow air ingress into the STS cask } \\
\text { and, subsequently, into the STSC. This } \\
\text { could lead to a hydrogen deflagration. }\end{array}$ & $\begin{array}{l}\text { - Pressure safety valve } \\
\text { ECRT-PSV-601 } \\
\text { - Valve position indicators } \\
\text { Oxygen concentration } \\
\text { instrumentation (AE-760-601) } \\
\text { - STSC active ventilation } \\
\text { - Modified KW Basin Annex } \\
\text { confinement ventilation } \\
\text { - Continuous air monitors }\end{array}$ & $\begin{array}{l}\text { - Procedures } \\
\text { - Training } \\
\text { - Radiological Control } \\
\text { Program } \\
\text { - Conduct of operations } \\
\text { verifies proper system } \\
\text { configuration } \\
\text { - Administrative control } \\
\text { requiring verification of } \mathrm{O}_{2} \\
\text { concentration }\end{array}$ & $\begin{array}{l}\text { The STS cask is rated at } 80 \text { psig. } \\
\text { Pressure control valve ECRT-PCV- } 602 \\
\text { reduces the pressure from } 425 \text { psig to } 65 \\
\text { psig. } \\
\text { If the STS cask failed, a hydrogen } \\
\text { deflagration could be prevented by } \\
\text { re-establishing STSC active ventilation. }\end{array}$ \\
\hline $6-8$ & Concentration & $\begin{array}{l}\text { Low } \\
\left(\mathrm{O}_{2}\right)\end{array}$ & $\begin{array}{l}\text { Purge duration too long } \\
\text { (see Item } 6-13 \text { below) }\end{array}$ & $\begin{array}{l}\text { None: } \\
\text { There is no hazard if the oxygen } \\
\text { concentration in the STSC is less than } \\
0.1 \% \text {. }\end{array}$ & N/A & N/A & . \\
\hline
\end{tabular}




\begin{tabular}{|c|c|c|c|c|c|c|c|}
\hline \multicolumn{8}{|c|}{ Table C-20. HAZOP Results, Node 6, STS Cask Nitrogen Purge } \\
\hline \multirow{2}{*}{ Item } & \multirow{2}{*}{$\begin{array}{l}\text { Process } \\
\text { Parameter }\end{array}$} & \multirow{2}{*}{ Deviation } & \multirow{2}{*}{ Cause } & \multirow{2}{*}{ Consequences } & \multicolumn{2}{|c|}{ Candidate Controls } & \multirow{2}{*}{ Remarks } \\
\hline & & & & & Engineered & Administrative & \\
\hline $6-9$ & Concentration & $\begin{array}{l}\text { High } \\
\left(\mathrm{O}_{2}\right)\end{array}$ & $\begin{array}{l}\text { - Purge duration too short } \\
\text { (see Item 6-12 below) } \\
\text { - Insufficient nitrogen } \\
\text { supply } \\
\text { - No nitrogen flow (see } \\
\text { Item 6-1 above) } \\
\text { - Misdirected nitrogen } \\
\text { flow (see Item 6-5 } \\
\text { above) }\end{array}$ & $\begin{array}{l}\text { Hydrogen Deflagration: } \\
\text { If the oxygen concentration in the STS } \\
\text { cask is high, then the STS cask will not be } \\
\text { inerted. This could result in a hydrogen } \\
\text { deflagration. }\end{array}$ & $\begin{array}{l}\text { - Oxygen concentration } \\
\text { instrumentation (AE-760-601) } \\
\text { - Inert gas system pressure } \\
\text { instrumentation (PI-760-601 } \\
\text { through -606) } \\
\text { - Flow indicator FI-760-601 } \\
\text { - Valve position indicators } \\
\text { - STSC active ventilation } \\
\text { - Modified KW Basin Annex } \\
\text { confinement ventilation } \\
\text { - Continuous air monitors }\end{array}$ & $\begin{array}{l}\text { - Procedures } \\
\text { - Training } \\
\text { - Conduct of operations } \\
\text { verifies proper system } \\
\text { configuration } \\
\text { - Administrative control } \\
\text { requiring verification of } \mathrm{O}_{2} \\
\text { concentration }\end{array}$ & $\begin{array}{l}\text { If the STS cask cannot be inerted, a } \\
\text { hydrogen deflagration could be prevented by } \\
\text { re-establishing STSC active ventilation. }\end{array}$ \\
\hline 6-10.a & Composition & $\begin{array}{l}\text { Other } \\
\text { (oxidant) }\end{array}$ & $\begin{array}{l}\text { Gas bottles containing an } \\
\text { oxidant (e.g., air) installed } \\
\text { at Inert Bottle Station }\end{array}$ & $\begin{array}{l}\text { Hydrogen Deflagration: } \\
\text { If gas bottles containing an oxidant are } \\
\text { installed at the Inert Bottle Station, then } \\
\text { the STS cask will not be inerted. This } \\
\text { could result in a hydrogen deflagration. }\end{array}$ & $\begin{array}{l}\text { - Nitrogen-specific fixtures } \\
\text { - Oxygen concentration } \\
\text { instrumentation (AE-760-601) } \\
\text { - STSC active ventilation } \\
\text { - Modified KW Basin Annex } \\
\text { confinement ventilation } \\
\text { - Continuous air monitors }\end{array}$ & $\begin{array}{l}\text { - Procedures } \\
\text { - Training } \\
\text { - Quality Assurance Program }\end{array}$ & $\begin{array}{l}\text { If the STS cask cannot be inerted, a } \\
\text { hydrogen deflagration could be prevented by } \\
\text { re-establishing STSC active ventilation. }\end{array}$ \\
\hline 6-10.b & Composition & $\begin{array}{l}\text { Other } \\
\text { (helium) }\end{array}$ & $\begin{array}{l}\text { Gas bottles containing } \\
\text { helium installed at Inert } \\
\text { Bottle Station }\end{array}$ & $\begin{array}{l}\text { Hydrogen Deflagration: } \\
\text { If helium gas bottles are installed at the } \\
\text { Bottle Station, then too much air ingress } \\
\text { will occur and the STS cask will not be } \\
\text { inerted (see remarks). }\end{array}$ & $\begin{array}{l}\text { - Nitrogen-specific fixtures } \\
\text { - Modified KW Basin Annex } \\
\text { confinement ventilation } \\
\text { - Continuous air monitors }\end{array}$ & $\begin{array}{l}\text { - Procedures } \\
\text { - Training } \\
\text { - Quality Assurance Program }\end{array}$ & $\begin{array}{l}\text { PRC-STP-00273 calculates counter-current } \\
\text { flow (of nitrogen out of the STSC and air into } \\
\text { the STSC).and establishes the dwell period } \\
\text { after nozzle closure and before STS cask } \\
\text { closure. If helium gas is used, instead of } \\
\text { nitrogen, then there will be greater } \\
\text { counter-current flow and the STSC/STS cask } \\
\text { will not be inerted. }\end{array}$ \\
\hline $6-11$ & Level & $\begin{array}{l}\text { Low } \\
\text { (nitrogen } \\
\text { bottle volume) }\end{array}$ & $\begin{array}{l}\text { - Leak in supply system } \\
\text { - Operator error (low } \\
\text { pressure bottles not } \\
\text { replaced as needed) }\end{array}$ & $\begin{array}{l}\text { Hydrogen Deflagration: } \\
\text { If the nitrogen volume is low, then there } \\
\text { could be insufficient nitrogen to inert the } \\
\text { STS cask. This could result in a } \\
\text { hydrogen deflagration. }\end{array}$ & $\begin{array}{l}\text { - Inert gas system pressure } \\
\text { indicator Pl-760-601 } \\
\text { - Oxygen concentration } \\
\text { instrumentation (AE-760-601) } \\
\text { - Modified KW Basin Annex } \\
\text { confinement ventilation } \\
\text { - Continuous air monitors }\end{array}$ & $\begin{array}{l}\text { - Procedures } \\
\text { - Training } \\
\text { - Conduct of operations } \\
\text { verifies proper system } \\
\text { configuration } \\
\text { - Administrative control } \\
\text { requiring verification of } \mathrm{O}_{2} \\
\text { concentration. }\end{array}$ & \\
\hline
\end{tabular}




\begin{tabular}{|c|c|c|c|c|c|c|c|}
\hline \multicolumn{8}{|c|}{ Table C-20. HAZOP Results, Node 6, STS Cask Nitrogen Purge } \\
\hline \multirow{2}{*}{ Item } & \multirow{2}{*}{$\begin{array}{l}\text { Process } \\
\text { Parameter }\end{array}$} & \multirow{2}{*}{ Deviation } & \multirow{2}{*}{ Cause } & \multirow{2}{*}{ Consequences } & \multicolumn{2}{|c|}{ Candidate Controls } & \multirow{2}{*}{ Remarks } \\
\hline & & & & & Engineered & Administrative & \\
\hline $6-12$ & Level & $\begin{array}{l}\text { High } \\
\text { (nitrogen } \\
\text { bottle volume) }\end{array}$ & N/A & N/A & N/A & N/A & N/A \\
\hline 6-13.a & Structural Integrity & $\begin{array}{l}\text { Leak/rupture } \\
\text { (nitrogen } \\
\text { supply } \\
\text { system) }\end{array}$ & $\begin{array}{l}\text { - Overpressurization } \\
\text { - Hose disconnects }\end{array}$ & $\begin{array}{l}\text { Hydrogen Deflagration: } \\
\text { If a leak or rupture in the nitrogen supply } \\
\text { occurs, then the STS cask will not be } \\
\text { inerted. This could result in a hydrogen } \\
\text { deflagration. } \\
\text { Industrial Safety: } \\
\text { If the there is leak/rupture in the nitrogen } \\
\text { supply system, then nitrogen will be } \\
\text { released at the point of failure. This could } \\
\text { result hose whip and the potential for an } \\
\text { oxygen deficient atmosphere. }\end{array}$ & $\begin{array}{l}\text { - Oxygen concentration } \\
\text { instrumentation (AE-760-601) } \\
\text { - Pressure safety valve } \\
\text { ECRT-PSV-601 } \\
\text { - Inert gas system pressure } \\
\text { instrumentation (PI-760-601 } \\
\text { through -606) } \\
\text { - Flow indicator FI-760-601 } \\
\text { - Piping and hoses designed to } \\
\text { B31.3, "Process Piping" } \\
\text { - Hose tie-downs } \\
\text { - Valve position indicators } \\
\text { - STSC active ventilation } \\
\text { - Modified KW Basin Annex } \\
\text { confinement ventilation } \\
\text { - Continuous air monitors }\end{array}$ & $\begin{array}{l}\text { - Procedures } \\
\text { - Training } \\
\text { - Conduct of operations } \\
\text { verifies proper system } \\
\text { configuration } \\
\text { - Administrative control } \\
\text { requiring verification of } \mathrm{O}_{2} \\
\text { concentration. } \\
\text { - Industrial Safety Program }\end{array}$ & $\begin{array}{l}\text { If the STS cask cannot be inerted, a } \\
\text { hydrogen deflagration could be prevented by } \\
\text { re-establishing STSC active ventilation. } \\
\text { Depending on the location of the nitrogen } \\
\text { supply system leak, the flow rate could be } \\
\text { much greater than } 10 \text { cfm and thus constitute } \\
\text { an oxygen deficient atmosphere hazard. }\end{array}$ \\
\hline $6-13 . b$ & Structural Integrity & $\begin{array}{l}\text { Leak/rupture } \\
\text { (STS cask) }\end{array}$ & $\begin{array}{l}\text { - Overpressurization } \\
\text { - Mechanical seal failure }\end{array}$ & $\begin{array}{l}\text { Hydrogen deflagration: } \\
\text { If the STS cask leaks, then air will leak } \\
\text { into the STS cask and, subsequently, into } \\
\text { the STSC. This could lead to a hydrogen } \\
\text { deflagration. }\end{array}$ & $\begin{array}{l}\text { - STS cask pressure boundary } \\
\text { - Oxygen concentration } \\
\text { instrumentation (AE-760-601) } \\
\text { - Pressure safety valve } \\
\text { ECRT-PSV-601 } \\
\text { - Inert gas system pressure } \\
\text { instrumentation (PI-760-601 } \\
\text { through -606) } \\
\text { - Valve position indicators } \\
\text { - STSC active ventilation } \\
\text { - Modified KW Basin Annex } \\
\text { confinement ventilation } \\
\text { - Continuous air monitors }\end{array}$ & $\begin{array}{l}\text { - Procedures } \\
\text { - Training } \\
\text { - Conduct of operations } \\
\text { verifies proper system } \\
\text { configuration } \\
\text { - Administrative control } \\
\text { requiring verification of } \mathrm{O}_{2} \\
\text { concentration }\end{array}$ & $\begin{array}{l}\text { If the STS cask failed, a hydrogen } \\
\text { deflagration could be prevented by } \\
\text { re-establishing STSC active ventilation. }\end{array}$ \\
\hline
\end{tabular}




\begin{tabular}{|c|c|c|c|c|c|c|c|}
\hline \multicolumn{8}{|c|}{ Table C-20. HAZOP Results, Node 6, STS Cask Nitrogen Purge } \\
\hline \multirow{2}{*}{ Item } & \multirow{2}{*}{$\begin{array}{l}\text { Process } \\
\text { Parameter }\end{array}$} & \multirow{2}{*}{ Deviation } & \multirow{2}{*}{ Cause } & \multirow{2}{*}{ Consequences } & \multicolumn{2}{|c|}{ Candidate Controls } & \multirow{2}{*}{ Remarks } \\
\hline & & & & & Engineered & Administrative & \\
\hline $6-14$ & Time Procedure & Too short & $\begin{array}{l}\text { - Operator error } \\
\text { - Instrumentation failure } \\
\text { (AE-760-601) }\end{array}$ & $\begin{array}{l}\text { Hydrogen Deflagration: } \\
\text { If the purge occurs for too short a period } \\
\text { of time (i.e., before the oxygen } \\
\text { concentration reaches } 0.1 \% \text { ), then a } \\
\text { hydrogen deflagration could occur. }\end{array}$ & $\begin{array}{l}\text { - Oxygen concentration } \\
\text { instrumentation (AE-760-601) } \\
\text { - Inert gas system pressure } \\
\text { instrumentation (PI-760-601 } \\
\text { through -606) } \\
\text { - STSC active ventilation } \\
\text { - Modified KW Basin Annex } \\
\text { confinement ventilation } \\
\text { - Continuous air monitors }\end{array}$ & $\begin{array}{l}\text { - Procedures } \\
\text { - Training } \\
\text { - Administrative control } \\
\text { requiring verification of } \mathrm{O}_{2} \\
\text { concentration }\end{array}$ & \\
\hline $6-15$ & Time Procedure & Too long & $\begin{array}{l}\text { - Operator error } \\
\text { - Instrumentation failure } \\
\text { (AE-760-601) }\end{array}$ & $\begin{array}{l}\text { None: } \\
\text { There is no hazard if the oxygen } \\
\text { concentration in the STS cask is less than } \\
0.1 \% \text {. }\end{array}$ & N/A & N/A & \\
\hline $6-16$ & Time Procedure & Skip action & Operator error & $\begin{array}{l}\text { Hydrogen Deflagration: } \\
\text { If the STS cask is not inerted, then a } \\
\text { hydrogen deflagration could occur. }\end{array}$ & $\begin{array}{l}\text { - Oxygen concentration } \\
\text { instrumentation (AE-760-601) } \\
\text { - Modified KW Basin Annex } \\
\text { confinement ventilation } \\
\text { - Continuous air monitors }\end{array}$ & $\begin{array}{l}\text { - Procedures } \\
\text { - Training } \\
\text { - Administrative control } \\
\text { requiring verification of } \mathrm{O}_{2} \\
\text { concentration }\end{array}$ & \\
\hline $6-17$ & Time Procedure & Wrong action & $N / A$ & N/A & N/A & N/A & $\begin{array}{l}\text { There is no wrong action associated with this } \\
\text { node. }\end{array}$ \\
\hline
\end{tabular}




\begin{tabular}{|c|c|c|}
\hline Process Parameter & Design Intent & Remarks \\
\hline Flow & Not applicable & The flow rate is controlled by manually opening needle valve ECRT-V-607. The flow rate is not monitored. \\
\hline Pressure & 3 psig > STC Cask <TBD psig & $\begin{array}{l}\text { The } 3 \text { psig lower limit on pressure is based on maintaining an inert atmosphere in the STS Cask for the } \\
\text { duration of the shipping window given a leak rate of } 2 \times 10^{-4} \text { standard } \mathrm{cm}^{3} / \mathrm{s} \text { air per ANSI N14.5-1997, American } \\
\text { National Standard for Radioactive Materials - Leakage Tests on Packages for Shipment. The upper bound } \\
\text { pressure has not yet been determined. It will be established to prevent overpressurization of the STS Cask } \\
\text { during transportation. In the following HAZOP tables, a value of } 15 \text { psig has been used. The } 15 \text { psig value was } \\
\text { previously established for shipping sludge to T Plant in Large Diameter Containers. }\end{array}$ \\
\hline Concentration & Not applicable & $\begin{array}{l}\text { At the time of STS Cask pressurization, the STS cask has already been purge with nitrogen to yield an oxygen } \\
\text { concentration less than } 0.1 \% \text {. }\end{array}$ \\
\hline Composition & Nitrogen & $\begin{array}{l}\text { The selection of nitrogen as the inerting gas is discussed in PRC-STP-00273, Analysis of Argon and Nitrogen } \\
\text { Purging and Inerting of Sludge Transport and Storage Container (STSC) and Sludge Transport System (STS) } \\
\text { Cask. }\end{array}$ \\
\hline Structural Integrity & Maintain integrity under normal operating conditions & \\
\hline Level & Nitrogen volume $>8.8 \mathrm{ft}^{3}$ & $\begin{array}{l}\text { The STS Cask has a headspace of } 1.236 \mathrm{~m}^{3} \text {. To raise the pressure from atmospheric to the minimum pressure } \\
\text { of } 3 \text { psig requires the addition of }>8.8 \mathrm{ft}^{3} \text { of nitrogen. }\end{array}$ \\
\hline Temperature & Not applicable & $\begin{array}{l}\text { Nitrogen gas temperature is not a process parameter that is monitored or controlled. Transportation safety } \\
\text { calculations are performed using conservative values for both the initial nitrogen gas temperature and the } \\
\text { ambient daytime temperature during transport. }\end{array}$ \\
\hline Time Procedure & Until acceptable pressure is achieved & Operators manually control needle valve ECRT-V-607 and stop the pressurization when the pressure indicated \\
\hline
\end{tabular}




\begin{tabular}{|c|c|c|c|c|c|c|c|}
\hline \multirow{2}{*}{ Item } & \multirow{2}{*}{$\begin{array}{l}\text { Process } \\
\text { Parameter }\end{array}$} & \multirow{2}{*}{ Deviation } & \multirow{2}{*}{ Cause } & \multirow{2}{*}{ Consequences } & \multicolumn{2}{|c|}{ Candidate Controls } & \multirow{2}{*}{ Remarks } \\
\hline & & & & & Engineered & Administrative & \\
\hline 7-1. & Flow & No & $\begin{array}{l}\text { - No nitrogen pressure } \\
\text { - Drain port closed } \\
\text { - A normally opened valve } \\
\text { is closed }\end{array}$ & $\begin{array}{l}\text { Hydrogen Deflagration: } \\
\text { If there is no flow, then the STS cask will } \\
\text { not be pressurized. Air inleakage could } \\
\text { occur eventually leading to a flammable } \\
\text { hydrogen concentration. }\end{array}$ & $\begin{array}{l}\text { - Inert gas system pressure } \\
\text { instrumentation (PI-760-601 } \\
\text { through -606) } \\
\text { - Valve position indicators }\end{array}$ & $\begin{array}{l}\text { - Procedures } \\
\text { - Training } \\
\text { - Conduct of operations } \\
\text { verifies proper system } \\
\text { configuration } \\
\text { - Administrative control } \\
\text { requiring verification of STS } \\
\text { cask pressure }\end{array}$ & $\begin{array}{l}\text { The STS cask is purged with nitrogen via the } \\
\text { drain port tool immediately prior to the cask } \\
\text { pressurization activity. Thus the drain port } \\
\text { would normally be open. If the drain port } \\
\text { was inadvertently closed, then a pressure } \\
\text { reading in the range of } 3 \text { to } 15 \text { psig could be } \\
\text { obtained on pressure indicator ECRT-PI-606 } \\
\text { without pressurizing the STS cask. However, } \\
\text { the pressure would be achieved very quickly } \\
\text { as the system would be deadheaded against } \\
\text { the closed drain port tool. }\end{array}$ \\
\hline $7-2$ & Flow & Low & $\begin{array}{l}\text { - Low nitrogen pressure } \\
\text { - Drain port partially } \\
\text { closed } \\
\text { - A normally opened valve } \\
\text { is partially closed }\end{array}$ & $\begin{array}{l}\text { Operational Upset: } \\
\text { If the nitrogen flow is low, then it will take } \\
\text { longer to reach the STS cask low } \\
\text { pressure limit. }\end{array}$ & $\begin{array}{l}\text { - Inert gas system pressure } \\
\text { instrumentation (PI-760-601 } \\
\text { through -606) } \\
\text { - Valve position indicators }\end{array}$ & $\begin{array}{l}\text { - Procedures } \\
\text { - Training } \\
\text { - Conduct of operations } \\
\text { verifies proper system } \\
\text { configuration } \\
\text { - Administrative control } \\
\text { requiring verification of STS } \\
\text { cask pressure }\end{array}$ & \\
\hline $7-3$ & Flow & High & High nitrogen pressure & $\begin{array}{l}\text { Overpressurization: } \\
\text { If the flow is high, then operators may } \\
\text { exceed the STS cask high pressure limit } \\
\text { (see remarks). This could result in cask } \\
\text { overpressurization. }\end{array}$ & $\begin{array}{l}\text { - Pressure control valve } \\
\text { ECRT-PCV-602 } \\
\text { - Inert gas system pressure } \\
\text { instrumentation (PI-760-601 } \\
\text { through -606) } \\
\text { - Valve position indicators } \\
\text { - Pressure safety valve } \\
\text { ECRT-PSV-601 } \\
\text { - Cask vent port tool }\end{array}$ & $\begin{array}{l}\text { - Procedures } \\
\text { - Training } \\
\text { - Conduct of operations } \\
\text { verifies proper system } \\
\text { configuration } \\
\text { - Administrative control } \\
\text { requiring verification of STS } \\
\text { cask pressure }\end{array}$ & $\begin{array}{l}\text { If the flow rate was high, operators would } \\
\text { have less time to stop the flow before } \\
\text { exceeding the high pressure limit. } \\
\text { If the STS cask high pressure limit is } \\
\text { exceeded. The cask vent port tool can be } \\
\text { used to reduce the pressure. }\end{array}$ \\
\hline
\end{tabular}




\begin{tabular}{|c|c|c|c|c|c|c|c|}
\hline \multirow{2}{*}{ Item } & \multirow{2}{*}{$\begin{array}{l}\text { Process } \\
\text { Parameter }\end{array}$} & \multirow{2}{*}{ Deviation } & \multirow{2}{*}{ Cause } & \multirow{2}{*}{ Consequences } & \multicolumn{2}{|c|}{ Candidate Controls } & \multirow{2}{*}{ Remarks } \\
\hline & & & & & Engineered & Administrative & \\
\hline $7-4$ & Flow & $\begin{array}{l}\text { Reverse } \\
\text { (nitrogen flow } \\
\text { out of STS } \\
\text { cask) }\end{array}$ & $\begin{array}{l}\text { - Leak or rupture of } \\
\text { nitrogen supply piping or } \\
\text { hose } \\
\text { - Vent port tool leak } \\
\text { - STS cask mechanical } \\
\text { seal leak }\end{array}$ & $\begin{array}{l}\text { Radiological Control: } \\
\text { If nitrogen flows out of the STS cask and } \\
\text { the inside of the STS cask was } \\
\text { contaminated, then there would be a } \\
\text { spread of contamination at the point of the } \\
\text { leak. } \\
\text { Industrial Safety: } \\
\text { If nitrogen flows out of the STS cask, then } \\
\text { it creates the potential for an inert } \\
\text { atmosphere. } \\
\text { Hydrogen Deflagration: } \\
\text { If the nitrogen flows out of the cask, then } \\
\text { the STS cask will not be pressurized. Air } \\
\text { inleakage could occur eventually leading } \\
\text { to a flammable hydrogen concentration. }\end{array}$ & $\begin{array}{l}\text { - Inert gas system pressure } \\
\text { instrumentation (PI-760-601 } \\
\text { through -606) } \\
\text { - Modified KW Basin Annex } \\
\text { confinement ventilation } \\
\text { - Continuous air monitors }\end{array}$ & $\begin{array}{l}\text { - Procedures } \\
\text { - Training } \\
\text { - Conduct of operations } \\
\text { verifies proper system } \\
\text { configuration } \\
\text { - Radiological Control } \\
\text { Program } \\
\text { - Industrial Safety Program } \\
\text { - Administrative control } \\
\text { requiring verification of STS } \\
\text { cask pressure } \\
\text { - STS cask leak test }\end{array}$ & \\
\hline $7-5$ & Flow & Misdirected & $\begin{array}{l}\text { Valve ECRT-V-609 } \\
\text { mispositioned }\end{array}$ & $\begin{array}{l}\text { Hydrogen Deflagration: } \\
\text { If valve ECRT-V-609 is mispositioned, } \\
\text { then the nitrogen flow would be directed } \\
\text { to the STSC purge inlet where it would } \\
\text { deadhead against the male Staubli } \\
\text { connector. The STS cask would not be } \\
\text { pressurized. Air inleakage could occur } \\
\text { eventually leading to a flammable } \\
\text { hydrogen concentration. } \\
\text { Industrial Safety } \\
\text { If valve ECRT-V-609 is mispositioned, } \\
\text { then the nitrogen flow would deadhead } \\
\text { against the male Staubli connector at a } \\
\text { pressure of } 65 \text { psig. Unmitigated, this } \\
\text { could result in failure of piping or hoses } \\
\text { which in turn could result in hose whip } \\
\text { and the potential for an oxygen deficient } \\
\text { atmosphere. }\end{array}$ & $\begin{array}{l}\text { - Valve position indicators } \\
\text { - Piping and hoses designed to } \\
\text { B31.3, "Process Piping" } \\
\text { - Modified KW Basin Annex } \\
\text { confinement ventilation } \\
\text { - Continuous air monitors }\end{array}$ & $\begin{array}{l}\text { - Procedures } \\
\text { - Training } \\
\text { - Conduct of operations } \\
\text { verifies proper system } \\
\text { configuration } \\
\text { - Administrative control } \\
\text { requiring verification of STS } \\
\text { cask pressure } \\
\text { - Industrial Safety Program }\end{array}$ & $\begin{array}{l}\text { If valve ECRT-V-609 was mispositioned, then } \\
\text { a pressure reading in the range of } 3 \text { to } 15 \\
\text { psig could be obtained on pressure indicator } \\
\text { ECRT-PI-606 without pressurizing the STS } \\
\text { cask. However, the pressure would be } \\
\text { achieved very quickly as the system would } \\
\text { be deadheaded }\end{array}$ \\
\hline
\end{tabular}




\begin{tabular}{|c|c|c|c|c|c|c|c|}
\hline \multirow{2}{*}{ Item } & \multirow{2}{*}{$\begin{array}{l}\text { Process } \\
\text { Parameter }\end{array}$} & \multirow{2}{*}{ Deviation } & \multirow{2}{*}{ Cause } & \multirow{2}{*}{ Consequences } & \multicolumn{2}{|c|}{ Candidate Controls } & \multirow{2}{*}{ Remarks } \\
\hline & & & & & Engineered & Administrative & \\
\hline $7-6 . a$ & Pressure & $\begin{array}{l}\text { Low } \\
\text { (nitrogen } \\
\text { supply } \\
\text { system) }\end{array}$ & $\begin{array}{l}\text { - Drain port partially } \\
\text { closed } \\
\text { - A normally opened valve } \\
\text { is partially closed } \\
\text { - Pressure control valve } \\
\text { failure }\end{array}$ & $\begin{array}{l}\text { Operational Upset: } \\
\text { If the nitrogen pressure is low, then the } \\
\text { flow will be low and it will take longer to } \\
\text { reach the STS cask low pressure limit. }\end{array}$ & $\begin{array}{l}\text { - Inert gas system pressure } \\
\text { instrumentation (PI-760-601 } \\
\text { through -606) } \\
\text { - Valve position indicators }\end{array}$ & $\begin{array}{l}\text { - Procedures } \\
\text { - Training } \\
\text { - Conduct of operations } \\
\text { verifies proper system } \\
\text { configuration } \\
\text { - Administrative control } \\
\text { requiring verification of STS } \\
\text { cask pressure }\end{array}$ & \\
\hline 7-6.b & Pressure & $\begin{array}{l}\text { Low } \\
\text { (STS cask } \\
\text { pressure } \\
<3 \text { psig) }\end{array}$ & See remarks & See remarks & See remarks & See remarks & $\begin{array}{l}\text { The HAZOP identified multiple ways in which } \\
\text { the STS cask pressure could be below the } \\
\text { STS cask low pressure limit of } 3 \text { psig leading } \\
\text { to the inleakage of air and a hydrogen } \\
\text { deflagration. See Items } 7-1,7-2,7-4,6-5 \text {, } \\
7-7 . a, 7-7 . b, 7-8 . b, 7-9,7-11 . a, 7-12 \text {, and } \\
7-14 \text {. }\end{array}$ \\
\hline 7-7.a & Pressure & $\begin{array}{l}\text { High } \\
\text { (nitrogen } \\
\text { supply } \\
\text { system) }\end{array}$ & $\begin{array}{l}\text { - A normally-opened valve } \\
\text { is closed or partially } \\
\text { closed } \\
\text { - Pressure control valve } \\
\text { failure }\end{array}$ & $\begin{array}{l}\text { Overpressurization } \\
\text { If the pressure is high then the flow rate } \\
\text { will be high and operators may exceed } \\
\text { the STS cask high pressure limit. This } \\
\text { could result in STS cask } \\
\text { overpressurization. } \\
\text { Industrial Safety: } \\
\text { If the pressure is high, then the piping or } \\
\text { hoses could fail. This could result in hose } \\
\text { whip and the potential for an oxygen } \\
\text { deficient atmosphere. } \\
\text { Hydrogen Deflagration: } \\
\text { If the pressure is high, then the piping or } \\
\text { hoses could fail such that the STS cask } \\
\text { would not be pressurized. Air inleakage } \\
\text { could occur eventually leading to a } \\
\text { flammable hydrogen concentration. }\end{array}$ & $\begin{array}{l}\text { - Inert gas system pressure } \\
\text { instrumentation (PI-760-601 } \\
\text { through -606) } \\
\text { - Valve position indicators } \\
\text { - Piping and hoses designed to } \\
\text { B31.3, "Process Piping" } \\
\text { - Pressure safety valve } \\
\text { ECRT-PSV-601 } \\
\text { - Cask vent port tool } \\
\text { - Hose tie-downs } \\
\text { - Modified KW Basin Annex } \\
\text { confinement ventilation } \\
\text { - Continuous air monitors }\end{array}$ & $\begin{array}{l}\text { - Procedures } \\
\text { - Training } \\
\text { - Radiological Control } \\
\text { Program } \\
\text { - Conduct of operations } \\
\text { verifies proper system } \\
\text { configuration } \\
\text { - Administrative control } \\
\text { requiring verification of STS } \\
\text { cask pressure }\end{array}$ & $\begin{array}{l}\text { If the flow rate was high, operators would } \\
\text { have less time to stop the flow before } \\
\text { exceeding the high pressure limit. } \\
\text { If the STS cask high pressure limit is } \\
\text { exceeded. The cask vent port tool can be } \\
\text { used to reduce the pressure. }\end{array}$ \\
\hline
\end{tabular}




\begin{tabular}{|c|c|c|c|c|c|c|c|}
\hline \multirow{2}{*}{ Item } & \multirow{2}{*}{$\begin{array}{l}\text { Process } \\
\text { Parameter }\end{array}$} & \multirow{2}{*}{ Deviation } & \multirow{2}{*}{ Cause } & \multirow{2}{*}{ Consequences } & \multicolumn{2}{|c|}{ Candidate Controls } & \multirow{2}{*}{ Remarks } \\
\hline & & & & & Engineered & Administrative & \\
\hline 7-7.b & Pressure & $\begin{array}{l}\text { High } \\
\text { (STS cask) }\end{array}$ & $\begin{array}{l}\text { Pressure control valve } \\
\text { failure }\end{array}$ & $\begin{array}{l}\text { Overpressurization: } \\
\text { If the pressure is greater than the STS } \\
\text { cask high pressure limit of } 15 \text { psig, then } \\
\text { the STS cask could overpressurize. } \\
\text { Radiological Control: } \\
\text { If the pressure is high, then the STS cask } \\
\text { mechanical seal could fail. If the inside of } \\
\text { the STS cask was contaminated, then } \\
\text { contaminated nitrogen would be } \\
\text { discharged into the loading bay. } \\
\text { Hydrogen Deflagration: } \\
\text { If the pressure is high, then the STS cask } \\
\text { mechanical seal could fail. This would } \\
\text { allow air inleakage once the nitrogen flow } \\
\text { was stopped. This could eventually lead } \\
\text { to a flammable hydrogen concentration. }\end{array}$ & $\begin{array}{l}\text { - Pressure safety valve } \\
\text { ECRT-PSV-601 } \\
\text { - Cask vent port tool } \\
\text { - STSC active ventilation } \\
\text { - Modified KW Basin Annex } \\
\text { confinement ventilation } \\
\text { - Continuous air monitors }\end{array}$ & $\begin{array}{l}\text { - Procedures } \\
\text { - Training } \\
\text { - Radiological Control } \\
\text { Program } \\
\text { - Conduct of operations } \\
\text { verifies proper system } \\
\text { configuration } \\
\text { - Administrative control } \\
\text { requiring verification of STS } \\
\text { cask pressure }\end{array}$ & $\begin{array}{l}\text { The STS cask is rated at } 80 \text { psig. } \\
\text { Pressure control valve ECRT-PCV-602 } \\
\text { reduces the pressure from } 425 \text { psig to } \\
65 \text { psig. } \\
\text { If the STS cask high pressure limit is } \\
\text { exceeded. The cask vent port tool can be } \\
\text { used to reduce the pressure. } \\
\text { If the STS cask failed, a hydrogen } \\
\text { deflagration could be prevented by } \\
\text { re-establishing STSC active ventilation. }\end{array}$ \\
\hline 7-8.a & Composition & $\begin{array}{l}\text { Other } \\
\text { (oxidant) }\end{array}$ & $\begin{array}{l}\text { Gas bottles containing an } \\
\text { oxidant (e.g., air) installed } \\
\text { at Inert Bottle Station }\end{array}$ & $\begin{array}{l}\text { Hydrogen Deflagration: } \\
\text { If gas bottles containing an oxidant are } \\
\text { installed at the Inert Bottle Station, then } \\
\text { an oxidant would be added to the STS } \\
\text { cask by the pressurization activity and } \\
\text { might not be inerted. This could result in a } \\
\text { hydrogen deflagration (see remarks). }\end{array}$ & $\begin{array}{l}\text { - Nitrogen-specific fixtures } \\
\text { - STSC active ventilation } \\
\text { - Modified KW Basin Annex } \\
\text { confinement ventilation } \\
\text { - Continuous air monitors }\end{array}$ & $\begin{array}{l}\text { - Procedures } \\
\text { - Training } \\
\text { - Quality Assurance Program }\end{array}$ & $\begin{array}{l}\text { The same gas bottles are used for both STS } \\
\text { cask inerting and STS cask pressurization. }\end{array}$ \\
\hline $7-8 . b$ & Composition & $\begin{array}{l}\text { Other } \\
\text { (helium) }\end{array}$ & $\begin{array}{l}\text { Gas bottles containing } \\
\text { helium installed at Inert } \\
\text { Bottle Station }\end{array}$ & $\begin{array}{l}\text { Hydrogen Deflagration: } \\
\text { If helium gas bottles are installed at the } \\
\text { Bottle Station, then too much air } \\
\text { inleakage will occur and the STS cask will } \\
\text { not be inerted (see remarks). }\end{array}$ & $\begin{array}{l}\text { - Nitrogen-specific fixtures } \\
\text { - Modified KW Basin Annex } \\
\text { confinement ventilation } \\
\text { - Continuous air monitors }\end{array}$ & $\begin{array}{l}\text { - Procedures } \\
\text { - Training } \\
\text { - Quality Assurance Program }\end{array}$ & $\begin{array}{l}\text { The same gas bottles are used for both STS } \\
\text { cask inerting and STS cask pressurization. }\end{array}$ \\
\hline
\end{tabular}




\begin{tabular}{|c|c|c|c|c|c|c|c|}
\hline \multicolumn{8}{|c|}{ Table C-22. HAZOP Results Node 7. STS Cask Pressurization } \\
\hline \multirow{2}{*}{ Item } & \multirow{2}{*}{$\begin{array}{c}\text { Process } \\
\text { Parameter }\end{array}$} & \multirow{2}{*}{ Deviation } & \multirow{2}{*}{ Cause } & \multirow{2}{*}{ Consequences } & \multicolumn{2}{|c|}{ Candidate Controls } & \multirow{2}{*}{ Remarks } \\
\hline & & & & & Engineered & Administrative & \\
\hline $7-9$ & Level & $\begin{array}{l}\text { Low } \\
\text { (nitrogen } \\
\text { bottle volume) }\end{array}$ & $\begin{array}{l}\text { - Leak in supply system } \\
\text { - Operator error (low } \\
\text { pressure bottles not } \\
\text { replaced as needed) }\end{array}$ & $\begin{array}{l}\text { Hydrogen Deflagration: } \\
\text { If the nitrogen volume is low, then there } \\
\text { could be insufficient nitrogen to pressurize } \\
\text { the STS cask to the low pressure limit. } \\
\text { Air inleakage could occur eventually } \\
\text { leading to a flammable hydrogen } \\
\text { concentration. }\end{array}$ & $\begin{array}{l}\text { - Inert gas system pressure } \\
\text { indicator PI-760-601 } \\
\text { - Modified KW Basin Annex } \\
\text { confinement ventilation } \\
\text { - Continuous air monitors }\end{array}$ & $\begin{array}{l}\text { - Procedures } \\
\text { - Training } \\
\text { - Conduct of operations } \\
\text { verifies proper system } \\
\text { configuration } \\
\text { - Administrative control } \\
\text { requiring verification of STS } \\
\text { cask pressure }\end{array}$ & \\
\hline $7-10$ & Level & $\begin{array}{l}\text { High } \\
\text { (nitrogen } \\
\text { bottle volume) }\end{array}$ & N/A & N/A & N/A & N/A & \\
\hline 7-11.a & Structural integrity & $\begin{array}{l}\text { Leak/rupture } \\
\text { (nitrogen } \\
\text { supply } \\
\text { system) }\end{array}$ & $\begin{array}{l}\text { - Overpressurization } \\
\text { - Manufacturing flaw } \\
\text { - Procurement error } \\
\text { - Hose connection } \\
\text { decouples }\end{array}$ & $\begin{array}{l}\text { Industrial Safety: } \\
\text { If the there is leak/rupture in the nitrogen } \\
\text { supply system, then nitrogen will be } \\
\text { released at the point of failure. This could } \\
\text { potentially result in an oxygen deficient } \\
\text { atmosphere. } \\
\text { Hydrogen Deflagration: } \\
\text { If there is a leak/rupture in the nitrogen } \\
\text { supply system, then the STS cask would } \\
\text { not be pressurized. Air inleakage could } \\
\text { occur eventually leading to a flammable } \\
\text { hydrogen concentration. }\end{array}$ & $\begin{array}{l}\text { - Inert gas system pressure } \\
\text { instrumentation (PI-760-601 } \\
\text { through -606) } \\
\text { - Valve position indicators } \\
\text { - Piping and hoses designed to } \\
\text { B31.3, "Process Piping" } \\
\text { - Hose tie-downs } \\
\text { - Pressure safety valve } \\
\text { ECRT-PSV-601 } \\
\text { - Modified KW Basin Annex } \\
\text { confinement ventilation } \\
\text { - Continuous air monitors }\end{array}$ & $\begin{array}{l}\text { - Procedures } \\
\text { - Training } \\
\text { - Hydro testing } \\
\text { - Industrial Safety Program } \\
\text { - Conduct of operations } \\
\text { verifies proper system } \\
\text { configuration } \\
\text { - Administrative control } \\
\text { requiring verification of STS } \\
\text { cask pressure }\end{array}$ & \\
\hline
\end{tabular}




\begin{tabular}{|c|c|c|c|c|c|c|c|}
\hline \multirow{2}{*}{ Item } & \multirow{2}{*}{$\begin{array}{l}\text { Process } \\
\text { Parameter }\end{array}$} & \multirow{2}{*}{ Deviation } & \multirow{2}{*}{ Cause } & \multirow{2}{*}{ Consequences } & \multicolumn{2}{|c|}{ Candidate Controls } & \multirow{2}{*}{ Remarks } \\
\hline & & & & & Engineered & Administrative & \\
\hline 7-11.b & Structural integrity & $\begin{array}{l}\text { Leak/rupture } \\
\text { (STS cask) }\end{array}$ & $\begin{array}{l}\text { - Overpressurization } \\
\text { - STS cask mechanical } \\
\text { seal failure }\end{array}$ & $\begin{array}{l}\text { Hydrogen deflagration: } \\
\text { If the STS cask leaks/ruptures, then air } \\
\text { will leak into the STS cask. This could } \\
\text { eventually lead to a hydrogen } \\
\text { deflagration. }\end{array}$ & $\begin{array}{l}\text { - STS cask pressure boundary } \\
\text { - Pressure control valves } \\
\text { ECRT-PCV-601, -602 } \\
\text { - Pressure safety valve } \\
\text { ECRT-PSV-601 } \\
\text { - Inert gas system pressure } \\
\text { instrumentation (PI-760-601 } \\
\text { through -606) } \\
\text { - Valve position indicators } \\
\text { - STSC active ventilation } \\
\text { - Modified KW Basin Annex } \\
\text { - confinement ventilation } \\
\text { - Continuous air monitors }\end{array}$ & $\begin{array}{l}\text { - Procedures } \\
\text { - Training } \\
\text { - Conduct of operations } \\
\text { verifies proper system } \\
\text { configuration } \\
\text { - STS cask leak test }\end{array}$ & \\
\hline $7-12$ & Time procedure & Too short & $\begin{array}{l}\text { - Operator error } \\
\text { - Instrumentation failure }\end{array}$ & $\begin{array}{l}\text { Hydrogen deflagration: } \\
\text { If the operator pressurizes the STS cask } \\
\text { for too short a period of time, then the } \\
\text { STS cask will not be pressurized to the } \\
\text { low pressure limit. Air inleakage could } \\
\text { occur eventually leading to a flammable } \\
\text { hydrogen concentration. }\end{array}$ & $\begin{array}{l}\text { STS cask pressure } \\
\text { instrumentation (PI-760-606) }\end{array}$ & $\begin{array}{l}\text { - Procedures } \\
\text { - Training } \\
\text { - Administrative control } \\
\text { requiring verification of STS } \\
\text { cask pressure }\end{array}$ & \\
\hline $7-13$ & Time Procedure & Too long & $\begin{array}{l}\text { - Operator error } \\
\text { - Instrumentation failure }\end{array}$ & $\begin{array}{l}\text { Overpressurization: } \\
\text { If the operator pressurizes the STS cask } \\
\text { for too long a period of time, then the STS } \\
\text { cask high pressure limit will be exceeded. } \\
\text { This could result in cask } \\
\text { overpressurization. }\end{array}$ & $\begin{array}{l}\text { - STS cask pressure } \\
\text { instrumentation (PI-760-606) } \\
\text { - Cask vent port tool }\end{array}$ & $\begin{array}{l}\text { - Procedures } \\
\text { - Training } \\
\text { - Administrative control } \\
\text { requiring verification of STS } \\
\text { cask pressure }\end{array}$ & $\begin{array}{l}\text { If the STS cask high pressure limit is } \\
\text { exceeded. The cask vent port tool can be } \\
\text { used to reduce the pressure. }\end{array}$ \\
\hline $7-14$ & Time Procedure & Skip action & - Operator error & $\begin{array}{l}\text { Hydrogen deflagration: } \\
\text { If the operator does not pressurize the } \\
\text { STS cask, then air inleakage could occur } \\
\text { eventually leading to a flammable } \\
\text { hydrogen concentration. }\end{array}$ & $\begin{array}{l}\text { - Modified KW Basin Annex } \\
\text { confinement ventilation } \\
\text { - Continuous air monitors }\end{array}$ & $\begin{array}{l}\text { - Procedures } \\
\text { - Training } \\
\text { - Administrative control } \\
\text { requiring verification of STS } \\
\text { cask pressure }\end{array}$ & \\
\hline $7-15$ & Time Procedure & Wrong action & N/A & N/A & N/A & N/A & \\
\hline
\end{tabular}




\begin{tabular}{|c|c|c|}
\hline Process Parameter & Design Intent & Remarks \\
\hline Flow & $530 \mathrm{ml} / \mathrm{min}(0.14 \mathrm{gpm})$ & The motive force is metering pump ECRT-P-203 \\
\hline Pressure & $70-85$ psig & $\begin{array}{l}\text { Based on calculations in PRC-STP-CN-CH00229, Sludge Treatment Project Engineered Container } \\
\text { Retrieval and Transfer System Preliminary Calculation - Flocculant System }\end{array}$ \\
\hline Concentration & $1 \mathrm{mg} / \mathrm{mL}$ & $\begin{array}{l}\text { This is the concentration of the flocculant solution in flocculant tank ECRT-TK-201. Operations personnel } \\
\text { will prepare the solution to this concentration. }\end{array}$ \\
\hline Composition & Clarifloc N-3300P & $\begin{array}{l}\text { The flocculant is a non-ionic water-soluble polymer. The NFPA } 704 \text { ratings are : } \\
\text { - Health } 1 \text { (exposure would cause irritation with only minor injury } \\
\text { - Flammability } 1 \text { (must be heated before ignition can occur. Flash point over } 93^{\circ} \mathrm{C} \text { ) } \\
\text { - Reactivity } 0 \text { (normally stable, even under fire exposure conditions, and is not reactive with water. }\end{array}$ \\
\hline Level & $>6 \mathrm{~L}$ & $\begin{array}{l}\text { Based on calculations in PRC-STP-CN-CH00229, approximately } 6 \mathrm{~L} \text { of flocculant is needed for } 1 \text { day of } \\
\text { operation. }\end{array}$ \\
\hline Structural Integrity & Maintain integrity under normal operating conditions & None \\
\hline Temperature & Not applicable & $\begin{array}{l}\text { Temperature is not a process parameter that is monitored or controlled. The flocculant addition tank is } \\
\text { located on the deck on the basin deck. The temperature of flocculant will be approximately the same as the } \\
\text { air temperature in the basin. }\end{array}$ \\
\hline Time Procedure & $\begin{array}{l}\text { Flocculant is added at the start of the transfer and continues } \\
\text { until the transfer is completed }\end{array}$ & Flocculant addition is manually started and is terminated by activation of interlock $1-5$. \\
\hline
\end{tabular}

PRC-STP-CN-CH00229, 2010, Sludge Treatment Project Engineered Container Retrieval and Transfer System Preliminary Calculation - Flocculant System, Rev. 1, CH2M HILL Plateau Remediation Company, Richland, Washington. 


\begin{tabular}{|c|c|c|c|c|c|c|c|}
\hline \multirow{2}{*}{ Item } & \multirow{2}{*}{$\begin{array}{l}\text { Process } \\
\text { Parameter }\end{array}$} & \multirow{2}{*}{ Deviation } & \multirow{2}{*}{ Cause } & \multirow{2}{*}{ Consequences } & \multicolumn{2}{|c|}{ Candidate Controls } & \multirow{2}{*}{ Remarks } \\
\hline & & & & & Engineered & Administrative & \\
\hline $8-1$ & Flow & No & $\begin{array}{l}\text { - Metering pump } \\
\text { ECRT-P-203 is not } \\
\text { operating } \\
\text { - A normally-opened valve } \\
\text { is closed } \\
\text { - Tank ECRT-TK-203 is } \\
\text { empty }\end{array}$ & $\begin{array}{l}\text { Operational Upset: } \\
\text { If there is no flow, then flocculant will not } \\
\text { be added to the sludge transfer. This } \\
\text { could result in longer settling times prior } \\
\text { to STSC decant. }\end{array}$ & $\begin{array}{l}\text { - Pressure instrumentation } \\
\text { (PIT-710-203) } \\
\text { - Valve position indicators }\end{array}$ & $\begin{array}{l}\text { - Procedures } \\
\text { - Training } \\
\text { - Conduct of operations } \\
\text { verifies proper system } \\
\text { configuration }\end{array}$ & $\begin{array}{l}\text { If tank ECRT-TK-201 is empty, there will be } \\
\text { no flow of flocculant, but pump ECRT-P-203 } \\
\text { would pump air }\end{array}$ \\
\hline $8-2$ & Flow & Low & $\begin{array}{l}\text { - Flow rate set incorrectly } \\
\text { - A normally-opened valve } \\
\text { is partially closed }\end{array}$ & $\begin{array}{l}\text { Operational Upset: } \\
\text { If the flow rate is low, then less flocculant } \\
\text { will be added to the sludge transfer. This } \\
\text { could result in longer settling times prior } \\
\text { to STSC decant. }\end{array}$ & $\begin{array}{l}\text { - Flow controller FC-710-201 } \\
\text { - Pressure instrumentation } \\
\text { (PIT-710-203) } \\
\text { - Valve position indicators }\end{array}$ & $\begin{array}{l}\text { - Procedures } \\
\text { - Training } \\
\text { - Conduct of operations } \\
\text { verifies proper system } \\
\text { configuration }\end{array}$ & $\begin{array}{l}\text { The flow rate is set using the calibration } \\
\text { column. }\end{array}$ \\
\hline $8-3$ & Flow & High & Flow rate set incorrectly & $\begin{array}{l}\text { Operation Upset: } \\
\text { If the flow rate is high, then more } \\
\text { flocculant will be added to the sludge } \\
\text { transfer. This could subsequently result } \\
\text { in plugging of the sand filters. }\end{array}$ & $\begin{array}{l}\text { - Flow controller FC-710-201 } \\
\text { - Pressure instrumentation } \\
\text { (PIT-710-203) } \\
\text { - Valve position indicators }\end{array}$ & $\begin{array}{l}\text { - Procedures } \\
\text { - Training } \\
\text { - Conduct of operations } \\
\text { verifies proper system } \\
\text { configuration }\end{array}$ & $\begin{array}{l}\text { The flow rate is set using the calibration } \\
\text { column. } \\
\text { Based on testing as MASF, it is unlikely that } \\
\text { excess flocculant would result in plugging of } \\
\text { the sand filter. } \\
\text { Amount of flocculant added is limited by the } \\
\text { capacity of tank ECRT-TK-201. }\end{array}$ \\
\hline 8-4.a & Flow & Reverse & $\begin{array}{l}\text { Metering pump } \\
\text { ECRT-P-203 runs in } \\
\text { reverse }\end{array}$ & $\begin{array}{l}\text { Uncontrolled Release: } \\
\text { If metering pump ECRT-P-203 runs in } \\
\text { reverse, then sludge would be pumped } \\
\text { into the flocculant addition system and } \\
\text { could result in a spray or splash and } \\
\text { splatter/pool release. }\end{array}$ & $\begin{array}{l}\text { Check valves ECRT-207 and } \\
-208\end{array}$ & $\begin{array}{l}\text { - Procedures } \\
\text { - Training } \\
\text { - Pre-operational testing }\end{array}$ & $\begin{array}{l}\text { Pump ECRT-P-203 is similar to an AODD, } \\
\text { except that it has one diaphragm and is } \\
\text { mechanically actuated. Regardless of which } \\
\text { way the motor is turning, the internal check } \\
\text { valves will only allow flow in one direction. } \\
\text { Once installed correctly, as verified by pre- } \\
\text { operational testing, it cannot pump in the } \\
\text { reverse direction. }\end{array}$ \\
\hline
\end{tabular}




\begin{tabular}{|c|c|c|c|c|c|c|c|}
\hline \multirow{2}{*}{ Item } & \multirow{2}{*}{$\begin{array}{l}\text { Process } \\
\text { Parameter }\end{array}$} & \multirow{2}{*}{ Deviation } & \multirow{2}{*}{ Cause } & \multirow{2}{*}{ Consequences } & \multicolumn{2}{|c|}{ Candidate Controls } & \multirow{2}{*}{ Remarks } \\
\hline & & & & & Engineered & Administrative & \\
\hline $8-4.6$ & Flow & Reverse & $\begin{array}{l}\text { Booster pump } \\
\text { ECRT-P-101 runs in } \\
\text { reverse }\end{array}$ & $\begin{array}{l}\text { Uncontrolled Release: } \\
\text { If booster pump ECRT-P-101 runs in } \\
\text { reverse, then sludge could flow into the } \\
\text { flocculant addition system to a point } \\
\text { above the basin water. } \\
\text { If the flocculant addition system line failed } \\
\text { due to the pressure generated by pump } \\
\text { ECRT-P-101, then a spray or splash and } \\
\text { splatter/pool release could occur. }\end{array}$ & $\begin{array}{l}\text { Check valves ECRT-CV-207 } \\
\text { and }-208\end{array}$ & $\begin{array}{l}\text { - Procedures } \\
\text { - Training } \\
\text { - Pre-operational testing }\end{array}$ & $\begin{array}{l}\text { The design of booster pump ECRT-P-101 is } \\
\text { such that it can be operated in the reverse } \\
\text { direction. However, there are no plans to } \\
\text { operate the pump in reverse. }\end{array}$ \\
\hline $8-5$ & Flow & Misdirected & $\begin{array}{l}\text { Operator error: metering } \\
\text { pump ECRT-P-203 started } \\
\text { when Xago Hydrolance } \\
\text { and booster pump } \\
\text { ECRT-P-101 are shut off }\end{array}$ & $\begin{array}{l}\text { Operational Upset: } \\
\text { If metering pump ECRT-P-203 operates } \\
\text { when the Xago Hydrolance }{ }^{m} \text { and booster } \\
\text { pump ECRT-P-101 are shut off, then } \\
\text { flocculant will be pumped into the } \\
\text { engineered container via the Xago } \\
\text { Hydrolance }{ }^{m} \text { Coanda head and into the } \\
\text { basin via the basin water flush valve. } \\
\text { If flocculant is added to the basin water, } \\
\text { then the performance of the IXM Skimmer } \\
\text { Water System sand filter could be } \\
\text { affected. }\end{array}$ & None & $\begin{array}{l}\text { - Procedures } \\
\text { - Training }\end{array}$ & $\begin{array}{l}\text { The flocculant would be added to the basin at } \\
\text { a very low flow rate and concentration. It is } \\
\text { unlikely it would affect the IXM Skimmer } \\
\text { Water System sand filter performance. }\end{array}$ \\
\hline $8-6$ & Pressure & Low & Flow rate set incorrectly & $\begin{array}{l}\text { Operational Upset: } \\
\text { If the pressure is low, then the flow will be } \\
\text { low. Consequences are as stated in } \\
\text { Item 8-2 above. }\end{array}$ & $\begin{array}{l}\text { - Flow controller FC-710-201 } \\
\text { - Pressure instrumentation } \\
\text { (PIT-710-203) }\end{array}$ & $\begin{array}{l}\text { - Procedures } \\
\text { - Training } \\
\text { - Conduct of operations } \\
\text { verifies proper system } \\
\text { configuration }\end{array}$ & \\
\hline
\end{tabular}




\begin{tabular}{|c|c|c|c|c|c|c|c|}
\hline \multirow{2}{*}{ Item } & \multirow{2}{*}{$\begin{array}{l}\text { Process } \\
\text { Parameter }\end{array}$} & \multirow{2}{*}{ Deviation } & \multirow{2}{*}{ Cause } & \multirow{2}{*}{ Consequences } & \multicolumn{2}{|c|}{ Candidate Controls } & \multirow{2}{*}{ Remarks } \\
\hline & & & & & Engineered & Administrative & \\
\hline $8-7$ & Pressure & High & $\begin{array}{l}\text { - Flow rate set incorrectly } \\
\text { - Normally opened valve } \\
\text { closed or partially closed }\end{array}$ & $\begin{array}{l}\text { Industrial Safety: } \\
\text { If the pressure is high, then the flocculant } \\
\text { supply hose could fail above the basin } \\
\text { water and whip causing a facility worker } \\
\text { injury. } \\
\text { Operational Upset: } \\
\text { If the pressure is high, then the flocculant } \\
\text { supply hose could fail below the basin } \\
\text { water and flocculant would be added to } \\
\text { the basin water. } \\
\text { If flocculant is added to the basin water, } \\
\text { then the performance of the IXM Skimmer } \\
\text { Water System sand filter could be } \\
\text { affected. }\end{array}$ & $\begin{array}{l}\text { - Pressure instrumentation } \\
\text { (PIT-710-203) } \\
\text { - Piping and hoses designed in } \\
\text { accordance with B31.3, } \\
\text { "Process Piping." } \\
\text { - Pressure safety valve } \\
\text { ECRT-PSV-201 } \\
\text { - Valve position indicators }\end{array}$ & $\begin{array}{l}\text { - Procedures } \\
\text { - Training } \\
\text { - Conduct of operations } \\
\text { verifies proper system } \\
\text { configuration }\end{array}$ & $\begin{array}{l}\text { The flocculant would be added to the basin at } \\
\text { a very low flow rate and concentration. It is } \\
\text { unlikely it would affect the IXM Skimmer } \\
\text { Water System sand filter performance. }\end{array}$ \\
\hline $8-8$ & Concentration & Low & $\begin{array}{l}\text { Error in preparing } \\
\text { flocculant solution }\end{array}$ & $\begin{array}{l}\text { Operational Upset: } \\
\text { If the concentration is low, then less } \\
\text { flocculant will be added to the sludge } \\
\text { transfer. This could result in longer } \\
\text { settling times prior to STSC decant. }\end{array}$ & None & $\begin{array}{l}\text { - Procedures } \\
\text { - Training }\end{array}$ & \\
\hline 8-9 & Concentration & High & $\begin{array}{l}\text { Error in preparing } \\
\text { flocculant solution }\end{array}$ & $\begin{array}{l}\text { Operation Upset: } \\
\text { If the concentration is high, then more } \\
\text { flocculant will be added to the sludge } \\
\text { transfer. This could subsequently result } \\
\text { in plugging of the sand filters. }\end{array}$ & None & - Procedures & $\begin{array}{l}\text { Based on testing as MASF, it is unlikely that } \\
\text { excess flocculant would result in plugging of } \\
\text { the sand filter. }\end{array}$ \\
\hline 8-10.a & Composition & $\begin{array}{l}\text { Other } \\
\text { (degraded } \\
\text { flocculant, see } \\
\text { remarks) }\end{array}$ & Operator error & $\begin{array}{l}\text { Operational Upset: } \\
\text { If the flocculant is degraded, then settling } \\
\text { will not be as efficient. This could result in } \\
\text { longer settling times prior to STSC } \\
\text { decant. }\end{array}$ & None & $\begin{array}{l}\text { - Procedures } \\
\text { - Training }\end{array}$ & $\begin{array}{l}\text { If the flocculant is not used within } 8 \text { days of } \\
\text { preparation, it begins to break-down and } \\
\text { becomes less effective. }\end{array}$ \\
\hline
\end{tabular}




\begin{tabular}{|c|c|c|c|c|c|c|c|}
\hline \multirow{2}{*}{ Item } & \multirow{2}{*}{$\begin{array}{l}\text { Process } \\
\text { Parameter }\end{array}$} & \multirow{2}{*}{ Deviation } & \multirow{2}{*}{ Cause } & \multirow{2}{*}{ Consequences } & \multicolumn{2}{|c|}{ Candidate Controls } & \multirow{2}{*}{ Remarks } \\
\hline & & & & & Engineered & Administrative & \\
\hline 8-10.b & Composition & $\begin{array}{l}\text { Other } \\
\text { (different } \\
\text { flocculant) }\end{array}$ & Procurement error & $\begin{array}{l}\text { Operational Upset: } \\
\text { If a flocculant other than Clarifloc } \\
\mathrm{N}-3300 \mathrm{P} \text { is used, then settling times prior } \\
\text { to STSC decant could be longer. In } \\
\text { addition, the different flocculant may } \\
\text { result in plugging of the sand filters. }\end{array}$ & None & $\begin{array}{l}\text { - Procedures } \\
\text { - Training } \\
\text { - Quality Assurance Program }\end{array}$ & \\
\hline $8-11$ & Level & High & Operator error & $\begin{array}{l}\text { Operational Upset: } \\
\text { If the level in flocculant tank } \\
\text { ECRT-TK-201 is high, then the tank could } \\
\text { overflow and spill flocculant onto the } \\
\text { basin deck. }\end{array}$ & None & $\begin{array}{l}\text { - Procedures } \\
\text { - Training } \\
\text { - Visual inspection }\end{array}$ & \\
\hline $8-12$ & Level & Low & Operator error & $\begin{array}{l}\text { Operational Upset: } \\
\text { If the level in flocculant tank } \\
\text { ECRT-TK-201 is low, then there will not } \\
\text { be sufficient flocculant for the transfer. } \\
\text { This could result in longer settling times } \\
\text { prior to STSC decant. } \\
\text { If the tank level was sufficiently low, then } \\
\text { pump ECRT-P-203 would begin to pump } \\
\text { air into the transfer line. }\end{array}$ & None & $\begin{array}{l}\text { - Procedures } \\
\text { - Training } \\
\text { - Visual inspection }\end{array}$ & \\
\hline 8-13.a & Structural Integrity & $\begin{array}{l}\text { Leak/rupture } \\
\text { (above basin } \\
\text { water) }\end{array}$ & $\begin{array}{l}\text { - Overfill tank } \\
\text { ECRT-TK-201 } \\
\text { - Overpressurization } \\
\text { - Hose disconnects }\end{array}$ & $\begin{array}{l}\text { Operational Upset: } \\
\text { If there is a leak or rupture above the } \\
\text { basin water, then the correct amount of } \\
\text { flocculant will not be added to the } \\
\text { transfer. This could result in longer } \\
\text { settling times prior to STSC decant. } \\
\text { In addition, the flocculant would run into } \\
\text { the basin water such that performance of } \\
\text { the IXM Skimmer Water System sand } \\
\text { filter could be affected. }\end{array}$ & $\begin{array}{l}\text { - Pressure instrumentation } \\
\text { (PIT-710-203) } \\
\text { - Piping designed in } \\
\text { accordance with B31.3, } \\
\text { "Process Piping." } \\
\text { - Pressure safety valve } \\
\text { ECRT-PSV-201 } \\
\text { - Valve position indicators }\end{array}$ & $\begin{array}{l}\text { - Procedures } \\
\text { - Training } \\
\text { - Conduct of operations } \\
\text { verifies proper system } \\
\text { configuration }\end{array}$ & $\begin{array}{l}\text { The flocculant would be added to the basin at } \\
\text { a very low flow rate and concentration. It is } \\
\text { unlikely it would affect the IXM Skimmer } \\
\text { Water System sand filter performance. }\end{array}$ \\
\hline
\end{tabular}




\begin{tabular}{|c|c|c|c|c|c|c|c|}
\hline \multirow{2}{*}{ Item } & \multirow{2}{*}{$\begin{array}{l}\text { Process } \\
\text { Parameter }\end{array}$} & \multirow{2}{*}{ Deviation } & \multirow{2}{*}{ Cause } & \multirow{2}{*}{ Consequences } & \multicolumn{2}{|c|}{ Candidate Controls } & \multirow{2}{*}{ Remarks } \\
\hline & & & & & Engineered & Administrative & \\
\hline 8-13.b & Structural Integrity & $\begin{array}{l}\text { Leak/rupture } \\
\text { (below basin } \\
\text { water) }\end{array}$ & $\begin{array}{l}\text { - Overpressurization } \\
\text { - Hose disconnects }\end{array}$ & $\begin{array}{l}\text { Operational Upset: } \\
\text { If there is a leak or rupture below the } \\
\text { basin water, then the correct amount of } \\
\text { flocculant will not be added to the } \\
\text { transfer. This could result in longer } \\
\text { settling times prior to STSC decant. } \\
\text { In addition, if flocculant is added to the } \\
\text { basin water, then the performance of the } \\
\text { IXM Skimmer Water System sand filter } \\
\text { could be affected. }\end{array}$ & $\begin{array}{l}\text { - Pressure instrumentation } \\
\text { (PIT-710-203) Piping } \\
\text { designed in accordance with } \\
\text { B31.3, “Process Piping." } \\
\text { - Pressure safety valve } \\
\text { ECRT-PSV-201 } \\
\text { - Valve position indicators }\end{array}$ & $\begin{array}{l}\text { - Procedures } \\
\text { - Training } \\
\text { - Conduct of operations } \\
\text { verifies proper system } \\
\text { configuration }\end{array}$ & $\begin{array}{l}\text { The flocculant would be added to the basin at } \\
\text { a very low flow rate and concentration. It is } \\
\text { unlikely it would affect the IXM Skimmer } \\
\text { Water System sand fitter performance. }\end{array}$ \\
\hline $8-14$ & Time Procedure & Too short & $\begin{array}{l}\text { - Operator error } \\
\text { - Equipment failure }\end{array}$ & $\begin{array}{l}\text { Operational Upset: } \\
\text { If the flocculant is added for too short a } \\
\text { period of time, then flocculant will not be } \\
\text { added to a portion of the transfer. This } \\
\text { could result in longer settling times prior } \\
\text { to STSC decant. }\end{array}$ & $\begin{array}{l}\text { Pressure instrumentation } \\
\text { (PIT-710-203) }\end{array}$ & $\begin{array}{l}\text { - Procedures } \\
\text { - Training }\end{array}$ & \\
\hline $8-15$ & Time Procedure & Too long & $\begin{array}{l}\text { - Operator error } \\
\text { - Equipment failure }\end{array}$ & $\begin{array}{l}\text { Operational Upset: } \\
\text { Adding flocculant after the transfer is } \\
\text { complete (i.e., after booster pump } \\
\text { ECRT-P-101 has been shut off) would } \\
\text { result in a misdirected flow of flocculant. } \\
\text { The consequences would be as state in } \\
\text { ltem } 8-5 \text { above. }\end{array}$ & $\begin{array}{l}\text { Check valve ECRT-CV-101 (on } \\
\text { the basin water check valve) }\end{array}$ & $\begin{array}{l}\text { - Procedures } \\
\text { - Training }\end{array}$ & \\
\hline $8-16$ & Time Procedure & Skip action & Operator error & $\begin{array}{l}\text { Operational Upset: } \\
\text { If the action is skipped, then flocculant will } \\
\text { not be added to the sludge transfer. This } \\
\text { could result in longer settling times prior } \\
\text { to STSC decant. }\end{array}$ & $\begin{array}{l}\text { Pressure instrumentation } \\
\text { (PIT-710-203) }\end{array}$ & $\begin{array}{l}\text { - Procedures } \\
\text { - Training }\end{array}$ & \\
\hline $8-17$ & Time Procedure & Wrong action & N/A & N/A & N/A & N/A & $\begin{array}{l}\text { There is no wrong action associated with this } \\
\text { node. }\end{array}$ \\
\hline
\end{tabular}




\begin{tabular}{|c|c|c|}
\hline Process Parameter & Design Intent & Remarks \\
\hline Flow & $45.4 \mathrm{ml} / \mathrm{min}(0.12 \mathrm{gpm})$ & $\begin{array}{l}\text { The motive force is metering pump ECRT-P-204. PRC-STP-CN-CH00229, Sludge Treatment Project Engineered Container } \\
\text { Retrieval and Transfer System Preliminary Calculation - Flocculant System, shows a range of flocculant addition rates } \\
\text { based on a range of flocculant concentrations. Subsequent to issuing PRC-STP-CN-CH00229, Rev. 1, a decision was made } \\
\text { to use a single concentration }\end{array}$ \\
\hline Pressure & 70 to $85 \mathrm{psi}$ & Based on calculations in PRC-STP-CN-CH00229. The pressure is restricted by the pressure rating on AE-720-201. \\
\hline Concentration & $1 \mathrm{mg} / \mathrm{mL}$ & $\begin{array}{l}\text { This is the concentration of the flocculant solution in flocculant tank ECRT-TK-202. Operations personnel will prepare the } \\
\text { solution to this concentration. }\end{array}$ \\
\hline Composition & Clarifloc $\mathrm{N}-3300 \mathrm{P}$ & $\begin{array}{l}\text { The flocculant is a non-ionic water-soluble polymer. The NFPA } 704 \text { ratings are : } \\
\text { - Health } 1 \text { (exposure would cause irritation with only minor injury } \\
\text { - Flammability } 1 \text { (must be heated before ignition can occur. Flash point over } 93^{\circ} \mathrm{C} \text { ) } \\
\text { - Reactivity } 0 \text { (normally stable, even under fire exposure conditions, and is not reactive with water. }\end{array}$ \\
\hline Level & $>7 \mathrm{~L}$ & Based on calculations in PRC-STP-CN-CH00229, approximately $6 \mathrm{~L}$ of flocculant is needed for 1 day of operation. \\
\hline Structural Integrity & $\begin{array}{l}\text { Maintain integrity under normal operating } \\
\text { conditions }\end{array}$ & None \\
\hline Temperature & Not applicable & $\begin{array}{l}\text { Temperature is not a process parameter that is monitored or controlled. The flocculant addition tank is located on the deck } \\
\text { on the basin deck. The temperature of flocculant will be approximately the same as the air temperature in the basin. }\end{array}$ \\
\hline Time Procedure & $\begin{array}{l}\text { Flocculant is added at the start of the } \\
\text { decant recycle and is added until the } \\
\text { turbidity decreases to } 210 \text { NTUs or until } \\
\text { further flocculant addition does not result in } \\
\text { a decrease in turbidity }\end{array}$ & Flocculant addition is manually started and stopped. \\
\hline
\end{tabular}

PRC-STP-CN-CH00229, 2010, Sludge Treatment Project Engineered Container Retrieval and Transfer System Preliminary Calculation - Flocculant System, Rev. 1, CH2M HILL Plateau Remediation Company, Richland, Washington. 


\begin{tabular}{|c|c|c|c|c|c|c|c|}
\hline \multirow{2}{*}{ Item } & \multirow{2}{*}{$\begin{array}{l}\text { Process } \\
\text { Parameter }\end{array}$} & \multirow{2}{*}{ Deviation } & \multirow{2}{*}{ Cause } & \multirow{2}{*}{ Consequences } & \multicolumn{2}{|c|}{ Candidate Controls } & \multirow{2}{*}{ Remarks } \\
\hline & & & & & Engineered & Administrative & \\
\hline 9.a-1 & Flow & No & $\begin{array}{l}\text { - Metering pump } \\
\text { ECRT-P-204 is not } \\
\text { operating } \\
\text { - A normally-opened valve } \\
\text { is closed } \\
\text { - Tank ECRT-TK-202 is } \\
\text { empty }\end{array}$ & $\begin{array}{l}\text { Operational Upset: } \\
\text { If there is no flow, then flocculant will not } \\
\text { be added to the recirculated supernate. } \\
\text { This could result in longer settling times } \\
\text { prior to STSC decant. }\end{array}$ & $\begin{array}{l}\text { - Pressure instrumentation } \\
\text { (PIT-710-204) } \\
\text { - Valve position indicators }\end{array}$ & $\begin{array}{l}\text { - Procedures } \\
\text { - Training } \\
\text { - Conduct of operations } \\
\text { verifies proper system } \\
\text { configuration }\end{array}$ & $\begin{array}{l}\text { If tank ECRT-TK-201 is empty, there will be } \\
\text { no flow of flocculant, but pump ECRT-P-203 } \\
\text { would pump air }\end{array}$ \\
\hline 9.a-2 & Flow & Low & $\begin{array}{l}\text { - Flow rate set incorrectly } \\
\text { - A normally-opened valve } \\
\text { is partially closed }\end{array}$ & $\begin{array}{l}\text { Operational Upset: } \\
\text { If the flow rate is low, then less flocculant } \\
\text { will be added to the recirculated } \\
\text { supernate. This could result in longer } \\
\text { settling times prior to STSC decant. }\end{array}$ & $\begin{array}{l}\text { - Flow controller FC-710-202 } \\
\text { - Pressure instrumentation } \\
\text { (PIT-710-204) } \\
\text { - Valve position indicators }\end{array}$ & $\begin{array}{l}\text { - Procedures } \\
\text { - Training } \\
\text { - Conduct of operations } \\
\text { verifies proper system } \\
\text { configuration }\end{array}$ & $\begin{array}{l}\text { The flow rate is set using the calibration } \\
\text { column. }\end{array}$ \\
\hline $9 . a-3$ & Flow & High & Flow rate set incorrectly & $\begin{array}{l}\text { Operation Upset: } \\
\text { If the flow rate is high, then more } \\
\text { flocculant will be added to the recirculated } \\
\text { supernate. This could subsequently } \\
\text { result in plugging of the sand filters. }\end{array}$ & $\begin{array}{l}\text { - Flow controller FC-710-202 } \\
\text { - Pressure instrumentation } \\
\text { (PIT-710-204) } \\
\text { - Valve position indicators }\end{array}$ & $\begin{array}{l}\text { - Procedures } \\
\text { - Training } \\
\text { - Conduct of operations } \\
\text { verifies proper system } \\
\text { configuration }\end{array}$ & $\begin{array}{l}\text { The flow rate is set using the calibration } \\
\text { column. } \\
\text { Based on testing as MASF, it is unlikely that } \\
\text { excess flocculant would result in plugging of } \\
\text { the sand filter. }\end{array}$ \\
\hline 9.a-4 & Flow & Reverse & $\begin{array}{l}\text { - Metering pump } \\
\text { ECRT-P-204 runs in } \\
\text { reverse } \\
\text { - Metering pump } \\
\text { ECRT-P-204 not } \\
\text { operating } \\
\text { - Low pressure in } \\
\text { flocculant addition line }\end{array}$ & $\begin{array}{l}\text { Uncontrolled Release: } \\
\text { If metering pump ECRT-P-204 runs in } \\
\text { reverse, then recirculated supernate } \\
\text { would be pumped into the flocculant } \\
\text { addition system and could result in a } \\
\text { spray or and splatter/pool release. } \\
\text { If metering pump ECRT-P-204 does not } \\
\text { operate, or if the pressure in the flocculant } \\
\text { addition line is low, then recirculated } \\
\text { supernate would be pumped into the } \\
\text { flocculant addition system (due to the } \\
80 \text { psi generated by decant pump } \\
\text { ECRT-P-201) and could result in a spray } \\
\text { or splash and splatter/pool release. }\end{array}$ & $\begin{array}{l}\text { - Check valve ECRT-CV-202 } \\
\text { - Pressure instrumentation } \\
\text { (PIT-710-204) } \\
\text { - Modified KW Basin Annex } \\
\text { confinement ventilation } \\
\text { - Continuous air monitors }\end{array}$ & $\begin{array}{l}\text { - Procedures } \\
\text { - Training } \\
\text { - Pre-operational testing } \\
\text { - Modified KW Basin Annex } \\
\text { is unmanned during decant } \\
\text { operations }\end{array}$ & $\begin{array}{l}\text { Pump ECRT-P-204 is similar to an AODD, } \\
\text { except that it has one diaphragm and is } \\
\text { mechanically actuated. Regardless of which } \\
\text { way the motor is turning, the internal check } \\
\text { valves will only allow flow in one direction. } \\
\text { Once installed correctly, as verified by pre- } \\
\text { operational testing, it cannot pump in the } \\
\text { reverse direction. }\end{array}$ \\
\hline 9.a-5 & Flow & Misdirected & N/A & N/A & N/A & N/A & This Node cannot be misdirected. \\
\hline
\end{tabular}


Table C-26. HAZOP Results, Node 9.a, Annex Flocculant Addition System - Flocculant Tank to In-Line Mixer

\begin{tabular}{|c|c|c|c|c|c|c|c|}
\hline \multirow{2}{*}{ Item } & \multirow{2}{*}{$\begin{array}{l}\text { Process } \\
\text { Parameter }\end{array}$} & \multirow{2}{*}{ Deviation } & \multirow{2}{*}{ Cause } & \multirow{2}{*}{ Consequences } & \multicolumn{2}{|c|}{ Candidate Controls } & \multirow{2}{*}{ Remarks } \\
\hline & & & & & Engineered & Administrative & \\
\hline $9 . a-6$ & Pressure & Low & Flow rate set incorrectly & $\begin{array}{l}\text { Uncontrolled Release: } \\
\text { If the pressure is low, then recirculated } \\
\text { supernate would be pumped into the } \\
\text { flocculant addition system (due to the } \\
80 \text { psi generated by decant pump } \\
\text { ECRT-P-201) and could result in a spray } \\
\text { or splash and splatter/pool release. }\end{array}$ & $\begin{array}{l}\text { - Flow controller FC-710-201 } \\
\text { - Pressure instrumentation } \\
\text { (PIT-710-204) }\end{array}$ & $\begin{array}{l}\text { - Procedures } \\
\text { - Training } \\
\text { - Conduct of operations } \\
\text { verifies proper system } \\
\text { configuration } \\
\text { - Modified KW Basin Annex } \\
\text { is unmanned during decant } \\
\text { operations }\end{array}$ & \\
\hline 9.a-7 & Pressure & High & $\begin{array}{l}\text { - Flow rate set incorrectly } \\
\text { - Normally opened valve } \\
\text { closed or partially closed }\end{array}$ & $\begin{array}{l}\text { Operational Upset: } \\
\text { If the pressure is high, then the flow rate } \\
\text { will be high. The consequences are as } \\
\text { shown in Item 8-3. } \\
\text { Uncontrolled Release: } \\
\text { If the pressure is high, then the } \\
\text { decant/flocculant recirculation line could } \\
\text { fail resulting in a spray or splash and } \\
\text { splatter/pool release } \\
\text { Hydrogen Deflagration: } \\
\text { If the pressure is high, then the } \\
\text { decant/flocculant recirculation line could } \\
\text { fail. Hydrogen generated by the } \\
\text { supernate could accumulate in the Decant } \\
\text { Pump Box resulting in a deflagration. }\end{array}$ & $\begin{array}{l}\text { - Flow controller FC-710-202 } \\
\text { - Pressure instrumentation } \\
\text { (PIT-710-204) } \\
\text { - Piping and hoses designed in } \\
\text { accordance with B31.3, } \\
\text { "Process Piping." } \\
\text { - Pressure safety valve } \\
\text { ECRT-PSV-202 } \\
\text { - Valve position indicators } \\
\text { - Secondary containment with } \\
\text { leak detection } \\
\text { - Leak detection interlocked to } \\
\text { shut off Decant pump } \\
\text { ECRT-P-201 } \\
\text { - Decant Pump Box } \\
\text { HEPA-filtered confinement } \\
\text { ventilation } \\
\text { - Modified KW Basin Annex } \\
\text { confinement ventilation } \\
\text { - Continuous air monitors }\end{array}$ & $\begin{array}{l}\text { - Procedures } \\
\text { - Training } \\
\text { - Conduct of operations } \\
\text { verifies proper system } \\
\text { configuration } \\
\text { - Modified KW Basin Annex } \\
\text { is unmanned during decant } \\
\text { operations } \\
\text { - Leak detection alarm } \\
\text { response }\end{array}$ & \\
\hline $9 . a-8$ & Concentration & Low & $\begin{array}{l}\text { Error in preparing } \\
\text { flocculant solution }\end{array}$ & $\begin{array}{l}\text { Operational Upset: } \\
\text { If the concentration is low, then less } \\
\text { flocculant will be added to the recirculated } \\
\text { decant. This could result in longer settling } \\
\text { times prior to STSC decant. }\end{array}$ & None & $\begin{array}{l}\text { - Procedures } \\
\text { - Training }\end{array}$ & \\
\hline
\end{tabular}




\begin{tabular}{|c|c|c|c|c|c|c|c|}
\hline \multirow{2}{*}{ Item } & \multirow{2}{*}{$\begin{array}{l}\text { Process } \\
\text { Parameter }\end{array}$} & \multirow{2}{*}{ Deviation } & \multirow{2}{*}{ Cause } & \multirow{2}{*}{ Consequences } & \multicolumn{2}{|c|}{ Candidate Controls } & \multirow{2}{*}{ Remarks } \\
\hline & & & & & Engineered & Administrative & \\
\hline 9.a-9 & Concentration & High & $\begin{array}{l}\text { Error in preparing } \\
\text { flocculant solution }\end{array}$ & $\begin{array}{l}\text { Operation Upset: } \\
\text { If the concentration is high, then more } \\
\text { flocculant will be added to the recirculated } \\
\text { decant. This could subsequently result in } \\
\text { plugging of the sand filters. }\end{array}$ & None & $\begin{array}{l}\text { - Procedures } \\
\text { - Training }\end{array}$ & $\begin{array}{l}\text { Based on testing as MASF, it is unlikely that } \\
\text { excess flocculant would result in plugging of } \\
\text { the sand filter. }\end{array}$ \\
\hline 9.a-10.a & Composition & $\begin{array}{l}\text { Other } \\
\text { (degraded } \\
\text { flocculant, see } \\
\text { remarks) }\end{array}$ & Operator error & $\begin{array}{l}\text { Operational Upset: } \\
\text { If the flocculant is degraded, then settling } \\
\text { will not be as efficient. This could result in } \\
\text { longer settling times prior to STSC } \\
\text { decant. }\end{array}$ & None & $\begin{array}{l}\text { - Procedures } \\
\text { - Training }\end{array}$ & $\begin{array}{l}\text { If the flocculant is not used within } 8 \text { days of } \\
\text { preparation, it begins to break-down and } \\
\text { becomes less effective. }\end{array}$ \\
\hline 9.a-10.b & Composition & $\begin{array}{l}\text { Other } \\
\text { (different } \\
\text { flocculant) }\end{array}$ & Procurement error & $\begin{array}{l}\text { Operational Upset: } \\
\text { If a flocculant other than Clarifloc } \\
\mathrm{N}-3300 \mathrm{P} \text { is used, then settling times prior } \\
\text { to STSC decant could be longer. In } \\
\text { addition, the different flocculant may } \\
\text { result in plugging of the sand filters. }\end{array}$ & None & $\begin{array}{l}\text { - Procedures } \\
\text { - Training } \\
\text { - Quality Assurance Program }\end{array}$ & \\
\hline $9 . a-11$ & Level & High & Operator error & $\begin{array}{l}\text { Operational Upset: } \\
\text { If the level in flocculant tank } \\
\text { ECRT-TK-202 is high, then the tank could } \\
\text { overflow and spill flocculant in the Annex. }\end{array}$ & None & $\begin{array}{l}\text { - Procedures } \\
\text { - Training } \\
\text { - Visual inspection }\end{array}$ & \\
\hline $9 . a-12$ & Level & Low & Operator error & $\begin{array}{l}\text { Operational Upset: } \\
\text { If the level in flocculant tank } \\
\text { ECRT-TK-202 is low, then there will not } \\
\text { be sufficient flocculant for the transfer. } \\
\text { This could result in longer settling times } \\
\text { prior to STSC decant. } \\
\text { If the tank level was sufficiently low, then } \\
\text { pump ECRT-P-204 would begin to pump } \\
\text { air into the decantflocculant recirculation } \\
\text { line. }\end{array}$ & None & $\begin{array}{l}\text { - Procedures } \\
\text { - Training } \\
\text { - Visual inspection }\end{array}$ & \\
\hline
\end{tabular}


Table C-26. HAZOP Results, Node 9.a, Annex Flocculant Addition System - Flocculant Tank to In-Line Mixer

\begin{tabular}{|c|c|c|c|c|c|c|c|}
\hline \multirow{2}{*}{ Item } & \multirow{2}{*}{$\begin{array}{l}\text { Process } \\
\text { Parameter }\end{array}$} & \multirow{2}{*}{ Deviation } & \multirow{2}{*}{ Cause } & \multirow{2}{*}{ Consequences } & \multicolumn{2}{|c|}{ Candidate Controls } & \multirow{2}{*}{ Remarks } \\
\hline & & & & & Engineered & Administrative & \\
\hline 9.a-13.a & Structural Integrity & $\begin{array}{l}\text { Leak/rupture } \\
\text { (inside Decant } \\
\text { Pump Box) }\end{array}$ & $\begin{array}{l}\text { - Overpressurization } \\
\text { - Hose disconnects }\end{array}$ & $\begin{array}{l}\text { Operational Upset: } \\
\text { If the leak is small, then flocculant will spill } \\
\text { into the Decant Pump Box. } \\
\text { Uncontrolled Release: } \\
\text { If the leak is large, then the pressure } \\
\text { could drop to the point that recirculated } \\
\text { supernate would be pumped into the } \\
\text { flocculant addition system (due to the } \\
80 \text { psi generated by decant pump } \\
\text { ECRT-P-201) which would result in a } \\
\text { spray or splash and splatter/pool release. } \\
\text { Hydrogen Deflagration: } \\
\text { If the leak is large, and recirculated } \\
\text { supernate is pumped into the Decant } \\
\text { Pump Box, then hydrogen generated by } \\
\text { the supernate could accumulate in the } \\
\text { box resulting in a deflagration. }\end{array}$ & $\begin{array}{l}\text { - Pressure instrumentation } \\
\text { (PIT-710-204) } \\
\text { - Check valve ECRT-CV-202 } \\
\text { - Piping and hoses designed in } \\
\text { accordance with B31.3, } \\
\text { "Process Piping." } \\
\text { - Pressure safety valve } \\
\text { ECRT-PSV-202 } \\
\text { - Valve position indicators } \\
\text { - Secondary confinement with } \\
\text { leak detection } \\
\text { - Leak detection interlocked to } \\
\text { shut off decant pump } \\
\text { ECRT-P-201 } \\
\text { Decant Pump Box } \\
\text { HEPA-filtered active } \\
\text { ventilation }\end{array}$ & $\begin{array}{l}\text { - Procedures } \\
\text { - Training } \\
\text { - Conduct of operations } \\
\text { verifies proper system } \\
\text { configuration } \\
\text { - Modified KW Basin Annex } \\
\text { is unmanned during decant } \\
\text { operations } \\
\text { - Leak detection alarm } \\
\text { response }\end{array}$ & \\
\hline 9.a-13.b & Structural Integrity & \begin{tabular}{|l} 
Leak/rupture \\
(outside \\
Decant Pump \\
Box)
\end{tabular} & $\begin{array}{l}\text { - Overpressurization } \\
\text { - Hose disconnects }\end{array}$ & $\begin{array}{l}\text { Operational Upset: } \\
\text { If the leak is small, then flocculant will spill } \\
\text { into the Modified KW Basin Annex } \\
\text { Uncontrolled Release: } \\
\text { If the leak is large, then the pressure } \\
\text { could drop to the point that recirculated } \\
\text { supernate would be pumped into the } \\
\text { flocculant addition system (due to the } 80 \\
\text { psi generated by decant pump ECRT- } \\
\text { P-201) which would result in a spray or } \\
\text { splash and splatter/pool release. }\end{array}$ & $\begin{array}{l}\text { - Pressure instrumentation } \\
\text { (PIT-710-204) } \\
\text { - Piping and hoses designed in } \\
\text { accordance with B31.3, } \\
\text { "Process Piping." } \\
\text { - Valve position indicators } \\
\text { - Check valve ECRT-CV-202 } \\
\text { - Modified KW Basin Annex } \\
\text { confinement ventilation } \\
\text { - Continuous air monitors }\end{array}$ & $\begin{array}{l}\text { - Procedures } \\
\text { - Training } \\
\text { - Conduct of operations } \\
\text { verifies proper system } \\
\text { configuration } \\
\text { - Modified KW Basin Annex } \\
\text { is unmanned during decant } \\
\text { operations }\end{array}$ & \\
\hline $9 . a-14$ & Time Procedure & Too short & $\begin{array}{l}\text { - Operator error } \\
\text { - Equipment failure }\end{array}$ & $\begin{array}{l}\text { Operational Upset: } \\
\text { If the flocculant is added for too short a } \\
\text { period of time, then an insufficient amount } \\
\text { of flocculant will be added. This could } \\
\text { result in longer settling times prior to } \\
\text { STSC decant. }\end{array}$ & $\begin{array}{l}\text { \% solids instrumentation } \\
\text { (AE-720-201) }\end{array}$ & $\begin{array}{l}\text { - Procedures } \\
\text { - Training }\end{array}$ & \\
\hline
\end{tabular}


Table C-26. HAZOP Results, Node 9.a, Annex Flocculant Addition System - Flocculant Tank to In-Line Mixer

\begin{tabular}{|c|c|c|c|c|c|c|c|}
\hline \multirow{2}{*}{ Item } & \multirow{2}{*}{$\begin{array}{l}\text { Process } \\
\text { Parameter }\end{array}$} & \multirow{2}{*}{ Deviation } & \multirow{2}{*}{ Cause } & \multirow{2}{*}{ Consequences } & \multicolumn{2}{|c|}{ Candidate Controls } & \multirow{2}{*}{ Remarks } \\
\hline & & & & & Engineered & Administrative & \\
\hline 9.a-15 & Time Procedure & Too long & $\begin{array}{l}\text { - Operator error } \\
\text { - Equipment failure }\end{array}$ & $\begin{array}{l}\text { Operational Upset: } \\
\text { If flocculant is added for too long a period } \\
\text { of time, then too much flocculant will be } \\
\text { added. This could subsequently result in } \\
\text { plugging of the sand filters. }\end{array}$ & $\begin{array}{l}\text { \% solids instrumentation } \\
\text { (AE-720-201) }\end{array}$ & $\begin{array}{l}\text { - Procedures } \\
\text { - Training }\end{array}$ & $\begin{array}{l}\text { The volume of flocculant tank ECRT-TK-202 } \\
\text { is too small to result in overfilling the STSC. }\end{array}$ \\
\hline 9.a-16 & Time Procedure & Skip action & Operator error & $\begin{array}{l}\text { Operational Upset: } \\
\text { If the action is skipped, then flocculant will } \\
\text { not be added to the recirculated decant. } \\
\text { This could result in longer settling times } \\
\text { prior to STSC decant. }\end{array}$ & $\begin{array}{l}\text { \% solids instrumentation } \\
\text { (AE-720-201) }\end{array}$ & $\begin{array}{l}\text { - Procedures } \\
\text { - Training }\end{array}$ & \\
\hline 9.a-17 & Time Procedure & Wrong action & N/A & N/A & N/A & N/A & $\begin{array}{l}\text { There is no wrong action associated with this } \\
\text { node. }\end{array}$ \\
\hline
\end{tabular}




\begin{tabular}{|c|c|c|}
\hline Process Parameter & Design Intent & Remarks \\
\hline Flow & $20 \mathrm{gpm}$ & $\begin{array}{l}\text { Motive force is decant pump ECRT-P-201. Decant pump ECRT-P-201 is an air-operated, double-diaphragm (AODD) } \\
\text { pump. }\end{array}$ \\
\hline Pressure & $80 \mathrm{psig}$ & $\begin{array}{l}\text { Pressure is controlled by the air pressure supplied to decant pump ECRT-P-201. The instrument air system produces } \\
212 \mathrm{scfm} \text { of dry air at } 100 \mathrm{psig} \text {. Pressure control valves are used to regulate the pressure to the pump. }\end{array}$ \\
\hline \multirow[t]{2}{*}{$\begin{array}{l}\text { Concentration } \\
\text { (solids in recirculated } \\
\text { decant) }\end{array}$} & $\begin{array}{l}\text { Prior to flocculant addition: } \\
\text { KE sludge }=11.9 \mathrm{~g} / \mathrm{L} \\
\mathrm{KW} \text { sludge }=16.8 \mathrm{~g} / \mathrm{L} \\
\text { Settler tank sludge }=39.3 \mathrm{~g} / \mathrm{L}\end{array}$ & The concentrations shown are maximums as documented in HNF-40151 for STSC decant. \\
\hline & After flocculant addition $<1,000 \mathrm{mg} / \mathrm{L}$ & \\
\hline Composition & STSC supernate and Clarifloc $\mathrm{N}-3300 \mathrm{P}$ & None \\
\hline Level & $\begin{array}{l}\text { STSC level at start/finish of decant recycle: } \\
\text { KE/KW sludge } \sim 925 \text { gal } \\
\text { Settler tank sludge } \sim 765 \text { gal }\end{array}$ & $\begin{array}{l}\text { Flocculant addition increases the STSC volume by approximately } 2 \text { gallons. The volume of flocculant tank ECRT-TK- } \\
202 \text { is too small to overfill the STSC. }\end{array}$ \\
\hline Structural Integrity & $\begin{array}{l}\text { Maintain integrity under normal operating } \\
\text { conditions }\end{array}$ & None \\
\hline Temperature & Not applicable & $\begin{array}{l}\text { Temperature is not a process parameter that is monitored or controlled. When initially transferred to the STSC, the } \\
\text { slurry temperature will be approximately } 10-15^{\circ} \mathrm{C}(\mathrm{i} . \mathrm{e} ., \\
\text { tempe same as basin water). Once transferred, the slurry } \\
\text { and (2) the quantity sly increase based on two factors: (1) the ambient temperature in the Modified KW Basin Annex, } \\
\text { design to maintain a minimum temperature of } 65^{\circ} \mathrm{F}\left(18^{\circ} \mathrm{C}\right) \text { given an metsal oxidation. The annex HVAC system is } \\
\text { temperature of } 80^{\circ} \mathrm{F}\left(27^{\circ} \mathrm{C}\right) \text { given an outside temperature of } 105^{\circ} \mathrm{F} \text {. }\end{array}$ \\
\hline Time Procedure & $\begin{array}{l}\text { The decant recycle continues until the turbidity } \\
\text { decreases to } 210 \text { NTUs or until further flocculant } \\
\text { addition does not result in a decrease in turbidity }\end{array}$ & None \\
\hline
\end{tabular}


Table C-28. HAZOP Results, Node 9.b, Annex Flocculant Addition System - Decant Recirculation

\begin{tabular}{|c|c|c|c|c|c|c|c|}
\hline \multirow{2}{*}{ Item } & \multirow{2}{*}{$\begin{array}{l}\text { Process } \\
\text { Parameter }\end{array}$} & \multirow{2}{*}{ Deviation } & \multirow{2}{*}{ Cause } & \multirow{2}{*}{ Consequences } & \multicolumn{2}{|c|}{ Candidate Controls } & \multirow{2}{*}{ Remarks } \\
\hline & & & & & Engineered & Administrative & \\
\hline $9 . b-1$ & Flow & No & $\begin{array}{l}\text { - Decant pump } \\
\text { ECRT-P-201 not } \\
\text { operating } \\
\text { - A normally-opened valve } \\
\text { is closed }\end{array}$ & $\begin{array}{l}\text { Operational Upset: } \\
\text { If there is no flow, then the STSC } \\
\text { supernate will not be recirculated. } \\
\text { If there is no flow because a } \\
\text { normally-opened valve is closed, then } \\
\text { decant pump ECRT-P-201 will deadhead } \\
\text { resulting in a high pressure. See item 9-7 } \\
\text { below. }\end{array}$ & $\begin{array}{l}\text { - Decant line pressure } \\
\text { instrumentation (PT-720-201 } \\
\text { and -202) } \\
\text { - Decant line flow } \\
\text { instrumentation (FE-720-201) } \\
\text { - Manual valve position } \\
\text { indicators }\end{array}$ & $\begin{array}{l}\text { - Procedures } \\
\text { - Training }\end{array}$ & \\
\hline 9.b-2 & Flow & Low & $\begin{array}{l}\text { - Low air pressure to } \\
\text { decant pump } \\
\text { ECRT-P-201 } \\
\text { - A normally-opened valve } \\
\text { is partially closed }\end{array}$ & $\begin{array}{l}\text { Operational Upset: } \\
\text { If the flow rate is low, then it will take } \\
\text { longer to recirculate the STSC supernate. }\end{array}$ & $\begin{array}{l}\text { - Decant line pressure } \\
\text { instrumentation (PT-720-201 } \\
\text { and -202) } \\
\text { - Decant line flow } \\
\text { instrumentation (FE-720-201) } \\
\text { - Manual valve position } \\
\text { indicators }\end{array}$ & $\begin{array}{l}\text { - Procedures } \\
\text { - Training }\end{array}$ & v \\
\hline 9.b-3 & Flow & High & $\begin{array}{l}\text { High air pressure to } \\
\text { decant pump ECRT-P-201 }\end{array}$ & $\begin{array}{l}\text { Operational Upset: } \\
\text { If the flow rate is high, then the STSC } \\
\text { supernate will be recirculated faster. }\end{array}$ & $\begin{array}{l}\text { - Pressure control valve } \\
\text { ECRT-PCV-760 } \\
\text { - Pressure control valve } \\
\text { ECRT-PCV-765 } \\
\text { - Decant line pressure } \\
\text { instrumentation (PT-720-201 } \\
\text { and -202) } \\
\text { - Decant line flow } \\
\text { instrumentation (FE-720-201) }\end{array}$ & $\begin{array}{l}\text { - Procedures } \\
\text { - Training }\end{array}$ & \\
\hline 9.b-4 & Flow & Reverse & $\begin{array}{l}\text { Decant pump } \\
\text { ECRT-P-201 runs in } \\
\text { reverse }\end{array}$ & $\begin{array}{l}\text { Operational Upset: } \\
\text { If the pump operated in reverse, then the } \\
\text { recirculation would occur in the reverse } \\
\text { direction. }\end{array}$ & $\begin{array}{l}\text { - Decant line pressure } \\
\text { instrumentation (PT-720-201 } \\
\text { and -202) } \\
\text { - Decant line flow } \\
\text { instrumentation (FE-720-201) }\end{array}$ & $\begin{array}{l}\text { - Procedures } \\
\text { - Training } \\
\text { - Pre-operational testing }\end{array}$ & $\begin{array}{l}\text { The only way to get reverse flow during } \\
\text { decant recirculation would be install decant } \\
\text { pump ECRT-P-201 backwards. Such an } \\
\text { error would be discovered in pre-operational } \\
\text { testing. }\end{array}$ \\
\hline
\end{tabular}


Table C-28. HAZOP Results, Node 9.b, Annex Flocculant Addition System - Decant Recirculation

\begin{tabular}{|c|c|c|c|c|c|c|c|}
\hline \multirow{2}{*}{ Item } & \multirow{2}{*}{$\begin{array}{l}\text { Process } \\
\text { Parameter }\end{array}$} & \multirow{2}{*}{ Deviation } & \multirow{2}{*}{ Cause } & \multirow{2}{*}{ Consequences } & \multicolumn{2}{|c|}{ Candidate Controls } & \multirow{2}{*}{ Remarks } \\
\hline & & & & & Engineered & Administrative & \\
\hline $9 . b-5 . a$ & Flow & $\begin{array}{l}\text { Misdirected } \\
\text { (into Decant } \\
\text { Pump Box) }\end{array}$ & $\begin{array}{l}\text { - Valving error such that } \\
\text { supernate enters box via } \\
\text { IXM water spray nozzles } \\
\text { - Valving error such that } \\
\text { supernate enters box via } \\
\text { siphon break }\end{array}$ & $\begin{array}{l}\text { Uncontrolled Release: } \\
\text { If supernate is misdirected into the Decant } \\
\text { Pump Box, then a splash and } \\
\text { splatter/pool release will occur. } \\
\text { Hydrogen Deflagration: } \\
\text { If supernate is misdirected into the Decant } \\
\text { Pump Box, then hydrogen generated by } \\
\text { the supernate could accumulate in the } \\
\text { box resulting in a deflagration. }\end{array}$ & $\begin{array}{l}\text { - Valve position indicators } \\
\text { - Secondary confinement with } \\
\text { leak detection } \\
\text { - Leak detection interlocked to } \\
\text { shut off Decant pump } \\
\text { ECRT-P-201 } \\
\text { - Decant Pump Box } \\
\text { HEPA-filtered active } \\
\text { ventilation }\end{array}$ & $\begin{array}{l}\text { - Procedures } \\
\text { - Training } \\
\text { - Conduct of operations } \\
\text { verifies proper system } \\
\text { configuration } \\
\text { - Modified KW Basin Annex is } \\
\text { unmanned during decant } \\
\text { operations } \\
\text { - Leak detection alarm } \\
\text { response }\end{array}$ & \\
\hline 9.b-5.b & Flow & $\begin{array}{l}\text { Misdirected } \\
\text { (into Transfer } \\
\text { Line Service Box) }\end{array}$ & $\begin{array}{l}\text { - Valving error such that } \\
\text { supernate enters box via } \\
\text { IXM water spray nozzles } \\
\text { - Valving error such that } \\
\text { supernate enters box via } \\
\text { siphon break }\end{array}$ & $\begin{array}{l}\text { Uncontrolled Release: } \\
\text { If supernate is misdirected into the } \\
\text { Transfer Line Service Box, then a splash } \\
\text { and splatter/pool release will occur. } \\
\text { Hydrogen Deflagration: } \\
\text { If supernate is misdirected into the } \\
\text { Transfer Line Service Box, then hydrogen } \\
\text { generated by the supernate could } \\
\text { accumulate in the box resulting in a } \\
\text { deflagration. }\end{array}$ & $\begin{array}{l}\text { - Valve position indicators } \\
\text { - Secondary confinement with } \\
\text { leak detection } \\
\text { - Leak detection interlocked to } \\
\text { shut off Decant pump } \\
\text { ECRT-P-201 } \\
\text { - Transfer Line Service Box } \\
\text { HEPA-filtered active } \\
\text { ventilation }\end{array}$ & $\begin{array}{l}\text { - Procedures } \\
\text { - Training } \\
\text { - Conduct of operations } \\
\text { verifies proper system } \\
\text { configuration } \\
\text { - Modified KW Basin Annex is } \\
\text { unmanned during decant } \\
\text { operations } \\
\text { - Leak detection alarm } \\
\text { response }\end{array}$ & \\
\hline 9.b-5.c & Flow & $\begin{array}{l}\text { Misdirected } \\
\text { (to sand filters) }\end{array}$ & $\begin{array}{l}\text { Valve ECRT-V-201 } \\
\text { misaligned }\end{array}$ & $\begin{array}{l}\text { Uncontrolled Release: } \\
\text { If supernate is misdirected into the sand } \\
\text { filter, then decant pump ECRT-P-201 will } \\
\text { deadhead resulting in a high pressure. } \\
\text { See Item 9-7 below. }\end{array}$ & Valve position indicators & $\begin{array}{l}\text { - Procedures } \\
\text { - Training } \\
\text { - Conduct of operations } \\
\text { verifies proper system } \\
\text { configuration }\end{array}$ & \\
\hline 9.b-5.d & Flow & $\begin{array}{l}\text { Misdirected } \\
\text { (into Decant } \\
\text { Pump Box IXM } \\
\text { water supply) }\end{array}$ & Valving error & $\begin{array}{l}\text { Uncontrolled Release: } \\
\text { If supernate is misdirected into the Decant } \\
\text { Pump Box IXM water supply, then a } \\
\text { splash and splatter/pool release could } \\
\text { occur. }\end{array}$ & $\begin{array}{l}\text { - Valve position indicators } \\
\text { - Check valve ECRT-CV-201 } \\
\text { - Modified KW Basin Annex } \\
\text { confinement ventilation } \\
\text { - Continuous air monitors }\end{array}$ & $\begin{array}{l}\text { - Procedures } \\
\text { - Training } \\
\text { - Conduct of operations } \\
\text { verifies proper system } \\
\text { configuration } \\
\text { - Modified KW Basin Annex is } \\
\text { unmanned during decant } \\
\text { operations }\end{array}$ & \\
\hline
\end{tabular}


Table C-28. HAZOP Results, Node 9.b, Annex Flocculant Addition System - Decant Recirculation

\begin{tabular}{|c|c|c|c|c|c|c|c|}
\hline \multirow{2}{*}{ Item } & \multirow{2}{*}{$\begin{array}{l}\text { Process } \\
\text { Parameter }\end{array}$} & \multirow{2}{*}{ Deviation } & \multirow{2}{*}{ Cause } & \multirow{2}{*}{ Consequences } & \multicolumn{2}{|c|}{ Candidate Controls } & \multirow{2}{*}{ Remarks } \\
\hline & & & & & Engineered & Administrative & \\
\hline $9 . b-5 . e$ & Flow & $\begin{array}{l}\text { Misdirected } \\
\text { (into Transfer } \\
\text { Line Service Box } \\
\text { IXM water } \\
\text { supply) }\end{array}$ & Valving error & $\begin{array}{l}\text { Uncontrolled Release: } \\
\text { If supernate is misdirected into the } \\
\text { Transfer Line Service Box IXM water } \\
\text { supply, then a splash and splatter/pool } \\
\text { release could occur. }\end{array}$ & $\begin{array}{l}\text { - Valve position indicators } \\
\text { - Check valve ECRT-CV-301 } \\
\text { and -302 } \\
\text { - Modified KW Basin Annex } \\
\text { confinement ventilation } \\
\text { - Continuous air monitors }\end{array}$ & $\begin{array}{l}\text { - Procedures } \\
\text { - Training Conduct of } \\
\text { operations verifies proper } \\
\text { system configuration } \\
\text { - Modified KW Basin Annex is } \\
\text { unmanned during decant } \\
\text { operations }\end{array}$ & \\
\hline 9.b-5.f & Flow & $\begin{array}{l}\text { Misdirected } \\
\text { (into flocculant } \\
\text { addition supply) }\end{array}$ & $\begin{array}{l}\text { - Valving error } \\
\text { - Low pressure in } \\
\text { flocculant addition line } \\
\text { - High pressure in the } \\
\text { decant/flocculant } \\
\text { recirculation line }\end{array}$ & $\begin{array}{l}\text { Uncontrolled Release: } \\
\text { If supernate is misdirected into the } \\
\text { flocculant addition supply, then a splash } \\
\text { and splatter/pool release could occur. }\end{array}$ & $\begin{array}{l}\text { - Valve position indicators } \\
\text { - Check valve ECRT-CV-202 } \\
\text { - Modified KW Basin Annex } \\
\text { confinement ventilation } \\
\text { - Continuous air monitors }\end{array}$ & $\begin{array}{l}\text { - Procedures } \\
\text { - Training } \\
\text { - Conduct of operations } \\
\text { verifies proper system } \\
\text { configuration } \\
\text { - Modified KW Basin Annex is } \\
\text { unmanned during decant } \\
\text { operations }\end{array}$ & \\
\hline $9 . b-6$ & Pressure & Low & $\begin{array}{l}\text { Low air pressure to decant } \\
\text { pump ECRT-P-201 }\end{array}$ & $\begin{array}{l}\text { Operational Upset: } \\
\text { If the pressure is low, then the flow rate } \\
\text { will be low and it will take longer to } \\
\text { recirculate the STSC supernate. }\end{array}$ & $\begin{array}{l}\text { Decant line pressure } \\
\text { instrumentation (PT-720-201 } \\
\text { and -202) } \\
\text { Decant line flow } \\
\text { instrumentation (FE-720-201) }\end{array}$ & $\begin{array}{l}\text { - Procedures } \\
\text { - Training }\end{array}$ & \\
\hline
\end{tabular}


Table C-28. HAZOP Results, Node 9.b, Annex Flocculant Addition System - Decant Recirculation

\begin{tabular}{|c|c|c|c|c|c|c|c|}
\hline \multicolumn{8}{|c|}{ Table C-28. HAZOP Results, Node 9.b, Annex Flocculant Addition System - Decant Recirculation } \\
\hline \multirow{2}{*}{ Item } & \multirow{2}{*}{$\begin{array}{l}\text { Process } \\
\text { Parameter }\end{array}$} & \multirow{2}{*}{ Deviation } & \multirow{2}{*}{ Cause } & \multirow{2}{*}{ Consequences } & \multicolumn{2}{|c|}{ Candidate Controls } & \multirow{2}{*}{ Remarks } \\
\hline & & & & & Engineered & Administrative & \\
\hline 9.b-7 & Pressure & High & $\begin{array}{l}\text { - High air pressure to } \\
\text { decant pump } \\
\text { ECRT-P-201 } \\
\text { - A normally-opened valve } \\
\text { is closed }\end{array}$ & $\begin{array}{l}\text { Uncontrolled Release: } \\
\text { If the pressure is high, then the } \\
\text { decantflocculant recirculation line or } \\
\text { flocculant addition line could fail resulting } \\
\text { in an airborne spray release or splash and } \\
\text { splatter/pool release. } \\
\text { Hydrogen Deflagration: } \\
\text { If the pressure is high, then the } \\
\text { decantflocculant recirculation line could } \\
\text { fail. Hydrogen generated by the } \\
\text { supernate could accumulate in the Decant } \\
\text { Pump Box or Transfer Line Service Box } \\
\text { resulting in a deflagration. }\end{array}$ & $\begin{array}{l}\text { - Piping designed in } \\
\text { accordance with B31.3, } \\
\text { "Process Piping" } \\
\text { - Valve position indicators } \\
\text { - Pressure control valve } \\
\text { ECRT-PCV-760 and -765 } \\
\text { - Decant line pressure } \\
\text { instrumentation (PT-720-201 } \\
\text { and -202) } \\
\text { - Secondary containment with } \\
\text { leak detection } \\
\text { - Leak detection interlocked to } \\
\text { shut off Decant pump } \\
\text { ECRT-P-201 } \\
\text { - Decant Pump Box } \\
\text { HEPA-filtered active } \\
\text { ventilation } \\
\text { - Transfer Line Service Box } \\
\text { HEPA-filtered active } \\
\text { ventilation }\end{array}$ & $\begin{array}{l}\text { - Procedures } \\
\text { - Training } \\
\text { - Conduct of operations } \\
\text { verifies proper system } \\
\text { configuration } \\
\text { - Modified KW Basin Annex is } \\
\text { unmanned during decant } \\
\text { operations } \\
\text { - Leak detection alarm } \\
\text { response }\end{array}$ & \\
\hline 9.b-8 & $\begin{array}{l}\text { Concentration } \\
\text { (solids in } \\
\text { recirculating } \\
\text { supernate) }\end{array}$ & Low & N/A & N/A & N/A & N/A & $\begin{array}{l}\text { A low turbidity in the decanted supernate is } \\
\text { desirable. }\end{array}$ \\
\hline 9.b-9 & $\begin{array}{l}\text { Concentration } \\
\text { (solids in } \\
\text { recirculated } \\
\text { supernate) }\end{array}$ & High & $\begin{array}{l}\text { - Settling time too short } \\
\text { - No flocculant addition }\end{array}$ & $\begin{array}{l}\text { Operational Upset: } \\
\text { If the turbidity is high, then the supernate } \\
\text { cannot be decanted to the sand filter. } \\
\text { See Table C-14, Item 3-9.a for the } \\
\text { consequences of transferring a high } \\
\text { concentration supernate to the sand } \\
\text { filters. }\end{array}$ & $\begin{array}{l}\text { Turbidity instrumentation } \\
\text { (AE-720-201) }\end{array}$ & $\begin{array}{l}\text { - Procedures } \\
\text { - Training }\end{array}$ & \\
\hline
\end{tabular}


Table C-28. HAZOP Results, Node 9.b, Annex Flocculant Addition System - Decant Recirculation

\begin{tabular}{|c|c|c|c|c|c|c|c|}
\hline \multirow{2}{*}{ Item } & \multirow{2}{*}{$\begin{array}{l}\text { Process } \\
\text { Parameter }\end{array}$} & \multirow{2}{*}{ Deviation } & \multirow{2}{*}{ Cause } & \multirow{2}{*}{ Consequences } & \multicolumn{2}{|c|}{ Candidate Controls } & \multirow{2}{*}{ Remarks } \\
\hline & & & & & Engineered & Administrative & \\
\hline 9.b-10 & Composition & $\begin{array}{l}\text { Other } \\
\text { (degraded } \\
\text { flocculant, } \\
\text { different } \\
\text { flocculant) }\end{array}$ & Operator error & See Table C-26, Items 8.a-10.a and -10.b & $\begin{array}{l}\text { See Table C-26, Items 8.a-10.a } \\
\text { and -10.b }\end{array}$ & $\begin{array}{l}\text { See Table C-26, Items } \\
\text { 8.a-10.a and -10.b }\end{array}$ & \\
\hline 9.b-11 & \begin{tabular}{|l} 
Level \\
(STSC)
\end{tabular} & Low & $\begin{array}{l}\text { STSC not filled to proper } \\
\text { level (see Table C-10, } \\
\text { Items 2.c-9.a and -b) }\end{array}$ & None & $\begin{array}{l}\text { Level switches } \\
\text { LS/LSH/LSHH-740-401 }\end{array}$ & $\begin{array}{l}\text { - Procedures } \\
\text { - Training }\end{array}$ & \\
\hline $9 . b-12$ & $\begin{array}{l}\text { Level } \\
\text { (STSC) }\end{array}$ & High & $\begin{array}{l}\text { STSC not filled to proper } \\
\text { level (see Table C-10, } \\
\text { Items 2.c-10.a and -b) }\end{array}$ & None & $\begin{array}{l}\text { Level switches } \\
\text { LS/LSH/LSHH-740-401 }\end{array}$ & $\begin{array}{l}\text { - Procedures } \\
\text { - Training }\end{array}$ & \\
\hline 9.b-13.a & \begin{tabular}{|l} 
Structural \\
Integrity
\end{tabular} & Leak/rupture & $\begin{array}{l}\text { Decant pump } \\
\text { ECRT-P-201 diaphragm } \\
\text { failure }\end{array}$ & $\begin{array}{l}\text { Uncontrolled Release: } \\
\text { If the decant pump diaphragm failed, then } \\
\text { supernate could enter the pump exhaust } \\
\text { resulting in a spray or splash and } \\
\text { splatter/pool release. }\end{array}$ & $\begin{array}{l}\text { - Decant line pressure } \\
\text { instrumentation (PT-720-201 } \\
\text { and-202) } \\
\text { - Decant line flow } \\
\text { instrumentation (FE-720-201) } \\
\text { - HEPA filtration of decant } \\
\text { pump exhaust }\end{array}$ & $\begin{array}{l}\text { - Procedures } \\
\text { - Training } \\
\text { - Modified KW Basin Annex is } \\
\text { unmanned during decant } \\
\text { operations }\end{array}$ & \\
\hline
\end{tabular}


Table C-28. HAZOP Results, Node 9.b, Annex Flocculant Addition System - Decant Recirculation

\begin{tabular}{|c|c|c|c|c|c|c|c|}
\hline \multirow{2}{*}{ Item } & \multirow{2}{*}{$\begin{array}{l}\text { Process } \\
\text { Parameter }\end{array}$} & \multirow{2}{*}{ Deviation } & \multirow{2}{*}{ Cause } & \multirow{2}{*}{ Consequences } & \multicolumn{2}{|c|}{ Candidate Controls } & \multirow{2}{*}{ Remarks } \\
\hline & & & & & Engineered & Administrative & \\
\hline 9.b-13.b & \begin{tabular}{|l} 
Structural \\
Integrity
\end{tabular} & $\begin{array}{l}\text { Leak/rupture } \\
\text { (decant/flocculant } \\
\text { recirculation line, } \\
\text { see remarks) }\end{array}$ & $\begin{array}{l}\text { - High pressure (see } \\
\text { Item 9.b-7 above) } \\
\text { - Manufacturing flaw } \\
\text { - Hose connection } \\
\text { decouples }\end{array}$ & $\begin{array}{l}\text { Uncontrolled Release: } \\
\text { If the decantflocculant recirculation line } \\
\text { fails, then a spray or splash and } \\
\text { splatter/pool release of STSC supernate } \\
\text { will occur. } \\
\text { Hydrogen Deflagration: } \\
\text { If the leak is large, and recirculated } \\
\text { supernate is pumped into the Decant } \\
\text { Pump Box or Transfer Line Service Box, } \\
\text { then hydrogen generated by the } \\
\text { supernate could accumulate in the box } \\
\text { resulting in a deflagration. }\end{array}$ & $\begin{array}{l}\text { - Piping designed in } \\
\text { accordance with B31.3, } \\
\text { "Process Piping" } \\
\text { - Decant line pressure } \\
\text { instrumentation (PT-720-201 } \\
\text { and -202) } \\
\text { - Decant line flow } \\
\text { instrumentation (FE-720-201) } \\
\text { - Secondary containment with } \\
\text { leak detection } \\
\text { - Leak detection interlocked to } \\
\text { shut off Decant pump } \\
\text { ECRT-P-201 } \\
\text { - Decant Pump Box } \\
\text { HEPA-filtered confinement } \\
\text { - Transfer Line Service Box } \\
\text { HEPA-filtered confinement } \\
\text { ventilation }\end{array}$ & $\begin{array}{l}\text { - Procedures } \\
\text { - Training } \\
\text { - Modified KW Basin Annex is } \\
\text { unmanned during decant } \\
\text { operations } \\
\text { - Leak detection alarm } \\
\text { response }\end{array}$ & $\begin{array}{l}\text { The decant/flocculant recirculation line is } \\
\text { comprised of a combination of hose-in-hose } \\
\text { transfer lines and hard piping. The hard } \\
\text { piping is located within the Decant Pump } \\
\text { Box and the Transfer Line Service Box. }\end{array}$ \\
\hline $9 . b-14$ & Time Procedure & Too soon & $\begin{array}{l}\text { - Operator error } \\
\text { - Instrumentation failure }\end{array}$ & $\begin{array}{l}\text { Operational Upset: } \\
\text { If the recirculation occurs for too short a } \\
\text { time, then an insufficient amount of } \\
\text { flocculant would be added. An additional } \\
\text { decant/flocculant recirculation step would } \\
\text { be required. }\end{array}$ & $\begin{array}{l}\text { Turbidity instrumentation } \\
\text { (AE-720-201) }\end{array}$ & $\begin{array}{l}\text { - Procedures } \\
\text { - Training }\end{array}$ & \\
\hline $9 . b-15$ & Time Procedure & Too late & $\begin{array}{l}\text { - Operator error } \\
\text { - Instrumentation failure }\end{array}$ & $\begin{array}{l}\text { Operational Upset: } \\
\text { If the recirculation occurs for too long a } \\
\text { time, then too much flocculant would be } \\
\text { added. This could subsequently result in } \\
\text { plugging of the sand filters. }\end{array}$ & $\begin{array}{l}\text { Turbidity instrumentation } \\
\text { (AE-720-201) }\end{array}$ & $\begin{array}{l}\text { - Procedures } \\
\text { - Training }\end{array}$ & \\
\hline
\end{tabular}


Table C-28. HAZOP Results, Node 9.b, Annex Flocculant Addition System - Decant Recirculation

\begin{tabular}{|c|c|c|c|c|c|c|c|}
\hline \multirow{2}{*}{ Item } & \multirow{2}{*}{$\begin{array}{l}\text { Process } \\
\text { Parameter }\end{array}$} & \multirow{2}{*}{ Deviation } & \multirow{2}{*}{ Cause } & \multirow{2}{*}{ Consequences } & \multicolumn{2}{|c|}{ Candidate Controls } & \multirow{2}{*}{ Remarks } \\
\hline & & & & & Engineered & Administrative & \\
\hline $9 . b-16$ & Time Procedure & Skip action & Operator error & $\begin{array}{l}\text { Uncontrolled Release: } \\
\text { If the decant/flocculant recirculation is not } \\
\text { performed, then flocculant will not be } \\
\text { added such that the decant transferred to } \\
\text { the sand filters will have a high solids } \\
\text { concentration. See Table C-14, } \\
\text { Item 3.9.a. }\end{array}$ & See Table C-14, Item 3.9a. & $\begin{array}{l}\text { - Procedures } \\
\text { - Training }\end{array}$ & \\
\hline $9 . b-17$ & Time Procedure & $\begin{array}{l}\text { Wrong action } \\
\text { (decant instead } \\
\text { of recirculate) }\end{array}$ & Operator error & $\begin{array}{l}\text { Uncontrolled Release: } \\
\text { If the supernate is decanted instead of } \\
\text { recirculated, then decant pump } \\
\text { ECRT-P-201 will deadhead resulting in a } \\
\text { high pressure. See Item 9-7 above. }\end{array}$ & See Item $9-7$ above. & $\begin{array}{l}\text { - Procedures } \\
\text { - Training }\end{array}$ & \\
\hline
\end{tabular}


Table C-29. Normal Operating Conditions, Node 10, Transfer Line Automatic Flush

\begin{tabular}{|c|c|c|}
\hline Process Parameter & Design Intent & Remarks \\
\hline Flow & $70 \mathrm{gpm}$ & $\begin{array}{l}\text { As calculated in PRC-STP-00021, Preliminary Hydraulic Analysis for Direct Loading of S/udge Transport and } \\
\text { Storage Containers, a flow rate of } 70 \mathrm{gpm} \text { at } 96 \mathrm{psi} \text { is required to provide enough motive force to flush the } \\
\text { transfer line and deter the settling of solids. }\end{array}$ \\
\hline Pressure & $\begin{array}{l}\text { Flush tank initial charge }=140 \mathrm{psi} \\
\text { Transfer line pressure } 96 \mathrm{psi}\end{array}$ & $\begin{array}{l}\text { As calculated inPRC-STP-CN-P-00196, S/udge Treatment Project Engineered Container Retrieval and Transfer } \\
\text { System Preliminary Equipment Sizing Calculation - Flush Tank, } 29 \text { gallons of water in the flush tank at an initial } \\
\text { charge pressure of } 135 \text { psi will discharge } 20 \text { gallons (one line volume) at a minimum flow rate of } 70 \mathrm{gpm} \text { at a } \\
\text { minimum pressure of } 96 \mathrm{psi} \text {. }\end{array}$ \\
\hline Concentration & Not applicable & $\begin{array}{l}\text { The autoflush is performed using IXM water in flush tank ECRT-TK-101. The Skimmer Water Cleanup System } \\
\text { takes basin water and pumps it first through a sand filter (for water clarity) and then through an IXM (to remove } \\
\text { ionic species). The IXM water composition/concentration is not a critical attribute of the autoflush. }\end{array}$ \\
\hline Composition & Not applicable & $\begin{array}{l}\text { There are no other process fluids at the KW Basin that could be inadvertently connected or directed to the } \\
\text { autoflush skid. }\end{array}$ \\
\hline Level & $\begin{array}{l}\text { Tank working volume }=50 \text { gallons } \\
\text { Flush volume }=29 \text { gallons }\end{array}$ & $\begin{array}{l}\text { The tank level is not monitored. Fifty gallons of IXM water are added to the tank as indicated by flow totalizer } \\
\text { FQ1-710-101. } \\
\text { Per PRC-STP-CN-P-00196, the line is to be flushed by } 1.5 \text { line volumes of water, which is equal to } \sim 29 \text { gallons. } \\
\text { As stated above, } 29 \text { gallons of water in the flush tank at an initial pressure of } 135 \mathrm{psi} \text { will discharge } 20 \text { gallons } \\
\text { (one line volume) at a minimum flow rate of } 70 \mathrm{gpm} \text { at a minimum pressure of } 96 \mathrm{psi} \text {. }\end{array}$ \\
\hline Structural Integrity & Maintain integrity under normal operating conditions & The autoflush system consists of a tank and a combination of piping and hoses. \\
\hline Temperature & Not applicable & $\begin{array}{l}\text { Temperature is not a process parameter that is monitored or controlled. The flush tank is located on the deck } \\
\text { on the basin deck. The temperature of water in the flush tank will be approximately the same as the air } \\
\text { temperature in the basin. }\end{array}$ \\
\hline Time Procedure & Upon activation of interlock $\mathrm{I}-1$ or $\mathrm{I}-3$ & $\begin{array}{l}\text { Upon activation of interlock I-1 or I-3, valves ECRT-AOV-102 and ECRT-AOV-103 open. The flush continues } \\
\text { until the pressure in flush tank ECRT-TK-101 normalizes to the transfer line pressure. }\end{array}$ \\
\hline
\end{tabular}




\begin{tabular}{|c|c|c|c|c|c|c|c|}
\hline \multicolumn{8}{|c|}{ Table C-30. HAZOP Results, Node 10, Transfer Line Automatic Flush } \\
\hline \multirow{2}{*}{ Item } & \multirow{2}{*}{$\begin{array}{l}\text { Process } \\
\text { Parameter }\end{array}$} & \multirow{2}{*}{ Deviation } & \multirow{2}{*}{ Cause } & \multirow{2}{*}{ Consequences } & \multicolumn{2}{|c|}{ Candidate Controls } & \multirow{2}{*}{ Remarks } \\
\hline & & & & & Engineered & Administrative & \\
\hline $10-1$ & Flow & No & $\begin{array}{l}\text { - Flush tank } \\
\text { ECRT-TK-101 not } \\
\text { pressurized } \\
\text { - No water in flush tank } \\
\text { ECRT-TK-101 } \\
\text { - Valve ECRT-AOV-102 or } \\
\text { ECRT-AOV-113 fails to } \\
\text { open } \\
\text { - Bladder flush disabled }\end{array}$ & $\begin{array}{l}\text { Operational Upset: } \\
\text { If there is no flow, then the transfer line } \\
\text { will not be flushed. This could result in a } \\
\text { plugged transfer line. See Table C-6, } \\
\text { Item 2.a-1. } \\
\text { Radiological Control: } \\
\text { If the autoflush is not performed, then } \\
\text { there is a higher probability of significant } \\
\text { contamination and higher dose rate } \\
\text { during STSC process disconnects. }\end{array}$ & $\begin{array}{l}\text { - Pressure instrumentation } \\
\text { (PIT-710-103) } \\
\text { - IXM water flow totalizer } \\
\text { FQI-710-101 }\end{array}$ & $\begin{array}{l}\text { - Procedures } \\
\text { - Training } \\
\text { - Conduct of operations } \\
\text { verifies proper system } \\
\text { configuration } \\
\text { - Radiological Control } \\
\text { Program } \\
\text { - Perform manual flush }\end{array}$ & $\begin{array}{l}\text { Testing at MASF has demonstrated that a } \\
\text { manual flush is capable of suspending and } \\
\text { transferring settled solids. }\end{array}$ \\
\hline $10-2$ & Flow & Low & $\begin{array}{l}\text { - Low pressure in flush } \\
\text { tank ECRT-TK-101 } \\
\text { - A normally-opened valve } \\
\text { is partially closed }\end{array}$ & $\begin{array}{l}\text { Operational Upset: } \\
\text { If the flow rate is less than } 70 \mathrm{gpm} \text {, then } \\
\text { solids will not be flushed efficiently. This } \\
\text { could result in a plugged transfer line. } \\
\text { See Table C-6, Item 2.a-1. } \\
\text { Radiological Control: } \\
\text { If the autoflush is not performed, then } \\
\text { there is a higher probability of significant } \\
\text { contamination and higher dose rate } \\
\text { during STSC process disconnects. }\end{array}$ & $\begin{array}{l}\text { Pressure instrumentation } \\
\text { (PIT-710-103) }\end{array}$ & $\begin{array}{l}\text { - Procedures } \\
\text { - Training } \\
\text { - Conduct of operations } \\
\text { verifies proper system } \\
\text { configuration } \\
\text { - Perform manual flush }\end{array}$ & $\begin{array}{l}\text { Testing at MASF has demonstrated that a } \\
\text { manual flush is capable of suspending and } \\
\text { transferring settled solids. }\end{array}$ \\
\hline $10-3$ & Flow & High & $\begin{array}{l}\text { High pressure in flush tank } \\
\text { ECRT-TK-101 }\end{array}$ & $\begin{array}{l}\text { None: } \\
\text { There are no consequences associated } \\
\text { with a high flow rate. }\end{array}$ & $\begin{array}{l}\text { Pressure instrumentation } \\
\text { (PIT-710-103) }\end{array}$ & 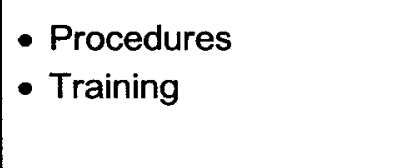 & \\
\hline
\end{tabular}




\begin{tabular}{|c|c|c|c|c|c|c|c|}
\hline \multirow{2}{*}{ Item } & \multirow{2}{*}{$\begin{array}{l}\text { Process } \\
\text { Parameter }\end{array}$} & \multirow{2}{*}{ Deviation } & \multirow{2}{*}{ Cause } & \multirow{2}{*}{ Consequences } & \multicolumn{2}{|c|}{ Candidate Controls } & \multirow{2}{*}{ Remarks } \\
\hline & & & & & Engineered & Administrative & \\
\hline $10-4$ & Flow & Reverse & $\begin{array}{l}\text { Valves ECRT-AOV-102 } \\
\text { and open during a slurry } \\
\text { transfer }\end{array}$ & $\begin{array}{l}\text { Uncontrolled Release: } \\
\text { If there is reverse flow, then sludge could } \\
\text { be pumped into the autoflush line } \\
\text { resulting in a spray or splash and } \\
\text { splatter/pool release (see remarks). }\end{array}$ & $\begin{array}{l}\text { - Piping designed in } \\
\text { accordance with B31.3, } \\
\text { "Process Piping" } \\
\text { - Check valves ECRT-CV-102, } \\
-103 \text {, and -104 }\end{array}$ & $\begin{array}{l}\text { - Procedures } \\
\text { - Training } \\
\text { - Conduct of operations } \\
\text { verifies proper system } \\
\text { configuration }\end{array}$ & $\begin{array}{l}\text { Valve ECRT-AOV-102 is normally closed } \\
\text { which would prevent backflow into the } \\
\text { autoflush line. } \\
\text { If valve ECRT-AOV-102 opened during a } \\
\text { transfer, there would be a small amount of } \\
\text { flow into the autoflush line because the } \\
\text { pressure in the transfer line ( } 100 \text { psi at the } \\
\text { booster pump discharg) is approximately } \\
\text { equal to the autoflush line pressure at its } \\
\text { connection point. } \\
\text { For a spray or splash and splatter/pool } \\
\text { release to occur, the reverse flow would } \\
\text { either need to overpressurize and fail the } \\
\text { autoflush system or the system would need } \\
\text { to be open to atmosphere. } \\
\text { The autoflush system is designed to the } \\
\text { same operating pressure as the transfer line. }\end{array}$ \\
\hline $10-5$ & Flow & Misdirected & N/A & N/A & N/A & N/A & This Node cannot be misdirected. \\
\hline $10-6$ & Pressure & Low & $\begin{array}{l}\text { - Operator error } \\
\text { - Pressure indication } \\
\text { reads incorrectly } \\
\text { - Air fitting leakage }\end{array}$ & $\begin{array}{l}\text { Operational Upset: } \\
\text { If the pressure is low, then the flow rate } \\
\text { will be low. The consequences are as } \\
\text { stated in Item } 10-1 \text { above. }\end{array}$ & $\begin{array}{l}\text { Pressure instrumentation } \\
\text { (PIT-710-103) }\end{array}$ & $\begin{array}{l}\text { - Procedures } \\
\text { - Training }\end{array}$ & \\
\hline $10-7$ & Pressure & High & $\begin{array}{l}\text { - Operator error } \\
\text { - Pressure indication } \\
\text { reads incorrectly }\end{array}$ & $\begin{array}{l}\text { Uncontrolled Release/Industrial Safety: } \\
\text { If the pressure is high, then the flush tank } \\
\text { or flush line could fail resulting in a } \\
\text { release of IXM water (see remarks). } \\
\text { Overpressurization of the tank or line } \\
\text { could potentially injure a facility worker. }\end{array}$ & $\begin{array}{l}\text { - Pressure instrumentation } \\
\text { (PIT-710-204) } \\
\text { - Pressure safety valve } \\
\text { ECRT-PSV-101 }\end{array}$ & $\begin{array}{l}\text { - Procedures } \\
\text { - Training } \\
\text { - Radiological Control } \\
\text { Program }\end{array}$ & $\begin{array}{l}\text { Spills of IXM water do not constitute a } \\
\text { radiological hazard to facility workers based } \\
\text { on operational experience at the KW Basin. }\end{array}$ \\
\hline $10-8$ & Level & High & $\begin{array}{l}\text { - Operator error } \\
\text { - Flow indication reads } \\
\text { incorrectly }\end{array}$ & $\begin{array}{l}\text { None: } \\
\text { There are no consequences associated } \\
\text { with a high IXM water level in the flush } \\
\text { tank (see remarks). }\end{array}$ & $\begin{array}{l}\text { Flow instrumentation } \\
\text { (FQl-710-101) }\end{array}$ & $\begin{array}{l}\text { - Procedures } \\
\text { - Training }\end{array}$ & $\begin{array}{l}\text { The volume of the flush tank is sufficiently } \\
\text { small that the STSC cannot be overfilled by } \\
\text { the autoflush system. }\end{array}$ \\
\hline
\end{tabular}


Table C-30. HAZOP Results, Node 10, Transfer Line Automatic Flush

\begin{tabular}{|c|c|c|c|c|c|c|c|}
\hline \multirow{2}{*}{ Item } & \multirow{2}{*}{$\begin{array}{l}\text { Process } \\
\text { Parameter }\end{array}$} & \multirow{2}{*}{ Deviation } & \multirow{2}{*}{ Cause } & \multirow{2}{*}{ Consequences } & \multicolumn{2}{|c|}{ Candidate Controls } & \multirow{2}{*}{ Remarks } \\
\hline & & & & & Engineered & Administrative & \\
\hline $10-9$ & Level & Low & $\begin{array}{l}\text { - Operator error } \\
\text { - Flow indication reads } \\
\text { incorrectly }\end{array}$ & $\begin{array}{l}\text { Operational Upset: } \\
\text { If the level in flush tank ECRT-TK-101 is } \\
\text { low, then there will not be sufficient water } \\
\text { to perform the flush. This could result in a } \\
\text { plugged transfer line. See Table C-6, } \\
\text { Item 2.a-1. }\end{array}$ & $\begin{array}{l}\text { Flow instrumentation } \\
\text { (FQI-710-101) }\end{array}$ & $\begin{array}{l}\text { - Procedures } \\
\text { - Training } \\
\text { - Perform manual flush }\end{array}$ & $\begin{array}{l}\text { Testing at MASF has demonstrated that a } \\
\text { manual flush is capable of suspending and } \\
\text { transferring settled solids. }\end{array}$ \\
\hline 10-10.a & Structural Integrity & $\begin{array}{l}\text { Leak/rupture } \\
\text { (flush tank, air } \\
\text { side) }\end{array}$ & $\begin{array}{l}\text { - Overpressurization } \\
\text { - Air fitting leakage }\end{array}$ & $\begin{array}{l}\text { Operational Upset/Radiological Control: } \\
\text { It the flush tank fails on the air side of the } \\
\text { bladder, then the pressure will bleed off. } \\
\text { When valve ECRT-AOV-102 opens, there } \\
\text { will be no flow. Consequences are as } \\
\text { stated in Item 10-1 above. }\end{array}$ & $\begin{array}{l}\text { - Pressure instrumentation } \\
\text { (PIT-710-204) } \\
\text { - Pressure safety valve } \\
\text { ECRT-PSV-101 }\end{array}$ & $\begin{array}{l}\text { - Procedures } \\
\text { - Training } \\
\text { - Perform manual flush }\end{array}$ & $\begin{array}{l}\text { Testing at MASF has demonstrated that a } \\
\text { manual flush is capable of suspending and } \\
\text { transferring settled solids. }\end{array}$ \\
\hline $10-10 . b$ & Structural Integrity & $\begin{array}{l}\text { Leak/rupture } \\
\text { (flush tank, } \\
\text { water side; } \\
\text { autoflush line } \\
\text { to valve } \\
\text { ECRT-V-102) }\end{array}$ & $\begin{array}{l}\text { - Overpressurization } \\
\text { - Valve ECRT-V-112 } \\
\text { leaks }\end{array}$ & $\begin{array}{l}\text { Uncontrolled Release: } \\
\text { If the tank fails on the water side, or the } \\
\text { autoflush line to valve ECRT-V-102 fails, } \\
\text { then a spray or splash and splatter/pool } \\
\text { release of IXM water will occur (see } \\
\text { remarks). } \\
\text { Operational Upset/Radiological Control: } \\
\text { If the water leaks from the tank, then } \\
\text { when valve ECRT-AOV-102 opens, there } \\
\text { will be no flow. Consequences are as } \\
\text { stated in Item 10-1 above. }\end{array}$ & $\begin{array}{l}\text { - Piping designed in } \\
\text { accordance with B31.3, } \\
\text { "Process Piping" } \\
\text { - Pressure instrumentation } \\
\text { (PIT-710-204) } \\
\text { - Pressure safety valve } \\
\text { ECRT-PSV-101 }\end{array}$ & $\begin{array}{l}\text { - Procedures } \\
\text { - Training } \\
\text { - Radiological Control } \\
\text { Program } \\
\text { - Perform manual flush }\end{array}$ & $\begin{array}{l}\text { Spills of IXM water do not constitute a } \\
\text { radiological hazard to facility workers based } \\
\text { on operational experience at the KW Basin. } \\
\text { Testing at MASF has demonstrated that a } \\
\text { manual flush is capable of suspending and } \\
\text { transferring settled solids. }\end{array}$ \\
\hline
\end{tabular}




\begin{tabular}{|c|c|c|c|c|c|c|c|}
\hline \multirow{2}{*}{ Item } & \multirow{2}{*}{$\begin{array}{l}\text { Process } \\
\text { Parameter }\end{array}$} & \multirow{2}{*}{ Deviation } & \multirow{2}{*}{ Cause } & \multirow{2}{*}{ Consequences } & \multicolumn{2}{|c|}{ Candidate Controls } & \multirow{2}{*}{ Remarks } \\
\hline & & & & & Engineered & Administrative & \\
\hline 10-10.c & Structural Integrity & $\begin{array}{l}\text { Leak/rupture } \\
\text { (autoflush line } \\
\text { from valve } \\
\text { ECRT-V-102 } \\
\text { to booster } \\
\text { pump skid) }\end{array}$ & $\begin{array}{l}\text { - Overpressurization } \\
\text { - Hose disconnects }\end{array}$ & $\begin{array}{l}\text { Uncontrolled Release: } \\
\text { If the autoflush fails between ECRT-V-102 } \\
\text { and the booster pump skid, then when } \\
\text { valve ECRT-AOV-102 opens, a spray or } \\
\text { splash and splatter/pool release of IXM } \\
\text { water will occur (see remarks). } \\
\text { Operational Upset: } \\
\text { Depending on the amount of IXM water } \\
\text { released via the leak/rupture, there may } \\
\text { be insufficient water to effectively flush } \\
\text { the transfer line. This could result in a } \\
\text { plugged transfer line. See Table C-6, } \\
\text { Item 2.a-1. }\end{array}$ & $\begin{array}{l}\text { Piping designed in accordance } \\
\text { with B31.3, "Process Piping" }\end{array}$ & $\begin{array}{l}\text { - Procedures } \\
\text { - Training } \\
\text { - Radiological Control } \\
\text { Program }\end{array}$ & $\begin{array}{l}\text { Spills of IXM water do not constitute a } \\
\text { radiological hazard to facility workers based } \\
\text { on operational experience at the KW Basin. }\end{array}$ \\
\hline 10-11.a & Time Procedure & $\begin{array}{l}\text { Too soon } \\
\text { (inadvertent } \\
\text { activation } \\
\text { during a } \\
\text { transfer) }\end{array}$ & $\begin{array}{l}\text { - Failure in interlock } \\
\text { sequence } \\
\text { - Loss of power }\end{array}$ & $\begin{array}{l}\text { Operational Upset: } \\
\text { If valve ECRT-AOV-102 opened during a } \\
\text { transfer, then only be a small amount of } \\
\text { sludge would flow into the autoflush line } \\
\text { because the pressure in the transfer line } \\
\text { ( } 100 \text { psi at the booster pump discharge) is } \\
\text { approximately equal to the autoflush line } \\
\text { pressure at its connection point ( } 96 \mathrm{psi}) \text {. }\end{array}$ & $\begin{array}{l}\text { - Pressure instrumentation } \\
\text { (PIT-710-204) } \\
\text { - Valve position indication for } \\
\text { valves ECRT-AOV-102 } \\
\text { - Interlock activation indication } \\
\text { (ECRT-IL-120, ECRT-IL-13) }\end{array}$ & $\begin{array}{l}\text { - Procedures } \\
\text { - Training }\end{array}$ & $\begin{array}{l}\text { Pressure instrumentation and valve position } \\
\text { indication could be used by operators to } \\
\text { ascertain that the autoflush was inadvertently } \\
\text { activated. }\end{array}$ \\
\hline
\end{tabular}




\begin{tabular}{|c|c|c|c|c|c|c|c|}
\hline \multirow{2}{*}{ Item } & \multirow{2}{*}{$\begin{array}{l}\text { Process } \\
\text { Parameter }\end{array}$} & \multirow{2}{*}{ Deviation } & \multirow{2}{*}{ Cause } & \multirow{2}{*}{ Consequences } & \multicolumn{2}{|c|}{ Candidate Controls } & \multirow{2}{*}{ Remarks } \\
\hline & & & & & Engineered & Administrative & \\
\hline 10-11.b & Time Procedure & $\begin{array}{l}\text { Too soon } \\
\text { (inadvertent } \\
\text { activation } \\
\text { after a } \\
\text { transfer) }\end{array}$ & $\begin{array}{l}\text { - Failure in interlock } \\
\text { sequence } \\
\text { - Loss of power }\end{array}$ & $\begin{array}{l}\text { Uncontrolled Release: } \\
\text { If the autoflush activated after a transfer } \\
\text { was complete and the transfer line was } \\
\text { disconnected from the STSC and was not } \\
\text { isolated, then a splash and splatter/pool } \\
\text { release could occur (see remarks). } \\
\text { Operational Upset: } \\
\text { If the autoflush activated after a transfer } \\
\text { was complete and the transfer line was } \\
\text { disconnected from the STSC and was } \\
\text { isolated, then the transfer line between } \\
\text { booster pump ECRT-P-101 and the } \\
\text { isolation valve would be pressurized (see } \\
\text { remarks). }\end{array}$ & $\begin{array}{l}\text { - Isolation valves } \\
\text { - Valve position indicators } \\
\text { - Modified KW Basin Annex } \\
\text { confinement ventilation } \\
\text { - Continuous air monitors }\end{array}$ & $\begin{array}{l}\text { - Procedures } \\
\text { - Training } \\
\text { - Conduct of operations } \\
\text { verifies proper system } \\
\text { configuration } \\
\text { - Autoflush disable }\end{array}$ & $\begin{array}{l}\text { After a transfer is complete, the autoflush } \\
\text { system is disabled via bladder flush } \\
\text { enable/disable handswitch ECRT-HS-113 } \\
\text { which closes valve ECRT-AOV-113. } \\
\text { After a transfer is complete and the transfer } \\
\text { line is disconnected from the STSC, isolation } \\
\text { valve ECRT-V-101 in the transfer line service } \\
\text { box is closed. } \\
\text { If the transfer line between booster pump } \\
\text { ECRT-P-101 and the isolation valve was } \\
\text { pressurized, then the line would depressurize } \\
\text { when a new STSC was put into place and a } \\
\text { slurry transfer initiated. Consequently, the } \\
\text { autoflush system would not be functional. } \\
\text { The consequences are as stated in Item 10-1 } \\
\text { above. }\end{array}$ \\
\hline $10-12$ & Time Procedure & $\begin{array}{l}\text { Too late } \\
\text { (activation of } \\
\text { autoflush } \\
\text { delayed) }\end{array}$ & $\begin{array}{l}\text { Failure in interlock } \\
\text { sequence }\end{array}$ & $\begin{array}{l}\text { None: } \\
\text { See remarks. }\end{array}$ & None & $\begin{array}{l}\text { - Procedures } \\
\text { - Training }\end{array}$ & $\begin{array}{l}\text { If the autoflush is delayed, then solids will } \\
\text { settle in the transfer line. Testing at MASF } \\
\text { has demonstrated that the autoflush system } \\
\text { is capable of suspending and transferring } \\
\text { settled solids. }\end{array}$ \\
\hline $10-13$ & Time Procedure & $\begin{array}{l}\text { Skip action } \\
\text { (autoflush not } \\
\text { performed) }\end{array}$ & $\begin{array}{l}\text { Failure in interlock } \\
\text { sequence }\end{array}$ & $\begin{array}{l}\text { Operational Upset: } \\
\text { If the autoflush is not performed, then the } \\
\text { transfer line could plug. See Table C-6, } \\
\text { Item 2.a-1. } \\
\text { Radiological Control: } \\
\text { If the autoflush is not performed, then } \\
\text { there is a higher probability of significant } \\
\text { contamination and higher dose rates } \\
\text { during STSC process disconnects. }\end{array}$ & $\begin{array}{l}\text { - Pressure instrumentation } \\
\text { (PI-710-204) } \\
\text { - Valve position indication for } \\
\text { valve ECRT-AOV-102 }\end{array}$ & $\begin{array}{l}\text { - Procedures } \\
\text { - Training } \\
\text { - Radiological Control } \\
\text { Program } \\
\text { - Perform manual flush }\end{array}$ & $\begin{array}{l}\text { Pressure instrumentation and valve position } \\
\text { indication could be used by operators to } \\
\text { ascertain that the autoflush was not } \\
\text { performed. } \\
\text { Testing at MASF has demonstrated that a } \\
\text { manual flush is capable of suspending and } \\
\text { transferring settled solids. }\end{array}$ \\
\hline $10-14$ & Time Procedure & Wrong action & N/A & N/A & N/A & N/A & $\begin{array}{l}\text { There is no wrong action associated with this } \\
\text { node. }\end{array}$ \\
\hline
\end{tabular}




\begin{tabular}{|c|c|c|}
\hline Process Parameter & Design Intent & Remarks \\
\hline Flow & $42 \mathrm{gpm}$ & $\begin{array}{l}\text { Motive force is fluidizing pump ECRT-P-302. The } 42 \mathrm{gpm} \text { is the flow rate when the fluidizing jets are on. When } \\
\text { the jets are not on, } 10 \mathrm{gpm} \text { flows to the fluidizing jets via bypass flow orifice ECRT-FO-301. }\end{array}$ \\
\hline Pressure & $\begin{array}{l}\text { Upstream of pump ECRT-P-302 }=100-130 \mathrm{psi} \\
\text { Downstream of pump ECRT-P-302 }=385 \mathrm{psi}\end{array}$ & $\begin{array}{l}\text { When the operators turn on the fluidizing jets, valve ECRT-AOV-304 opens and high pressure water is directed } \\
\text { to the jets. }\end{array}$ \\
\hline Concentration & Not applicable & $\begin{array}{l}\text { The Skimmer Water Cleanup System takes basin water and pumps it first through a sand filter (for water clarity) } \\
\text { and then through an IXM (to remove ionic species). The IXM water concentration is not a critical attribute of } \\
\text { recovery tool operability. }\end{array}$ \\
\hline Composition & Not applicable & $\begin{array}{l}\text { There are no other process fluids at the KW Basin that could be inadvertently connected or directed to the } \\
\text { overfill recovery pump skid. }\end{array}$ \\
\hline Structural Integrity & Maintain integrity under normal operating conditions & The IXM water lines are a combination of piping and hoses. \\
\hline Level & Maintain liquid level in STSC below LE-740-401 setting & $\begin{array}{l}\text { If the liquid level in the STSC reached the setting of LSH-740-402, then interlock I-3 would terminate IXM water } \\
\text { flow. }\end{array}$ \\
\hline Temperature & Not applicable & $\begin{array}{l}\text { Temperature is not a process parameter that is monitored or controlled. The } 1.3 \text { million gallons of water in the } \\
\text { KW Basin is maintained at a temperature of } 10-15^{\circ} \mathrm{C} \text {. The IXM water is approximately the same temperature } \\
\text { as the basin water, i.e., the pumps of the Skimmer Water Cleanup System do not impart significant thermal } \\
\text { energy to the water. Fluctuations in basin water temperature occur very slowly. The IXM water temperature is } \\
\text { not a critical attribute of recovery tool operability, }\end{array}$ \\
\hline Time Procedure & Variable & $\begin{array}{l}\text { In contrast to the sludge retrieval using the Xago Hydrolance 'm where the fluidizing jets are periodically pulsed } \\
\text { for } 3-5 \text { seconds to achieve a target vol \% solids, the recovery tool fluidizing jets are operated on an as-needed } \\
\text { basis to recovery the necessary amount of sludge. Operators determine the need to operate the jets based on } \\
\text { differential weight indication (DWI-740-401) and STSC liquid level (LIT-740-401). Fluidizing jet pump } \\
\text { ECRT-P-301 is manually stopped when the target recovery has been achieved. }\end{array}$ \\
\hline
\end{tabular}


Table C-32. HAZOP Results, Node 11.a. Overfill Recovery - IXM Water to Recovery Tool Fluidizing Jets

\begin{tabular}{|c|c|c|c|c|c|c|c|}
\hline \multirow{2}{*}{ Item } & \multirow{2}{*}{$\begin{array}{l}\text { Process } \\
\text { Parameter }\end{array}$} & \multirow{2}{*}{ Deviation } & \multirow{2}{*}{ Cause } & \multirow{2}{*}{ Consequences } & \multicolumn{2}{|c|}{ Candidate Controls } & \multirow{2}{*}{ Remarks } \\
\hline & & & & & Engineered & Administrative & \\
\hline 11.a-1 & Flow & No & $\begin{array}{l}\text { - No IXM water supply } \\
\text { from the Skimmer } \\
\text { Water Cleanup System } \\
\text { - A normally-open valve is } \\
\text { closed } \\
\text { - Fluidizing jets are } \\
\text { plugged }\end{array}$ & $\begin{array}{l}\text { Overpressurization/Hydrogen } \\
\text { Deflagration: } \\
\text { If there is no flow because there is no IXM } \\
\text { water supply, then there will be no flow to } \\
\text { the fluidizing jets and there will be no } \\
\text { dilution water. Overfill recovery pump } \\
\text { ECRT-P-301 would continue to operate } \\
\text { which could plug the overfill recovery tool. } \\
\text { If the plug could not be cleared, then the } \\
\text { targeted recovery would not be achieved. } \\
\text { In an unmitigated scenario, exceeding the } \\
\text { sludge limits could result in STS cask } \\
\text { overpressurization or a hydrogen } \\
\text { deflagration. } \\
\text { If there is no flow because valve } \\
\text { ECRT-V-704, ECRT-AOV-701, or } \\
\text { ECRT-V-303 is closed, then there will be } \\
\text { no flow to the fluidizing jets and there will } \\
\text { be no dilution water. Consequences are } \\
\text { as stated above. } \\
\text { If there is no flow because the fluidizing } \\
\text { jets are plugged, then the sludge will not } \\
\text { be fluidized. Dilution water alone might } \\
\text { be sufficient to achieve the targeted } \\
\text { recovery. If dilution water alone cannot } \\
\text { achieve the targeted recovery, then the } \\
\text { sludge limits would be exceeded. In an } \\
\text { unmitigated scenario, exceeding the } \\
\text { sludge limits could result in STS cask } \\
\text { overpressurization or a hydrogen } \\
\text { deflagration }\end{array}$ & $\begin{array}{l}\text { - Valve position indicators } \\
\text { - Fluidizing water pump } \\
\text { ECRT-P-302 inlet and outlet } \\
\text { pressure instrumentation } \\
\text { (PIT-730-303, -304) } \\
\text { - Fluidizing water flow rate } \\
\text { instrumentation } \\
\text { (FQIT-730-301) } \\
\text { - Fluidizing jet O-rings (to } \\
\text { - Drevent plugging) } \\
\text { - Differential sludge weight } \\
\text { instrumentation } \\
\text { (DWI-740-704) } \\
\text { - STSC active ventilation } \\
\text { - Auxiliary ventilation system } \\
\text { - Modified KW Basin Annex } \\
\text { confinement ventilation } \\
\text { - Continuous air monitors }\end{array}$ & $\begin{array}{l}\text { - Procedures } \\
\text { - Training } \\
\text { - Conduct of operations } \\
\text { verifies proper system } \\
\text { configuration } \\
\text { - STSC sludge limit } \\
\text { verification } \\
\text { - Recovery Plan } \\
\text { - Modified KW Basin Annex } \\
\text { is unmanned during overfill } \\
\text { recovery operations }\end{array}$ & $\begin{array}{l}\text { It would be readily apparent to operators at } \\
\text { the start-up of overfill recovery operations if } \\
\text { there was no IXM water supply as prior to } \\
\text { overfill recovery IXM water is used to fill the } \\
\text { overfill recovery tool discharge line with } \\
\text { water. } \\
\text { Valve ECRT-AOV-701 is an air-operated } \\
\text { valve. The valve closes on loss of air. The } \\
\text { valve also closes on loss of power to } \\
\text { solenoid-operated valve ECRT-SOV-701. } \\
\text { If the overfill recovery tool becomes plugged, } \\
\text { it can be backflushed with IXM water. } \\
\text { Operation of fluidizing water pump } \\
\text { ECRT-P-302 is not required for fluidizing } \\
\text { water flow. If the pump is not operating IXM } \\
\text { water will flow through the centrifugal pump } \\
\text { at the flow rate and pressure provided by the } \\
\text { IXM water supply. } \\
\text { The STSC sludge limit verification control will } \\
\text { prevent disconnecting the STSC active } \\
\text { ventilation and the auxiliary ventilation } \\
\text { system from the STSC until the applicable } \\
\text { sludge limit is met. } \\
\text { The overpressurization hazard does not exist } \\
\text { until the STS Cask lid is bolted onto the cask. } \\
\text { The STSC sludge limit verification } \\
\text { administrative control will prevent this activity } \\
\text { if the sludge limits are not met. } \\
\text { In the event that the targeted recovery could } \\
\text { not be achieved by the installed overfill } \\
\text { recovery tool, a Recovery Plan would be } \\
\text { developed. }\end{array}$ \\
\hline
\end{tabular}


Table C-32. HAZOP Results, Node 11.a. Overfill Recovery - IXM Water to Recovery Tool Fluidizing Jets

\begin{tabular}{|c|c|c|c|c|c|c|c|}
\hline \multirow{2}{*}{ Item } & \multirow{2}{*}{$\begin{array}{l}\text { Process } \\
\text { Parameter }\end{array}$} & \multirow{2}{*}{ Deviation } & \multirow{2}{*}{ Cause } & \multirow{2}{*}{ Consequences } & \multicolumn{2}{|c|}{ Candidate Controls } & \multirow{2}{*}{ Remarks } \\
\hline & & & & & Engineered & Administrative & \\
\hline 11.a-2 & Flow & Low & $\begin{array}{l}\text { - Low IXM water supply } \\
\text { flow rate from the } \\
\text { Skimmer Water Cleanup } \\
\text { System } \\
\text { - Fluidizing pump } \\
\text { ECRT-P-302 not } \\
\text { operating } \\
\text { - Fluidizing pump } \\
\text { ECRT-P-302 speed low } \\
\text { - Valve ECRT-AOV-304 } \\
\text { is closed } \\
\text { - Fluidizing jets are } \\
\text { partially plugged } \\
\text { - A normally open valve is } \\
\text { partially closed }\end{array}$ & $\begin{array}{l}\text { Operational Upset: } \\
\text { If the flow is low, then it could take longer } \\
\text { to achieve the targeted recovery. } \\
\text { Overpressurization/Hydrogen } \\
\text { Deflagration: } \\
\text { If the flow is low, then sludge might not be } \\
\text { sufficiently fluidized to achieve the } \\
\text { targeted recovery. In an unmitigated } \\
\text { scenario, exceeding the sludge limits } \\
\text { could result in STS cask } \\
\text { overpressurization or a hydrogen } \\
\text { deflagration }\end{array}$ & $\begin{array}{l}\text { - Valve position indicators } \\
\text { - Fluidizing water pump } \\
\text { ECRT-P-302 inlet and outlet } \\
\text { pressure instrumentation } \\
\text { (PIT-730-303, -304) } \\
\text { - Fluidizing water flow rate } \\
\text { instrumentation } \\
\text { (FQIT-730-301) } \\
\text { - Fluidizing jet O-rings (to } \\
\text { prevent plugging) } \\
\text { - Differential sludge weight } \\
\text { instrumentation } \\
\text { (DWI-740-704) } \\
\text { - STSC active ventilation } \\
\text { - Auxiliary ventilation system } \\
\text { - Modified KW Basin Annex } \\
\text { confinement ventilation } \\
\text { - Continuous air monitors }\end{array}$ & $\begin{array}{l}\text { - Procedures } \\
\text { - Training } \\
\text { - Conduct of operations } \\
\text { verifies proper system } \\
\text { configuration } \\
\text { - STSC sludge limit } \\
\text { verification } \\
\text { - Recovery Plan } \\
\text { - Modified KW Basin Annex } \\
\text { is unmanned during overfill } \\
\text { recovery operations }\end{array}$ & $\begin{array}{l}\text { The fluidizing pump speed is controlled by } \\
\text { variable frequency drive ECRT-VFD-302. } \\
\text { The pump speed will be set during } \\
\text { pre-operational testing. There will be no } \\
\text { procedural steps directing operators to adjust } \\
\text { the pump speed. } \\
\text { The STSC sludge limit verification control will } \\
\text { prevent disconnecting the STSC active } \\
\text { ventilation system and the auxiliary } \\
\text { ventilation system from the STSC until the } \\
\text { applicable sludge limit is met. } \\
\text { The overpressurization hazard does not exist } \\
\text { until the STS Cask lid is bolted onto the cask. } \\
\text { The STSC sludge limit verification } \\
\text { administrative control will prevent this activity } \\
\text { if the sludge limits are not met. } \\
\text { In the event that the targeted recovery could } \\
\text { not be achieved by the installed overfill } \\
\text { recovery tool, a Recovery Plan would be } \\
\text { developed. }\end{array}$ \\
\hline 11.a-3 & Flow & High & $\begin{array}{l}\text { Fluidizing pump } \\
\text { ECRT-P-302 speed high }\end{array}$ & $\begin{array}{l}\text { Uncontrolled Release: } \\
\text { If the flow rate is sufficiently high, then } \\
\text { eventually the STSC will be overfilled and } \\
\text { slurry will overflow into the } 4 \text {-in and } 1 \text {-in. } \\
\text { ventilation exhaust lines, and into the } 1 \text {-in. } \\
\text { ventilation inlet line, leading to a splash } \\
\text { and splatter/pool release. }\end{array}$ & $\begin{array}{l}\text { - Fluidizing water flow rate } \\
\text { instrumentation } \\
\text { (FQIT-730-301) } \\
\text { - Level switches } \\
\text { LS/LSH/LSHH-740-401 } \\
\text { - High level switch } \\
\text { LSH-740-402 } \\
\text { - Emergency stop switch } \\
\text { ECRT-ES-1 } \\
\text { - Modified KW Basin Annex } \\
\text { confinement ventilation } \\
\text { - Continuous air monitors }\end{array}$ & $\begin{array}{l}\text { - Procedures } \\
\text { - Training } \\
\text { - Radiological Control } \\
\text { Program } \\
\text { - Modified KW Basin Annex } \\
\text { is unmanned during overfill } \\
\text { recovery operations }\end{array}$ & $\begin{array}{l}\text { Under normal operating conditions } 62 \mathrm{gpm} \text { is } \\
\text { added to the STSC ( } 42 \mathrm{gpm} \text { from the } \\
\text { fluidizing jets and } 20 \mathrm{gpm} \text { dilution water) and } \\
70 \mathrm{gpm} \text { is withdrawn by the overfill recovery } \\
\text { pump. } \\
\text { The fluidizing pump speed is controlled by } \\
\text { variable frequency drive ECRT-VFD-302. } \\
\text { The pump speed will be set during } \\
\text { pre-operational testing. There will be no } \\
\text { procedural steps directing operators to adjust } \\
\text { the pump speed. }\end{array}$ \\
\hline
\end{tabular}


Table C-32. HAZOP Results, Node 11.a. Overfill Recovery - IXM Water to Recovery Tool Fluidizing Jets

\begin{tabular}{|c|c|c|c|c|c|c|c|}
\hline \multirow{2}{*}{ Item } & \multirow{2}{*}{$\begin{array}{l}\text { Process } \\
\text { Parameter }\end{array}$} & \multirow{2}{*}{ Deviation } & \multirow{2}{*}{ Cause } & \multirow{2}{*}{ Consequences } & \multicolumn{2}{|c|}{ Candidate Controls } & \multirow{2}{*}{ Remarks } \\
\hline & & & & & Engineered & Administrative & \\
\hline 11.a-4 & Flow & Reverse & $\begin{array}{l}\text { Siphon from STSC (see } \\
\text { remarks) }\end{array}$ & $\begin{array}{l}\text { Uncontrolled Release: } \\
\text { If a siphon is created, then liquid would be } \\
\text { drawn out of the STSC through the } \\
\text { fluidizing jets and discharged at the } \\
\text { location of system breach leading to } \\
\text { splash and splatter/pool release. }\end{array}$ & $\begin{array}{l}\text { - Check valve ECRT-CV-302 } \\
\text { - Modified KW Basin Annex } \\
\text { confinement ventilation } \\
\text { - Continuous air monitors }\end{array}$ & $\begin{array}{l}\text { - Procedures } \\
\text { - Training } \\
\text { - Radiological Control } \\
\text { Program } \\
\text { - Modified KW Basin Annex } \\
\text { is unmanned during overfill } \\
\text { recovery operations }\end{array}$ & $\begin{array}{l}\text { If fluidizing pump ECRT-P-302 is not } \\
\text { operating and there is a system breach } \\
\text { below STSC liquid level, then a siphon could } \\
\text { be created. } \\
\text { There are eight fluidizing jet nozzles, each } \\
\text { approximately } 3 \mathrm{~mm} \text { in diameter. The } \\
\text { nozzles could plug with solids and either limit } \\
\text { or stop the siphon flow. }\end{array}$ \\
\hline 11.a-5 & Flow & $\begin{array}{l}\text { Misdirected } \\
\text { (to overfill } \\
\text { recovery tool } \\
\text { dilution water } \\
\text { connection) }\end{array}$ & $\begin{array}{l}\text { Operator error in making } \\
\text { hose connections }\end{array}$ & $\begin{array}{l}\text { Overpressurization/Hydrogen } \\
\text { Deflagration: } \\
\text { If the fluidizing and dilution water hoses } \\
\text { are cross-connected, then the sludge } \\
\text { might not be sufficiently fluidized to } \\
\text { achieve the targeted recovery. In an } \\
\text { unmitigated scenario, exceeding the } \\
\text { sludge limits could result in STS cask } \\
\text { overpressurization or a hydrogen } \\
\text { deflagration }\end{array}$ & $\begin{array}{l}\text { - Unique process connections } \\
\text { - STSC active ventilation } \\
\text { - Auxiliary ventilation system } \\
\text { - Modified KW Basin Annex } \\
\text { confinement ventilation } \\
\text { - Continuous air monitors }\end{array}$ & $\begin{array}{l}\text { - Procedures } \\
\text { - Training } \\
\text { - Conduct of operations } \\
\text { verifies proper system } \\
\text { configuration } \\
\text { - STSC sludge limit } \\
\text { verification } \\
\text { - Recovery Plan } \\
\text { - Modified KW Basin Annex } \\
\text { is unmanned during overfill } \\
\text { recovery operations }\end{array}$ & $\begin{array}{l}\text { The overpressurization hazard does not exist } \\
\text { until the STS Cask lid is bolted onto the cask. } \\
\text { The STSC sludge limit verification } \\
\text { administrative control will prevent this activity } \\
\text { if the sludge limits are not met. } \\
\text { In the event that the targeted recovery could } \\
\text { not be achieved by the installed overfill } \\
\text { recovery tool, a Recovery Plan would be } \\
\text { developed. }\end{array}$ \\
\hline $11 . a-6$ & Pressure & Low & $\begin{array}{l}\text { - Fluidizing pump } \\
\text { ECRT-P-302 not } \\
\text { operating } \\
\text { - Fluidizing pump } \\
\text { ECRT-P-302 speed low }\end{array}$ & $\begin{array}{l}\text { Operational Upset: } \\
\text { If the pressure is low, then it could take } \\
\text { longer to achieve the targeted recovery. } \\
\text { Overpressurization/Hydrogen } \\
\text { Deflagration: } \\
\text { If the pressure is low, then the sludge } \\
\text { might not be sufficiently fluidized to } \\
\text { achieve the targeted recovery. In an } \\
\text { unmitigated scenario, exceeding the } \\
\text { sludge limits could result in STS cask } \\
\text { overpressurization or a hydrogen } \\
\text { deflagration }\end{array}$ & $\begin{array}{l}\text { - Fluidizing water pump } \\
\text { ECRT-P-302 inlet and outlet } \\
\text { pressure instrumentation } \\
\text { (PIT-730-303, -304) } \\
\text { - Fluidizing water flow rate } \\
\text { instrumentation } \\
\text { (FQIT-730-301) } \\
\text { - Differential sludge weight } \\
\text { instrumentation } \\
\text { (DWI-740-704) } \\
\text { - STSC active ventilation } \\
\text { - Auxiliary ventilation system } \\
\text { - Modified KW Basin Annex } \\
\text { confinement ventilation } \\
\text { - Continuous air monitors }\end{array}$ & $\begin{array}{l}\text { - Procedures } \\
\text { - Training } \\
\text { - Conduct of operations } \\
\text { verifies proper system } \\
\text { configuration } \\
\text { - STSC sludge limit } \\
\text { verification } \\
\text { - Recovery Plan } \\
\text { - Modified KW Basin Annex } \\
\text { is unmanned during overfill } \\
\text { recovery operations }\end{array}$ & $\begin{array}{l}\text { The fluidizing pump speed is controlled by } \\
\text { variable frequency drive ECRT-VFD-302. } \\
\text { The pump speed will be set during } \\
\text { pre-operational testing. There will be no } \\
\text { procedural steps directing operators to adjust } \\
\text { the pump speed. } \\
\text { The overpressurization hazard does not exist } \\
\text { until the STS Cask lid is bolted onto the cask. } \\
\text { The STSC sludge limit verification } \\
\text { administrative control will prevent this activity } \\
\text { if the sludge limits are not met. } \\
\text { In the event that the targeted recovery could } \\
\text { not be achieved by the installed overfill } \\
\text { recovery tool, a Recovery Plan would be } \\
\text { developed. }\end{array}$ \\
\hline
\end{tabular}




\begin{tabular}{|c|c|c|c|c|c|c|c|}
\hline \multirow{2}{*}{ Item } & \multirow{2}{*}{$\begin{array}{l}\text { Process } \\
\text { Parameter }\end{array}$} & \multirow{2}{*}{ Deviation } & \multirow{2}{*}{ Cause } & \multirow{2}{*}{ Consequences } & \multicolumn{2}{|c|}{ Candidate Controls } & \multirow{2}{*}{ Remarks } \\
\hline & & & & & Engineered & Administrative & \\
\hline 11.a-7 & Pressure & High & $\begin{array}{l}\text { - Fluidizing pump } \\
\text { ECRT-P-302 speed high } \\
\text { - Fluidizing jets are } \\
\text { plugged }\end{array}$ & $\begin{array}{l}\text { Uncontrolled Release/lndustrial Safety: } \\
\text { If the fluidizing pump speed is high then } \\
\text { the flow rate will be high. If sufficiently } \\
\text { high, then eventually the STSC will be } \\
\text { overfilled and slurry will overflow into the } \\
\text { 4-in and 1-in. ventilation exhaust lines, } \\
\text { and into the } 1 \text {-in. ventilation inlet line, } \\
\text { leading to a splash and splatter/pool } \\
\text { release. } \\
\text { If the pressure is high, then the fluidizing } \\
\text { water line could fail. This would result in } \\
\text { a spill of IXM water. } \\
\text { If hose ECRT-H-302 failed completely or } \\
\text { became disconnected, then hose whip } \\
\text { could potentially whip and injure a faciility } \\
\text { worker or damage other equipment. } \\
\text { If hose ECRT-H-302 failed completely or } \\
\text { became disconnected, then liquid could } \\
\text { be siphoned from the STSC leading to } \\
\text { splash and splatter/pool release. }\end{array}$ & $\begin{array}{l}\text { - Fluidizing jet O-rings (to } \\
\text { prevent plugging) } \\
\text { - Level switches } \\
\text { LS/LSH/LSHH-740-401 } \\
\text { - High level switch } \\
\text { LSH-740-402 } \\
\text { - Emergency stop switch } \\
\text { ECRT-ES-1 } \\
\text { - Piping designed to B31.3, } \\
\text { "Process Piping" } \\
\text { - Check valve ECRT-CV-302 } \\
\text { - Modified KW Basin Annex } \\
\text { confinement ventilation } \\
\text { - Continuous air monitors. }\end{array}$ & $\begin{array}{l}\text { - Procedures } \\
\text { - Training } \\
\text { - Radiological Control } \\
\text { Program } \\
\text { - Industrial Safety Program } \\
\text { - Modified KW Basin Annex } \\
\text { is unmanned during overfill } \\
\text { recovery operations }\end{array}$ & $\begin{array}{l}\text { The fluidizing pump speed is controlled by } \\
\text { variable frequency drive ECRT-VFD-302. } \\
\text { The pump speed will be set during } \\
\text { pre-operational testing. There will be no } \\
\text { procedural steps directing operators to adjust } \\
\text { the pump speed. } \\
\text { Relative to B31.3, the piping and hoses are } \\
\text { designed to withstand the deadhead } \\
\text { pressure of fluidizing water pump } \\
\text { ECRT-P-302. } \\
\text { Spills of IXM water constitute a minor } \\
\text { radiological hazard to facility workers based } \\
\text { on operational experience at the KW Basin. }\end{array}$ \\
\hline $11 . a-8$ & $\begin{array}{l}\text { Structural } \\
\text { Integrity }\end{array}$ & Leak/rupture & $\begin{array}{l}\text { - High pressure (see } \\
\text { Item 11.a-7 above) } \\
\text { - Manufacturing flaw } \\
\text { - Procurement error } \\
\text { - Hose connection } \\
\text { decouples }\end{array}$ & $\begin{array}{l}\text { Uncontrolled Release/Industrial Safety: } \\
\text { If the fluidizing water line failed, then there } \\
\text { would be a spill of IXM water. } \\
\text { If hose ECRT-H-302 failed completely or } \\
\text { became disconnected, then hose whip } \\
\text { could potentially whip and injure a facility } \\
\text { worker or damage other equipment. } \\
\text { If hose ECRT-H-302 failed completely or } \\
\text { became disconnected, then liquid could } \\
\text { be siphoned from the STSC leading to } \\
\text { splash and splatter/pool release. }\end{array}$ & $\begin{array}{l}\text { - Piping designed to B31.3, } \\
\text { "Process Piping" } \\
\text { - Check valve ECRT-CV-302 } \\
\text { - Modified KW Basin Annex } \\
\text { confinement ventilation } \\
\text { - Continuous air monitors }\end{array}$ & $\begin{array}{l}\text { - Procedures } \\
\text { - Training } \\
\text { - Hydro testing } \\
\text { - Radiological Control } \\
\text { Program } \\
\text { - Industrial Safety Program } \\
\text { - Modified KW Basin Annex } \\
\text { is unmanned during overfill } \\
\text { recovery operations }\end{array}$ & $\begin{array}{l}\text { Relative to B31.3, the piping and hoses are } \\
\text { designed to withstand the deadhead } \\
\text { pressure of fluidizing water pump } \\
\text { ECRT-P-302. } \\
\text { Spills of IXM water constitute a minor } \\
\text { radiological hazard to facility workers based } \\
\text { on operational experience at the KW Basin. }\end{array}$ \\
\hline
\end{tabular}


Table C-32. HAZOP Results, Node 11.a. Overfill Recovery - IXM Water to Recovery Tool Fluidizing Jets

\begin{tabular}{|c|c|c|c|c|c|c|c|}
\hline \multirow{2}{*}{ Item } & \multirow{2}{*}{$\begin{array}{l}\text { Process } \\
\text { Parameter }\end{array}$} & \multirow{2}{*}{ Deviation } & \multirow{2}{*}{ Cause } & \multirow{2}{*}{ Consequences } & \multicolumn{2}{|c|}{ Candidate Controls } & \multirow{2}{*}{ Remarks } \\
\hline & & & & & Engineered & Administrative & \\
\hline 11.a-9 & Time Procedure & Too short & $\begin{array}{l}\text { - Operator error } \\
\text { - Instrumentation failure }\end{array}$ & $\begin{array}{l}\text { Operational Upset: } \\
\text { If the fluidizing flow valve is open for too } \\
\text { short a period of time, then it could take } \\
\text { longer to achieve the targeted recovery. } \\
\text { Overpressurization/Hydrogen } \\
\text { Deflagration: } \\
\text { If the fluidizing jets are operated for too } \\
\text { short a period of time, sludge might not be } \\
\text { sufficiently fluidized to achieve the } \\
\text { targeted recovery. In an unmitigated } \\
\text { scenario, exceeding the sludge limits } \\
\text { could result in STS cask } \\
\text { overpressurization or a hydrogen } \\
\text { deflagration. }\end{array}$ & $\begin{array}{l}\text { - Differential sludge weight } \\
\text { instrumentation } \\
\text { (DWI-740-704) } \\
\text { - STSC active ventilation } \\
\text { - Auxiliary ventilation system } \\
\text { - Modified KW Basin Annex } \\
\text { - confinement ventilation } \\
\text { - Continuous air monitors }\end{array}$ & $\begin{array}{l}\text { - Procedures } \\
\text { - Training } \\
\text { - STSC sludge limit } \\
\text { verification } \\
\text { - Recovery Plan } \\
\text { - Modified KW Basin Annex } \\
\text { is unmanned during overfill } \\
\text { recovery operations }\end{array}$ & $\begin{array}{l}\text { The overpressurization hazard does not exist } \\
\text { until the STS Cask lid is bolted onto the cask. } \\
\text { The STSC sludge limit verification } \\
\text { administrative control will prevent this activity } \\
\text { if the sludge limits are not met. } \\
\text { In the event that the targeted recovery could } \\
\text { not be achieved by the installed overfill } \\
\text { recovery tool, a Recovery Plan would be } \\
\text { developed }\end{array}$ \\
\hline 11.a-10 & Time Procedure & Too long & $\begin{array}{l}\text { - Operator error } \\
\text { - Instrumentation failure }\end{array}$ & $\begin{array}{l}\text { Operational Upset: } \\
\text { If the fluidizing flow valve is opened for } \\
\text { too long a period of time, then too much } \\
\text { sludge could be recovered such that an } \\
\text { STSC is sent to T Plant with a low } \\
\text { as-settled sludge level. } \\
\text { Uncontrolled Release: } \\
\text { If the fluidizing water flow is not } \\
\text { terminated and overfill recovery pump } \\
\text { ECRT-P-301 is stopped, then eventually } \\
\text { the STSC will be overfilled and slurry will } \\
\text { overflow into the } 4 \text {-in and } 1 \text {-in. ventilation } \\
\text { exhaust lines, and into the } 1 \text {-in. ventilation } \\
\text { inlet line, leading to a splash and } \\
\text { splatter/pool release. }\end{array}$ & $\begin{array}{l}\text { - Differential sludge weight } \\
\text { instrumentation } \\
\text { (DWI-740-401) } \\
\text { - Level switches } \\
\text { LS/LSH/LSHH-740-401 } \\
\text { - High level switch } \\
\text { LSH-740-402 } \\
\text { - Emergency stop switch } \\
\text { ECRT-ES-1 } \\
\text { - Modified KW Basin Annex } \\
\text { confinement ventilation } \\
\text { - Continuous air monitors }\end{array}$ & $\begin{array}{l}\text { - Procedures } \\
\text { - Training } \\
\text { - Radiological Control } \\
\text { Program } \\
\text { - Modified KW Basin Annex } \\
\text { is unmanned during overfill } \\
\text { recovery operations }\end{array}$ & \\
\hline
\end{tabular}


Table C-32. HAZOP Results, Node 11.a. Overfill Recovery - IXM Water to Recovery Tool Fluidizing Jets

\begin{tabular}{|c|c|c|c|c|c|c|c|}
\hline \multirow{2}{*}{ Item } & \multirow{2}{*}{$\begin{array}{l}\text { Process } \\
\text { Parameter }\end{array}$} & \multirow{2}{*}{ Deviation } & \multirow{2}{*}{ Cause } & \multirow{2}{*}{ Consequences } & \multicolumn{2}{|c|}{ Candidate Controls } & \multirow{2}{*}{ Remarks } \\
\hline & & & & & Engineered & Administrative & \\
\hline 11.a-11 & Time Procedure & $\begin{array}{l}\text { Skip action } \\
\text { (fluidizing } \\
\text { water valve } \\
\text { not opened) }\end{array}$ & $\begin{array}{l}\text { - Operator error } \\
\text { - Instrumentation failure }\end{array}$ & $\begin{array}{l}\text { Operational Upset: } \\
\text { If operators do not open fluidizing water } \\
\text { valve ECRT-AOV-304, then IXM water } \\
\text { will flow to the fluidizing jets via bypass } \\
\text { orifice ECRT-FO-301 at a reduced } \\
\text { pressure and flow rate such that it could } \\
\text { take longer to achieve the targeted } \\
\text { recovery. } \\
\text { Overpressurization/Hydrogen } \\
\text { Deflagration: } \\
\text { If operators do not open fluidizing water } \\
\text { valve ECRT-AOV-304, then IXM water } \\
\text { will flow to the fluidizing jets via bypass } \\
\text { orifice ECRT-FO-301 at a reduced } \\
\text { pressure and flow rate. The pressure and } \\
\text { flow rate might not be sufficiently fluidized } \\
\text { to achieve the targeted recovery. In an } \\
\text { unmitigated scenario, exceeding the } \\
\text { sludge limits could result in STS cask } \\
\text { overpressurization or a hydrogen } \\
\text { deflagration }\end{array}$ & $\begin{array}{l}\text { - Differential sludge weight } \\
\text { instrumentation } \\
\text { (DWI-740-704) } \\
\text { - STSC active ventilation } \\
\text { - Auxiliary ventilation system } \\
\text { - Modified KW Basin Annex } \\
\text { confinement ventilation } \\
\text { - Continuous air monitors }\end{array}$ & $\begin{array}{l}\text { - Procedures } \\
\text { - Training } \\
\text { - STSC sludge limit } \\
\text { verification } \\
\text { - Recovery Plan } \\
\text { - Modified KW Basin Annex } \\
\text { is unmanned during overfill } \\
\text { recovery operations }\end{array}$ & $\begin{array}{l}\text { The overpressurization hazard does not exist } \\
\text { until the STS Cask lid is bolted onto the cask. } \\
\text { The STSC sludge limit verification } \\
\text { administrative control will prevent this activity } \\
\text { if the sludge limits are not met. } \\
\text { In the event that the targeted recovery could } \\
\text { not be achieved by the installed overfill } \\
\text { recovery tool, a Recovery Plan would be } \\
\text { developed }\end{array}$ \\
\hline 11.a-12 & Time Procedure & Wrong action & N/A & N/A & N/A & N/A & $\begin{array}{l}\text { There are no wrong actions associated with } \\
\text { this node. }\end{array}$ \\
\hline
\end{tabular}




\begin{tabular}{|c|c|c|}
\hline Process Parameter & Design Intent & Remarks \\
\hline Flow & $20 \mathrm{gpm}$ & The $20 \mathrm{gpm}$ is established by the dilution water line pressure and the number and size of dilution water orifices. \\
\hline Pressure & $100 \mathrm{psi}$ & The pressure is the based on the IXM water supply pressure. \\
\hline Concentration & Not applicable & $\begin{array}{l}\text { The Skimmer Water Cleanup System takes basin water and pumps it first through a sand filter (for water clarity) } \\
\text { and then through an IXM (to remove ionic species). The IXM water concentration is not a critical attribute of } \\
\text { recovery tool operability. }\end{array}$ \\
\hline Composition & Not applicable & $\begin{array}{l}\text { There are no other process fluids at the KW Basin that could be inadvertently connected or directed to the } \\
\text { overfill recovery pump skid. }\end{array}$ \\
\hline Structural Integrity & Maintain integrity under normal operating conditions & The IXM water lines are a combination of piping and hoses. \\
\hline Level & Maintain liquid level in STSC below LE-740-401 setting & $\begin{array}{l}\text { If the liquid level in the STSC reached the setting of LSH-740-402, then interlock I-3 would terminate IXM water } \\
\text { flow. }\end{array}$ \\
\hline Temperature & Not applicable & $\begin{array}{l}\text { Temperature is not a process parameter that is monitored or controlled. The } 1.3 \text { million gallons of water in the } \\
\mathrm{KW} \text { Basin is maintained at a temperature of } 10-15^{\circ} \mathrm{C} \text {. The IXM water is approximately the same temperature } \\
\text { as the basin water, i.e., the pumps of the Skimmer Water Cleanup System do not impart significant thermal } \\
\text { energy to the water. Fluctuations in basin water temperature occur very slowly. The IXM water temperature is } \\
\text { not a critical attribute of recovery tool operability, }\end{array}$ \\
\hline Time Procedure & For the duration of the overfill recovery & $\begin{array}{l}\text { Dilution water flow is initiated prior to operation of the fluidizing jets and is terminated when the target recovery } \\
\text { has been achieved. This is a manual operation. }\end{array}$ \\
\hline
\end{tabular}


Table C-34. HAZOP Results, Node 11.b. Overfill Recovery - IXM Water to Recovery Tool Dilution Water

\begin{tabular}{|c|c|c|c|c|c|c|c|}
\hline \multicolumn{8}{|c|}{ Table C-34. HAZOP Results, Node 11.b. Overfill Recovery - IXM Water to Recovery Tool Dilution Water } \\
\hline \multirow{2}{*}{ Item } & \multirow{2}{*}{$\begin{array}{l}\text { Process } \\
\text { Parameter }\end{array}$} & \multirow{2}{*}{ Deviation } & \multirow{2}{*}{ Cause } & \multirow{2}{*}{ Consequences } & \multicolumn{2}{|c|}{ Candidate Controls } & \multirow{2}{*}{ Remarks } \\
\hline & & & & & Engineered & Administrative & \\
\hline 11.b-1. & Flow & No & $\begin{array}{l}\text { No IXM water supply } \\
\text { from the Skimmer } \\
\text { Water Cleanup System } \\
\text { - A normally-open valve is } \\
\text { closed }\end{array}$ & $\begin{array}{l}\text { Overpressurization/Hydrogen } \\
\text { Deflagration: } \\
\text { If there is no flow because there is no IXM } \\
\text { water supply, then there will be no dilution } \\
\text { water flow and there will be no flow to the } \\
\text { fluidizing jets. Overfill recovery pump } \\
\text { ECRT-P-301 would continue to operate } \\
\text { which could plug the overfill recovery tool. } \\
\text { If the plug could not be cleared, then the } \\
\text { targeted recovery would not be achieved. } \\
\text { In an unmitigated scenario, exceeding the } \\
\text { sludge limits could result in STS cask } \\
\text { overpressurization or a hydrogen } \\
\text { deflagration. } \\
\text { If there is no flow to because valve } \\
\text { ECRT-V-704, ECRT-AOV-701, or } \\
\text { ECRT-V-303 is closed, then there will be } \\
\text { no dilution water flow and there will be no } \\
\text { flow to the fluidizing jets. Consequences } \\
\text { are as stated above. } \\
\text { If there is no flow because valve } \\
\text { ECRT-AOV-706 is closed then there will } \\
\text { be no dilution water. Fluidizing jet water } \\
\text { alone might be sufficient to achieve the } \\
\text { targeted recovery. However, the overfill } \\
\text { recovery tool could plug. Consequences } \\
\text { are as stated above. }\end{array}$ & $\begin{array}{l}\text { - Valve position indicators } \\
\text { - Fluidizing water pump } \\
\text { ECRT-P-302 inlet and outlet } \\
\text { pressure instrumentation } \\
\text { (PIT-730-303, -304) } \\
\text { - Fluidizing water flow rate } \\
\text { instrumentation } \\
\text { (FQIT-730-301) } \\
\text { - Differential sludge weight } \\
\text { instrumentation } \\
\text { (DWI-740-704) } \\
\text { - STSC active ventilation } \\
\text { - Auxiliary ventilation system } \\
\text { - Modified KW Basin Annex } \\
\text { confinement ventilation } \\
\text { - Continuous air monitors }\end{array}$ & $\begin{array}{l}\text { - Procedures } \\
\text { - Training } \\
\text { - Conduct of operations } \\
\text { verifies proper system } \\
\text { configuration } \\
\text { - STSC sludge limit } \\
\text { verification } \\
\text { - Recovery Plan } \\
\text { - Modified KW Basin Annex } \\
\text { is unmanned during overfill } \\
\text { recovery operations }\end{array}$ & $\begin{array}{l}\text { There is no flow or pressure monitoring } \\
\text { instrumentation on the dilution water line. } \\
\text { It would be readily apparent to operators at } \\
\text { the start-up of overfill recovery operations if } \\
\text { there was no IXM water supply as prior to } \\
\text { overfill recovery IXM water is used to fill the } \\
\text { overfill recovery tool discharge line with } \\
\text { water. } \\
\text { Valve ECRT-AOV-701 is an air-operated } \\
\text { valve. The valve closes on loss of air. The } \\
\text { valve also closes on loss of power to } \\
\text { solenoid-operated valve ECRT-SOV-701. } \\
\text { If the overfill recovery tool becomes plugged, } \\
\text { it can be backflushed with IXM water. } \\
\text { The STSC sludge limit verification control will } \\
\text { prevent disconnecting the STSC active } \\
\text { ventilation and the auxiliary ventilation } \\
\text { system from the STSC until the applicable } \\
\text { sludge limit is met. } \\
\text { The overpressurization hazard does not exist } \\
\text { until the STS Cask lid is bolted onto the cask. } \\
\text { The STSC sludge limit verification } \\
\text { administrative control will prevent this activity } \\
\text { if the sludge limits are not met. } \\
\text { In the event that the targeted recovery could } \\
\text { not be achieved by the installed overfill } \\
\text { recovery tool, a Recovery Plan would be } \\
\text { developed. }\end{array}$ \\
\hline
\end{tabular}




\begin{tabular}{|c|c|c|c|c|c|c|c|}
\hline \multirow{2}{*}{ Item } & \multirow{2}{*}{$\begin{array}{l}\text { Process } \\
\text { Parameter }\end{array}$} & \multirow{2}{*}{ Deviation } & \multirow{2}{*}{ Cause } & \multirow{2}{*}{ Consequences } & \multicolumn{2}{|c|}{ Candidate Controls } & \multirow{2}{*}{ Remarks } \\
\hline & & & & & Engineered & Administrative & \\
\hline 11.b-2 & Flow & Low & $\begin{array}{l}\text { - Low IXM water supply } \\
\text { flow rate from the } \\
\text { Skimmer Water Cleanup } \\
\text { System } \\
\text { - A normally open valve is } \\
\text { partially closed }\end{array}$ & $\begin{array}{l}\text { Overpressurization/Hydrogen } \\
\text { Deflagration: } \\
\text { If there is low dilution water flow, fluidizing } \\
\text { jet water alone could be sufficient to } \\
\text { achieve the targeted recovery. However, } \\
\text { the overfill recovery tool could plug. If the } \\
\text { plug could not be cleared, then the } \\
\text { targeted recovery would not be achieved. } \\
\text { In an unmitigated scenario, exceeding the } \\
\text { sludge limits could result in STS cask } \\
\text { overpressurization or a hydrogen } \\
\text { deflagration. }\end{array}$ & $\begin{array}{l}\text { - Valve position indicators } \\
\text { - Differential sludge weight } \\
\text { instrumentation } \\
\text { (DWI-740-704) } \\
\text { - STSC active ventilation } \\
\text { - Auxiliary ventilation system } \\
\text { - Modified KW Basin Annex } \\
\text { confinement ventilation } \\
\text { - Continuous air monitors }\end{array}$ & $\begin{array}{l}\text { - Procedures } \\
\text { - Training } \\
\text { - Conduct of operations } \\
\text { verifies proper system } \\
\text { configuration } \\
\text { - STSC sludge limit } \\
\text { verification } \\
\text { - Recovery Plan } \\
\text { - Modified KW Basin Annex } \\
\text { is unmanned during overfill } \\
\text { recovery operations }\end{array}$ & $\begin{array}{l}\text { There is no flow or pressure monitoring } \\
\text { instrumentation on the dilution water line. } \\
\text { The overpressurization hazard does not exist } \\
\text { until the STS Cask lid is bolted onto the cask. } \\
\text { The STSC sludge limit verification } \\
\text { administrative control will prevent this activity } \\
\text { if the sludge limits are not met. } \\
\text { In the event that the targeted recovery could } \\
\text { not be achieved by the installed overfill } \\
\text { recovery tool, a Recovery Plan would be } \\
\text { developed }\end{array}$ \\
\hline 11.b-3 & Flow & High & $\begin{array}{l}\text { High IXM water supply } \\
\text { flow rate from the } \\
\text { Skimmer Water Cleanup } \\
\text { System }\end{array}$ & $\begin{array}{l}\text { Uncontrolled Release: } \\
\text { If the flow rate is sufficiently high, then } \\
\text { eventually the STSC will be overfilled and } \\
\text { slurry will overflow into the } 4 \text {-in and } 1 \text {-in. } \\
\text { ventilation exhaust lines, and into the } 1 \text {-in. } \\
\text { ventilation inlet line, leading to a splash } \\
\text { and splatter/pool release. }\end{array}$ & $\begin{array}{l}\text { - Level switches } \\
\text { LS/LSH/LSHH-740-401 } \\
\text { - High level switch } \\
\text { LSH-740-402 } \\
\text { - Emergency stop switch } \\
\text { ECRT-ES-1 } \\
\text { - Modified KW Basin Annex } \\
\text { confinement ventilation } \\
\text { - Continuous air monitors }\end{array}$ & $\begin{array}{l}\text { - Procedures } \\
\text { - Training } \\
\text { - Radiological Control } \\
\text { Program } \\
\text { - Modified KW Basin Annex } \\
\text { is unmanned during overfill } \\
\text { recovery operations }\end{array}$ & $\begin{array}{l}\text { Under normal operating conditions } 62 \mathrm{gpm} \text { is } \\
\text { added to the STSC ( } 42 \mathrm{gpm} \text { from the } \\
\text { fluidizing jets and } 20 \mathrm{gpm} \text { dilution water) and } \\
70 \mathrm{gpm} \text { is withdrawn by the overfill recovery } \\
\text { pump. } \\
\text { The dilution water flow rate is a function of } \\
\text { the Skimmer Water Cleanup System } \\
\text { pressure and the number and diameter of the } \\
\text { overfill recovery tool dilution water orifices }\end{array}$ \\
\hline 11.b-4 & Flow & Reverse & $\begin{array}{l}\text { Siphon from STSC (see } \\
\text { remarks) }\end{array}$ & $\begin{array}{l}\text { Uncontrolled Release: } \\
\text { If a siphon is created, then liquid would be } \\
\text { drawn out of the STSC through the } \\
\text { dilution water orifices and discharged at } \\
\text { the location of system breach leading to } \\
\text { splash and splatter/pool release. }\end{array}$ & $\begin{array}{l}\text { - Check valve ECRT-CV-301 } \\
\text { - Modified KW Basin Annex } \\
\text { confinement ventilation } \\
\text { - Continuous air monitors }\end{array}$ & $\begin{array}{l}\text { - Procedures } \\
\text { - Training } \\
\text { - Radiological Control } \\
\text { Program } \\
\text { - Modified KW Basin Annex } \\
\text { is unmanned during overfill } \\
\text { recovery operations }\end{array}$ & $\begin{array}{l}\text { If valve ECRT-AOC-706 is closed and there } \\
\text { is a system breach below STSC liquid level, } \\
\text { then a siphon could be created. } \\
\text { There are three dilution water orifices, each } \\
\text { approximately } 3 \mathrm{~mm} \text { in diameter. The } \\
\text { orifices could plug with solids and either limit } \\
\text { or stop the siphon flow. }\end{array}$ \\
\hline
\end{tabular}




\begin{tabular}{|c|c|c|c|c|c|c|c|}
\hline \multirow{2}{*}{ Item } & \multirow{2}{*}{$\begin{array}{l}\text { Process } \\
\text { Parameter }\end{array}$} & \multirow{2}{*}{ Deviation } & \multirow{2}{*}{ Cause } & \multirow{2}{*}{ Consequences } & \multicolumn{2}{|c|}{ Candidate Controls } & \multirow{2}{*}{ Remarks } \\
\hline & & & & & Engineered & Administrative & \\
\hline 11.b-5 & Flow & $\begin{array}{l}\text { Misdirected } \\
\text { (to overfill } \\
\text { recovery tool } \\
\text { fluidizing jet } \\
\text { connection) }\end{array}$ & $\begin{array}{l}\text { Operator error in making } \\
\text { hose connections }\end{array}$ & $\begin{array}{l}\text { Overpressurization/Hydrogen } \\
\text { Deflagration: } \\
\text { If the dilution water and fluidizing water } \\
\text { hoses are cross-connected, then the } \\
\text { sludge might not be sufficiently fluidized } \\
\text { to achieve the targeted recovery. In an } \\
\text { unmitigated scenario, exceeding the } \\
\text { sludge limits could result in STS cask } \\
\text { overpressurization or a hydrogen } \\
\text { deflagration }\end{array}$ & $\begin{array}{l}\text { - Unique process connections } \\
\text { - STSC active ventilation } \\
\text { - Auxiliary ventilation system } \\
\text { - Modified KW Basin Annex } \\
\text { confinement ventilation } \\
\text { - Continuous air monitors }\end{array}$ & $\begin{array}{l}\text { - Procedures } \\
\text { - Training } \\
\text { - Conduct of operations } \\
\text { verifies proper system } \\
\text { configuration } \\
\text { - STSC sludge limit } \\
\text { verification } \\
\text { - Recovery Plan } \\
\text { - Modified KW Basin Annex } \\
\text { is unmanned during overfill } \\
\text { recovery operations }\end{array}$ & $\begin{array}{l}\text { The overpressurization hazard does not exist } \\
\text { until the STS Cask lid is bolted onto the cask. } \\
\text { The STSC sludge limit verification } \\
\text { administrative control will prevent this activity } \\
\text { if the sludge limits are not met. } \\
\text { In the event that the targeted recovery could } \\
\text { not be achieved by the installed overfill } \\
\text { recovery tool, a Recovery Plan would be } \\
\text { developed }\end{array}$ \\
\hline 11.b-6 & Pressure & Low & $\begin{array}{l}\text { - Low IXM water supply } \\
\text { pressure from the } \\
\text { Skimmer Water Cleanup } \\
\text { System }\end{array}$ & $\begin{array}{l}\text { Overpressurization/Hydrogen } \\
\text { Deflagration: } \\
\text { If there is dilution water pressure is low } \\
\text { then the flow will be low. Fluidizing jet } \\
\text { water alone might be sufficient to achieve } \\
\text { the targeted recovery. However, the } \\
\text { overfill recovery tool could plug. If the } \\
\text { plug could not be cleared, then the } \\
\text { targeted recovery would not be achieved. } \\
\text { In an unmitigated scenario, exceeding the } \\
\text { sludge limits could result in STS cask } \\
\text { overpressurization or a hydrogen } \\
\text { deflagration. }\end{array}$ & $\begin{array}{l}\text { - Valve position indicators } \\
\text { - Differential sludge weight } \\
\text { instrumentation } \\
\text { (DWI-740-704) } \\
\text { - STSC active ventilation } \\
\text { - Auxiliary ventilation system } \\
\text { - Modified KW Basin Annex } \\
\text { confinement ventilation } \\
\text { - Continuous air monitors }\end{array}$ & $\begin{array}{l}\text { - Procedures } \\
\text { - Training } \\
\text { - Conduct of operations } \\
\text { verifies proper system } \\
\text { configuration } \\
\text { - STSC sludge limit } \\
\text { verification } \\
\text { - Recovery Plan } \\
\text { - Modified KW Basin Annex } \\
\text { is unmanned during overfill } \\
\text { recovery operations }\end{array}$ & $\begin{array}{l}\text { There is no flow or pressure monitoring } \\
\text { instrumentation on the dilution water line. } \\
\text { The overpressurization hazard does not exist } \\
\text { until the STS Cask lid is bolted onto the cask. } \\
\text { The STSC sludge limit verification } \\
\text { administrative control will prevent this activity } \\
\text { if the sludge limits are not met. } \\
\text { In the event that the targeted recovery could } \\
\text { not be achieved by the installed overfill } \\
\text { recovery tool, a Recovery Plan would be } \\
\text { developed }\end{array}$ \\
\hline
\end{tabular}


Table C-34. HAZOP Results, Node 11.b. Overfill Recovery - IXM Water to Recovery Tool Dilution Water

\begin{tabular}{|c|c|c|c|c|c|c|c|}
\hline \multirow{2}{*}{ Item } & \multirow{2}{*}{$\begin{array}{l}\text { Process } \\
\text { Parameter }\end{array}$} & \multirow{2}{*}{ Deviation } & \multirow{2}{*}{ Cause } & \multirow{2}{*}{ Consequences } & \multicolumn{2}{|c|}{ Candidate Controls } & \multirow{2}{*}{ Remarks } \\
\hline & & & & & Engineered & Administrative & \\
\hline $11 . b-7$ & Pressure & High & $\begin{array}{l}\text { - High IXM water supply } \\
\text { pressure from the } \\
\text { Skimmer Water Cleanup } \\
\text { System }\end{array}$ & $\begin{array}{l}\text { Uncontrolled Release/Industrial Safety: } \\
\text { If the pressure is high then the flow rate } \\
\text { will be high. If sufficiently high, then } \\
\text { eventually the STSC will be overfilled and } \\
\text { slurry will overflow into the } 4 \text {-in and } 1 \text {-in. } \\
\text { ventilation exhaust lines, and into the } 1 \text {-in. } \\
\text { ventilation inlet line, leading to a splash } \\
\text { and splatter/pool release. } \\
\text { If the pressure is high, then the dilution } \\
\text { water line could fail. This would result in } \\
\text { a spill of IXM water. } \\
\text { If hose ECRT-H-301 failed completely or } \\
\text { became disconnected, then hose whip } \\
\text { could potentially whip and injure a facility } \\
\text { worker or damage other equipment. } \\
\text { If hose ECRT-H-301 failed completely or } \\
\text { became disconnected, then liquid could } \\
\text { be siphoned from the STSC leading to } \\
\text { splash and splatter/pool release. }\end{array}$ & $\begin{array}{l}\text { - Level switches } \\
\text { LS/LSH/LSHH-740-401 } \\
\text { - High level switch } \\
\text { LSH-740-402 } \\
\text { - Emergency stop switch } \\
\text { ECRT-ES-1 } \\
\text { - Piping designed to B31.3, } \\
\text { "Process Piping" } \\
\text { - Check valve ECRT-CV-301 } \\
\text { - Modified KW Basin Annex } \\
\text { confinement ventilation } \\
\text { - Continuous air monitors }\end{array}$ & $\begin{array}{l}\text { - Procedures } \\
\text { - Training } \\
\text { - Radiological Control } \\
\text { Program } \\
\text { - Industrial Safety Program } \\
\text { - Modified KW Basin Annex } \\
\text { is unmanned during overfill } \\
\text { recovery operations }\end{array}$ & $\begin{array}{l}\text { The fluidizing pump speed is controlled by } \\
\text { variable frequency drive ECRT-VFD-302. } \\
\text { The pump speed will be set during } \\
\text { pre-operational testing. There will be no } \\
\text { procedural steps directing operators to adjust } \\
\text { the pump speed. } \\
\text { Relative to B31.3, the piping and hoses are } \\
\text { designed to withstand the deadhead } \\
\text { pressure of Skimmer Water Cleanup System } \\
\text { Spills of IXM water constitute a minor } \\
\text { radiological hazard to facility workers based } \\
\text { on operational experience at the KW Basin. }\end{array}$ \\
\hline $11 . b-8$ & $\begin{array}{l}\text { Structural } \\
\text { Integrity }\end{array}$ & Leak/rupture & $\begin{array}{l}\text { - High pressure (see } \\
\text { Item 11.b-7 above) } \\
\text { - Manufacturing flaw } \\
\text { - Procurement error }\end{array}$ & $\begin{array}{l}\text { Uncontrolled Release/Industrial Safety: } \\
\text { If the pressure is high, then the dilution } \\
\text { water line could fail. This would result in } \\
\text { a spill of IXM water. } \\
\text { If hose ECRT-H-301 failed completely or } \\
\text { became disconnected, then hose whip } \\
\text { could potentially whip and injure a facility } \\
\text { worker or damage other equipment. } \\
\text { If hose ECRT-H-301 failed completely or } \\
\text { became disconnected, then liquid could } \\
\text { be siphoned from the STSC leading to } \\
\text { splash and splatter/pool release. }\end{array}$ & $\begin{array}{l}\text { - Piping designed to B31.3, } \\
\text { "Process Piping" } \\
\text { - Check valve ECRT-CV-301 } \\
\text { - Modified KW Basin Annex } \\
\text { confinement ventilation } \\
\text { - Continuous air monitors }\end{array}$ & $\begin{array}{l}\text { - Procedures } \\
\text { - Training } \\
\text { - Hydro testing } \\
\text { - Radiological Control } \\
\text { Program } \\
\text { - Industrial Safety Program } \\
\text { - Modified KW Basin Annex } \\
\text { is unmanned during overfill } \\
\text { recovery operations }\end{array}$ & $\begin{array}{l}\text { Relative to B } 31.3 \text {, the piping and hoses are } \\
\text { designed to withstand the deadhead } \\
\text { pressure of fluidizing water pump } \\
\text { ECRT-P-302. } \\
\text { Spills of IXM water constitute a minor } \\
\text { radiological hazard to facility workers based } \\
\text { on operational experience at the KW Basin. }\end{array}$ \\
\hline
\end{tabular}


Table C-34. HAZOP Results, Node 11.b. Overfill Recovery - IXM Water to Recovery Tool Dilution Water

\begin{tabular}{|c|c|c|c|c|c|c|c|}
\hline \multirow{2}{*}{ Item } & \multirow{2}{*}{$\begin{array}{l}\text { Process } \\
\text { Parameter }\end{array}$} & \multirow{2}{*}{ Deviation } & \multirow{2}{*}{ Cause } & \multirow{2}{*}{ Consequences } & \multicolumn{2}{|c|}{ Candidate Controls } & \multirow{2}{*}{ Remarks } \\
\hline & & & & & Engineered & Administrative & \\
\hline $11 . b-9$ & Time Procedure & Too short & $\begin{array}{l}\text { - Operator error } \\
\text { - Instrumentation failure }\end{array}$ & $\begin{array}{l}\text { Operational Upset: } \\
\text { If the dilution water flow is terminated } \\
\text { early, then it could take longer to achieve } \\
\text { the targeted recovery. } \\
\text { Overpressurization/Hydrogen } \\
\text { Deflagration: } \\
\text { If the dilution water flow is terminated } \\
\text { early, fluidizing jet water alone might be } \\
\text { sufficient to achieve the targeted } \\
\text { recovery. However, the overfill recovery } \\
\text { tool could plug. If the plug could not be } \\
\text { cleared, then the targeted recovery would } \\
\text { not be achieved. In an unmitigated } \\
\text { scenario, exceeding the sludge limits } \\
\text { could result in STS cask } \\
\text { overpressurization or a hydrogen } \\
\text { deflagration. }\end{array}$ & $\begin{array}{l}\text { - Differential sludge weight } \\
\text { instrumentation } \\
\text { (DWI-740-704) } \\
\text { - STSC active ventilation } \\
\text { - Auxiliary ventilation system } \\
\text { - Modified KW Basin Annex } \\
\text { confinement ventilation } \\
\text { - Continuous air monitors }\end{array}$ & $\begin{array}{l}\text { - Procedures } \\
\text { - Training } \\
\text { - STSC sludge limit } \\
\text { verification } \\
\text { - Recovery Plan } \\
\text { - Modified KW Basin Annex } \\
\text { is unmanned during overfill } \\
\text { recovery operations }\end{array}$ & $\begin{array}{l}\text { The overpressurization hazard does not exist } \\
\text { until the STS Cask lid is bolted onto the cask. } \\
\text { The STSC sludge limit verification } \\
\text { administrative control will prevent this activity } \\
\text { if the sludge limits are not met. } \\
\text { In the event that the targeted recovery could } \\
\text { not be achieved by the installed overfill } \\
\text { recovery tool, a Recovery Plan would be } \\
\text { developed }\end{array}$ \\
\hline 11.b-10 & Time Procedure & Too long & $\begin{array}{l}\text { - Operator error } \\
\text { - Instrumentation failure }\end{array}$ & $\begin{array}{l}\text { Uncontrolled Release: } \\
\text { If the dilution water flow is not terminated } \\
\text { and overfill recovery pump ECRT-P-301 } \\
\text { is stopped, then eventually the STSC will } \\
\text { be overfilled and slurry will overflow into } \\
\text { the } 4 \text {-in and } 1 \text {-in. ventilation exhaust lines, } \\
\text { and into the } 1 \text {-in. ventilation inlet line, } \\
\text { leading to a splash and splatter/pool } \\
\text { release. }\end{array}$ & $\begin{array}{l}\text { - Level switches } \\
\text { LS/LSH/LSHH-740-401 } \\
\text { - High level switch } \\
\text { LSH-740-402 } \\
\text { - Emergency stop switch } \\
\text { ECRT-ES-1 } \\
\text { - Modified KW Basin Annex } \\
\text { confinement ventilation } \\
\text { - Continuous air monitors }\end{array}$ & $\begin{array}{l}\text { - Procedures } \\
\text { - Training } \\
\text { - Radiological Control } \\
\text { Program } \\
\text { - Modified KW Basin Annex } \\
\text { is unmanned during overfill } \\
\text { recovery operations }\end{array}$ & \\
\hline
\end{tabular}


Table C-34. HAZOP Results, Node 11.b. Overfill Recovery - IXM Water to Recovery Tool Dilution Water

\begin{tabular}{|c|c|c|c|c|c|c|c|}
\hline \multirow{2}{*}{ Item } & \multirow{2}{*}{$\begin{array}{l}\text { Process } \\
\text { Parameter }\end{array}$} & \multirow{2}{*}{ Deviation } & \multirow{2}{*}{ Cause } & \multirow{2}{*}{ Consequences } & \multicolumn{2}{|c|}{ Candidate Controls } & \multirow{2}{*}{ Remarks } \\
\hline & & & & & Engineered & Administrative & \\
\hline $11 . b-11$ & Time Procedure & $\begin{array}{l}\text { Skip action } \\
\text { (dilution water } \\
\text { valve not } \\
\text { opened) }\end{array}$ & Operator error & $\begin{array}{l}\text { Overpressurization/Hydrogen } \\
\text { Deflagration: } \\
\text { If operators do not open dilution water } \\
\text { valve ECRT AOV-706, then there will be } \\
\text { no dilution water. Fluidizing jet water } \\
\text { alone might be sufficient to achieve the } \\
\text { targeted recovery. However, the overfill } \\
\text { recovery tool could plug. If the plug could } \\
\text { not be cleared, then the targeted recovery } \\
\text { would not be achieved. In an unmitigated } \\
\text { scenario, exceeding the sludge limits } \\
\text { could result in STS cask } \\
\text { overpressurization or a hydrogen } \\
\text { deflagration. }\end{array}$ & $\begin{array}{l}\text { - Valve position indicators } \\
\text { - Differential sludge weight } \\
\text { instrumentation } \\
\text { (DWI-740-704) } \\
\text { - STSC active ventilation } \\
\text { - Auxiliary ventilation system } \\
\text { - Modified KW Basin Annex } \\
\text { confinement ventilation } \\
\text { - Continuous air monitors }\end{array}$ & $\begin{array}{l}\text { - Procedures } \\
\text { - Training } \\
\text { - Conduct of operations } \\
\text { verifies proper system } \\
\text { configuration } \\
\text { - STSC sludge limit } \\
\text { verification } \\
\text { - Recovery Plan } \\
\text { - Modified KW Basin Annex } \\
\text { is unmanned during overfill } \\
\text { recovery operations }\end{array}$ & $\begin{array}{l}\text { The overpressurization hazard does not exist } \\
\text { until the STS Cask lid is bolted onto the cask. } \\
\text { The STSC sludge limit verification } \\
\text { administrative control will prevent this activity } \\
\text { if the sludge limits are not met. } \\
\text { In the event that the targeted recovery could } \\
\text { not be achieved by the installed overfill } \\
\text { recovery tool, a Recovery Plan would be } \\
\text { developed }\end{array}$ \\
\hline 11.b-12 & Time Procedure & Wrong action & N/A & N/A & N/A & N/A & $\begin{array}{l}\text { There are no wrong actions associated with } \\
\text { this node. }\end{array}$ \\
\hline
\end{tabular}




\begin{tabular}{|c|c|c|}
\hline Process Parameter & Design Intent & Remarks \\
\hline Flow & Nominally $70 \mathrm{gpm}$ & $\begin{array}{l}\text { Motive force is overfill recovery pump ECRT-P-301 located in the transfer line service box. Overfill recovery } \\
\text { pump ECRT-P-301 is an air-operated, double-diaphragm (AODD) pump }\end{array}$ \\
\hline Pressure & Full vacuum to $0 \mathrm{psi}$ & This segment of the overfill recovery tool discharge line is under suction during overfill recovery. \\
\hline Concentration & Not applicable & The vol \% solids in the recovered sludge is not monitored or controlled. \\
\hline Composition & Not applicable & $\begin{array}{l}\text { The composition of the recovered sludge (i.e., KE, KW, or settler tank sludge) depends on the engineered } \\
\text { container from which the sludge was originally retrieved. }\end{array}$ \\
\hline Structural Integrity & Maintain integrity under normal operating conditions & The overfill recovery tool discharge line is a combination of hose and piping. \\
\hline Level & Maintain liquid level in STSC below LE-740-401 setting & $\begin{array}{l}\text { If the liquid level in the STSC reached the setting of LSH-740-402, then interlock I-3 would terminate IXM water } \\
\text { flow. }\end{array}$ \\
\hline Temperature & Not applicable & $\begin{array}{l}\text { Temperature is not a process parameter that is monitored or controlled. The } 1.3 \text { million gallons of water in the } \\
\mathrm{KW} \text { Basin is maintained at a temperature of } 10-15^{\circ} \mathrm{C} \text {. The IXM water is approximately the same temperature } \\
\text { as the basin water, i.e., the pumps of the Skimmer Water Cleanup System do not impart significant thermal } \\
\text { energy to the water. Fluctuations in basin water temperature occur very slowly. The IXM water temperature is } \\
\text { not a critical attribute of recovery tool operability, }\end{array}$ \\
\hline Time Procedure & For the duration of the overfill recovery & The overfill recovery pump is manually stopped when the target recovery has been achieved. \\
\hline
\end{tabular}


Table C-36. HAZOP Results, Node 11.c. Overfill Recovery - STSC to Pump ECRT-P-301

\begin{tabular}{|c|c|c|c|c|c|c|c|}
\hline \multirow{2}{*}{ Item } & \multirow{2}{*}{$\begin{array}{l}\text { Process } \\
\text { Parameter }\end{array}$} & \multirow{2}{*}{ Deviation } & \multirow{2}{*}{ Cause } & \multirow{2}{*}{ Consequences } & \multicolumn{2}{|c|}{ Candidate Controls } & \multirow{2}{*}{ Remarks } \\
\hline & & & & & Engineered & Administrative & \\
\hline 11.c-1 & Flow & No & $\begin{array}{l}\text { - Overfill recovery pump } \\
\text { ECRT-P-301 not } \\
\text { operating } \\
\text { - A normally opened valve } \\
\text { is closed } \\
\text { - Overfill recovery tool } \\
\text { rupture disk fails to } \\
\text { rupture } \\
\text { - Overfill recovery tool or } \\
\text { discharge line plugged }\end{array}$ & $\begin{array}{l}\text { Uncontrolled Release: } \\
\text { If there is no flow, then the STSC will } \\
\text { eventually be overfilled with IXM water } \\
\text { from the overfill recovery tool and slurry } \\
\text { will overflow into the } 4 \text {-in and 1-in. } \\
\text { ventilation exhaust lines, and into the } 1 \text {-in. } \\
\text { ventilation inlet line, leading to a splash } \\
\text { and splatter/pool release. } \\
\text { Overpressurization/Hydrogen } \\
\text { Deflagration: } \\
\text { If there was no flow, then there would be } \\
\text { no overfill recovery. In an unmitigated } \\
\text { scenario, exceeding the sludge limits } \\
\text { could result in STS cask } \\
\text { overpressurization or a hydrogen } \\
\text { deflagration. }\end{array}$ & $\begin{array}{l}\text { - Overfill recovery pump } \\
\text { ECRT-P-301 inlet and outlet } \\
\text { pressure instrumentation } \\
\text { (PIT-730-301, -302) } \\
\text { - Valve position indicators } \\
\text { - Level switches } \\
\text { LS/LSH/LSHH-740-401 } \\
\text { - High level switch } \\
\text { LSH-740-402 } \\
\text { - Emergency stop switch } \\
\text { ECRT-ES-1 } \\
\text { - Differential sludge weight } \\
\text { instrumentation } \\
\text { (DWI-740-704) } \\
\text { - STSC active ventilation } \\
\text { - Auxiliary ventilation system } \\
\text { - Modified KW Basin Annex } \\
\text { confinement ventilation } \\
\text { - Continuous air monitors }\end{array}$ & $\begin{array}{l}\text { - Procedures } \\
\text { - Training } \\
\text { - Radiological Control } \\
\text { Program } \\
\text { - STSC sludge limit } \\
\text { verification } \\
\text { - Recovery Plan } \\
\text { - Modified KW Basin Annex } \\
\text { is unmanned during overfill } \\
\text { recovery operations }\end{array}$ & $\begin{array}{l}\text { Under normal operating conditions } 62 \mathrm{gpm} \text { is } \\
\text { added to the STSC ( } 42 \mathrm{gpm} \text { from the } \\
\text { fluidizing jets and } 20 \mathrm{gpm} \text { dilution water) and } \\
70 \mathrm{gpm} \text { is withdrawn by the overfill recovery } \\
\text { pump. } \\
\text { The overpressurization hazard does not exist } \\
\text { until the STS Cask lid is bolted onto the cask. } \\
\text { The STSC sludge limit verification } \\
\text { administrative control will prevent this activity } \\
\text { if the sludge limits are not met. } \\
\text { In the event that the targeted recovery could } \\
\text { not be achieved by the installed overfill } \\
\text { recovery tool, a Recovery Plan would be } \\
\text { developed }\end{array}$ \\
\hline
\end{tabular}


Table C-36. HAZOP Results, Node 11.c. Overfill Recovery - STSC to Pump ECRT-P-301

\begin{tabular}{|c|c|c|c|c|c|c|c|}
\hline \multirow{2}{*}{ Item } & \multirow{2}{*}{$\begin{array}{l}\text { Process } \\
\text { Parameter }\end{array}$} & \multirow{2}{*}{ Deviation } & \multirow{2}{*}{ Cause } & \multirow{2}{*}{ Consequences } & \multicolumn{2}{|c|}{ Candidate Controls } & \multirow{2}{*}{ Remarks } \\
\hline & & & & & Engineered & Administrative & \\
\hline $11 . c-2$ & Flow & Low & $\begin{array}{l}\text { - Low air pressure to } \\
\text { Overfill recovery pump } \\
\text { ECRT-P-301 } \\
\text { - A normally open valve is } \\
\text { partially closed }\end{array}$ & $\begin{array}{l}\text { Operational Upset: } \\
\text { If the flow is low, then it could take longer } \\
\text { to achieve the targeted recovery. } \\
\text { Uncontrolled Release: } \\
\text { If the flow rate is sufficiently low, then } \\
\text { eventually the STSC will be overfilled with } \\
\text { IXM water from the overfill recovery tool } \\
\text { and slurry will overflow into the } 4 \text {-in and } \\
\text { 1-in. ventilation exhaust lines, and into the } \\
\text { 1-in. ventilation inlet line, leading to a } \\
\text { splash and splatter/pool release. } \\
\text { Overpressurization/Hydrogen } \\
\text { Deflagration: } \\
\text { If the flow rate is low, then sludge could } \\
\text { settle out and plug the line. If the line } \\
\text { plugs, then there would be no overfill } \\
\text { recovery. If the plug could not be cleared, } \\
\text { then the targeted recovery would not be } \\
\text { achieved. In an unmitigated scenario, } \\
\text { exceeding the sludge limits could result in } \\
\text { STS cask overpressurization or a } \\
\text { hydrogen deflagration. }\end{array}$ & $\begin{array}{l}\text { - Instrument air pressure } \\
\text { control valve ECRT-PCV-761 } \\
\text { - Level switches } \\
\text { LS/LSH/LSHH-740-401 } \\
\text { - High level switch } \\
\text { LSH-740-402 } \\
\text { - Emergency stop switch } \\
\text { ECRT-ES-1 } \\
\text { - Differential sludge weight } \\
\text { instrumentation } \\
\text { (DWI-740-704) } \\
\text { - STSC active ventilation } \\
\text { - Auxiliary ventilation system } \\
\text { - Modified KW Basin Annex } \\
\text { confinement ventilation } \\
\text { - Continuous air monitors }\end{array}$ & $\begin{array}{l}\text { - Procedures } \\
\text { - Training } \\
\text { - Radiological Control } \\
\text { Program } \\
\text { - Modified KW Basin Annex } \\
\text { is unmanned during overfill } \\
\text { recovery operations }\end{array}$ & $\begin{array}{l}\text { The overpressurization hazard does not exist } \\
\text { until the STS Cask lid is bolted onto the cask. } \\
\text { The STSC sludge limit verification } \\
\text { administrative control will prevent this activity } \\
\text { if the sludge limits are not met. } \\
\text { In the event that the targeted recovery could } \\
\text { not be achieved by the installed overfill } \\
\text { recovery tool, a Recovery Plan would be } \\
\text { developed }\end{array}$ \\
\hline
\end{tabular}




\begin{tabular}{|c|c|c|c|c|c|c|c|}
\hline \multicolumn{8}{|c|}{ Table C-36. HAZOP Results, Node 11.c. Overfill Recovery - STSC to Pump ECRT-P-301 } \\
\hline \multirow{2}{*}{ Item } & \multirow{2}{*}{$\begin{array}{l}\text { Process } \\
\text { Parameter }\end{array}$} & \multirow{2}{*}{ Deviation } & \multirow{2}{*}{ Cause } & \multirow{2}{*}{ Consequences } & \multicolumn{2}{|c|}{ Candidate Controls } & \multirow{2}{*}{ Remarks } \\
\hline & & & & & Engineered & Administrative & \\
\hline $11 . c-3$ & Flow & High & $\begin{array}{l}\text { High air pressure to } \\
\text { Overfill recovery pump } \\
\text { ECRT-P-301 }\end{array}$ & $\begin{array}{l}\text { Overpressurization/Hydrogen } \\
\text { Deflagration: } \\
\text { If the flow was high, then the overfill } \\
\text { recovery tool could plug. If the plug could } \\
\text { not be cleared, then the targeted recovery } \\
\text { would not be achieved. In an unmitigated } \\
\text { scenario, exceeding the sludge limits } \\
\text { could result in STS cask } \\
\text { overpressurization or a hydrogen } \\
\text { deflagration. }\end{array}$ & $\begin{array}{l}\text { - Instrument air pressure } \\
\text { control valve ECRT-PCV-761 } \\
\text { - Overfill recovery pump air } \\
\text { supply pressure indication } \\
\text { (PI-270-767 } \\
\text { - Overfill recovery pump } \\
\text { ECRT-P-301 inlet and outlet } \\
\text { pressure instrumentation } \\
\text { (PIT-730-301, -302) } \\
\text { - Differential sludge weight } \\
\text { instrumentation } \\
\text { (DWI-740-704) } \\
\text { - STSC active ventilation } \\
\text { - Auxiliary ventilation system } \\
\text { - Modified KW Basin Annex } \\
\text { confinement ventilation } \\
\text { - Continuous air monitors }\end{array}$ & $\begin{array}{l}\text { - Procedures } \\
\text { - Training } \\
\text { - STSC sludge limit } \\
\text { verification } \\
\text { - Recovery Plan } \\
\text { - Modified KW Basin Annex } \\
\text { is unmanned during overfill } \\
\text { recovery operations }\end{array}$ & $\begin{array}{l}\text { If the high flow did not result in a line plug, } \\
\text { then the target recovery would be achieved } \\
\text { in a shorter period of time. } \\
\text { The overpressurization hazard does not exist } \\
\text { until the STS Cask lid is bolted onto the cask. } \\
\text { The STSC sludge limit verification } \\
\text { administrative control will prevent this activity } \\
\text { if the sludge limits are not met. }\end{array}$ \\
\hline $11 . c-4$ & Flow & Reverse & $\begin{array}{l}\text { Overfill recovery flush } \\
\text { valve open }\end{array}$ & $\begin{array}{l}\text { Uncontrolled Release: } \\
\text { If overfill recovery flush valve } \\
\text { ECRT-AOV-103 is open, then } 100 \mathrm{gpm} \text { of } \\
\text { IXM water at } 100 \text { psi will enter the overfill } \\
\text { recovery discharge line upstream of } \\
\text { overfill recovery pump ECRT-P-301. As } \\
\text { ECRT-P-301 pumps } 70 \mathrm{gpm} \text {, } \\
\text { approximately } 30 \mathrm{gpm} \text { of IXM water would } \\
\text { reverse flow to the STSC. Eventually the } \\
\text { STSC would be overfilled and slurry } \\
\text { would overflow into the } 4 \text {-in and } 1 \text {-in. } \\
\text { ventilation exhaust lines, and into the } 1 \text {-in. } \\
\text { ventilation inlet line, leading to a splash } \\
\text { and splatter/pool release. }\end{array}$ & $\begin{array}{l}\text { - Valve position indicators } \\
\text { - Level switches } \\
\text { LS/LSH/LSHH-740-401 } \\
\text { - High level switch } \\
\text { LSH-740-402 } \\
\text { - Emergency stop switch } \\
\text { ECRT-ES-1 } \\
\text { - Modified KW Basin Annex } \\
\text { confinement ventilation } \\
\text { - Continuous air monitors }\end{array}$ & $\begin{array}{l}\text { - Procedures } \\
\text { - Training } \\
\text { - Radiological Control } \\
\text { Program } \\
\text { - Modified KW Basin Annex } \\
\text { is unmanned during overfill } \\
\text { recovery operations }\end{array}$ & $\begin{array}{l}\text { Overfill recovery pump ECRT-P-301 cannot } \\
\text { run in reverse. The only way it could pump in } \\
\text { the reverse direction would be if it was } \\
\text { installed backwards. Such an error would be } \\
\text { discovered during pre-operation testing. }\end{array}$ \\
\hline 11.c-5 & Flow & Misdirected & N/A & N/A & N/A & N/A & $\begin{array}{l}\text { The flow from the STSC to overfill recovery } \\
\text { pump ECRT-P-301 cannot be misdirected. }\end{array}$ \\
\hline
\end{tabular}




\begin{tabular}{|c|c|c|c|c|c|c|c|}
\hline \multirow{2}{*}{ Item } & \multirow{2}{*}{$\begin{array}{l}\text { Process } \\
\text { Parameter }\end{array}$} & \multirow{2}{*}{ Deviation } & \multirow{2}{*}{ Cause } & \multirow{2}{*}{ Consequences } & \multicolumn{2}{|c|}{ Candidate Controls } & \multirow{2}{*}{ Remarks } \\
\hline & & & & & Engineered & Administrative & \\
\hline $11 . c-6$ & Pressure & Low & $N / A$ & $N / A$ & N/A & N/A & $\begin{array}{l}\text { This portion of the overfill recovery discharge } \\
\text { line is on the suction side of overfill recovery } \\
\text { pump ECRT-P-301. The hose is rate to full } \\
\text { vacuum. }\end{array}$ \\
\hline 11.c-7 & Pressure & High & $\begin{array}{l}\text { Line or valve closed plug } \\
\text { during flushing (see } \\
\text { remarks) }\end{array}$ & $\begin{array}{l}\text { Uncontrolled Release: } \\
\text { If the pressure is high, then the overfill } \\
\text { recovery tool discharge line could fail } \\
\text { resulting in an airborne spray or splash } \\
\text { and splatter/pool release.. }\end{array}$ & $\begin{array}{l}\text { - Piping designed to B31.3, } \\
\text { "Process Piping" } \\
\text { - Secondary containment with } \\
\text { leak detection (if failure } \\
\text { occurs within transfer line } \\
\text { service box. } \\
\text { - Modified KW Basin Annex } \\
\text { confinement ventilation } \\
\text { - Continuous air monitors }\end{array}$ & $\begin{array}{l}\text { Modified KW Basin Annex } \\
\text { is unmanned during overfill } \\
\text { recovery operations }\end{array}$ & $\begin{array}{l}\text { This portion of the overfill recovery discharge } \\
\text { line is on the suction side of overfill recovery } \\
\text { pump ECRT-P-301. However, after the } \\
\text { overfill recovery operation is complete the } \\
\text { line is flushed with IXM water. If the overfill } \\
\text { recovery tool or a portion of the line was } \\
\text { plugged, or if isolation valve ECRT-V-301 } \\
\text { was not opened, then the IXM water supply } \\
\text { would be deadhead. }\end{array}$ \\
\hline $11 . c-8$ & $\begin{array}{l}\text { Structural } \\
\text { integrity }\end{array}$ & Leak/rupture & $\begin{array}{l}\text { - Manufacturing flaw } \\
\text { - Procurement error } \\
\text { - Hose connection } \\
\text { decouples }\end{array}$ & $\begin{array}{l}\text { Radiological Control: } \\
\text { If there is a leak in the overfill recovery } \\
\text { discharge line, then air will be drawn into } \\
\text { the flow stream. This would result in air } \\
\text { bubbles in the KW Basin (see remarks) } \\
\text { Uncontrolled Release: } \\
\text { If overfill recovery discharge hose } \\
\text { ECRT-H-306 decouples at the transfer } \\
\text { line service box and drops below the } \\
\text { liquid level in the STSC, then a siphon } \\
\text { would be created. Liquid would be drawn } \\
\text { out of the STSC }\end{array}$ & $\begin{array}{l}\text { - Sump with leak detection } \\
\text { - Modified KW Basin Annex } \\
\text { confinement ventilation } \\
\text { - Continuous air monitors }\end{array}$ & $\begin{array}{l}\text { - Procedures } \\
\text { - Training } \\
\text { - Hydro testing } \\
\text { - Radiological Control } \\
\text { Program } \\
\text { - Modified KW Basin Annex } \\
\text { is unmanned during overfill } \\
\text { recovery operations } \\
\text { - Quality Assurance Program }\end{array}$ & $\begin{array}{l}\text { Historically, air bubbles in the KW Basin have } \\
\text { not resulted in a high airborne radioactivity or } \\
\text { a spread of contamination. }\end{array}$ \\
\hline 11.c-9 & Time procedure & Too short & $\begin{array}{l}\text { - Operator error } \\
\text { - Instrumentation failure } \\
\text { - Overfill recovery pump } \\
\text { failure }\end{array}$ & $\begin{array}{l}\text { Overpressurization/Hydrogen } \\
\text { Deflagration: } \\
\text { If the recovery operation occurs for too } \\
\text { short a period of time, then the targeted } \\
\text { recovery would not be achieved. In an } \\
\text { unmitigated scenario, exceeding the } \\
\text { sludge limits could result in STS cask } \\
\text { overpressurization or a hydrogen } \\
\text { deflagration. }\end{array}$ & $\begin{array}{l}\text { - Differential sludge weight } \\
\text { instrumentation } \\
\text { (DWI-740-704) } \\
\text { - STSC active ventilation } \\
\text { - Auxiliary ventilation system } \\
\text { - Modified KW Basin Annex } \\
\text { confinement ventilation } \\
\text { - Continuous air monitors }\end{array}$ & $\begin{array}{l}\text { - Procedures } \\
\text { - Training } \\
\text { - STSC sludge limit } \\
\text { verification } \\
\text { - Recovery Plan } \\
\text { - Modified KW Basin Annex } \\
\text { is unmanned during overfill } \\
\text { recovery operations }\end{array}$ & \\
\hline
\end{tabular}


Table C-36. HAZOP Results, Node 11.c. Overfill Recovery - STSC to Pump ECRT-P-301

\begin{tabular}{|c|c|c|c|c|c|c|c|}
\hline \multirow{2}{*}{ Item } & \multirow{2}{*}{$\begin{array}{l}\text { Process } \\
\text { Parameter }\end{array}$} & \multirow{2}{*}{ Deviation } & \multirow{2}{*}{ Cause } & \multirow{2}{*}{ Consequences } & \multicolumn{2}{|c|}{ Candidate Controls } & \multirow{2}{*}{ Remarks } \\
\hline & & & & & Engineered & Administrative & \\
\hline 11.c-10 & Time Procedure & Too long & $\begin{array}{l}\text { - Operator error } \\
\text { - Instrumentation failure }\end{array}$ & $\begin{array}{l}\text { Operational Upset: } \\
\text { If the recovery operation occurs for too } \\
\text { long a period of time, then too much } \\
\text { sludge could be recovered such that an } \\
\text { STSC is sent to T Plant with a low } \\
\text { as-settled sludge level. }\end{array}$ & $\begin{array}{l}\text { - Differential sludge weight } \\
\text { instrumentation } \\
\text { (DWI-740-704) }\end{array}$ & $\begin{array}{l}\text { - Procedures } \\
\text { - Training }\end{array}$ & \\
\hline 11.c-11 & Time Procedure & $\begin{array}{l}\text { Skip action } \\
\text { (Overfill } \\
\text { recovery } \\
\text { pump not } \\
\text { started) }\end{array}$ & Operator error & $\begin{array}{l}\text { Uncontrolled Release: } \\
\text { If operators do not start overfill recovery } \\
\text { pump ECRT-P-301, then there will be no } \\
\text { flow. If there is no flow then the STSC will } \\
\text { eventually be overfilled with IXM water } \\
\text { from the overfill recovery tool and slurry } \\
\text { will overflow into the } 4 \text {-in and } 1 \text {-in. } \\
\text { ventilation exhaust lines, and into the } 1 \text {-in. } \\
\text { ventilation inlet line, leading to a splash } \\
\text { and splatter/pool release. } \\
\text { Overpressurization/Hydrogen } \\
\text { Deflagration: } \\
\text { If the operators do not start overfill } \\
\text { recovery pump ECRT-P-301, then there } \\
\text { would be no overfill recovery. In an } \\
\text { unmitigated scenario, exceeding the } \\
\text { sludge limits could result in STS cask } \\
\text { overpressurization or a hydrogen } \\
\text { deflagration. }\end{array}$ & $\begin{array}{l}\text { - Level switches } \\
\text { LS/LSH/LSHH-740-401 } \\
\text { - High level switch } \\
\text { LSH-740-402 } \\
\text { - Differential sludge weight } \\
\text { instrumentation } \\
\text { (DWI-740-704) } \\
\text { - STSC active ventilation } \\
\text { - Auxiliary ventilation system } \\
\text { - Modified KW Basin Annex } \\
\text { confinement ventilation } \\
\text { - Continuous air monitors }\end{array}$ & $\begin{array}{l}\text { - Procedures } \\
\text { - Training } \\
\text { - STSC sludge limit } \\
\text { verification } \\
\text { - Recovery Plan } \\
\text { - Modified KW Basin Annex } \\
\text { is unmanned during overfill } \\
\text { recovery operations }\end{array}$ & $\begin{array}{l}\text { The overpressurization hazard does not exist } \\
\text { until the STS Cask lid is bolted onto the cask. } \\
\text { The STSC sludge limit verification } \\
\text { administrative control will prevent this activity } \\
\text { if the sludge limits are not met. }\end{array}$ \\
\hline 11.c-12 & Time Procedure & Wrong action & N/A & N/A & N/A & N/A & $\begin{array}{l}\text { There are no wrong actions associated with } \\
\text { this node. }\end{array}$ \\
\hline
\end{tabular}




\begin{tabular}{|c|c|c|}
\hline Process Parameter & Design Intent & Remarks \\
\hline Flow & Nominally $70 \mathrm{gpm}$ & $\begin{array}{l}\text { Motive force is overfill recovery pump ECRT-P-301 located in the transfer line service box. Overfill recovery } \\
\text { pump ECRT-P-301 is an air-operated, double-diaphragm (AODD) pump }\end{array}$ \\
\hline Pressure & Nominally 60 psig & $\begin{array}{l}\text { Pressure is controlled by the air pressure supplied to overfill recovery pump ECRT-P-301. The instrument air } \\
\text { system produces } 212 \mathrm{scfm} \text { of dry air at } 120 \mathrm{psig.} \text {. Pressure control valves are used to regulate the pressure to } \\
\text { the pump. }\end{array}$ \\
\hline Concentration & Not applicable & The vol \% solids in the recovered sludge is not monitored or controlled. \\
\hline Composition & Not applicable & $\begin{array}{l}\text { The composition of the recovered sludge (i.e., KE, KW, or settler tank sludge) depends on the engineered } \\
\text { container from which the sludge was originally retrieved. }\end{array}$ \\
\hline Structural Integrity & Maintain integrity under normal operating conditions & The overfill recovery tool discharge line is a combination of hose and piping. \\
\hline Level & Maintain liquid level in STSC below LE-740-401 setting & $\begin{array}{l}\text { If the liquid level in the STSC reached the setting of LSH-740-402, then interlock I-3 would terminate IXM water } \\
\text { flow. }\end{array}$ \\
\hline Temperature & Not applicable & $\begin{array}{l}\text { Temperature is not a process parameter that is monitored or controlled. The } 1.3 \text { million gallons of water in the } \\
\mathrm{KW} \text { Basin is maintained at a temperature of } 10-15^{\circ} \mathrm{C} \text {. The IXM water is approximately the same temperature } \\
\text { as the basin water, i.e., the pumps of the Skimmer Water Cleanup System do not impart significant thermal } \\
\text { energy to the water. Fluctuations in basin water temperature occur very slowly. The IXM water temperature is } \\
\text { not a critical attribute of recovery tool operability, }\end{array}$ \\
\hline Time Procedure & For the duration of the overfill recovery & The overfill recovery pump is manually stopped when the target recovery has been achieved. \\
\hline
\end{tabular}


Table C-38. HAZOP Results, Node 11.d. Overfill Recovery - Pump ECRT-P-301 to Engineered Container

\begin{tabular}{|c|c|c|c|c|c|c|c|}
\hline \multicolumn{8}{|c|}{ Table C-38. HAZOP Results, Node 11.d. Overfill Recovery - Pump ECRT-P-301 to Engineered Container } \\
\hline \multirow{2}{*}{ Item } & \multirow{2}{*}{$\begin{array}{l}\text { Process } \\
\text { Parameter }\end{array}$} & \multirow{2}{*}{ Deviation } & \multirow{2}{*}{ Cause } & \multirow{2}{*}{ Consequences } & \multicolumn{2}{|c|}{ Candidate Controls } & \multirow{2}{*}{ Remarks } \\
\hline & & & & & Engineered & Administrative & \\
\hline 11.d-1 & Flow & No & $\begin{array}{l}\text { - Overfill recovery pump } \\
\text { ECRT-P-301 not } \\
\text { operating } \\
\text { - A normally opened valve } \\
\text { is closed } \\
\text { - Overfill recovery tool } \\
\text { rupture disk fails to } \\
\text { rupture } \\
\text { - Overfill recovery tool or } \\
\text { discharge line plugged }\end{array}$ & $\begin{array}{l}\text { Uncontrolled Release: } \\
\text { If there is no flow, then the STSC will } \\
\text { eventually be overfilled with IXM water } \\
\text { from the overfill recovery tool and slurry } \\
\text { will overflow into the 4-in and 1-in. } \\
\text { ventilation exhaust lines, and into the 1-in. } \\
\text { ventilation inlet line, leading to a splash } \\
\text { and splatter/pool release. } \\
\text { Overpressurization/Hydrogen } \\
\text { Deflagration: } \\
\text { If there was no flow, then there would be } \\
\text { no overfill recovery. In an unmitigated } \\
\text { scenario, exceeding the sludge limits } \\
\text { could result in STS cask } \\
\text { overpressurization or a hydrogen } \\
\text { deflagration. }\end{array}$ & $\begin{array}{l}\text { - Overfill recovery pump } \\
\text { ECRT-P-301 inlet and outlet } \\
\text { pressure instrumentation } \\
\text { (PIT-730-301, -302) } \\
\text { - Valve position indicators } \\
\text { - Level switches } \\
\text { - LS/LSH/LSHH-740-401 } \\
\text { - High level switch } \\
\text { LSH-740-402 } \\
\text { - Emergency stop switch } \\
\text { ECRT-ES-1 } \\
\text { - Differential sludge weight } \\
\text { instrumentation } \\
\text { (DWI-740-704) } \\
\text { - STSC active ventilation } \\
\text { - Auxiliary ventilation system } \\
\text { - Modified KW Basin Annex } \\
\text { confinement ventilation } \\
\text { - Continuous air monitors }\end{array}$ & $\begin{array}{l}\text { - Procedures } \\
\text { - Training } \\
\text { - Radiological Control } \\
\text { Program } \\
\text { - STSC sludge limit } \\
\text { verification } \\
\text { - Recovery Plan } \\
\text { - Modified KW Basin Annex } \\
\text { is unmanned during overfill } \\
\text { recovery operations }\end{array}$ & $\begin{array}{l}\text { Under normal operating conditions } 62 \mathrm{gpm} \text { is } \\
\text { added to the STSC ( } 42 \mathrm{gpm} \text { from the } \\
\text { fluidizing jets and } 20 \mathrm{gpm} \text { dilution water) and } \\
70 \mathrm{gpm} \text { is withdrawn by the overfill recovery } \\
\text { pump. } \\
\text { The overpressurization hazard does not exist } \\
\text { until the STS Cask lid is bolted onto the cask. } \\
\text { The STSC sludge limit verification } \\
\text { administrative control will prevent this activity } \\
\text { if the sludge limits are not met. } \\
\text { In the event that the targeted recovery could } \\
\text { not be achieved by the installed overfill } \\
\text { recovery tool, a Recovery Plan would be } \\
\text { developed }\end{array}$ \\
\hline
\end{tabular}


Table C-38. HAZOP Results, Node 11.d. Overfill Recovery - Pump ECRT-P-301 to Engineered Container

\begin{tabular}{|c|c|c|c|c|c|c|c|}
\hline \multirow{2}{*}{ Item } & \multirow{2}{*}{$\begin{array}{l}\text { Process } \\
\text { Parameter }\end{array}$} & \multirow{2}{*}{ Deviation } & \multirow{2}{*}{ Cause } & \multirow{2}{*}{ Consequences } & \multicolumn{2}{|c|}{ Candidate Controls } & \multirow{2}{*}{ Remarks } \\
\hline & & & & & Engineered & Administrative & \\
\hline 11.d-2 & Flow & Low & $\begin{array}{l}\text { - Low air pressure to } \\
\text { Overfill recovery pump } \\
\text { ECRT-P-301 } \\
\text { - A normally open valve is } \\
\text { partially closed }\end{array}$ & $\begin{array}{l}\text { Operational Upset: } \\
\text { If the flow is low, then it could take longer } \\
\text { to achieve the targeted recovery. } \\
\text { Uncontrolled Release: } \\
\text { If the flow rate is sufficiently low, then } \\
\text { eventually the STSC will be overfilled with } \\
\text { IXM water from the overfill recovery tool } \\
\text { and slurry will overflow into the } 4 \text {-in and } \\
1 \text {-in. ventilation exhaust lines, and into the } \\
1 \text {-in. ventilation inlet line, leading to a } \\
\text { splash and splatter/pool release. } \\
\text { Overpressurization/Hydrogen } \\
\text { Deflagration: } \\
\text { If the flow rate is low, then sludge could } \\
\text { settle out and plug the line. If the line } \\
\text { plugs, then there would be no overfill } \\
\text { recovery. If the plug could not be cleared, } \\
\text { then the targeted recovery would not be } \\
\text { achieved. In an unmitigated scenario, } \\
\text { exceeding the sludge limits could result in } \\
\text { STS cask overpressurization or a } \\
\text { hydrogen deflagration. }\end{array}$ & $\begin{array}{l}\text { - Instrument air pressure } \\
\text { control valve ECRT-PCV-761 } \\
\text { - Level switches } \\
\text { LS/LSH/LSHH-740-401 } \\
\text { - High level switch } \\
\text { LSH-740-402 } \\
\text { - Emergency stop switch } \\
\text { ECRT-ES-1 } \\
\text { - Differential sludge weight } \\
\text { instrumentation } \\
\text { (DWI-740-704) } \\
\text { - STSC active ventilation } \\
\text { - Auxiliary ventilation system } \\
\text { - Modified KW Basin Annex } \\
\text { confinement ventilation } \\
\text { - Continuous air monitors }\end{array}$ & $\begin{array}{l}\text { - Procedures } \\
\text { - Training } \\
\text { - Radiological Control } \\
\text { Program } \\
\text { - Recovery Plan } \\
\text { - Modified KW Basin Annex } \\
\text { is unmanned during overfill } \\
\text { recovery operations }\end{array}$ & $\begin{array}{l}\text { The overpressurization hazard does not exist } \\
\text { until the STS Cask lid is bolted onto the cask. } \\
\text { The STSC sludge limit verification } \\
\text { administrative control will prevent this activity } \\
\text { if the sludge limits are not met. } \\
\text { In the event that the targeted recovery could } \\
\text { not be achieved by the installed overfill } \\
\text { recovery tool, a Recovery Plan would be } \\
\text { developed }\end{array}$ \\
\hline
\end{tabular}




\begin{tabular}{|c|c|c|c|c|c|c|c|}
\hline \multirow{2}{*}{ Item } & \multirow{2}{*}{$\begin{array}{l}\text { Process } \\
\text { Parameter }\end{array}$} & \multirow{2}{*}{ Deviation } & \multirow{2}{*}{ Cause } & \multirow{2}{*}{ Consequences } & \multicolumn{2}{|c|}{ Candidate Controls } & \multirow{2}{*}{ Remarks } \\
\hline & & & & & Engineered & Administrative & \\
\hline 11.d-3 & Flow & High & $\begin{array}{l}\text { High air pressure to } \\
\text { Overfill recovery pump } \\
\text { ECRT-P-301 }\end{array}$ & $\begin{array}{l}\text { Overpressurization/Hydrogen } \\
\text { Deflagration: } \\
\text { If the flow was high, then the overfill } \\
\text { recovery tool could plug. If the plug could } \\
\text { not be cleared, then the targeted recovery } \\
\text { would not be achieved. In an unmitigated } \\
\text { scenario, exceeding the sludge limits } \\
\text { could result in STS cask } \\
\text { overpressurization or a hydrogen } \\
\text { deflagration. }\end{array}$ & $\begin{array}{l}\text { - Instrument air pressure } \\
\text { control valve ECRT-PCV-761 } \\
\text { - Overfill recovery pump air } \\
\text { supply pressure indication } \\
\text { (PI-270-767 } \\
\text { - Overfill recovery pump } \\
\text { ECRT-P-301 inlet and outlet } \\
\text { pressure instrumentation } \\
\text { (PIT-730-301, -302) } \\
\text { - Differential sludge weight } \\
\text { instrumentation } \\
\text { (DWI-740-704) } \\
\text { - STSC active ventilation } \\
\text { - Auxiliary ventilation system } \\
\text { - Modified KW Basin Annex } \\
\text { confinement ventilation } \\
\text { - Continuous air monitors }\end{array}$ & $\begin{array}{l}\text { - Procedures } \\
\text { - Training } \\
\text { - STSC sludge limit } \\
\text { verification } \\
\text { - Recovery Plan } \\
\text { - Modified KW Basin Annex } \\
\text { is unmanned during overfill } \\
\text { recovery operations }\end{array}$ & $\begin{array}{l}\text { If the high flow did not result in a line plug, } \\
\text { then the target recovery would be achieved } \\
\text { in a shorter period of time. } \\
\text { The overpressurization hazard does not exist } \\
\text { until the STS Cask lid is bolted onto the cask. } \\
\text { The STSC sludge limit verification } \\
\text { administrative control will prevent this activity } \\
\text { if the sludge limits are not met. } \\
\text { In the event that the targeted recovery could } \\
\text { not be achieved by the installed overfill } \\
\text { recovery tool, a Recovery Plan would be } \\
\text { developed }\end{array}$ \\
\hline 11.d-4 & Flow & Reverse & N/A & N/A & N/A & N/A & $\begin{array}{l}\text { Overfill recovery pump ECRT-P-301 cannot } \\
\text { run in reverse. The only way it could pump in } \\
\text { the reverse direction would be if it was } \\
\text { installed backwards. Such an error would be } \\
\text { discovered during pre-operation testing. } \\
\text { During a slurry transfer, slurry could be } \\
\text { misdirected to the overfill recovery pump is } \\
\text { valve ECRT-V-102 is misaligned. Such an } \\
\text { event is addressed in Node 2.b, "Sludge } \\
\text { Transfer - Ingress/Egress Pipe to STSC." } \\
\text { See Table C-8, Item 2.b-5.d. }\end{array}$ \\
\hline
\end{tabular}




\begin{tabular}{|c|c|c|c|c|c|c|c|}
\hline \multirow{2}{*}{ Item } & \multirow{2}{*}{$\begin{array}{l}\text { Process } \\
\text { Parameter }\end{array}$} & \multirow{2}{*}{ Deviation } & \multirow{2}{*}{ Cause } & \multirow{2}{*}{ Consequences } & \multicolumn{2}{|c|}{ Candidate Controls } & \multirow{2}{*}{ Remarks } \\
\hline & & & & & Engineered & Administrative & \\
\hline 11.d-5.a & Flow & $\begin{array}{l}\text { Misdirected } \\
\text { (to booster } \\
\text { pump) }\end{array}$ & $\begin{array}{l}\text { Operator error } \\
\text { (see remarks) }\end{array}$ & $\begin{array}{l}\text { Uncontrolled Release: } \\
\text { If the flow is misdirected to booster pump } \\
\text { ECRT-P-101, then overfill recovery pump } \\
\text { ECRT-P-301 will deadhead resulting in } \\
\text { high pressure in the transfer line. The } \\
\text { high pressure could result in a transfer } \\
\text { line failure resulting in an airborne spray } \\
\text { or splash and splatter/pool release. }\end{array}$ & $\begin{array}{l}\text { - Piping designed to B31.3, } \\
\text { "Process Piping" } \\
\text { - Overfill recovery pump } \\
\text { ECRT-P-301 inlet and outlet } \\
\text { pressure instrumentation } \\
\text { (PIT-730-301,-302) } \\
\text { - Secondary containment with } \\
\text { leak detection } \\
\text { - Modified KW Basin Annex } \\
\text { confinement ventilation } \\
\text { - Continuous air monitors }\end{array}$ & $\begin{array}{l}\text { - Procedures } \\
\text { - Training } \\
\text { - Conduct of Operations } \\
\text { verifies proper system } \\
\text { configuration } \\
\text { - Radiological Control } \\
\text { Program } \\
\text { - Modified KW Basin.Annex } \\
\text { is unmanned during overfill } \\
\text { recovery operations }\end{array}$ & $\begin{array}{l}\text { For overfill recovery, hose ECRT-H-102 is } \\
\text { disconnected and a routing to the } \\
\text { engineering container is established. If hose } \\
\text { ECRT-H-102 is not disconnected, then } \\
\text { overfill recovery pump ECRT-P-301 would } \\
\text { deadhead against booster pump } \\
\text { ECRT-P-101. } \\
\text { Relative to B31.3, the piping and hoses are } \\
\text { designed to withstand the deadhead } \\
\text { pressure of overfill recovery pump } \\
\text { ECRT-P-301. }\end{array}$ \\
\hline 11.d-5.b & Flow & $\begin{array}{l}\text { Misdirected } \\
\text { (into basin) }\end{array}$ & $\begin{array}{l}\text { - Operator error } \\
\text { - Hose connection } \\
\text { decouples } \\
\text { (see remarks) }\end{array}$ & $\begin{array}{l}\text { Operational Upset: } \\
\text { If the flow is misdirected into the basin, } \\
\text { then the recovered sludge would be } \\
\text { deposited on the basin floor. }\end{array}$ & None & $\begin{array}{l}\text { - Procedures } \\
\text { - Training } \\
\text { - Conduct of Operations } \\
\text { verifies proper system } \\
\text { configuration }\end{array}$ & $\begin{array}{l}\text { For overfill recovery, hose ECRT-H-102 is } \\
\text { disconnected and a routing to the } \\
\text { engineering container is established. If the } \\
\text { hose was not connected to an engineered } \\
\text { container, or is the hose connected } \\
\text { decoupled at either the ingress/egress pipe } \\
\text { or engineered container, then sludge would } \\
\text { be deposited on the basin floor. }\end{array}$ \\
\hline 11.d-5.c & Flow & $\begin{array}{l}\text { Misdirected } \\
\text { (to incorrect } \\
\text { engineered } \\
\text { container) }\end{array}$ & $\begin{array}{l}\text { Operator error } \\
\text { (see remarks) }\end{array}$ & $\begin{array}{l}\text { Operational Upset: } \\
\text { If the flow is misdirected into the wrong } \\
\text { container, then sludge streams could be } \\
\text { mixed (e.g., settler tank sludge could be } \\
\text { mixed with KE sludge). }\end{array}$ & None & $\begin{array}{l}\text { - Procedures } \\
\text { - Training } \\
\text { - Conduct of Operations } \\
\text { verifies proper system } \\
\text { configuration } \\
\text { - Recovery Plan }\end{array}$ & $\begin{array}{l}\text { CHPRC has been directed to maintained the } \\
\text { sludge streams separate. If the streams were } \\
\text { mixed, a recovery plan would be developed } \\
\text { to determine the disposition of the mixed } \\
\text { stream. }\end{array}$ \\
\hline
\end{tabular}


PRC-STP-00467 REV 0

\begin{tabular}{|c|c|c|c|c|c|c|c|}
\hline \multicolumn{8}{|c|}{ Table C-38. HAZOP Results, Node 11.d. Overfill Recovery - Pump ECRT-P-301 to Engineered Container } \\
\hline \multirow{2}{*}{ Item } & \multirow{2}{*}{$\begin{array}{l}\text { Process } \\
\text { Parameter }\end{array}$} & \multirow{2}{*}{ Deviation } & \multirow{2}{*}{ Cause } & \multirow{2}{*}{ Consequences } & \multicolumn{2}{|c|}{ Candidate Controls } & \multirow{2}{*}{ Remarks } \\
\hline & & & & & Engineered & Administrative & \\
\hline 11.d-5.d & Flow & $\begin{array}{l}\text { Misdirected } \\
\text { (into STSC) }\end{array}$ & $\begin{array}{l}\text { Valve ECRT-V-102 } \\
\text { positioned incorrectly }\end{array}$ & $\begin{array}{l}\text { Uncontrolled Release: } \\
\text { If valve ECRT-V-102 is positioned } \\
\text { incorrectly, then the recovered sludge } \\
\text { would be directed back to the STSC. } \\
\text { Eventually the STSC will be overfilled with } \\
\text { IXM water from the overfill recovery tool } \\
\text { and slurry will overflow into the 4-in and } \\
1 \text {-in. ventilation exhaust lines, and into the } \\
1 \text {-in. ventilation inlet line, leading to a } \\
\text { splash and splatter/pool release. }\end{array}$ & $\begin{array}{l}\text { - Valve position indicators } \\
\text { - Differential sludge weight } \\
\text { instrumentation } \\
\text { (DWI-740-704) Level switches } \\
\text { LS/LSH/LSHH-740-401 } \\
\text { - High level switch } \\
\text { LSH-740-402 } \\
\text { - Emergency stop switch } \\
\text { ECRT-ES-1 } \\
\text { - STSC active ventilation } \\
\text { - Auxiliary ventilation system } \\
\text { - Modified KW Basin Annex } \\
\text { confinement ventilation } \\
\text { - Continuous air monitors }\end{array}$ & $\begin{array}{l}\text { - Procedures } \\
\text { - Training } \\
\text { - Radiological Control } \\
\text { Program } \\
\text { - Modified KW Basin Annex } \\
\text { is unmanned during overfill } \\
\text { recovery operations }\end{array}$ & \\
\hline
\end{tabular}




\begin{tabular}{|c|c|c|c|c|c|c|c|}
\hline \multirow{2}{*}{ Item } & \multirow{2}{*}{$\begin{array}{l}\text { Process } \\
\text { Parameter }\end{array}$} & \multirow{2}{*}{ Deviation } & \multirow{2}{*}{ Cause } & \multirow{2}{*}{ Consequences } & \multicolumn{2}{|c|}{ Candidate Controls } & \multirow{2}{*}{ Remarks } \\
\hline & & & & & Engineered & Administrative & \\
\hline $11 . d-6$ & Pressure & Low & $\begin{array}{l}\text { Low air pressure to overfill } \\
\text { recovery pump } \\
\text { ECRT-P-301 }\end{array}$ & $\begin{array}{l}\text { Operational Upset: } \\
\text { If the pressure is low, then the flow rate } \\
\text { will be low. If the flow rate is low, then it } \\
\text { could take longer to achieve the targeted } \\
\text { recovery. } \\
\text { Uncontrolled Release: } \\
\text { If the pressure is low, then the flow rate } \\
\text { will be low. If the flow rate is sufficiently } \\
\text { low, then eventually the STSC will be } \\
\text { overfilled with IXM water from the overfill } \\
\text { recovery tool and slurry will overflow into } \\
\text { the } 4 \text {-in and } 1 \text {-in. ventilation exhaust lines, } \\
\text { and into the } 1 \text {-in. ventilation inlet line, } \\
\text { leading to a splash and splatter/pool } \\
\text { release. } \\
\text { Overpressurization/Hydrogen } \\
\text { Deflagration: } \\
\text { If the pressure is low, then the flow rate } \\
\text { will be low. Sludge could settle out and } \\
\text { plug the line. If the line plugs, then there } \\
\text { would be no overfill recovery. If the plug } \\
\text { could not be cleared, then the targeted } \\
\text { recovery would not be achieved. In an } \\
\text { unmitigated scenario, exceeding the } \\
\text { sludge limits could result in STS cask } \\
\text { overpressurization or a hydrogen } \\
\text { deflagration. }\end{array}$ & $\begin{array}{l}\text { - Instrument air pressure } \\
\text { control valve ECRT-PCV-761 } \\
\text { - Level switches } \\
\text { LS/LSH/LSHH-740-401 } \\
\text { - High level switch } \\
\text { LSH-740-402 } \\
\text { - Emergency stop switch } \\
\text { ECRT-ES-1 } \\
\text { - Differential sludge weight } \\
\text { instrumentation } \\
\text { (DWI-740-704) } \\
\text { - STSC active ventilation } \\
\text { - Auxiliary ventilation system } \\
\text { - Modified KW Basin Annex } \\
\text { confinement ventilation } \\
\text { - Continuous air monitors }\end{array}$ & $\begin{array}{l}\text { - Procedures } \\
\text { - Training } \\
\text { - Radiological Control } \\
\text { Program } \\
\text { - Recovery Plan } \\
\text { - Modified KW Basin Annex } \\
\text { is unmanned during overfill } \\
\text { recovery operations }\end{array}$ & $\begin{array}{l}\text { The overpressurization hazard does not exist } \\
\text { until the STS Cask lid is bolted onto the cask. } \\
\text { The STSC sludge limit verification } \\
\text { administrative control will prevent this activity } \\
\text { if the sludge limits are not met. } \\
\text { In the event that the targeted recovery could } \\
\text { not be achieved by the installed overfill } \\
\text { recovery tool, a Recovery Plan would be } \\
\text { developed }\end{array}$ \\
\hline
\end{tabular}




\begin{tabular}{|c|c|c|c|c|c|c|c|}
\hline \multirow{2}{*}{ Item } & \multirow{2}{*}{$\begin{array}{l}\text { Process } \\
\text { Parameter }\end{array}$} & \multirow{2}{*}{ Deviation } & \multirow{2}{*}{ Cause } & \multirow{2}{*}{ Consequences } & \multicolumn{2}{|c|}{ Candidate Controls } & \multirow{2}{*}{ Remarks } \\
\hline & & & & & Engineered & Administrative & \\
\hline 11.d-7 & Pressure & High & $\begin{array}{l}\text { - High air pressure to } \\
\text { overfill recovery pump } \\
\text { ECRT-P-301 } \\
\text { - A normally-opened valve } \\
\text { is closed } \\
\text { - Transfer line plugged }\end{array}$ & $\begin{array}{l}\text { Uncontrolled Release: } \\
\text { If the pressure is high, then transfer line } \\
\text { could fail resulting in an airborne spray or } \\
\text { splash and splatter/pool release. } \\
\text { Overpressurization/Hydrogen } \\
\text { Deflagration: } \\
\text { If the pressure high, then the flow rate will } \\
\text { be high. If the flow rate is high, then the } \\
\text { overfill recovery tool could plug. If the } \\
\text { plug could not be cleared, then the } \\
\text { targeted recovery would not be achieved. } \\
\text { In an unmitigated scenario, exceeding the } \\
\text { sludge limits could result in STS cask } \\
\text { overpressurization or a hydrogen } \\
\text { deflagration. }\end{array}$ & $\begin{array}{l}\text { - Piping designed to B31.3, } \\
\text { "Process Piping" } \\
\text { - Instrument air pressure } \\
\text { control valve ECRT-PCV-761 } \\
\text { - Level switches } \\
\text { LS/LSH/LSHH-740-401 } \\
\text { - High level switch } \\
\text { LSH-740-402 } \\
\text { - Emergency stop switch } \\
\text { ECRT-ES-1 } \\
\text { - Differential sludge weight } \\
\text { instrumentation } \\
\text { (DWI-740-704) } \\
\text { - STSC active ventilation } \\
\text { - Auxiliary ventilation system } \\
\text { - Modified KW Basin Annex } \\
\text { confinement ventilation } \\
\text { - Continuous air monitors }\end{array}$ & $\begin{array}{l}\text { - Procedures } \\
\text { - Training } \\
\text { - Radiological Control } \\
\text { Program } \\
\text { - Recovery Plan } \\
\text { - Modified KW Basin Annex } \\
\text { is unmanned during overfill } \\
\text { recovery operations }\end{array}$ & $\begin{array}{l}\text { The overpressurization hazard does not exist } \\
\text { until the STS Cask lid is bolted onto the cask. } \\
\text { The STSC sludge limit verification } \\
\text { administrative control will prevent this activity } \\
\text { if the sludge limits are not met. } \\
\text { In the event that the targeted recovery could } \\
\text { not be achieved by the installed overfill } \\
\text { recovery tool, a Recovery Plan would be } \\
\text { developed }\end{array}$ \\
\hline $11 . d-8$ & $\begin{array}{l}\text { Structural } \\
\text { integrity }\end{array}$ & $\begin{array}{l}\text { Leak/rupture } \\
\text { (transfer line) }\end{array}$ & $\begin{array}{l}\text { - High pressure (see } \\
\text { Item } 7 \text { above) } \\
\text { - Pulsation damper failure } \\
\text { - Manufacturing flaw } \\
\text { - Procurement error } \\
\text { - External event }\end{array}$ & $\begin{array}{l}\text { Uncontrolled Release: } \\
\text { If the overfill recovery tool discharge line } \\
\text { fails, then there will be an airborne spray } \\
\text { or splash and splatter/pool release. }\end{array}$ & $\begin{array}{l}\text { - Piping designed to B31.3, } \\
\text { "Process Piping" } \\
\text { - Modified KW Basin Annex } \\
\text { confinement ventilation } \\
\text { - Continuous air monitors }\end{array}$ & $\begin{array}{l}\text { - Procedures } \\
\text { - Training } \\
\text { - Hydro testing } \\
\text { - Quality Assurance Program } \\
\text { - Leak detection alarm } \\
\text { response. }\end{array}$ & $\begin{array}{l}\text { Relative to B31.3, the piping and hoses are } \\
\text { designed to withstand the deadhead } \\
\text { pressure of overfill recovery pump } \\
\text { ECRT-P-301. }\end{array}$ \\
\hline 11.d-9 & $\begin{array}{l}\text { Structural } \\
\text { Integrity }\end{array}$ & $\begin{array}{l}\text { Leak/rupture } \\
\text { (pump } \\
\text { diaphragm) }\end{array}$ & $\begin{array}{l}\text { - Erosion } \\
\text { - Manufacturing flaw } \\
\text { - Procurement error }\end{array}$ & $\begin{array}{l}\text { Uncontrolled Release: } \\
\text { If the pump diaphragm fails, then sludge } \\
\text { could enter the overfill recovery pump } \\
\text { exhaust resulting in a spray or splash and } \\
\text { splatter/pool release. }\end{array}$ & $\begin{array}{l}\text { - Modified KW Basin Annex } \\
\text { confinement ventilation } \\
\text { - Continuous air monitors }\end{array}$ & $\begin{array}{l}\text { - Procedures } \\
\text { - Training } \\
\text { - Radiological Control } \\
\text { Program } \\
\text { - Modified KW Basin Annex } \\
\text { is unmanned during overfill } \\
\text { recovery operations }\end{array}$ & \\
\hline
\end{tabular}


Table C-38. HAZOP Results, Node 11.d. Overfill Recovery - Pump ECRT-P-301 to Engineered Container

\begin{tabular}{|c|c|c|c|c|c|c|c|}
\hline \multirow{2}{*}{ Item } & \multirow{2}{*}{$\begin{array}{l}\text { Process } \\
\text { Parameter }\end{array}$} & \multirow{2}{*}{ Deviation } & \multirow{2}{*}{ Cause } & \multirow{2}{*}{ Consequences } & \multicolumn{2}{|c|}{ Candidate Controls } & \multirow{2}{*}{ Remarks } \\
\hline & & & & & Engineered & Administrative & \\
\hline $11 . d-10$ & Time procedure & Too short & $\begin{array}{l}\text { - Operator error } \\
\text { - Instrumentation failure } \\
\text { - Overfill recovery pump } \\
\text { failure }\end{array}$ & $\begin{array}{l}\text { Overpressurization/Hydrogen } \\
\text { Deflagration: } \\
\text { If the recovery operation occurs for too } \\
\text { short a period of time, then the targeted } \\
\text { recovery would not be achieved. In an } \\
\text { unmitigated scenario, exceeding the } \\
\text { sludge limits could result in STS cask } \\
\text { overpressurization or a hydrogen } \\
\text { deflagration. }\end{array}$ & $\begin{array}{l}\text { - Differential sludge weight } \\
\text { instrumentation } \\
\text { (DWI-740-704) } \\
\text { - STSC active ventilation } \\
\text { - Auxiliary ventilation system } \\
\text { - Modified KW Basin Annex } \\
\text { confinement ventilation } \\
\text { - Continuous air monitors }\end{array}$ & $\begin{array}{l}\text { - Procedures } \\
\text { - Training } \\
\text { - STSC sludge limit } \\
\text { verification } \\
\text { - Recovery Plan } \\
\text { - Modified KW Basin Annex } \\
\text { is unmanned during overfill } \\
\text { recovery operations }\end{array}$ & $\begin{array}{l}\text { If the overfill recovery was stopped before } \\
\text { the targeted recovery was achieved it might } \\
\text { be possible to restart the tool and complete } \\
\text { the recovery. However, it is also possible } \\
\text { that the fluidizing jets would plug. } \\
\text { The overpressurization hazard does not exist } \\
\text { until the STS Cask lid is bolted onto the cask. } \\
\text { The STSC sludge limit verification } \\
\text { administrative control will prevent this activity } \\
\text { if the sludge limits are not met. } \\
\text { In the event that the targeted recovery could } \\
\text { not be achieved by the installed overfill } \\
\text { recovery tool, a Recovery Plan would be } \\
\text { developed }\end{array}$ \\
\hline $11 . d-11$ & Time Procedure & Too long & $\begin{array}{l}\text { - Operator error } \\
\text { - Instrumentation failure }\end{array}$ & $\begin{array}{l}\text { Operational Upset: } \\
\text { If the recovery operation occurs for too } \\
\text { long a period of time, then too much } \\
\text { sludge could be recovered such that an } \\
\text { STSC is sent to T Plant with a low } \\
\text { as-settled sludge level. }\end{array}$ & $\begin{array}{l}\text { - Differential sludge weight } \\
\text { instrumentation } \\
\text { (DWI-740-704) }\end{array}$ & - Procedures & \\
\hline
\end{tabular}


Table C-38. HAZOP Results, Node 11.d. Overfill Recovery - Pump ECRT-P-301 to Engineered Container

\begin{tabular}{|c|c|c|c|c|c|c|c|}
\hline \multirow{2}{*}{ Item } & \multirow{2}{*}{$\begin{array}{l}\text { Process } \\
\text { Parameter }\end{array}$} & \multirow{2}{*}{ Deviation } & \multirow{2}{*}{ Cause } & \multirow{2}{*}{ Consequences } & \multicolumn{2}{|c|}{ Candidate Controls } & \multirow{2}{*}{ Remarks } \\
\hline & & & & & Engineered & Administrative & \\
\hline 11.d-12 & Time Procedure & $\begin{array}{l}\text { Skip action } \\
\text { (overfill } \\
\text { recovery } \\
\text { pump not } \\
\text { started) }\end{array}$ & Operator error & $\begin{array}{l}\text { Uncontrolled Release: } \\
\text { If operators do not start overfill recovery } \\
\text { pump ECRT-P-301, then there will be no } \\
\text { flow. If there is no flow then the STSC will } \\
\text { eventually be overfilled with IXM water } \\
\text { from the overfill recovery tool and slurry } \\
\text { will overflow into the } 4 \text {-in and } 1 \text {-in. } \\
\text { ventilation exhaust lines, and into the } 1 \text {-in. } \\
\text { ventilation inlet line, leading to a splash } \\
\text { and splatter/pool release. } \\
\text { Overpressurization/Hydrogen } \\
\text { Deflagration: } \\
\text { If the operators do not start overfill } \\
\text { recovery pump ECRT-P-301, then there } \\
\text { would be no overfill recovery. In an } \\
\text { unmitigated scenario, exceeding the } \\
\text { sludge limits could result in STS cask } \\
\text { overpressurization or a hydrogen } \\
\text { deflagration. }\end{array}$ & $\begin{array}{l}\text { - Level switches } \\
\text { LS/LSH/LSHH-740-401 } \\
\text { - High level switch } \\
\text { LSH-740-402 } \\
\text { - Differential sludge weight } \\
\text { instrumentation } \\
\text { (DWI-740-704) } \\
\text { - STSC active ventilation } \\
\text { - Auxiliary ventilation system } \\
\text { - Modified KW Basin Annex } \\
\text { confinement ventilation } \\
\text { - Continuous air monitors }\end{array}$ & $\begin{array}{l}\text { - Procedures } \\
\text { - Training } \\
\text { - STSC sludge limit } \\
\text { verification } \\
\text { - Recovery Plan } \\
\text { - Modified KW Basin Annex } \\
\text { is unmanned during overfill } \\
\text { recovery operations }\end{array}$ & $\begin{array}{l}\text { The overpressurization hazard does not exist } \\
\text { until the STS Cask lid is bolted onto the cask. } \\
\text { The STSC sludge limit verification } \\
\text { administrative control will prevent this activity } \\
\text { if the sludge limits are not met. } \\
\text { In the event that the targeted recovery could } \\
\text { not be achieved by the installed overfill. } \\
\text { recovery tool, a Recovery Plan would be } \\
\text { developed }\end{array}$ \\
\hline 11.d-13 & Time Procedure & Wrong action & N/A & N/A & N/A & N/A & $\begin{array}{l}\text { There are no wrong actions associated with } \\
\text { this node. }\end{array}$ \\
\hline
\end{tabular}


PRC-STP-00467 REV 0

APPENDIX D

FREQUENCY AND CONSEQUENCE LEVELS

D-i 
Table D-1. Frequency and Consequence Levels

\begin{tabular}{|c|c|c|c|c|c|c|c|c|}
\hline \multirow{2}{*}{ Item } & \multirow{2}{*}{$\begin{array}{l}\text { Process } \\
\text { Parameter }\end{array}$} & \multirow{2}{*}{ Deviation } & \multirow{2}{*}{ Cause } & \multirow{2}{*}{ Hazardous Condition } & \multirow{2}{*}{$\begin{array}{l}\text { Unmitigated } \\
\text { Frequency }\end{array}$} & \multicolumn{3}{|c|}{$\begin{array}{l}\text { Unmitigated } \\
\text { Consequences }\end{array}$} \\
\hline & & & & & & FW & Onsite & Offsite \\
\hline \multirow[t]{2}{*}{ 1.a-4 } & \multirow[t]{2}{*}{ Flow } & \multirow[t]{2}{*}{ Reverse } & \multirow[t]{2}{*}{$\begin{array}{l}\text { Booster pump ECRT-P-101 } \\
\text { runs in reverse }\end{array}$} & $\begin{array}{l}\text { Uncontrolled Release: } \\
\text { If booster pump ECRT-P-101 runs in reverse, then sludge/basin water could } \\
\text { flow into the fluidizing jet IXM water supply line to a point above the basin } \\
\text { water. If the fluidizing jet IXM water supply line failed due to the pressure } \\
\text { generated by pump ECRT-P-101, then a spray or splash and splatter/pool } \\
\text { release could occur. }\end{array}$ & EU & $H$ & H & L \\
\hline & & & & $\begin{array}{l}\text { Radiological Control: } \\
\text { If air is pumped into an Engineered Container, then it will bubble to the } \\
\text { surface of basin water and could result in elevated airborne radioactivity } \\
\text { levels. }\end{array}$ & EU & $\mathbf{L}$ & N/A & N/A \\
\hline 1.a-8 & Pressure & High & $\begin{array}{l}\text { - Fluidizing pump speed high } \\
\text { - A normally-open valve is } \\
\text { closed } \\
\text { - Fluidizing jets are plugged }\end{array}$ & $\begin{array}{l}\text { Uncontrolled Release: } \\
\text { If the pressure is high, then the fluidizing jet IXM water supply line could fail } \\
\text { at a location above the basin water. This would result in a spill of IXM water. }\end{array}$ & A & L & L & L \\
\hline 1.a-9 & $\begin{array}{l}\text { Structural } \\
\text { Integrity }\end{array}$ & Leak/rupture & $\begin{array}{l}\text { - High pressure } \\
\text { - Manufacturing flaw } \\
\text { - Procurement error }\end{array}$ & $\begin{array}{l}\text { Uncontrolled Release: } \\
\text { If the fluidizing jet IXM water supply line failed at a location above the basin } \\
\text { water, then IXM water would be spilled. }\end{array}$ & A & $L$ & L & L \\
\hline \multirow[t]{2}{*}{ 1.b-4 } & \multirow[t]{2}{*}{ Flow } & \multirow[t]{2}{*}{ Reverse } & \multirow[t]{2}{*}{$\begin{array}{l}\text { Booster pump ECRT-P-101 } \\
\text { runs in reverse }\end{array}$} & $\begin{array}{l}\text { Uncontrolled Release: } \\
\text { If booster pump ECRT-P-101 runs in reverse, then sludge/basin water could } \\
\text { flow into the motive IXM water supply line to a point above the basin water. } \\
\text { If the motive water IXM water supply line failed due to the pressure } \\
\text { generated by pump ECRT-P-101, then a spray or splash and splatter/pool } \\
\text { release could occur. }\end{array}$ & EU & $\mathrm{H}$ & $\mathrm{H}$ & L \\
\hline & & & & $\begin{array}{l}\text { Radiological Control: } \\
\text { If air is pumped into an Engineered Container, then it will bubble to the } \\
\text { surface of basin water and could result in elevated airborne radioactivity } \\
\text { levels. }\end{array}$ & EU & L & $N / A$ & $N / A$ \\
\hline
\end{tabular}


Table D-1. Frequency and Consequence Levels

\begin{tabular}{|c|c|c|c|c|c|c|c|c|}
\hline \multirow{2}{*}{ Item } & \multirow{2}{*}{$\begin{array}{l}\text { Process } \\
\text { Parameter }\end{array}$} & \multirow{2}{*}{ Deviation } & \multirow{2}{*}{ Cause } & \multirow{2}{*}{ Hazardous Condition } & \multirow{2}{*}{$\begin{array}{l}\text { Unmitigated } \\
\text { Frequency }\end{array}$} & \multicolumn{3}{|c|}{$\begin{array}{c}\text { Unmitigated } \\
\text { Consequences }\end{array}$} \\
\hline & & & & & & FW & Onsite & Offsite \\
\hline 1.b-7 & Pressure & High & $\begin{array}{l}\text { - A normally-open valve is } \\
\text { closed } \\
\text { - Booster pump ECRT-P-101 } \\
\text { not operating }\end{array}$ & $\begin{array}{l}\text { Uncontrolled Release: } \\
\text { If the pressure is high, then the motive water IXM water supply line could fail } \\
\text { at a location above the basin water. This would result in a spill of IXM water. }\end{array}$ & A & $\mathrm{L}$ & $\mathrm{L}$ & $\mathrm{L}$ \\
\hline 1.b-8 & $\begin{array}{l}\text { Structural } \\
\text { Integrity }\end{array}$ & Leak/rupture & $\begin{array}{l}\text { - High pressure } \\
\text { - Manufacturing flaw } \\
\text { - Procurement error }\end{array}$ & $\begin{array}{l}\text { Uncontrolled Release: } \\
\text { If the motive water IXM water supply line failed at a location above the basin } \\
\text { water, then IXM water would be spilled. }\end{array}$ & A & $\mathrm{L}$ & $\mathrm{L}$ & L \\
\hline \multirow[t]{2}{*}{ 2.a-4 } & \multirow[t]{2}{*}{ Flow } & \multirow[t]{2}{*}{ Reverse } & \multirow[t]{2}{*}{$\begin{array}{l}\text { Booster pump ECRT-P-101 } \\
\text { runs in reverse } \\
\text { See also Table C-8, Item 2.b-4 }\end{array}$} & $\begin{array}{l}\text { Uncontrolled Release: } \\
\text { If booster pump ECRT-P-101 runs in reverse, then sludge/basin water could } \\
\text { flow into the motive IXM water supply line to a point above the basin water. } \\
\text { If the motive water IXM water supply line failed due to the pressure } \\
\text { generated by pump ECRT-P-101, then a spray or splash and splatter/pool } \\
\text { release could occur. }\end{array}$ & EU & $\mathrm{H}$ & $\mathrm{H}$ & $\mathrm{L}$ \\
\hline & & & & $\begin{array}{l}\text { Radiological Control: } \\
\text { If air is pumped into an Engineered Container, then it will bubble to the } \\
\text { surface of basin water and could result in elevated airborne radioactivity } \\
\text { levels. }\end{array}$ & EU & L & N/A & N/A \\
\hline 2.b-3 & Flow & High & $\begin{array}{l}\text { Booster pump ECRT-P-101 } \\
\text { speed high }\end{array}$ & $\begin{array}{l}\text { Uncontrolled Release: } \\
\text { If the flow rate is high because booster pump ECRT-P-101 speed is high, } \\
\text { then the booster pump will become suction-starved. This could cause } \\
\text { rupture disk ECRT-PSE-101 or -102 downstream of the booster pump to } \\
\text { rupture and sludge would be released under the basin water surface. } \\
\text { In an unmitigated scenario where no credit is taken for the rupture disks, } \\
\text { then the transfer line downstream of the booster pump could fail. This could } \\
\text { result in an airborne spray or splash and splatter/pool release of sludge. }\end{array}$ & A & $\mathrm{H}$ & $\mathrm{H}$ & L \\
\hline
\end{tabular}


Table D-1. Frequency and Consequence Levels

\begin{tabular}{|c|c|c|c|c|c|c|c|c|}
\hline \multirow{2}{*}{ Item } & \multirow{2}{*}{$\begin{array}{l}\text { Process } \\
\text { Parameter }\end{array}$} & \multirow{2}{*}{ Deviation } & \multirow{2}{*}{ Cause } & \multirow{2}{*}{ Hazardous Condition } & \multirow{2}{*}{$\begin{array}{l}\text { Unmitigated } \\
\text { Frequency }\end{array}$} & \multicolumn{3}{|c|}{$\begin{array}{l}\text { Unmitigated } \\
\text { Consequences }\end{array}$} \\
\hline & & & & & & FW & Onsite & Offsite \\
\hline \multirow[t]{2}{*}{ 2.b-4.a } & \multirow[t]{2}{*}{ Flow } & \multirow[t]{2}{*}{ Reverse } & \multirow[t]{2}{*}{$\begin{array}{l}\text { Booster pump ECRT-P-101 } \\
\text { runs in reverse }\end{array}$} & $\begin{array}{l}\text { Uncontrolled Release: } \\
\text { If booster pump ECRT-P-101 runs in reverse, then sludge/basin water could } \\
\text { flow into the motive IXM water supply line to a point above the basin water. } \\
\text { If the motive water IXM water supply line failed due to the pressure } \\
\text { generated by pump ECRT-P-101, then a spray or splash and splatter/pool } \\
\text { release could occur. }\end{array}$ & EU & $H$ & $\mathrm{H}$ & $\mathrm{L}$ \\
\hline & & & & $\begin{array}{l}\text { Radiological Control: } \\
\text { If air is pumped into an Engineered Container, then it will bubble to the } \\
\text { surface of basin water and could result in elevated airborne radioactivity } \\
\text { levels. }\end{array}$ & EU & $\mathrm{L}$ & N/A & $N / A$ \\
\hline \multirow[t]{2}{*}{ 2.b-4.b } & \multirow[t]{2}{*}{ Flow } & \multirow[t]{2}{*}{ Reverse } & \multirow[t]{2}{*}{ Siphon from STSC } & $\begin{array}{l}\text { Uncontrolled Release: } \\
\text { If sludge was siphoned from the STSC due to a breach in the transfer line, } \\
\text { then a splash and splatter/pool release could occur. }\end{array}$ & A & $\mathrm{H}$ & $\mathrm{H}$ & L \\
\hline & & & & $\begin{array}{l}\text { Hydrogen Deflagration: } \\
\text { If the release was into the Transfer Line Service Box, then hydrogen } \\
\text { generated by the sludge could accumulate in the box resulting in a } \\
\text { deflagration. }\end{array}$ & A & H & $\mathrm{L}$ & $\mathrm{L}$ \\
\hline \multirow[t]{2}{*}{ 2.b-5.a } & \multirow[t]{2}{*}{ Flow } & \multirow[t]{2}{*}{$\begin{array}{l}\text { Misdirected } \\
\text { (into Transfer Line } \\
\text { Service Box) }\end{array}$} & \multirow{2}{*}{$\begin{array}{l}\text { - Valving error such that sludge } \\
\text { enters box via IXM water } \\
\text { spray nozzles } \\
\text { - Valving error such that sludge } \\
\text { enters box via siphon break } \\
\text { - Valving error such that sludge } \\
\text { enters box via sump pump }\end{array}$} & $\begin{array}{l}\text { Uncontrolled Release: } \\
\text { If sludge is misdirected into the Transfer Line Service Box, then a splash and } \\
\text { splatter/pool release would occur. }\end{array}$ & A & $\mathrm{H}$ & $\mathrm{H}$ & $\mathrm{L}$ \\
\hline & & & & $\begin{array}{l}\text { Hydrogen Deflagration: } \\
\text { If sludge is misdirected into the Transfer Line Service Box, then hydrogen } \\
\text { generated by the sludge could accumulate in the box resulting in a } \\
\text { deflagration. }\end{array}$ & A & $\mathrm{H}$ & L & L \\
\hline 2.b-5.b & Flow & $\begin{array}{l}\text { Misdirected } \\
\text { (into Transfer Line } \\
\text { Service Box IXM } \\
\text { water supply }\end{array}$ & Valving error & $\begin{array}{l}\text { Uncontrolled Release: } \\
\text { If sludge is misdirected into the Transfer Line Service Box IXM water supply, } \\
\text { then a spray or splash and splatter/pool release could occur. }\end{array}$ & A & $\mathrm{H}$ & $\mathrm{H}$ & $\mathrm{L}$ \\
\hline
\end{tabular}


Table D-1. Frequency and Consequence Levels

\begin{tabular}{|c|c|c|c|c|c|c|c|c|}
\hline \multirow{2}{*}{ Item } & \multirow{2}{*}{$\begin{array}{l}\text { Process } \\
\text { Parameter }\end{array}$} & \multirow{2}{*}{ Deviation } & \multirow{2}{*}{ Cause } & \multirow{2}{*}{ Hazardous Condition } & \multirow{2}{*}{$\begin{array}{l}\text { Unmitigated } \\
\text { Frequency }\end{array}$} & \multicolumn{3}{|c|}{$\begin{array}{l}\text { Unmitigated } \\
\text { Consequences }\end{array}$} \\
\hline & & & & & & FW & Onsite & Offsite \\
\hline 2.b-5.c & Flow & $\begin{array}{l}\text { Misdirected } \\
\text { (into } \\
\text { decant/flocculant } \\
\text { recirculation line) }\end{array}$ & Valving error & $\begin{array}{l}\text { Uncontrolled Release: } \\
\text { If sludge is misdirected into the decant/flocculant recirculation line, then the } \\
\text { line could be overpressurized and fail resulting in as spray or splash and } \\
\text { splatter/pool release. }\end{array}$ & A & $\mathrm{H}$ & $\mathrm{H}$ & L \\
\hline $2 . b-5 . d$ & Flow & $\begin{array}{l}\text { Misdirected } \\
\text { (to overfill } \\
\text { recovery pump) }\end{array}$ & Valving error & $\begin{array}{l}\text { Uncontrolled Release: } \\
\text { If the slurry flow is misdirect to the overfill recovery pump, then booster pump } \\
\text { ECRT-P-101 will deadhead resulting in high pressure in the transfer line. In } \\
\text { an unmitigated scenario where no credit is taken for the rupture disks, then } \\
\text { high pressure could result in a transfer line failure resulting in an airborne } \\
\text { spray or splash and splatter/pool release. }\end{array}$ & A & $\mathrm{H}$ & $\mathrm{H}$ & L \\
\hline 2.b-7 & Pressure & High & $\begin{array}{l}\text { - Booster pump ECRT-P-101 } \\
\text { speed high } \\
\text { - A normally-open valve is } \\
\text { closed } \\
\text { - Transfer line plugged }\end{array}$ & $\begin{array}{l}\text { Uncontrolled Release: } \\
\text { In an unmitigated scenario where no credit is taken for the rupture disks, } \\
\text { then high pressure could result in a transfer line failure resulting in an } \\
\text { airborne spray or splash and splatter/pool release. }\end{array}$ & A & $\mathrm{H}$ & $\mathrm{H}$ & L \\
\hline $2 . b-10$ & Concentration & High & $\begin{array}{l}\text { - Xago Hydrolance }{ }^{\mathrm{m}} \text { lowered } \\
\text { into sludge too fast } \\
\text { - Fluidizing jets pulsed too } \\
\text { frequently }\end{array}$ & $\begin{array}{l}\text { Uncontrolled Release: } \\
\text { If the vol\% solids is too high, then sludge may settle out in the transfer line } \\
\text { and form a plug. If a plug forms and booster pump ECRT-P-101 continues } \\
\text { to operate, then rupture disk ECRT-PSE-101 would fail and sludge would be } \\
\text { released under the surface of the basin water. In an unmitigated scenario } \\
\text { where no credit is taken for the rupture disk, then high pressure could result } \\
\text { in a transfer line failure resulting in an airborne spray or splash and } \\
\text { splatter/pool release. }\end{array}$ & A & $\mathrm{H}$ & $\mathrm{H}$ & L \\
\hline \multirow[t]{2}{*}{$2 . b-12$} & \multirow[t]{2}{*}{$\begin{array}{l}\text { Structural } \\
\text { Integrity }\end{array}$} & \multirow[t]{2}{*}{ Leak/rupture } & \multirow{2}{*}{$\begin{array}{l}\text { - High pressure (see Item 2.b- } \\
6 \text { above) } \\
\text { - Pulsation damper failure } \\
\text { - Manufacturing flaw } \\
\text { - Procurement error } \\
\text { - External event }\end{array}$} & $\begin{array}{l}\text { Uncontrolled Release: } \\
\text { If the transfer line leaks or ruptures, then there will be an airborne spray or } \\
\text { splash and splatter/pool release. }\end{array}$ & A & $\mathrm{H}$ & $\mathrm{H}$ & $\mathrm{L}$ \\
\hline & & & & $\begin{array}{l}\text { Hydrogen Deflagration: } \\
\text { If the transfer line leaks or ruptures inside the transfer line service box, then } \\
\text { sludge would be spilled into the box. Hydrogen generated by the sludge } \\
\text { could accumulate in the box resulting in a deflagration. }\end{array}$ & A & $\mathrm{H}$ & L & L \\
\hline
\end{tabular}


Table D-1. Frequency and Consequence Levels

\begin{tabular}{|c|c|c|c|c|c|c|c|c|}
\hline \multirow{2}{*}{ Item } & \multirow{2}{*}{$\begin{array}{l}\text { Process } \\
\text { Parameter }\end{array}$} & \multirow{2}{*}{ Deviation } & \multirow{2}{*}{ Cause } & \multirow{2}{*}{ Hazardous Condition } & \multirow{2}{*}{$\begin{array}{l}\text { Unmitigated } \\
\text { Frequency }\end{array}$} & \multicolumn{3}{|c|}{$\begin{array}{c}\text { Unmitigated } \\
\text { Consequences }\end{array}$} \\
\hline & & & & & & FW & Onsite & Offsite \\
\hline \multirow[t]{2}{*}{ 2.c-7.a } & \multirow[t]{2}{*}{ Composition } & \multirow[t]{2}{*}{$\begin{array}{l}\text { Other } \\
\text { (settler tank } \\
\text { sludge retrieved } \\
\text { instead of KE/KW } \\
\text { sludge) }\end{array}$} & \multirow[t]{2}{*}{$\begin{array}{l}\text { Xago Hydrolance }{ }^{\text {Tw }} \text { lowered into } \\
\text { incorrect Engineered Container } \\
\text { due to operator error }\end{array}$} & $\begin{array}{l}\text { Overpressurization: } \\
\text { The STSC sludge limits have been established, in part, to prevent the sludge } \\
\text { from reaching a temperature of approximately } 100^{\circ} \mathrm{C} \text { in order to prevent } \\
\text { excessive headspace pressures. If the Xago Hydrolance } e^{m} \text { is erroneously } \\
\text { lowered into SCS-CON-230, then settler tank sludge would be retrieved into } \\
\text { an STSC without an annulus. Placing settler tank sludge in an STSC without } \\
\text { an annulus could result in the sludge temperature reaching } 100^{\circ} \mathrm{C} \text { and } \\
\text { overpressurizing the STS cask. }\end{array}$ & A & L & $\mathrm{L}$ & $\mathbf{L}$ \\
\hline & & & & $\begin{array}{l}\text { Hydrogen Deflagration: } \\
\text { The STSC sludge limits have been established, in part, to control the } \\
\text { hydrogen concentration in the headspace of the STSC. Placing settler tank } \\
\text { sludge in an STSC without an annulus could result in a hydrogen } \\
\text { deflagration. }\end{array}$ & A & $H$ & $\mathrm{~L}$ & $\mathrm{~L}$ \\
\hline 2.c-7.b & Composition & $\begin{array}{l}\text { Other } \\
\text { (KE/KW sludge } \\
\text { retrieved instead } \\
\text { of settler tank } \\
\text { sludge) }\end{array}$ & $\begin{array}{l}\text { Xago Hydrolance }{ }^{m} \text { lowered into } \\
\text { incorrect Engineered Container } \\
\text { due to operator error }\end{array}$ & $\begin{array}{l}\text { Radiological Control: } \\
\text { If the Xago Hydrolance } \\
\text { SCS-CON-230, then KE or KW B Basin sludge would be retrieved into an } \\
\text { STSC with an inner core. This could result in higher than expected dose } \\
\text { rates at the top of the STSC. In addition, If the sludge were to subsequently } \\
\text { expand at the safety basis expansion rate, then sludge could escape the } \\
\text { STSC during long-term storage at T Plant. }\end{array}$ & A & L & L & $L$ \\
\hline 2.c-7.d & Composition & $\begin{array}{l}\text { Other } \\
\text { (KW sludge } \\
\text { retrieved instead } \\
\text { of KE sludge) }\end{array}$ & $\begin{array}{l}\text { Xago Hydrolance }{ }^{\text {mu }} \text { lowered into } \\
\text { incorrect Engineered Container } \\
\text { due to operator error }\end{array}$ & $\begin{array}{l}\text { Radiological Control (T Plant): } \\
\text { If the Xago Hydrolance } \\
\text { instead is erroneously lowered into SCS-CON-210 or } 220 \\
\text { instead of KE sludge. Consequently, the STSC volume limit for KW sludge } \\
\text { would be exceeded. If the sludge were to subsequently expand at the safety } \\
\text { basis expansion rate, then sludge could escape the STSC during long-term } \\
\text { storage at T Plant. }\end{array}$ & A & $L$ & L & $\mathrm{L}$ \\
\hline
\end{tabular}


Table D-1. Frequency and Consequence Levels

\begin{tabular}{|c|c|c|c|c|c|c|c|c|}
\hline \multirow{2}{*}{ Item } & \multirow{2}{*}{$\begin{array}{l}\text { Process } \\
\text { Parameter }\end{array}$} & \multirow{2}{*}{ Deviation } & \multirow{2}{*}{ Cause } & \multirow{2}{*}{ Hazardous Condition } & \multirow{2}{*}{$\begin{array}{l}\text { Unmitigated } \\
\text { Frequency }\end{array}$} & \multicolumn{3}{|c|}{$\begin{array}{l}\text { Unmitigated } \\
\text { Consequences }\end{array}$} \\
\hline & & & & & & FW & Onsite & Offsite \\
\hline $2 . c-8$ & $\begin{array}{l}\text { Structural } \\
\text { Integrity }\end{array}$ & Leak/rupture & $\begin{array}{l}\text { - High pressure (see Table 2- } \\
\text { 12, Item 2.d-6.b) } \\
\text { - Manufacturing flaw } \\
\text { - Corrosion }\end{array}$ & $\begin{array}{l}\text { Uncontrolled Release: } \\
\text { For non-pressurized scenarios, if the breach occurred above the liquid level, } \\
\text { then contaminated air could exit the STSC. } \\
\text { For non-pressurized scenarios, if the breach occurred below the liquid level, } \\
\text { then sludge would leak into the STS cask. } \\
\text { The consequences of a leak due to high pressure are as stated in } \\
\text { Table 2-12, Item 2.d-6b. }\end{array}$ & A & $H$ & $H$ & $\mathrm{~L}$ \\
\hline 2.c-10.a & $\begin{array}{l}\text { Level } \\
\text { (KE/KW } \\
\text { slurry) }\end{array}$ & High & $\begin{array}{l}\text { Instrumentation and control } \\
\text { failure }\end{array}$ & $\begin{array}{l}\text { Uncontrolled Release: } \\
\text { If the KE/KW slurry transfer is not stopped, then the STSC will be overfilled } \\
\text { and slurry will be pumped into the } 4 \text {-in and } 1 \text {-in. ventilation exhaust lines and } \\
\text { into the } 1 \text {-in. ventilation inlet line leading to a splash and splatter/pool } \\
\text { release. }\end{array}$ & A & L & L & L \\
\hline \multirow[t]{3}{*}{ 2.c-10.b } & \multirow[t]{3}{*}{$\begin{array}{l}\text { Level } \\
\text { (settler tank } \\
\text { slurry) }\end{array}$} & \multirow[t]{3}{*}{ High } & \multirow[t]{3}{*}{$\begin{array}{l}\text { Instrumentation and control } \\
\text { failure }\end{array}$} & $\begin{array}{l}\text { Uncontrolled Release: } \\
\text { If the settler tank slurry transfer is not stopped, then the STSC will be } \\
\text { ovefilled and slurry will be pumped into the } 4 \text {-in and } 1 \text {-in. ventilation exhaust } \\
\text { lines and into the 1-in. ventilation inlet line leading to a splash and } \\
\text { splatter/pool release. }\end{array}$ & A & L & $\mathrm{L}$ & $\mathrm{L}$ \\
\hline & & & & $\begin{array}{l}\text { Overpressurization: } \\
\text { Thermal modeling of settler tank sludge in an STSC with an annulus } \\
\text { assumes that the core region is filled with water. If the settler sludge level is } \\
\text { high, then a small amount of sludge could enter the core region. If a large } \\
\text { amount of sludge was present in the core region, then the sludge } \\
\text { temperature could eventually reach } 100^{\circ} \mathrm{C} \text { and overpressurize the STS } \\
\text { cask. }\end{array}$ & A & L & $\mathrm{L}$ & L \\
\hline & & & & $\begin{array}{l}\text { Hydrogen Deflagration: } \\
\text { Gas generation analyses of settler sludge in an STSC with an annulus } \\
\text { assume that the core region if filled with water. If the settler sludge level is } \\
\text { high, then a small amount of sludge could enter the core region. If a large } \\
\text { amount of sludge was present in the core region, a hydrogen deflagration } \\
\text { could occur. }\end{array}$ & A & $\mathrm{H}$ & $\mathrm{L}$ & L \\
\hline
\end{tabular}


Table D-1. Frequency and Consequence Levels

\begin{tabular}{|c|c|c|c|c|c|c|c|c|}
\hline \multirow{2}{*}{ Item } & \multirow{2}{*}{$\begin{array}{l}\text { Process } \\
\text { Parameter }\end{array}$} & \multirow{2}{*}{ Deviation } & \multirow{2}{*}{ Cause } & \multirow{2}{*}{ Hazardous Condition } & \multirow{2}{*}{$\begin{array}{l}\text { Unmitigated } \\
\text { Frequency }\end{array}$} & \multicolumn{3}{|c|}{$\begin{array}{c}\text { Unmitigated } \\
\text { Consequences }\end{array}$} \\
\hline & & & & & & FW & Onsite & Offsite \\
\hline 2.c-10.c & $\begin{array}{l}\text { Level } \\
\text { (KE/KW as- } \\
\text { settle sludge) }\end{array}$ & High & $\begin{array}{l}\text { - Instrumentation and control } \\
\text { failure } \\
\text { - Operator error }\end{array}$ & $\begin{array}{l}\text { Radiological Control (T Plant) } \\
\text { If the as-settled sludge level is high and the sludge was to subsequently } \\
\text { expand at the safety basis expansion rate, then sludge could escape the } \\
\text { STSC during long-term storage at T Plant. }\end{array}$ & A & $\mathrm{L}$ & L & $\mathrm{L}$ \\
\hline \multirow[t]{2}{*}{ 2.c-10.d } & \multirow[t]{2}{*}{$\begin{array}{l}\text { Level } \\
\text { (settler tank } \\
\text { as-settled } \\
\text { sludge) }\end{array}$} & \multirow[t]{2}{*}{ High } & \multirow[t]{2}{*}{$\begin{array}{l}\text { - Instrumentation and control } \\
\text { failure } \\
\text { - Operator error }\end{array}$} & $\begin{array}{l}\text { Overpressurization: } \\
\text { Settler tank sludge limits have been established, in part, to prevent the } \\
\text { sludge from reaching a temperature of } 100^{\circ} \mathrm{C} \text { in order to prevent excessive } \\
\text { headspace pressures. If the as-settled sludge level is high, then the sludge } \\
\text { temperature could reach } 100^{\circ} \mathrm{C} \text { and overpressurize the STS cask. }\end{array}$ & A & $\mathrm{L}$ & $\mathrm{L}$ & $\mathrm{L}$ \\
\hline & & & & $\begin{array}{l}\text { Hydrogen Deflagration: } \\
\text { The settler tank sludge limits have been established, in part, to control the } \\
\text { hydrogen concentration in the headspace of the STSC. If the as-settled } \\
\text { sludge level is high, then a hydrogen deflagration could occur. }\end{array}$ & A & $\mathrm{H}$ & $\mathrm{L}$ & $\mathrm{L}$ \\
\hline \multirow[t]{2}{*}{ 2.d-1 } & \multirow[t]{2}{*}{ Flow } & \multirow[t]{2}{*}{ No } & \multirow{2}{*}{$\begin{array}{l}\text { - Air inlet valve ECRT-V-732 } \\
\text { closed } \\
\text { - STSC inlet HEPA filter } \\
\text { plugged } \\
\text { - Exhaust fan ECRT-EF-502 or } \\
\text {-503 not operating }\end{array}$} & $\begin{array}{l}\text { Hydrogen Deflagration: } \\
\text { If there is no ventilation system flow, then a hydrogen deflagration could } \\
\text { occur. }\end{array}$ & A & $\mathrm{H}$ & L & L \\
\hline & & & & $\begin{array}{l}\text { Radiological Control: } \\
\text { If there is no ventilation system flow, then the pressure in the STSC will be } \\
\text { slightly greater than atmospheric during a transfer. See Item } 2 . d-6 . \text { a below. }\end{array}$ & A & $\mathrm{L}$ & $\mathrm{L}$ & $\mathrm{L}$ \\
\hline 2.d-2 & Flow & Low & $\begin{array}{l}\text { - Inlet HEPA filter partially } \\
\text { plugged } \\
\text { - Air Inlet and outlet valves set } \\
\text { incorrectly } \\
\text { - Exhaust fan ECRT-EF-502 or } \\
\text {-503 speed low }\end{array}$ & $\begin{array}{l}\text { Hydrogen Deflagration: } \\
\text { If the flow rate falls below } 1 \mathrm{cfm} \text {, then a hydrogen deflagration could occur. }\end{array}$ & A & $H$ & $\mathrm{~L}$ & $\mathrm{~L}$ \\
\hline
\end{tabular}


Table D-1. Frequency and Consequence Levels

\begin{tabular}{|c|c|c|c|c|c|c|c|c|}
\hline \multirow{2}{*}{ Item } & \multirow{2}{*}{$\begin{array}{l}\text { Process } \\
\text { Parameter }\end{array}$} & \multirow{2}{*}{ Deviation } & \multirow{2}{*}{ Cause } & \multirow{2}{*}{ Hazardous Condition } & \multirow{2}{*}{$\begin{array}{l}\text { Unmitigated } \\
\text { Frequency }\end{array}$} & \multicolumn{3}{|c|}{$\begin{array}{c}\text { Unmitigated } \\
\text { Consequences }\end{array}$} \\
\hline & & & & & & FW & Onsite & Offsite \\
\hline 2.d-3 & Flow & High & $\begin{array}{l}\text { - Air inlet and outlet valves set } \\
\text { incorrectly } \\
\text { - Exhaust fan ECRT-EF-502 or } \\
-503 \text { speed high }\end{array}$ & $\begin{array}{l}\text { Radiological Control: } \\
\text { If the flow rate is high, then more aerosol may be swept out of the STSC. } \\
\text { This could result in increased deposition in the vent line resulting in an } \\
\text { increased dose rate and an increased potential for contamination. See also } \\
\text { Item 2.d-8.a below. }\end{array}$ & A & L & L & L \\
\hline 2.d-5 & $\begin{array}{l}\text { Pressure } \\
\text { (absolute) }\end{array}$ & $\begin{array}{l}\text { Low } \\
\text { (less than }-1.0 \text { in. } \\
\text { wg) }\end{array}$ & $\begin{array}{l}\text { - Air inlet and outlet valves set } \\
\text { incorrectly } \\
\text { - Exhaust fan ECRT-EF-502 or } \\
-503 \text { speed high }\end{array}$ & $\begin{array}{l}\text { Radiological Control: } \\
\text { If the pressure is low (i.e., less than }-1.0 \mathrm{in.} w \mathrm{wg} \text { ), then the flow rate will } \\
\text { increase. If the flow rate is high, then more aerosol may be swept out of the } \\
\text { STSC. Consequences are as stated in Item } 2 . \mathrm{d}-3 \text { above. }\end{array}$ & A & L & L & L \\
\hline 2.d-6 & $\begin{array}{l}\text { Pressure } \\
\text { (absolute) }\end{array}$ & $\begin{array}{l}\text { High } \\
\text { (greater than }-1.0 \\
\text { in. wg) }\end{array}$ & $\begin{array}{l}\text { No flow (see Item 2.d-1, } \\
\text { above) } \\
\text { - Low flow (see Item 2.d-2, } \\
\text { above) }\end{array}$ & $\begin{array}{l}\text { Radiological Control: } \\
\text { If the pressure in the STSC is greater than atmospheric, then the potential } \\
\text { exists for a spread of contamination. }\end{array}$ & A & L & $\mathrm{L}$ & L \\
\hline 2.d-8.a & $\begin{array}{l}\text { Concentration } \\
\text { (moisture in } \\
\text { STSC } \\
\text { exhaust) }\end{array}$ & High & $\begin{array}{l}\text { High flow rate, see Item } 2 . d-3 \\
\text { above }\end{array}$ & $\begin{array}{l}\text { Radiological Control: } \\
\text { If there is too much moisture in the exhaust air, then the HEPA filters could } \\
\text { be damaged. }\end{array}$ & A & $\mathrm{L}$ & $\mathrm{L}$ & L \\
\hline $2 . d-8 . b$ & $\begin{array}{l}\text { Concentration } \\
\text { (radionuclide } \\
\text { in STSC } \\
\text { exhaust)) }\end{array}$ & High & High flow rate, see Item $2 . d-3$ & $\begin{array}{l}\text { Radiological Control: } \\
\text { If the flow rate is high, then more aerosol may be swept out of the STSC. } \\
\text { This could result in increased deposition in the vent line resulting in an } \\
\text { increased dose rate and an increased potential for contamination. }\end{array}$ & A & L & L & L \\
\hline \multirow[t]{2}{*}{ 2.d-10.b } & \multirow[t]{2}{*}{$\begin{array}{l}\text { Structural } \\
\text { Integrity } \\
\text { (STSC outlet } \\
\text { line) }\end{array}$} & \multirow[t]{2}{*}{ Leak/rupture } & \multirow{2}{*}{$\begin{array}{l}\text { - Physical damage to outlet } \\
\text { line(s) } \\
\text { - Hose ECRT-H-501 } \\
\text { disconnects from STSC at } \\
\text { nozzle F1 } \\
\text { - Hose ECRT-H-659 } \\
\text { disconnects from STSC at } \\
\text { nozzle F2 }\end{array}$} & $\begin{array}{l}\text { Hydrogen Deflagration: } \\
\text { If there is a leak/rupture in the outlet line, then the flow rate through the } \\
\text { STSC will decrease. If the flow rate drops below } 1 \mathrm{cfm} \text {, a hydrogen } \\
\text { deflagration could occur. }\end{array}$ & A & $H$ & L & L \\
\hline & & & & $\begin{array}{l}\text { Radiological Control: } \\
\text { The interior of the outlet lines will be contaminated. Although the lines are } \\
\text { under negative pressure, if there is a leak/rupture then a spread of } \\
\text { contamination could occur. }\end{array}$ & A & $\mathrm{L}$ & $\mathrm{L}$ & L \\
\hline
\end{tabular}


Table D-1. Frequency and Consequence Levels

\begin{tabular}{|c|c|c|c|c|c|c|c|c|}
\hline \multirow{2}{*}{ Item } & \multirow{2}{*}{$\begin{array}{l}\text { Process } \\
\text { Parameter }\end{array}$} & \multirow{2}{*}{ Deviation } & \multirow{2}{*}{ Cause } & \multirow{2}{*}{ Hazardous Condition } & \multirow{2}{*}{$\begin{array}{l}\text { Unmitigated } \\
\text { Frequency }\end{array}$} & \multicolumn{3}{|c|}{$\begin{array}{l}\text { Unmitigated } \\
\text { Consequences }\end{array}$} \\
\hline & & & & & & FW & Onsite & Offsite \\
\hline 2.d.-10.c & $\begin{array}{l}\text { Structural } \\
\text { Integrity } \\
\text { (exhaust } \\
\text { HEPA filters) }\end{array}$ & Leak/rupture & $\begin{array}{l}\text { - High differential pressure } \\
\text { (e.g., moisture build-up, } \\
\text { particulate loading) } \\
\text { - Incorrect installation } \\
\text { - Manufacturing flaw } \\
\text { - Mechanical insult }\end{array}$ & $\begin{array}{l}\text { Radiological Control: } \\
\text { If the HEPA filters leak/rupture, then the exhaust air from the STSC would } \\
\text { not be filtered, or would not be filtered as efficiently. }\end{array}$ & A & $\mathrm{L}$ & L & L \\
\hline 2.d-12 & $\begin{array}{l}\text { Level } \\
\text { (demisters) }\end{array}$ & High & $\begin{array}{l}\text { High moisture content of STSC } \\
\text { exhaust air (see Item 2.d-8.a) } \\
\text { or other inlet stream coupled } \\
\text { with closed isolation valve } \\
\text { ECRT-V-501) }\end{array}$ & $\begin{array}{l}\text { Radiological Control: } \\
\text { If the liquid level in the demisters is high, then moisture will not be removed } \\
\text { from the airstream. This could result in moisture build-up on the HEPA filters } \\
\text { resulting in their failure. }\end{array}$ & A & $\mathrm{L}$ & L & L \\
\hline \multirow[t]{2}{*}{ 2.d-13 } & \multirow[t]{2}{*}{$\begin{array}{l}\text { Level } \\
\text { (condensate } \\
\text { tank) }\end{array}$} & \multirow[t]{2}{*}{ Low } & \multirow[t]{2}{*}{$\begin{array}{l}\text { - Instrumentation failure } \\
\text { - Operator error (failure to add } \\
\text { water to tank) }\end{array}$} & $\begin{array}{l}\text { Radiological Control: } \\
\text { If the liquid level in condensate tank ECRT-TK- } 502 \text { drops below the diplegs, } \\
\text { then the ventilation system will draw a room air through the tank via the } \\
\text { condensate tank vent. This will unbalance the confinement ventilation } \\
\text { system airflows with the result that negative air pressure differentials may } \\
\text { not be properly maintained leading to a spread of contamination. }\end{array}$ & A & $\mathrm{L}$ & L & L \\
\hline & & & & $\begin{array}{l}\text { Hydrogen Deflagration: } \\
\text { If the airflows are unbalanced to the point that less than } 1 \mathrm{cfm} \text { is exhausted } \\
\text { from the STSC, then a hydrogen deflagration could occur. }\end{array}$ & A & $\mathrm{H}$ & L & $\mathrm{L}$ \\
\hline 2.d-14 & $\begin{array}{l}\text { Level } \\
\text { (condensate } \\
\text { tank) }\end{array}$ & High & $\begin{array}{l}\text { - High moisture content of } \\
\text { STSC exhaust air (see Item } \\
\text { 2.d-8.a) or other inlet air } \\
\text { stream } \\
\text { - STSC overfill } \\
\text { - Sand filter valving error (see } \\
\text { Table C-14, Item 3-5.c and } \\
\text { Table C-16, Item 4-5.c) }\end{array}$ & $\begin{array}{l}\text { Uncontrolled Release: } \\
\text { If the liquid level in condensate tank ECRT-TK- } 502 \text { is high, then the liquid } \\
\text { can overflow the tank resulting in a splash and splatter/pool release. }\end{array}$ & A & $\mathrm{L}$ & L & $\mathrm{L}$ \\
\hline
\end{tabular}


Table D-1. Frequency and Consequence Levels

\begin{tabular}{|c|c|c|c|c|c|c|c|c|}
\hline \multirow{2}{*}{ Item } & \multirow{2}{*}{$\begin{array}{l}\text { Process } \\
\text { Parameter }\end{array}$} & \multirow{2}{*}{ Deviation } & \multirow{2}{*}{ Cause } & \multirow{2}{*}{ Hazardous Condition } & \multirow{2}{*}{$\begin{array}{l}\text { Unmitigated } \\
\text { Frequency }\end{array}$} & \multicolumn{3}{|c|}{$\begin{array}{c}\text { Unmitigated } \\
\text { Consequences }\end{array}$} \\
\hline & & & & & & FW & Onsite & Offsite \\
\hline \multirow[t]{2}{*}{ 3-5.a } & \multirow[t]{2}{*}{ Flow } & \multirow[t]{2}{*}{$\begin{array}{l}\text { Misdirected } \\
\text { (into Decant Pump } \\
\text { Box) }\end{array}$} & \multirow{2}{*}{$\begin{array}{l}\text { - Valving error such that } \\
\text { supernate enters box via IXM } \\
\text { water spray nozzles } \\
\text { - Valving error such that } \\
\text { supernate enters box via } \\
\text { siphon break }\end{array}$} & $\begin{array}{l}\text { Uncontrolled Release: } \\
\text { If supernate is misdirected into the Decant Pump Box, then a splash and } \\
\text { splatter/pool release will occur. }\end{array}$ & A & L & L & L \\
\hline & & & & $\begin{array}{l}\text { Hydrogen deflagration: } \\
\text { If supernate is misdirected into the Decant Pump Box, then hydrogen } \\
\text { generated by the supernate could accumulate in the box resulting in a } \\
\text { deflagration. }\end{array}$ & A & $\mathrm{H}$ & L & L \\
\hline \multirow[t]{2}{*}{ 3-5.b } & \multirow[t]{2}{*}{ Flow } & \multirow[t]{2}{*}{$\begin{array}{l}\text { Misdirected } \\
\text { (into Sand Filter } \\
\text { Enclosure) }\end{array}$} & \multirow{2}{*}{$\begin{array}{l}\text { - Pressure safety valve PSV-1A } \\
\text { or -01B open } \\
\text { - Drain valve HV-03A/3B open } \\
\text { - Valving error such that } \\
\text { supernate enters enclosure } \\
\text { via siphon break }\end{array}$} & $\begin{array}{l}\text { Uncontrolled Release: } \\
\text { If supernate is misdirected into the Sand Filter Enclosure, then a splash and } \\
\text { splatter/pool release will occur. }\end{array}$ & A & $\mathrm{L}$ & L & $\mathrm{L}$ \\
\hline & & & & $\begin{array}{l}\text { Hydrogen Deflagration: } \\
\text { If supernate is misdirected into the Sand Filter Enclosure, then hydrogen } \\
\text { generated by the supernate could accumulate in the enclosure resulting in a } \\
\text { deflagration. }\end{array}$ & A & $\mathrm{H}$ & L & $\mathrm{L}$ \\
\hline 3-5.c & Flow & $\begin{array}{l}\text { Misdirected } \\
\text { (into sand filter } \\
\text { sparge exhaust) }\end{array}$ & Valving error (FV-06A/B) & $\begin{array}{l}\text { Uncontrolled Release: } \\
\text { If supernate is misdirected into the sand filter sparge exhaust, then catch } \\
\text { tank ECRT-TK- } 502 \text { will overflow and a splash and splatter/pool release will } \\
\text { occur. }\end{array}$ & A & L & L & L \\
\hline $3-5 . d$ & Flow & $\begin{array}{l}\text { Misdirected } \\
\text { (into Decant Pump } \\
\text { Box IXM water } \\
\text { supply) }\end{array}$ & Valving error & $\begin{array}{l}\text { Uncontrolled Release: } \\
\text { If supernate is misdirected into the Decant Pump Box IXM water supply, then } \\
\text { a splash and splatter/pool release could occur. }\end{array}$ & A & L & $\mathrm{L}$ & $\mathrm{L}$ \\
\hline 3-5.e & Flow & $\begin{array}{l}\text { Misdirected } \\
\text { (into Sand Filter } \\
\text { Enclosure IXM } \\
\text { water supply) }\end{array}$ & Valving error & $\begin{array}{l}\text { Uncontrolled Release: } \\
\text { If supernate is misdirected into the Sand Filter Enclosure IXM water supply, } \\
\text { then a splash and splatter/pool release could occur. }\end{array}$ & A & $\mathrm{L}$ & L & L \\
\hline
\end{tabular}


Table D-1. Frequency and Consequence Levels

\begin{tabular}{|c|c|c|c|c|c|c|c|c|}
\hline \multirow{2}{*}{ Item } & \multirow{2}{*}{$\begin{array}{l}\text { Process } \\
\text { Parameter }\end{array}$} & \multirow{2}{*}{ Deviation } & \multirow{2}{*}{ Cause } & \multirow{2}{*}{ Hazardous Condition } & \multirow{2}{*}{$\begin{array}{l}\text { Unmitigated } \\
\text { Frequency }\end{array}$} & \multicolumn{3}{|c|}{$\begin{array}{l}\text { Unmitigated } \\
\text { Consequences }\end{array}$} \\
\hline & & & & & & FW & Onsite & Offsite \\
\hline $3-5 . f$ & Flow & $\begin{array}{l}\text { Misdirected } \\
\text { (into Sand Filter } \\
\text { Enclosure } \\
\text { instrument air } \\
\text { supply) }\end{array}$ & Valving error & $\begin{array}{l}\text { Uncontrolled Release: } \\
\text { If supernate is misdirected into the Sand Filter Enclosure instrument air } \\
\text { supply, then a splash and splatter/pool release could occur. }\end{array}$ & A & L & L & L \\
\hline $3-5.9$ & Flow & $\begin{array}{l}\text { Misdirected } \\
\text { (into flocculant } \\
\text { addition supply) }\end{array}$ & Valving error & $\begin{array}{l}\text { Uncontrolled Release: } \\
\text { If supernate is misdirected into the flocculant addition supply, then a splash } \\
\text { and splatter/pool release could occur. }\end{array}$ & A & L & L & L \\
\hline 3-7 & Pressure & High & $\begin{array}{l}\text { - High air pressure to decant } \\
\text { pump ECRT-P-201 } \\
\text { - A normally-opened valve is } \\
\text { closed } \\
\text { - Sand filter media plugged }\end{array}$ & $\begin{array}{l}\text { Uncontrolled Release: } \\
\text { If the pressure is high, then the decant line or sand filter could fail resulting in } \\
\text { an airborne spray or splash and splatter/pool release. }\end{array}$ & A & $\mathrm{L}$ & L & L \\
\hline 3-9.a & $\begin{array}{l}\text { Concentration } \\
\text { (decanted } \\
\text { supernate) }\end{array}$ & High & $\begin{array}{l}\text { - Settling time too short } \\
\text { - Operator error }\end{array}$ & $\begin{array}{l}\text { Uncontrolled Release: } \\
\text { If the high turbidity results in plugging the sand filter, then decant pump } \\
\text { ECRT-P-201 will deadhead resulting in a high pressure. The consequences } \\
\text { are as stated in ltem } 3-7 \text { above. }\end{array}$ & A & L & L & L \\
\hline 3-13.a & $\begin{array}{l}\text { Structural } \\
\text { Integrity }\end{array}$ & $\begin{array}{l}\text { Leak/rupture } \\
\text { (diaphragm pümp) }\end{array}$ & $\begin{array}{l}\text { Decant pump ECRT-P-201 } \\
\text { diaphragm failure }\end{array}$ & $\begin{array}{l}\text { Uncontrolled Release: } \\
\text { If the decant pump diaphragm failed, then supernate could enter the pump } \\
\text { exhaust resulting in a spray or splash and splatter/pool release. }\end{array}$ & A & $\mathrm{L}$ & L & L \\
\hline \multirow[t]{2}{*}{$3-13 . b$} & \multirow[t]{2}{*}{$\begin{array}{l}\text { Structural } \\
\text { Integrity }\end{array}$} & \multirow[t]{2}{*}{$\begin{array}{l}\text { Leak/rupture } \\
\text { (sand filter) }\end{array}$} & \multirow[t]{2}{*}{$\begin{array}{l}\text { - High pressure (see Item 3-7 } \\
\text { above) } \\
\text { - Manufacturing flaw }\end{array}$} & $\begin{array}{l}\text { Uncontrolled Release: } \\
\text { If the sand filter fails, then a spray or splash and splatter/pool release will } \\
\text { occur inside the sand filter enclosure. }\end{array}$ & A & $\mathrm{L}$ & L & L \\
\hline & & & & $\begin{array}{l}\text { Hydrogen Deflagration: } \\
\text { If the sand filter fails, then decanted supernate would be spilled into the sand } \\
\text { filter enclosure. Hydrogen generated by the supernate could accumulate in } \\
\text { the enclosure resulting in a deflagration. }\end{array}$ & A & $H$ & $\mathrm{~L}$ & L \\
\hline
\end{tabular}


Table D-1. Frequency and Consequence Levels

\begin{tabular}{|c|c|c|c|c|c|c|c|c|}
\hline \multirow{2}{*}{ Item } & \multirow{2}{*}{$\begin{array}{l}\text { Process } \\
\text { Parameter }\end{array}$} & \multirow{2}{*}{ Deviation } & \multirow{2}{*}{ Cause } & \multirow{2}{*}{ Hazardous Condition } & \multirow{2}{*}{$\begin{array}{l}\text { Unmitigated } \\
\text { Frequency }\end{array}$} & \multicolumn{3}{|c|}{$\begin{array}{c}\text { Unmitigated } \\
\text { Consequences }\end{array}$} \\
\hline & & & & & & FW & Onsite & Offsite \\
\hline \multirow[t]{2}{*}{ 3-13.c } & \multirow[t]{2}{*}{$\begin{array}{l}\text { Structural } \\
\text { Integrity }\end{array}$} & \multirow[t]{2}{*}{$\begin{array}{l}\text { Leak/rupture } \\
\text { (decant line- } \\
\text { STSC to sand } \\
\text { filter) }\end{array}$} & \multirow[t]{2}{*}{$\begin{array}{l}\text { - High pressure (see Item 3-7 } \\
\text { above) } \\
\text { - Manufacturing flaw } \\
\text { - Hose connection decouples }\end{array}$} & $\begin{array}{l}\text { Uncontrolled Release: } \\
\text { If the decant line fails, then a spray or splash and splatter/pool release of } \\
\text { STSC supernate will occur. }\end{array}$ & A & $\mathrm{L}$ & $\mathrm{L}$ & $\mathrm{L}$ \\
\hline & & & & $\begin{array}{l}\text { Hydrogen deflagration: } \\
\text { If the decant line leaks or ruptures inside the decant pump box, then } \\
\text { decanted supernate would be spilled into the box. Hydrogen generated by } \\
\text { the supernate could accumulate in the box resulting in a deflagration. }\end{array}$ & A & $\mathrm{H}$ & $\mathrm{L}$ & L \\
\hline 3-13.d & $\begin{array}{l}\text { Structural } \\
\text { Integrity }\end{array}$ & $\begin{array}{l}\text { Leak/rupture } \\
\text { (decant line- } \\
\text { sand filter to } \\
\text { basin) }\end{array}$ & $\begin{array}{l}\text { - Manufacturing flaw } \\
\text { - Hose connection decouples } \\
\text { - External event }\end{array}$ & $\begin{array}{l}\text { Uncontrolled Release: } \\
\text { If the decant line fails, then a spray or splash and splatter/pool release of } \\
\text { filtered STSC supernate will occur. }\end{array}$ & A & $\mathrm{L}$ & $\mathrm{L}$ & $\mathrm{L}$ \\
\hline $3-16$ & $\begin{array}{l}\text { Time } \\
\text { Procedure }\end{array}$ & Skip action & Operator error & $\begin{array}{l}\text { Uncontrolled Release: } \\
\text { If the decant is not performed, the next process step is to backwash the sand } \\
\text { filters. This would result in pumping } 20-45 \mathrm{gpm} \text { of IXM water into the STSC. } \\
\text { The STSC would go solid and liquid would be pumped into the } 4 \text {-in and } 1 \text {-in. } \\
\text { ventilation exhaust lines and into the } 1 \text {-in. ventilation inlet line leading to a } \\
\text { splash and splatter/pool release. }\end{array}$ & A & $\mathrm{L}$ & $\mathrm{L}$ & $\mathrm{L}$ \\
\hline 3-17.b & $\begin{array}{l}\text { Time } \\
\text { Procedure }\end{array}$ & $\begin{array}{l}\text { Wrong action } \\
\text { (recirculate } \\
\text { instead of decant) }\end{array}$ & Operator error & $\begin{array}{l}\text { Uncontrolled Release: } \\
\text { If the supernate is recirculated instead of decanted, then decant pump *- } \\
\text { P-201 will deadhead resulting in high pressure. See Item 3-7 above. }\end{array}$ & A & $\mathrm{L}$ & $\mathrm{L}$ & L \\
\hline 4-4 & Flow & Reverse & $\begin{array}{l}\text { Breach in the IXM water supply } \\
\text { line results in siphoning of } \\
\text { supernate from the STSC } \\
\text { See also Table C-14, Item 3-5.3 }\end{array}$ & $\begin{array}{l}\text { Uncontrolled Release: } \\
\text { If the IXM water supply line is breached, then STSC supernate could be } \\
\text { siphoned from the STSC. The supernate would be filtered by a portion of } \\
\text { the sand filter bed. }\end{array}$ & A & L & $\mathrm{L}$ & L \\
\hline 4-5.a & Flow & $\begin{array}{l}\text { Misdirected } \\
\text { (into Sand Filter } \\
\text { Enclosure) }\end{array}$ & $\begin{array}{l}\text { - Pressure safety valve PSV-1A } \\
\text { or -01B open } \\
\text { - Valving error such that } \\
\text { supernate enters enclosure } \\
\text { via siphon break }\end{array}$ & $\begin{array}{l}\text { Uncontrolled Release: } \\
\text { If the release is via pressure safety valve PSV-1A or - } 01 B \text {, then sand filter } \\
\text { backwash will be misdirected into the Sand Filter Enclosure and a splash } \\
\text { and splatter/pool release will occur }\end{array}$ & A & $\mathrm{L}$ & $\mathrm{L}$ & L \\
\hline
\end{tabular}


Table D-1. Frequency and Consequence Levels

\begin{tabular}{|c|c|c|c|c|c|c|c|c|}
\hline \multirow{2}{*}{ Item } & \multirow{2}{*}{$\begin{array}{l}\text { Process } \\
\text { Parameter }\end{array}$} & \multirow{2}{*}{ Deviation } & \multirow{2}{*}{ Cause } & \multirow{2}{*}{ Hazardous Condition } & \multirow{2}{*}{$\begin{array}{l}\text { Unmitigated } \\
\text { Frequency }\end{array}$} & \multicolumn{3}{|c|}{$\begin{array}{l}\text { Unmitigated } \\
\text { Consequences }\end{array}$} \\
\hline & & & & & & FW & Onsite & Offsite \\
\hline 4-5.b & Flow & $\begin{array}{l}\text { Misdirected } \\
\text { (into Decant Pump } \\
\text { Box) }\end{array}$ & $\begin{array}{l}\text { - Valving error such that sand } \\
\text { filter backwash enters box via } \\
\text { IXM water spray nozzles } \\
\text { - Valving error such that } \\
\text { supernate enters box via } \\
\text { siphon break }\end{array}$ & $\begin{array}{l}\text { Uncontrolled Release: } \\
\text { If sand filter backwash is misdirected into the Decant Pump Box, then a } \\
\text { splash and splatter/pool release will occur. }\end{array}$ & A & $\mathrm{L}$ & L & L \\
\hline 4-5.c & Flow & $\begin{array}{l}\text { Misdirected } \\
\text { (into sand filter } \\
\text { sparge exhaust) }\end{array}$ & Valving error (FV-06A/B) & $\begin{array}{l}\text { Uncontrolled Release: } \\
\text { If backwash is misdirected into the sand filter sparge exhaust, then catch } \\
\text { tank ECRT-TK-502 will overflow and a splash and splatter/pool release will } \\
\text { occur. }\end{array}$ & A & L & L & L \\
\hline $4-5 . d$ & Flow & \begin{tabular}{l|} 
Misdirected \\
(into Decant Pump \\
Box IXM water \\
supply)
\end{tabular} & Valving error & $\begin{array}{l}\text { Uncontrolled Release: } \\
\text { If sand filter backwash is misdirected into the Decant Pump Box IXM water } \\
\text { supply, then a splash and splatter/pool release could occur. }\end{array}$ & A & L & L & L \\
\hline $4-5 . e$ & Flow & $\begin{array}{l}\text { Misdirected } \\
\text { (into Sand Filter } \\
\text { Enclosure } \\
\text { instrument air } \\
\text { supply) }\end{array}$ & Valving error & $\begin{array}{l}\text { Uncontrolled Release: } \\
\text { If misdirected into the Sand Filter Enclosure instrument air supply, then a } \\
\text { splash and splatter/pool release could occur. The release would be primarily } \\
\text { IXM water. }\end{array}$ & A & L & L & L \\
\hline $4-5 . f$ & Flow & $\begin{array}{l}\text { Misdirected } \\
\text { (into flocculant } \\
\text { addition supply) }\end{array}$ & Valving error & $\begin{array}{l}\text { Uncontrolled Release: } \\
\text { If sand filter backwash is misdirected into the flocculant addition supply, then } \\
\text { a splash and splatter/pool release could occur. }\end{array}$ & A & $\mathrm{L}$ & L & $\mathrm{L}$ \\
\hline 4-7 & Pressure & High & $\begin{array}{l}\text { - High water pressure from the } \\
\text { Skimmer Water Cleanup } \\
\text { System } \\
\text { - Throttle valve HCV-511 set } \\
\text { incorrectly } \\
\text { - A normally-opened valve is } \\
\text { closed }\end{array}$ & $\begin{array}{l}\text { Uncontrolled Release: } \\
\text { If a normally-opened valve is closed, then high pressure could result in a } \\
\text { failure in the filter backwash system resulting in a spray or splash and } \\
\text { splatter/pool release. }\end{array}$ & A & $\mathrm{L}$ & L & L \\
\hline
\end{tabular}


Table D-1. Frequency and Consequence Levels

\begin{tabular}{|c|c|c|c|c|c|c|c|c|}
\hline \multirow{2}{*}{ Item } & \multirow{2}{*}{$\begin{array}{l}\text { Process } \\
\text { Parameter }\end{array}$} & \multirow{2}{*}{ Deviation } & \multirow{2}{*}{ Cause } & \multirow{2}{*}{ Hazardous Condition } & \multirow{2}{*}{$\begin{array}{l}\text { Unmitigated } \\
\text { Frequency }\end{array}$} & \multicolumn{3}{|c|}{$\begin{array}{c}\text { Unmitigated } \\
\text { Consequences }\end{array}$} \\
\hline & & & & & & FW & Onsite & Offsite \\
\hline 4-12.a & $\begin{array}{l}\text { Level } \\
\text { (STSC at end } \\
\text { of backwash) }\end{array}$ & High & $\begin{array}{l}\text { Instrumentation and control } \\
\text { failure }\end{array}$ & $\begin{array}{l}\text { Uncontrolled Release: } \\
\text { If the backwash is not stopped, then the STSC will go solid and sand filter } \\
\text { backwash will be pumped into the } 4 \text {-in and } 1 \text {-in. ventilation exhaust lines and } \\
\text { into the } 1 \text {-in. ventilation inlet line leading to a splash and splatter/pool } \\
\text { release. }\end{array}$ & A & L & L & $\mathrm{L}$ \\
\hline \multirow[t]{2}{*}{ 4-13.a } & \multirow[t]{2}{*}{$\begin{array}{l}\text { Structural } \\
\text { Integrity }\end{array}$} & \multirow[t]{2}{*}{$\begin{array}{l}\text { Leak/rupture } \\
\text { (sand filter) }\end{array}$} & \multirow[t]{2}{*}{$\begin{array}{l}\text { - High pressure (see Item 4-7 } \\
\text { above) } \\
\text { - Manufacturing flaw }\end{array}$} & $\begin{array}{l}\text { Uncontrolled Release: } \\
\text { If the sand filter fails, then a spray or splash and splatter/pool release will } \\
\text { occur. }\end{array}$ & A & L & L & L \\
\hline & & & & $\begin{array}{l}\text { Hydrogen Deflagration: } \\
\text { If the sand filter fails, then sand filter backwash would be spilled into the } \\
\text { sand filter enclosure. Hydrogen generated by the backwash could } \\
\text { accumulate in the enclosure resulting in a deflagration. }\end{array}$ & A & $\mathrm{H}$ & $\mathrm{L}$ & $\mathrm{L}$ \\
\hline \multirow[t]{2}{*}{ 4-13.b } & \multirow[t]{2}{*}{$\begin{array}{l}\text { Structural } \\
\text { Integrity }\end{array}$} & \multirow[t]{2}{*}{$\begin{array}{l}\text { Leak/rupture } \\
\text { (backwash line- } \\
\text { sand filter to } \\
\text { STSC) }\end{array}$} & \multirow[t]{2}{*}{$\begin{array}{l}\text { - High pressure (see Item 4-7 } \\
\text { above) } \\
\text { - Manufacturing flaw } \\
\text { - Hose connection decouples }\end{array}$} & $\begin{array}{l}\text { Uncontrolled Release: } \\
\text { If the backwash line fails, then a spray or splash and splatter/pool release } \\
\text { will occur. }\end{array}$ & A & $\mathrm{H}$ & $\mathrm{H}$ & L \\
\hline & & & & $\begin{array}{l}\text { Hydrogen deflagration: } \\
\text { If the backwash line leaks or ruptures inside the sand filter enclosure, then } \\
\text { sand filter backwash would be spilled into the sand filter enclosure. } \\
\text { Hydrogen generated by the backwash could accumulate in the box resulting } \\
\text { in a deflagration. }\end{array}$ & A & $\mathrm{H}$ & L & $\mathrm{L}$ \\
\hline $4-16$ & $\begin{array}{l}\text { Time } \\
\text { Procedure }\end{array}$ & Skip action & Operator error & $\begin{array}{l}\text { Hydrogen Deflagration: } \\
\text { If the backwash is not performed, then hydrogen generated by the sludge } \\
\text { captured on the sand filter media could accumulate in the headspace of the } \\
\text { sand filter resulting in a deflagration. }\end{array}$ & A & $\mathrm{H}$ & L & $\mathrm{L}$ \\
\hline $5-1$ & Flow & No & $\begin{array}{l}\text { - Nitrogen bottles empty } \\
\text { - A normally-opened valve is } \\
\text { closed }\end{array}$ & $\begin{array}{l}\text { Hydrogen Deflagration: } \\
\text { If there is no nitrogen flow, then the STSC will not be inerted. This could } \\
\text { result in a hydrogen deflagration. }\end{array}$ & A & $\mathrm{H}$ & $\mathrm{L}$ & $\mathrm{L}$ \\
\hline
\end{tabular}


Table D-1. Frequency and Consequence Levels

\begin{tabular}{|c|c|c|c|c|c|c|c|c|}
\hline \multirow{2}{*}{ Item } & \multirow{2}{*}{$\begin{array}{l}\text { Process } \\
\text { Parameter }\end{array}$} & \multirow{2}{*}{ Deviation } & \multirow{2}{*}{ Cause } & \multirow{2}{*}{ Hazardous Condition } & \multirow{2}{*}{$\begin{array}{l}\text { Unmitigated } \\
\text { Frequency }\end{array}$} & \multicolumn{3}{|c|}{$\begin{array}{c}\text { Unmitigated } \\
\text { Consequences }\end{array}$} \\
\hline & & & & & & FW & Onsite & Offsite \\
\hline $5-5 . a$ & Flow & $\begin{array}{l}\text { Misdirected } \\
\text { (flow into STS } \\
\text { cask) }\end{array}$ & $\begin{array}{l}\text { Valve ECRT-V-609 set } \\
\text { incorrectly }\end{array}$ & $\begin{array}{l}\text { Hydrogen Deflagration: } \\
\text { If the nitrogen flow is misdirected to the STS cask, then the STSC will not be } \\
\text { inerted. This could result in a hydrogen deflagration. }\end{array}$ & A & $\mathrm{H}$ & L & L \\
\hline $5-5 . b$ & Flow & $\begin{array}{l}\text { Misdirected } \\
\text { (flow into Annex) }\end{array}$ & Valve ECRT-V-732 open & $\begin{array}{l}\text { Hydrogen Deflagration: } \\
\text { If the nitrogen flow is misdirected into the Loading Bay, then the STSC will } \\
\text { not be inerted. This could result in a hydrogen deflagration. }\end{array}$ & A & $\mathrm{H}$ & $\mathrm{L}$ & $\mathrm{L}$ \\
\hline $5-9$ & Concentration & $\begin{array}{l}\text { High } \\
\left(\mathrm{O}_{2}\right)\end{array}$ & $\begin{array}{l}\text { - Purge duration too short (see } \\
\text { Item 5-14 below) } \\
\text { - Insufficient nitrogen supply } \\
\text { - No nitrogen flow (see Item 5- } \\
1 \text { above) } \\
\text { - Misdirected nitrogen flow } \\
\text { (see Item 5-5.a, and .b } \\
\text { above) }\end{array}$ & $\begin{array}{l}\text { Hydrogen Deflagration: } \\
\text { If the oxygen concentration in the STSC is high, then the STSC will not be } \\
\text { inerted. This could result in a hydrogen deflagration. }\end{array}$ & A & $\mathrm{H}$ & L & $L$ \\
\hline 5-10.a & Composition & $\begin{array}{l}\text { Other } \\
\text { (oxidant) }\end{array}$ & $\begin{array}{l}\text { Gas bottles containing an } \\
\text { oxidant (e.g., air) installed at } \\
\text { Inert Bottle Station }\end{array}$ & $\begin{array}{l}\text { Hydrogen Deflagration: } \\
\text { If gas bottles containing an oxidant are installed at the Inert Bottle Station, } \\
\text { then the STSC will not be inerted. This could result in a hydrogen } \\
\text { deflagration. }\end{array}$ & A & $\mathrm{H}$ & L & $\mathrm{L}$ \\
\hline 5-10.b & Composition & $\begin{array}{l}\text { Other } \\
\text { (helium) }\end{array}$ & $\begin{array}{l}\text { Gas bottles containing helium } \\
\text { installed at Inert Bottle Station }\end{array}$ & $\begin{array}{l}\text { Hydrogen Deflagration: } \\
\text { If helium gas bottles are installed, then too much counter-current flow will } \\
\text { occur and the STSC will not be inerted. }\end{array}$ & A & $\mathrm{H}$ & L & $\mathrm{L}$ \\
\hline $5-12 . b$ & Level & $\begin{array}{l}\text { Low } \\
\text { (nitrogen bottle } \\
\text { volume) }\end{array}$ & $\begin{array}{l}\text { - Leak in supply system } \\
\text { - Operator error (low pressure } \\
\text { bottles not replaced as } \\
\text { needed) }\end{array}$ & $\begin{array}{l}\text { Hydrogen Deflagration: } \\
\text { If the nitrogen volume is low, then there could be insufficient nitrogen to inert } \\
\text { the STSC. This could result in a hydrogen deflagration. }\end{array}$ & A & $\mathrm{H}$ & $\mathrm{L}$ & $\mathrm{L}$ \\
\hline $5-13$ & $\begin{array}{l}\text { Structural } \\
\text { Integrity }\end{array}$ & $\begin{array}{l}\text { Leak/rupture } \\
\text { (nitrogen supply } \\
\text { system) }\end{array}$ & $\begin{array}{l}\text { - Overpressurization } \\
\text { - Hose disconnects }\end{array}$ & $\begin{array}{l}\text { Hydrogen Deflagration: } \\
\text { If a leak or rupture in the nitrogen supply occurs, then the STSC will not be } \\
\text { inerted. This could result in a hydrogen deflagration. }\end{array}$ & A & $\mathrm{H}$ & L & $\mathrm{L}$ \\
\hline
\end{tabular}


Table D-1. Frequency and Consequence Levels

\begin{tabular}{|c|c|c|c|c|c|c|c|c|}
\hline \multirow{2}{*}{ Item } & \multirow{2}{*}{$\begin{array}{l}\text { Process } \\
\text { Parameter }\end{array}$} & \multirow{2}{*}{ Deviation } & \multirow{2}{*}{ Cause } & \multirow{2}{*}{ Hazardous Condition } & \multirow{2}{*}{$\begin{array}{l}\text { Unmitigated } \\
\text { Frequency }\end{array}$} & \multicolumn{3}{|c|}{$\begin{array}{l}\text { Unmitigated } \\
\text { Consequences }\end{array}$} \\
\hline & & & & & & FW & Onsite & Offsite \\
\hline $5-14$ & \begin{tabular}{|l} 
Time \\
Procedure
\end{tabular} & Too short & $\begin{array}{l}\text { - Operator error } \\
\text { - Instrumentation failure (AE- } \\
760-601)\end{array}$ & $\begin{array}{l}\text { Hydrogen Deflagration: } \\
\text { If the purge occurs for too short a period of time (i.e., before the oxygen } \\
\text { concentration reaches } 0.1 \% \text { ), then a hydrogen deflagration could occur. }\end{array}$ & A & H & $\mathrm{L}$ & $\mathrm{L}$ \\
\hline $5-16$ & $\begin{array}{l}\text { Time } \\
\text { Procedure }\end{array}$ & Skip action & Operator error & $\begin{array}{l}\text { Hydrogen Deflagration: } \\
\text { If the STSC is not inerted, then a hydrogen deflagration could occur. }\end{array}$ & A & $\mathrm{H}$ & $\mathrm{L}$ & $\mathrm{L}$ \\
\hline $6-1$ & Flow & No & $\begin{array}{l}\text { - Nitrogen bottles empty } \\
\text { - A normally-opened valve is } \\
\text { closed }\end{array}$ & $\begin{array}{l}\text { Hydrogen Deflagration: } \\
\text { If there is no nitrogen flow, then the STS cask will not be inerted. This could } \\
\text { result in a hydrogen deflagration. }\end{array}$ & A & $H$ & $\mathrm{~L}$ & $\mathrm{~L}$ \\
\hline $6-5$ & Flow & $\begin{array}{l}\text { Misdirected } \\
\text { (flow into Annex) }\end{array}$ & $\begin{array}{l}\text { Valve ECRT-V-609 set } \\
\text { incorrectly }\end{array}$ & $\begin{array}{l}\text { Hydrogen Deflagration: } \\
\text { If valve ECRT-V- } 609 \text { is mispositioned, then the nitrogen flow would be } \\
\text { directed to the STSC purge inlet where it would deadhead against the male } \\
\text { Staubli connector. The STS cask would not be inerted. }\end{array}$ & A & $\mathrm{H}$ & $\mathrm{L}$ & $\mathrm{L}$ \\
\hline 6-7.a & Pressure & $\begin{array}{l}\text { High } \\
\text { (nitrogen supply } \\
\text { system) }\end{array}$ & $\begin{array}{l}\text { - A normally-opened valve is } \\
\text { partially closed } \\
\text { - Pressure control valve failure }\end{array}$ & $\begin{array}{l}\text { Hydrogen Deflagration: } \\
\text { If the pressure is high, then the piping or hoses could fail such that the STS } \\
\text { cask is not inerted. This could result in a hydrogen deflagration. }\end{array}$ & A & $\mathrm{H}$ & $\mathrm{L}$ & L \\
\hline \multirow[t]{2}{*}{$6-7 . b$} & \multirow[t]{2}{*}{ Pressure } & \multirow[t]{2}{*}{$\begin{array}{l}\text { High } \\
\text { (STS cask) }\end{array}$} & \multirow[t]{2}{*}{$\begin{array}{l}\text { Pressure control valve failure } \\
\text { and vent port tool closed }\end{array}$} & $\begin{array}{l}\text { Radiological Control: } \\
\text { If the pressure is high, then the STS cask mechanical seal could fail. If the } \\
\text { inside of the STS cask was contaminated, then contaminated nitrogen would } \\
\text { be discharged into the loading bay. }\end{array}$ & A & L & $\mathrm{L}$ & $\mathrm{L}$ \\
\hline & & & & $\begin{array}{l}\text { Hydrogen Deflagration: } \\
\text { Overpressurizing the STS cask would cause the mechanical seal to fail. } \\
\text { This would allow air ingress into the STS cask and, subsequently, into the } \\
\text { STSC. This could lead to a hydrogen deflagration. }\end{array}$ & A & $\mathrm{H}$ & $\mathrm{L}$ & $\mathrm{L}$ \\
\hline
\end{tabular}


Table D-1. Frequency and Consequence Levels

\begin{tabular}{|c|c|c|c|c|c|c|c|c|}
\hline \multirow{2}{*}{ Item } & \multirow{2}{*}{$\begin{array}{l}\text { Process } \\
\text { Parameter }\end{array}$} & \multirow{2}{*}{ Deviation } & \multirow{2}{*}{ Cause } & \multirow{2}{*}{ Hazardous Condition } & \multirow{2}{*}{$\begin{array}{l}\text { Unmitigated } \\
\text { Frequency }\end{array}$} & \multicolumn{3}{|c|}{$\begin{array}{l}\text { Unmitigated } \\
\text { Consequences }\end{array}$} \\
\hline & & & & & & FW & Onsite & Offsite \\
\hline 6-9 & Concentration & $\begin{array}{l}\text { High } \\
\left(\mathrm{O}_{2}\right)\end{array}$ & $\begin{array}{l}\text { - Purge duration too short (see } \\
\text { Item 6-12 below) } \\
\text { - Insufficient nitrogen supply } \\
\text { - No nitrogen flow (see ltem 6- } \\
1 \text { above) } \\
\text { - Misdirected nitrogen flow } \\
\text { (see ltem 6-5 above) }\end{array}$ & $\begin{array}{l}\text { Hydrogen Deflagration: } \\
\text { If the oxygen concentration in the STS cask is high, then the STS cask will } \\
\text { not be inerted. This could result in a hydrogen deflagration. }\end{array}$ & A & $\mathrm{H}$ & L & L \\
\hline 6-10.a & Composition & $\begin{array}{l}\text { Other } \\
\text { (oxidant) }\end{array}$ & $\begin{array}{l}\text { Gas bottles containing an } \\
\text { oxidant (e.g., air) installed at } \\
\text { Inert Bottle Station }\end{array}$ & $\begin{array}{l}\text { Hydrogen Deflagration: } \\
\text { If gas bottles containing an oxidant are installed at the Inert Bottle Station, } \\
\text { then the STS cask will not be inerted. This could result in a hydrogen } \\
\text { deflagration. }\end{array}$ & A & $H$ & L & L \\
\hline $6-10 . b$ & Composition & $\begin{array}{l}\text { Other } \\
\text { (helium) }\end{array}$ & $\begin{array}{l}\text { Gas bottles containing helium } \\
\text { installed at Inert Bottle Station }\end{array}$ & $\begin{array}{l}\text { Hydrogen Deflagration: } \\
\text { If helium gas bottles are installed at the Bottle Station, then too much air } \\
\text { ingress will occur and the STS cask will not be inerted. }\end{array}$ & A & $\mathrm{H}$ & L & L \\
\hline $6-11$ & Level & $\begin{array}{l}\text { Low } \\
\text { (nitrogen bottle } \\
\text { volume) }\end{array}$ & $\begin{array}{l}\text { - Leak in supply system } \\
\text { - Operator error (low pressure } \\
\text { bottles not replaced as } \\
\text { needed) }\end{array}$ & $\begin{array}{l}\text { Hydrogen Deflagration: } \\
\text { If the nitrogen volume is low, then there could be insufficient nitrogen to inert } \\
\text { the STS cask. This could result in a hydrogen deflagration. }\end{array}$ & A & $\mathrm{H}$ & $\mathrm{L}$ & L \\
\hline 6-13.a & $\begin{array}{l}\text { Structural } \\
\text { Integrity }\end{array}$ & $\begin{array}{l}\text { Leak/rupture } \\
\text { (nitrogen supply } \\
\text { system) }\end{array}$ & $\begin{array}{l}\text { - Overpressurization } \\
\text { - Hose disconnects }\end{array}$ & $\begin{array}{l}\text { Hydrogen Deflagration: } \\
\text { If a leak or rupture in the nitrogen supply occurs, then the STS cask will not } \\
\text { be inerted. This could result in a hydrogen deflagration. }\end{array}$ & A & $\mathrm{H}$ & L & L \\
\hline $6-13 . b$ & $\begin{array}{l}\text { Structural } \\
\text { Integrity }\end{array}$ & $\begin{array}{l}\text { Leak/rupture } \\
\text { (STS cask) }\end{array}$ & $\begin{array}{l}\text { - Overpressurization } \\
\text { - Mechanical seal failure }\end{array}$ & $\begin{array}{l}\text { Hydrogen deflagration: } \\
\text { If the STS cask leaks, then air will leak into the STS cask and, subsequently, } \\
\text { into the STSC. This could lead to a hydrogen deflagration. }\end{array}$ & A & $\mathrm{H}$ & $\mathrm{L}$ & $\mathrm{L}$ \\
\hline $6-14$ & $\begin{array}{l}\text { Time } \\
\text { Procedure }\end{array}$ & Too short & $\begin{array}{l}\text { - Operator error } \\
\text { - Instrumentation failure (AE- } \\
760-601)\end{array}$ & $\begin{array}{l}\text { Hydrogen Deflagration: } \\
\text { If the purge occurs for too short a period of time (i.e., before the oxygen } \\
\text { concentration reaches } 0.1 \% \text { ), then a hydrogen deflagration could occur. }\end{array}$ & A & $\mathrm{H}$ & $\mathrm{L}$ & L \\
\hline $6-16$ & $\begin{array}{l}\text { Time } \\
\text { Procedure }\end{array}$ & Skip action & Operator error & $\begin{array}{l}\text { Hydrogen Deflagration: } \\
\text { If the STS cask is not inerted, then a hydrogen deflagration could occur. }\end{array}$ & A & $H$ & L & $\mathrm{L}$ \\
\hline
\end{tabular}


Table D-1. Frequency and Consequence Levels

\begin{tabular}{|c|c|c|c|c|c|c|c|c|}
\hline \multirow{2}{*}{ Item } & \multirow{2}{*}{$\begin{array}{l}\text { Process } \\
\text { Parameter }\end{array}$} & \multirow{2}{*}{ Deviation } & \multirow{2}{*}{ Cause } & \multirow{2}{*}{ Hazardous Condition } & \multirow{2}{*}{$\begin{array}{l}\text { Unmitigated } \\
\text { Frequency }\end{array}$} & \multicolumn{3}{|c|}{$\begin{array}{l}\text { Unmitigated } \\
\text { Consequences }\end{array}$} \\
\hline & & & & & & FW & Onsite & Offsite \\
\hline 7-1. & Flow & No & $\begin{array}{l}\text { - No nitrogen pressure } \\
\text { - Drain port closed } \\
\text { - A normally opened valve is } \\
\text { closed }\end{array}$ & $\begin{array}{l}\text { Hydrogen Deflagration: } \\
\text { If there is no flow, then the STS cask will not be pressurized. Air inleakage } \\
\text { could occur eventually leading to a flammable hydrogen concentration. }\end{array}$ & A & $\mathrm{H}$ & $\mathrm{L}$ & $\mathrm{L}$ \\
\hline $7-3$ & Flow & High & High nitrogen pressure & $\begin{array}{l}\text { Overpressurization: } \\
\text { If the flow is high, then operators may exceed the STS cask high pressure } \\
\text { limit. This could result in cask overpressurization. }\end{array}$ & A & L & $\mathrm{L}$ & $\mathrm{L}$ \\
\hline \multirow[t]{2}{*}{$7-4$} & \multirow[t]{2}{*}{ Flow } & \multirow[t]{2}{*}{$\begin{array}{l}\text { Reverse } \\
\text { (nitrogen flow out } \\
\text { of STS cask) }\end{array}$} & \multirow[t]{2}{*}{$\begin{array}{l}\text { - Leak or rupture of nitrogen } \\
\text { supply piping or hose } \\
\text { - Vent port tool leak } \\
\text { - STS cask mechanical seal } \\
\text { leak }\end{array}$} & $\begin{array}{l}\text { Radiological Control: } \\
\text { If nitrogen flows out of the STS cask and the inside of the STS cask was } \\
\text { contaminated, then there would be a spread of contamination at the point of } \\
\text { the leak. }\end{array}$ & A & $\mathrm{L}$ & $\mathrm{L}$ & $\mathrm{L}$ \\
\hline & & & & $\begin{array}{l}\text { Hydrogen Deflagration: } \\
\text { If the nitrogen flows out of the cask, then the STS cask will not be } \\
\text { pressurized. Air inleakage could occur eventually leading to a flammable } \\
\text { hydrogen concentration. }\end{array}$ & A & $\mathrm{H}$ & $\mathrm{L}$ & $\mathrm{L}$ \\
\hline $7-5$ & Flow & Misdirected & $\begin{array}{l}\text { Valve ECRT-V-609 } \\
\text { mispositioned }\end{array}$ & $\begin{array}{l}\text { Hydrogen Deflagration: } \\
\text { If valve ECRT-V-609 is mispositioned, then the nitrogen flow would be } \\
\text { directed to the STSC purge inlet where it would deadhead against the male } \\
\text { Staubli connector. The STS cask would not be pressurized. Air inleakage } \\
\text { could occur eventually leading to a flammable hydrogen concentration. }\end{array}$ & A & $\mathrm{H}$ & $\mathrm{L}$ & $\mathrm{L}$ \\
\hline \multirow[t]{2}{*}{$7-7 . a$} & \multirow[t]{2}{*}{ Pressure } & \multirow[t]{2}{*}{$\begin{array}{l}\text { High } \\
\text { (nitrogen supply } \\
\text { system) }\end{array}$} & \multirow[t]{2}{*}{$\begin{array}{l}\text { - A normally-opened valve is } \\
\text { closed or partially closed } \\
\text { - Pressure control valve failure }\end{array}$} & $\begin{array}{l}\text { Overpressurization } \\
\text { If the pressure is high then the flow rate will be high and operators may } \\
\text { exceed the STS cask high pressure limit. This could result in STS cask } \\
\text { overpressurization. }\end{array}$ & A & $\mathrm{L}$ & $\mathrm{L}$ & $\mathrm{L}$ \\
\hline & & & & $\begin{array}{l}\text { Hydrogen Deflagration: } \\
\text { If the pressure is high, then the piping or hoses could fail such that the STS } \\
\text { cask would not be pressurized. Air inleakage could occur eventually leading } \\
\text { to a flammable hydrogen concentration. }\end{array}$ & A & $H$ & $\mathrm{~L}$ & L \\
\hline
\end{tabular}


Table D-1. Frequency and Consequence Levels

\begin{tabular}{|c|c|c|c|c|c|c|c|c|}
\hline \multirow{2}{*}{ Item } & \multirow{2}{*}{$\begin{array}{l}\text { Process } \\
\text { Parameter }\end{array}$} & \multirow{2}{*}{ Deviation } & \multirow{2}{*}{ Cause } & \multirow{2}{*}{ Hazardous Condition } & \multirow{2}{*}{$\begin{array}{l}\text { Unmitigated } \\
\text { Frequency }\end{array}$} & \multicolumn{3}{|c|}{$\begin{array}{l}\text { Unmitigated } \\
\text { Consequences }\end{array}$} \\
\hline & & & & & & FW & Onsite & Offsite \\
\hline \multirow[t]{2}{*}{ 7-7.b } & \multirow[t]{2}{*}{ Pressure } & \multirow[t]{2}{*}{$\begin{array}{l}\text { High } \\
\text { (STS cask) }\end{array}$} & \multirow[t]{2}{*}{ Pressure control valve failure } & $\begin{array}{l}\text { Overpressurization: } \\
\text { If the pressure is greater than the STS cask high pressure limit of } 15 \text { psig, } \\
\text { then the STS cask could overpressurize. }\end{array}$ & A & L & L & L \\
\hline & & & & $\begin{array}{l}\text { Hydrogen Deflagration: } \\
\text { If the pressure is high, then the STS cask mechanical seal could fail. This } \\
\text { would allow air inleakage once the nitrogen flow was stopped. This could } \\
\text { eventually lead to a flammable hydrogen concentration. }\end{array}$ & A & $\mathrm{H}$ & L & L \\
\hline 7-8.a & Composition & $\begin{array}{l}\text { Other } \\
\text { (oxidant) }\end{array}$ & $\begin{array}{l}\text { Gas bottles containing an } \\
\text { oxidant (e.g., air) installed at } \\
\text { Inert Bottle Station }\end{array}$ & $\begin{array}{l}\text { Hydrogen Deflagration: } \\
\text { If gas bottles containing an oxidant are installed at the Inert Bottle Station, } \\
\text { then an oxidant would be added to the STS cask by the pressurization } \\
\text { activity and might not be inerted. This could result in a hydrogen } \\
\text { deflagration. }\end{array}$ & A & $\mathrm{H}$ & L & L \\
\hline $7-8 . b$ & Composition & $\begin{array}{l}\text { Other } \\
\text { (helium) }\end{array}$ & $\begin{array}{l}\text { Gas bottles containing helium } \\
\text { installed at Inert Bottle Station }\end{array}$ & $\begin{array}{l}\text { Hydrogen Deflagration: } \\
\text { If helium gas bottles are installed at the Bottle Station, then too much air } \\
\text { inleakage will occur and the STS cask will not be inerted. }\end{array}$ & A & $H$ & L & $\mathrm{L}$ \\
\hline 7-9 & Level & $\begin{array}{l}\text { Low } \\
\text { (nitrogen bottle } \\
\text { volume) }\end{array}$ & $\begin{array}{l}\text { - Leak in supply system } \\
\text { - Operator error (low pressure } \\
\text { bottles not replaced as } \\
\text { needed) }\end{array}$ & $\begin{array}{l}\text { Hydrogen Deflagration: } \\
\text { If the nitrogen volume is low, then there could be insufficient nitrogen to } \\
\text { pressurize the STS cask to the low pressure limit. Air inleakage could occur } \\
\text { eventually leading to a flammable hydrogen concentration. }\end{array}$ & A & $\mathrm{H}$ & $\mathrm{L}$ & $\mathrm{L}$ \\
\hline 7-11.a & $\begin{array}{l}\text { Structural } \\
\text { integrity }\end{array}$ & $\begin{array}{l}\text { Leak/rupture } \\
\text { (nitrogen supply } \\
\text { system) }\end{array}$ & $\begin{array}{l}\text { - Overpressurization } \\
\text { - Manufacturing flaw } \\
\text { - Procurement error } \\
\text { - Hose connection decouples }\end{array}$ & $\begin{array}{l}\text { Hydrogen Deflagration: } \\
\text { If there is a leak/rupture in the nitrogen supply system, then the STS cask } \\
\text { would not be pressurized. Air inleakage could occur eventually leading to a } \\
\text { flammable hydrogen concentration. }\end{array}$ & A & $H$ & L & L \\
\hline 7-11.b & $\begin{array}{l}\text { Structural } \\
\text { integrity }\end{array}$ & $\begin{array}{l}\text { Leak/rupture } \\
\text { (STS cask) }\end{array}$ & $\begin{array}{l}\text { - Overpressurization } \\
\text { - STS cask mechanical seal } \\
\text { failure }\end{array}$ & $\begin{array}{l}\text { Hydrogen deflagration: } \\
\text { If the STS cask leaks/ruptures, then air will leak into the STS cask. This } \\
\text { could eventually lead to a hydrogen deflagration. }\end{array}$ & A & $\mathrm{H}$ & L & L \\
\hline
\end{tabular}


Table D-1. Frequency and Consequence Levels

\begin{tabular}{|c|c|c|c|c|c|c|c|c|}
\hline \multirow{2}{*}{ Item } & \multirow{2}{*}{$\begin{array}{l}\text { Process } \\
\text { Parameter }\end{array}$} & \multirow{2}{*}{ Deviation } & \multirow{2}{*}{ Cause } & \multirow{2}{*}{ Hazardous Condition } & \multirow{2}{*}{$\begin{array}{l}\text { Unmitigated } \\
\text { Frequency }\end{array}$} & \multicolumn{3}{|c|}{$\begin{array}{c}\text { Unmitigated } \\
\text { Consequences }\end{array}$} \\
\hline & & & & & & FW & Onsite & Offsite \\
\hline $7-12$ & $\begin{array}{l}\text { Time } \\
\text { procedure }\end{array}$ & Too short & $\begin{array}{l}\text { - Operator error } \\
\text { - Instrumentation failure }\end{array}$ & $\begin{array}{l}\text { Hydrogen deflagration: } \\
\text { If the operator pressurizes the STS cask for too short a period of time, then } \\
\text { the STS cask will not be pressurized to the low pressure limit. Air inleakage } \\
\text { could occur eventually leading to a flammable hydrogen concentration. }\end{array}$ & A & $\mathrm{H}$ & $\mathrm{L}$ & $\mathrm{L}$ \\
\hline $7-13$ & $\begin{array}{l}\text { Time } \\
\text { Procedure }\end{array}$ & Too long & $\begin{array}{l}\text { - Operator error } \\
\text { - Instrumentation failure }\end{array}$ & $\begin{array}{l}\text { Overpressurization: } \\
\text { If the operator pressurizes the STS cask for too long a period of time, then } \\
\text { the STS cask high pressure limit will be exceeded. This could result in cask } \\
\text { overpressurization. }\end{array}$ & A & $\mathrm{L}$ & $\mathrm{L}$ & $\mathrm{L}$ \\
\hline 7-14 & $\begin{array}{l}\text { Time } \\
\text { Procedure }\end{array}$ & Skip action & - Operator error & $\begin{array}{l}\text { Hydrogen deflagration: } \\
\text { If the operator does not pressurize the STS cask, then air inleakage could } \\
\text { occur eventually leading to a flammable hydrogen concentration. }\end{array}$ & A & $\mathrm{H}$ & $\mathrm{L}$ & $\mathbf{L}$ \\
\hline 8-4.a & Flow & Reverse & $\begin{array}{l}\text { Metering pump ECRT-P-203 } \\
\text { runs in reverse }\end{array}$ & $\begin{array}{l}\text { Uncontrolled Release: } \\
\text { If metering pump ECRT-P-203 runs in reverse, then sludge would be } \\
\text { pumped into the flocculant addition system and could result in a spray or } \\
\text { splash and splatter/pool release. }\end{array}$ & A & $\mathrm{L}$ & $\mathrm{L}$ & $\mathrm{L}$ \\
\hline 8-4.b & Flow & Reverse & $\begin{array}{l}\text { Booster pump ECRT-P-101 } \\
\text { runs in reverse }\end{array}$ & $\begin{array}{l}\text { Uncontrolled Release: } \\
\text { If booster pump ECRT-P-101 runs in reverse, then sludge could flow into the } \\
\text { flocculant addition system to a point above the basin water. } \\
\text { If the flocculant addition system line failed due to the pressure generated by } \\
\text { pump ECRT-P-101, then a spray or splash and splatter/pool release could } \\
\text { occur. }\end{array}$ & A & $\mathrm{H}$ & $\mathrm{H}$ & $\mathrm{L}$ \\
\hline $9 . a-4$ & Flow & Reverse & $\begin{array}{l}\text { - Metering pump ECRT-P-204 } \\
\text { runs in reverse } \\
\text { - Metering pump ECRT-P-204 } \\
\text { not operating } \\
\text { - Low pressure in flocculant } \\
\text { addition line }\end{array}$ & $\begin{array}{l}\text { Uncontrolled Release: } \\
\text { If metering pump ECRT-P-204 runs in reverse, then recirculated supernate } \\
\text { would be pumped into the flocculant addition system and could result in a } \\
\text { spray or and splatter/pool release. } \\
\text { If metering pump ECRT-P-204 does not operate, or if the pressure in the } \\
\text { flocculant addition line is low, then recirculated supernate would be pumped } \\
\text { into the flocculant addition system (due to the } 80 \text { psi generated by decant } \\
\text { pump ECRT-P-201) and could result in a spray or splash and splatter/pool } \\
\text { release. }\end{array}$ & A & $\mathrm{L}$ & $\mathrm{L}$ & $\mathrm{L}$ \\
\hline
\end{tabular}


Table D-1. Frequency and Consequence Levels

\begin{tabular}{|c|c|c|c|c|c|c|c|c|}
\hline \multirow{2}{*}{ Item } & \multirow{2}{*}{$\begin{array}{l}\text { Process } \\
\text { Parameter }\end{array}$} & \multirow{2}{*}{ Deviation } & \multirow{2}{*}{ Cause } & \multirow{2}{*}{ Hazardous Condition } & \multirow{2}{*}{$\begin{array}{l}\text { Unmitigated } \\
\text { Frequency }\end{array}$} & \multicolumn{3}{|c|}{$\begin{array}{c}\text { Unmitigated } \\
\text { Consequences }\end{array}$} \\
\hline & & & & & & FW & Onsite & Offsite \\
\hline $9 . a-6$ & Pressure & Low & - Flow rate set incorrectly & $\begin{array}{l}\text { Uncontrolled Release: } \\
\text { If the pressure is low, then recirculated supernate would be pumped into the } \\
\text { flocculant addition system (due to the } 80 \text { psi generated by decant pump } \\
\text { ECRT-P-201) and could result in a spray or splash and splatter/pool release. }\end{array}$ & A & $\mathrm{L}$ & $\mathrm{L}$ & $\mathrm{L}$ \\
\hline \multirow[t]{2}{*}{ 9.a-7 } & \multirow[t]{2}{*}{ Pressure } & \multirow[t]{2}{*}{ High } & \multirow[t]{2}{*}{$\begin{array}{l}\text { - Flow rate set incorrectly } \\
\text { - Normally opened valve closed } \\
\text { or partially closed }\end{array}$} & $\begin{array}{l}\text { Uncontrolled Release: } \\
\text { If the pressure is high, then the decantflocculant recirculation line could fail } \\
\text { resulting in a spray or splash and splatter/pool release }\end{array}$ & A & $\mathrm{L}$ & $\mathrm{L}$ & L \\
\hline & & & & $\begin{array}{l}\text { Hydrogen Deflagration: } \\
\text { If the pressure is high, then the decant/flocculant recirculation line could fail. } \\
\text { Hydrogen generated by the supernate could accumulate in the Decant Pump } \\
\text { Box resulting in a deflagration. }\end{array}$ & A & $\mathrm{H}$ & $\mathrm{L}$ & $\mathrm{L}$ \\
\hline \multirow[t]{2}{*}{ 9.a-13.a } & \multirow[t]{2}{*}{$\begin{array}{l}\text { Structural } \\
\text { Integrity }\end{array}$} & \multirow[t]{2}{*}{$\begin{array}{l}\text { Leak/rupture } \\
\text { (inside Decant } \\
\text { Pump Box) }\end{array}$} & \multirow[t]{2}{*}{$\begin{array}{l}\text { - Overpressurization } \\
\text { - Hose disconnects }\end{array}$} & $\begin{array}{l}\text { Uncontrolled Release: } \\
\text { If the leak is large, then the pressure could drop to the point that recirculated } \\
\text { supernate would be pumped into the flocculant addition system (due to the } \\
80 \text { psi generated by decant pump ECRT-P-201) which would result in a } \\
\text { spray or splash and splatter/pool release. }\end{array}$ & A & L & $\mathrm{L}$ & $\mathrm{L}$ \\
\hline & & & & $\begin{array}{l}\text { Hydrogen Deflagration: } \\
\text { If the leak is large, and recirculated supernate is pumped into the Decant } \\
\text { Pump Box, then hydrogen generated by the supernate could accumulate in } \\
\text { the box resulting in a deflagration. }\end{array}$ & A & $\mathrm{H}$ & L & $\mathrm{L}$ \\
\hline 9.a-13.b & \begin{tabular}{|l} 
Structural \\
Integrity
\end{tabular} & $\begin{array}{l}\text { Leak/rupture } \\
\text { (outside Decant } \\
\text { Pump Box) }\end{array}$ & $\begin{array}{l}\text { - Overpressurization } \\
\text { - Hose disconnects }\end{array}$ & $\begin{array}{l}\text { Uncontrolled Release: } \\
\text { If the leak is large, then the pressure could drop to the point that recirculated } \\
\text { supernate would be pumped into the flocculant addition system (due to the } \\
80 \text { psi generated by decant pump ECRT-P-201) which would result in a } \\
\text { spray or splash and splatter/pool release. }\end{array}$ & A & $\mathrm{L}$ & $\mathrm{L}$ & $\mathrm{L}$ \\
\hline
\end{tabular}


Table D-1. Frequency and Consequence Levels

\begin{tabular}{|c|c|c|c|c|c|c|c|c|}
\hline \multirow{2}{*}{ Item } & \multirow{2}{*}{$\begin{array}{l}\text { Process } \\
\text { Parameter }\end{array}$} & \multirow{2}{*}{ Deviation } & \multirow{2}{*}{ Cause } & \multirow{2}{*}{ Hazardous Condition } & \multirow{2}{*}{$\begin{array}{l}\text { Unmitigated } \\
\text { Frequency }\end{array}$} & \multicolumn{3}{|c|}{$\begin{array}{l}\text { Unmitigated } \\
\text { Consequences }\end{array}$} \\
\hline & & & & & & FW & Onsite & Offsite \\
\hline \multirow[t]{2}{*}{ 9.b-5.a } & \multirow[t]{2}{*}{ Flow } & \multirow[t]{2}{*}{$\begin{array}{l}\text { Misdirected } \\
\text { (into Decant Pump } \\
\text { Box) }\end{array}$} & \multirow{2}{*}{$\begin{array}{l}\text { - Valving error such that } \\
\text { supernate enters box via IXM } \\
\text { water spray nozzles } \\
\text { - Valving error such that } \\
\text { supernate enters box via } \\
\text { siphon break }\end{array}$} & $\begin{array}{l}\text { Uncontrolled Release: } \\
\text { If supernate is misdirected into the Decant Pump Box, then a splash and } \\
\text { splatter/pool release will occur. }\end{array}$ & A & $\mathrm{L}$ & $\mathrm{L}$ & $\mathrm{L}$ \\
\hline & & & & $\begin{array}{l}\text { Hydrogen Deflagration: } \\
\text { If supernate is misdirected into the Decant Pump Box, then hydrogen } \\
\text { generated by the supernate could accumulate in the box resulting in a } \\
\text { deflagration. }\end{array}$ & A & $\mathrm{H}$ & L & L \\
\hline \multirow[t]{2}{*}{ 9.b-5.b } & \multirow[t]{2}{*}{ Flow } & \multirow[t]{2}{*}{\begin{tabular}{l|} 
Misdirected \\
(into Transfer Line \\
Service Box)
\end{tabular}} & \multirow{2}{*}{$\begin{array}{l}\text { - Valving error such that } \\
\text { supernate enters box via IXM } \\
\text { water spray nozzles } \\
\text { - Valving error such that } \\
\text { supernate enters box via } \\
\text { siphon break }\end{array}$} & $\begin{array}{l}\text { Uncontrolled Release: } \\
\text { If supernate is misdirected into the Transfer Line Service Box, then a splash } \\
\text { and splatter/pool release will occur. }\end{array}$ & A & $\mathrm{L}$ & $\mathrm{L}$ & L \\
\hline & & & & $\begin{array}{l}\text { Hydrogen Deflagration: } \\
\text { If supernate is misdirected into the Transfer Line Service Box, then hydrogen } \\
\text { generated by the supernate could accumulate in the box resulting in a } \\
\text { deflagration. }\end{array}$ & A & $\mathrm{H}$ & L & L \\
\hline 9.b-5.c & Flow & $\begin{array}{l}\text { Misdirected } \\
\text { (to sand filters) }\end{array}$ & Valve ECRT-V-201 misaligned & $\begin{array}{l}\text { Uncontrolled Release: } \\
\text { If supernate is misdirected into the sand filter, then decant pump } \\
\text { ECRT-P-201 will deadhead resulting in a high pressure. See Item 9-7 } \\
\text { below. }\end{array}$ & A & $\mathrm{L}$ & L & $\mathrm{L}$ \\
\hline $9 . b-5 . d$ & Flow & $\begin{array}{l}\text { Misdirected } \\
\text { (into Decant Pump } \\
\text { Box IXM water } \\
\text { supply) }\end{array}$ & Valving error & $\begin{array}{l}\text { Uncontrolled Release: } \\
\text { If supernate is misdirected into the Decant Pump Box IXM water supply, then } \\
\text { a splash and splatter/pool release could occur. }\end{array}$ & A & L & $\mathrm{L}$ & L \\
\hline 9.b-5.e & Flow & $\begin{array}{l}\text { Misdirected } \\
\text { (into Transfer Line } \\
\text { Service Box IXM } \\
\text { water supply) }\end{array}$ & Valving error & $\begin{array}{l}\text { Uncontrolled Release: } \\
\text { If supernate is misdirected into the Transfer Line Service Box IXM water } \\
\text { supply, then a splash and splatter/pool release could occur. }\end{array}$ & LA & L & L & L \\
\hline
\end{tabular}


Table D-1. Frequency and Consequence Levels

\begin{tabular}{|c|c|c|c|c|c|c|c|c|}
\hline \multirow{2}{*}{ Item } & \multirow{2}{*}{$\begin{array}{l}\text { Process } \\
\text { Parameter }\end{array}$} & \multirow{2}{*}{ Deviation } & \multirow{2}{*}{ Cause } & \multirow{2}{*}{ Hazardous Condition } & \multirow{2}{*}{$\begin{array}{l}\text { Unmitigated } \\
\text { Frequency }\end{array}$} & \multicolumn{3}{|c|}{$\begin{array}{l}\text { Unmitigated } \\
\text { Consequences }\end{array}$} \\
\hline & & & & & & FW & Onsite & Offsite \\
\hline 9.b-5.f & Flow & $\begin{array}{l}\text { Misdirected } \\
\text { (into flocculant } \\
\text { addition supply) }\end{array}$ & $\begin{array}{l}\text { - Valving error } \\
\text { - Low pressure in flocculant } \\
\text { addition line } \\
\text { - High pressure in the } \\
\text { decantflocculant recirculation } \\
\text { line }\end{array}$ & $\begin{array}{l}\text { Uncontrolled Release: } \\
\text { If supernate is misdirected into the flocculant addition supply, then a splash } \\
\text { and splatter/pool release could occur. }\end{array}$ & A & $\mathrm{L}$ & $\mathrm{L}$ & L \\
\hline \multirow[t]{2}{*}{ 9.b-7 } & \multirow[t]{2}{*}{ Pressure } & \multirow[t]{2}{*}{ High } & \multirow[t]{2}{*}{$\begin{array}{l}\text { - High air pressure to decant } \\
\text { pump ECRT-P-201 } \\
\text { - A normally-opened valve is } \\
\text { closed }\end{array}$} & $\begin{array}{l}\text { Uncontrolled Release: } \\
\text { If the pressure is high, then the decant/flocculant recirculation line or } \\
\text { flocculant addition line could fail resulting in an airborne spray release or } \\
\text { splash and splatter/pool release. }\end{array}$ & A & L & $\mathrm{L}$ & $\mathrm{L}$ \\
\hline & & & & $\begin{array}{l}\text { Hydrogen Deflagration: } \\
\text { If the pressure is high, then the decantflocculant recirculation line could fail. } \\
\text { Hydrogen generated by the supernate could accumulate in the Decant Pump } \\
\text { Box or Transfer Line Service Box resulting in a deflagration. }\end{array}$ & A & $\mathrm{H}$ & L & $\mathrm{L}$ \\
\hline 9.b-13.a & $\begin{array}{l}\text { Structural } \\
\text { Integrity }\end{array}$ & Leak/rupture & $\begin{array}{l}\text { Decant pump ECRT-P-201 } \\
\text { diaphragm failure }\end{array}$ & $\begin{array}{l}\text { Uncontrolled Release: } \\
\text { If the decant pump diaphragm failed, then supernate could enter the pump } \\
\text { exhaust resulting in a spray or splash and splatter/pool release. }\end{array}$ & A & L & L & L \\
\hline \multirow[t]{2}{*}{ 9.b-13.b } & \multirow[t]{2}{*}{$\begin{array}{l}\text { Structural } \\
\text { Integrity }\end{array}$} & \multirow[t]{2}{*}{$\begin{array}{l}\text { Leak/rupture } \\
\text { (decantflocculant } \\
\text { recirculation line) }\end{array}$} & \multirow[t]{2}{*}{$\begin{array}{l}\text { - High pressure (see Item 9.b-7 } \\
\text { above) } \\
\text { - Manufacturing flaw } \\
\text { - Hose connection decouples }\end{array}$} & $\begin{array}{l}\text { Uncontrolled Release: } \\
\text { If the decant/flocculant recirculation line fails, then a spray or splash and } \\
\text { splatter/pool release of STSC supernate will occur. }\end{array}$ & A & L & L & L \\
\hline & & & & $\begin{array}{l}\text { Hydrogen Deflagration: } \\
\text { If the leak is large, and recirculated supernate is pumped into the Decant } \\
\text { Pump Box or Transfer Line Service Box, then hydrogen generated by the } \\
\text { supernate could accumulate in the box resulting in a deflagration. }\end{array}$ & A & $H$ & $\mathrm{~L}$ & $\mathrm{~L}$ \\
\hline $9 . b-16$ & $\begin{array}{l}\text { Time } \\
\text { Procedure }\end{array}$ & Skip action & Operator error & $\begin{array}{l}\text { Uncontrolled Release: } \\
\text { If the decant/flocculant recirculation is not performed, then flocculant will not } \\
\text { be added such that the decant transferred to the sand filters will have a high } \\
\text { solids concentration. See Item 3.9.a above. }\end{array}$ & A & $\mathrm{L}$ & $\mathrm{L}$ & L \\
\hline
\end{tabular}


Table D-1. Frequency and Consequence Levels

\begin{tabular}{|c|c|c|c|c|c|c|c|c|}
\hline \multirow{2}{*}{ Item } & \multirow{2}{*}{$\begin{array}{l}\text { Process } \\
\text { Parameter }\end{array}$} & \multirow{2}{*}{ Deviation } & \multirow{2}{*}{ Cause } & \multirow{2}{*}{ Hazardous Condition } & \multirow{2}{*}{$\begin{array}{l}\text { Unmitigated } \\
\text { Frequency }\end{array}$} & \multicolumn{3}{|c|}{$\begin{array}{c}\text { Unmitigated } \\
\text { Consequences }\end{array}$} \\
\hline & & & & & & FW & Onsite & Offsite \\
\hline \multirow[t]{2}{*}{$9 . b-17$} & \multirow[t]{2}{*}{$\begin{array}{l}\text { Time } \\
\text { Procedure }\end{array}$} & \multirow[t]{2}{*}{$\begin{array}{l}\text { Wrong action } \\
\text { (decant instead of } \\
\text { recirculate) }\end{array}$} & \multirow[t]{2}{*}{ Operator error } & $\begin{array}{l}\text { Uncontrolled Release: } \\
\text { If the supernate is decanted instead of recirculated, then decant pump } \\
\text { ECRT-P-201 will deadhead resulting in a high pressure. See ltem 9.b-7 } \\
\text { above. }\end{array}$ & A & $\mathrm{L}$ & $\mathrm{L}$ & $\mathrm{L}$ \\
\hline & & & & $\begin{array}{l}\text { Hydrogen Deflagration: } \\
\text { If the supernate is decanted instead of recirculated, then decant pump } \\
\text { ECRT-P-201 will deadhead resulting in a high pressure. See Item 9.b-7 } \\
\text { above. }\end{array}$ & A & $\mathrm{H}$ & $\mathrm{L}$ & $\mathrm{L}$ \\
\hline $10-1$ & Flow & No & $\begin{array}{l}\text { - Flush tank ECRT-TK-101 not } \\
\text { pressurized } \\
\text { - No water in flush tank } \\
\text { ECRT-TK-101 } \\
\text { - Valve ECRT-AOV-102 or } \\
\text { ECRT-AOV-113 fails to open } \\
\text { - Bladder flush disabled }\end{array}$ & $\begin{array}{l}\text { Radiological Control: } \\
\text { If the autoflush is not performed, then there is a higher probability of } \\
\text { significant contamination and higher dose rate during STSC process } \\
\text { disconnects. }\end{array}$ & A & L & $\mathrm{L}$ & $\mathrm{L}$ \\
\hline $10-2$ & Flow & Low & $\begin{array}{l}\text { - Low pressure in flush tank } \\
\text { ECRT-TK-101 } \\
\text { - A normally-opened valve is } \\
\text { partially closed }\end{array}$ & $\begin{array}{l}\text { Radiological Control: } \\
\text { If the autoflush is not performed, then there is a higher probability of } \\
\text { significant contamination and higher dose rate during STSC process } \\
\text { disconnects. }\end{array}$ & A & L & $\mathrm{L}$ & $\mathrm{L}$ \\
\hline $10-4$ & Flow & Reverse & $\begin{array}{l}\text { Valves ECRT-AOV-102 and } \\
\text { open during a slurry transfer }\end{array}$ & $\begin{array}{l}\text { Uncontrolled Release: } \\
\text { If there is reverse flow, then sludge could be pumped into the autoflush line } \\
\text { resulting in a spray or splash and splatter/pool release. }\end{array}$ & A & $\mathrm{H}$ & L & L \\
\hline $10-7$ & Pressure & High & $\begin{array}{l}\text { - Operator error } \\
\text { - Pressure indication reads } \\
\text { incorrectly }\end{array}$ & $\begin{array}{l}\text { Uncontrolled Release: } \\
\text { If the pressure is high, then the flush tank or flush line could fail resulting in a } \\
\text { release of IXM water will occur. }\end{array}$ & A & $\mathrm{L}$ & $\mathrm{L}$ & L \\
\hline 10-10.a & $\begin{array}{l}\text { Structural } \\
\text { Integrity }\end{array}$ & $\begin{array}{l}\text { Leak/rupture } \\
\text { (flush tank, air } \\
\text { side) }\end{array}$ & $\begin{array}{l}\text { - Overpressurization } \\
\text { - Air fitting leakage }\end{array}$ & $\begin{array}{l}\text { Radiological Control: } \\
\text { If the autoflush is not performed, then there is a higher probability of } \\
\text { significant contamination and higher dose rate during STSC process } \\
\text { disconnects. }\end{array}$ & A & $\mathrm{L}$ & L & L \\
\hline
\end{tabular}


Table D-1. Frequency and Consequence Levels

\begin{tabular}{|c|c|c|c|c|c|c|c|c|}
\hline \multirow{2}{*}{ Item } & \multirow{2}{*}{$\begin{array}{l}\text { Process } \\
\text { Parameter }\end{array}$} & \multirow{2}{*}{ Deviation } & \multirow{2}{*}{ Cause } & \multirow{2}{*}{ Hazardous Condition } & \multirow{2}{*}{$\begin{array}{l}\text { Unmitigated } \\
\text { Frequency }\end{array}$} & \multicolumn{3}{|c|}{$\begin{array}{l}\text { Unmitigated } \\
\text { Consequences }\end{array}$} \\
\hline & & & & & & FW & Onsite & Offsite \\
\hline \multirow[t]{2}{*}{ 10-10.b } & \multirow[t]{2}{*}{$\begin{array}{l}\text { Structural } \\
\text { Integrity }\end{array}$} & \multirow{2}{*}{$\begin{array}{l}\text { Leak/rupture } \\
\text { (flush tank, water } \\
\text { side; autoflush line } \\
\text { to valve } \\
\text { ECRT-V-102) }\end{array}$} & \multirow[t]{2}{*}{$\begin{array}{l}\text { - Overpressurization } \\
\text { - Valve ECRT-V-112 leaks }\end{array}$} & $\begin{array}{l}\text { Uncontrolled Release: } \\
\text { If the tank fails on the water side, or the autoflush line to valve ECRT-V-102 } \\
\text { fails, then a spray or splash and splatter/pool release of IXM water will occur. }\end{array}$ & A & $L$ & $L$ & $\mathrm{~L}$ \\
\hline & & & & $\begin{array}{l}\text { Radiological Control: } \\
\text { If the autoflush is not performed, then there is a higher probability of } \\
\text { significant contamination and higher dose rate during STSC process } \\
\text { disconnects. }\end{array}$ & A & $L$ & $\mathrm{~L}$ & $\mathrm{~L}$ \\
\hline 10-10.c & $\begin{array}{l}\text { Structural } \\
\text { Integrity }\end{array}$ & $\begin{array}{l}\text { Leak/rupture } \\
\text { (autoflush line } \\
\text { from valve } \\
\text { ECRT-V-102 to } \\
\text { booster pump } \\
\text { skid) }\end{array}$ & $\begin{array}{l}\text { - Overpressurization } \\
\text { - Hose disconnects }\end{array}$ & $\begin{array}{l}\text { Uncontrolled Release: } \\
\text { If the autoflush fails between ECRT-V-102 and the booster pump skid, then } \\
\text { when valve ECRT-AOV-102 opens, a spray or splash and splatter/pool } \\
\text { release of IXM water will occur. }\end{array}$ & A & L & L & L \\
\hline 10-11.b & $\begin{array}{l}\text { Time } \\
\text { Procedure }\end{array}$ & $\begin{array}{l}\text { Too soon } \\
\text { (inadvertent } \\
\text { activation after a } \\
\text { transfer) }\end{array}$ & $\begin{array}{l}\text { - Failure in interlock sequence } \\
\text { - Loss of power }\end{array}$ & $\begin{array}{l}\text { Uncontrolled Release: } \\
\text { If the autoflush activated after a transfer was complete and the transfer line } \\
\text { was disconnected from the STSC and was not isolated, then a splash and } \\
\text { splatter/pool release could occur. }\end{array}$ & A & L & L & L \\
\hline $10-13$ & $\begin{array}{l}\text { Time } \\
\text { Procedure }\end{array}$ & $\begin{array}{l}\text { Skip action } \\
\text { (autoflush not } \\
\text { performed) }\end{array}$ & Failure in interlock sequence & $\begin{array}{l}\text { Radiological Control: } \\
\text { If the autoflush is not performed, then there is a higher probability of } \\
\text { significant contamination and higher dose rates during STSC process } \\
\text { disconnects. }\end{array}$ & A & L & L & L \\
\hline \multirow[t]{2}{*}{ 11.a-1 } & \multirow[t]{2}{*}{ Flow } & \multirow[t]{2}{*}{ No } & \multirow{2}{*}{$\begin{array}{l}\text { - No IXM water supply from } \\
\text { the Skimmer Water Cleanup } \\
\text { System } \\
\text { - A normally-open valve is } \\
\text { closed } \\
\text { - Fluidizing jets are plugged }\end{array}$} & $\begin{array}{l}\text { Overpressurization: } \\
\text { If there is no flow, then the targeted recovery would not be achieved. In an } \\
\text { unmitigated scenario, exceeding the sludge limits could result in STS cask } \\
\text { overpressurization. }\end{array}$ & A & L & L & L \\
\hline & & & & $\begin{array}{l}\text { Hydrogen Deflagration: } \\
\text { If there is no flow, then the targeted recovery would not be achieved. In an } \\
\text { unmitigated scenario, exceeding the sludge limits could result in a hydrogen } \\
\text { deflagration. }\end{array}$ & A & H & L & L \\
\hline
\end{tabular}


Table D-1. Frequency and Consequence Levels

\begin{tabular}{|c|c|c|c|c|c|c|c|c|}
\hline \multirow{2}{*}{ Item } & \multirow{2}{*}{$\begin{array}{l}\text { Process } \\
\text { Parameter }\end{array}$} & \multirow{2}{*}{ Deviation } & \multirow{2}{*}{ Cause } & \multirow{2}{*}{ Hazardous Condition } & \multirow{2}{*}{$\begin{array}{l}\text { Unmitigated } \\
\text { Frequency }\end{array}$} & \multicolumn{3}{|c|}{$\begin{array}{c}\text { Unmitigated } \\
\text { Consequences }\end{array}$} \\
\hline & & & & & & FW & Onsite & Offsite \\
\hline \multirow[t]{2}{*}{ 11.a-2 } & \multirow[t]{2}{*}{ Flow } & \multirow[t]{2}{*}{ Low } & \multirow{2}{*}{$\begin{array}{l}\text { - Low IXM water supply flow } \\
\text { rate from the Skimmer Water } \\
\text { Cleanup System } \\
\text { - Fluidizing pump ECRT-P-302 } \\
\text { not operating } \\
\text { - Fluidizing pump ECRT-P-302 } \\
\text { speed low } \\
\text { - Valve ECRT-AOV-304 is } \\
\text { closed } \\
\text { - Fluidizing jets are partially } \\
\text { plugged } \\
\text { - A normally open valve is } \\
\text { partially closed }\end{array}$} & $\begin{array}{l}\text { Overpressurization: } \\
\text { If the flow is low, then the targeted recovery would not be achieved. In an } \\
\text { unmitigated scenario, exceeding the sludge limits could result in STS cask } \\
\text { overpressurization. }\end{array}$ & A & L & L & L \\
\hline & & & & $\begin{array}{l}\text { Hydrogen Deflagration: } \\
\text { If the flow is low, then the targeted recovery would not be achieved. In an } \\
\text { unmitigated scenario, exceeding the sludge limits could result in a hydrogen } \\
\text { deflagration. }\end{array}$ & A & $\mathrm{H}$ & $\mathrm{L}$ & $\mathrm{L}$ \\
\hline $11 . a-3$ & Flow & High & $\begin{array}{l}\text { Fluidizing pump ECRT-P-302 } \\
\text { speed high }\end{array}$ & $\begin{array}{l}\text { Uncontrolled Release: } \\
\text { If the flow rate is sufficiently high, then eventually the STSC will be overfilled } \\
\text { and slurry will overflow into the } 4 \text {-in and } 1 \text {-in. ventilation exhaust lines, and } \\
\text { into the } 1 \text {-in. ventilation inlet line, leading to a splash and splatter/pool } \\
\text { release. }\end{array}$ & A & $\mathrm{L}$ & $\mathrm{L}$ & $\mathrm{L}$ \\
\hline 11.a-4 & Flow & Reverse & Siphon from STSC & $\begin{array}{l}\text { Uncontrolled Release: } \\
\text { If a siphon is created, then liquid would be drawn out of the STSC through } \\
\text { the fluidizing jets and discharged at the location of system breach leading to } \\
\text { splash and splatter/pool release. }\end{array}$ & A & L & $\mathrm{L}$ & $\mathrm{L}$ \\
\hline \multirow[t]{2}{*}{$11 . a-5$} & \multirow[t]{2}{*}{ Flow } & \multirow[t]{2}{*}{$\begin{array}{l}\text { Misdirected } \\
\text { (to overfill } \\
\text { recovery tool } \\
\text { dilution water } \\
\text { connection) }\end{array}$} & \multirow[t]{2}{*}{$\begin{array}{l}\text { Operator error in making hose } \\
\text { connections }\end{array}$} & $\begin{array}{l}\text { Overpressurization: } \\
\text { If the fluidizing and dilution water hoses are cross-connected, then the } \\
\text { sludge might not be sufficiently fluidized to achieve the targeted recovery. In } \\
\text { an unmitigated scenario, exceeding the sludge limits could result in STS } \\
\text { cask overpressurization. }\end{array}$ & A & L & $\mathrm{L}$ & $\mathrm{L}$ \\
\hline & & & & $\begin{array}{l}\text { Hydrogen Deflagration: } \\
\text { If the fluidizing and dilution water hoses are cross-connected, then the } \\
\text { sludge might not be sufficiently fluidized to achieve the targeted recovery. In } \\
\text { an unmitigated scenario, exceeding the sludge limits could result in a } \\
\text { hydrogen deflagration. }\end{array}$ & A & $\mathrm{H}$ & $\mathrm{L}$ & $\mathrm{L}$ \\
\hline
\end{tabular}


Table D-1. Frequency and Consequence Levels

\begin{tabular}{|c|c|c|c|c|c|c|c|c|}
\hline \multirow{2}{*}{ Item } & \multirow{2}{*}{$\begin{array}{l}\text { Process } \\
\text { Parameter }\end{array}$} & \multirow{2}{*}{ Deviation } & \multirow{2}{*}{ Cause } & \multirow{2}{*}{ Hazardous Condition } & \multirow{2}{*}{$\begin{array}{l}\text { Unmitigated } \\
\text { Frequency }\end{array}$} & \multicolumn{3}{|c|}{$\begin{array}{c}\text { Unmitigated } \\
\text { Consequences }\end{array}$} \\
\hline & & & & & & FW & Onsite & Offsite \\
\hline \multirow[t]{2}{*}{ 11.a-6 } & \multirow[t]{2}{*}{ Pressure } & \multirow[t]{2}{*}{ Low } & \multirow[t]{2}{*}{$\begin{array}{l}\text { - Fluidizing pump ECRT-P-302 } \\
\text { not operating } \\
\text { - Fluidizing pump ECRT-P-302 } \\
\text { speed low }\end{array}$} & $\begin{array}{l}\text { Overpressurization: } \\
\text { If the pressure is low, then the sludge might not be sufficiently fluidized to } \\
\text { achieve the targeted recovery. In an unmitigated scenario, exceeding the } \\
\text { sludge limits could result in STS cask overpressurization. }\end{array}$ & A & $\mathrm{L}$ & $\mathrm{L}$ & $\mathrm{L}$ \\
\hline & & & & $\begin{array}{l}\text { Hydrogen Deflagration: } \\
\text { If the pressure is low, then the sludge might not be sufficiently fluidized to } \\
\text { achieve the targeted recovery. In an unmitigated scenario, exceeding the } \\
\text { sludge limits could result in a hydrogen deflagration. }\end{array}$ & A & $\mathrm{H}$ & $L$ & $\mathrm{~L}$ \\
\hline 11.a-7 & Pressure & High & $\begin{array}{l}\text { - Fluidizing pump ECRT-P-302 } \\
\text { speed high } \\
\text { - Fluidizing jets are plugged }\end{array}$ & $\begin{array}{l}\text { Uncontrolled Release: } \\
\text { If the fluidizing pump speed is high then the flow rate will be high. If } \\
\text { sufficiently high, then eventually the STSC will be overfilled and slurry will } \\
\text { overflow into the } 4 \text {-in and } 1 \text {-in. ventilation exhaust lines, and into the } 1 \text {-in. } \\
\text { ventilation inlet line, leading to a splash and splatter/pool release. } \\
\text { If the pressure is high, then the fluidizing water line could fail. This would } \\
\text { result in a spill of IXM water. } \\
\text { If hose ECRT-H-302 failed completely or became disconnected, then liquid } \\
\text { could be siphoned from the STSC leading to splash and splatter/pool } \\
\text { release. }\end{array}$ & A & L & $\mathrm{L}$ & L \\
\hline $11 . a-8$ & $\begin{array}{l}\text { Structural } \\
\text { Integrity }\end{array}$ & Leak/rupture & $\begin{array}{l}\text { - High pressure (see } \\
\text { Item 11.a-7 above) } \\
\text { - Manufacturing flaw } \\
\text { - Procurement error } \\
\text { - Hose connection decouples }\end{array}$ & $\begin{array}{l}\text { Uncontrolled Release: } \\
\text { If the fluidizing water line failed, then there would be a spill of IXM water. } \\
\text { If hose ECRT-H-302 failed completely or became disconnected, then liquid } \\
\text { could be siphoned from the STSC leading to splash and splatter/pool } \\
\text { release. }\end{array}$ & A & $\mathrm{L}$ & $\mathrm{L}$ & $\mathrm{L}$ \\
\hline
\end{tabular}


Table D-1. Frequency and Consequence Levels

\begin{tabular}{|c|c|c|c|c|c|c|c|c|}
\hline \multirow{2}{*}{ Item } & \multirow{2}{*}{$\begin{array}{l}\text { Process } \\
\text { Parameter }\end{array}$} & \multirow{2}{*}{ Deviation } & \multirow{2}{*}{ Cause } & \multirow{2}{*}{ Hazardous Condition } & \multirow{2}{*}{$\begin{array}{l}\text { Unmitigated } \\
\text { Frequency }\end{array}$} & \multicolumn{3}{|c|}{$\begin{array}{c}\text { Unmitigated } \\
\text { Consequences }\end{array}$} \\
\hline & & & & & & FW & Onsite & Offsite \\
\hline \multirow[t]{2}{*}{ 11.a-9 } & \multirow[t]{2}{*}{$\begin{array}{l}\text { Time } \\
\text { Procedure }\end{array}$} & \multirow[t]{2}{*}{ Too short } & \multirow[t]{2}{*}{$\begin{array}{l}\text { - Operator error } \\
\text { - Instrumentation failure }\end{array}$} & $\begin{array}{l}\text { Overpressurization: } \\
\text { If the fluidizing jets are operated for too short a period of time, then the } \\
\text { sludge might not be sufficiently fluidized to achieve the targeted recovery. In } \\
\text { an unmitigated scenario, exceeding the sludge limits could result in STS } \\
\text { cask overpressurization. }\end{array}$ & A & L & L & $\mathrm{L}$ \\
\hline & & & & $\begin{array}{l}\text { Hydrogen Deflagration: } \\
\text { If the fluidizing jets are operated for too short a period of time, then the } \\
\text { sludge might not be sufficiently fluidized to achieve the targeted recovery. In } \\
\text { an unmitigated scenario, exceeding the sludge limits could result in a } \\
\text { hydrogen deflagration. }\end{array}$ & A & H & $\mathrm{L}$ & $\mathrm{L}$ \\
\hline 11.a-10 & $\begin{array}{l}\text { Time } \\
\text { Procedure }\end{array}$ & Too long & $\begin{array}{l}\text { - Operator error } \\
\text { - Instrumentation failure }\end{array}$ & $\begin{array}{l}\text { Uncontrolled Release: } \\
\text { If the fluidizing water flow is not terminated and overfill recovery pump } \\
\text { ECRT-P-301 is stopped, then eventually the STSC will be overfilled and } \\
\text { slurry will overflow into the } 4 \text {-in and } 1 \text {-in. ventilation exhaust lines, and into } \\
\text { the } 1 \text {-in. ventilation inlet line, leading to a splash and splatter/pool release. }\end{array}$ & A & L & L & L \\
\hline \multirow[t]{2}{*}{ 11.a-11 } & \multirow[t]{2}{*}{$\begin{array}{l}\text { Time } \\
\text { Procedure }\end{array}$} & \multirow[t]{2}{*}{$\begin{array}{l}\text { Skip action } \\
\text { (fluidizing water } \\
\text { valve not opened) }\end{array}$} & \multirow[t]{2}{*}{$\begin{array}{l}\text { - Operator error } \\
\text { - Instrumentation failure }\end{array}$} & $\begin{array}{l}\text { Overpressurization: } \\
\text { If operators do not open fluidizing water valve ECRT-AOV-304, then IXM } \\
\text { water will flow to the fluidizing jets via bypass orifice ECRT-FO-301 at a } \\
\text { reduced pressure and flow rate. The pressure and flow rate might not be } \\
\text { sufficiently fluidized to achieve the targeted recovery. In an unmitigated } \\
\text { scenario, exceeding the sludge limits could result in STS cask } \\
\text { overpressurization. }\end{array}$ & A & $\mathrm{L}$ & $\mathrm{L}$ & L \\
\hline & & & & $\begin{array}{l}\text { Hydrogen Deflagration: } \\
\text { If operators do not open fluidizing water valve ECRT-AOV-304, then IXM } \\
\text { water will flow to the fluidizing jets via bypass orifice ECRT-FO-301 at a } \\
\text { reduced pressure and flow rate. The pressure and flow rate might not be } \\
\text { sufficiently fluidized to achieve the targeted recovery. In an unmitigated } \\
\text { scenario, exceeding the sludge limits could result in a hydrogen deflagration. }\end{array}$ & A & $\mathrm{H}$ & L & L \\
\hline
\end{tabular}


Table D-1. Frequency and Consequence Levels

\begin{tabular}{|c|c|c|c|c|c|c|c|c|}
\hline \multirow{2}{*}{ Item } & \multirow{2}{*}{$\begin{array}{l}\text { Process } \\
\text { Parameter }\end{array}$} & \multirow{2}{*}{ Deviation } & \multirow{2}{*}{ Cause } & \multirow{2}{*}{ Hazardous Condition } & \multirow{2}{*}{$\begin{array}{l}\text { Unmitigated } \\
\text { Frequency }\end{array}$} & \multicolumn{3}{|c|}{$\begin{array}{l}\text { Unmitigated } \\
\text { Consequences }\end{array}$} \\
\hline & & & & & & FW & Onsite & Offsite \\
\hline \multirow[t]{2}{*}{ 11.b-1. } & \multirow[t]{2}{*}{ Flow } & \multirow[t]{2}{*}{ No } & \multirow[t]{2}{*}{$\begin{array}{l}\text { - No IXM water supply from } \\
\text { the Skimmer Water Cleanup } \\
\text { System } \\
\text { - A normally-open valve is } \\
\text { closed }\end{array}$} & $\begin{array}{l}\text { Overpressurization: } \\
\text { If there is no flow, then the targeted recovery would not be achieved. In an } \\
\text { unmitigated scenario, exceeding the sludge limits could result in STS cask } \\
\text { overpressurization }\end{array}$ & A & L & L & L \\
\hline & & & & $\begin{array}{l}\text { Hydrogen Deflagration: } \\
\text { If there is no flow, then the targeted recovery would not be achieved. In an } \\
\text { unmitigated scenario, exceeding the sludge limits could result in a hydrogen } \\
\text { deflagration. }\end{array}$ & A & $H$ & L & L \\
\hline \multirow[t]{2}{*}{ 11.b-2 } & \multirow[t]{2}{*}{ Flow } & \multirow[t]{2}{*}{ Low } & \multirow[t]{2}{*}{$\begin{array}{l}\text { - Low IXM water supply flow } \\
\text { rate from the Skimmer Water } \\
\text { Cleanup System } \\
\text { - A normally open valve is } \\
\text { partially closed }\end{array}$} & $\begin{array}{l}\text { Overpressurization: } \\
\text { If the flow is low, then the targeted recovery would not be achieved. In an } \\
\text { unmitigated scenario, exceeding the sludge limits could result in STS cask } \\
\text { overpressurization. }\end{array}$ & A & L & L & L \\
\hline & & & & $\begin{array}{l}\text { Hydrogen Deflagration: } \\
\text { If the flow is low, then the targeted recovery would not be achieved. In an } \\
\text { unmitigated scenario, exceeding the sludge limits could result in a hydrogen } \\
\text { deflagration. }\end{array}$ & A & $\mathrm{H}$ & $\mathrm{L}$ & L \\
\hline 11.b-3 & Flow & High & $\begin{array}{l}\text { High IXM water supply flow rate } \\
\text { from the Skimmer Water } \\
\text { Cleanup System }\end{array}$ & $\begin{array}{l}\text { Uncontrolled Release: } \\
\text { If the flow rate is sufficiently high, then eventually the STSC will be overfilled } \\
\text { and slurry will overflow into the } 4 \text {-in and } 1 \text {-in. ventilation exhaust lines, and } \\
\text { into the } 1 \text {-in. ventilation inlet line, leading to a splash and splatter/pool } \\
\text { release. }\end{array}$ & A & L & L & L \\
\hline 11.b-4 & Flow & Reverse & Siphon from STSC & $\begin{array}{l}\text { Uncontrolled Release: } \\
\text { If a siphon is created, then liquid would be drawn out of the STSC through } \\
\text { the dilution water orifices and discharged at the location of system breach } \\
\text { leading to splash and splatter/pool release. }\end{array}$ & A & L & $\mathrm{L}$ & $\mathrm{L}$ \\
\hline
\end{tabular}


Table D-1. Frequency and Consequence Levels

\begin{tabular}{|c|c|c|c|c|c|c|c|c|}
\hline \multirow{2}{*}{ Item } & \multirow{2}{*}{$\begin{array}{l}\text { Process } \\
\text { Parameter }\end{array}$} & \multirow{2}{*}{ Deviation } & \multirow{2}{*}{ Cause } & \multirow{2}{*}{ Hazardous Condition } & \multirow{2}{*}{$\begin{array}{l}\text { Unmitigated } \\
\text { Frequency }\end{array}$} & \multicolumn{3}{|c|}{$\begin{array}{l}\text { Unmitigated } \\
\text { Consequences }\end{array}$} \\
\hline & & & & & & FW & Onsite & Offsite \\
\hline \multirow[t]{2}{*}{ 11.b-5 } & \multirow[t]{2}{*}{ Flow } & \multirow[t]{2}{*}{$\begin{array}{l}\text { Misdirected } \\
\text { (to overfill } \\
\text { recovery tool } \\
\text { fluidizing jet } \\
\text { connection) }\end{array}$} & \multirow[t]{2}{*}{$\begin{array}{l}\text { Operator error in making hose } \\
\text { connections }\end{array}$} & $\begin{array}{l}\text { Overpressurization: } \\
\text { If the fluidizing and dilution water hoses are cross-connected, then the } \\
\text { sludge might not be sufficiently fluidized to achieve the targeted recovery. In } \\
\text { an unmitigated scenario, exceeding the sludge limits could result in STS } \\
\text { cask overpressurization. }\end{array}$ & A & $\mathrm{L}$ & L & $\mathrm{L}$ \\
\hline & & & & $\begin{array}{l}\text { Hydrogen Deflagration: } \\
\text { If the fluidizing and dilution water hoses are cross-connected, then the } \\
\text { sludge might not be sufficiently fluidized to achieve the targeted recovery. In } \\
\text { an unmitigated scenario, exceeding the sludge limits could result in a } \\
\text { hydrogen deflagration. }\end{array}$ & A & $\mathrm{H}$ & $\mathrm{L}$ & $\mathbf{L}$ \\
\hline \multirow[t]{2}{*}{ 11.b-6 } & \multirow[t]{2}{*}{ Pressure } & \multirow[t]{2}{*}{ Low } & \multirow[t]{2}{*}{$\begin{array}{l}\text { - Low IXM water supply } \\
\text { pressure from the Skimmer } \\
\text { Water Cleanup System }\end{array}$} & $\begin{array}{l}\text { Overpressurization: } \\
\text { If there is dilution water pressure is low then the flow will be low. Fluidizing } \\
\text { jet water alone might be sufficient to achieve the targeted recovery. } \\
\text { However, the overfill recovery tool could plug. If the plug could not be } \\
\text { cleared, then the targeted recovery would not be achieved. In an } \\
\text { unmitigated scenario, exceeding the sludge limits could result in STS cask } \\
\text { overpressurization. }\end{array}$ & A & $\mathrm{L}$ & L & L \\
\hline & & & & $\begin{array}{l}\text { Hydrogen Deflagration: } \\
\text { If there is dilution water pressure is low then the flow will be low. Fluidizing } \\
\text { jet water alone might be sufficient to achieve the targeted recovery. } \\
\text { However, the overfill recovery tool could plug. If the plug could not be } \\
\text { cleared, then the targeted recovery would not be achieved. In an } \\
\text { unmitigated scenario, exceeding the sludge limits could result in a hydrogen } \\
\text { deflagration. }\end{array}$ & A & $\mathrm{H}$ & $\mathrm{L}$ & $\mathrm{L}$ \\
\hline
\end{tabular}


Table D-1. Frequency and Consequence Levels

\begin{tabular}{|c|c|c|c|c|c|c|c|c|}
\hline \multirow{2}{*}{ Item } & \multirow{2}{*}{$\begin{array}{l}\text { Process } \\
\text { Parameter }\end{array}$} & \multirow{2}{*}{ Deviation } & \multirow{2}{*}{ Cause } & \multirow{2}{*}{ Hazardous Condition } & \multirow{2}{*}{$\begin{array}{l}\text { Unmitigated } \\
\text { Frequency }\end{array}$} & \multicolumn{3}{|c|}{$\begin{array}{l}\text { Unmitigated } \\
\text { Consequences }\end{array}$} \\
\hline & & & & & & FW & Onsite & Offsite \\
\hline 11.b-7 & Pressure & High & $\begin{array}{l}\text { - High IXM water supply } \\
\text { pressure from the Skimmer } \\
\text { Water Cleanup System }\end{array}$ & $\begin{array}{l}\text { Uncontrolled Release: } \\
\text { If the pressure is high then the flow rate will be high. If sufficiently high, then } \\
\text { eventually the STSC will be overfilled and slurry will overflow into the } 4 \text {-in } \\
\text { and } 1 \text {-in. ventilation exhaust lines, and into the 1-in. ventilation inlet line, } \\
\text { leading to a splash and splatter/pool release. } \\
\text { If the pressure is high, then the dilution water line could fail. This would } \\
\text { result in a spill of IXM water. } \\
\text { If hose ECRT-H-301 failed completely or became disconnected, then liquid } \\
\text { could be siphoned from the STSC leading to splash and splatter/pool } \\
\text { release. }\end{array}$ & A & $\mathrm{L}$ & $\mathrm{L}$ & $\mathbf{L}$ \\
\hline 11.b-8 & $\begin{array}{l}\text { Structural } \\
\text { Integrity }\end{array}$ & Leak/rupture & $\begin{array}{l}\text { - High pressure (see } \\
\text { Item 11.b-7 above) } \\
\text { - Manufacturing flaw } \\
\text { - Procurement error }\end{array}$ & $\begin{array}{l}\text { Uncontrolled Release: } \\
\text { If the dilution water line failed, then there would be a spill of IXM water. } \\
\text { If hose ECRT-H-301 failed completely or became disconnected, then liquid } \\
\text { could be siphoned from the STSC leading to splash and splatter/pool } \\
\text { release. }\end{array}$ & A & L & L & L \\
\hline \multirow[t]{2}{*}{$11 . b-9$} & \multirow[t]{2}{*}{$\begin{array}{l}\text { Time } \\
\text { Procedure }\end{array}$} & \multirow[t]{2}{*}{ Too short } & \multirow[t]{2}{*}{$\begin{array}{l}\text { - Operator error } \\
\text { - Instrumentation failure }\end{array}$} & $\begin{array}{l}\text { Overpressurization: } \\
\text { If the dilution water flow is terminated early, fluidizing jet water alone might } \\
\text { be sufficient to achieve the targeted recovery. However, the overfill recovery } \\
\text { tool could plug. If the plug could not be cleared, then the targeted recovery } \\
\text { would not be achieved. In an unmitigated scenario, exceeding the sludge } \\
\text { limits could result in STS cask overpressurization. }\end{array}$ & A & L & L & L \\
\hline & & & & $\begin{array}{l}\text { Hydrogen Deflagration: } \\
\text { If the dilution water flow is terminated early, fluidizing jet water alone might } \\
\text { be sufficient to achieve the targeted recovery. However, the overfill recovery } \\
\text { tool could plug. If the plug could not be cleared, then the targeted recovery } \\
\text { would not be achieved. In an unmitigated scenario, exceeding the sludge } \\
\text { limits could result in a hydrogen deflagration. }\end{array}$ & A & H & L & L \\
\hline 11.b-10 & $\begin{array}{l}\text { Time } \\
\text { Procedure }\end{array}$ & Too long & $\begin{array}{l}\text { - Operator error } \\
\text { - Instrumentation failure }\end{array}$ & $\begin{array}{l}\text { Uncontrolled Release: } \\
\text { If the dilution water flow is not terminated and overfill recovery pump ECRT- } \\
\text { P-301 is stopped, then eventually the STSC will be overfilled and slurry will } \\
\text { overflow into the } 4 \text {-in and } 1 \text {-in. ventilation exhaust lines, and into the } 1 \text {-in. } \\
\text { ventilation inlet line, leading to a splash and sppatter/pool release. }\end{array}$ & A & $\mathrm{L}$ & $\mathrm{L}$ & $\mathrm{L}$ \\
\hline
\end{tabular}


Table D-1. Frequency and Consequence Levels

\begin{tabular}{|c|c|c|c|c|c|c|c|c|}
\hline \multirow{2}{*}{ Item } & \multirow{2}{*}{$\begin{array}{l}\text { Process } \\
\text { Parameter }\end{array}$} & \multirow{2}{*}{ Deviation } & \multirow{2}{*}{ Cause } & \multirow{2}{*}{ Hazardous Condition } & \multirow{2}{*}{$\begin{array}{l}\text { Unmitigated } \\
\text { Frequency }\end{array}$} & \multicolumn{3}{|c|}{$\begin{array}{c}\text { Unmitigated } \\
\text { Consequences }\end{array}$} \\
\hline & & & & & & FW & Onsite & Offsite \\
\hline \multirow[t]{2}{*}{ 11.b-11 } & \multirow[t]{2}{*}{\begin{tabular}{|l|} 
Time \\
Procedure
\end{tabular}} & \multirow[t]{2}{*}{$\begin{array}{l}\text { Skip action } \\
\text { (dilution water } \\
\text { valve not opened) }\end{array}$} & \multirow[t]{2}{*}{ - Operator error } & $\begin{array}{l}\text { Overpressurization: } \\
\text { If operators do not open dilution water valve ECRT AOV-706, then there will } \\
\text { be no dilution water. Fluidizing jet water alone might be sufficient to achieve } \\
\text { the targeted recovery. However, the overfill recovery tool could plug. If the } \\
\text { plug could not be cleared, then the targeted recovery would not be achieved. } \\
\text { In an unmitigated scenario, exceeding the sludge limits could result in STS } \\
\text { cask overpressurization. }\end{array}$ & A & $\mathrm{L}$ & $\mathrm{L}$ & $\mathrm{L}$ \\
\hline & & & & $\begin{array}{l}\text { Hydrogen Deflagration: } \\
\text { If operators do not open dilution water valve ECRT AOV-706, then there will } \\
\text { be no dilution water. Fluidizing jet water alone might be sufficient to achieve } \\
\text { the targeted recovery. However, the overfill recovery tool could plug. If the } \\
\text { plug could not be cleared, then the targeted recovery would not be achieved. } \\
\text { In an unmitigated scenario, exceeding the sludge limits could result in a } \\
\text { hydrogen deflagration. }\end{array}$ & A & $H$ & $\mathrm{~L}$ & $\mathrm{~L}$ \\
\hline \multirow[t]{3}{*}{ 11.c-1 } & \multirow[t]{3}{*}{ Flow } & \multirow[t]{3}{*}{ No } & \multirow{3}{*}{$\begin{array}{l}\text { - Overfill recovery pump ECRT- } \\
\text { P-301 not operating } \\
\text { - A normally opened valve is } \\
\text { closed } \\
\text { - Overfill recovery tool rupture } \\
\text { disk fails to rupture } \\
\text { - Overfill recovery tool or } \\
\text { discharge line plugged }\end{array}$} & $\begin{array}{l}\text { Uncontrolled Release: } \\
\text { If there is no flow, then the STSC will eventually be overfilled with IXM water } \\
\text { from the overfill recovery tool and slurry will overflow into the } 4 \text {-in and } 1 \text {-in. } \\
\text { ventilation exhaust lines, and into the } 1 \text {-in. ventilation inlet line, leading to a } \\
\text { splash and splatter/pool release. }\end{array}$ & A & L & L & L \\
\hline & & & & $\begin{array}{l}\text { Overpressurization: } \\
\text { If there was no flow, then there would be no overfill recovery. In an } \\
\text { unmitigated scenario, exceeding the sludge limits could result in STS cask } \\
\text { overpressurization. }\end{array}$ & A & L & L & L \\
\hline & & & & $\begin{array}{l}\text { Hydrogen Deflagration: } \\
\text { If there was no flow, then there would be no overfill recovery. In an } \\
\text { unmitigated scenario, exceeding the sludge limits could result in a hydrogen } \\
\text { deflagration. }\end{array}$ & A & $\mathrm{H}$ & $\mathrm{L}$ & $\mathrm{L}$ \\
\hline
\end{tabular}


Table D-1. Frequency and Consequence Levels

\begin{tabular}{|c|c|c|c|c|c|c|c|c|}
\hline \multirow{2}{*}{ Item } & \multirow{2}{*}{$\begin{array}{l}\text { Process } \\
\text { Parameter }\end{array}$} & \multirow{2}{*}{ Deviation } & \multirow{2}{*}{ Cause } & \multirow{2}{*}{ Hazardous Condition } & \multirow{2}{*}{$\begin{array}{l}\text { Unmitigated } \\
\text { Frequency }\end{array}$} & \multicolumn{3}{|c|}{$\begin{array}{l}\text { Unmitigated } \\
\text { Consequences }\end{array}$} \\
\hline & & & & & & FW & Onsite & Offsite \\
\hline \multirow[t]{3}{*}{ 11.c-2 } & \multirow[t]{3}{*}{ Flow } & \multirow[t]{3}{*}{ Low } & \multirow[t]{3}{*}{$\begin{array}{l}\text { - Low air pressure to overfill } \\
\text { recovery pump ECRT-P-301 } \\
\text { - A normally open valve is } \\
\text { partially closed }\end{array}$} & $\begin{array}{l}\text { Uncontrolled Release: } \\
\text { If the flow rate is sufficiently low, then eventually the STSC will be overfilled } \\
\text { with IXM water from the overfill recovery tool and slurry will overflow into the } \\
\text { 4-in and 1-in. ventilation exhaust lines, and into the 1-in. ventilation inlet line, } \\
\text { leading to a splash and splatter/pool release. }\end{array}$ & A & L & $\mathrm{L}$ & L \\
\hline & & & & $\begin{array}{l}\text { Overpressurization: } \\
\text { If the flow rate is low, then sludge could settle out and plug the line. If the } \\
\text { line plugs, then there would be no overfill recovery. If the plug could not be } \\
\text { cleared, then the targeted recovery would not be achieved. In an unmitigated } \\
\text { scenario, exceeding the sludge limits could result in STS cask } \\
\text { overpressurization. }\end{array}$ & A & L & L & L \\
\hline & & & & $\begin{array}{l}\text { Hydrogen Deflagration: } \\
\text { If the flow rate is low, then sludge could settle out and plug the line. If the } \\
\text { line plugs, then there would be no overfill recovery. If the plug could not be } \\
\text { cleared, then the targeted recovery would not be achieved. In an unmitigated } \\
\text { scenario, exceeding the sludge limits could result in a hydrogen deflagration. }\end{array}$ & A & H & L & $\mathrm{L}$ \\
\hline \multirow[t]{2}{*}{$11 . c-3$} & \multirow[t]{2}{*}{ Flow } & \multirow[t]{2}{*}{ High } & \multirow[t]{2}{*}{$\begin{array}{l}\text { High air pressure to overfill } \\
\text { recovery pump ECRT-P-301 }\end{array}$} & $\begin{array}{l}\text { Overpressurization: } \\
\text { If the flow was high, then the overfill recovery tool could plug. If the plug } \\
\text { could not be cleared, then the targeted recovery would not be achieved. In } \\
\text { an unmitigated scenario, exceeding the sludge limits could result in STS } \\
\text { cask overpressurization. }\end{array}$ & A & L & $\mathrm{L}$ & $\mathrm{L}$ \\
\hline & & & & $\begin{array}{l}\text { Hydrogen Deflagration: } \\
\text { If the flow was high, then the overfill recovery tool could plug. If the plug } \\
\text { could not be cleared, then the targeted recovery would not be achieved. In } \\
\text { an unmitigated scenario, exceeding the sludge limits could result in a } \\
\text { hydrogen deflagration. }\end{array}$ & A & $\mathrm{H}$ & $\mathrm{L}$ & L \\
\hline
\end{tabular}


Table D-1. Frequency and Consequence Levels

\begin{tabular}{|c|c|c|c|c|c|c|c|c|}
\hline \multirow{2}{*}{ Item } & \multirow{2}{*}{$\begin{array}{l}\text { Process } \\
\text { Parameter }\end{array}$} & \multirow{2}{*}{ Deviation } & \multirow{2}{*}{ Cause } & \multirow{2}{*}{ Hazardous Condition } & \multirow{2}{*}{$\begin{array}{l}\text { Unmitigated } \\
\text { Frequency }\end{array}$} & \multicolumn{3}{|c|}{$\begin{array}{l}\text { Unmitigated } \\
\text { Consequences }\end{array}$} \\
\hline & & & & & & FW & Onsite & Offsite \\
\hline 11.c-4 & Flow & Reverse & $\begin{array}{l}\text { Overfill recovery flush valve } \\
\text { open }\end{array}$ & $\begin{array}{l}\text { Uncontrolled Release: } \\
\text { If overfill recovery flush valve ECRT-AOV-103 is open, then } 100 \mathrm{gpm} \text { of IXM } \\
\text { water at } 100 \text { psi will enter the overfill recovery discharge line upstream of } \\
\text { overfill recovery pump ECRT-P-301. As ECRT-P-301 pumps } 70 \mathrm{gpm} \text {, } \\
\text { approximately } 30 \mathrm{gpm} \text { of IXM water would reverse flow to the STSC. } \\
\text { Eventually the STSC would be overfilled and slurry would overflow into the } \\
4 \text {-in and } 1 \text {-in. ventilation exhaust lines, and into the } 1 \text {-in. ventilation inlet line, } \\
\text { leading to a splash and splatter/pool release. }\end{array}$ & A & $\mathrm{L}$ & $\mathrm{L}$ & L \\
\hline 11.c-7 & Pressure & High & $\begin{array}{l}\text { Line or valve closed plug during } \\
\text { flushing }\end{array}$ & $\begin{array}{l}\text { Uncontrolled Release: } \\
\text { If the pressure is high, then the overfill recovery tool discharge line could fail } \\
\text { resulting in an airborne spray or splash and splatter/pool release. } \\
\text { (Note: the consequences are qualitatively judged to be low based on the } \\
\text { limited volume of slurry and relatively low pressure (i.e., } 130 \mathrm{psi} \text { ) at which a } \\
\text { spray release would occur. }\end{array}$ & A & $\mathrm{L}$ & $\mathrm{L}$ & L \\
\hline \multirow[t]{2}{*}{ 11.c-8 } & \multirow[t]{2}{*}{$\begin{array}{l}\text { Structural } \\
\text { integrity }\end{array}$} & \multirow[t]{2}{*}{ Leak/rupture } & \multirow[t]{2}{*}{$\begin{array}{l}\text { - Manufacturing flaw } \\
\text { - Procurement error } \\
\text { - Hose connection decouples }\end{array}$} & $\begin{array}{l}\text { Radiological Control: } \\
\text { If there is a leak in the overfill recovery discharge line, then air will be drawn } \\
\text { into the flow stream. This would result in air bubbles in the KW Basin. }\end{array}$ & A & $\mathrm{L}$ & $\mathrm{L}$ & $\mathrm{L}$ \\
\hline & & & & $\begin{array}{l}\text { Uncontrolled Release: } \\
\text { If overfill recovery discharge hose ECRT-H-306 decouples at the transfer } \\
\text { line service box and drops below the liquid level in the STSC, then a siphon } \\
\text { would be created. Liquid would be drawn out of the STSC. }\end{array}$ & A & L & $\mathrm{L}$ & L \\
\hline \multirow[t]{2}{*}{ 11.c-9 } & \multirow[t]{2}{*}{$\begin{array}{l}\text { Time } \\
\text { procedure }\end{array}$} & \multirow[t]{2}{*}{ Too short } & \multirow[t]{2}{*}{$\begin{array}{l}\text { - Operator error } \\
\text { - Instrumentation failure } \\
\text { - Overfill recovery pump failure }\end{array}$} & $\begin{array}{l}\text { Overpressurization: } \\
\text { If the recovery operation occurs for too short a period of time, then the } \\
\text { targeted recovery would not be achieved. In an unmitigated scenario, } \\
\text { exceeding the sludge limits could result in STS cask overpressurization. }\end{array}$ & A & $\mathrm{L}$ & $\mathrm{L}$ & $\mathrm{L}$ \\
\hline & & & & $\begin{array}{l}\text { Hydrogen Deflagration: } \\
\text { If the recovery operation occurs for too short a period of time, then the } \\
\text { targeted recovery would not be achieved. In an unmitigated scenario, } \\
\text { exceeding the sludge limits could result in a hydrogen deflagration. }\end{array}$ & A & $H$ & $\mathrm{~L}$ & $\mathrm{~L}$ \\
\hline
\end{tabular}


Table D-1. Frequency and Consequence Levels

\begin{tabular}{|c|c|c|c|c|c|c|c|c|}
\hline \multirow{2}{*}{ Item } & \multirow{2}{*}{$\begin{array}{l}\text { Process } \\
\text { Parameter }\end{array}$} & \multirow{2}{*}{ Deviation } & \multirow{2}{*}{ Cause } & \multirow{2}{*}{ Hazardous Condition } & \multirow{2}{*}{$\begin{array}{l}\text { Unmitigated } \\
\text { Frequency }\end{array}$} & \multicolumn{3}{|c|}{$\begin{array}{l}\text { Unmitigated } \\
\text { Consequences }\end{array}$} \\
\hline & & & & & & FW & Onsite & Offsite \\
\hline \multirow[t]{3}{*}{$11 . c-11$} & \multirow[t]{3}{*}{$\begin{array}{l}\text { Time } \\
\text { Procedure }\end{array}$} & \multirow[t]{3}{*}{$\begin{array}{l}\text { Skip action } \\
\text { (overfill recovery } \\
\text { pump not started) }\end{array}$} & \multirow[t]{3}{*}{ Operator error } & $\begin{array}{l}\text { Uncontrolled Release: } \\
\text { If operators do not start overfill recovery pump ECRT-P-301, then there will } \\
\text { be no flow. If there is no flow then the STSC will eventually be overfilled with } \\
\text { IXM water from the overfill recovery tool and slurry will overflow into the 4-in } \\
\text { and } 1 \text {-in. ventilation exhaust lines, and into the } 1 \text {-in. ventilation inlet line, } \\
\text { leading to a splash and splatter/pool release. }\end{array}$ & A & $\mathrm{L}$ & $\mathrm{L}$ & $\mathrm{L}$ \\
\hline & & & & $\begin{array}{l}\text { Overpressurization: } \\
\text { If the operators do not start overfill recovery pump ECRT-P-301, then there } \\
\text { would be no overfill recovery. In an unmitigated scenario, exceeding the } \\
\text { sludge limits could result in STS cask overpressurization. }\end{array}$ & A & L & L & L \\
\hline & & & & $\begin{array}{l}\text { Hydrogen Deflagration: } \\
\text { If the operators do not start overfill recovery pump ECRT-P-301, then there } \\
\text { would be no overfill recovery. In an unmitigated scenario, exceeding the } \\
\text { sludge limits could result in a hydrogen deflagration. }\end{array}$ & A & $\mathrm{H}$ & $\mathrm{L}$ & $\mathrm{L}$ \\
\hline \multirow[t]{3}{*}{ 11.d-1 } & \multirow[t]{3}{*}{ Flow } & \multirow[t]{3}{*}{ No } & \multirow{3}{*}{$\begin{array}{l}\text { - Overfill recovery pump ECRT- } \\
\text { P-301 not operating } \\
\text { - A normally opened valve is } \\
\text { closed } \\
\text { - Overfill recovery tool rupture } \\
\text { disk fails to rupture } \\
\text { - Overfill recovery tool or } \\
\text { discharge line plugged }\end{array}$} & $\begin{array}{l}\text { Uncontrolled Release: } \\
\text { If there is no flow, then the STSC will eventually be overfilled with IXM water } \\
\text { from the overfill recovery tool and slurry will overflow into the } 4 \text {-in and } 1 \text {-in. } \\
\text { ventilation exhaust lines, and into the } 1 \text {-in. ventilation inlet line, leading to a } \\
\text { splash and splatter/pool release. }\end{array}$ & A & $\mathrm{L}$ & L & L \\
\hline & & & & $\begin{array}{l}\text { Overpressurization: } \\
\text { If there was no flow, then there would be no overfill recovery. In an } \\
\text { unmitigated scenario, exceeding the sludge limits could result in STS cask } \\
\text { overpressurization. }\end{array}$ & A & L & L & L \\
\hline & & & & $\begin{array}{l}\text { Hydrogen Deflagration: } \\
\text { If there was no flow, then there would be no overfill recovery. In an } \\
\text { unmitigated scenario, exceeding the sludge limits could result in a hydrogen } \\
\text { deflagration. }\end{array}$ & A & $\mathrm{H}$ & L & L \\
\hline
\end{tabular}


Table D-1. Frequency and Consequence Levels

\begin{tabular}{|c|c|c|c|c|c|c|c|c|}
\hline \multirow{2}{*}{ Item } & \multirow{2}{*}{$\begin{array}{l}\text { Process } \\
\text { Parameter }\end{array}$} & \multirow{2}{*}{ Deviation } & \multirow{2}{*}{ Cause } & \multirow{2}{*}{ Hazardous Condition } & \multirow{2}{*}{$\begin{array}{l}\text { Unmitigated } \\
\text { Frequency }\end{array}$} & \multicolumn{3}{|c|}{$\begin{array}{l}\text { Unmitigated } \\
\text { Consequences }\end{array}$} \\
\hline & & & & & & FW & Onsite & Offsite \\
\hline \multirow[t]{3}{*}{$11 . d-2$} & \multirow[t]{3}{*}{ Flow } & \multirow[t]{3}{*}{ Low } & \multirow[t]{3}{*}{$\begin{array}{l}\text { - Low air pressure to overfill } \\
\text { recovery pump ECRT-P-301 } \\
\text { - A normally open valve is } \\
\text { partially closed }\end{array}$} & $\begin{array}{l}\text { Uncontrolled Release: } \\
\text { If the flow rate is sufficiently low, then eventually the STSC will be overfilled } \\
\text { with IXM water from the overfill recovery tool and slurry will overflow into the } \\
\text { 4-in and 1-in. ventilation exhaust lines, and into the 1-in. ventilation inlet line, } \\
\text { leading to a splash and splatter/pool release. }\end{array}$ & A & $\mathrm{L}$ & $\mathrm{L}$ & $\mathrm{L}$ \\
\hline & & & & $\begin{array}{l}\text { Overpressurization: } \\
\text { If the flow rate is low, then sludge could settle out and plug the line. If the } \\
\text { line plugs, then there would be no overfill recovery. If the plug could not be } \\
\text { cleared, then the targeted recovery would not be achieved. In an unmitigated } \\
\text { scenario, exceeding the sludge limits could result in STS cask } \\
\text { overpressurization. }\end{array}$ & A & L & $\mathrm{L}$ & $\mathrm{L}$ \\
\hline & & & & $\begin{array}{l}\text { Hydrogen Deflagration: } \\
\text { If the flow rate is low, then sludge could settle out and plug the line. If the } \\
\text { line plugs, then there would be no overfill recovery. If the plug could not be } \\
\text { cleared, then the targeted recovery would not be achieved. In an unmitigated } \\
\text { scenario, exceeding the sludge limits could result in a hydrogen deflagration. }\end{array}$ & A & $\mathrm{H}$ & $\mathrm{L}$ & $\mathrm{L}$ \\
\hline \multirow[t]{2}{*}{$11 . d-3$} & \multirow[t]{2}{*}{ Flow } & \multirow[t]{2}{*}{ High } & \multirow[t]{2}{*}{$\begin{array}{l}\text { High air pressure to overfill } \\
\text { recovery pump ECRT-P-301 }\end{array}$} & $\begin{array}{l}\text { Overpressurization: } \\
\text { If the flow was high, then the overfill recovery tool could plug. If the plug } \\
\text { could not be cleared, then the targeted recovery would not be achieved. In } \\
\text { an unmitigated scenario, exceeding the sludge limits could result in STS } \\
\text { cask overpressurization. }\end{array}$ & A & $\mathrm{L}$ & $\mathrm{L}$ & $\mathrm{L}$ \\
\hline & & & & $\begin{array}{l}\text { Hydrogen Deflagration: } \\
\text { If the flow was high, then the overfill recovery tool could plug. If the plug } \\
\text { could not be cleared, then the targeted recovery would not be achieved. In } \\
\text { an unmitigated scenario, exceeding the sludge limits could result in a } \\
\text { hydrogen deflagration. }\end{array}$ & A & $H$ & $\mathrm{~L}$ & $\mathrm{~L}$ \\
\hline 11.d-5.a & Flow & $\begin{array}{l}\text { Misdirected } \\
\text { (to booster pump) }\end{array}$ & Operator error & $\begin{array}{l}\text { Uncontrolled Release: } \\
\text { If the flow is misdirected to booster pump ECRT-P-101, then overfill recovery } \\
\text { pump ECRT-P- } 301 \text { will deadhead resulting in high pressure in the transfer } \\
\text { line. The high pressure could result in a transfer line failure resulting in an } \\
\text { airborne spray or splash and splatter/pool release. }\end{array}$ & A & $\mathrm{H}$ & $\mathrm{H}$ & $\mathrm{L}$ \\
\hline
\end{tabular}


Table D-1. Frequency and Consequence Levels

\begin{tabular}{|c|c|c|c|c|c|c|c|c|}
\hline \multirow{2}{*}{ Item } & \multirow{2}{*}{$\begin{array}{l}\text { Process } \\
\text { Parameter }\end{array}$} & \multirow{2}{*}{ Deviation } & \multirow{2}{*}{ Cause } & \multirow{2}{*}{ Hazardous Condition } & \multirow{2}{*}{$\begin{array}{l}\text { Unmitigated } \\
\text { Frequency }\end{array}$} & \multicolumn{3}{|c|}{$\begin{array}{l}\text { Unmitigated } \\
\text { Consequences }\end{array}$} \\
\hline & & & & & & FW & Onsite & Offsite \\
\hline 11.d-5.d & Flow & $\begin{array}{l}\text { Misdirected } \\
\text { (into STSC) }\end{array}$ & $\begin{array}{l}\text { Valve ECRT-V-102 positioned } \\
\text { incorrectly }\end{array}$ & $\begin{array}{l}\text { Uncontrolled Release: } \\
\text { If valve ECRT-V-102 is positioned incorrectly, then the recovered sludge } \\
\text { would be directed back to the STSC. Eventually the STSC will be overfilled } \\
\text { with IXM water from the overfill recovery tool and slurry will overflow into the } \\
\text { 4-in and 1-in. ventilation exhaust lines, and into the 1-in. ventilation inlet line, } \\
\text { leading to a splash and splatter/pool release. }\end{array}$ & A & $\mathrm{L}$ & $\mathrm{L}$ & L \\
\hline \multirow[t]{3}{*}{$11 . d-6$} & \multirow[t]{3}{*}{ Pressure } & \multirow[t]{3}{*}{ Low } & \multirow[t]{3}{*}{$\begin{array}{l}\text { Low air pressure to overfill } \\
\text { recovery pump ECRT-P-301 }\end{array}$} & $\begin{array}{l}\text { Uncontrolled Release: } \\
\text { If the pressure is low, then the flow rate will be low. If the flow rate is } \\
\text { sufficiently low, then eventually the STSC will be overfilled with IXM water } \\
\text { from the overfill recovery tool and slurry will overflow into the 4-in and 1-in. } \\
\text { ventilation exhaust lines, and into the 1-in. ventilation inlet line, leading to a } \\
\text { splash and splatter/pool release. }\end{array}$ & A & L & $\mathrm{L}$ & $\mathrm{L}$ \\
\hline & & & & $\begin{array}{l}\text { Overpressurization: } \\
\text { If the pressure is low, then the flow rate will be low. Sludge could settle out } \\
\text { and plug the line. If the line plugs, then there would be no overfill recovery. } \\
\text { If the plug could not be cleared, then the targeted recovery would not be } \\
\text { achieved. In an unmitigated scenario, exceeding the sludge limits could } \\
\text { result in STS cask overpressurization. }\end{array}$ & A & $\mathrm{L}$ & $\mathrm{L}$ & $\mathrm{L}$ \\
\hline & & & & $\begin{array}{l}\text { Hydrogen Deflagration: } \\
\text { If the pressure is low, then the flow rate will be low. Sludge could settle out } \\
\text { and plug the line. If the line plugs, then there would be no overfill recovery. } \\
\text { If the plug could not be cleared, then the targeted recovery would not be } \\
\text { achieved. In an unmitigated scenario, exceeding the sludge limits could } \\
\text { result in a hydrogen deflagration. }\end{array}$ & A & $\mathrm{H}$ & $\mathrm{L}$ & L \\
\hline
\end{tabular}


Table D-1. Frequency and Consequence Levels

\begin{tabular}{|c|c|c|c|c|c|c|c|c|}
\hline \multirow{2}{*}{ Item } & \multirow{2}{*}{$\begin{array}{l}\text { Process } \\
\text { Parameter }\end{array}$} & \multirow{2}{*}{ Deviation } & \multirow{2}{*}{ Cause } & \multirow{2}{*}{ Hazardous Condition } & \multirow{2}{*}{$\begin{array}{l}\text { Unmitigated } \\
\text { Frequency }\end{array}$} & \multicolumn{3}{|c|}{$\begin{array}{c}\text { Unmitigated } \\
\text { Consequences }\end{array}$} \\
\hline & & & & & & FW & Onsite & Offsite \\
\hline \multirow[t]{3}{*}{ 11.d-7 } & \multirow[t]{3}{*}{ Pressure } & \multirow[t]{3}{*}{ High } & \multirow{3}{*}{$\begin{array}{l}\text { - High air pressure to overfill } \\
\text { recovery pump ECRT-P-301 } \\
\text { - A normally-opened valve is } \\
\text { closed } \\
\text { - Transfer line plugged }\end{array}$} & $\begin{array}{l}\text { Uncontrolled Release: } \\
\text { If the pressure is high, then transfer line could fail resulting in an airborne } \\
\text { spray or splash and splatter/pool release }\end{array}$ & A & $\mathrm{H}$ & $\mathrm{H}$ & $\mathrm{H}$ \\
\hline & & & & $\begin{array}{l}\text { Overpressurization: } \\
\text { If the pressure high, then the flow rate will be high. If the flow rate is high, } \\
\text { then the overfill recovery tool could plug. If the plug could not be cleared, } \\
\text { then the targeted recovery would not be achieved. In an unmitigated } \\
\text { scenario, exceeding the sludge limits could result in STS cask } \\
\text { overpressurization. }\end{array}$ & A & L & $\mathrm{L}$ & $L$ \\
\hline & & & & $\begin{array}{l}\text { Hydrogen Deflagration: } \\
\text { If the pressure high, then the flow rate will be high. If the flow rate is high, } \\
\text { then the overfill recovery tool could plug. If the plug could not be cleared, } \\
\text { then the targeted recovery would not be achieved. In an unmitigated } \\
\text { scenario, exceeding the sludge limits could result in a hydrogen deflagration. }\end{array}$ & A & $\mathrm{H}$ & $\mathrm{L}$ & $\mathrm{L}$ \\
\hline 11.d-8 & $\begin{array}{l}\text { Structural } \\
\text { integrity }\end{array}$ & $\begin{array}{l}\text { Leak/rupture } \\
\text { (transfer line) }\end{array}$ & $\begin{array}{l}\text { - High pressure (see Item } 7 \\
\text { above) } \\
\text { - Pulsation damper failure } \\
\text { - Manufacturing flaw } \\
\text { - Procurement error } \\
\text { - External event }\end{array}$ & $\begin{array}{l}\text { Uncontrolled Release: } \\
\text { If the overfill recovery tool discharge line fails, then there will be an airborne } \\
\text { spray or splash and splatter/pool release. }\end{array}$ & A & $\mathrm{H}$ & $H$ & $\mathrm{~L}$ \\
\hline 11.d-9 & $\begin{array}{l}\text { Structural } \\
\text { Integrity }\end{array}$ & $\begin{array}{l}\text { Leak/rupture } \\
\text { (pump diaphragm) }\end{array}$ & $\begin{array}{l}\text { - Erosion } \\
\text { - Manufacturing flaw } \\
\text { - Procurement error }\end{array}$ & $\begin{array}{l}\text { Uncontrolled Release: } \\
\text { If the pump diaphragm fails, then sludge could enter the overfill recovery } \\
\text { pump exhaust resulting in a spray or splash and splatter/pool release. }\end{array}$ & A & L & $\mathrm{L}$ & $\mathrm{L}$ \\
\hline \multirow[t]{2}{*}{ 11.d-10 } & \multirow[t]{2}{*}{$\begin{array}{l}\text { Time } \\
\text { procedure }\end{array}$} & \multirow[t]{2}{*}{ Too short } & \multirow[t]{2}{*}{$\begin{array}{l}\text { - Operator error } \\
\text { - Instrumentation failure } \\
\text { - Overfill recovery pump failure }\end{array}$} & $\begin{array}{l}\text { Overpressurization: } \\
\text { If the recovery operation occurs for too short a period of time, then the } \\
\text { targeted recovery would not be achieved. In an unmitigated scenario, } \\
\text { exceeding the sludge limits could result in STS cask overpressurization. }\end{array}$ & A & L & L & L \\
\hline & & & & $\begin{array}{l}\text { Hydrogen Deflagration: } \\
\text { If the recovery operation occurs for too short a period of time, then the } \\
\text { targeted recovery would not be achieved. In an unmitigated scenario, } \\
\text { exceedina the sludae limits could result in a hydrogen deflagration. }\end{array}$ & A & $H$ & L & L \\
\hline
\end{tabular}


Table D-1. Frequency and Consequence Levels

\begin{tabular}{|c|c|c|c|c|c|c|c|c|}
\hline \multirow{2}{*}{ Item } & \multirow{2}{*}{$\begin{array}{c}\text { Process } \\
\text { Parameter }\end{array}$} & \multirow{2}{*}{ Deviation } & \multirow{2}{*}{ Cause } & \multirow{2}{*}{ Hazardous Condition } & \multirow{2}{*}{$\begin{array}{l}\text { Unmitigated } \\
\text { Frequency }\end{array}$} & \multicolumn{3}{|c|}{$\begin{array}{c}\text { Unmitigated } \\
\text { Consequences }\end{array}$} \\
\hline & & & & & & FW & Onsite & Offsite \\
\hline \multirow[t]{3}{*}{$11 . d-12$} & \multirow[t]{3}{*}{$\begin{array}{l}\text { Time } \\
\text { Procedure }\end{array}$} & \multirow[t]{3}{*}{$\begin{array}{l}\text { Skip action } \\
\text { (overfill recovery } \\
\text { pump not started) }\end{array}$} & \multirow[t]{3}{*}{ Operator error } & $\begin{array}{l}\text { Uncontrolled Release: } \\
\text { If operators do not start overfill recovery pump ECRT-P-301, then there will } \\
\text { be no flow. If there is no flow then the STSC will eventually be overfilled with } \\
\text { IXM water from the overfill recovery tool and slurry will overflow into the 4-in } \\
\text { and } 1 \text {-in. ventilation exhaust lines, and into the } 1 \text {-in. ventilation inlet line, } \\
\text { leading to a splash and splatter/pool release. }\end{array}$ & A & $\mathrm{L}$ & $\mathrm{L}$ & $\mathbf{L}$ \\
\hline & & & & $\begin{array}{l}\text { Overpressurization: } \\
\text { If the operators do not start overfill recovery pump ECRT-P-301, then there } \\
\text { would be no overfill recovery. In an unmitigated scenario, exceeding the } \\
\text { sludge limits could result in STS cask overpressurization. }\end{array}$ & $A$ & L & L & $\mathrm{L}$ \\
\hline & & & & $\begin{array}{l}\text { Hydrogen Deflagration: } \\
\text { If the operators do not start overfill recovery pump ECRT-P-301, then there } \\
\text { would be no overfill recovery. In an unmitigated scenario, exceeding the } \\
\text { sludge limits could result in a hydrogen deflagration. }\end{array}$ & A & $\mathrm{H}$ & $\mathrm{L}$ & $\mathrm{L}$ \\
\hline
\end{tabular}


PRC-STP-00346 REV 0

APPENDIX E

PEER REVIEW 


\section{CHPRC REVIEW CHECKLIST}

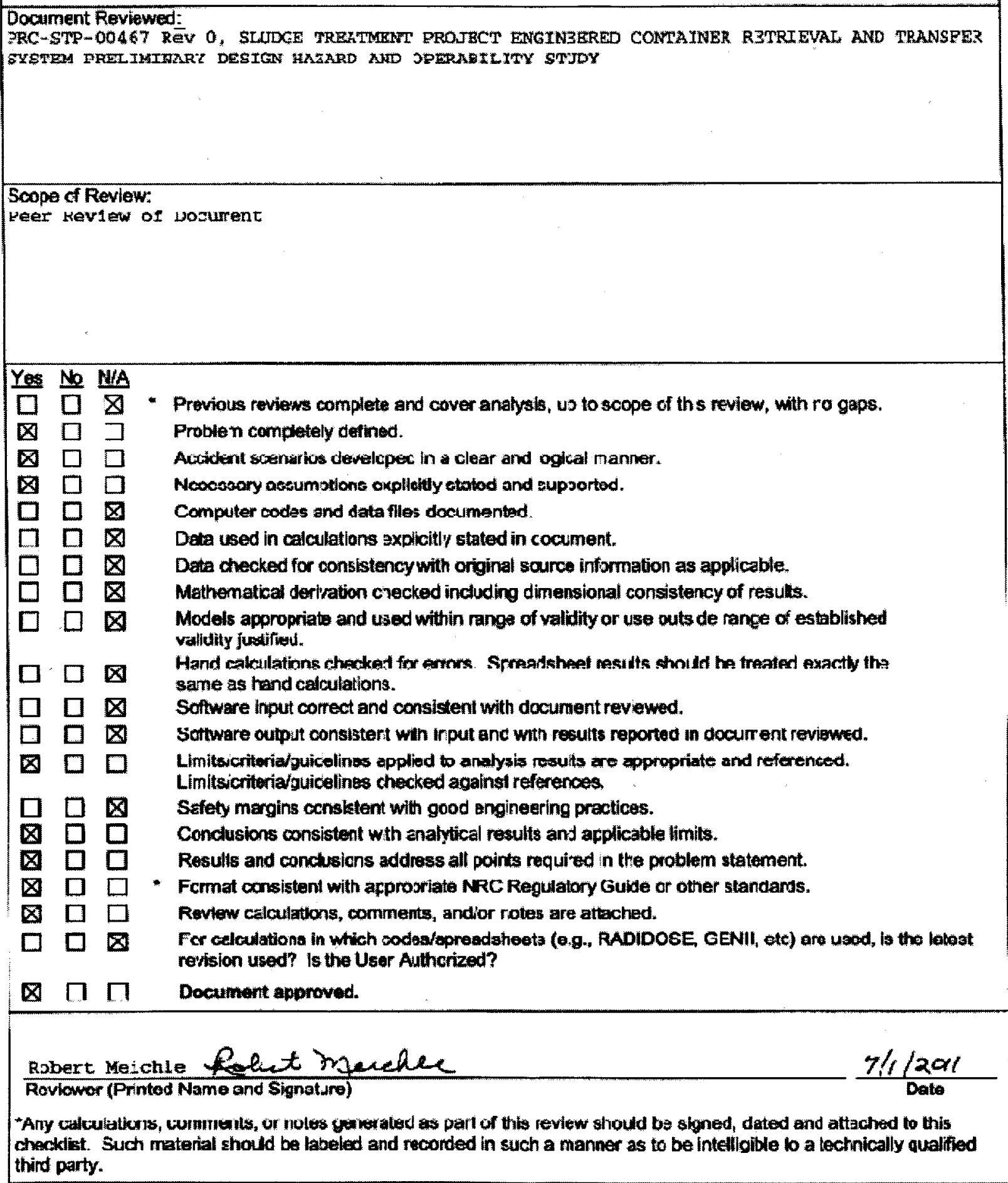




\section{Attachment to CHPRC Review Checklist \\ Peer Review of PRC-STP-00467 Rev 0}

\section{Sludge Treatment Project Engineered Container Retrieval and Transfer System Preliminary Design Hazard and Operability Study}

Problem completely defined. - Hazard analysis consistent with ECRTS Process Description, ECRTS Process Flow Diagram and ECRTS P\&ID.

Accident scenarios developed in a clear and logical. - HAZOP methodology appropriate for system evaluation. Method is consistent with HAZOP description in Guidelines for Hazard Evaluation Procedures (by the American Institute of Chemical Engineers). Analyses provide unmitigated hazardous conditions that are to be used for future accident analysis and developed in a clear and logical manner.

Necessary assumptions explicitly stated and supported. - Reference Flow Diagram and P\&IDs, operational modes, and normal operating conditions consistent with preliminary design provided.

Limits/criteria/guidelines applied to analysis results are appropriate and referenced. Limits/criteria/guidelines checked against references. - The frequency and consequence guidelines from PRC-STD-NS-8739 (SARAH) as modified by DOE-STD-1189 are provided and their application is appropriate. Guidelines have been checked against references.

Conclusions consistent with analytical results and applicable limits. - The results of the hazards evaluation are consistent with the HAZOP and applicable limits.

Results and conclusions address all points required in the problem statement. - Results and conclusions address all of the preliminary design ECRTS operations. An unmitigated hazard analysis was conducted and natural phenomena hazards were considered.

Format consistent with appropriate NRC Regulatory Guide or other standards. - Format is consistent with requirements and guidance of PRC-PRO-NS-700 and PRC-STD-NS-8739. 